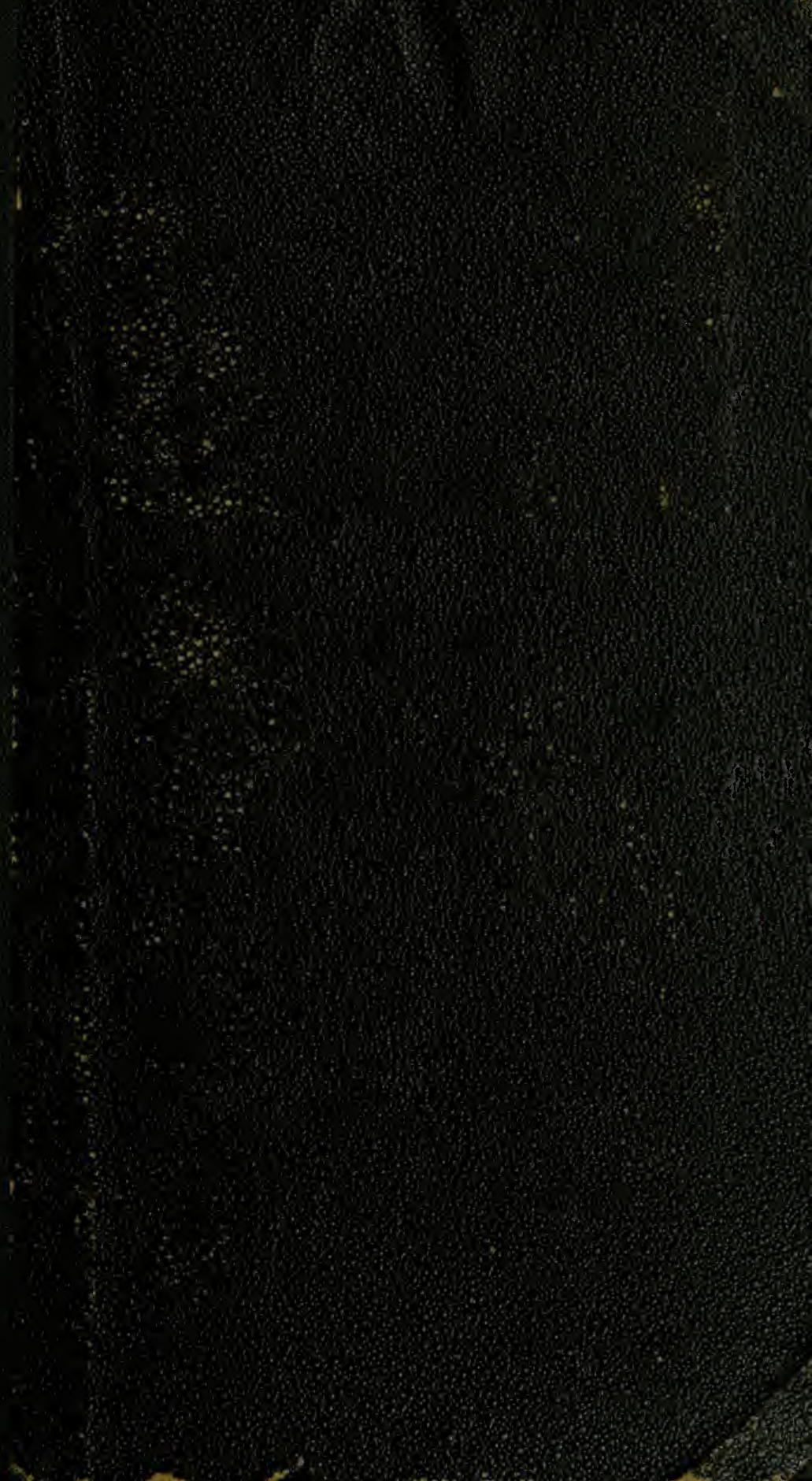



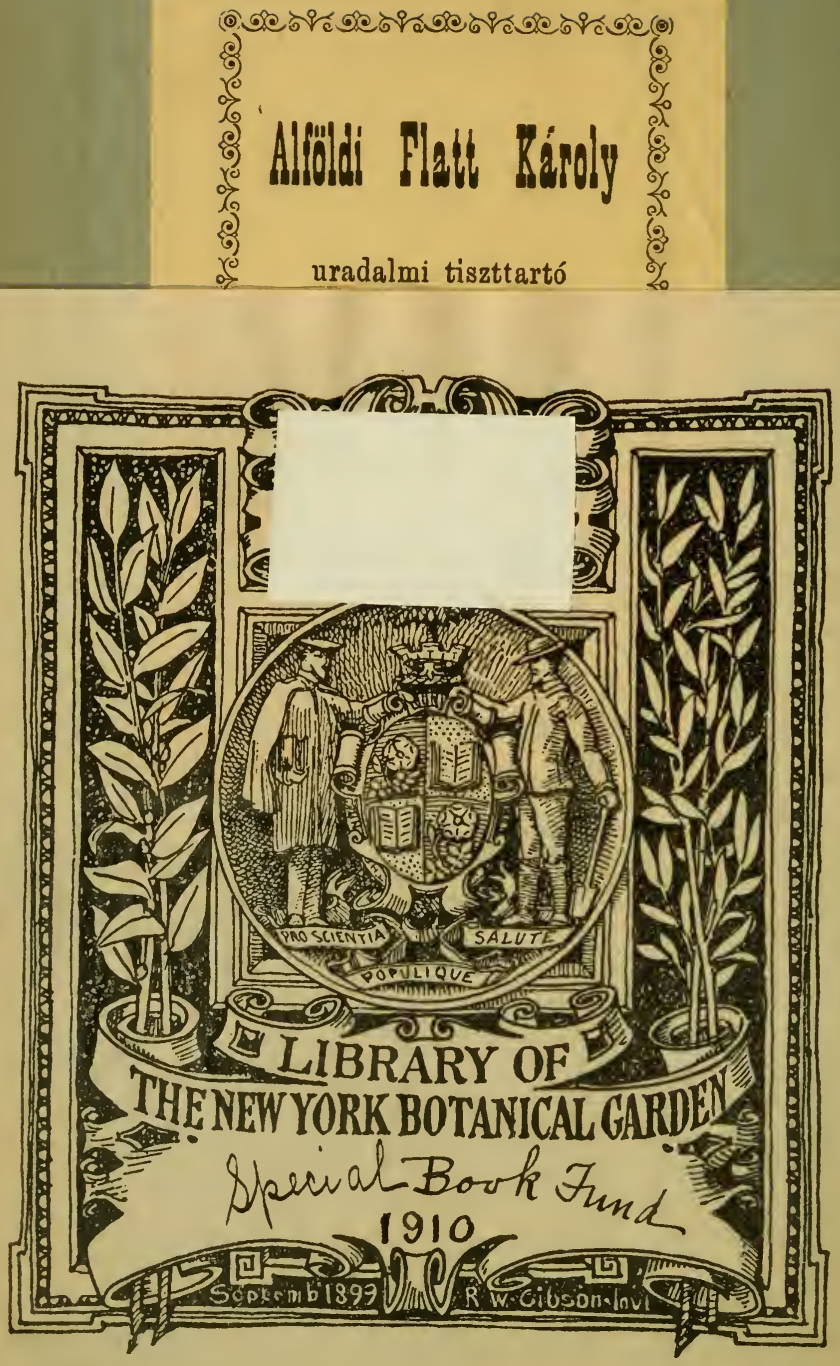




\section{PESTMEGYE ÉS TÁJÉKA}

\section{I R Á N Y A. \\ VEZÉRFONAL}

AZ E MIEGYÉBEN ÉS ANNAK KÖRNYÉKÉN VADON TERMŐ NÖVÉNYEK KÖNNYÜ ÉS BIZTOS MEGHATÁROZÁSÁRA.

\section{A TANULÓ IFJUSÁg}

ÉS

A FÜVÉSZETKEDVELỎK SZÁMÁRA

IRTA

\section{GÖNCZY PÁL,}

A MAGYAR TUD. AKADEMIA LEVELEZÖ S TÜBB TUDOMÁNYOS TARSULAT TAGJA.

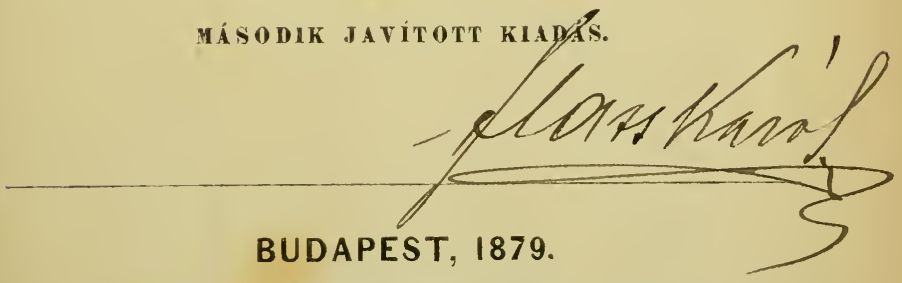

A MAGYAR KIRÁLYI EGYETEMI NYOMDA SAJÁTJA. 
Huc ades!

Hic ver purpureum, varios hic flumina circum Fundit humus fiores. . . .

Tivgil. Eccloga $1 \mathrm{X}$. 


\section{F L Ö S \% Ó}

UARDEN

A nemzeti átalános mivelődés csak azóta halad biztos pályán elöre, mióta az abstract tudományok sikeres megérthetésére, az oktatás ujabb s helyesebb elvei szerint, a tanuló ismerete körét saját vizsgálódása ntján, az őt legközelebb környező s igy bizonyosan leginkább is érdeklö természeti tárgyak szemlélgetéséu kezdi és az igy szelzett tapasztalati ismeretek lépcsőjén, mint egyedüli és biztos fokozatokon törekszik felemelkedni az eszme világába.

Ezen önerőn való vizsgálódásra a természet nagy könyve állandóul nyitva áll ugyan; de mivel bemne az eyyszeri", egyszersmind a szép és magasztos, oly sokféleségben tünik fel, hogy e miatt egészben nayyszerüvé válik; e nagyszerüség a kezdő vizsgálódó elött az egyszerüt gyakran mintegy elleprlezni látszik s haladásában nem ritkán meg-megállítja. Ugyanazért, hogy a természet által a növényalakokra ruházott sokféleségből a kezdő vizsgáló az egyszerüt könnyen kikereshesse, im itt nynjtom hozzá a biztos vezérfonalat.

Az egyszerü feltalálhatására a vizsgálódót a fejtegető módszer (methodus analytica) vezethetrén 
legbiztosabban el ; vezérfonalomat a Lamarck-Cuiriéféle fejteg’ető két-két áğu módszer (dichotomethodus) szerint készítettem. - Mivel azouban az egyes ismeretek csak ugy válhatnak egyetemes s tudományos ismeretté, ha azokat bizonyos rendszerben birjuk felfoğni s áttekinteni: munkám szerkesztésében nem téveszthettem szemem elől, hogy a vizsgálódó a gyakorlati úton is észrevétlenül juthasson a Linné mesterséges és az Endlicher természetes rendszere ismeretéhez s végül a megismert növényeket mindkét rendszerben áttekinthesse.

'Továbbá mivel olyan füvészetkedvelö is ohajthat müvem segítségével a növények ismergetésében elöhaladni, ki iskolailag nem szerezhette meg az ehhez megkivántató elöismereteket; az ilyenek kedveért kettős segédeszközt kivántam nyujtani : egyiket a bevezetésben olvasható lehetö legrövidebb s népszerü növényi alaktant (Morphologia), másikat a könyv végén levő növénytani rövid müszótárt. A növények rövid alaktanát azért írtam, hogy az önerején vizsgálódó, a növény lényeges részeit egymás mellett rendben láthassa; a növénytani müszótárt pedig azért, hogy a könyv szövegében elöforduló minden egyes müszó jelentését szïkség szerint felkereshesse.

A növénytani münyelvet (terminologia) illetőleg, még az 1852-ben megjelent növénytani munkámban *) kifejtett nézetemhez híven a Diószeghi

*) Vezérkönyv a növénytan tanítása és tanulására. Pesten, 1852. 
Fazekas Magyal fïvészkönyve müszavaihoz tartottam magamat, esupán ott kivántam ettől eltérni, a hol a tudomány és az izlés, vagy a szükség kényszerítettek. Vajha a magyar füvészek ezen elvet követve, a münyelvre nézve egységre juthatnának!

A tudoniány fejlődésével ez év száz eleje óta ‘ növények elnevezése (Nomenclatura) változott is, gyarapodott is; ehhez képpest a Diószeghi Fazekas magyar elnevezéseihez, hogy a nagyszerüen megkezdett magyar elnevezés során csorba ne maradjon, pótlékul ujakat kellett készítenem s az 1852-ben készitettekhez most ismét készítettem ujakat, ezek mellett felhasználtam a Brassai Sámuel és Kiorács Fyula tudós füvészek által készítetteket; ezenkirül a növényfajok leirásához lehetöleg hozzácsatoltam a növények népies neveit is.

A növények rendei és nemei sorozatában szorosan követtem Endlichert, a nemek és fajok jellemzésére és leirására nézve magokon a természetes növényeken kivül, Cürie ,Anleitung stb. Pflanzen zu bestimmen'; Maly ,Flora v. Deutschland'; Koch ,Deutschlands Florá-t és Sadler ,Flora Comitatus Pestiensis'-t (1840) használtam. Ott, hol nem látszott szïkségesnek, a lehetö legrövidebben írtam le a növények legföbb jellemeit; ott pedig; hol hittem. hogy a kezdő füvész tévutra könnyen juthatna, a részletesebb leirást tartottam szemem elött.

Jelen müben csupán a Pestmegyében és tájékán vadon termő s nehány mivelés alatti átalánosabban elterjedt közhasznú nörény van leirva, nem- 
csak azért, mivel 15 éven át e vidéken folytatott kirándulásaim alatt ezeken tettem legközelebbi észleleteimet, hanem föleg azért, mivel a budapesti és e megyében létező számos közép és felsőbb tanintézetek növendékei egy ilyen segédkönyvet nem nélkülözhetnek; és hogy a kezdö füvész az ilyen segédköny vek használata mellett nyerhet, e gyakorlati úton megszerezhető tantárgyhoz teljes kedvet, kirándulásai alkalmával nem levén kénytelen, olyan növények tömkelegében tévedezni és e miatt elkedvetlenedni, melyek e vidéken nem is találhatók. *)

Vajha ezen müvem minél több barátot szerezne a növénytamnak s általában a tudománynak !

Irtam Pesten, 186t. martius havában.

$$
\text { A szer*ö. }
$$

*) Némely fajok, mint a Crocns ret., a vidéken kiveszni látszanak; azonban be kellett soroznom ezeket is, mivel ismét elökerülhetnek. 


\section{BEVEZETES. \\ I.}

\section{Növényi alaktan.}

Ha meleg időben, vagy meleg szobában termöföldbe növénymagvakat vetïnk, azt tapasztaljuk, hogy azok rövid idön kikelnek, vagy más szóval : a magvakban rejlö csira, vagyis picziny növények elkezdenek nöni.

A növény növése kikelésekor azommal két irányban indul meg, egyik része nevezetesen lefelé, a másik része pedig telfelé nő.

A növény lefelé növő részét gyöherẻnet, feltelé növö részét töræsének (szárának, derekának) hivjuk.

A magból kelö, vagy magból kelt növények liajtásairól növekedett növények bármelyikének, vannak lefelé és felfelé növő részei, azaz : van mindenilknek gyökere, van törzse.

A növény gyökere és törzse közt esö azon közép részét, melyb̋̋l a gyökere lefelé, tör'zse pedig felfelé indul, a növény tövének nevezzïk.

A növénynek mind a gyökere, mind a törzse rendszerint el szokott ágazni. A gyökér elágazásait általánosan oldalgyökeveknek, gyökérrostoknak, a törzs elágazásait oldalágaknak, leveleknek, virágnak és termésnek szoktuk nevezni.

Minthogy a növények ezen részeik által szerzik meg és szívják fel az életök fentartására s részeik gyarapodásíra sziilkséges táplálékot; a növény 
ezen részeit, egyszóval szervelunek, ragy élctmüvelinek (organa) hívják.

A ki valamely növényt meg akar vizsgálni s vizsgálata után határozottan meg is akar ismermi: annak a növény mindezen részeit (szerveit) apróra meg kell szemlélni s azután ezen részek alakjait: mint az egész növény ismertetö jegyeit (bélyegeit) szorosan meg kell tudni határozni. - Ezen ismertetö jegyek többnyire oly szembetiinők, hogy azokat első tekintetre meg lehet egymástól különböztetni; azonban több esetben fordulnak a növényeken olyan bélyegek is elö, melyeknek alakját esak nagyító üveg: (Loupe) segitségével lehet megszemlélni. Ilyen esetekre a fưvésznek egy közönséges kézi nagyító iiveget kell szerezni.

Hogy a kezdö füvész a növények szervei föbb alakjairól helyes ismeretre tehessen szert; a növények szervei alakjait föbb vonalaiban a következőkben elöadom.

\section{1. §. A gyökérröl.}

1. A növény tövéböl lefelé növő azou részt, melynek rendeltetése $a z, h o g y$ a növény táplálása és gyarapodására szolgáló anyagokat összegyiijtse és felszívja s melynél fogva a növény helyén megállhasson, a nörény gyölierénck (radix) nevezzïk.

A gyökér a növény tövéből vagy egy fö, vagy sok ággal indul ki. Ha egy föággal indul ki s azután ezen föág oldalából nőnek ki, a főágnál kisebb ágak, azon esetben az ilyen növényeket tögyöłieres növényeknek, ha pedig a növény tövéböl egyszerre sok ág indul ki s ezen ágak mind egyenlö átméröjüek, az ilyen növényeket rostos gyökerü növényeknek nevezzük. Mind a két esetben a gyökér lényeges részei : a rostjai vagy a rostocstiái s ennek taplós 
szövetü végei, melyekkel a tápscert összegyüti s felszedi, vagyis a túpssivói.

2. A tögyöliér (rhizoma) alakjára nézve különféle. - Ha a tögyökér csaknem mindenütt egyenlö, azonban egy zsinegnél nem rastagabh, akkor fonculalatiunat: (r. filiformis); ha az ilyen gyökér a zsinegnél vastagabb, akkor hengeralakinnali (r. cylindrica) hivják. Fonalalakn tögyökere ran a Házi Lennek, hengeresalaku tögyökere van a Kerek Kapotnyaknak. - Ha a tögyökér teteje lassanként kezd aláfelé vastagodni, a közepe felé legrastagabbá lesz, onnan aztán ismét lassanként rékonyodik el; akkor orsóclalur (r. fusciformis) a neve. Ilyen orsóalaku tögyökere ran a Terjöke Kigyószisznek és a Tetési Konkolynak. - Ha a tögyökér ¿ növénytövénél legszélesebls s onnan kezdre aláfelé menedékesen hegyesedik el, akkor murolialaliunck nevezil. Ilyen tögyökere van a Sárga Muroknak. - Ha a tögyökér felül elszélesedvén hasason hirtelen elkerekedik s alján vékonyan nyulik ki, akkor répacalalin (r. napiformis) a neve. Ilyen tögrökere van a Reteknek. - Néha a tögyökér, söt a mellék gyökerek vég’ei is kolonczosan megvastagodnak, a midőn az ilyen gyökereket gumós gyöliereknek nevezik, mint a milyen a Kolonczos Baj.nóczáé, a Mogyorós Bükkönyé stb.; de az ilyen g'umókat nem kell a riigy tulajdonságával biró gumókkal felcserélni.

3. A rostos gyötiér rostjai alakjukra nézve vagy fonal- vagy czérnaalakuak.

4. A gyökerek helyzetiikre nézve is liülönböznek egymástól. Legtöbb növény gyökere a földben, némelyeké a vizben, másoké pedig a leregöben van elhelyezkedve $s$ ott találja fel tápszerét is; de vamnak olyan növények is, melyek egy másik növénybe eresztik gyökereiket s ezektöl 
sxívják el életnedvöket, e’z utóbbiakat élödl növémyelune?: (plantae parasiticae) hivják. - Földben álö gyökerï növényeket nem szükség nevezui ; vizben élö a Lencsés Lepese ; levegöben élö a Repkény Borostyán gyökere; élődi a Fejér Fagyöngyé.

5. A gyökerek életideje nem egyforma ideig tartó. Vammak gyökerek, melyek a növény többi részével együtt esak azon évben tartanak el, melyben a magról kikelvén, felnevelték s magba liajtották az egész növényt; az ilyen gyökereket: egy mycurictinck: (radix annua) hivják s irásban rövidség okáért a nap jegyével jelelik: ๑. Ilyen egy nyári gyökere van: a Paszulynak, Napraforgónak stb.

Vannak olyan gyökerek, melyek a magból kikelés évét átélvén kitelelnek s a következö évben szárba és magba hajtják a növényt s e második évben stárarlnak el; az ilyen gyökereket két nyáriaknak (i. biemis) nevezik s e jegygyel jelölik: $\odot$. „Ilyen kétnyári növények : a Murok, a Káposzta, az Oszbuza stl).

Vammak olyan gyökerek, melyek számtala! íven át elélnek, minden tavaszszal leveleket, szálakat hajtanak s magot nevelnek; azonban a levél- és a szárhajtásaik egy-egy nyárnál továbl nem tartanak, hanem elszáradnak s pusztán gyökereik maradnak meg; az ilyen gyökereket az egész növénynyel együtt füféle évelö (r. peremnis) gyökereknek hivják s jegyök, Jupiter bolygó jegye : 4. Ilyenek: a Vereshagyma, a Liliom, a Viola, a pázsitfüvek legnagyobb része.

Tannak végre olyan gyökerek, melyek nem esak magok, hanem az általok nevelt és élö szárok is számtalan éven át elélnek; ezeket, mivel gyökerök helszerkeztete egészen megfásul, faféle év lö néven szokás a füféle évelőktöl megkülünböztetni: jegyök Saturnus bolygó jegye: †. Mlyen gÿ̈kereik vannak a fáknak és a eserjéknek. 


\section{2. §. A tỏröl és a törzsröl.}

1. Mint tenebb is érintém, a növény azon közép részét, melyböl a gyökere lefelé, törzse perig felfelé nö, a növény tövénel (caudex intermedius) nevezik. A növény töve, néhi esupán egy pontot foglal el a göökér és a törzs között, néha több hiivelyknyire megnö mint p. o. a Tavaszi Ibolyáé. Ha a tö egy pontot foglal el, akkor csupán a növény törzse kifejtésére, de ha hosszabbacskára meg’nyulik, azon esetben a növény élete fenmaradására és a növényfaj szaporitására nézve bir jelentőségoel, mivel ez esetben önálló növénynyé levö részeket is nevel.

2. Mindenkor a töből nö a növény felfelé emelkedö része, vagyis a törzse (caudex ascendens), melyböl azután az oldalágak, levelek, virág és termés nevekedmek. A töızs már mag̃a is a tön fejlödött. rïgyböl fejlik ki s azután az ágak, levelek, virág és termés nevelúsére nézve rajta uj meg uj riigyek alakulnak. Ezen rïyyel nem egyebek, mint egy uj törzs kis durványa köriil fejlöđő s egymást pikkelyesen hátaló levéldurványok, melyekből az ágªk és a levelek fejledezmek lki; ha a törzs és ágak hegyén vagy oldalain fejlö riigyek, a törzsdurványa és a levélnemii képzödmények mellett még virág’észeket is tartalmaznak, akkor az ilyen rïg*yeket bimbonati (gemma) szoktuk nevezmi.

3. Valamint a felfelé növö s igy a föld felett esö törzs önálló részei kifejlödhetéseért riigyeket és bimbókat bír teremni; éppen úgy tejt ki a tö föld alatt esö részén is rïgyeket. - Igy például a Szilvafa, Akászfa föld alól jövö hcujtúscii, mind a tövön támadó föld alatti ugynevezett valuriigyelibo"l (lenticellae) fejlenek ki. - A Földieper Ṡzamócza indcii (flagellum) a Tavaszi Ibolya ostorinctúi (stolo) mind a tö földalatti riigyeiböl jönek létre. - A tö ezen említett 
rïgy terményein kivïl némely növény tövén, a törzsön termő mag tulajdonságaival biró s az anyanövénytől elszakadó rïgyek is szoktak teremni. Ilyen földalatti rïgyek és bimbók nevezetesen a hrogymu (bulbus) és a gumó (tuber). (Lásd ezeket a növénytani müszótárban bövebben.)

4. Ha a töböl felfelé emelkedö törzs egy nyáron tart s oldalán olyan rügyek teremnek, melyekböl ágak, levelek és virág fejlenek ki, akkor szárnak (caulis) nevezik. - Ha a szár csöves s ez bïtykök által izekre van tagolva, ha bütykeiböl induló levelei, a szár izeit (közeit) hüvely módra burkolják be, akkor a szárnak saclma (culmus) nevet arlnak, mint a milyenek a pázsitfïivek szárai; ha pedig a szalmához, csaknem mindenben hasonlító szár bütykei belölröl egymásba nyílnak, csöve belső iiregei pedig taplós, likacsos anyaggal vannak kitöltve, akkor gcı' (culmus) neret visel; mint a milyenek a Sás és a Káka szárai. $\mathrm{Az}$ olyan felfelé emelkedö törzsöt azonban, melynek oldalán sem ágak, sem levelek nem nőnek, csupán a hegyén fejlenek ki levélnemü rïgyei és bimbói, tôlioesányncki (scapus) hivják, mint a Tavaszi kankaliné.

Ha a növény tövéből felfelé nött része nem csak egy nyáron, hanem évek során át elél, oldalain s hegyein évröl évre uj meg uj rügyeket terem,azon esetben derélnnek (truncus) nevezik. A derék szót azonban szoros értelemben csak a magános szálu fák törzséröl mondják. Ilyen derekuk van p. o. “ Cseresznye, Dió, Szilva stb. fáknak; ha valamely firféle növény tövéből azonban több törzs nö egymás mellett, az olyan fák törzseit ágaknak v. vesszőknek. magokat a fákat cserjéknck (frutex) hivják; söt ha az ily cserjefélék törzsei nem fásulnak meg oly keményre, mint a fa, akkor cscrjésectölnck, vagy liónólnak (frutescens, v. fruticulus) nevezik. Cserjék pél- 
dául : a \$zöllö, Ribiszke, Fagyal stb. kórós törzsüek: a Zsálya, a Tetemtoldó stl).

5. A növények törzsei alakjokra nézve különfélék: ha például keresztmetszetök köralaku, akkor henyeres (caulis teres); ha keresztmetszetök körkörös, akkor lapított (c. compressus); vannak továbbá fêthengeres, továbbá húromszögü (c. triquetrus) midön keresztmetszetök háromszögöt alkot; négysä̈gï, (c. quadriquetrus) háromélü, négyélü stb. törzsek.

6. A növények törzsei, állásokia nézve is kïlönböznek egymástól. Ha törzs a töböl egyenesen, azaz : függőlegesen emelkedik fel, akkor fóćllló (c. erectus); ha a töböl kiindulásakor oldalra hajolva indul - mintha le akarna feküdni, azonban meg:fordul és nagyrésze függőleg nö fel: felegyenesecto" (c. ascendens); ha a tőről induló szár a földre elterül de hegyei felé felegyenesedik, akkor henyélö (c. decumbens); lia ugy ternll el a földön, hogy a hegyei sem emelkednek fel, akkor lecsepullt (c. prostratus); ha azután az ilyen henyélö vagy lecsepült szárak ittott gyökeret vernek gyökerezo” (c. repens v. reptans) ; ha továbbá, a szároldalaiból vagy a levelek nyelei végeiről hajtott kacesaiknál fogva fák oldalaira vagy grepükre aggatódznak, akkor liapasakodó (c. scandens) ; ha végre más növények vagy tárgyak oldalaira tekergőznek, akkor folfutó (c. volubilis) nevekkel szokták egymástól megkïlönböztetni.

7. A szárak oldalnövéseit ágaknal (ramus), ezek vékonyabb elágazásait galyaknali (ramulus), a ki nem fejlett hegyes végü ágtöveket pedig töviseknek (spinae) hivják.

\section{3. §. A levélröl.}

1. Levélnek hivjuk a növény tövéröl és a szíráról növő azon zöldszinü, rendszerint lapos szerve- 
ket. melyeknél fogra a növény a légkïrböl tápszereket szír fel, és a melyeken át az élete fentartására felesleğes nedreket és légnemeket kigörölgi. Ha i növény levelei laposan terinlnek ki. akkor a nörényt, lomìnos-. ha hengerdedek és hegrestéginek, akkor tülerelinnek, ha pedig apró lapocskákká fejlödre, a tövére vagy szárára borulnak, pitikelyesnel: nevezik.

2. A lerelek ragy egy nyujtránynál. ragy egyenesen alsó részöknél fingra vannak a nörény tövéhez vagy a szárához foglalva. A levelek ezen foglaló nyujtrányát, a Terél nyelénet (petiolus) s igy a levelet nyelesnek, a nyélnélkiili levelet pedig nycletlennck (sessilis) hirják. - Akár van a levélnek nyele, akár nincs, a levél lapja közepén egy rastag, rendszerint kiálló ronal nyulik végig, ezt a részt, mely a nyeles levelekben a levélnyele folytatása, a levél gcrinczének (costa intermedia) hivják. - Némely nörémylevele gerinczéböl mind a két oldalán ágazatok erednek s haladnak a levél éle felé, ezeket pełig egymás között még rékonyabb ágacskák foglalják egymással össze. A levél gerinczéböl induló oldalágakat nevezik 7evél incincu? (nervus), az ezeket egymással összefoglaló ágacskákat pedig lerél ercinel;; ezen inak és erek közeit töltik aztán ki a levél legpuhábl részei, mely puha részeket, ha egy korlıadásnak induló levél inai és erei közül keférel kidörzsöliink, akkor olyan formárá lesz a levél, mint valamely háló, ugyanazért az ilyen inazatu s erezet:" leveleket in- vagy ćphílizatos 7cvelcknel: szokás rerezni. Ilyen inhálózatos lc velei rammak a Rózsafának, Almafának, a Paszulynak stb. Más növémy levele gerinczéből nem nönek ki oldal inak, hanem a levélinai az aljától fel a régéig. a gerinczérel párhuzamosan futnak. az inakat egrmással összekötö erei pedig puszta szemmol nézre ki sem rehetök : az ilyen 
nörényeket jưhuramos inu lerelüclincli hivják.

Ilyen levelei vannak a pázsitfüveknek, Tulipámmak, Hagymának sth. - A levél gerinczét inai és erei közeit kitöltö puha részeket finom felbör vonja be, melyet hammak (epidermis) nevezvek: ezen hámon állati szájhoz hasonló, de csak erösen nagyító ïreg segítségével látható sacajacsoli (stomata) rannak, melyeken át a növények a légböl táplálkoznak és felesleges nedvöket ki.özölgik.

A levél alsó és felső szinét a levél alsó és felső layjának (pagina), alsó részét, ott, hol a nyele beleér, vagy a gerincze kezdödik, a levél két vóllának (basis), a vállaival átellenes azon részét, a hol a gerincze végződik, a levél hieryének (apex), a vállától a hegyéig s imnen ismét a vállához menő keriiletét élénol: (margo) nerezil.

3. A növényfajok egyik fö megkiilönböztető jelét a füvészek a levelek alakjaiban találván, a füvésznek ig’en jól kell ismerni a levelek kïlöntéle alakjait. A levelek alap alakjai következők:

Kerel: vagy köralculu (folium orbiculare) az olyan levél, mely a körhöz hasonló; - körkörrös (f. ellipticum) az olyan levél, melynek a válla és a hegye csaknem egyenlöen van elkerekedve, azonban olyan hosszukás köralaku, mintha két központtal volna két kör egymásba irva; ilyen a Szilvafa és a (Ayöngyvirág levele. - Tojúst.ar (f. ovatum) az olyan levél. melrnek a válla szélesebhen a hegye pedig keskenyebben kerek ragy épen hegves, vagy olyan. mint egy keményre fözött s hosszáhan kétfelé vágott tojásnak a lapja. Ilyen levele van a Körtefának. Tissástojiscdad (f. obovatum) midőn a levél hegye szélesehhen kerek, mint a válla; ilyen levele van az Éklerelü Fütéjnek. - Hossaudad (f. oblongum), midön 2-4szer hosszabb a levél, mint szélesehb; ilyen levele van a Halmi Kacskanyaknak. - Lainesás (f. lanceo- 
latum) az olyan levél, melynek a két vége egyenlöen keskenyedik el, azonban a közepe mintegy kihasasodik p. o. Fagyalfa levele. - Lupicakuis (f. spatulatum), ha a vége el, van kerekítve s a válla ugy keskenyedik el, mint a lán csás levélé; ilyen levele van a fatubóvirágnak. - Szálas (f. lineare) az olyan levél, mely vállától hegyéig csaknem egyenlö széles, szélességénél legalább négyszer hosszabb ; ilyen a Hóvirágé. - Krurdculculu (f. ensiforme) az oly levél, mely olyan forma, mint a szálas levél, de mindkét éle éles; ilyen a Nösziromé.

A levelek ezen alap alakjai változnak a válluk bevágása, hegyök megnnyulása, és egyik alaknak a másikkal való összenövése által.

Ha a levél válla köze ki van vág`va s vállai kerekdedek, hegye pedig hegyes, a levelet akkor szívesnel (f. cordatum) hivják, mint az Orgona Lila levele, de ha a szíves levél hegye le van kerekítve, akkor szíves-tojásdad, mint a Tavaszi Ibolyáé. - Vissácis szives (f. obcordatum) az olyan levél, melynek a hegye van szívesen kikanyarítva, a válla pedig hegyes'; ilyen a Madár Sósdi levélkéje. - Vesculaku (f. renitorme) az olyan levél, melynek a válla köze szívesen van kikanyarítva, vállai és hegye is le vannak kerekítve; ilyen a Kerek Kapotnyak levele. - Nyilcolaku (f. sagittatum) levél az, melynek vállai hegyesen meg vammak nyulva s függöleg állanak ; ilyen levele van a Nyíllevelü Nyílfünek. Dúrdculcuctiı (f. hastatum) az olyan levél, melynek kihegyesedett vállai vízirányosan állanak; ilyen a Keserédes Csucsór levele. - A levél hegye változásánál fogva is más alakuvá lesz a levél, p. o. ha hirtelen hegyesedik el, akkor hegyesnek, lithegyezettnek, (f. acuminatum), ha tompa, butulóncik (f. obtusum), mint az Ükörke Lonczé; ha lecsapott végü, csonkinak (f. truncatum) Tulipánfa Liriodendron; ha a hegye alig van ki- 
kanyaritva, licsipettuek (f. emarginatum), mint a Tavaszi Pimpóé; ha kurta hegyben, vagy tühegyben végzödik, szúllia vagy fulántios hegyünek (f. mucronatum) nerezik.

Az említett levélalakok egymással való egyesülését az elnevezésböl kömnyen meg lehet érteni, itt csak egy pár példát hozok fel. Ha a levél válla és vége láncsaalaku, azonban a közepén nem hasas, hanem szélességéhez mérve minteg:y 4-6-szorta hoszszabban párhuzamos, akkor szúlas-lancsásincti (f. lineare-lanceolatum) hivják; mint a milyen a Törékeny Füz levele.

4. A levél éle is kiváló ismertetö jegyéül szolgál a növénynek. Némely levélnek az éle síma, s ezen esetben épélünel (f. integerrimum), vagy bemctszett, bevagdalt. Ha levél éle bevágásai nem hatnak a szélétöl messzebb, akkor a levelet, bárha nem épélü is, de mivel szabdalatlan, épnek (f. integrum), ha ellenben a bevágások a levél lapja közepe felé benyomultak, akkor saccbialtuch (f. sectum) nevezik. Ha az éplevél éle fennyeden ugy van bevagdalva, hogy bevágásai szük szegletüek, külső hegyei pedig hegyesek, akkor fürészes (f. serratum) élünek, mint a Pózsafáé ; ha bevágásai szük szegleteűk, de kiülö hegyei tompák, akkor csipliésnek (f. crenatum), mint a Tavaszi Ibolyáé; ha pedig a bevágásai tompaszögüek, kiülö hegyei hegyesek, akkor fogasnak (f. dentatum) mondják, mint a Füzfáké. Ha továbbá mind bevágásai, mind kuilső részei tompák, akkor cscucugós elik (f. repandum), mint az Ostorindás Kacskanyaké; ha bevágásai s karélyai mélyek és kerekek, akkor öblös (f. sinuatum), mint a Tölgyfáé; ha pedig karélyai ránezba vannak szedve, akkor fodros (f. crispum), mint a Bodros Uszányé, neveket visehnek.

A szabdalt élü levelek közuil ezek a nevezetesebbek. Ha a levél mély bevágásai szük 'szegletüek, 
kiülö részei pedig tompák, mint ‘ szöllöé, akkn liàélyos (f. lobatum); ha bevágásai szük szegletüek. kiálló r'észei is hegyesek, akkor sallangos (f. laciniatum); ha bevágásai nemcsak nagyok, hanem a levél közepéig is érnek, mint a Mezei Kazupáé, akkor számyason hasadt (f. pinnatifidum); ha a levél éle szányason hasadt karélyai végei le- vagy hátr‘afelé tartanak, mint a Pongyola Pitypangé, akkor licauros (f. runcinatum); ha bevágásai közepénél is mélyebbre hatnak, mint a Sikkantyus Csüküllöé, akkor sacurnyason hasogatott (f. pinnati partitum); ha pedig szárnya metszetei vagy hasábjai még egyszer vagy kétszer bevagdaltak s ismét be vamnak metszve, akkor litszer vagy háromsaror sacimycilt (folium bipinnatum, f. tripinnatum) a neve. - Továbbá. ha a szárnyason hasarlt levélnek végsö karélya nagy, mint a Vetési Mustárnak, akkor f'l-

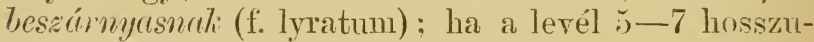
dad hasábra vall bevágra, mint a Rózsás Gerelyé, akkor tenyeresnek (palmatum), ha pedig 5-- 7 levélke van egy nyélre füzve, mint a Bokrétafáé, akkor ujjusncti (f. digitatum) hivják.

5. Bármely alaku vagy bevaggdalt élü legyen ‘ levél, ha egy nyelen csak egy levéllap van, mindig magános levélnel: (folium simplex) nevezik; mihelyt azomban egy nyélre több levél nö, azonnal fïzött leiéllé (f. compositum) válik. Az egy nyélre füzött levél egyes tagjait lexélliének (foliolum) hivják. A füzött levelek köziil leginkább ezek fordulnak elö : a hrímus levél. (f. ternatum), midön egy nyélre három levélke van füzve, mint a Lóheréé; ïtös 7evél. (f. quinatum), mint a Liba Pimpóé; hetes levél. (f. sejotenatum), mint néha a Bokrétafáé, ez utóhbiakat nijusoli-

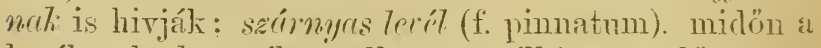
levélnyele hosszában ellenesen álló, egyenlö nağ ságu levélkék ramuak nőve; jrírortlun sari)myus (im- 
pari pinnatum), ha az ily levél nyele regén egy levélke magáuosan áll. mint a Fejér Akászfáé : puiros sán.nycus (f. abrupte pimmatum), lia végső magános levélkéje nines, mint az Abrak Babóé ; csonkictollas szúrmyas (f. interrupte pinnatum), ha a szárnyas levél átellenes levélkéi váltogatva nagyobbak és kisebhek. mint a Burgonya r. Kolompér C'sucsóré ; liétszer-szúmycs (f. bipinnatum), ha a fonyelére átellenesen álló nvelecskéken álló szárnyas levelek nöttek, mint az Ostorindás Haramagé ; huromszor szányys (f. tripinnatum), ha fönyelére átellenesen nött nyelecskéin kétszer számyas levélkéi vamnak, mint az Ánizsé.

6. A levelek a növénynek vagy a tövéböl, vagy! a szárából nönek ki; ha a tövéböl nönek, akkor tö́lecelehncl: (folia radicalia), ha a szárából hajtanak ki, akkor sacirlevelelnel: (folia caulina) nevezil.

A tölevelek állásukira nézve néha juizsitosrti, (f. caespitosa), midön a tövet tömötten benövik, mint p. o. a szegfüfajoké szokott lemni; néha rózsćsoli (f. rosulantia v. rosulata), ha állásuk a teljes rózsa szirmai állásához hasonlítanak, mint a Fülfü tövén.

A szárlevelek állásukia nézve : vailtúgatíli (f. alterna), midőn egyik levél a szár eggyik oldalán alább, a másik levél pedig a szár másik oldalán telebb áll; elleneseli (f. opposita), midőn két levél egyenlö magasan nö ki a szár oldalából, mint a F'agyalfáé, Bodzafáé : csillagnsali r. gyürvilsök (f. stellata v. verticillata), midőn 4 \& több levél nö egyenl"; magasságban a szároldaláról. mint a Galaj fajaié: zilćltuk (f. sparsa), midőn a levelek állásáhan határozott rendet alig lehet felferlezni. mint a Közönséges Gyujtoványé.

Tamak továbbá olyan állásu levelek, melyek vállaikkal ragy körüilnövik, ragr körüilfogják a szárat, az ilyeneket ritnótt ragy cithuri leveleknek (f. perfoliatuin) nerezik, ilyenek a Jerikói Loncz. a Bn- 
vák Színgallér levelei: vammak olyanok, melyeknek vállai nem fogják egrészen, vagy csak félig fogják köruil a szárat, az ilyeneket saruölelóknek (f. amplexicaule), ilyen levele van p. o. a Karórépa Káposztának. Ha a levél nemesak megöleli a szárát, hanem vállai a szároldalán egy darabig le is nönek, akkor saruvrafutónak (f. decurrens) mondják, ilyen levele van a Fekete Narlálytönek; ha pedig a levél ugy fut le vagy a nyélre, vagy a szárra, hogy vállai széles szalag- vagy szegélyként állanak ki, akkor a nyelét vagy a szárat ycíýisncik (alatus v. alatum) nevezik. A levélnyeléuek a szárhoz növéséröl megjegyzendö, hogy némely növényén csak hozzá van a szárhoz csuklózva, mint p. o. a gyümöles és erdei fákon s e miatt rólok időnként leválnak s az ilyeneket lehullóknak hivják, másokhoz ellenben erösen hozzá rannak növe s vagy több éven át a növényeken maradnak, vagy soha le nem hullanak, hanem a növény élete fogytáig rajta maradnak, az ilyeneket cillunctó levelelinek hivják; ha mindig zöldek, örükzölcl lecelelineli nevezik, ilyenek a tülevelü fák levelei. Némeì növényekhez állandóul hozzá vammak növe, de mint maga a növény, vele együtt egy nyár folytán éluek; nevezetesek az ilyenek között a pázsitfélék, mivel ezek levelei nyele a buityköknél kezdődvén, csöres száruk közeit beburkolják s ug*yanazért szúrhiicelyeaüknek (f. vaginantia) nevezik: a hol a szártól elhajolni s lapossá lemui kezdenek, ott rendszerint még egy hártyanemü folytatásuk, myelvecsliéjök (ligula) is nö. - A pázsitféléken kivül is vammak olyan növények, melyeknek levelei nyele a szárat v. tökocsányt behiivelyezi, ilyenek p. o. a sások, Májusi Gyöngyvirág sth.

7. A nönények szárain, söt magokon a levelek nyelein és lapjain is fejlenek ki levélnemü részek, melyeket a levél mellék vagy segédszerveinek szokás 
nevezni. Ilyeeneli : a száron rag̊y tökocsányou rendesen a virág alatt kifejleni szokott grürübe vagy egygyé nött levelek, melyeket gallémati (involucrum), mint a Kökörcsinelée. ragy ha az ilyeu fögalléron felïl még kisebh gallér is van, gallérliáncti (involucellum), ha pedig levelnemü gallér helyett hártya foglalja be a virágot, mint a Hóvirágot, akkor burolincli (spatha), neveznek; - ilyenek továbbá a szár vagy levélnyele ol talára tapadt, de nem belső részéből nött szúrók, melyeket fulúnlinuli (aculens) hivnak; a levélnyele tövén kifejlett különféle alakn levelecskék, melyeknek púllı (stipula) a nerök; a szároldalából mött, vagy igen sokszor a levélnyele rége meghoszszabodásából álló fogódzó szálak, meiyeket 7iaces (cirrhus) néren ismerünk, mint a Sző!llö. és a Babó kapaszkodó szálai; ilyenek régre a szörölineli (pili) mindenféle fajai. (A szörö̈k egyes fạjait lásd a müszótárban.)

\section{4. §. A virágzatról.}

A szár vagy áğ azon részét, melyen a virág van, lioscúmyncili (pedunculus) hivják. Ha a liocsányon csupán egy virág van, akkor maganos riraignati (flos solitarius); ha ellenben egy kocsányra töbl, virág nött, azt viragzutnali (inflorescentia) nevezik. Ha a közös kocsálny elágazik, elágazásait liocsćmbyTicilinat: (pedicellus) hivják. A kocsányon vagy kocsánykákon a virág fö részein kivïl nélıa zöld ragy más színü levélkéket is látunk; az ilyen levélnemü növést murcuncali (bractea) hivják. A rirágzzatols kïlönbözö nemei a következök:

1. Ha a virágok a szár ragy a kocsámy hegyém alig kivehető kocsányokra vag! azok nélkiil tömötten együvé nönek, a virágzatot akkor csoportosnati (i. aggregata) nevezik. A csoportos virágzat három- 
féle ; ilyen : a) A féskkes virrigzut (Hos compositus), midőn egy csészealaku gallérban. - fészekben (calathidium), a szár vagy kocsány kiszélesedett ( - vaczok, receptaculum) kopasz, vagy polyvás v. szörös hegyén több virág ül, mint a milyen Napraforgóé. b) I gombos virágácut (capitulum), midőn a szár vagy kocsány megvastagodott hegyén egy csomó olyan rirág "il, melyek köziil mindeniknek kiilöı csészéje vall. mint a Lóbere fajai virágzata.

2. Ha a virágok egy megnnyúlt kocsányra kocsámykák nélkül vanmak felfüzve, akkor a virágzatot fïzúresfélének hivják; ilyenek : (i) A. toræsa (spadix), midőn a virág lényeges szervei, mint a terme és a joroda (lásd a virág alatt) egy meghusosolott kocsányra tömötten eg:ymás mellé nönek s be rannak hmrokkal takarva. mint a Kontyvirág virág'zatábau. - 7) A lur lia (amentum), midőn a fökocsány hosszában pikkelyes s a pikkelyek tövein vammak a tenyész-zervek; ilyen barkái vamnak a Diófának, Füznek ; a liarka virágzás után rendszerint lehull. - c) A toboz (strobilus) az olyan virágzat. melynek fökocsányján egymásfelibe növö megfásult tömött pikkelyei vannak s tenyészszervei ezen pikkelyek tövén ülnek, ez azomban csak a mag*va meg’érésekor hull le. - (l) A f̈ï:év (spica) az olyan virág"zat, melynek a fökocsányjára kocsánytalanul nőnek a virágok, mint az Utifïé. - e) Füáerlie (spicula) az olyan virágzat, melyben 2 s több virágot, alólıól 1-2 polyva (murva) toglal be, mint a pászitfélék virágzatai. p. o. a Buzáé. 3. Ha virágok kocsányjai a szárhegye tetejéröl eğy ponthól többen induluak s végökön egy-egy virágot tartanak, mint a Kankalin, akkor a virágzatot 1) ermyönch: (umbella), ha pedig az ernyö kocsányjai végei megint ermyösell ágazmak el, és ezen ágak hegyein van a virág, mint a Kapor virágzatán, akkor b) liétsaeres emyön hirják. Ha pedig egy pont- 
ból ugy indulnak a koesányok, mintha ernyövé alakulnának, azonban a kocsányok kiilönbözö hosszuságuvá ágbogosan fejlenek ki végre s a rajtok levö virágokkal mégis egy síkban terülnek ki, mint a Bodzafa, Kánya Bangita virágzatai, akkor bogemyo"nek (cyma) nevezik.

4. Ha a fökocsányból különbözö magasságban, vagy váltogatva vagy féloldalon apró kocsánykák fejlenek ki s ezekuek a végein vamnak a virágok, mint a Káposzta virágzatán, akkor azt (1) fürtneł (racemus) hivják, a kocsány féloldalán nött kocsánykálkon álló virágzatot féloldrili für tnek (r. secundus), mint a Gyöngyvirágé, mikor pedig a fuirt több apró fürtböl áll, mint a Szöllöé. akkor billengnek (r. compositus) nevezik.

b) Mikor a főkocsányból különbözö magassághan kocsánykák fejlenek ki s azután ezen kocsánykák különféleképen elágaznak s a virágok ezen kiilöıféle mag*asságra érő kocsánykák hegyein vamnak, a virágzatot ilyenkor bugćnali (panicula) nevezik. Azonban ezen bugás virágzat többféle : ha p. o. a buga ágai széllyel vagy kinyílva állanak, mint a zabé, akkor pongyola buga (p. patens) a neve ; ha pedig a sokféleképpen elágazó buga kocsánykái messze kiıyúlnak, mint a Derczefüé, akkor lucglyos bugúnak (p. cliffusa), ha pedig a fökocsányból kiinduló kocsánykák meg’öököntek, mint a Berzedt Galajé, akkor sséllyelber:sedt (p. divaricata); ha végre a fökocsány elágazásai ugy tartanak össze, hogy mintegy bunkót alkotnak, mint a Fagyalfáé, akkor fejes buga (thyrsus) nevet viselnek. - c) Ha a kocsányjai kiilönbözö magasságból induluak s heg’yök felé épen ily különböző magasságból indulva ágaznak s a virágai végıe mégis egy síkban terủlnek ki, mint a Salátáé, vagy a Csengö Linkáé, akkor sútoraó virúgzatuali (corymbus) hivják. - c) Ha a virágok szára tetejében igen kurta kocsánykákon tömötten n̈lnek. 
mint a Barát iszegfü virágzatában, akkor csomóncli (fasciculus) nevezik. - e) Ha a szára körïl egyenlö magasságban, körben ülnek a virágok, mint a Mezei Zsályáé vagy a Tatkanafé, akkor gyürlís vivcigautnak (verticillus) hivják.

\section{5. §. A virágról.}

1. A kocsány hegyén a mag kifejlödhetése végett növő s a bimbóban átalakult leveleket vivágnak (flos) hivják.

A tökélyes virág négy fö részből áll. A rirág külső zöld takaróját csészéneł (calyx), az ezen belöl álló színes leveleket bokirétunck (corolla), a bokrétán belöl esö virágjort tartalmazó részeket porodcinut: (stamen), s a porodánal még beljebb álló magtermésre átalakult leveleket termének (pistillum) nevezik. A csésze és bokréta, vagy a két külső takaró, mint a melyek a két belső rész (poroda és terme), védöszereül szolgálnak, a virágnnak nem lényeges. a két belsö rész ellenben lényeges részeit teszik. - Ugyanazért vannak olyan virágok, melyeknek, egyszerülen vagyis alaktanilag véve a dolgot, nincsen csészéjök, hanem a kuilső takarójok is bokrétaszinü, a milyen p. a Liliom, Tulipán stb.; az ilyen virágok küilsö takaróját aztán se nem csészének se nem bokrétának. hanem lepelnct: (perigonium) nevezik; vannak ismét olyanok, melyekmek se esészéjök, se bokrétájok ninesen, mint a Büdös Körisnek, az ilyeneket csupasaokinali (flos nudus) vagy sairontclanolinuli (flos apetalus) hivják.

Azomban arra is van elég eset, hogy a rirágban nemesak a lényegtelen, hanem a lényeges részek és hiányzanak; van p. o. olyan virág; melyben ¿ csésze és poroda vannak meg, mint milyenek átalában a barkák; vagy a csészén és bokrétín belöl csak a porodák vannak meg, mint a Tök némely virágá- 
ban: s ismét van olyall, melyben a esésze és a terme vall meg, mint a Diófa némely virágában, és olyan, melyben a csésze a bokréta mellett csak a terme van meg, mint a Tök némely virágában. Minthogy az ilyen virágokban a virág lényeges részei különváltak, vagy kiilön-kïlön virágban fejlettek ki; tehát külön lakóknak laticaknali (flores diclini) nevezik. - Ha a virág ezen lényeges szervei ugy válnak el, vagy kiilön-külön virágban ugy laknak, hogy mind a porodás, mind a termésvirág ugyanazon egr növényen van, mint a Diófáé, Töké stb., akkor egyTakialinali (monoici vagy monoecia); ha pedig az igy kuilön vált szervek két külön növényen fejlenek ki, mint a Kenderé, Nyárfáé, akkor kétlakiakinak (dioici r. dioecia) hivják; - ha továbbá ugyanazon egy növényen a porodás s egyszersmind termés, vagyis tökélyes virágok között olyan virágok is fejlenek ki, melyeknek egyikében csupán poroda. másikában csupán terme van, az ilyen növényeket ziiiracurt vagy felemás virciguchinali (flores polygami) nevezik, ilyen virág’u növények a Jávor fajai és a Falfü.

Midőn a virágnak mind a négy förésze megvan, akkor széles értelemben, ha pedig legalább a porodája és terméje van meg, akkor szorosabb értelemben tökélyes vivágnal*) (flos completus v. hermaphroditus), ha pedig a négy förész közül valamelyik hiányzik, akkor tölélytelen virágnal: (flos incompletus) nevezik.

2. Minden virág a kocsány vagy a kocsánykit végén szokott kifejleni. A kocsány vagy a kocsányka vége rendszerint kisebb-nagyobb mértékben el

*) A seregek, nemek és fajok meghatározására szolgáló alábbi táblázatokban, a tökélyes virág alatt mindenkor olyan virágot kell érteni, melynek mind a 4 fö alkotó része megvan, a tökélytelen virigon ellenben olyat, melynek valamelyik része hiányzik. 
szokott lapului s ezell ellapult végét, mivel a virág részei rajta teküszuek, vaczoknak (receptaculum) hivják. Megesik néha, hogy a vaczok teteje ikrás karika vagy tányérformán fejlik ki, mint p.o. a Nadálytö; ¿ Vaczok ilyen feldudorodását vinkiosnckl (torus), ha pedig nyelecskeformán emelkedik felemint a Mécsvirághan, akkor a terme locscinylicijúnuli nevezik.

A terme alsó r'észe, melyet maghonuak (g’ermen v. ovarium) nevezünk, mindenkor a vaczokra, vagy mint említök, néha a vánkosira, néha a terme koc`ánykájára van nőve; a maghont környezik aztán, a virág többi részei, ugyancsak a vaczok tetejére ragy anmak az oldalára növe. A maghonnak a virág többi részeihez növéséböl, vagy attól szabadon való állásáloól, a virág állását izokás meghatározni. Nevezetesen, ha a maghou a virág közepéu ugy áll szabarlon, hogy a virág többi részével nimcenen üsszenöve, mint p. o. a Szegfüben és Gyöngyvirágban ; aklior azt mondjuk, hogy a virág alsú (hypogynus), mivel mind a esésze, mind a bokréta, vagy a Gyöngyvirágban a lepel kiindulása, a maghonon alól kezdődik; ha ellenben a csésze vagy a lepel alsó része ugy van a maghonnal összenöve, hogy metszetei és * bokréta ragy a lepel szirmai, a porodákkal egriitt ¿ maghon felső széléről indulnak, mint a Bodza rirágában és a Hóvirágban ; akkor a virágot felsönck (f. epigynus) nevezzïk; mivel ilyen esetben a maghon mindig a virág alatt van. - A virág lészei küilönféle összenövéseihöl vagy egymáshoz állásából szálmazó többféle elnevezéseket, mint a melyek a kezdő füvészt kömnyen zavarba hozhatnák, itt elhagyván átmegyek a virág egyes részei rövid leirására.

1) A csésae (calyx) a virág négy fö részei közüil mindég a külső kört alkotja s akár egy, akál több tagból áll, tagjai a vaczokból mindig egyenlö magassághan indulnak ki, mely fö jelleménél foḡva 
a esészét a kiilönbözö mag’asságłból induló murva levelektöl meg lehet különböztetni, ez rendszerint zöldszinű. A esésze szabályszerüleg eg. körben álló levelekböl alakul, vammak azonban virágok. melyekben a rendes csészén kiviul még egy alsó csésze is alakul : a csészén kivül álló alsó csészét livillsö csészéneli (epicalyx, calyculus) nevezik. Ilyen külsö csészéjök van a mályvaféléknek, a Földieper Szamóczának. A fészkes virágok külsö zöld takaróját a csészével nem kell összezavarni, mivel ez, mint fennebl) említve volt, a gallérnath (involucrum) egy sajátszerü faja, melyet fészelneli (calathidium) nevezïnk. A fészket is környezi néha alsó csészeforma, mint p. o. az Üszögör virágában; de mivel ez nem a csésze, hanem a gallér alatt van, kïlsö csészének nem nevezhetö, hanem mivel murvaforma. murvaliör a neve. - A fészkes virág csészéit a fészken belöl, az egyes virág körïil kell keresni, melyek ott a maghon aljával össze vannak növe s anmak a tetején vagy mint pikkelyek, vagy mint szörök, azaz : bóbitce (pappus) láthatók.

Ha a csésze levelei egész aljokig szabadok, akkor a csészét szabadon állónak s amnyi levelünek mondják, a hány levélböl áll; van p. o. 2, 3, t, 5 levelü esésze; ha a csésze levelei akármily kis részben össze vamnak növe, akkor a esészét egytagunuli hivják. Azonban az egy tagu esésze levelei nem mindenkor egyenlö magasságig levén összenöve, az egy tagn esésze, levelei összenővése szerint különbözö név alatt ismeretes. Ha például az egy tagu esézze levelei nem nöttek a esésze közepéig össze, vagy a mint mondani szokás, félignél lejjebb vamnak behasítva : akkor husúbosucte (c. partitus) hivják. Négy hasábu csészéje van, p. o. a Cser. Szigorállnak; öt hasábu esészéje van a Fekete Nadálytönek stl. Ha a csésze levelei félignél feljebb vannak össze- 
nőve, vagy legfelebb félig vanuạk behasítra, akkor bemetsacttncli (c. fidus) nevezik. Ötmetszetü csészéje van p. o. a Kökény Szilvának, a K. Csucsormak stł. - Ha esak a hegyei nincsenek összenőve, ragy cisak a hegyei rammak bevagdalva, akkor fogas (c. dentatus) a neve. Négy fogu csészéje van a Fagyalnak, öt fogu a Szegfünek stb. Néha a csésze metszetei ragy fogai nem érnek egyenlő magasságra, hanem például 2 foga jóval, alább, 3 jóval felebb áll s a nyilása e miatt a tátott szájhoz hasonlít, mint a Zanóté; ilyenkor a csészét a cijlicusnati (c. labiatus) nevezik.

A csésze tartósságáról jegyezzïk meg̀, hogy vammak virágok, melyeknek a csészéje csak addig tart, míg a virágot bimbójában takarja és mihelyt a virág kinyílik, azonnal lepattan: ilyen a Mák, a Gódircz sth. csészéje, az ilyen esészét lepattanóncti: hivják. Vamnak virágok, melyeknek a csészéje elvirágzás után esik le, mint a Szółokfáé, Szirontáké stb.; az ilyen esészét Tchullóncti nevezik. Tanmak végie csészék, melyek a virág elnyilása utín is megmaraduak s a termését vagy betakarják, vagy azzal eg yüvé is nőnek, mint a Bolonditó C'salmatoké, az Almáé, Körtrélyé stb.; az ilyen cisésze cillandó neret visel.

b) A bolivét (corrolla) a virág négy fö része között mindig a csészén közvetlen belöl eső rendszerint színes levél kör, ez is hasonlóul levélanyaghól alakult át, esakhogy nem zöld, hanein a fekete szín kivételérel, minden más színben játszó finom levelekből, vagy a mint az ilyen színes leveleket hirják, scirmoliból (petalum) áll. A szirmok épen ugy, mint a esésze levelei kisebb nagyobb mértékben vagy összenőttek, vagy külön vammak válva. Ha összenôttek, akkor egy taguaknal: v. forrtszimmalinati (gamopetalae) ragy cyytuguctinct: (monopetalae), mint a Nadálytő bokiétája; ha kiilön rannak válva, akkor váltszirmualinati (dialypetale) ragy szirmosctinati (po- 
lypetalae), a milyen a szegfü, a lózsa bokrétája; ha pedig szilma sincs, hanem azt csak pikkelyek helyettesítik, akkor sziromialanolinuk (apetalae) szokták nevezni. A forrtszirmu bokréták liarimúi vagy ereszei (limbus) épen ugy, mint a esészéröl fenebb mondva volt, lehetnek vagy fogacok, vagy bemetsettek, vagy husciboscki, söt a bokréta karimája némely esetben ép is ; - épen ily kïlönféleképpen lehetnek bevagdalva a vílt szirmu bokrétál szirmai is.

Ha akár az egytag’u bokréta bevagdalásai, akár a több tagu bokréta szirmai egyenlö szabásuak, akkor a bokrétát szabúlyosnali nevezik; ha ellenben bármelyik féle bokréta bevágásai vagy szirmai egyenetlen szabásuak, vagy alsó részököı valami szembctïnö kinövése p. o. sarkantyuja van, akkor a bokréta szabrilytalan nevet visel.

Az egytagu $\nabla$. forrtszirmu bokréták alakjokri nézve egymástól igen nagyon különböznek. Ismerkedjünk megg föbb alakjaikkal. - Az olyan bokiétát, melynek a karimája laposan kiterült, habár hasábos is, de alól ig'en kurta, vagy alig kivelıetö esővé van növe : kevéliclcklunal: (cor. rotata) nevezilk; ilyen bokrétája vall a Szigorállnak, a Bodza virágának. dz olyat, melynek a karimája ugy terül ki, mint a kerékalakue, azonban az alja hossza esöve nött, mint a Kankalin bokrétája, Iygrtyatuctócalatunati (hypocrateriformis) hivják.

Az olyan egytagu bokrétát, mely alól hasas, telül kissé össze felé tart, de karimája ismét kihajlik, mint a C'sengetyüke fajaié, hurangulakumali (cor. campanulata) nevezik. Az olyan eyytagu bokrétát, melynek a karimája alig hajlik ki s omman kezdve lefelé lassanként elszűkủl, mint a Szulák fajaié, tölcséresnek (cor. infundibuliformis) nevezik. - $\mathrm{Az}$ olyan egytagu bokrétát, melynek mind a karimája, mind a dereka és az alja csaknem egyenlö tág; 
mint Napraforgó középvirágai. rsïresnet: (cor. tubalosa) hivják.

Az egytag"u szabálytalan bokréták kï̈ött nevezetesebb alakok a következök : Ha a bokréta alja esövé nőtt, teteje pedig ngy van be és kétfelé rágrva, hogy egy tátott szájhoz hasoulít, akkor cijalicusnali, (corrolla labiata) nevezik. Az ajakas bokréta felsö nagyobb metszete felsó, alsó nagyobb metszete, alsó ajak néven ismeretes; a\% alsó ajaknak rendesen két oldal és egy közép kerélya van. Ilyen ajakas bokrétájuak: a 'l'átkanaf, a Zsálya stb. - Ha a bokréta ugy van bemetszve, mint az ajakas, de tátott szája helyett alsó ajaka (imye = palatum) torkát bezárja, mint a Pintyöé és a Gyujtoványé, akkor culaliosncti: (cor. personata) nevezik. - A l intyő szabálytalanságát, tövén nött pupja. a Gyujtoványét sarkantyuja is neveli. - Ha a bokréta alsó része vékony csöré van alakulva, azonban ezen eső közepétöl kezdve a csönek csak féloldala fejlik ki, akkor félszerneli vagy myelectakumat: (cor. ligulata) szokták nerezni. Ilyen bokrétája van a Napraforgó sugár (szélső) rirágainak.

Az egytagu bokrétáknak néha az elszükülésénél, a torlicibun (fanx) sziromnemü ikrás pikkelyek nőnek, mint a Nadálytö vagy az Atraczél bokrétájában. s az ilyen kinövést boltpiktielyelineli (fornices) nevezik; néha a csöveben, mint a Tátkanaféban, sziokïr (anmulus pilosus v. pilorum) fejlik ki.

A váltszirmu bokréták szirnai alakjaikra nėzve a levél alakjaival vetendők egybe. csupán azt kell rólok megjegyezni, hogy a felsö részök kiterül, mint á Szegfü szirmaié, kihajló lapos részét lemeznel: vagy eresznek (lamina), a csészébe nyuló elkeskenyedett részét myalinali (ungovis) nevezik. - E mellett a ráltszirmu bokréták között is vamnak szabálytalanok, söt sarkantyusak, mint a Taraszi ibolya bokiétáia. mely 
strirmai egyenetlensége és sarkantyujánál fog*va egyaránt szabálytalan.

c) A lepel (perigonium) mind minemüségére, mind rendeltetésére nézve néha a bokrétához, néha a csészéhez hasonló; a virágnak ez is külsö, de egyszeres takarója; a barkákban pikkelyalaku, a pázsitfüvekben murvanemü ( polyva*), a Tulipán és a Gyöngyvirágban sziromnemü. - Ez is épen ugy, mint a bokréta, vagy szabályos, vagy szabálytalan; alakjaira nézve a bokréta alakjaival vethetö egybe.

r.) A pilis v. pót (nectarium) sziromnemü levél vagy pikkely, mely a lepel vagy a bokréta tövén kivül vagy belöl fejlik ki s többnyire a virágok mézedényen̋l vagy ezek fedöi ragy takaróiul szolgál : ilyen pilise van kivülröl a Sarkvirágnak, Czámolynak, belső pilise, pikkelye, van a Szirontáknak; néha a pilis fedetlen gödör vag.y esatorna, mint a Liliom szirmain.

A hokréta, a lepel és a pilis tartósságáról, megjegyezhetjük, hogy azok a virágzás után rendszerint lehullanak vagy elszáradnak.

c) A porodík (Stamina) a bokrétán vagy a leylen belöl álló részei a virágnak, épen úgy, mint a virág küisö takarói a bimbóhan kifejlett apró levelekből alakultak át. A poroda lényeges két fö része a zacskóforma portol: (anthera) és a portokba zárt vircigjor (pollen), a harmadik nem lényeges s annál fogra nem is mindenkor kifejlett része, azon vékony fonalszálforma nyujtrány, melynél fogva a poroda vagy a vaczokhoz vagy a bokrétához vagy a esészélhez van növe: ezen fonalalaku alsó részét sáúlcscincli (filamentum) nerezik. - Mikor a poroda megérik, portokai felrepednek s a bemük levö virágpor kiömlik vagy kiszóródik.

\section{*) Tuísd a nemi táblízatban a. III. sureg 2. rende} alatt a polyvás fürek virágai ré́szei leirását. 
Hia a porodák egyenlö magasak és semmi részök nincs eggyüvé növe, akkor esak megszokták számlálni s azt mondják a virágról : 1, 2, 3, 4. 5, 6, $7,8,9,10,12$ porodások ; ha a porodák egyenlö magasak és semmi részök nem nőtt egymással egybe, 12-15-nél többen vammak, akkor azt nézik rajtok, homman indulnak ki. Ugyanis, ha a bokréta vagy csésze karimájáról indulnak: akkor a virágot 20 porodcismak, mint az almafa virágában; ha pedig a vaczokból a maghon tövéröl nőnek, mint a Kököresinbeu, akkor a virágot sol poroclúsncul hivják. - Ha a porodák négyen vaminak, kettő közïlök egyenlö magas és kettő egyenlö alacsony, mint a Tátkanafỉan : akkor a virágot liét füb poroclásucti nevezik. Ha hat poroda van a virágban s azok köziil négy egyenlö magas, 2 egyenlö alacsony, mint a Retek v. a Káposzta virágában: akkor a virágot négy föbb porodicisncil nevezik. Ha a porodáknak a szálesái valamely részben vagy egészben összenöttek, de a portokok szabadok, akkor a virágot falkásnak, mint az Árorr, Mályva, Ákász, Linka (1, 2 és sokfalkás). Ha pedig portokai nöttek össze, mint a Napraforgó középvirágaiban, akkor fortportokuncti hivják. Ha a porodák a termére nöttek, mint a Kosborfélékben, akkor porodristermújiiekneli; ha végre a porodák küilön, a terme is kïlön virágban lakik, mint a Tök s a Nyárfa virágaiban: akkor laliaknak nevezik. A növények porodái egyenlő és viszonyos magassága, szálesái vagy portokai össze, vagy a termére növése, vagy külön virágban való lakása, szolgál a Linné rendszere alapjául. (Lásd az I. táblán XLV. lap a Limué seregei meghatározását.)

f) A terme (pistillum) a virág legbelső részén a bimbóban átalakuló termő levelekből (carpella) alakul. Ha egy termö levélből alakul, mint a Paszulyé, akkor eyyszer innek (pistillum simplex), ha több termö- 
levélböl forr össze, mint a Konkolyé, akkor összetettnek (pist. compositum) nevezik. Ha egy vagy több termő levél összeforradásából áll elő a terme, akkor a növényt egyterméjïnek (planta monocarpica); ha pedig egy virágban sok termö levél fejlik ki s egymás mellett mindenikböl önálló terme áll elö, akkor a növényt sok terméjünek (pl. polycarpica) nevezik ; ilyen p. o. a Szirontáké.

A termének reudszerint három förésze van: a vaczokra vagy vánkosra nőtt maghon (g’ermen s. ovarium) az erről felfelé emelkedő száracska vagy a bibeszár (stylus), a bibeszáron, vagy ha ez hiányzik a maghon tetején ülö bilıe (stigma). A termének a maghon és a bibe lényeges, a bibeszár mellékes része.

A maghont alkotó termő levelek úgy hajolnak s forrnak össze, hogy belöl üreget alkotnak; befordult élei pedig vagy a belső oldalain kiálló sinórokká lesznek, mint a mák maghonában, vagy pedig a maghon közepén összeforrván, rekeszeket alkotó válaszfalakká alakulnak. Az első esetben a maghon egy, a második esetben több rekeszűvé válik. - A levelek befordult széleiböl alakult sinórokon vagy válaszfalalakon apró hólyagocskák támadnak, melyek egy-egy kis kötölélinél (podospernium v. funiculus) fogva a levelek éleivel összeköttetésben vannak. Ezen apró hólyagocskákból fejlölnek ki a növény magvacstiái (ovula). - Hogy ha a növényt még virágzása idején meg akarjuk határozni, gyakran van rá szükség, hogy a maghont keresztbe át kell metszenünk s nagyító üveggel meg kell vizsgálni: vajjon egy vagy több rekeszüé a maghon s vajjon a rekeszeiben egy vagy több magcsa van-e? -- Néha a maghon egyenesen fedetlen magesákból áll, a mikor csak meg kell számlálni mint a Tátkanafban és a Nadálytöben.

A maghonra rendszerint egy vagy több bibeszár szokott nöni. Ha a bibeszárat a maghonnal együtt 
hosszáhan végig metszjük s jó nagyítóval megrizsgáljuk, azt fogjuk látni, hogy ezen végig több finom csatorna van, melyek a maghonban levö magesákkal összeköttetésben vannak.

A bibeszár kïlönféle alaku, van p. o. fonal claliu, hengeres, buntiós, liripalculu stb.

A bibeszár tetején, vagy ha ez hiányzik, a maghon tetején ül a bibe. Ez ikrás vagy ikrásszörös brbugolbból (papillae) áll, melyek a virágzás idején ragacsos nedvvel vamnak bevonva. A ragacsos nedv a portokokból a bibére hulló port felfogja, melyek ott rajta finom szütyőkké (hólyagokká) fejlenek s ezen hólyagok a bibeszár, vagy ha ez nincs, a maghon csatornáin a magesákba behatolnak s a magesák ezek hatására magvakká fejlenek ki.

A bibe alakjára nézve különféle. Van p. o. szirommemü bibe (stigma petaloideum), mint a Pompás Nösziromé; van fonculculcku (st. filiforme), mint az Ecsetpázsité; van tollas (st. plumosum), mint a Rozsé; van gombos (st. capitatum), mint a Kankaliné; van sugáros (st. radiatum), mint a Máké stb.

\section{6. §. A termésról.}

A növények elvirágzása után a maghon vagy maghonok, néha velek együtt a csésze, kezdenek fejledezni s lassanként terméssé, vagy gyümölcscsé (fructus) fejlenek ki. - A termés lényeges része mindenkor a mag. Azonban a magot legalább a hám v. felbör, legtöbb esetben még e felett vagy husos vagy száraz takaró burkolja be; a mag takaróját magrejtönek (pericarpium) nevezik.

A magrejtöket e szerint szár(ızokra és husosokra osztják fel.

1) Száraz magrejtök.

r) A makkocska és makk (caryopsis, achenium, 
nucula, nux) olyan termés, melyet különféle vastagság'u és keménységii kéreg borít, melyen belől van a mag bele és szíke. - A fiivészek a makkocska termést kïlönféle névvel nevezik, a szerint a mint azok vékonyabb vagy vastagabb, simább vagy érdesebb kéreggel vannak bekérgezve. Ezen kiilönféle elnevezések azonban nem pusztán a mag kérgétől, hanem annak életkifejlődésétöl is erednek. Minthogy azonban a növényeket meghatározni akaró füvésznek föképen a termés alakjával van dolga, azért is, hogy a meg*határozási foglalatosságot egyszerüsítsem, azért is mivel a fiivészek által kérgeiknél fogøa eg־mástól megkiilönböztetett $s$ különféleképen nevezett makkocskák lényegesen nem is különböznek; a kïlönféle kérgi̋ magrakat mind a makkocska név alá foglaltam össze. - Makkocska termései vanmak szirontákféléknek, a czikkszárfajainak, a fészkeseknek, a borágóféléknek. - Feltünö a makkocskák közt az ernyősök makkocskája*), mivel ezek látszólag kétféle magból vannak együvé foglalva (diachenium) s ha megérnek. elválnak egymástól. Ha a makkocska termés nagyocska, akkor makknak, nux hivják. Ilyen makk termése van a 'lölgynek, Mogyorónak, Gesztenyének stb. ; az ezeket félig takaró levélnemü vagy husos boritékot lopáncsnak (cupula) nevezik.

b) A leppendét (samara) egy vagy több magot magába záró tok, melynek vagy köröskörül, vagy két oldalról hártyanemü szárnya van, mint a Szilfa és Jávorfa termésének.

c) A ti"szö (folliculus) egyetlen termő levélböl alakult toknemü termés, melynek befelé forclult szélén állanak a magvai s a belsö oldalán egy felöl nyílik fel; ilyen a Gólyahir és a Sarkvirág termése.

*) Lásd az ernyősök makkocskái leirását a nemek táblázatában, az V. sereg 2-ik rende alá tett jegyzetben. 
d) A hïvely (legumen) hasonlóul egyetlen termölevélböl alakult magrejtö, melynek befordult élén egy vagy két sorban vannak a magvai; a levél gerincze helye, vagy is a folic vastagabb, a levél éle összeforradása, tehát az éle élesebb; válaszfala nincs, mind a fokán mind az élén s igy két részie feselve (azaz: két kopácscsal = valvula) nyílik fel. Ilyen termése van a Paszulynak, Borsónak. A hïvely alakjára nézve egyenes, kard- vagy sarló- vagy csigaalaku, mint a Csigacsö termése.

A hüvelylyel alakulása és fejlödésére nézve mindenben megegyezik a czilikhïvely (lomentum) azonban a kettö között az a különbség, hogy a czikkhüvelyben minden mag kereszt rekeszszel van egymástól elzárva és hogy czikkein keresztbe nyílik, mint a Kornilla termése.

e) A beczö (siliqua) két termő levélből alakult magrejtö, melynek ellenesen álló vastag forradása között belöl egy hártya válaszfal (dissipimentum) van, mely a forradásai belsö oldalára egy kis kötöléknél fogra (podospermium) nött magvakat egymástól elválasztja. Két kopácsesal nyílik fel, kopácsai azonban alólról, a kocsány felöl kezdenek felfesleni. Ilyen termése van a Káposztának, Mustárnak stb.

Ha azonban az ilyen becző termés szélessége akkora, mint a hossza, akkor téskínali (silicula) nevezik; ilyen táska termése van a Csapkának, a Tarsókának, Tormának stb.

Néha a beczötermés keresztbe el van rekgetve s rekgetésein.czikkekben szakadozik el s uyílik fel ; mint a Kerti Retek terméséé s ilyenkor czilikes beczönek (sil. lomentacea) neverik.

f) A tok (capsula) termés több termö levélböl alakult s különféleképen fel vagy fel sem nyíló magrejtö. Ha a tokot alkotó termőlevelek élei csak úgy fordultak be $\mathrm{s}$ forrtak össze, hogy a közepéig nem 
nyulnak be, akkor a tok egy rekesz"l (cap. unilocularis) s ilyenkor a magvak a tok falához vannak nőve. Ilyen egy rekeszü s három kopácscsal nyiló tokja van a Tavaszi Ibolyának. Ha a termölevelek olyan egy rekeszü tokot alkotnak, hogy a közepökön egy oszlop áll szabadon, melyhez vannak a magvak nőve; akkor a tok tetején 4,5 v. 10 kopácscsal vagy foggal szokott megnyílni ; mint a Szegfü, Konkoly és a Kankalin termései. - Ha a tokot alkotó termö levelek élei olyan erősen befordulnak, hogy a tok átméröjét egészen keresztülérik, akkor a tok több rekeszűvé válik. Két rekeszü s két kopácscsal nyíló tokja van a Śzigorállnak. - Három rekeszü s három kopácsesal nyiló tokja van a Hóvirágnnak, a Tulipánnak. - Öt rekeszü tokja van a Gerelynek stb.

Ha a termőlevelek eg’ymásra fordulva nönek össze s a belölök alakult magrejtő egy v. két rekeszü marad; akkor a tok termés keresztbe szokott felnyílni. - Ilyen nyilásu s két rekeszü tokja van a B. C'salmatoknak s ilyen nyílásu, de egy rekeszü tokja vall a P. Tikszemnek.

2) Husos magrejtök.

a) A bogyó (bacca) termés, husos. leves azaz olyan magrejtö, melynek mag'vát a husa között finom háitya vagy meg nem fásult bör $r$. pergamen környezi; ez is szokoti lenui 1, 2,3 s több rekeszü. - Egy rekeszü bogyója van a K. Bangitának, a Szőllőnek, három rekeszü bogyója van a Gyöngyvirágnak stb.

A bogyóhoz mindenben hasonló a Kabak (Pepo) és rılma (pomum). Ezen terméseket némely füvészek meg szokták különböztetni; azonban ezek, habár a szoros értelemben vett bogyóknál nagyobbak is, léпyegesen nem különböznek. - Az almatermés a csésze meghusosodásából fejlik ki, jellemzi föleg husa közepén levő pergamenszerü 5 rekesze. - A kabaktermés vastag husán belöl üreges, melyet finom ros- 
tok rekgetnek el s ezeken fejlenek ki magvai. - Kahak termése van a 'Töknek, Ugorkának; almatermése van a Körtvélynek.

b) A csontár (Drupa) hasonlóul husos termés, melyben a magtakaró belső hártyája kemény héjjá (putamen) alakul. Síma kemény héju csontára van a Cseresznyének, ránczos, barázdolt vagy likacsos héju csontára van a Szilvának, a Diónak, a Mandolának.

Megemlítendök még az összetett husos gyümölcsök közül az egy vaczkon megtelepült apró csontáru Szederj s Eper gyümölesei; valamint a figetermés (syconium), melynek husa belső oldalain fejlenek ki apró csontárai stb.

\section{7. §. A magról.}

A maghonban fejledezö magcsák a virágopor hatására elkezdenek nőni s idő folytán maggá (semen) fejlenek ki. A magot kivülröl rendszerint egyszeres vagy kétszeres hám (integumentum vagy epidermis) takarja. E hám egyik pontját egy kis kötölék (podospermium) foglalja össze a maghonnal vagy magrejtövel; ezen kötöléknél fogva táplálkozik a mag a növény gyökere tápszívói és levelei által felszívott tápszerböl s csak ezen csatorna által fejlödhetnek ki a mag hámján belöl eső részei. - Mindən rendesen kifejlett magnak leglényegesebb része a csirája (embryo). A csirának három fö részét lehet megkïlönböztetni, t. i. a kötölékkel egybeköttetésben volt alsó kupos végét vagy a gyölöcsliéjét (radicula) a közép részét vagyis a töras churványát (cauliculus) és a gyököcskével átellenes vége bimbóját vagy a kiclöjét (plumula).

A rendes kifejlett mag csiráját vagy beburkolja vagy két oldalról fogja körül a mag bele. Ez némely esetben szíjjas vagy porczogós, némely esethen tisz- 
tán lisztes állomány, sok esetben pedig mind a kétféle egymás mellett. - A mag szíjjas vagy porczogós belét, vegyi alkotó részei miatt fejérnyének (albumen), lisztes állományát pedig keményitönek (amylum) nevezik. A mag belének ezen két alkotó része közé egyéb állományokon kivül gyakran olaj (oleum) is regyïl. A mag bele rendeltetése az, hogy az uj életre kelö mag csirája, mielött gyökerei és levelei kifejlenek. belöle vegye a táplálékát.

A növények meghatározására szolgáló vezérfonalnak feladata föleg a növény részei külső alakjait ismertetni, élettani fejtegretésekbe tehát itt nem bocsátkozhatni, elég legyen jelenleg a mag־ak különféle kelését és kiilső alakjait érinteni.

A megérett mag esirája a mag belében mindaddig nyugton, hogy úgy mondjam, alva marad, míg azt kedvező helyzet és körïlmény uj életre nem ébreszti. Ha a mag ily kedvezö köriilmények közé jut s esirája fejledezni kezd, azt mondjuk : a mag kikél. A kikeléskor mindenik mag csirájának a gyököeskéje nőni kezd lefelé, kelöje pedig emelkedik felfelé. - Ha a kelö bimbójából egyetlen levélke (cotyledon) emelkedik s buvik ki, akkor az ilyen magról az egész növényt egy lielölevelünel vagy egyszitüneli (pl. monocotyledonea) nevezik; ha pedig a kelö bimbójából két levélke emelkedik s búvik ki, akkor az ilyen magról az egész növényt liétszikünek (pl. dicotyledonea) hivják. - Az egyszikü mag`vak belei, ha földbe vannak kelés alatt, mindig a földben maradnak s ott szolgáltatják a tápot a fejlödő növénynek; a kétszikủ magvak belei ellenben két ágra hajolva a föld felületére bujnak s midőn egyrészről alkató részeiket az uj növény eledeleül nyujtják, egyszersmind a levegöböl is vesznek fel táplálékot.

Egyszikü vagy egy levéllel kelö növények a pázsit-, a liliom-, a koshor- stb. félék; két levéllel 
kelö v. kétszikü növények a Paszuly, Lencse, a gyümölesfák stb. magvai.

A magrvak csiráinak nemcsak a kelői fejlenek olyan jellemzően, hanem gyököcskéi is. Ugyanis az egysziküek gyököcskéi fejlöclésök első perczében azonnal több rostot eresztenek, holott a kétsziküek csirái gyököcskéje rendszerint tögyökérré alakul, melynek az oldalából indulnak aztán ki oldal gyökérszálai.

A növénymag csiráinak ilyen különböző módon történő kifejlése szolgált alajul a növények természetes rendbe állítására vagy rendszerezésére. A növény magva ezen különféle módon történö keléseu alauul a Jussieu s ennek számbavétele mellett a növény törzse kifejlésén vagy amnak nem létezésén áll az Endlicher természetes rendszere.

A füvész sokszor olvas hivatkozást a mag fejérnyéjére, mint p. o. az ernyős félék meghatározásánál, legtöbbször azonban a mag alakjára vagy hámja simasága, horpadozottságára, tüskésségére stb., e mellett a mag alakjára; épen ez oknál fog*a el kellene itt számlálnom a magvak mindezen jegyeit. Miután azonban ezen jegyek a növények egyéb részein oly sokszor vannak megmagyarázva, sőt miután ezen jegyek a mindennapi életben annyira ismeretesek: feleslegessé válik itt azok ismétlése. Ha azonban valamely kïlönösebb, a mindennapi életben közönségesen nem ismert jegy fordul a magon elö, arról a könyv hátulján levő müszótárból a kezdő füvész szerezhet magának felvilágosítást. 
II.

\section{A növények meghatározására és e könyv használatára szolgáló rövid utasítás.}

1. A ki ezen könyv szerint valạmely növényt meg akar határozni, minthogy annak minden föbb részét meg kell vizsgálni, olyan növényt kell vizsgálat alá vennie, melynek minden része gyökerétől kezdve, nemcsak megran, hanem tökéletesen ki is van fejlödve. E mellett a szemlélet alá vett növénynek virágzó, ha lehetö, oly állapotban kell lenni, hogy termése is ki legyen fejlödve. Minthogy pedig ez a kettö, t. i. virág és termés, nem minden növényen látható egyidőben; a füvésznek az olyan növényt. melyet virágzása iclején tökéletesen meg nem határozhat, kifejlett termésével ujra elö kell keríteni s az azon közben megszáraztott virágzó példánynỵal összehasonlítva, két izben kell meghatározni.

A kezdőnek egyébiránt leg.jobb, kezdetben ismeretes növényt vemni a kezébe s azon próbálgatni mind a növény szervei megismergetését s egymástól való megkülönböztetését, mind a könyv használatát. A mint egy ismeretes növény részeit a könyv segítségével megismerte s magának jól megjegyezte, csak akkor olvashatja el haszonnal a könyv elején levö bevezetést, melyből a gyakorlat közben szerezhet kellö elméleti ismeretet.

2. A könyvben levő két, illetöleg három táblázat használatára következő gyakorlati utasítás szolgáljon utmutatásul.

Keressen a kezdö füvész kora tavaszszal a Tavaszi Ibolyának egy virágzó példányát s nyissa ki a könyvet a XLV. lapon; itt találja az A) betü alatt a Linné seregei meghatározására szolgáló táblázatot. 
Olvassa az I. szám alatti két kérdést. Az egyik kérdésben azt kérdezi a könyv a virágról, hogy virúgc tökélyes, a másik kérdésben, hogy virúga töliélytelen. Az Ibolya virágán láthatja, hogy megvan a csészéje, bokrétája, porodája és terméje ; és így az Ibolya virága tökélyes. A tökélyes szó után oda van téve a 2. szám, nézzen tehát az alább következő 3-dik sor elejére, ott találja a 2. számot. Itt azt kérdezi a könyv : Porodaii terméjét v. terméit kürnyezit s minthogy az Ibolyában így találja, a másik kérdést el sem kell olvasnia, hanem a 3-as szám utasításánál fogra, a sorok elején álló 3. számot kell felkeresni. - Itt ezt olvassa: Porodái egymús közt szabadol, azuz : egymússal semmi részben nem nötteli össze s mivel az Ibolyában így találja, az itt következő 4 -es szám utasítja a sorok elején álló 4-es számra. A 4-es szám alatt ezt olvassa: Porodái mind egyenlo" hosszuli stb. s mivel az Ibolyálban ezt is úgy találja, a kérdés végén álló $\breve{~}$ szám vezérleténél fogva megy a sorok elején álló 5̆-re. Itt ezt olvassa: Porodcii számszevint 1-12-en vamnali. - Itt már nem talál a kérdés végén vezérlő számot, hanem a. b. c. stb. kikezdés alatt egymás alá irott tizenegy kérdést lát; hogy tehát eligazodhassék, melyik kérdés illik a kezében levő növényre, olvassa meg porodáit s látván, hogy az Ibolyának 5 porodája van, nézze meg ez e alatti kérdést, itt ezt olvassa: (̈tporodások. Pentundriu. (V. Sereg.) Most amnyira jutott, miszerint tudja, hogy az Ibolya a Linné T-dik seregébe tartozik, vagyis meghatározta azt, hogy az Ibolya melyik seregbe tartozik.

Az V. sereg szó után levő LXII. sz. azt mutatja, hogy keresse az ötporodások seregét a LXII. lapon; a LXII. lapra fordít tehát s ott megtalálja az V. sereget. Itt a sereg neve alatt olvasván : I. Rend. Eg: terméjűek. Monogynia; megvizsgálja az Ibolya terméjét s látván, hogy abban egy terme van, keresi azt 
ezek között. Ha 2, 3, 4 vagy 5 termét találna az Ibolyában, akkor ugyanezen seregben a 2-ik, 3-ik, 4-ik vagy az 5-ik rendben fogná keresni, a többi rendet természetesen elmellözné. Az Ibolyának tehát egy terméje levén, következőleg keresi :

Olvassa az 1. szám alatti kérdést, ez így van: Virágai töléllyesek, ezt már felebb megvizsgálta, tehát világos, hogy az Ibolyát a sor végére irott 2. számnál fogva a sorok elejére irott 2-ik szám alatt kell keresni. Itt ezen kérdéseket olvassa:

Bokiétája vailt szirmu 3.

Bokvétíja egytagu 10. - A két kérdés közïl könnyü a választás, mert az Ibolya bokrétája csak ugyan vált szirmu s nem egy tagu; tehát a 3 . szám utasitásánál fogva megy a sorok elején álló 3-as számra. Itt ezeket olvassa :

3. Bolivétája felsö 4.

Bokrétéja alsó. 5. - A választás itt épen olyan könnyü, mert látható, hogy az Ibolya virága, t. i. esészéje és bokrétája a maghonánál alább áll s így virága alsó; megy tehát az 5-dik számra. Itt ezeket olvassa:

5. Bolirétája szabálytalan. 6.

Bokrétája szabúlyos. 7. - Ugy de azt is láthatja, hogy a bokréta szirmai nem egyenlö szabásuak, söt egy közülök épen sarkantyus is; és így az Ibolya bokrétája szabálytalan. Keresse tehát a 6 -ik szám alatt. Itt ezt olvassa: Ötlevelü csészéje tövei pillenpútyosak; bokrétája ら szirmu, az alsó szirma sarkantyus. Ibolya. Viola. Vagy is addig vizsgálódott a kezében levő virág részein, hogy észrevétlenül ráment az Ibolya nemi nevére. Ha igy nézegeti meg a vizsgálódó a kezébe vett ismeretlen növény minden részeit s az elébe tett két (ritkán 3) kérdés közül a növényre illö kérdést jól megválasztja; minden növény nemi nevére a felmutatott módon biztosan rá fog menni. Ha azon- 
ban véletlenségböl megtévedne, akkor nincs más mód, mint az, hogy a dolgot ujra elöl kell kezdeni s mindaddig ujra vizsgálni, mig a kezében levő növényt meg nem találja.

Most már tudván az Ibolya nemi nevét, ażt kell meghatározni, micsoda faju Ibolya van a kezében. Ezt így folytatja: A Viola szó után találja a 221. számot; forditson tehát a könyv II. táblázatában eső 221 . lapra, ott a 76. Rend. Ibolyg féléli stb. 1. száma alatt megleli: Ibolya. Viola. L. - Itt ismét mint a seregek és a nemek táblázatában a számok segítségével halad elöre. Olvassa tehát 1. szám alatt: Száratlanok: stb. stb. 2.

Sźúba inclulók. 4. - Úgy de a kezében levö Ibolya száratlan; a sor elején álló 2 szám alatt, ha rá olvassa: Töre ostorindákicet hrijt. stb. stb.. alatta ott találja: Tavaszi I. azaz Ibolya. V. odorata, - s ekkor meghatározta a kezében levő növényt tökéletesen.

Így bánjék aztán az elötte ismeretlen minden növénynyel. - Ha a növényen található jegyek megvizsgálása után így rá tud menni a növény nemi és faji nevére, akkor a növényt meghatározta. 


\section{I.}

A seregek es a nemek meghatározására szolgáló táblázat.

Linné rendszere szerint rendezve.

A.

A Linné seregei meghatálozása. Virágos növények. Phánerogamia.

Lapon

1. Virága tökélyes, azaz : van benne poroda és terme $\boldsymbol{2}$. Virága tökélytelen, azaz : porodái más, terméi is más virágban vannak. 11.

2. Porodái terméjét, vagy terméit környezik. 3. Porodái terméjére nőttek: Porodásterméjüek.

Gynandria (XX. Sereg) lásd a CXVIII

3. Porodái egymás közt szabadok, azaz egymással semmi részben nem nöttek össze. 4.

Porodái valamely részben egymással összenöttek. $\mathbf{8}$. 4. Porodái mind egyenlö hosszuk, néha a 10 porodás virágban 5 egyenlö magas; 5 egyenlö alacsony. 5. Porodái egyenetlen hosszuságuak, azonban bizonyos szám közülök egymással egyenlö. 7 .

๖. Porodái számszerint 1-12-en vannak s ilyenek:

a) Egyporodások. Monandria. I. Sereg. . . . X XLVII

b) Kétporodások. Diandria. II. Sereg . . . . . X XLVIII

c) Háromporodások. Triandria. III. Sereg . . XLIX

d) Négyporodások. Tetrandria. IV. Sereg ... I IJVIII

e) Ötporodások. Pentandria. V. Sereg ..... LX LXII

f) Hatporodások. Hexandira. VI. Sereg . . . L LXXVIII

g) Hétporodások. Heptandria. VII. Sereg ... LXXXI 
h) Nyolezporodások. Octandria. VIII. Sereg .

i) Kilenczporodások. Enneandria. IX. Sereg .

LXX XIII

k) Tizporodások. Decandria. X. Sereg .

LXXXIII

1) Tizenkétporodlások. Dodecandria. XI. Sereg LXXXTII Porodái száma 12-ön felül van, vagy porodái sokan vannak. 6.

6. Porodái (szirmaival együtt) a csésze torkolatáról nöttek: Huszporodások. Icosandria. XII. S. IXXXVIII Porodái a vaczokból, vagy a maghon alól induhnak:

Sokporollások. I'olyandria. XIII. Sereg. . . . XCI

7. Porodái számszerint 4-en vannak, azonban ẹzek közül 2 egyenlö magas, 2 egyenlő alacsony: Két föbb porodások. Didynamia. XIV. Sereg.

Porodái számszerint 6-an vannak, azonban ezek közül 4 egyenlö magas, 2 egyenlö alacsony : Négy föbb porodások. Tetradynamia. XV. Sereg.

\$. Szálcsái kisebb-nagyobb részben összeforrtak. portokaik szabadok. 9.

Portokai forrtak össze és szálesái szabadok: Forrtportokuak. Syngenesia. XIX. Sereg.

9. Szálcsái oszlopalakuan függöleg állva forrtak egybe ; csészéjök mindenkor alsó és állandó: Egyfalkások. Monarlelphica. XVI. Sereg

Szálcsái rnás módon forrtak egybe. 10.

10. Porodái száma 6 , vagy 8 , vagy 10 ; a tiz porodások szálcsái közül rendszerint 9 szálcsa nött együvé s eg'y szabadon áll, vannak azonban olyanok is, melyeknek mind a 10 szálcsája egybenött; bokrétájok pillangós: Kétfalkások. Diadelphia. XVII. Ser. . CVI Porodái sokan vannak, de szálcsái tövön 3-5 csomóba nőttek: Sokfalkások. Polyadelphia. XVIII. Sereg.

11. Tirágai ugyanazon egy növényen fejlenek ki, azonban porodái külön, terméi is külön virágban vannak: Egylakiak. MIonoecia. XXI. Sereg. 
Virágai két külön növényen fejlenek ki, még pedig ugy, hogy egyik növényen csak a porodás, a másikon csak a termésvirágai vannak: Kétlakiak. Dioecia. XXII. Sereg. . . . . . . . . . CXXVII

\section{B.}

A nemek meghatározása.

I. Sereg. EGYPORODÁSOK. Monandria.

1. Rend. Egyterméjủek. Monogynia.

1. Levelei gyürüsek, bokrétája nincs; maghonát parkányozó csészéje 1-2 fogból áll.

Uszszakál. Hippuris. 257

2. Levele nincs; szára czikkes (II. Sereg. 1. R.)

Somócsing. Salicomia. 74

\section{Rend. Kétterméjủek. Digynia.}

1. Vízi növény; levelei ellenesek; virágai hónaljiak, tövén ellenes 2 murva van. (XXI. Sereg. 1. R.)

Mocsárhúr. Callitriche. 61

Szárazi növény; levelei váltogatók. 2.

2. Levelei háromszögüek vagy dárdások; leple 3-5 metszetü ; virága csomós; husos termése veres. (V. Sereg. 2. R).

Mángolt. Blitum. 71

Levelei szálasok; hónalji virá gai magánosak. 3.

3. Leple 5 szirmu, murvája 2 ; termése tojásdad. (III. Sereg. 1. R.)

Torzon. Polychnemum. 76

Leple 1-3 szirmu; murvája nincs; szárnyas termése egyik oldalán domboru. (V. Sereg. 2. R.)

Poloskamag. Corispermum. 74 


\section{Rend. Háromterméjúek. 'Trigynia.}

Lapon

Vízi növény; szára és levelei fonalalakuak; virága hónalji; 3-4 termésén paizsaalaku bibéi rajta vannak. (XXI. Sereg. 1. R.) Galáz. Zanichellia. 56

\section{Sereg. KÉTPORODÁSOK. Diandria.}

\section{Rend. Egyterméjủek. Monogynia.}

1. Virága tökélytelen ${ }^{*}$ ) vagy van leple, vagy nines 2. Virága tökélyes. 4.

2. Szárnyas levelü nagy fa; termése 2 rekeszü leppendék.

Körisfa. Fraximus. 129

Füféle növény. 3.

3. Leple húsos, egy tagu, repedéssel nyíló ; szára czikkes; levele nincs. Szíki növény.

Somóesing. Salicornia. 74

Leple hártya, egy tagu, az éle néha csipkés; néha porodája s terméje együtt van, néha kétlaki; szára levélnemü. Vizen uszó növény. Lepcse. Lemna. 58

4. Bokrétája 2 szirmu, felső. Szirompár. Circea. 257 Bokrétája egy tagu, alsó. 5.

5. Faféle növény; bokrétája szabályos. 6. Füféle növény; bokrétája szabálytalan. 8. 6. Csészéje 4 fogu; bokrétája 4 metszetü. 7. Csészéje 5 fogu; bokrétája 5-8 metszetü.

Jázmin. Jasminum. 128

7. Termése 2 rekeszü, öszszel megfeketedő bogyó.

Fagyal. Ligustrum. 128

Termése 2 rekeszü, 2 kopácsu tok.

Lila. Syringa. 128

*) A nemek táblájában a tölétyes virág alatt mindig oly virág értetik, melynek mind a négy fö alkotó része megvan, a tökélytelen virág alatt pedig az, melynek a négy förész közül valamelyik hiányzik. 
8. Bokrétája sarkantyus ; ćisító. Vízi növény. (XIV. Ser. 2. Rend.)

Rencze. Utricularia. 167

Bokrétája sarkantyutlan. 9.

9. Termése 2 rekeszü tok. 10.

Termése 4 makkocska. 11.

10. Bokrétája ajakas, 2 porodája mellett van még 2 ki nem fejlett porodája is. (XIV. Ser. 2 Rend.)

Gorka. Csikratiola. 159

Bokrétája csaknem kerékalaku, 4 karélyu, felsỏ karélyai nagyobbak; tokja csorba.

Szigoráll. Veronica. 159

11. Csészéje 5 fogu; bokrétája tölcséres, 4 metszetü. (XIV.Ser. 1. Rend.)

Peszércz. Lycopus. 133

Csészéje 2 ajaku; bokrétája ajakas, felső ajaka sarlóalakuan elöre hajló, alsó ajaka 3 karélyu; szálcsái felső részei alsó részére esuklósan nőttek. (XIV. Ser. 1. Rend.)

Zsálya. Salvia. 134

Porodái számánál fogva ide tartoznék még nehány növény, azonban ezeket is a magok természetes helyén fogjuk megemlíteni; ilyenek: a Scirpus nehány faja és a Cladium III. Ser. 1. R.; a LythIum Hyssopifolia XI. Ser. 1.R.; a Lepidium vuderale XV.Ser. 1. R.; a Verbena XIV. Sereg. 2. R.

\section{Rend. Kétterméjúek. Digynia.}

Ide a pázsitfélék közül az Anthoxanthum, Hierochloa és Bromus. III. Ser. 2 R. és a Salix XXII. Sereg 2 R. tartozának, de ezeket a magok helyén adjuk elö.

\section{Sereg. HÁROMPORODÁSOK. Triandria. \\ I. Rend. Egyterméjủek. Monogynia.}

1. Tökélyes viráguak. 2. Tökélytelen viráguak. 5.

2. Levelęi 4-8-ával gyürüsek. 3. Leveleî ellenesek. 4. 
3. Bokrétája harangalaku (lásd IT. Ser. 1. Rend).

Müge. Asperula. 126

Bokrétája kerékalaku (lásd [V. Ser. 1. Rend).

Galaj. Galium. 122

4. Csészéje karimája érett termésén bóbítává fejlik; bokrétája tövén pupos.

Gyökönke. Valeriana. 86 Csészéje kicsiny, fogas, néha alig észrevehetö.

5. Virága polyvás. \%.

Galambbegr. Valerianella. 84

Virága másnemü, azaz leple van. 6.

6. Leple sziromnemü. $\mathbf{7}$.

Leple csészenemü, öt levelü, melynek tövén két murva van; néha 1,2 vagy 5 porodás.

Torzon. P'olycnemum. 76

7. Leple szabátytalan, b hasábu, esaknem két ajaku.

Dákoska. Gladiolus. 48

Leple szabályos, hat hasábu. 8 .

8. Leple három külsö szirma kifelé hajlik. a három belsö befelé hajló.

Nöszirom. Iris.

Leple egyenszabásu, harangalaku; bibéje felfelé kiszélesedö.

Sáfrán. Crocus.

9. Füzérkéi kétsoruak. 19.

Füzérkéi főkocsányját mindenfelöl fedelékesen fedik 11.

10. Virágzata csomós v. füzéres ; polyvája egy kopácsu, minden polyvájában vannak tenyészszervek, csak néha a két alsó kisebb üres.

Palka. ('yperus. $: 36$

Virágzata egyszerü füzér, kétsora alig kivehetö; (:-9) polyvája egy-egy kopácsu, melyek közüil csak 2-4-1,en vammak tenyészszervek, az alsó 3-6 kisebl, és üres

Csáté. Schoemes. 36

11. Az alsó polyvái nagyobbak, mint a többi, raggy azokkal egyenlök, az alsók közül 1-2 üres 12. A 3-4 alsó polyrái kisebbek, mint a felsők és üresek. 13. 
12. Érett makkocskáit selymes hosszu szörök burkolják be, melyek bóbitaalakulag hosszan kinyulnak.

Gyapu. Eriophorum. 3.5

Érett makocskáit a rájok, nőtt bibeszár töve kihegyezi.

Káka. Scirpms. 33

13. Makkocskáját törékeny kéreg borítja; bibeszára fonalaku, lehulló.

Sátorsás. Clartium. 32

\section{Rend. Kétterméjúek. Dig̛ynia.}

Polyvás virágu pázsitfüvek. *)

1. Füzérkéi kocsánytalanok, vagy a fökocsány mélyedéseibe, vagy a fỏkocsányból induló fogacskákra nöttek; bibeszáruk igen kurta, vagy nincs is: tollas bibéik a virág aljából két oldalı’a kihajolnak. 2 .

*) A polyvás virágu pázsitfïvek meghatározásához a kezdö füvész mindig tartózkodva fog, holott ezek meghatározása nem oly nehéz, mint egyelöre látszik. Ugyan is, ha a virágzatot és a virág részeit rendluen vizsgálja és bonezolgatja fel, természetesen egy kézi nagyító segítségével, azonnal kitalálja a dolog nyitját. A rendben való vizsgálás így történik :

1. Megnézi a virágzatot. A virágzat mindig egy főkocsányon áll, mely nem egyéb, mint a szár vége. A főkocsányon vagy füzéresen, vagy hugcisan van a virágzat s ez szembetünö.

2. Akár füzéres. akár bugás, akár a kettő összetételéből származó a virágzata, egy esoportba rendszerint 1-2 s töbl, virágocska van összeállva; a virágocskák ezen csoportosulását hivják: füzérliének. A második megnézni való tehát a füzérke.

8. A harmadik nézni valók magok a virágocslicili: volnának, azonban, mielött ezek szoros vizsgálatához fogna a vizsgálódó, nézze meg', nines-e a füzérke vagy a virágocska tövén valamely levélnemñ 1-2 kinövés, ha van, ez a murve vagy a pilikely.

4. Vizsgálja meg a virigocslicit. A virágocskáit kivülrö rendszerint 1-2 darabból álló s 1-2 nyilással (kopáesesal biró) zöld takaró fedi; a virágocska ezen külső takaróját 
Füzérkéi kurtálbb vagy hosszabb, néha igen rövid kocsányuak; vagy a, füzér bütykeire nöttek; vagy czikkes és szörös bugájának egyike kocsánykátlan, másika kocsánykás. $\mathbf{8}$.

2. Füzérkéi, czikkes főkocsánya mélyedéseibe egyenkint nöttek; virágát polyvái 1-2 kopácsesal takarják.

Törfü. Lepturus.

Fủzérkéi főkocsányja mélyedéseiből induló fogacskáral nöttek. 3.

3. Oldalt álló füzérkéi polyvái egy kopácsuak, a végsők két kopácsuak, kopácsában 3- sok virága van; külső ondója kalásztalan vagy a hegyén egy kis kalásza van; füzérkéi magánosak, váltogatók, a fökocsány felé éllel állanak.

Polyvái két kopácsuak. 4.

Vadócz. Lolium. 4

4. Füzérkéi fökocsányja fogacskái közepén hármával állanak. Бّ.

Füzérkéi magánosak, a tökocsány felé oldalt fordultak. 6.

э. Füzérkéi egy viráguak, a nyeletlen középsöben terme és poroda, a nyeles két szélsöben csak poroda van, ezekben azonban néha ez is hiányzik.

írpa. Hordeum.

polyvanal hivják. Ez alatt rendesen van ismét 1-2 zöldes fejér takaró, ez az ondó, ez néha rá is nő a magra, mint a kölesre, az árpára stb. Néha a polyva és az ondó közt is van ondó forma murva, mint a Porodapár - Anthoxanthumban.

Az ondón belól van aztán a 2 vagy 3 poroda, ezeken belöl a terme. Néha némely polyvában esak porodák, másokban esak termék vannak foglalva; néha megesik, hogy a polyva záp, azaz üres.

5. A polyváról vagy az ondóról néha egy szálka nö, ez a lialcisz.

A füivésznek tehát a pázsitfü virágzata és virága mindezen részét elöre s ily rendben kell vizsgálni; azután biztosan rá fog találni e kezében levö pázsitfüre. 
Füzérkéi 2 - sok riráguak, mindegyik rirágban van terme és poroda is.

Czimbor. Elymus.

6. Polyvái 3-4 viráguak. polyvája kopácsai domboruak, ormótlanok, a hegyei 2-4 foguak, kalászosak ragy kalásztalanok, külsö ondói hegyein 1-4 kalász van.

Kalászbojt. Acgitops.

Polyvái kopácsai ormósak, külső ondója kalászos vagy kalásztalan. 7.

7. Kopácsai tojásdadok, vagy tojásdad láncsások, füzérkéiben több virág van.

Buza. Triticum.

Kopácsai áralakuak; füzérkéiben két virág s e mellett egy harmadik rirággá ki nem fejlett pótlék, vagy durvány van.

Rozs. Secale. 3

S. Füzézkéi füzére bütykein kettenként állanak, egyike kocsánykátlan, másika kocsánykás; a kocsánykátlanban terme és poroda a kocsánykásban csupán poroda van. Füzére ujjas. Fenyer. Andropogon. Füzérkéi rövid, vagy hosszu kocsányuak. \%.

9. Fűzérkéi egy viráguak, vagy olyanok. hogy ezen egy virága mellett van egy felső, ragy két alsó virágot helyettesítö pótlék. 10.

Füzérkéi 2 - sok viráguak, alsó virágaiban néha nincsenek tenyészszervek, ragy csak porodák vannak bennök. felsö virágai gyakran elsatnyultak. 25.

10. Füzérkéi hátuk felöl lapítottak. 11.

Füzérkéi oldalról lapítottak. 15.

11. Polyvája a kopácsu. 12.

Polyrája 2 kopácsu. 13.

12. Murrája nincs.

Köles. Panicum.

Murvája virága kocsányjai töréhez nött kalászalaku sertékböl áll ; bugája füzéralaku. Mulıar. Setaria.

13. Polyvája alsó kopácsa igen kicsiny, hártyás, a felsö börnemü, tövises, ondói hártyások.

Polyrabor\%. Trames. 
Polyvái kopácsai egyenlők. 14.

14. Porezogóssá víló ondói kalásztalanok.

Kásafiï. Milium.

Porczogóssá váló ondói kalászosak, kalászai lehullók.

Kásakalász. Piptatherum.

15. Polyvája nines \& magvát bezáró ondói csaknem egyenlök, kalísztalanok.

Dureza. Teersia.

Polyvája kétkopácsu. 16.

16. Virága tövén két kalásztalan pikkely- vagy ondóalakn murva van. 17.

Polyvája 1-2 virágu, vagy egy virágu, de ennek tövén egy másik virágot helyettesítö murva van. 18.

17. Porodája 3 ; bugája füzéralaku vagy karélyos; ondói kalásztalanok, fénylők, kisebbek, mint a tövökön levö kopácsok. Polyracsukk. Pluctaris. 18

Porodája 2; virága tövén a 2 kalásztalan murván belöl, két kalászos ondója van, melyek a legbelső és al valóságos ondójánál valamivel nagyobbak.

Porodapár. Anthoxanthum.

18. Füzérkéje tetejéből kinyuló bibéje fonalaku. 19.

Füzérkéje hegye alól, vagy a tövéröl induló bibéje legyezöalaku, vagy tollas. 21 .

19. Két kopácsu polyvájában egy ondója van ; füzérkéi egy viráguak, második virágot pótló murva nélkül.

Ecsetpázsit. $4 l o$ jecumes.

Két kopá esu polyvájában két ondója van. 20.

20. Kopácsai esaknem egyenlök, ormósak, lapítottak, hegyök le van csapva (néha, hegyes), hosszabloak, mint ondói.

Komócsin. Phleum. 18

Kopácsai kurtábbak, mint ondói ; ondói egyenetlenek, láncsások, a felsö hosszabb. Bajuszfü. Crypsis.

21. Megnyult bibeszárán ülö bibéje a virág hegye alól indul ki s legyezöalaku. $\mathbf{2}$.

Kurta bibeszáron ïlö tollas bibéje füzérkéje tövén ér ki. 29. 
2.2. Polyvájja kopácsai boltosak, 2 viráguak, hegyes ondói polyváival egyenlő magasak; magva szabad, virágzata fürtösen bugás, féloldali.

Hernyóka. Heckmannia. 18

Polyvája kopácsai keskenyek, kinyíltak; szálas felsỏ ondója kivölgyelt, az alsó oldalról lapított, tojáiclad; virágzata füzéres, füzére ujjas.

Csillagpázsit. Cynoçon.

23. Alsó ondója hengeresen lapitott, porczogós, melynek tetején állandó, erős, tövön czikkes kalásza van.

Hajka. Stipa. 18

Alsó ondója nines hengeresen lapítva, kalásza tövön nem czikkes. 24 .

24. Ondója hártyás, kopasz, vagy a töve igen kurta szőrrel van körülvéve.

Tipluan. Agrostis. 17

Onclója tövét, keresztmetszeténél hosszabb szörök környezik. Nádtippan. Calamagrostis.

๑5. Fonalaku bibéje virága hegyéböl hosszan kinyulik; tüzérkéje 2-6 virágu ; alsó ondója épélü, fulánkos vagy kalászos, vagy a hegye 3-.5 fogu, fogai fulánkosak, vagy kalászosak.

Bibikia. Sesleric.

Bibéje vagy a virág hegye alatt, vagy tövén nyulik ki, ivalaku, vagy tollas. $\mathbf{2 6 .}$

26. Ívalaku bibéje a virág hegye alatt nyulik ki. 27.

Tollas bibéje a virág tövén nyulik ki. 28 .

27. Füzérkéi sok viráguak, alsó virágaiban csak poiroda a többiben poroda és terme van; virágait kocsánykájáról növö hosszı szörök veszik körül.

Boginád. Phragmites.

Füzérkéi három viráguak; két alsó virágában három három poroda terme nélkül, felső virágában két poroda és terme van. Harmadmag. Hierochloa.

28. Füzérkéiben tökélyes tenyészszervi̋ virágai mellett, vannak olyanok is, melyek csak porodások. 29. 
Füzérkéiben minden virágban megvan a poroda is, terme is. $\mathbf{3 1 .}$

29. Virágai kalásztalanok, az alsó vagy a két alsó tökélyes tenyészszervekkel bir, a második vagy a harmadikban csak poroda van, melybu aztán még egy vagy több elsatnyult virág van befoglalva.

Lélıapót. Melica.

Füzérkeje két virága közül az egyik legalább kalászos. 30.

30. Meggyökönt hosszu kalászu alsó virága porodás, tökélyes tenyészszervn, felső virága kalásztalan, vagy csak kurta kalászu. Ürezab. Arrhenatherum. 13 Kalásztalan alsó virágában meg van a terme is, a poroda is, kalászos felső virágában csak poroda van.

Mézfiï. Holcus. 13

31. Bibeszála vagy bibéje, szörös hegyü maghona közepén felüli elöoldalából nö ki; füzérkéi sokviráguak; virágai láncsások. vagy tojásdad lánesások, kalászosak vagy kalásztalanok. Rozsnok. Promus. Bibeszára maghonából másként nö ki. 32.

32. Kalásza alsó ondója háta közepéböl, vagy a tövéből nö ki. 33.

Kalásza alsó ondójának vagy a hegyéből, vagy a hegye alól nö ki. vagy ninesen is kalásza. 3 J̋.

33. Ondója tövéről növő kalásza felső része bunkós, közepén gyürüs, ondója hegye épélü.

Bunkópót. Corynephorus.

Kalásza hegyes. 34.

34. Alsó ondója hegye csonka, négyfogu. tövéről vaggy a hátáról növő kalásza tövön megcsavarított, meggyökönt vagy csaknem egyenes. Nápicz. Aiva. 16 Alsó ondója hegye két metszetï vagy két kalászu, hátáról növő kalásza tövön meg van csavarodva. 
35. Felsö ondójia szélén fésü alaku serte szemszörök vannak.

Nyelecz. Brachypodium.

Felsö ondója szélén finom szemszörök nöttek, szörös vagy kopasz, de nem fésüalakulag sertés. 36.

36. Alsó ondója tojásdad, tompa, felpuffadt hasu, tövén fülesen szívalaku; kalásztalan; polyrája 3 - sok virágu; füzérkéi kétsoruak, kocsányosak.

Rezge. Briza.

Poylvája nem hasas; füzérkéi kocsányosak; bibeszára igen kurta vagy nincsen. 37.

37. Virága háta felöl lapított ormós. 38.

Tirága félhengeres vagy hengeres, nem lapított s ormótlan. 41.

38. Alsó ondója ép, kicsípett vagy két metszetü hegyén kalász vagy fulánk nött. $\mathbf{3 9 .}$

Kalásztalan ondói tojásdadok vagy láncsások. 40.

39. Felső ondói tojásdadok, hegyei befelé görbültek, az alsók egyenetlen oldaluak: füzérkéi $3-8$ több viráguak.

Eloíx. Dactylis. 8

Ondói láncsások, egyenesek, füzérkéi 2-sok riráguak, nagy polyvái virágát betakarják; bugája füzéralaku.

Polyvabur. Koeleria.

40. Virágai fökocsámyja bütykeivel hullanak le; bibeszára igen kurta vagy nincs.

Perje. Poa. 8

Alsó ondója lehulló, felső ondója a fökocsányon s vele együtt állandó; bibeszára megnyult.

Bajuszpázsit. Éragrostis.

41. Virága háta félhengeres, egyébkint hosszukás, vagy kupalaku, befelé csaknem hasas. 42.

Virága háta hengeres, egyébként láncsás vagy áralaku, befelé nem hasas ; felsö ondója szélén finom szemször nött. 43.

42. Virágai hosszukások, tompák, kalásztalanok. 
Virágai befelé hasasodó tövüktöl kezdve kupalakuak. kalásztalanok, vagy kalászosak, ez esetben kalászai egyenesek.

Kéhene\%. Mollinia.

43. Egyes füzérkéje tövét, váltogatva két soru szárnyas kopácsokból alakult murva fedi.

Czinczor. Cynosurus. 8

Ilyen murvája nines; felső ondója szélén finom szemszürök nöttek.

Csenkesz. Festuca. .5

\section{Rend. Háromterméjủek. Trigynia.}

1. Crészéje :-4 metszetü vagy hasábu; bokr. 3-4 szirmu; tokja 3-4 rekeszü. (VIII. Ser. 4. R.)

Látonya. Elatine. 241

Csészéje 5 hasábu vagy 5 levelü; bokr. 5 szirmu. 2. 2. Szirmai 2 hasábuak. (X. Ser. 3. R.)

Csillaghúr. Stellaria. 229

Szirmai épek, kicsípettek, vagy fogasok. 3.

3. Virágzata 5-7 virágu ernyö; szirmai fogasok, porodája 3-5; tokja 6 fogu. Oloesáll. Holosteum. 228 Virágai magánosak; szirmai épek, vagy alig kiesípettek. 4.

4. Tokja :3 kopácsu. (X. Ser. 3. R.) Ludhúr. Alsine. 227 Tokja 6 kopássú. (X. Ser. 3. R.)

Homokhir. Arenaria. 228

\section{Sereg. NÉGYPORODÁSOK. Tetrandria.}

1. Rend. Egyterméjủiek. Monogynia.

1. Virágai tökélyesek. $\mathbf{2}$.

Virágai tökélytelenek. 18.

2. Virágai egy közös vaczokra csoportosan nöttek. esoportja alatt galléros; csészéje kettös; bokrétája egy tagu. 3.

Virágai csoportosak, esoportja gallértalan, esészéje egyszeres. 7. 
3. Szára ormói és kocsínyjai fulánkosak; galléra levelei csillagalakulag kiterültek; polyváinál hoszszilbluak; vaczka kupalaku, polyvás, polyvái fulánkosan vagy sertésen szemszörösek; csészéje karimája fogas vagy csipkés ; bokrétája 4 metszetï.

Yácsonya. Dipsacus. 86

Szcíra és kocsínyjai fulánktallanok; vaczka lappos vagy domboru. 4 .

4. Vaczka érdes, szörös, polyvátlan; galléra levelei csillagalakuan kiterülnek; külső csészéje 4 vagy több kurta fogu; belsỏ esészéje medenczealaku, ;-cok serte fogu; bokrétája 4 metszetü.

Kazupa. Knautia. 87

\section{Vilezka polyvís. j.}

5. Galléra félgömbalaku, tömötten feclelékes. polyváinál kurtább. fejéres; külsö esészéje 4 - sok fogu, a belsö tál vagy medenezealaku vagy sok fogu vagy épélü ; bokrétája 4 metszetü.

Fejvirág. Cephaluria. 87

Galléra esillagalakulag kiterült, 1 - több soru, polyvájánál hosszabb ; belső esészéje tálalaku 1-5 kalász fogu, vagy épélü. $\mathbf{6}$.

6. Bokrétája 4 metszetü ; fünemü külsö esészéje 4 fogou.

Sutabub. Succisa. 87

Bokrétája う̌ metszetü; külső csészéje harang vagy kerékalaku, csészéje karimája áttetszö hártyaszegélyü.

Sikkantyu. Scabiose. 87

7. Bokrétája egy tagu. 8. Bokrétája 4 szirmu. 15.

8. Bokrétája alsó. 9. Bokrétája felső. 12.

9. Virágesoportja gombos vagy füzéres. 10. Virágai magánosak. 11.

10. Virágesoportja gombo: csészéje 5 metszetü; színes bokrétája karimája caknem ajakas, felsö 
ajaka kisebl, 2 metszetü, az alsó 3 metszetü; szütyő termése egymagu. Gubóvirág. Globularia. 145

Virágcsoportja füzéres vagy gombos ; csészéje 4 metszetü; hártyanemü bokrétája 4 metszetü, metszetei letüremlettek, toktermése sok magví, derekán nyiló.

Utifï. Plantago. 82

11. Csészéje 5 fogu; bokrétája csöves-harangalaku, 5 metszetü; kocsányja és levelei a tövéröl nőnek. (XIV. Ser. 2. R.) Iszaprojt. Limosolia. 1 )9

Csészéje 4-9 metszetü vagy hasábu, vagy féloldali vagy buroknemü; bokr. ékalakuan harangalaku. 4-7 metszetü; bibéje 2 ; virága szárhegyi. (V. Ser. 2. R.)

Tarnies. Gentiana. 130

12. Bokrétája kerékalaku, lapos, 2-5 metzzetī ; csészéje fogai alig kivehetők. 13.

Bokrétája tölcséres vagy tölcséresen harangalaku, karimája 4 metszetü. 14.

13. Bokrétája 4-5 metszetï; bogyónemü termése husus, kettös.

Buzér. Fulbia. 125

Bokrétája kerékalaku 4. ritkán 3 metszetī; száraz termése kettös.

Galaj. Galium. 122

14. Tölcséres bokrétája 3, 4-5 metszetü, 4-6 fogu. csészéje állandó, megérett, magva tetején is ott áll.

Magabár. Scherardia. 126

Harangalaku vagy tölcséres bokrétája 3-4 hasálıu ; esészéje fogai alig kivehetök. nem állandó.

Miige. Asperula. 126

15. Termése csontár. 16.

Termése tok vagy makkocska. 17.

16. Csontára porczogós, hosszálıan nyiló; bokrétája 4-7 szirmu; porodái 4-5 szirma elött állnak. ( $\mathrm{T}$. Ser. 1. R.) Benge. Rhammus. 245 Csontár termése husos, 2 rekeszü. Somfa. Cormus. 185 
17. Toktermése színes, 3-5 rekeszü ; 4-.5 porodája bibircsós vánkosához nött. (V. Ser. 1. R.)

Kecskerágó. Evonymus. 241

Makktermése 4 szarvu, egyrekeszü, egymagu.

Sulyom. Trapa. 258

18. Faféle növény, levelei ezüstszinü felomlásosak; leple harangalaku, 1-5 metszetü, tövön esöves; porodája 4-5; maghona leple csövébe van rejtve, szabad; bibeszára fonalaku.

Eziistfa. Eleagnus. 82 Füféle növény. 19.

19. Levelei szírnyaltak; virágzata gombos; esészéje $t$ hasábu, felső; 4 ormóju maghonát 2-3 murva környezi.

Vérfö. Sanguisorba. 268

Levelei épek, áralikkuak vagy tojásclad-láncsások. 20. 20. Leple 4 fogu, átellenes 2 foga nagyobb; porodái leple tövéhez nöttek. Szíkör. Camphorosma

Leple harang vagy tölcséralaku. 21.

21. Leple harangalaku, virágai felemások, t. i. van porodás és termés és pusztán termés virága; bibéje ecsetalaku.

Falfï. Parietaria. 65

Leple tölcséralaku, 4-5 metszetü; porodája 4-5, szörcsomó foglalja be; csontára egymagvu.

Bögretok. Thesium.

\section{Rend. Négyterméjúek. 'Tetrag’ynia.}

1. Leple 4 hasábu; esontára 4, kocsánytalan. Vízi növény.

Uszány. Potamogeton. 56

Csészés és bokrétás viríguak. 2.

2. Más növényeken élödö; bokr. 4-.5 metszetü; tokja 2-4 magva. (V. Ser. 2. R.)

Fïmyüg. Cuscuta. 152

Nem élödi növény. 3.

3. Csészéje 4-.j levelü; bokr. 4-5 szimmu; tokja 4-.5 kopácsu ; magva vesealaku. (X. Ser. 6. R.) 
Csészéje 4-3 metszetü vagy hasábu, vagy féloldalis buroknemü; bokr. egytagu, 4-5 metszetü; tokja 2-4 magru. (T. Ser. 2. R.) Tarnies. Gentiana. 130

\section{Sereg. ÖTPORODÁSOK. Pentandria.}

\section{Rend. Egyterméjủek. Monogynia.}

1. Virágai tökélyesek. 2.

Virágai tökélytelenek. 48.

2. Bokrétája vált szirmu. 3.

Bokrétája egytagu. 10.

ஓ. Bokrétája felső. 4.

Bokrétája alsó. 5.

4. Bokrétája 5 szirmu, szirmai nyakasok; termése sokmagvu bogyó.

Ribiszlie. Rilso. 187

Bokrétája 5-20 szirmu, szirmai tövön szélesek; porodája 5-10 ; termése $5-10$ rekeszü bogyó.

5. Bokrétáj̣a szabálytalan. 6.

Borostyán. Hedera. 184

Bokrétája szabályos. 7 .

6. Öt levelü csészéje tövei pillenpátyosak; bokrétája 5 szirmu, az alsó szirma sarkantyus. Ibolya. Tiola. 221 Ötlevelü esészéje szabálytalan, hátsó levele a többinél sokkal nagyobb, sziromnemü és sarkantyus. két elsö levele igen apró, néha meg sincs; bokrétája 5 szirmu, oldalt álló szirmai páronként együvé nőttek, portokai együvé ragadtak.

Fájvirág. Imjatiens. 255

7. Termése 2 rekeszü bogyó; bokrétája 5 szirmu, hegyökön összeragad s a maghonról aljukkal válnak el.

Termése nem bogyó 8 .

Szöllo. Tritis. 244

8. Termése 3-5 rekeszü színes tok; 4-っ̌ szirmu bokrétája csészéjéhez, szirmaival váltogató 4-5 porodáija pedig bibiresós vánkosához nöttek.

Kecskerágó. Exom gmus. 244 
Termése csontár. 9.

9. Csontára porczogós, hosszáluan felnyíló; 4-7 szirmu bokrétája csészéjéhez nőtt; porodái szirmai előtt állanak, néha igen kicsinyek vagy nincsenek is.

Benge. Rhamms. 245

Fel new nyíló esontárát köralaku hártyaszárny segélyezi.

Tiiskepár. T'atiume. 245

10. Bokrétájja alsó 11.

Bokrétíja felső. 44.

11. Termése 2 v. 4 makkocska, mindenik makkocska 1 magvu, vagy 2 makocska s ilyenkor mindenik makkocska 2 magvu. 12.

Termése tok. $\mathbf{2 7}$.

Termése bogyó. 41.

12. Maghona 4 forradásu alig látszik, hogy négy, mely megérésekor lapos alju 4 makkocskára válik el; nyílt torkn és tölcséres bokrétája karimája ránczos.

Kunkor. Heliotropium. 145

Maghona 4 vagy 2, melyekböl azonban nem mindenkor fejlik ki mind a 4 makkocskája. 13.

13. Makkocskái hátukkal állandó bibeszárához nönek. 14.

Makkocskái az alattok levő vánkushoz nőnek. $\mathbf{1 7}$.

14. Termése csészéje virágzás után megno” s makkocskáival egyuitt lapítottá fejlik.

Magiszák. Asperugi). 150

Termése esészéje harangalaku vagy kiterült. 15.

15. Makkocskái puha tüskések, bojtorjánosak. 16.

Makkocskái símák, laposak, a hegyöknél összevont s behajlott élü hártyaszegélyüek.

Köldönez. Omphatodes. 151

16. Makkocskái puha tüskéjüek, laposak.

Árnï. (ynoglossum. 151

Makkocskái háromszögüek, élökön bojtorjánosak. 
17. Makkocskái tövén egy felputtiadt és sinóros gyürü van, a gyürün belöl esö alja homoru. 18.

Makkocskái alja nem homoru. 22.

18. Bokrétája hengeres, harangalaku; áralaku boltpikkelyei kuposan hajlanak össze.

Nadálytö. Symphytum. 146

Bokrétája tölcséres vagy gyertyatartóalaku. 19.

19. Bokrétája görbenyaku; torkát 5 tompa bolt pikkely szükiti el.

Nyakó. Lycopsis. 147

Bokrétája egyenes nyaku. $\mathbf{0 0}$.

20. Bokrétája torka nyílt, szakálas vagy kurta szörös.

Apácz. Nonnea. 146

Bokrétája torka be van záródva. 21.

21. Boltpikeiyei tompák, babugosak.

Atraczél. Anchusa. 147

Boltpikkelyei kurták s portokai alánőttek; gyökere a kezet pirosra festi.

Alk̄anna. Alkamna. 149

22. Makkocskája 2, mindenik makkocskákan két mag van; hengeres-harangalaku bokrétája torka nyílt; portokai nyílalakuak, tövön összekapesolódtak.

Szeplén. Cerinthe. 145

Makkoeskája 4. 23.

23. Bokrétája torkát 5 kopasz boltpikkely zárja be; makkocskái prémetlenek.

Nefelejts. Myosotis. 149

Bokrétája torkában ninesenek pikkelyek. ㅃ.

24. Bokrétája torka szörös. 25.

Bokrétája torka kopasz. 26.

25. Csészéje 5 metszetü vagy fogu, 5 ormóju, termése megérésekor felfuvódott.

Gálna. Pulmonaria. 148

Csészéje 5 hasábu, termése megérésekor sem változik; bokrétája torka szörös 5 ránezú.

Kömag. Iithospermum. 148

26. Bokrétája harangalaku, lassanként kiszélesedö ferde karimájn; tojásdad portokai szabadok.

Kígyószisz. Echizum. 146 
Bokrétája hengeres-harangalaku; nyílalaku portokai tövön összekapcsolódtak.

Vértö. Onosma. 148

27. Tokja 1 rekeszü. $\mathbf{2 9 .}$

Tokja 2-5 rekeszü. 35.

28. Tokjok közepén szabadon álló magoszlopuk van. $\mathbf{2 9 .}$

Tokjok oldalához nött 2 magtartójuk van. 34.

29. Bokrétája metszetei csöve oldalára hátra türemlettek, bokrétája csöve harangalaku.

Tiirtszirom. Cyclamen. 168

Bokrétája tölcséres, vagy gyertyatartó, vagy kerék alaku. 30.

30. Csészéje 5 metszetü. 31.

Csészéje 5 hasábu. 32.

31. Bokrétája csöve hengeres vagy ékalaku.

Kankalin. Primula. 168

Bokrétåja tojásdad, hegye felé elszükül.

Iiiköes. Androsace. 167

32. Tokja derekán nyiló; bokrétája kerékalaku, 5 hasábu.

Tikszem. Anagallis. 169

Tokja 5 kopácscsal nyiló. 33.

33. Bokrétája gyertyatartó alaku, csöve hengeres, karimája ¡ hasábu (fésïalaliulag szármyalt levelï vizinövény).

Tónya. Hottonia. 169

Bokrétája kerékalaku, 5 hasábu.

Lizinka. Lysimachia. 168

34. Bokrétája töleséres, karimája 5 hasábu, hasábjai belölről szakálosak; bibéje ép.

Vidrafï. Menyanthes. 130

Bokrétája kerékalaku, 5 hasábu, torka szakálas; bibéje 2 hasábu.

Eleczke. Limnanthemum. 130

35. Csészéje állandó. 36.

Csészéje lehulló, azonban az alja gyürüsalakban maghonán marad; termése tüskés.

Redőszirom.Datura. 154 
36. Tokja hasas, teteje felé nyakas s itt köröskörül kupakosan nyílik fel; bokrétája tölcséres.

Tokja kopácsesal nyiló. 37.

Csalmatok. Hyosciamus. 154 37. Bibéje kettö 38.

Bibéje egy $\mathbf{3 9}$.

38. Bokrétája tölcséres vagy gyertyatartóalaku; portokai elvirágzás után srófosan megcsavarodnak.

Földepe. Erythrciea. 131

Bokrétája tölcséresen harangalaku, 5 ránczú.

Sznlák. Comvolvulus. 151

39. Bokrétája tölcséres. 5 ránczú; tokja 4 foggal nyílik.

Dohány. Nicotiana. 154

Bokrétája kerék- vagy gyertyatartó alaku. 40.

40. Bokrétája kerékalaku; porodái egyenetlenek, pỏtokai szálcsáin keresztbe vagy ferdén állanak.

Farkkóró. Verbascum. 154

Bokrétája gyertyatartó alaku, metszetei ferdén csonkák; 2 maghonának 1 közös bibeszára van.

Meténg. Vinca. 129

41. Bogyóját felfuvódott veresszinü csészéje zárja be; bokrétája kerékalaku.

Páponya. Physalis. 153

Bogyója szabad. 42.

42. Portokai hegyeiken 2 lyukkal nyílnak fel; bokrétája kerékalaku; bogyója kiterült esészéjén ül.

Portokai oldalról nyílnak. 43.

Csuesór. Solamım. 153

43. Bokrétája tölcséres, torkát szálcsái szőrei bezárják; termése csészéje kicsiny s bogyója legalját fedi.

Fánzár. Lyciuım. 152

Bokrétája harangalaku, két rekeszü bogyója tövét megnőtt csészéje környezi.

Nadragulya. Atropa. 153

44. Termése tok. 45.

Termése 2-3 rekeszü bogyó; bokrétája szabálytalan; cserje.

Lonez. Lonicera. 127 
45. Tokja tetején vagy kopácscsal nyílik, ragy kilyukad. 46.

Tokja oldalain lyukadozik ki. 47.

46. Tokja 5 kopácsesal nyíló, egy rekeszü; porodája 10, melyek közül 5 terméketlen felebb áll; csészéje csöve maghona fele részével egybenött.

Számolya. Samolus. 169

Tokja tetején lyukad ki, két rekeszü; portokai tövön csillagformára összenöttek $\mathrm{s}$ bibeszárát körülfogják; szílcsái áralakuak.

Csékesillag. Jasione. 120

47. Bokrétája 5 hasábu, hasábjai felül összenőttek, alól szabadok; szálcsái tövön széles 3 szögüek, portokai szabadon állanak; tokja 2-3 rekeszü.

Raponcz. Phyteuma. 120

Bokrétája harangalaku, 5 karélyu vagy 5 metszetü, tövön elszélesedett szálesái maghonát fedik; tokja 3-5 oldal lyukkal nyílik ki.

Csenget yüke. Campanula. 120

48. Leple felső, állandó 4-6 metszetü, tölcséres, lepléhez nőtt 4-5 porodáit egy ször csomó fogja be ; csontára egy magvu.

Bögretok. Thesium. 80

Leple alsó, öt hasábu. 49.

49. Porodája 10, melyek közül az 5 váltogatva állónak nincs portoka. 50.

Porodája 5-8; levelei váltogatók; pálhái hártyatölcséresek (VII. Ser. 1.R.) Czikkszár. Polygonum.

50. Szárhegyi gombos virágát száraz hártya s ezüst színü nagy murvák veszik körül; leple hasábjai láncsások, hegyesek; bibeszára 2 metszetü.

Aszgallér. Paronychia. 225

Oldalt álló esomós virágait, apró murvák környezik; leple csészenemü, hasábjai tojásdadok, tompák; bibéje 2.

Porczika. Herniaria. 225 


\section{Rend. Kétterméjüek. Digynia.}

1. Virága tökélytelen. 2.

Lapon Virága tökélyes. 13.

2. Faféle növény. 3. Füféle növény. 4.

3. Leple harangalaku 4-5 vagy 8 metszetü; virágai oldali csomót alkotnak, a fa kilevelezése elött nyitnak; termése lapos leppendék. Szilfa. Ulmus. Leple 5-6 hasábu, virágai fiatal hajtásai levelei hónaljaiban magánosak; termése csontár.

Czeltis. Celtis. 64

4. Leple nincs; csészéje 4-5 fogu; megkeményedett csészéje fenekén ülö termése 1 magvu. (X. Ser. 2. R.)

Sziklár. Scleranthus. 225

\section{Leplesek. 5.}

5. Virágaiban néha van poroda is, terme is, azonban rendesen 1 laki. (XXI. Ser.) Maglapél. Atriplex. 71 Virágaiban mindig van terme is poroda is. 6.

6. Leple 1-3 áttetsző pikkelyecskékből áll ; szárnyas termése egyik oldalán domboru.

Poloskamag. Corispermum. 74

Leple 5 netszetü vagy 5 hasábu, néha 3 hasábu. 7 .

7. Ötmetszetü leple tövön egy husos csövé huzódik össze, mely maghonát magába zárja $s$ a melyre porodái is növe vannak.

Czékla. Beta. 69 Öt hasábu leple tövön husos csövé nem húzódik össze. 8.

8. Leple hasábjai hátán, pilise vagy pótja van. 9. Leple hasábjai hátán nines pilise vagy pótja. 11.

9. Leple hasábjai széllyelálló tüskealaku 5 póttá alakultak.

Sïnhaj. Echinopsilon. 75

Leple hasábjai nem tüskealakuak. 10.

10. Leple hasábjai hátán keresztbe álló pót van; csirája csavaros; levele hegyei tövisesek.

Savar. Salsola. 74 
Leple hasábjai hátán keresztben álló hártyanemü szárny, vagy keresztben álló ráncz van; csirája gyürüalaku; levelei nem tövises hegyủek.

Sepröfü. Kochic.

11. Magvai felállók vagy vamnak közöttük vízirányosak is; leple $3-5$ hasálu; lapított szütyő termését száraz vagy bogyónemü leple takarja.

Mángolt. Blitum. 71

Magvai vízirányosan állók. 12.

12. Magvait kemény kéreg borítja ; csavaralaku lapos csírája kevés fejérnyéjét 2 csomóra osztja.

Sutlap. Schoboeric.

Magvait kemény kéreg borítja; gyürüalaku csirája lisztes fejérnyéjét keríti. Libatopp. Chenoporlium.

13. Bokrétája egy tagu, alsó. 14.

Bokrétája 5 szirmu. 17.

14. Kettős maghonán egy a bibéje. 15.

Maghona egy. 16.

15. Bokrétája kerékalaku, 5 hasábu, porodái törön, bokrétája torkát beleplezö, husos, taplós, 5 fogu hengerbe nőttek össze; két hegyes tüszöben levö magvai selyem takaróba vannak foglalva.

Czinka. Cynanchum. 130

Bokrétája 5 hasábu, hasábjai többnyire hátra türemlettek; tojásdad husos-taplós csomóba nött porodái maghonát befedik; hasas vagy kihegyesedő tüszöbe zárt nnagvai gyapot takaróba vannak foglalva.

Krepin. Asclepicus. 129

16. Bokrétája ékalakuan-harangalaku. vagy nyakas gyertyatartóalaku. karimája 4-7 metszetü; csészéje 4-9) metazetü vagy hasábu, vagy féloldali s buroknemü, bibeszára 2 vagy 1 , bibéje 2 . 
Bokrétája és esészéje kancsóalaku; 4-5 metszetü; porodája 4-5; tokja 2-4 magvu. Más növényeken élődik.

Fünyüg. Cuscutc. 152

17. Bokrétája alsó ; fa vagy cserje; levelei szárnyasok; termése felfuvódott hỏlyag. Halyogfa. Staphylea. 244 Bokrétája felső. (Az ernyősök.) 1S.

18. Virágzata gombos vagy egyszerü ernyő.*) 19. Virágzata kétszeres ernyő. 20.

19. Magvai visszás-tojásdadok, sinórtalanok, pikkelyesek vagy puposak; virága gombjai kerekdedek vagy tojásdadok; 5 fogu csészéje hegyei tövisen végzödők; szírmai felállók. Iringó. Eryngium. 170

Magvai hosszudadok, félmagvacskáin kiálló ránczosan fogasolt 5 sinór van; felemás virágai hosszu ko. csányuak, gallérkái láncsások, színesek.

Zapócza. Astrantia. 170

*) Az ernyösféle növények termetökre nézve igen nagyon hasonlítván egymáchoz, megkülönböztetö nemi jegyeiket csupán magvaikon lehet feltalálni; az ernyösöket vizsgáló füvész ennélfogva ezen növények magvain a következö jegyeket keresse :

1. Az ernyösféle növény félérett vagy érett egész magica (makkocskája $=$ diachenium) két félmagvacskáva (meicarppia) válik el, melyek kétfelé ágazó fonalaku kocsánykái vég'ein függenek; mindenik félmagvacskában van bél (fejérnye $=$ albumen) s ebbe van foglalva a csirája.

2. A kétfél magvacska külső részét, a mag hitcinak, egymáshoz fekvő lapjaikat pedig, belső vagy érintkezési lapjának (comissura) hívják.

3. Mindenik félmagvacska hátán 5 fö s e mellett néha 4 mellék kiálló vonal = sinór (stria) van; ezen sinórok vagy fonalakuak vagy tüskések vagy hártyaszárnyasok.

4. A sinórok közein esö völgyecskéket rovaitl-nak (vallecula) hívják, ilyen rovátkok a belső vagy érintkezési lapon is vannak.

5. A rovátkokban néha 1-3 gyanta anyagu olajos csík nyulik végig, melyet egyszerüen olajcsiknali (vitta) fogunk nevezni. 
20. Nindlkét fél magvacskája bele, az egymást érintő lapok felöl, lapos vagy domboru. $\mathbf{2 1 .}$

Mindkét félmagvacskája bele, az egymást érintő lapok szélén vagy begöngyölödött, vagy egy mélyecske rovátk van rajta. 49.

21. Fél magvacskáján 5 fö sinór van, mellék sinórjai nincsenek. 22.

Félnagvacskáján 5 fö és 4 mellék sinór van; az egėsz magva háta felöl kisebb nagyobb mértékben lapított. 46.

22. Egész magva oldalról éle felöl; lapított, fö sinórjai fonalakuak. $\mathbf{2 3 .}$

Egész magva keresztmetszete köralaku, vagy háta felöl lapított, de nem lencsealaku; fösinórjai fonalalakuak, vagy hártyaszárnyasok. 32.

Egész magva háta felöl lapos vagy lencsealakuan lapos, széle vagy meg van vastagodva, vagy hártya karima (szárny) veszi körül. 40.

29. Szirmai épek, csészéje szélei ki nem vehetök. 24.

Szirmai visszás-szívesek; szirmain levö karélyocskái befelé hajoltak. $\mathbf{2 6 .}$

24. Levelei épek; galléra 1 - több levelü vagy nincs, gallérkája több levelü. szirmai csonkák, begöngyölödöttek. sárgák; magva tojásdad.

Szingallér. Bupleurum. 174

Levelei szárnyasok vagy szárnyason hasogattak. $\mathbf{2 5}$.

25. Tojásdad szirmai csillagosan kiterültek, hegyeik begöngyölödöttek; magva kerekded két göcsü; rovátkáiban 2-3 olaj-csík van. Zeller. Apium. 171

Tojásdad szírmai befelé hajlott karélyoeskája miatt kisebb nagyobb mértékben csorba; magva tojásdad, csaknem 2 görcsü ; galléra nincs, gallérkája több levelü.

Petrezselyem. Petroselinum. 171

26. Csészéjének alig van, vagy nines széle. $\mathbf{2 7}$.

Csészéje 5 fogu. $\mathbf{2 9}$. 
27. Rovátkaiban 3 olajesík van; magva tojásdad lapított, 2 göcsü; bokrétája szabályos, széllyelálló bibéje hajszálalaku.

Pimpinella. Pimpinella. 17\%.

Rovátkaiban vagy nincs olajesík vagy csak 1 ran. 2S. 28. Rovátkaiban nincs olajesík; hegyén behasított termésthordó kocsánykái sertealakuak; galléra és gallérkája nincs. Baktopp. Aegopodium. 172

Rovátkaiban egy olajcsík van, termése hosszukás; bibeszárai hátrahajoltak; galléra és gallérkái 1-3 levelüek.

Kömény. Carum. 172

29. Rovátkaiban 1 olajesík van. 30.

Rovátkaiban 3 olajesík van. 31.

30. Magva gömbded; lapított, csaknem 2 göesü; rovátkait betöltő olajcsíkjai sinórjainál kijebb állanak; fejérnyéje keresztmetszete köralaku (tőgyökere rekeszes).

Csomorika. Cicutt. 171

Magva hosszukás; sinórjai fonalakuak; fejérnyéje hengeres, elöl lapos ; szirmai visszás-szívesek.

Sarlófü. Falcaria. 172

31. Magva tojásdad, esaknem 2 göcsü; rovátkaiban és belsö lapján 3- sok olajesík van, külsö olajcsíkjait kérges magrejtője fedezi ; fejérnyéje átmetszete kör- vagy hatszögalaku; galléra és gallérkái soklevelüek.

Korsóka. Berula. 173

Magva tojásdad vagy csaknem 2 göcsï ; rovátkaiban 3, belső lapján 6 olajcsík van; fejérnyéje átmetszete félhengeres; galléra és gallérkái soklevelüek.

Bolonyik. Sium. 173

32. Szirmai épek, láncsások, kihegyezettek; esészéje fogai ki nem vehetők; oldal 2 sinórja széles szárnyu, szárnya szélessége félmagvacskájával egyenlö ; rovátka 1, belső lapján 2-4 olajcsíkuak.

Szirmai más szabásuak. 33.

Angyélika. Angelica. 178 
33. Szirmai kerekdedek, esonkák, begöngyölödöttek ; fél magvacskáján kiálló tompaélủ 5 sinórja van ; rovátkaiban 1, belső lapján 2 olajesík van; galléra és gallérkái nincsenek. Ánizs. Foeniculum. 176 Szirmai befelé hajló karélyocskájuak, vagy befelé hajolva meggyököntek. 34.

34. Szirmai felálló közepöktől befelé hajolva meggyököntek ; csészéje fogai levélnemüek ; magvai gömbdedek, horgas sürü tüskéjüek ; ernyőcskéi gömbalakuan állanak össze, gallérkái igen aprók.

Gomberuyö. Sanicula. 170

Szirmai kerekdedek, visszás-szívesek vagy visszástojásdadok, karélyocskái befelé hajlók. 35.

35. Rovátkai 3, belső lapjaik 4-6 olajcsíkuak, csaknem egyenlő sinórjai élesen kiállók, vagy szárnyasok; szirmai szálas aljuak; bibeszárai hátrahajoltak; gallérkái soklevelüek

Szila. Silaus. 177

Rovátkái egy olajcsíkuak. 36.

36. Csészéje széle ki nem vehető. 37.

Csészéje fogas. 38.

37. Szirmai visszás-szívesek; rovátkai néha 2, belső lapjai 2-4 olajesíkuak; oldali sínórjai szárnyai a háta sinórjai szárnyainál kétszerte nagyobbak; galléra nincs. gallérkái sok levelüek.

Derezle. Selinum. 17ð

Szirmai egyenetlenek, ernyőcskéi szélső szirmai a belsőknél nagyobbak; rovátkai 1, belsö lapjai 2 olajcsíkuak; magva gömb-tojásdad; fél magvacskája 5 sinórja kiálló, vastag s éles or'móju; galléra nincs, szálas 3 levelü gallérkája féloldali, lefüggő.

Adáz. Aethusu. 17 ;

38. Bibeszárai felállók; magtartó kocsánykái belső lapjaihoz forrtak.

Har amag. Oenanthe. 175

Bibeszárai lekonyultak, magtartó kocsánykái szabadok, azaz: nem nöttek a belső lapokhoz, 2 hasábuak. 39. 
39. Magvai tojásdadok, 5 sinóruak, sinórjai kiállók vagy vastag szárnyuak; rovátkai 1-3, belsö lapjaik 2-4 olajcsíkuak; szirmai visszás-tojásdadok, csorbák.

Gurgulya. Seseli. 176

Magvai tojásdadok, 5 sinóruak, sinórjai vastagocskák, tompák ; rovátkai 1, belsö lapjaik 2-4 olajcsíkuak; szirmai visszás-szívesek.

Bibepár. Libanotis. 177

40. Olajcsíkja igen sok, vagy a rovátkaiban 3 , belső lapján 4 van; szirmai tojásdadok épek, hegyesek, hegyök felegyenesedö vagy begörbült.

Husáng. Ferula. 178

Olajesíkja mindenik rovatkában 1-2 van. 41.

41. Középső 3 sinórja egymástól egyenlö távolságra van, oldal sinórjai ezektöl távolabb esnek és kiszélesedett szélét érik, vagy ez által el vannak fedve. 42.

Sinórjai egymástól egyenlö távolságra vannak; olajcsíkjai fonalakuak. 44.

42. Olajesíkjai ékalakuak; magvai széle ellapult; szirmai visszás-szívesek, a külsők néha sugárosak.

Olajcsíkjai fonalakuak. 43.

Tapsír. Heracleum. 180

43. Magva tojásdad vagy kerek, lapított, karimája meg van vastagodva, ránczosan görcsös; 5 sinórja alig kivehetö; csészéje 5 fogu; szirmai sugárosak.

Magtaraj. Tordylium. 181

Magva körkörös, lapos, 5 sinórja alig emelkedik fel, igen finom, oldali 2 sinorját kiszélesedett karimájától egy rovátk választja el; belsö lapja 2-4 olajcsíku; sárga virágu. Pásztinák. Pastinaca. 180

44. Csészéje széle ki nem vehető; szirmai csonkák, erösen begönyölödöttek, sárgák ; 5 sinórja fonalaku, a 3 középsỏ élesebb, az oldalt álló 2 kisebb; belsö lapja 2 olajesíku.

Kapor. Anethum. 180 Csészéje 5 fogu. 45. 
45. Belsö lapjain 2-6 olajesíkja alig kivehetö; magvai kerekdedek vagy tojásdadok vagy hosszukások, laposak, széles hártyások; 5 sinórja fonalaku, tompa; galléra és gallérkái nincsenek, vagy 1 — sok levelüek ; szirmai visszás-tojásdadok, csorbák.

Kocsord. Peucedanum. 178

Belső lapjai olajcsíkjait magrejtője befedi, egyébként

a Kocsordhoz mindenben hasonló.

46. Sinórjai kopaszok. 47.

Tejér. Thysselinum. 180

Sinórjai serte szőrősek. 48.

47. Fő sinórjai kiállók, fonalakuak, 4 mellék sinórja kevésbé kiálló; belső lapjai 4 olajesíkuak.

Sujtár. Siler. 181

Fö sinórjai fonalakuak, 4 mellék sinórja szárnyas, szárnyai épek; belső lapjai 2 olajesíkuak.

Bordamag. Laserpitium. 181

48. Fö sinórjai szálas sertések, mellék sinórjai egy soros tüskések; virágai tökélyesek; galléra levélkẻi szárnyason szabaltak.

Murok. Dancus. 181

Fő sinórjai szálas sertések, mellék sínórjai 2-3 soros tüskések ; virágai felemások ; galléra levélkéi épek, láncsások.

Sziromör. Orlaya. 181

49. Magvai tüskések; 5 fö sinórján kivül 4 mellék sinórja van, oldali két fö sinórja szárnya felületén ran. 50.

Magrai nem tüskések, hanem néha sertés görcsökkel rakottak; mellék sinórjai nincsenek. 52.

50. Magvacskái 7 tüskés sinóruak, mindenik sinóron 2-3 sor tiiske van; levelei egyszerủen szárnyaltak.

Degencs. Turgenia. 182

Háta fó és mellék sinórjai mind alakjuk, mind tüskéikre nézve különbözők; levelei 2-3-szor szárnyaltak vagy hármasok. 51.

51. Magvacskái 4 tüskés sinóruak, tüskéi 1-3 soruak.

Borzol. Caucalis. 182 
Magvacskái háta sürü tüskés, melyek közt 3 sor serte van.

T'iiskemag. Torilis. 182

52. Magracskái sinórtalanok, csaknem hengeresek, csőre 5 sinóru.

Órmánka. Anthriscus 183

Magvacskái sinórosak. sinóraik egyenlők, a két szélső a mag karimáját alkotja. 53.

53. Magvai szálas-hosszukások, csőrtelenek; magvacskái 5 tompa sinórúak; rovátkai 1 olajesíkuak; szirmai visszás-szívesek ; bibeszára fonalalaku.

Baraboly. Chaerophyllum. 183

Magvai gömb-tojásdadok, oldalról kissé lapítotttak; 5 sinórja kiálló, hullámosan csipkés, rovátkai olajesík nélküliek.

Biirök. Conium. 184

\section{Rend. Háromterméjủek. Trigynia.}

1. Virága tökélyes, alsó. 2.

Virága tökélyes, felső. 7.

2. Fák vagy cserjék. 3.

Füféle növények. 5 .

3. Tövises fulánku cserjék; tövesei párosak. (T. Ser. 1.R.)

Tövisnélküli cserjék. 4 .

Tiiskepár. Paliurus. 245

4. Csészéje 5 hasábu bokrétája 5 szirmú; csontárja

egymagvu cserje. Szömörcze. Rhus. 249

Sziromnemü csészéje 5 hasábu, bokrétája 5 szirmu;

2-3 tokja felfuvódott hólyag, mindenikben 1-2

makkja van. (Néha csak 2 terméje fejlik ki.)

Halyogfa. Staphylea. 244

5. Virágzata 5-7 águ ernyö ; szirmai fogasok. (III. Ser.

3. és X. Ser. 3. R.) Olocsán. Holosteum. 228

Virága magános; hónalji vagy szárhegyi. 6.

6. Tokja 3 kopácsu; szirmai épek. (X. Ser. 3. R.)

Ludhúr. Alsine. 227

Tokja 6 kopácsu; szirmai 2 hasábuak. (X. Ser. 3. R.)

Csillaghurr. Stellaria. 229 
7. Bokrétája némelyike kerékalaku, némelyike csöves, bogyója egyrekeszü, egymagvu.

Bangita. Viburnum. 127

Bokrétája mind kerékalaku, végre letüremlett; bogyója 3 rekeszü, 3 magvu.

Bodza. Sambucus. 127

\section{Rend. Négyterméjúek. Tetragynia.}

Csészéje 5 levelü; 5 szirmu bokrétája elött husos 5

5 pilise van, melyeken behasogatott ikra gombocskák vannak; hegyén nyiló sok kopácsu tokja 1 rekeszü.

Boglárpót. Parnassia. 221

\section{Rend. Ötterméjúek. Pentagynia.}

1. Levelei szárnyason szabdaltak; virágzata elnyös.

(XVI. Ser. 1. R.)

Árorr. Erodium. 250

Levelei épek. 2.

2. Bokrétája szabálytalan, sarkantyus. (V. Ser. 1. R.)

Fájvirág. Impatiens. 255

Bokrétája szabályos, nem sarkantyus. 3.

3. Virágzata bugás; egytagu csészéjét aszott hártya szegélyezi; bokrétája 5 szirmu; maghona 1 magesáju.

Lelleg. Statice. 84

Virága magános. 4.

4. Tokja 10 rekeszü, 5 kopácsu, rekeszei 1 magvuak; csészéje ร̄ levelü, bokrétája 5 szirmu.

Len. Linum. 253

Tokja egyrekeszü, közepén magoszlop áll. Б.

5. Tokja 10 kopácsu. (X. Ser. 4. R.)

Madárhúr. Cerastium. 228

Tokja 5 kopácsu. 6.

6. Levelei csomósak, álgyürüsek. (X. S er. 4. R.)

Csibehúr. Spergula. 225

Levelei ellenesek, pálhátlanok. (X. Ser. 4. R.) 


\section{Rend. Sokterméjǔek. Polygynia.}

1. Levelei szálasok; csészéje 5 levelủ, tövön sarkantyus

Mizura. Myosurus. 192

Levelei 3 hasábuak vagy tenyeresek; 5 levelü csészéje sarkantyutlan. Fulánes. Ceratocephalus. 192

\section{Sereg. HATPORODÁSOK. Hexandria.}

\section{Rend. Egyterméjủek. Monogynia.}

1. Virágai csészesek és bokrétások. 2.

Virágai leplesek. 4.

2. Virágai alsók. 3.

Virágai felsők, csészéje 6 fogu párkány, bokrétája 4-8 szirmu; bogyója egy magvu. Fákon élődő cserjécske. (Lásd XXI. Ser.) Fakín. Loranthus. 185

3. Csészéje 6 levelü; bokrétája 6 szirmu, szirmai tövén két-két ikra van; bogyója 2-3 magvu.

Borbolya. Berberis. 198

Csészéje 12 fogu, harangalaku; bokrétája 6 szirmu, hamar elhulló; két rekeszü tokja sok magvu.

4. Leple sziromnemü. 5.

Locsahúr. Peplis. 258

Leple csészenemü (átlátszó vagy aszott hártyás) 6 levelü. 16.

ஏ. Leple felsö. 6.

Leple alsó. 8.

6. Leple tölcséralaku, 6 hasábu ; egyenes szálcsái bokrétája csöve felső részéhez nőttek, 3 porodája a másik 3-nál kisebb.

Sárika. Sternbergia.

Leple harangalaku. 7 .

7. Szirmai egyenetlenek, külső 3 szirma tojásdad láncsás-liegyes, fejér, a 3 belső kurtább, hegyén kicsípett, sárgás zöld csíkos.

Hóvirág. Galanthus. 49

Mind a 6 szirma egyenlö, tompádadon megvastagodotthegy".

Tözike. Leucojum. 
8. Leple 6 fogu vagy 6 metszetü. 9.

Leple 6 szirmu. $\mathbf{1 0 .}$

9. Termése bogyó, bogyója 3 rekeszü, rekeszei 1 magvuak; leple harangalaku vagy csöves.

Gyöngyvirág. Convallaria. 46

Termése tok; leple gömbded vagy hengeres, tetején elsz ükült s igen apró 6 fogu.

Gyöngyike. Muscari.

10. Bibeszára hegye 3 metszetü; harangalaku leple kocsánykája czikkes; bogyója 3 rekeszü, rekeszei

2 magruak.

Nyulárnyék. Asparagus.

Bibeszára hegye ép vagy nincs is; bibéje tompa vagy 3 karélyu. 11.

11. Felálló portokai aljokkal nőttek szálcsái hegyeire, szálcsái fonalakuak; szirmai tövön egyenlök, felül kinyíltak, sárgák; tokja 3 rekeszü.

Sárma. Gagea. 41

Portokai bigyesztve derekkukkal nöttek szálcsái hegyeire. 12.

12. Leple tövén egy hosszu mézbarázda van; bibeszára egytagu; bibéje 3 szögü. Leplében nincs mézgödör. 13.

13. Leple töve kocsánykájával czikkesen összeragadt kocsánykává huzódik össze. Hölye. Anthericum.

Leple töve nem huzódik össze czikkes kocsánykává. 14.

14. Ernyőjét virágzás elött közös hártya-burok zárja magába ; porodái tövei leplével összenöttek.

Hagyma. Allium. 42

Közös burokhártyája nincs. 15.

15. Leple kékszinü; porodái leple tövéhez nöttek.

Csilla. Scilla.

Leple fejér vagy zöldes fejér, porodái szirmain belöl a vaczkából nőttek.

Zöldesík. Ornithogalum. 
16. Virágai oldalt álló buzogány alaku hengeres torzaán ülnek; leple 6 szirmu; bibéje száratlan.

Kálmos. Acorus. 58

Virágzata sátorozó vagy tömött füzér; bibe szárán fonalaku 3 bibe van. 17.

17. Tokja 3 kopácsu, 1 rekeszü, 3 magu ; levelei pázsitnemüek, laposak.

Lucza. Luzula.

'Tokja 3 kopácsu, 3 rekeszü, sok magvu; levelei félhengeresek, válusformák vagy nincsenek.

Szittyó. Juncus.

\section{Rend. Kétterméjủek. Digynia.}

Láncsás levelü fa. (V. Ser. 2. R.)

Celtisz. Celtis. 64

3. Rend. Háromterméjúek. Trigynia.

1. Virága esészés és bokrétás; esészéje 3"4 metszetü vagy hasábu; bokrétája 3-4 szirmu; porodája 3-4-6-8. (VIII. Ser. 4. R.) Iatonya. Elatine. 241 Virágának nincs csészéje, csupán leple van. 2.

2. Leple egytagu, tölcséres, csöve hosszu, 3 rekeszü tokja felfuvódott. Kikeries. Colchicum.

Leple 4-6 hasábu. vagy szirmu, csövetlen ; virágzata fïzéres. 3.

3. Leple 4-5 hasábu, hasábjai egyenetlenek. (VIII. Ser. 1. R.)

Czikkszár. Polygonum. 78

Leple 6 szirmu. 4.

4. Maghona egy, bibeszára :3, bibéje tollas; leple csśszenemü; leple belső szirmai a külsőknél nagyobbak, összetartók s később háromszögü magvait takarják; virágai néha porodások és termések, néha felemások, néha kétlakiak. Iórom. Rumex. Maghona három. 5.

๖. Maghona tövön összenött s teteje bibeszárrá keskenyedő; portokai keresztbe nyílnak fel s ilyenkor tálcsaalakuak.

Zászpa. Veratrum. 
Maghona :3-6, tokja megérésekor tengelyéröl alól felfelé hasadva válik el ; bibeszára nincs, 3-6 bibéje tollas.

Hutsza. Triglochin. 36

\section{Rend. Hat - sokterméjǔek. Polygynia.}

1. Leple 6 szirmu. (VI. Ser. 3. R.) Hutsza. Triglochin. 36 Virága tökélyes; csészés és bokrétás. 2.

2. Csészéje 3 levelü; bokrétája 3 szirmu ; termése gyürüben álló, legalább ' $\mathrm{j}$ vagy sok tokból áll. mindenikben egy mag van.

Hídör. Alisma. 37 Csészéje 6-10 hasábu, bokr. 6-20 szirmu. (XI. Ser. 4. R.)

Fülfü. Sempervivum. 186

\section{Sereg. HÉTPORODÁSOK. Heptandria.}

1. Rend. Egyterméjủek. Monogynia.

Csészéje 5 fogu, harangalaku; bokrétája egyenetlen 5 szirmu; tüskés, leginkább 3 rekeszü tokja csaknem gömbalaku.

Bokrétafa. Aesculus. 243

\section{Sereg. NYOLCZPORODÁSOK. Octandria.}

1. Rend. Egyterméjúek. Monogynia.

1. Virágai tökélyesek. ‥

Virágai tökélytelenek, alsók. 6.

2. Leveletlen, pikkelyes száru növény; virágzata szárhegyi fürt; 5 szirmu bokrétája 10, négyszirmu bokrétája $\&$ porodás. (X. Ser. 1. R.)

Leveles száru növények. 3.

Gazillat. Monotropa. 170

3. Fa vagy cserje; virágai felemások; csészéje 5 fogu bokrétája 5 szirmu; bibeszára 1-3 bibéjü; termése 1-2 magvu s két szárnyu leppendék. (XXII. Ser.)

Jávor. Acer. 241

Füféle növények. $t$. 
4. Bokrétája 4 szirmu. 5.

Bokrétája egytagu; csészéje 8 metszetü; bokrétája gyertyatartóalaku, 8 metszetü, sárga; porodái bokrétája csövéhez nöttek.

Klóra. Chlora. 131

5. Piros szirmai a csészéjéhez nöttek; hosszu, csöres tokjába zárt magvai koszorusak, azaz pelyhes bóbitájuak.

Csőviries. Epilobium. 255

Sárga szirmai a csészéje torkolatjához nőttek, magvai nem koszorusak, azaz bóbitátlanok.

Csészekiirt. Oenothera. 255

6. Bibéje 2-3; porodája 5-8; 3-5 hasábu leple felsö része színes, később egy magvu makkocskáját tatakarja.

Czikkszár. Polygonum. 78 Bibéje egy. 7.

7. Leple 4 metszetü, színes, lehulló; porodái leple csövéhez nőttek; csontára 1 magvu. Apró cserje.

Boroszlán. Daplıne. 81

Leple 4 metszetü, zöldszinü, elhervadó s egymagvu makkkocskáján állandó; porodái csészéje csövéhez nöttek. Egy nyári növény.

Cziczö. Passerina. 81

\section{Rend. Kétterméjúek. Digynia.}

1. Faféle növény; leple harangalaku 4-5 ragy 8 metszetü. (V. Ser. 2. R.)

Szilfa. Ulmus.

63 Füféle növény. 2.

2. Csészéje 4 tagu; bokr. 4 szirmu. (X. Ser. 3. R.)

Csitre. Moehringia. 228

Leples virágu növények. 3.

3. Leple 4-5 metszetü, félig felső, belől sárga színü; egy rekeszü tokja 2 csörü, sok magvu. A felsőbb virágai 10 porodások. Veselke. Chrysosplenium. 187

Leple alsó 4-5 hasábu, verhenyes vagy zöld. (VIII. Ser. 1. R.)

Czikkszár. Polygonum. 78 
3. Rend. Háromterméjủek. Trigynia.

1. Csészéje 4 tagu; bokr. 4 szirmu. (X. Ser. 3. R.)

2. Leple 4-5 hasábu. (VIII. Ser. 1. R.)

Lulhúr. A7sine. 227

Czikkszár. Polygomum.

78

4. Rend. Négyterméjủek. Tetragynia.

1. Csészéje 4 levelü; bokrétája 4 szirmu, szirmai csészéje leveleinél keskenyebbek; bogyója 4 rekeszü.

Czillár. Paris. 45

2. Csészéje félig felső, szárhegyi virágában levö 2 karélyu, az oldaliban 3 karélyu; szárhegyi virága bokrétája 4 metszetü, az oldalié 5 metszetü ; porodája 8-10; bogyónemï tokja 4-5 rekeszü.

Koczk agyöngy. Adoxa. 128

3. Csészéje 3-4 metszetü vagy hasábu; bokrétája 3-4 szirinu ; porodája 3-4-6-8; tokja 3-4 rekeszü.

Látonya. Elatine. 241

\section{Sereg. KILENCZPORODÁSOK. Enneandria.}

1. Rend. Hatterméjủek. Hexagynia.

Leple 6 szirmu, színes; 6 tokja össze van növe s ezek belső oldalaikon nyílnak. Elecs. Butomus. 37

\section{Sereg. TIZPORODÁSOK. Decandria.}

1. Rend. Egyterméjủek. Monogynia.

1. Bokrétája szabályos. 2.

Bokrétája szabálytalan. 5.

2. Szálcsái tövön összenöttek. 3. Szálcsái szabadok. 4.

3. Kocsányai 1-2 viráguak; porodája 10 vagy 5 , tokja kalászai kopaszok. (XVI. Ser. 1. R.)

Gerely. Geranium. 251 
Kocsányja ernyősek porodája 10, öt terméketlen; tokja kalászai belőlről szakálosak. (XVI. Ser. 1. R.)

Árórr. Erortium. 250

4. Csészéje 4-5 levelü, 5 szirmu vagy hasábu bokrétája sárga ; tokja 5̆ pupı vagy 5 tövisü.

Szurdanes. Tribulus. 250

Csészéje 4-5 levelü; szirmai harangalakulag állanak össze, tövön puposak; tokja 5 kopácsu, halvány sárga, levél helyett pikkelyes száru; élödi növény.

Gazillat. Monotropa. 170

э. Vurágzata szćrhegyi fürt; bokrétája 4 szirma felfelé, az ötöclik lefelé áll ; 5 karélyu maghona kurta kocsánykán ül.

Ezerjó. Dictammus. 250 Virágai a fa ágai oldalából csomósan nőnek ki; bokrétája pillangós szabásu. 5 szirmu; termése hüvely.

Czerczis. Cercis. 298

\section{Rend. Kétterméjủek. Digynia.}

1. Virága tökélytelen. 2 .

Virága tökélyes. 3.

2. Leple 4-5 fogu; inegkeskenyedett esészéje fenekén álló termése egy magvu. Sziklár. Scleranthus. 225

Leple félig felső, 4-5 metszetü, súrga; tokja 2 csörü; levelei vesealakuak. (VIII. Ser. 2. R.)

Veselke. Chrysosplenium. 187

3. Tokja 2 csőrü, 2 rekeszü, megérésekor csőrei között kilyukad; csészéje 5 fogu vagy 5 hasíbu.

Kötör. Saxifraga. 187

'T'okjának nincs csőre, 4 kopácscsal nyílik fel. 4.

t. Csészéje töve pikkelyes. 5.

Csészéje tövén nincsenek pikkelyek. $\mathbf{6}$.

5. Szirmai hosszu nyakuak, csészéje csöves hengeres; virágzata vagy csomós, vagy magános.

Szegfii. Dianthus. 231 
Szirmai nyakatlanok, lassanként szélesednek el; csészéje harangalaku; virágzata szárhegyi bogernyö.

Ékfï. Tunica. 233

6. Szirmai nyakatlanok, lassanként szélesednek el ékalakuvá.

Derczefï. Gypsophyla. 232

Szirmai hosszu nyakuak. 7.

7. Ötfogu csészéje hengeres körkörös-hosszudad; mag-

hona 1 rekeszü, sok magvu. Szappanfü. Saponaria. 23:

Öt fogu csészéje tojásdad-tornyadzó alaku. tcrmése csészéje megno" s 5 szárnyu; maghona alja 2-3 rekeszü.

Bögreszeg. Vaccaria. 233

\section{Rend. Háromterméjủek. 'I'rigynia.}

1. Csészéje egytagu, 5 fogu; bokrétája 5 szirmu. ‥ Csészéje 5, néha 4 levelü; bokrétája is 5, néha 4 szirmu. tokja mélyen hasábos, vagy a hegyén fogas. 3.

2. Bogyó termése 1 rekeszü; csészéje poháralakum harangalaku; egymástól távolacska álló szirmai 2 metszetüek.

Kukuba. Cucubalus. 236

Tok termése fenekén 3 rekeszü; csészéje hengeres vagy ékalaku $10-20$ vagy 30 sinórú; szirmai épek, kicsípettek vagy 2 metszetüek.

3. Tokja 3 kopácsıl. 4.

Sziléne. Silene. 234 Tokja 6, néha 4 kopácsu. 5.

4. Szirmai épek, néha csorbák; magvai vesealakuak, szárnyatlanok.

Luthur. Alsine. 227

Szirmai épek; magvai háromszögüek vagy kerekded risszás-tojásdadok, szárnyatlanok, vagy szárnyasok.

Pikkelyhúr. Lepigomum. 226

5. Szirmai épek, vagy alig csorbák. 6. Szirmai fogasok vagy bemetszettek. 7.

6. Tokja 4-6 kopácsu; magvainak köpenyalaku pótléka van.

Csitre. Moehringia. 223 
Tokja 5 kopácsu, magva vesealaku, pótnélküli.

Homokhúr. Arenaria. 228

7. Szirmai fogasok; porodája 3-5; ernyős virágzata 3-7 virágu.

0locsán. Holosteum. 228

Szirmai mélyen csorbák, vagy 2 hasábuak.

Csillaghúr. Stellaria. 229

\section{t. Rend. Ötterméjüek. Pentagynia.}

1. Maghona egy. $\mathbf{2}$

Maghona 5, melyek tövön összenöttek; az egész növény husos (pozsgás).

Szaka. Sedum. 186

2. Csészéje egy tagu, 5 fogu; bokrétája 5 szirmu, szirmai nyakasok, és torokban pillenpátyosak. 3. Csészéje 5 levelü; bokrétája 5 szirmu. 5.

3. Tokja tövön 5 rekeszü, felső részén nines elrekgetve szirmaival szemben eső részén 5 foggal nyílik fel.

Tokja 1 rekeszü. 4.

Enyvencz. Viscaria. $2: 37$

4. Tokja csészéje fogaival szemben eső részén 5 foggal nyílik fel; bibeszárai csésze fogaival állanak szemben.

Konkoly. Agrostemma. 237

Tokja 10 foggal nyílik fel. Mécsvirág. Lychnis. 236

5. Szálcsái tövön összenöttek; tokja 3 ormóju s ormóin nyílik fel; levelei hármasok; levélkéi visszás-szí-

vesek. Sósdi. Oxalis. 255

Szálesái szabadok, azaz: semmi részök sem nött össze. 6.

6. Termése bogyónemü, 4-5 rekeszü; csészéje félig felsö, szárhegyi virágában két, az oldaliban három karélyu; szárhegyi virága bokrétája 4, az oldalié 5 metszetü, porodája 8-10. (VIII. Ser. 4. R.)

Termése tok. 7.

Koczkagyöngy. Adoxa. 128

7. Magva köralaku, szárnyas; tokja 5 kopácsu, porodája 5 vagy 10 ; pálhái vékony hártyások. 
Magva szárnyatlan. 8.

8. Szirmai épek, 4-5-en vannak; porodái 4-5-10 ; tokja 4-5 kopácsu; magvai vesealakuak.

Szagyán. Sagina. 226

Szirmai csorbák, vagy bemetszettek, 5-en vannak; porodája 10 vagy 5.9.

9. Szirmai 2 metszetüek, vagy a hegyén csorbák ; tokja hengeres vagy hengeres-kupalaku, tetején 10 kis foggal nyílik fel. Madárhúr. Cerastium. 228 Szirmai 2 hasábuak; tokja tojásdad-ötszögü, 5 kopácsu, kopácsai hegyükön behasítottak.

Puhar. Malachivom. 230

\section{Sereg. TIZENKÉTPORODÁSOK. Dodecandria.}

\section{Rend. Fgyterméjủek. Monogynia.}

1. Virága tökélytelen; harangalaku leple felső, 3 metszetü, állandó : portokai áralaku szálcsái közepére nöttek. Kapotnyak. Asarum.

Virága tökélyes. $\mathbf{2}$.

2. Tokja derekán nyíló.

Csészéje 2 hasábu; sárga bokrétája 5 szirmu; porodája 6-12.

Poresín. Portulaca. 224

Tokja tetején nyíló. 3.

3. Csészéje hengeres, 8-12 fogu; piros bokrétája 6

szirmu. porodája 12 vagy 6 . Füzény. Lythrum. 258 Csészéje 5 levelü; bokrétája 5 szirmu; porodája

12-15; tokja 3 rekeszü, sokmagvu.

Harmala. Peganum. 250

\section{Rend. Kétterméjủek. Digynia.}

Csészéje 5 metszetî, csészéje csövén kezdetben puha, később megnött s megkeményedett horgas tüskék nőnek; porodái 6 vagy 12 , vagy 15.

Párló. Agrimonia. 267 
3. Rend. Háromterméjủek. 'Irigyuia.

1. Virága tökélyes; csészéje 5-7 hasábu; bokrétája szabálytalan, 5-7 egyenetlen szirmu; tokja hártyanemü, 3-6 foggal tetején nyíló, sokmagvu.

Rezeda. Reseda. 218

2. Virága tökélytelen; leple harangalaku, 4-5 metszetï; kocsánykás tokja 3 czikkü. (XXI. Ser. 2. R.)

Fütéj. Enpllorbic. 245

\section{Rend. Öt - sokterméjǔek. Penta-polygynia.}

Csészéje 6-12 hasáluu; bokrétája 6-20 szirmu, melyek tövön egymással és a porodákkal összenöttek; porodája 12-40; bibeszára és tüszője 6-20.

Fülfii. Sempervivum. 186

\section{Sereg. HUSZPORODÁSOK. Icosandria.}

1. Rend. Egyterméjúek. Monogynia.

1. Virága felsö. 2.

Virága alsó; csészéje 5 metszetü; bokrétája 5 szirmu. 3.

2. Csészéje 4-5 hasábu; bokrétája 4-5 szirmu; bibeszára 4 metszetü; tokja 4-5 kopácsu.

Jézsafa. Philadelphus. 259

Csészéje 5 metszetü; bokrétája 5 szirmu, csontárja 1-5 esontmagvu.

Galagonya. Crategus. 260

3. Csontár termése nem husos, száraz takarója szabálytalanul felrepedezik, csontja lyukacsos.

Mondola. Amygdalus. 268

Csontár termése husos. 4.

4. Csontára csontja ránczosan barázdolt, barázdáiban lyukak vannak.

Baraczk. Persica. 269 
Csontára esontja síma, vagy ránczosan barázdolt, azonban ninesen meglyukgatva. ๖.

5. Virágai magánosak vagy kettösek; husos termése mindkét végén elhegyesedő vagy körkörös ragy gömbalaku, hámja mindenkor hamvas.

Szílva. Prumus. 269

Virágzata csomós, vagy ernyös, vagy fürtös; husos termése gömb- vagy szívalaku, hámja nem hamvas.

Meggr. Cerasus. 270

\section{Rend. Két - öt terméjüek. Di-pentagynia.}

1. Virágai tökélytelenek, szárhegyi gombot alkotuak; leple alsó, 4 hasábu; maghona 2-3; bibeszára és bibéje ecsetalaku. (XXI. Ser. 2. R.)

Csábair. Poterium. 268

Virágai tökélyesek. 2.

2. Virágai alsók vagy félig alsók; csészéje 5 metszetü; bokrétája 5 szirmu; 3-12 tokja (tüszője) 2-6 magvu; virágai néha kétlakiak. (XXII. ser.)

Bajnóeza. Spriraea. 268

Virágai felsők; csészéje 5 hasábu, állandó. 3.

3. Termése csontár. 4.

Termése alma vagy bogyó. 5.

4. Csontára végén levő gödre keskenyebb, mint a csontára átméröje. 1-5 csontmag van husában.

Galagonya. Crategus. 260

Csontára végén levő gödre csaknem olyan széles, mint a csontára átméröje, husában 5 csontmagva van.

Nászpolya. Mespilus. 260

5. Bogyója 1-5 magu, nincsen elrekeszelve, hanem magvait finom hártya takarja; virágzata bogernyős ; bokrétája szirmai kerekdedek.

Berekenye. Sorbus. 259 
Alma termésében magvait rugalmas pergamen hártya takarja. 6.

6. Almája 5 rekeszü, rekeszeiben 2 mag van.

Körtefa. Pyrus. 259

Almája 5 rekeszü, rekeszeiben sok mag van.

Birs. Cydonia. 259

\section{Rend. Solkterméjủek. Polygynia.}

1. Csészéje 5-9 metszetü, metszetei egy sorban vannak. 2.

Csészéje 8-10 metszetü, metszetei két sorban vannak, a külső sorban álló metszetek pótléknak látszanak. 4.

๑. Csészéje alja és csöve husos, kancsó vagy gömbalaku, ebből kifejlett husos, - esipke, - termésébe van számos magva bezárva.

Rózsa. Rosa. 261

Csészéje lapos vagy harangalaku. 3.

3. Csészéje harangalaku, termése 3-12 tok (tüszö). (Lásd 2. Rend.) Bajnócza. Spircuea. 268

Csészéje csaknem lapos; sok maghona félgömb vagy kupalaku vaczkára van nőve; maghonai egy gömbded vagy kupalaku csomóban egyesült apró esontárokká fejlenek ki.

Szederj. Rubus. 262

4. Terméskéire állandó bibeszára csákósan ránő.

Cziklász. Geum. 267

Terméskéi csákótlanok. ウ̆.

5. Vaczka virágzás után husos leves álbogyóvá fejlik ki, melynek felszinébe vannak a magvai besüppedve. Szamócza. Fragaria. 263 Vaczka száraz, nem husos, domboru vagy golyóalaku; bokrétája 5, néha 4 szirmu.

Pimpó. Potentilla. 264 


\section{Sereg. SOKPORODÁSOK. Polyandria.}

\section{Rend. Egyterméjüek. Monogynia.}

1. Csészéje sziromnemü, a felső levele sarkantyus. (XIII. Ser. 2. R.)

Sarkvirág. Delphinium. 197

Sem a csészéje, sem a bokrétája nem sarkantyus. 2.

2. Szárazi növények; 4-5 szirmu bokrétások. 3.

Vízi növények, sok szirmu bokrétások. 8.

3. Bokrétája 4 szirmu. 4.

Bokrétája 5 szirmu. 7 .

4. Csészéje 2 levelü, lehulló. 5.

Csészéje 4 levelü, lehulló; portokai szálcsái kiszélesedett tetejére nőttek; termése 1 rekeszü, bogyó.

Takta. Actea. 198 .

5. Bibéje 2 karélyu; tokja beczőalaku, 2 kopácsu. 6. Bibéi maghona tetején sugárosan körben állanak, 4-20 sugáruak; tokjának középen össze nem érő 4-20 válaszfala van, tokja állandó bibéi tövén lyukadozik ki.

Mák. Papaver. 198.

6. Virágzata ernyős; tokja 1 rekeszü, magvai kopácsai közé nőtt magtartóra nőnek s tövéröl kezd felnyilni. Az elszakasztott növényböl verhenyes sárga téj foly.

Gódirez. Chelidonium. 199

Virágai magánosak; tokja kopácsai közt kifejlett taplós válaszfalánál fogva 2 rekeszü, hegye felöl kezd felnyílni.

Szarutok. Glaucium. 199

7. Fa, kocsányjain pergamennemü sárgás zöld marvaja van; csészéje 5 levelü, elhulló; makkocskanemü tokja 1-2 magvu.

Szodókfa. Tilia. 240 .

Füféle növény, vagy apró cserje ; csészéje állandó; tokja 1 rekeszü vagy tökélytelen 3 rekeszü, 3 kopácsu.

Tetemtoldó. Helianthemum. 220. 
8. Csészéje 4 levelü; bokrétája fejér, külsö szirmai csészéjénél valamivel hosszabbak, nincss rajtok mézgödör.

Nimfa. Nymphaea. 219

Csészéje 5 levelü; bokrétája sárga, szirmai csészéjénél kurtábbak, hátukon mézgödör van,

Tórózsa. Nuџhar. 220

\section{Rend. Két-sokterméjǔek. Di-polygynia.}

1. Maghona sok magcsáju; tokja belsö oldalán nyílik. 2. Maghona 1 magesáju; termései fel nem nyíló makkocskák. 9.

2. Virága szabálytalan; csészéje sziromnemü pilis, a felső sisakos vagy sarkantyus. 3.

Virága szabályos; csészéje hasonlóul sziromnemü pilis. 4.

3. Pilise felsö levele sisakosan boltos; 2-j szirma csészéje leveleinél kisebb, sisakja alárejtözött, a 2 felső nyakas, kámzsaalaku, a 3 alsó szálas vagy nincs meg; tüszöje $3-5$.

Sisakvirág. Aconitum. 198

Pilise felsö levele tövön csöves sarkatyus, bokrétája 4 szirmu, a 2 felső sarkantyus szirma a csésze sarkantyuja csövébe nyulik, vagy minden szirma sarkantyuvá nött össze; tüszöje 1-5.

Sarkvirág. Delphinium. 197

4. Virágának csupán leple van, leple 5 szirmu, sárga; tüszöje 5-10.

Gólyahir. Caltha. 196

Virága csészés és bokirétás, de a csészéje színes pilis. 5. 5. Egyenlöen tölcséres 5 szirma alól sarkantyus, melyek pilise lapos 5 levelével váltogatva állanak.

Czámoly. Aquilegia. 197

Szirmai csövesek. 6.

6. Pilise lehulló. 7.

Pilise állandó; bokrétája 8-10 szirmu, szirmai csövesek.

Hunyor. Helleborus. 196 
7. Tokja kocsánytalan. 8.

Tokja hosszu kocsányu ; csészéje 5-8 levelü ; bokrétája nyakas, lemeze csöves.

Sziralj. Eranthis. 196

8. Pilise 5 levelü ; 5-10 szirma nyeles, csöves, 2 ajjaku, mindenik tövén egy pikelylyel fedett mézgödör van; felfuvódott 5-10 tokja egymással félig öszszenött.

Kandilla. Nigella. 197

Pilise 5-8 levelü; szirma 5, csöves, ajakas; lapitott 2-3 tokja nincs összenöve. Galamó. Isopyrum. 197

9. Virága tökélyes; bokrétáíja $5-\mathrm{s}$ több szirmu. $\mathbf{1 0}$. Virága tökélytelen. 13.

10. Szirmai nyaka fonalaku, lemezénél hosszabb. Apró növény.

Mizura. Myosurus. 192

Szirmai nyaka kurta vagy nines is. 11.

11. Szirmai nyakatlanok s tövükön ninesen mézgödör ; esészéje 5 levelü.

Héries. Adonis. 191

Szirmai kurta nyakuak s tövükön pikkelyes mézgödör van. 12.

12. Terméskéi egyrekeszủek ; esészéje 3-5 levelü ; bokrétája 5 s több szirmu. Szironták. Remunculus. 192

Terméskéi 3 rekeszüek, rekeszei közül egyben van mag, kettö terméketlen. Fulánes. Ceratocephalus. 192

13. Leplei a bimbóban fedelékesen hátalják egymást. 14.

Leplei a bimbóban kopácsosak, vagy a széleik befelé türödtek; magvai tollas esákosak.

Bérese. Clematis. 188

14. Csőrös vagy esákós magvai félgömb vagy kupalaku vaczkához nöttek.

Kököresín. Anemone. 190

Csőrtelen magvai tányéralaku vaczkához nöttek.

Virnánez. Thalictinum. 188 


\section{Sereg. KÉT FÖBB PORODÁSOK. Didynamia.}

\section{Rend. Fedetlen magruak. Gymnospermia.}

Ezen rendle tartozó nörények csészéje fenckén 4 maghon ian.

1. Porodája kettö. 2.

Porodája négy, melyek közül 2 egyenlö magas, 2 egyenlö alacsony. 3.

2. Bokrétája tölcséres, 4 metszetü; szélesebb metszete kicsípett; csészéje 5 fogu. (II. Ser. 1. R.)

Peszércz. Lycopus. 133

Bokrétája ajakas, felső ajaka sarlóalakuan elörehajló, alsó ajaka 3 karélyu ; szálcsái felső részei al só részére csuklósan nőttek. (II. Ser. 1. R.)

Zsálya. Salvia. 134

3. Porodái és bibeszára bokrétája csövébool nem érnek ki. 4.

Porodái és bibeszára, vagy legalább a bibeszára bokrétája csövéböl egészen a torkáig érnek. 6.

4. Bokrétája nem ajakas, szük csövü, kiterült karimája. 5 metszetü, metszetei egyenetlenek, az alsó a többinél nagyobb; 4 maghona összenöttnek látszik, azonban a belöle fejlett s megérett 4 makkocskája széllyelválik. (XIV. Ser. 2. R.) Galambócz. Verbena. 145 Bokrétája ajakas vagy ásitó. 5.

๖. Bokrétája csészéjénél hosszabb, felső ajaka felálló, 2 metszetü; csészéje csöves $5-10$ fogu, nem ajakas vagy néha csaknem ajakas; makkocskái 3-élüek, felül csonkák.

Pemet. Marrubium. 139

Bokrétája csészéjénél kurtább, felső ajaka ép; csészéje 2 ajaku; gyürüi 6 virágu; makkocskái tompa ormójuak, felső részök lekerekített tompák.

Bibetyü. Sideritis. 138

6. Porodái szorosan egymás mellett állanak s legalább a virág kinyilásakor párhuzamosan a bokréta felső ajaka alá vonulnak. 7 . 
Porodái elállanak egymástól, felsö részök ragy nagyon széllyeláll, vagy összefelé tart, azonban egyenesek. $\mathbf{2 8 .}$

7. Bokrétája felső ajaka vagy egészen híányzik, vagy igen kurta, porodáinál sokkal kurtább. 8.

Bokrétája felsö ajaka elöre tartó, legalább is akkora, mint a porodái. 9.

8. Felsö ajaka nincs, hanem ennek a helye be van hasítva, melyből nyulnak ki a porodái; bokrétája csövében nincsen szörkör.

Tarorja. Teucrium. 143

Felső ajaka igen kurta, kicsípett; bokrétája esövében belöl szörkör van. Kaeskanyak. Ajuga. 144

9. Csészéje egyenlö 5 vagy 5-nél kevesebb fogu, fogai nem alkotnak két ajakat. 10.

Csészéje 5, vagy 5-nél kevesebb fogu, fogai szembetünőleg 2 ajakot alkotnak. 20.

10. Bokrétája alsó ajaka 2 karélyu, alsó ajaka két oldalán a torka szélénél két szálka foga nőtt.

Tátkanaf. Lamium. 142

Bokrétája alsó ajaka 3 karélyu, vagy apró oldalkarélyai miatt épnek látszik. 11.

11. Bokrétája csöve alsó részében belöl szőrkör van melynek kivülről begyürödzés felel meg. 12.

Bokrétája csövében nincs szőrkör. 16.

12. Bokrétája alsó ajaka metszetei virága kinyílása után egy áralaku metszetté göngyölödnek össze; makko cskái 3 élïek, csonkák ; tenyeres levelei 3-5 metszetüek.

Gyöngyhim. Leonurus. 141

Bokrétája alsó ajaka metszetei nem göngyölödnek össze ; levelei épek. 13.

13. Szálcsái tövén bokrétájához nött részén alól felfelé görbülö pótok vannak; bokrétája felsö ajaka boltos.

Bundi. Phlomis. 143

Szálcsái tövén nincsenek pótok. 14. 
14. Bokrétája alsó ajakának mind a három metszete hegyes, felsö ajaka boltos, esipkés; bokrétája sárga.

Mamó. Graleobrlolon. 143

Bokrétája alsó ajakának legalább a közép metszete vagy tompa vagy ki van csípve; bokrétája nem sárga, hanem más szinü. 15.

15. Hosszabb két porodája virágpora kiszórása után, a virágból kifelé fordul, kihajlik. Hunyász. Stachys. 139

Porodái virágpora kiszórása után is felfelé állanak.

Pesztercze. Ballota. 143

16. Alsó ajaka mindkét oldalán egy-egy púpja van, ezen kiálló púpok alól üregesek. Foganött. Galeopsis. 140) Alsó ajakán nincsenek púpok. 17.

17. Felsö ajaka mélyen kicsípett, vagy esaknem a közepéig be van metszve. 18.

Felső ajaka ép, vagy alig sekélyen kicsípett. 19.

18. Alsó ajaka közép karélya kerekded, domboru, csipkés, oldalkarélyai aprók s ugy látszanak, mintha a torka szélei volnának letüremlvę.

Csipkepitty. Nepeta. 136

Alsó ajaka közép karélya visszás-szíves; oldalkarélyai ki vannak fejlődve; portokai páronként X-et alkotnak.

Repkény. Glechoma. 136

19. Makkocskái tetejei le vannak kerekítve; levelei szíves-hosszukások.

Betónika. Betonica. 139

Makkocskái esonkák, tetejei 3-szögü lapuak; levelei nyélbe keskenyedők.

Kajtár. Chaiturus. 142

20. Bokrétája csövében belöl szörkör van; szálcsái portokain felül kurta fulánkkal vagy foggal végzödnek; csészéje felsö ajaka csonka és csekély 3 fogu, alsó ajaka ? metszetü; bokrétája fels" ajaka boltos, ép, alsó ajaka 3 metszetü, középső metszete a két oldalinál nagyobb.

Villahím. Prunella. 137 
Bokrétája csövében nines szörkör; szálesái nem nyulnak portokain át fogason. 21.

21. Csészéje 2 ajaku, ajakai épek, felső ajaka hátán egy felfelé álló pikkelyalaku pótja van, ajakai virágzás után becsukódnak; bokrétája felső ajaka bóltos, 3 metszetü, alsó ajaka ép. Csukóka. Scutellaria. 137

Crészéjének legalább az egyik ajaka be van vagdalva. 22.

22. Csészéje harangalaku, bokrétája csövénél sokkal bövebb, szabálytalan 3-4 fogu; bokrétája felső ajaka ép, vagy sekélyen kiesípett.

Mozsárvirág. Melittis. 138

Csészéje csöves, két ajaku; bokrétája felső ajaka 2 hasábu, torka felfuvódott. Pofóka. Dracocephalutm. 137

23. Bokrétája ajakai csaknem egyenlök. 24.

Bokrétája ajakas vagy ásitó. $\mathbf{2 5}$.

24. Csészéje 5 fogu, nem ajakas, torka nyílt; azaz elvirágzás után szörök nem zárják be; bokrétája tölcséres 4 metszetü.

Ménta. Mentha. 132

Csészéje 2 ajaku, felsö ajaka 3 metszetü, fogai 3 szögü-láncsások, alsó ajaka 2 metszetü, fogai áralakuak, elvirágzás után torkát szörök zárják be ; tölcséres bokrétája csöve hasas torku.

Csombor. Pulegium. 132

25. Hosszabb két porodája egyenes s felül egymástól elállanak. 26.

Mindenik porodája portokaival együtt összetart 27. 26. Csészéje tövét csészéjénél hosszabb murvák környezik.

Murvapikk. Origanum. 139

Csészéjét murvák nem környezik, csészéje 2 ajaku torkát virágzás után szemszőrök zárják be.

Démutka. Thymus. 139

27. Virágzata gyürüit sertealaku számos murva gallélérozza körïl; csöve hengeres csészéje torkát szem- 
Lapon

szőrök zárják be ; bokrétája felső ajaka lapos, alsó ajaka 3 metszetü.

Pereszlén. Clinopodium. 134 Virágzata gyürüinek serte murva gallérai nincsenek; tojásdad esészéje tövön rendszerint pupos.

Kalaminta. Calamintha. 134

\section{Rend. Fedett magvuak, vagy magrejtősek. Angiospermia.}

1. Porodája kettő. 2.

Po rodája négy, melyek köziil 2 egyenlö hosszu, 2 egyenlö alacsony. $\mathbf{3}$.

2. Bokrétája sarkantyus, ásitó, ínyes; csészéje z egyenlö levelü, tokja egyrekeszü. - Vízi növény. (II. Ser. 1. R.)

Rencze. Utricularia. 167

Bokrétája ajakas, 2 ép porodája mellett van még két ki nem fejlett porodája is; tokja 2 rekeszü. (II. Ser. 1. R.)

Csikorka. Gratiola. 159

3. Maghona 4 rekeszü, 4 magcsáju, inegérésekor azonban 4 makkocskává válik el. (XIV. Ser. 1. R.)

Galambócz. Verbena. 145

Maghona 1-2 rekeszü, kifejlésekor tok terméssé válik. 4.

4. Leveletlen pikkelyes száru halvány sárga, verhenyes vagy kékes szinü növények; bokrétájok ajakas. 5.

Leveles száru növények. 6.

5. Maghona tövén elöl egy szabadon álló tojásdad ikra van; csészéje harangalaku, egyenlő 4 metszetü ; virágzás után bokrétája töve kereken leválik s lehull.

Vicsor. Lathraea. 167

Maghona tövén nincsen ikra; csészéje néha 2 levelü, csészéje levelei épek vagy bemetszettek; néha 1 levelü, 4-5 fogu; bokrétája töve virágzás után felválik ugyan, de nem hull el. Szádor. Orobanche. 166 6. Csészéje 4 fogu, fogai épélüek. 7 . 
Iapon

Csészéje 5 fogu, vagy 5 metszetü, vagy 5 levelü, néla kevescbb mint 5 levelü, levelei azonban bevagdalt esipkések. 9.

7. Tojásdad alaku ceészéje felfúvódott, bokrétájánál szélesebb, lapított; lapos, síma magva hártya prémes.

Lapór. Rhinanthus. 164

Csöves csészéje nincs felfuvódva. $\mathbf{S}$.

8. Bokrétája felső ajaka 3-szögü-lapított, kicsípett, alsó ajaka 3 fogu, alsó részén homoru, felül 2 prípú; tokja rekeszeiben 1-2 mag van; magvai prémetlenek. símák.

Fintor. Melampyrum. 165

Bokrétája felső ajaka sisakosan boltos, 2 karélyu, kícsípett vagy csonka, de nem lapított; alsó ajaka 3 metszetü, metszetei épek vagy kicsípettek; tokja rekeszeiben sok mag van, magvai prémetlenek, hosszában karczoltak. Szálkacsék. Euphrasia. 163

9. Tokja 1 rekeszü, 2 kopácsu, magoszlopa szabadon álló, sok magvu ; csészéje 5 fogu; bokr. 5 metszetü csaknem szabályos.

Iszaprojt. Limosella. 159

Tokja 2 rekeszü. 10.

10. Bokrétája tövön púpos vagy sarkantyus; csészéję mélyen 5 hasábu. 11.

Bokrétája töve se nem púpos, se nem sarkantyus. 12.

11. Bokrétája türön púpos, két ajaku, alsó ajaka felpuffadt ínye száját bezárja; csészéje 5 hasábu.

Pintyö. Antirhinum. 158

Bokrétája tövön sarkantyus, két ajaku, alsó ajaka felpuffadt ínye száját bezárja; csészéje 5 metszetü.

Gyujtovány. Linctio. 156

12. Bokrétája csaknem gömbalaku, karimája kurta; felsö ajaka 2 metszetü, alsó ajaka közép karélya letüremlett.

Tákajak. Scrophularia. 158

Bokrétája hosszudad. 13.

13. Bokrétája ferde harangalaku, nyílt száju, karimája 
egyenetlenül bemetszett esészéje 2 hasábu vagy 5 levelü.

Gyüszüvir’ág. Digitalis. 159

Bokrétája ásító, felső ajaka sisak- vagy sarlóalaku; esészéje többnyire felfuvódott, fogai vagy csipkések -vagy épélüek.

Kajmacsór. Pedicularis. 164

XV. Sereg. NÉGY FÖBB PORODẢSOK. Tetradynamia.

1. Rend. Táskások. Siliculosa.

1. Táskája gömbalaku; kemény, fel nem nyíló, válaszfala elenyészése miatt néha egy rekeszü $\mathbf{2}$.

Táskája oldalról lapított, kopácsai gerinczei kiálló ormójuak vagy szárnyasok $\mathbf{S}$.

Táskája, csaknem gömbalaku, válaszfala olyan széles, mint a táskája; vagy a táskája háta felöl kisebb nagyobb mértékben lapított, felnyíló. 14.

2. Táskája egyetlen bütyökből áll. 3.

Táskája egymás félibe helyezett 2 czikkü, a két tag megéréskor egymástól elválik, de azért fel nem nyílik. 7.

3. Táskája egy rekeszü és egy magvu. 4. Táskájának egynél több rekesze van. o.

4. Gömbalaku s hálózatosan ránczos táskája tetején bibeszára megmaradt; bokrétája aranyszínü.

Sömörge. Neslia. 217

Kerekded-tojásalaku táskája tetején kupalaku kurta bibeszára megvan; bokrétája fejér.

Matyó. Calepina 217

5. Táskája körtealaku, 3 rekeszü, egymás mellett eső, 2 felsö rekesze üres Táskája kerekded vagy tojásdad. 6.

6. Táskája tojásdad vagy körkörös gömbded, tetejét bibeszára hegyezi ki; két rekesze egymás mellett áll s mindenikben egy-egy mag van; bokrétája fejér.

Táskazár. Euclidium. 216 
Táskája tojásdad csaknem 4 olmóju; egymás felibe helyezett két ragy két pár rekeszil rekeszeiben egy mag van; bokrétája sárga. Szuimesö. Bunias. 217

7. Két czikkü táskája alsó tagja kocsánykaalaku, 1 - sok magvu, a felsö tojásdad, vagy kerekded, egy magvu; kötőléke igen kurta; virága sárga.

Rekenyö. Rapistrum. 217

Két czikkï táskája alsó tagja kocsánykaalaku, üres ; a felső gömbalaku, egy magru; kötőléke hosszu; virága fejér.

Tátorjál. Crambe. 218

8. Táskája fel nem nyiló, vagy ha két czikküvé válik is, magvát akkor is magába záró. 9. Táskája felnyílik és magvát kiszórja. 11.

9. Számytalan táskája vesealaku, vagy 2 göcsü, lapított, szélesebb mint hosszabb, hálózatosan ránczos, kopasz.

T'áskarag. Senebiera. 216

Szárnyas táskája más alaku. 10.

10. Egy pár paizsból alakult szárnyas táskája hegyén és tövén kikanyarított.

Paizspár. Biscutella. 214

Hosszukás vagy csaknem tojásdad szárnyas táskạja válaszfala át van furva s e miatt egyrekeszủ s egy magvu.

C'siilleng. Isatis. 216

11. Táskája kopácsai különösen a hegyök felé szárnyasok. 12.

Táskája kopácsai nem szárnyasok vagy alig szárnyasok. 13.

12. Táskája szíves vagy tojásdad kopácsai esolnakalakuak, hegyein egy kis szárnya van; rekeszei 1 magvuak.

Zsázsa. Lepidium. 214

Táskája háromszögü szíves vagy kerek, rekeszei 2 s több magruak.

Tarsóka. Thlaspi. 213

13. Táskája körkörös tompa; rekeszei 2 magruak. 
Táskája háromszögü visszás-szíves, hegye ép, vagy alig kicsípett: rekeszei sok magvuak.

Csapka. Całsella. 215

14. Szálesáin szárnynemü fogak vagy pupok vannak, táskái felnyílók. 15.

Szálcsái fogatlanok táskái felnyílók. 16.

15. Táskája kerekded, vagy tojásdad hátil lencsealakuan lapított, kopasz vagy lelapnlt csillagszőrétöl szïrke; rekeszei 1-4 magvuak.

Ternye. Alyssum. 210

Táskája körkörös, lapos, molyhos; rekeszei $6 \mathrm{~s}$ több magvuak.

Hamuka. Farsetia. 211

16. Táskái puffadtak, körte- vagy gömbalakuak. 17.

Táskái lapítottak, néha puffadtak. 18.

17. 'Táskája körtealaku, állandó bibeszárát kopácsa hegyéhez egy pót foglalja; bibeszára táskája felnyílásakor kopácsaival együtt paitan le.

Gomborka. Camelina. 213

'Táskája nagyon fel van fuvódva, vagy esaknem gömbalaku ; bibeszára táskája felnyilásakor válaszfalán marad.

Torma. Cochlearia. 212

18. Körkörös-láncsás s csaknem lapított táskája egy megnyult fonalaku termekocsánykán ül; kötölékei válasz falához nöttek.

Lapicz. Lunarice. 212

Láncsás vagy tojásdad vagy hosszukás s háta felöl lapított sok magvu táskája nem ül termekocsánykán.

Daravirág. Draba. 212

\section{Rend. Beczősek. Siliquosa.}

1. Beczöje nem nyílik fel, hengeres vagy gyüngysoralaku, megéréskor azonban néha czikkekre szakadozik.

Retek. Raphanus. 21 \& 
Beczöje alólról feslö két kopácsesal nyílik fel. 2.

2. Magvai beczöje mindenik rekeszében 2 soruak, vagy egyenetlenül 2 soruak. 3.

Magvai beczöje mindenik rekeszében 1 soruak. 6. 3. Beczöje kopácsai innélküliek vagy csak töveiken van az in kezdetének némi jele; beczője lapított vagy hengeres, néha igen kurta.

Rézsuka. Nasturtium. 200

Beczöje kopáesai 1 inuak. 4.

4. Beczője hegye csőrös, csőre áralaku, felényi, mint a beczöje; szálas beczöje lapított 4 ormóju ; magvai tojásdadok.

Álszegees. Syrenia. 208

Beczöje hegye nem csörös. 5.

5. Lapos beczői sugáron felállók, száxlevelei nyílalakuak; bokr. szirmai keskenyek, hosszukás ékalakuak, sárgás fejérek. Toronszál. Turritis. 202

Szálas vagy szálas láncsás beczöi egymástól távol állanak, kihajlók ; bokrétája szirmai kerekded viszszás-tojásdadok, sárgák; alsó levelei szárnyason hasgattak vagy félbeszárnyasok.

Sorapár. Diplotaxis. 210

6. Bibéje felálló s egymásıa boruló 2 lemezecskéböl áll, 4 fölbb porodája töve szárnyas.

Estike. Hesperis. 204

Bibéje egyszerủ tompa, vagy hegyes, néha 2 lemezü is, de lemezei letüremlettek; szálcsái nem szárnyasok. 7.

7. Beczöje kopácsai innélküliek, vagy csak töveiken van az in kezdetének némi jele. 8.

Beczöje kopácsai hosszában menő $1,3,5$ vagy sok inúak. 9.

8. Csirája kelö levelei éle mindkét felöl összeránczoltak; husos és pikkelyes fogú tögyökere vízirányosan áll.

Fogasír. Dentaria. 203 
Csirája kelő levelei laposan kiterültek; csonka tögyökere nem fogas, tögyökere ragy rostos, ragy orsóalaku.

Foszlár. Cardamine. 203

9. Beczöjök hengeres, áralaku vagy lapos csőrön végzödik; magrok gömbalaku. 10.

Beczöjöknek nincsen csöre; ha pedig kurta csörïk van, akkor magvai hosszukások vagy tojásdadok. 11. 10. Kopácsain egy hosszában menö, vagy e mellett két felöl csavargós, alig szembetünő oldal ina ran.

Káposzta. Brassica. 208

Kopácsain 3, vagy 5 kiálló ina van.

Mustál. Sinapis. 209

11. Kopácsain hosszában menő egy in, ragy e helyett hosszában menö több ér van. 12.

Kopácsain hosszában menő 3 ina ran. 1 ó.

12. Beczöje lapos, vagy valamennyire domboru, kopácsai kiálló vagy elmosódott egy-inúak, vagy e helyett hosszában menö eresek; csészéje levelei törein belöl pikkelylyé nőtt egy-egy ikra van.

Ikrapikk. Arabis. 202

Beczője 4 szögü vagy hengeres. 13.

13. Levelei épek, épélüek vagy fogasok; beczője 4 szögü.

Szegees. Erysimum. 207

Levelei szárnyason szabdaltak, vagy az alsók legalább félbeszárnyasok. 14.

14. Beczője lapított, 4 szögü; magvai gömbalakuak.

Tormáncs. Barbarea. 201

Beczöje csaknem hengeres; magvai tojásdadok ragy hosszukások.

Nyulga. Evucastrum. 209

15. Bibéje tompa, ép vagy alig kicsípett; beczője hengeres, szálas vagy áralaku.

Zsombor. Sisymbrium. 205

Bibéje hegyes, kúp- ragy áralaku, karélyai kissé széllyelállók; beczője régén bibéjéből lett kupalaku kurta esöre van.

Málika. Malcolmia. 204 


\section{Sereg. EGYFALKÁSOK. Monadelphia.}

1. Rend. Ötporodájuak. Pentandria.

1. Bokrétája 5 szirmu. 2.

Lapor.

Bokrétája egy tagu, 5 metszeti̋. 3.

2. Levelei szárnyason bevagdaltak, vagy karélyosak.

(Lásd XVI. Ser. 2. R.)

Árórr. Erodium. Gerely. Geranium. 250-251

Levelei épek és épélüek. (Lásd V. Ser. 5. R.)

Len. Limum. 253

3. Bokrétája torkát husos hengerkévé nőtt porodái zárják be. (Lásd T. Ser. 2. R.)

Czinka. Cynanchum. 180

Bokrétája torka nyílt (V. Ser. 1. R.)

Lizinka. Lysimachia. 168

\section{Rend. Tizporodájuak. Decandria.}

1. Levelei hármasok. levélkéi visszás-szívesek. (Lásd X. Ser. 5. R.) Sósdi. Oxalis. 255

Levelei tenyereseu karélyosak, vagy szárnyason bevagdaltak. 2.

2. Mind a tiz porodája ki van fejlödve; tokja kopácsai megérésekor alólról feselve, !ívalakulag kunkorodnak fel.

Gerely. Geranium. 251

Öt porodája ki van fejlödve, öt nincs tökéletesen kifejlödve ; tokja kopácsai megérésekor alulról feselve csavarosan kunkorodnak fel.

Árórr. Erodium. 250

3. Rend. Sokporodájuak. Polyandria.

1. Csészéje egyszeres.

Sárla. Abutilon. 239

Csészéje kétszeres. 2.

2. Külső csészéje 3-12 levelü. 3.

Külső csészéje 2-9 metszetü. 4 . 
3. Külsö esészéje :3 levelü; termései lappos sajtalaku körben ülnek s megérésekor egymagvu termésekre hullanak széllyel.

Mályva. Malva. 238 Külsö esészéje 6-12 levelü; 5 rekeszü tok termése 5 kopácscsal nyílik fel.

Hibik. Hibiscus. 239

4. Külső csészéje 3 metszetü. Külsö csészéje 6-9 metszetü.

Paizssajt. Lavatera. 237 Zilíz. Althea. 238

\section{Sereg. KÉTFALKÁSOK. Diadelphia.}

1. Rend. Hatporodájuak. Hexandria.

1. Bokrétája f’első szirma tövön zacskós; kerekded termése makkocskanemü, egy magvu, fel nem nyíló.

Fiistike. Fumaria. 200

2. Bokrétája hosszu sarkantyus; termése beczőnemü tok, sokmagvu, két kopácsu. Likasír. Corydalis. 209

\section{Rend. Nyolczporodájuak. Octandria.}

Csészéje 5 levelü, a két belsö levele igen nagy, szárnyhoz hasonló, sziromnemü ; $3-8$ szirma szálcxáival összenött. Csészeszárny. Polygala. 243

\section{Rend. Tizporodájuak. Decandria.}

\section{Pillangós viráguali.}

1. Mind a tiz szálesája szabadon áll. (X. Ser. 1. R.)

Czerczisz. Cercis. L. 293

Mind a tiz szálesája egy csomóba nött. 2.

2. Egyűvé nőtt szálcsái maghonát behüvelyezik; termésök hüvely. 3.

Szálcsái két csomóba nöttek, azaz: 9 szálcsa összenött, a vitorlája felöl álló egy szálesa szabadon áll; termésök ugyancsak hüvely. 9.

3. Bokrétája szárnyai felső részén ránczosak; csészéje 1-2 ajaku. 4. 
Bolrtétája szárnyai nem ránczosak; csészéje 5 fogu vagy alig két ajaku. 6.

4. Csészéje felül mélyen behasított, egy ajaku, aszottas hártya széle 3-5 foggal tóldott, csolnakja 2 szirmu; hüvelye lapos.

Jenester. Spartium. 271

Csészéje harangalaku vagy csöves, 2 ajaku. 5.

5. Levelei egyszerüek, épek ; csolnakja tompa végü ; szálcsái hegyek felé elszélesedők ; bibéje belső oldalán menedékes, ferde.

Rekettye. Fenista. 271

Levelei hármasok, csolnakja tompa végü; szálcsái hegyök felé nem szélesednek el; bibéje külső oldalán menedékes.

Zanót. Cytisus. 272

6. Levelei hármasok csolnakja hegyes végü; szálcsái hegyök felé kiszélesednek.

Iglicz. Ononis. 273

Levelei páratlan szárnyasok. 7.

7. C'sészéje 5 fogu, magva megérésekor száraz széleivel hüvelyét bezárja s hasas; szálcsái felül kiszélesedők; virágzata szárhegyi csomóban van.

Szapuka. Anthyllis. 274

8. Ćsészéje 5 metszetü, magva megérésekor is nyitva marad, hártya szélü; szálcsái áralakuak, virágzata hónalji fürt.

Gálga. Galega. 282

9. Hüvelye 2 kopácsu s nem czikkes. 10.

Hüvelye czikkes, keresztbe szakadozó. 28.

10. Bibeszára kopasz. 11.

Bibeszára szőrös. 21.

11. Csolnakja csörös, kihegyezett. 12.

Csolnakja nem csörös, egyszerüen hegyes vagy tompa. 13.

12. Hüvelye hengeres, vagy lapított szárnyatlan, felnyílt kopácsai csavarosan megtekeredettek; bibeszára lassankint hegyesedik el. Kerep. Lotus. 281 Hüvelye négyszögü, mindenik ormóján széles szárnyas ; bibeszára felfelé vastagabb.

Szárnyók. Tetragonolobus. 282. 
13. Csomóba nőtt szálesái szirmaival ki.ebł nagyobb mértékben összenöttek ; 1 -5 magvu hiivelyét elszáradt virágai takarják.

Lóherc. Trifolium. 276

Csomóba nött szálcsái szimaival nem nöttek össze. 14.

14. Csolnakja 2 szirmu; hïvelye börnemü, , lapított.

Csolnakja 1 szirmu. 15,

Higviricz. Glycyrhiza. 282

15. Hüvelye hosszában kisebb nagyobb mértékben két rekeszü. 16.

Hüvelye egy rekeszü. 17.

16. Tompa végü csolnakján nines szálka; hüvelye alsó forradása válaszfallá hajlik be.

Bóka. Astrógalus. 283

Tompa végü csolnakja vége alól egy kalászalaku szálka indul ki; hüvelye felsö forradása válaszfallá nyomul be. Sajkorr. Oxytropis. 283

17. H ïvelye csigamódra tekeredett, vagy sarlóalaku. 1 - sokmagvu.

C'sigaesö. Meticago. 274

Hüvelye más alaku. 18.

1S. Csolnakja hegye ferdén csonka; egy magvu kemény hïvelye, visszás-tojásdad, alsó forradásán szárnyas ormóju, síma vagy fésüfogas, hálózatosan horpadozott.

Esparczet. Onobrychis. 280

Csolnakja hegye tompa. 19.

19. Szárnya hegyei összenöttek, közepén hólyagosan felfuvóduttak, csolnakja hegye sötét lilaszínü: hïvelye gömbalaku.

Dornik. Dorycnium. $2 s 1$

Szárnya hegyei nem nöttek össze. 20.

20. Hüvelye kurta, 'puffadt, tojásdad, 1-3̂ magru, virágzata tojásdad, vagy lefïggő fürt.

Mézkerep. Melilotus. 275

Hüvelye szálas lapos, sok magvu; virágzata 6 vagy

több ernyős csomó.

Lepkeszeg. Trigonella. 275

21. Fák vagy cserjék. 22.

Füféle növények $\mathbf{2 s .}$ 
92. Bibeszára fonalalaku szörös, elől szakálas; bibéje bibeszára végén van, hüvelye lapos, szálas hosszukás; fürtje függő, virága fejér. Ákász. Robinia. 282

Bibeszára félhengeres, tövétől fel tömötten szörös, hegye horgas; bibéje horga hajlásában van; hüvelye hólyagosan felfuvódott ; fürtje felálló, virága sárga vagy piros.

Dudafiirt. Colutea. 283

23. Bibeszára köröskörül, vagy a belsö oldalán hoszszában szőrös. 24.

Bibeszára hegye alatt a külső oldalán szakálas, egyébütt kopasz vagy molyhos. $\mathbf{2 7}$.

24. Bibeszára fonalalaku, hegyén köröskörül szörös, egyébütt kopasz.

Lencse. Ervum.

289

Bibeszíra nem fonalalaku. $\mathbf{2 5}$.

25. Bibeszára 3-élü, oldalról lapított, tövén felül ormós, alól válus, hegye szakálas.

Borsó. Pisum. 290

Bibeszára hegye lapos, egyenlö széles vagy felül szélesebb, hegye befelé hajló. 26.

26. Párosan. szárnyas, vagy páros levele nyelei kacscson végzödnek.

Bükköny. Lathyrus. 290

Párosan szárnyas levele nyelei végén nincsen kaccs.

Lednek. Orobus. 292

27. Bibeszára egyenes, alól szakálas, felül s körül molyhos; csészéje 5 fogu, vagy 5 metszetü, a felső foga kurtább.

Babó. Vicia. 286

Bibeszára, porodái és csolnakja csavarosan megtekeredett, csészéje 2 ajaku. Paszuly. Phaseolus. 293

28. Hüvelye csaknem hengeres; vagy 4 ormóju czikkein begyüremlett, 1 magu. Kornilla. Coronilla. 285. Hüvelye lapított, magva sinórját tartó forradása felöl öblösen kikanyarított, vagy karélyos; magva félköralakulag meggörbült.

Patkóczím. Hippocrepis. 286 
XVIII. Sereg. SOKFALKÁSOK. Polyadelphia.

1. Rend. Sokporodájuak. Polyandria.

Szálcsái 3, 5 vagy 6 falkába nöttek; csészéje 5 levelü vagy 5 hasábu; bokrétája 5 szirmu; bibeszára 3; tokja 3 rekeszü. Linka. Hypericum. 240

XIX. Sereg. FORRT-PORTOKUAK. Syngenesia.

Ezen seregbe tartozó növények rendeit szándéliosan mellözöm, hogy meghatcivozásuli ez ciltal is könnyitve leggen.

1. Minden virága félszer vagyis nyelvalaku.. Minden virága csöves, 5 (ritkán kevesebb) fogu; vagy néha fészke kerületén levő virágainak nincs is bokrétája, hanem e helyett fészke belsö színes levelei alkotják a sugarát. 16.

Fészke kerületén levő virágai félszeresek, vagy nyelvalakuak; a többiek (közép virágai) csövesek, 5 foguak. 42.

2. Magvának (söt a maghonának is) bóbitája van. 3. Magvának (és annálfogva maghonának) nincs bóbitája; magván azonban a bóbita helyett néha egy bokrocska polyva van. 15.

3. Bóbitája szőrei egyszerüek, ágatlanok. 4.

Bóbitája szőrei ágasok vagy tollasok, azaz: oldaláról ismét szőröcskék nőttek. 10.

4. Virágai számszerint öten vannak, s egyetlen kört alkotnak.

Csakkör. Prenanthes. 115

Virágai számosak, kettős vagy többes körben állanak. 5.

5. Magvai csőrnélküliek, bóbitája emnélfogva nyeletlen. 6.

Magvai vékony csőrủek, bóbitái ennélfogva nyelesek. 8. 
6. Magvai lapítottak; bóbitája hajlós nem törékeny ; levelei kopaszok, élein tüskés szemszőrtỉek.

C'sorbóka. Sonchus. 116

Magvai hengeresek, vagy alig laposak; levelei élén nincsenek tüskés szemszőrök. 7.

7. Magvai felső végei vékonyabbak, mint az alsó elhegyesedésıe hajlók; bóbitája szép fejér, rendszerint hajlós és nem törékeny. Aszász. Crepis. 116

Magvai felső végei alsó végeinél nem vékonyabbak, sőt vastagabbak, csonkák: bóbitája piszkos sárgás, nem hajlós, törékeny. Holgyomál. Hieracium. 117

8. Tökocsányja egy virágu, csöves; virágai többszörös körüek; magvai hegyeiken puha tüske pikkelyüek, vagy finoman görcsösek.

Pitypang. Taraxacum. 113

Sok virágu szára van. ".

9. Magvai esőre tövét polyvanemü koszoruk vagy pikkelyek veszik körül; virágai két körben állanak; fészke alatt nehány levélből álló murvaköre van.

Kakies. Chondrilla. 114

Magvai csőre tövén sem koszoruk, sem pikkelyek nincsenek; fészke fedelékesen egymásra boruló egyenetlen pikkelyekből áll; virágai 1-3 köıt alkotuak; magvai lapítottak.

Saláta. Lactuca. 114

10. Taczka polyvás, polyvái egyes virágait egymástól elkülönözik, a magva megérésekor, magvával együtt leválnak. Polyvahordó. Hypochaeris. 110 Vaczka kopasz. 11.

11. Fészke levélkéi mind egyenlök; tövön összenöttek, murvaköre nincs. Kecskedísz. Tragopogon. 111

Fészlke levélkéi egyenetlen hosszuságuak. 12.

12. Fészke murvaköre levélkéi lekonyultak; bóbitája tövön egy gyürübe nőtt s könnyen lehulló. 
Fészkének nincs murvaköre, fészke levélkéi vagy pikkelyei mind lelapultak. 13.

19. Bóbitája olclal szöröcskéi nincsenek egymásba szövödve, bóbitája nem hull le; fészke pikkelyei mind egyenlö szélesek, szálas láncsások; tőkocsányja van.

Arszlánfog. Leontodon. 111

Bóbitája oldal szöröcskéi egymásba szövődtek ; fészke pikkelyei tövön szélesebbek, felfelé lassanként elkeskenyednek; száruk van. 14.

14. Fészke alsó pikkelyei hátán lefelé álló apró fogai vannak; magva alja, egyéb részénél jóval vastagabb, ezen levő poczka alsó részén homoru.

Magpoczok. Podospermum. 113

Fészke alsó pikkelyei hátán nincsenek fogak; magvai tövön nem poczkosak. Pozlor. Ścorzonera. 112

15. Fészke levélkéi konyák; magvai láncsás polyvákkal vannak koszoruzva; virága kék.

Katáng. Cichorium. 110

Fészke levélkéi lelapultak; magvain nines polyva koszoru ; magvai 20 rovátkuak ; virága sárga.

Válupikk. Lapsana. 110

16. Minden virágnak fedelékes kïlön csészéje van s mindnyája együtt egy golyóalakú gömböt alkot; bóbitája koszorúalaku; kopasz vaczka golyóalaku.

Laptaborz. Echinops. 102

Az egyes virágoknak nincs külön csészéjök. 17.

17. Magva bóbitás. 18.

Magva bóbitátlan. 40.

18. Vaczka polyvás, vagy sertés, vagy sejtes. 19.

Vaczka kopasz. 31.

19. Fészke pikkelyei 2 soruak, a külsö sor letïremlett; levelei ellenesek. (Lásd 56. sz.)

Villamag. Bidens. 94

Fészke pikkelyei fedelélkesek; levelei váltogatók. 20. 20. Vaczka sejtes, sejtgödre szélei megszakadozottak, 
sok soru szörös csaknem tollas bóbitája tövön egy gyürübe nött össze; magva visszás tojásclad, lapított 4-szögü ; fészke levei tövishegyüek.

Bordon. Onorpodon. 106

Vaczka polyvás vagy sertés, de nem sejtes, 21.

21. Bóbitája tollas. 22.

Bóbitája szőrös, sertés vagy polyvás. 23.

22. Fészke belső levélkéi sugárzók, szálasok, szímesek, száraz hártyások és tövistelenek, a külsők kurtábbak, füneműek és tövisesek; bóbitája egy soru minden virágában van poroda is terme is.

Körfény. Carlina. 103

Fészke belső levélkéi nem sugárzók; bóbitája sok soru, mindenik tollas, alól gyürübe nöttek s lehullók; virága csöves-harangalaku, rendszerint tökélytelen kétlaki; magva lapított, hosszukás.

Báres. Cirsium. 108

28. Fészke belső levélkéi a külsőknél hosszabbak, sugárzók, színesek és tövistelenek, a külsők száraz hártyások; szélső virágai csövesek, kétajakuak s bennök terme van, közép virágai csövesek, 5 foguak, porodások és termések; belső magvai bóbitái 5-10 láncsás polyvából állanak; vaczka is polyvás.

Vasvirág:. Xeranthemum. 103

Fészke belső levélkéi nem sugárosak. 24.

24. Vaczka belső szélén köröskörül termésvirágai között polyvás, közepén kopasz; fészke apró 5 szögű vagy kupalaku, külső levélkéi gyapjasok, a belsők hártyások.

Pamár. Filago. 99

Vaczka egészen polyvás vagy szörös. 25.

25. Fészke levélkéi horoghegyüek; virágaiban megvan 
a terme is, a poroda is; sok soru bóbitája serte polyvás; fészke csaknem gömbalaku.

Bojtorján. Lappa. 109

Fészke levélkéi nem horoghegyüek, különféleképen alakultak. $\mathbf{2 6}$.

26. Tojásdad fészke kïlső levélkéi szára felső leveleivel egyenlök, öblös szárnyas szabásuak, a belsök hosszudad láncsások, hártyanemüek; virágai tökélyesek, 5́ metszetüek; 4 lapu magvai visszás-tojásdadok.

Gordon. Kentrophyllum. 106

Fészke külsö levélkéi szára felső leveleitől különböznek. 27.

27. Bóbitája 3-sok soru, állandó gyürübe nem nőtt össze, külső sora a többinél hosszabb, a belsö kurtább. 28.

Bóbitája 2-sok soru. lehulló ; bokrétája mind egyenlö csöves. $\mathbf{2 9}$.

28. Magva hosszukás, lapított; bóbitája sok soru; bokrétája egyenlö vagy a szélsők nagyobbak a többinél s tölcséresek, ïresek; fészke levélkéi rojtosak, vagy prémesek vagy néha tövisesek.

Csiikiillö. Centanea. 104

Magva hengeres, visszás-tojásdad; bóbitája 3 soru; szélsö virágai a többinél hosszabbak szálas tölcséresek, ferde szélüek, ïresek; fészke levélkéi láncsások, kihegyezettek, prémetlenek és tövistelenek.

Bóbitagyász. Cprupina. 103

29. Magvai visszás tornyadzó alakuak, négyszögüek; 2-3 soru serte polyvás bóbitája magva tetején álló, kurta hengeres vánkosra nött és ezzel egyïtt lehulló; csőre belső sora a külsőnél hosszabb.

Puhonez. Jurinea. 105 
Magvai hosszukások, lapítottak; bóbitája sok soru. 30. 30. Bóbitája sertepolyvás, gyürübe nem növő, a belső sor’a hosszabb a többinél; virágai tökélyesek vagy kétalakiak.

Zsoltima. Serratula. 109

Bóbitája szörös; tövön gyürübe nőtt, sorai egyenlők; virágai tökélyesek.

Bogáes. Carduus. 106

31. Fészke levélkéi egysoruak vagy ez alatt még egy murvakör is van. 32.

Fészke levélkéi fedelékesek, vagy 2-3 soruak. 34.

32. Fökocsányja alacsony, pikkelyes tetején fejes bugás virágzata van; fészkei kétalakiak; termésvirágu fészkeiben sugárvirágai többsoruak. porodás virágu fészkeiben egysoruak. Kalapfü. Petasites.

Szára leveles. 33.

33. Fészkét 1 vagy több levélkéből álló murvakör veszi körül.

Üszögör. Senecio. 101

Fészkét murvakör nem környezi.

Dugasor. Cineraria. 102

34. Levelei ellenesek. 3-5 hasábuak; fészkei 5-6 viráguak, virágai tökélyesek; bibeszára fonalalaku s megnyult.

Pakócza. Eupatorium. 88

Levelei váltogatók, épek; fészkei sokviráguak. 35.

35. Minden virága tőkélyes, 5 metszetü, sárga; bibéje tojásdad.

Aranyfürt. Linosyris.

Sugárvirágaiban csupán terme van; bibéi félhengeresek. 36.

36. Portokai tövéröl serteszálak nöttek. 37.

Portokai tővéről nem nöttek serteszálak.

Kiillörojt. Erigeron. 90

37. Sugárvirágai szabálytalanok, 3 metszetüek, egysoruak. 38.

Sugárvirágai fonalalakuak, 1-5 soruak, hegyökön fogasoltak. $\mathbf{3 9}$. 
Lapon

38. Bóbitája szörei egyenlők; sugárvirágaiban csupán terme van, középvirágai 5 foguak, tökélyesek ; portokai tövéről két szál serte nött.

Sertecsék. Inula. 91

Bóbitája szőrös, szörei külsö köre kurta s egy koszoruba nött.

Balluafï. Pulicaria. 93

39. Fészke 5 szögű, vagy kupalaku, apró ; külső levélkéi gyapjasok. (Lásd 24.)

Pamár. Filago. 99

Fészke félgömb vagy hengeralaku, levélkéi száraz hártyások, vagy a külsők fünemüek, kopaszok, különféle szinüek.

Gyopár. Gnaphatium.

40. Fészke levélkéi 5-9 egy sorban s lazâll állanak; minden virága csöves, szélsö virágai is 5-9 magot termők, közép virágai tökélyesek vagy csak porodások, de terméketlenek, vaczka kopasz.

Molyhár. Micropus.

Fészke levélkéi fedelékesek. 41.

41. Fészke félgömbalaku vagy tojásdad; vaczka kopasz vagy gyapjas bolyhos; virágzata füzéres vagy füirtös ; virágai tökélyesek, vagy a szélsők fonalalakuak s termések; magrvai visszás-tojásdadok, tetejökön egy kis keskeny tányérocska van.

Üröm. Artemisia.

Fészke félgömbalaku, virágzata bogernyös; vaczka kopasz; virágai tökélyesek, vagy a szélsők fonalalakuak, 3 foguak ; magvai szegletesen rovátkoltak, a tetejökön levö tányérocska olyan széles, mint a mag teteje.

Varádics. Tanacetum. 99

42. Magvai mindnyájan vagy legalább a középsök bóbitások. 48.

Minden magva bóbitátlan. 53. 
43. Pikkelyes tőkocsánya van; levelei tövéről nőttek. 44.

Leveles száruak. 45.

44. Szára hegyén egy fészke van ; sugárvirágai többsoruak, sárgák, csupán terme van bennök; középvirágai tökélyesek.

Szattyu. Tussilago. 88

Virágzata fejes bugás (Lásd a 32. szám alatt.)

Kalapfï. Petasites. 88

45. Sugárvirágai sárgák. 46.

Sugárvirágai más szinüek. 51 .

46. Fészke levélkéi mind egyenlők. 47.

Fészke levélkéi egyenetlenek s egymást többszörösen hátalják. 49.

47. Fészkét 1 vagy több levélböl álló murvakör veszi körül; fészke levélkéi hegyei rendszerint feketék ; néha nincs sugáros virága. (Lásd 33. sz.)

Üs\%ögör. Senecio. 101

Fészkét murvakör nem környezi. 48.

45. A szélső körben álló magvainak nincs bóbitájok; bibéjök hegye egyéb részöknél vastagabb.

Tarkör. Doronicum. 100

Minden magra bóbitás; bibéje csonka, vagy fonalalaku.

Dugasor. Cineraria. 102

49. Portokai tövéről nem nöttek serteszálak; sugárvirágai egy sorban állanak, számszerint 5-5.

Ritkaréj. Solidago. 90

Portokai tövéről két serteszál nőtt; sugárvirágai sokan vannak. $\mathbf{5 0}$.

50. Bobitája egyenlö szörökböl áll. (Lásd 38. szám.)

Sertecsék. Inula. 91

Bóbitája szőrei külső köre egy koszoruba nött s a belsőknél kurtább. (Lásd 38. szám.)

Ballıafï. Pulicaria. 93 
Lapon

51. Termét tartalmazó szélső virágai több soruak, ezek közül a külsökör keskeny nyelvalaku és a sugárát alkotja. (Lásd 36. szám.)

Kiillörojt. Erigeron.

Termét tartalmazó szélsö virágai egysoruak, széles láncsások. 52.

52. Termés sugárvirágai is teremuek magvakat.

Gerepesill. Aster.

Sugárvirágaiban nincsenek tenyészszervek s annál fogva nem is teremnek magvakat.

Csillagesín. Galatella.

53. Vaczka kopasz. ๖4.

Vaczka polyvás. 56.

54. Fészke pikkelyei szegélytelenek s egyenlö hoszszuk; vaczka kupos ; töliocsányja egy virágu ; magvai egyformák.

Rukercz. Bellis. 90

Fészke pikkelyei hártyaszegélyüek. jo.

5.5. Vaczka laposan domboru.

Aranyvirág. Chrysanthemum. 96

Vaczka kupos.

Szikfii. Matricaria. 96

56. Fészke pikkelyei kétsoruak, egyenlök, a belső sorbeliek felállók, a külsők letüremlettek ; négyszögü magvainak 2-4 horgas foga van; szélső virágai néha sugárosak, néha nem. (Lásd 19 szám.)

Villamag. Bidens. 94

Fészke pikkelyei egyenetlenek, fedelékesek. 57.

57. Fészke pikkelyei hegyei lehajlók; magvairól 2-4 polyva bóbitája lehulló. Napvirág. Helianthus. 93

Fészke pikkelyei egymásra lapultak; magvai bóbitátlanok. 58.

58. Sugárvirágai igen szélesek, csaknem kerekdedek, vagy szívesek, 10-nél nem igen több.

Criczkóró. Achillea. 94 
Sugárvirágai hosszukások, számosak; fészke félgömbalaku vagy lapos.

Montika. Anthemis. 95

\section{Sereg. PORODÁS TERMÉJÜEK. Gynandria.}

1. Rend. Egyporodájuak. Monandria.

1. Alsó ajaka (mézajaka) alólról sarkantyus vagy zacskós. 2.

Alsó ajaka se nem sarkantyus, se nem zacskós. 8.

2. Levelei helyett tökocsányján burkok vannak, portokai terméje hegyén szabadon állanak; sarkantyuja áralaku, lefelé álló. Gérbicz. Limodorum.

Tövéről vagy száráról levelei nöttek; kétrekeszü portokai terméje elörészén állanak. 3.

3. Alsó ajaka ép, szálas; portoka rekeszei aláfelé csöröcskéje kikanyarított öble által vannak elválasztva.

Sarkar. Platanthera.

Alsó ajaka több karélyu, vagy éle bevagdalt, vagy csipkés. 4.

4. Alsó ajjaka 1-2 hüvelyk s a még ki nem nyílt, vagy épen nyíló félben levő virágában sodros; portokai rekeszei alól egy zacskócskával vannak egybekötve.

Sodortajk. Himanthoglossum.

Alsó ajaka sokkal kurtább s nem sodros. 5.

5. Portokai 2 nyelecskéje, egy rekeszü zacskócskájánál fogva van a bibe ikrájához növe; 3 felsö szirma összeáll, a két oldali nyílt; alsó ajaka 3 metszetü; sarkantyúja akkora. mint a maghona, vagy valamivel hosszabb.

Ragikra. Anacamptys. 52

Portoka 2 nyelecskéje mindegyike bibéje 2 ikrájára van nőve. 6. 
6. Portoka rekeszei alól egymástól elállanak, zacskócskájok nincs; alsó ajaka széles láncsás, a hegye felé kiszélesedő, 3 fogú ; kurta sarkantyuja zacskóalaku.

Nyelvür. Coeloglossum.

Portoka rekeszei párhuzamosak; alsó ajaka széles, leginkább karélyos. 7.

7. Bibéje mindkét ikrája 2 rekeszü zacskócskába van záródva.

Kosbor. Orchis.

Zacskócskája nincs.

Csorikra. Gymnadenia.

8. Alsó ajaka 2 tagu. 9. Alsó ajaka nem tagolt. 10.

9. Leple harangalaku, kissé nyílt; maghona kurta esavaros nyelen függ. azonban maga nem csavaros.

Bibak. Epipactis. 54

Leple szirmai felállók, összetartók; nyeletlen ma.ghona csavaros.

Porfej. Cephalanthera.

10. Tökocsányja kopasz vagy hártya pikkelyes, levelei nincsenek; ajaka visszás-szíves; portokai szabadok. Az egész növény piszkos sárga, végre barnás.

Tokafék. Neottia.

Szára leveles. 11.

11. Leple szirmai kiterültek, vagy más szóval: virága kinyílt. 12.

Leple szirmai felfelé állók, vagy összetartók. 14.

12. Alsó ajaka előre álló, széles, bársonyos-barna; portoka rekeszei maghonához nöttek, de alól egymástól elállók.

Bangó. Ophrys.

Alsó ajaka hátra felé fordult, felálló; portokai szabadok. 13.

13. Portokai állandók, 4 porgolyója páronként nőtt a maghonára; leple nyílt, belső szirmai tojásdadok.

Bibefog. Malaxis. 
Portokai lehullók; tompa ajaka tojásdad; leple szirmai szálas-ékalakuak. Hagymabur. Stırmia.

14. Alsó ajaka szabadon lefüggö, 2 metszetü; leple szirmai sisakalakulag összeállanak; maghona teteje hátsó része tojásdad-kontyu, melynek a tövére vagy a tetejére nött a portoka; szárán 2 ellenes levele van.

Bibekonty. Listera.

Alsó ajakát leple alsó szirmai foglalják be, vagy alsó ajaka felfelé álló, ép, igen tompa, elől csipkés ; portokai szabadok, nyeletlenek.

Füzértekercs. Spiranthes.

2. Rend. Kétporodájuak. Diandria.

Leple 4 szirmu keresztalakuan kinyílt, az alsó 2 metszetü; ajaka czipőalakuan felfuvódott, lefelé álló; maghona teteje 3 metszetü, portokai ezen metszetek 2 szélsőjére nöttek.

Czipöczim. Cypripedium.

3. Rend. Hatporodájuak. Hexandria.

Leple sárgás szinü csöres, csöve tövön hasas, hegye lepittyedt nyelvalaku. Gégevirág. Avistolochia.

\section{Sereg. EGYLAKIAK. Monoecia.}

A XXI. és XXII-clik seregbeta rtozónö vényeket Limné porodáiz szamánál fogva aillitotta rendekibe; de mivel mind a két sereg számos rendet foglal magúban és mivel némely rendbe 1-2 növény jut; a növények könnyebb meghatcirozhatcisa miatt a rendeliet itt jónak láttam mellözni.

1. Vízi növények. 2.

Szárazi növények. 9. 
2. Vizen uszó s gyökerét a vizbe eresztő növény ; szára levélnemü; van 2 porodája s 1 maghona.

Lepese. Lemna. 58

Gyökerét az iszapba ereszti. szára és levelei a vizben, vagy a vizen usznak, vagy a víz felett állanak. 3.

3. Virágai magánosak, hónaljiak. 4.

Virágai virágzatot alkotnak. 6.

4. Porodás virága leple 10-12 metszetü; 5-sok portoka van. - Termés virága leple 9-12 metszetü, maghona 1, termésén bibeszára megmarad; levelei gyürüsek.

Locsagaz. Ceratophyllum. 60

Porodás virágai leplét 1-2 murva pótolja, levelei ellenesek, épek. ò.

5. Egy porodáját 2 ellenes murva védi; bibeszára 2 ; száraz csontár termése 4 felé esik; levelei hosszuékalakuak, vagy szálasok. Moesárhúr. Callitriche.

Egy porodáját egy hártyanemü murva védi; porodás virágában levő 1 porodája fonalaku ; tökélyes virágában porodája szintén 1, maghona 4, bibéje paizsalaku; levelei sertés-szálasok. Galáz. Zanichellia. 56

6. Virágzata gyürüs vagy esomós; levelei sertealakuak vagy keskeny szálasok. 7.

Virágzata buzogányos füzér, levelei laposak, széles szálasok. 8.

7. Porodás virága esészéje 4 karélyu ; bokrétája 4 szirmu, lehulló; porodája 8. Termésvirága 4 fogu, csészéje felsö; szirmai igen aprók; bibéje 4, bolyhos; termése száraz esontár, mely megérésekor 4 felé esik; víz alá merült levelei gyürüsek, mélyen szárnyason hasgatott serte sallanguak.

Tóborosta: Myriophyllum. 257

Kancsóalaku egy tagu, 2-3 fogu porodás burka 1 portokát magába zárja. 'Termésvirága 2-3 bibe- 
Lapon

száru egy csupasz maghonból áll ; száraz csontára 1 magvu; csavargós élü levelei szálasok.

Hínár. Najas. 56

8. Porodás és termés virágai hengeres fïzérben (buzogányban) szára hegyén vannak, felül a porodás, alattok a termés virágok; maghonait serték veszik körül; állandó bibeszára termésére rá van növe.

Gyékény. Tyдһa. 59

Füzérei gömbalakuak, felsö gömbjében porodás, az alsókban termésvirágai vannak; leple több levelü, polyvanemü; száraz és szurós csontára kocsánykátlan.

Baka. Sparganium. 59

9. Füféle növények. 10.

Faféle növények. 23.

10. Pázsit vagy palkafélék (sások.) 11.

Nem pázsitfélék. 12.

11. Porodás virágai szárhegyi széllyelterpedt lugában állanak; termés virágai egy vagy több oldali torzsán (csövön) vannak, melyet levelek hüvelyeznek be, bibeszára igen sok, hajhoz hasonló.

Kukoricza. Zea.

Egy-, ritkán kétlaki virágai füzéresek; egyes virágait egy polyva burkolja; porodás virágai 3 porodások; termés virágai kancsóalaku leple makkocskájával összenőnek.

Sás. Caìex. 23

12. Virágai csészések és bokrétások. 13.

Virágai leplesek, leple 1-sok szirmu vagy levelï, vagy ez is hiányzik s burok helyettesíti. 16.

13. Csészéje 3 levelü, bokrétája 3 szirmu ; porodája sok. Termés virága porodás virágához hasonló, sok maghona csak gömbalaku vaczkán ül.

Syilfü. Sugittaria. 33 
Csészéje és bokrétája egy tagu, 4-5 metszetü, vagy hasábu. 14.

14. Termése borsó nagyságu, síma, fekete bogyó; virágzata fürtösen sátorozó; virága 1, vagy 2 laki.

Gönye. Bryonia. 224

Termése nagy kabak; 1 laki virágai magánosak. hónaljiak. 15.

15. Magvai kiálló szegélytuiek; portokai csővé nőttek össze. kaccsai ágasok.

Tök. Cucurbita. 223

Magvai élesek, szegélytelenek; portokai összetartók; kaccsai egyszerüek.

Ugorka. Cucumis. 224

16. Virágzata torzsa, melyet egy tölcséres hártyacsuklya burkol, vagy hüvelyez be; torzsája hegye bunkós, kopasz; közepén vannak köröskörül porodái, töve felé szőrös bibéjü maghonai; termései 1 magru bogyók.

Kontyvirág. Arum. 58

Virágzata másalaku. 17.

17. Levelei szárnyasok; virágzata szárhegyi csomós, a csomó felső részén esők termések, az alsóbbak porodások ; leple helyét pótló csészéje 4 metszetü ; porodája 20-30; bibéje ecsetalaku.

Csábair. Poterium. 268

Levelei egyszerüek, épek vagy karélyosak. 18.

18. Porodája 10-sok, kocsányos maghona hasas lepléből kinyulik; leple harangalaku 4-5 fogu, fogai félhold vagy 2 szarvu fedöjével (ikrájával) váltogatva állanak; bibeszára 3 , két metszetü; tokja 3 czikkü, czikkei egy magvuak; virágzata ernyős.

Fütéj. Fuphorbia. 245

Porodája 3-5. 19.

19. Virágait fészekalaku gallér veszi körül; porodás virágai galléra sok levelü, termésvirágai galléra 
egytagu, 2 virágu; termés virágának leple nines; horgas tüskéjü magrrejtöje megkeményedö gallérából fejlik ki.

Csimpaj. Xanthium. 119

Virágai nincsenek gallérban. 20.

20. Bibéje gombos ecsetalaku; porodás virága leple 4 hasábu, porodája 4. 21.

Bibéje vagy bibeszáta 2, fonalaku. 2:2.

21. Egy vagy kétlaki virágai bugás virágzatot alkotnak; porodás virága leple 4 hasábu, termésvirágaié keresztbeálló 4 levelü ; levelei ellenesek s szárával együtt csípős fulánkos szőrüek.

Csalán. Urtica. 64

Virágai felemások ; csípő fulánkszőrei nincsenek. (Lásd IV. Ser. 1. R.)

Falfï. Parietaria. 65

22. Mind kétféle virágai leple 3-5 levelü, mindenik virága alatt 3 murva van, porodás virágaiban $3-5$ poroda, termés virágaiban 2-3 bibe van; 1 magvu szütyő termése derekán nyíló.

Amaránt. Amaranthus.

Termés virága termésével együtt növő leple 2 kopácsu, murvanemü s lapított; porodás és felemás virágaié $3-5$ hasábu; porodája $3-5$; termésvirágából származott magva felfelé, tökélyes virágáról fejlett magvai vízirányosan állanak; egyikféle virága tövén sines murva.

Maglapél. Atriplex.

23. Körtealaku husos vaczka bezáródott, virágai vaczka belső oldalán vannak; felül eső porodás virágai leple 3 hasábu, porodája 3; termésvirágai leple 5 hasábu, maghona kocsánykás, bibeszára 2 bibéjü.

Fige. Ficus. 64

Virágai külsők, nincsenek a vaczkába záródva. 24. 
24. Termés virágai barkában vannak ragy füzéresek. 25.

Termés virígai magánosak, vagy 2-3-sok $\mathbf{3 0}$.

25. Porodás és termésbarkái golyóalakuak, igen kurta, számos porodái közt esalknem ékalaku pikkelyek vannak; visszás tornyadzóalaku terméi is számosak sं ezek közt is pikkelyek vannak; makkocskái tövön koszorusak.

Boglárfa. Platames.

Barkái nem golyóalakuak. 26.

26. Porodás és termés barkái 3-5-ével fürtösek, hengeres, porodás barkái pikkelyei paizsalakuak. kocsányosak. mindenikben 3 lepel, mindenik leplében 4 poroda van; termésbarkái hosszukások, pikkelyei tojásdadok, 2 viráguak; magva megérésekor megfásulnak; magva lapított.

Égerfa. Alnus. 61

Barkái vagy füzérei magánosak. 27.

27. Porodás és termés füzérei tömöttek; termés barkái tojásdadok; leple 4 szirmu, maghona 2 bibéjü; makkocskáját husossá fejlö leple zárja be. termése esomós álbogyó vagy csontár; porodás füzérei hosszukás-hengeresek; leple 4 hasábu. porodája 4.

Eperfa. Morus. 64

Porodás és termés barkái pikkelyalaku murvákból alakultak. 28 .

23. Porodás barkája fedelékes pikkelyei paizsalakuak. kocsányosak. mindenik pikkely belső oldalán 3 kisebb murva van 4 porodával, portokai nem szakálasok; termés barkái pikkelyei kocsánykátlanok, töveiken 2-4 mellékpikkelylyel és 2-4 maghonnal; bibeszára 2. magva szárnyas. 
Porodás barkái pikkelyei mellett nincsenek murvák, porodạ́ja 12 - s több, portokai hegyei szakálasok; telmésbarkái pikkelyei lazán állanak; makkocskái nem szárnyasok. 29.

99. Termés barkái szálasok, lehulló murvái láncsások. minclenik murva tövén 3 karélyu, szegletes fogu s kocsánykás 2 pikkely van, melyek magva megerésekor 2 burokká s együtt mindnyájan tobozzá fejlenek ki.

Gyertyánfa. Carpinus.

T'ermés barkái egyes virágai mellett 2 murvája van, melyek épélüek, tövön szörösek, éleiknél fogva összenöttek s maghonait befoglalják; érett magvait tartalmazó toboza tojásdad, a komlóéhoz nagyon hasonló.

Veniczfa. Ostrya.

30. Levelei páratlan szárnyasok; porodás barkái oldaliak, karélyos pikkelyeik alatt 12-24 porodája van; termés virága 1-3-ankint az ághegyeken ülnek; csöves esészéje maghonához nött, 4 fogu, bokrétája 4 fogból áll, bibéje 2 ; termése csontár.

Diófa. Juglans. 249

Levelei magánosak, épek, vagy öblösen karélyosak. 31.

31. Porodás virágai hosszu kocsányon függő, esaknem golyóalaku barkában vannak, 5-6 metszetü leple harangalaku; porodája 8-12, termésvirága felálló, hónalji, vagy szárhegyi, burka kancsóalaku. csaknem 4 karélyu, szálas murváiba göngyölt s azzal összenött. 2 maghonán 2 bibe van; tojásdad termése makknemü négyélï borzas-tüskés kopánes, bele :-szögü.

Bikkfa. Fagns. 36

Porodás barkái hengeresek vagy szálasok. 32.

32. Porodás barkái szálasok. felállók, leple 5̆-6 hasábu, porodája 10-20, termésvirágai magánosak, 
vagy 2-3-an vannak együtt s borzas tüskés gallér fogja öket körül; 5-8 metszetü leple maghonával egygyénőtt, bibéje 5-8; tüskés kopácsában 1-3 makkja van, makkja héjja börnemü, belső oldalán selymes szörü.

Gesztenyefa. Castanea.

Porodás barkái lefüggők. 33.

33. Porodás barkái hengeresek; fedelékes pikkelyei alatt 2 pikkelyecske és 8 poroda van; termés virágai bimbóalakuak, fedelékesen pikkelyesek, alsó pikkelyei üresek, a felsők 2 viráguak, bibeszára 2; egy rekeszü makkját rongyos, fogas száju kopánes burkolja be. Mogyorófa. Corylus.

Porodás barkái szakgatottak, leple 6-8 hasábu, porodája 6-8; termésvirágai bimbóalakuak, fedelékesen pikkelyesek, egyviráguak, bibéje 3 karélyu; félgolyóalaku kopáncsban îlö makkjai egyrekeszüek.

Tölgyfa. Quercus.

\section{Sereg. KÉTLAKIAK. Dioecia.}

1. Virágai csészések és bokrétások. 2. Virágai leplesek vagy polyvások. 13.

2. Fák vagy eserjék. 3. Füféle növények. 9.

3. Fákon élődő, villás ágazatu cserjék. 4. Földböl növő fák vagy cserjék. う̌.

4. Virágai szárhegyi fürtben vannak, tökélyesek vagy kétlakiak; csészéje szélei igen kurták, felsök; szirma 6 ; porodás virágaiban 6 poroda van, termés virága 1 ; maghona tetején egy bibeszára van; termése 1 magvu bogyó. Fakín. Loranthus. 185 Virágai szára hegyén 3-5-tével állanak csomóban; porodás virága husos-börnemü, csészéje 4 hasábu, 


\section{CXXIX}

Lapon

porodája 4 ; termésvirága esészéje karimája elmosódott, szabadon álló husos-börnemü szirma 4, bibéje száratlan; termése 1 magvu bogyó.

Fagyöngy. Viscum. 185

5. Levelei füzöttek. 6 .

Levelei egyszerỉek, épek, vagy karélyosak. 8.

6. Levelei hármasok. (Lásd V. Ser. 3. R.)

Szömörcze. Rhus. L. 249

Levelei szál’nyasok. 7.

7. Porodás virágaiban két portokos szálesi van. (Lásd II. Ser. 1. R.)

Körisfa. Fraxinus. L. 129

Porodás virágaiban 4 portokos szálcsa van.

ítorua. Negundo. Mönch. 242

8. Porodás virágaiban 8 poroda van; esészeje 5 hasábu, bokrétája 5 szirmu, levelei ellenesek. (Lásd VIII. Ser. 1. R.)

Jávor. Acer. 241

Porodás virágaiban porodái szirmaival ellenesen állanak; termés virága maghona felsö; termése esontár. (Lásd V. Ser. 1. R.) Benge. Rhamnus. 245

9. Bokrétája egy tagu, harangalaku; csészéje 5 fogu; termése bogyó. (Lásd XXI. Ser. 14. szám alatt.)

Gönye. Bryonia. 224

Bokrétája ’̈-5 szirmu. 10.

10. Vízi növények; esészéje 3 hasábu; bokrétája 3 szirmu. 11.

Szárazi növények. 12.

11. Tőkocsányja hegyén levő porodás 1-5 virágát 2 levelü burok fogja körül; porodája 9, hárma tövéről bibeszáralaku' szálacska nyulik virága közepére ; termésvirága tövén, burkában 1 virág van, 3-6 porodájának esak a szálcsája van meg; portoka nincs, bibéje 6 , két hasábu; termése bogyó.

Potnya. Hydrocharis. 46 
Porodás virágar tőkocsányja hegyén levő 2 levelü burkában 1-5-en vannak, sokporodások. Termésvirága, tökocsányja hegyén 2 levelü burkában, csak egy van, sok porodájának esak szálcsái vannak meg, portokai hiányzanak; bibéje 6 , két metszetü; termése bogyó. Kolokán. Stratiotes.

12. Szirmai két metszetűek. torkolatán pilisesek; termésvirágaiban 5bibesz ár van. (Lásd X. Ser. 5. R.)

Mécsvirág. Lychnis. 236

Szirmai épek, torkán pilistelenek ; termésvirágaiban 3 bibeszára van. (Lásd X. Sereg 3. R.)

Sziléne. Silene. 294

13. Palka- vagy füféle növények. 14.

Fák vagy cserjék. 23.

14. Palkaféle növény; virágzata szárhegyi egyszerü füzér. (Lásd XXI. Ser. 11. szám alatt.) Sás. Carex. 23 Füféle növények. 15.

15. Vizen úszók, vagy víz alámerültek. 16. Szárazföldi növények. 17.

16. Kerek- vagy hosszukás levelei a vízszínén usznak, gyökereit a vízbe ereszti stb. (Lásd II. Ser. 1. Rend; XXI. Ser. 2. szám alatt.) Lepese. Lemna. 58 Csavargós élï levelei szálasok, virágai hónaljiak. (Lásd XXI. Ser. 7. szám.) Hínár. Nąjas. jo

17. Porodás és termésvirágai leple 6 hasábu. 18. Porodás és termésvirágai leple 6-nál kevesebb hasábu vagy épen hiányzik. 20.

19. Virágzata szárhegyi álgyürüs-fürt. (Lásd VI. Ser. 3. Rend.)

Lórom. Rumex. 76

Kocsányjai az ág vagy a levél hónaljából nőttek. 19.

19. Kocsányjai magánosak, az ág hónaljából nőttek; levelei serte- vagy láncsaalakuak. (Lásd. VI. Ser. 
Fürtjei levélhónaljiak; leple harangalaku; porodás virágaiban 6 poroda van; termésvirágaiban maghona alsó, bibeszára 3 metszetï ; termése bogyó ; levelei szívesek.

Folyondár. Tamus.

20. Levelei ujjasok, porodás virágai leple 5 hasábu. porodája 5 ; termésvirágai leple egytagu, oldalról felhasított; bibeszára 2.

Kender. Cannabis. 65

Levelei egyszerüek, vagy karélyosak. 21.

21. Szára felfutó; levelei 3-5 karélyuak; porodás virágai bugások, leple 5 hasábu, porodája 5 ; termésvirágai fedelékesen egymást hátaló murvákból alakult barkában vagy tobozban, mindenik murva alatt 2 virága van; bibeszára 2 .

Komló. Humulus.

Szára felálló; levelei épek. 22.

22. Levelei ellenesek, szárával együtt csípős fulánkos szőrűek. (Lásd XXI. Ser. 21. szám alatt.)

Csalán. Urtica.

Levelei ellenesek, csípős ször vagy fulánk nélküliek;

leple 3-4 hasábu; porodás virágaiban 8-12 poroda van; termés virágai 2-3 bibeszáruak; tokja 2-3 golyóju; mindenikben egy-egy mag van.

Szélfü. Mercurialis. 248

93. Leveletlen cserjécske; porodás virágai füzéralaku barkában vannak, leple 2 metszetü, porodája 1s több, szálcsái együvé nőttek; termésvirágai bimbóalaku 2 viráguak, tövén 2 pikkely van; bibeszára 2 ; termése bogyó. Bogyópikk. Fphedra. 60 Leveles cserjék, vagy fák. 24.

24. Levelei szárnyasok; csészéje és bokrétája 4 hasábu, vagy mindkettő hiányzik ; porodás viráguiban 2 poroda van. Termésvirágai egy bibeszáruak és 2 bibéjüek; termése 2 rekeszü leppendék. (Lásd II. Ser. 1. R.)

Körisfa. Fraxinus. 129

Levelei egyszerüek, vagy öblösek. 25. 
25. Virágai körtealaku husos vaczka belső oldalán fejlenek ki s abba vannak záródva. (Lásd XXI. Ser. 23. szánı alatt.)

Figefa. Ficus. 64

Virágai külsők, nincsenek a vaczkába záródva. 26.

26. Levelei szálasok, mindég zöldek, tüalakuak; gömbalaku porodás barkái tojásdad pikkelyekböl alakultak, mindenik pikkelye alsó s előszélén 4-6 portok van. Termésvirágai pikkelyalaku murvákból alakult bimbó, 3 maghona tövön összenött ; termése csontárnenü 1-3 magvu gyümölcs.

Boróka. Juniperus. 60

Levelei más szabásuak, legalább is szálas láncsások. Lomıos fák. 27.

27. Barkái nuuvái rongyosak; leple f’erde száju poháralaku; porodás virágaiban 7-20 poroda van. Termésvirágai maghonai magánosak, 2 bibéjének egy bibeszára van; 2 kopácsu tokja sok magvu, magvai bóbitások.

Nyárfa. Populus. 68

Barkái murvái pikkelyalakuak, épek; leple nincs, e helyett 1-2 mézikrája van; porodás virágai 1-5 porodások. Termésvirágai maghonai egyrekeszüek, bibeszára 1 vagy egy sincs, bibéje 2 ; sok magvu tokja 2 kopácsu, magvai bóbitások.

Füz. Salix. 


\section{II.}

A fajok meghatározására szolgáló táblázat.

Endlicher rendszere szerint rendezve.

TÖRZSNÖVÉNYEK. Cormophyta.

II. Al-Osztály.

\section{Körnövök. Amphibrya.*)}

1. Rend. Pázsitfélék. Gramineae. Juss.

1. TÖRFÜ. Lepturus. $R$. Br.

Füzére hengerded, áralaku, súgár; levelei rövidek, szálasok, hegyesek, levele hüvelyei kopaszok, felsö levele szélesebb, mint az alsóbbak, nyelvecskéje hosszukás, fogas ; szalmája felegyenesedő, bütykös. $\odot$ Szíkes-téreken, tavak mellett. Üllö, Alberti, Tass vidékén. Jun. Juli $3-\delta^{\prime \prime}$. (Pholiurus Trin, Rotbellia. Roth.)

Széki T. L. pannonicus. Trin.

\section{Kolászbojt. Aegilops. L.}

Fűzére súgár hengeres ; levelei kopaszok, ritka szörüek, érdesek, levele hüvelyei szemszőrösek, nyelvecskéje igen kurta. ( Homokos helyeken. Maj.-Jun. ${ }^{1 / 2}-1^{1 / 2}$.

Üstökös K. Ae. caudata. $L$.

*) Az I. Alosztály, Csúcsnövők = Acrobrya, mint a mely a virágtalan növények (Cryptogamia) egy részét foglalja magában, e virányban előadva nincs; e mü csupán a virágos növényekre (Phanerogamia) szoritkozik. 


\section{3. ÁRPA. Hordeum. L.}

1. Minden virága tökélyes, vagy csak az oldalt állók olỵanok, melyekben csupán poroda van, de ezek mindig. kalásztalanok. $\mathbf{2}$.

Oldalt álló virágaiban csupán poroda van, vagy a sines, minden virága kalászos. 5.

2. Mindenil füzérkéje tökélyes. 3.

Oldalt álló füzérkéiben csupán poroda van s ezek kalásztalanok, csak a középen álló virágok tökélyesek és kalászosak. 4.

3. Füzére egyenetlenül hatsoru, két sor a két oldalán kijjebb áll. Mivelik $\odot$

Közönséges Á. II. vulgare. $I$. Füzére egyenlöen hatsoru. Mivelik $\odot$. (Ösz (i)pa.)

Hatsoros Á. H. hexastichon. I.

4. Füzére kétsoru ; tökélyes virágán a füzérhez lapult kalász van. Mivelik $\odot$

Laposfejï Á. H. distichon. $L$.

Füzére kétsoru, tökélyes közép virágán levö kalásza lefelé hajló. Mivelik $\odot$.

Német Á. H. zeocriton. L.

5. Középfüzérkéi murvái szálas láncsások, mindkétfelül szemszörösek. oldalt álló füzérkéje külsö murvája sertealaku. Útakon, legelökön, falakon stb. közönséges. $\odot$ Jun.-Sept. ${ }^{1}{ }_{2-1}$. $\quad$ Egér Á. H. murimum. L. Középfüzérkéi murvái sertésen érdesek, vagy csak érdesek, nem szemszörösek. Mindenütt, futóhomokon is. (-) 3-8". Maj.-Jun. Tengeri i. H. maritimum. With.

\section{CZImbor. Elymus. I.}

1. Murvái ormói szemszörösek, áralakuan láncsások, hegỵesek, füzérkéinél hosszabbak. levelei durvák, begöngyölödöttek. 4. Jul.-Ang.

Fövény Cz. E. arenarius. I.

Murvái ormói szemszörtelenek, egyenesek, áralakuak. kalászosak, alsó ondói durvák, kalászosak, levelei laposak 2. 
2. Levelei laposak, gindárok, hegyesek, érdesek, tövön szörösek, éleik visszásan borzasok. Ligetekben, vágásokon, bokrokban 24. Jun.-Aug. 1-3'.

Europai Cz. E. Europaeus. L.

Levelei keskenyek. élök érdes; murvái sertealakuak; kalászai különbözö hosszuságuak. Terméketlen homokon, Sz.-Endre mellett. $\odot$. Maj.-Jun. ${ }^{1}{ }_{2}-1 / 1 / 2$.

Hajas Cz. L. crinitus. L.

\section{RoZs. Secale. T.}

1. Főkocsányja szíjjas: murvái kurtábbak, mint füzérkéi, s kalászosak. Mivelik. azonban útfeleken vadon is nö. $\odot$ és $\odot$. Jun-Aug.

Gahona R. S. cereale. $L$.

2. Fökocsányja czikkesen törékeny. murvái s kalászai igen hosszuk. Homokos mezön. a pesti városliget körnỵékén. ๑. Jun.-Jul. 1-2'.

Törékeny R. S. fragile. MI. I3.

\section{BUZA. Triticum. L.}

1. Füzérkéi kisebb-nagyobb mértékben felfuvódott hasasok ${ }_{2}$ kopácsai tojásdadok. vagy hosszukások. 2.

Füzérkéi nem fuvodtak fel hasason, kopácsai láncsísok, vagy láncsásan hosszukások, hegyök egyenes, nincs kifelé hajolva; füzérei két soruak. 4.

2. Füzére két sorn; füzérkéi leginkább 3-4 viráguak, lapitottak, murvái kalászosak, külsö murvái kalászai hoszszabbak, murvái inai szörösek, levelei szálasok, mind a két lapján szörösödők. - A pesti váczi töltésen

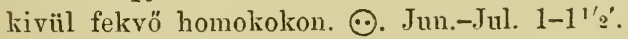

Bolyhos B. T. villosum. M. T.

Füzére négy oldalu. vagy oldalról lapitott. Mivelés alatti fajaink. 3.

3. Fökocsányja törékeny; füzére fökocsányja szélesebb oldala felöl lapitott, laza s fedelékes; füzérkéi töbl. nyire 4 viráguak; kopácsai széles tojásdadok, csonkák. 
2 foguak, elsö foga kisebh, termése ondójába zárt. (-). Jun.-Jul. Mivelik. (Töntöly; tenkely; piros alakor).

Tönköly B. T. Spelta. L.

Főkocsányja szíjjas, éle szörös; kopácsa háta kerekded boltozatos, melyen egy kiálló tompa ina van : termése szabad. Nivelik $\odot$ és $\odot$. Jun.-Jul. (Ösz ès tarasz buz(i).

Közönséges B. T. vulgare. $L$.

4. Kopácsai láncsások, hegyesek, vagy hosszukások. 5.

Kopácsai áralakuak, kihegyezettek. 6.

๖. Kopácsai lánesások, う̌ inuak, hegyesek, virágai hegyesek vagy tompák. Mezökön, legelökön közönséges gaz. 2-4'. 24. Jun.-Jul. (Perje, ebgyógyitó fü; tarackk.)

Taraczk B. T. repens. $L$.

Kopácsai hosszukások, $5-7$ inuak, tompák ; virágai is tompák, egyébkint az elöbbivel egyenlö. - Köves helyeken, gyepükben és útfeleken 4. Jul.-Aug.

Hamvas B. T. glaucum. Dest.

6. Füzérkéi 5 viráguak, kopácsai áralakuak, kihegyezettek, virágai hosszu kalászosak; levelei laposak, mindkét oldalán érdesek. - Ligeteken, vágásokon, Buda vidékén. 2-6'. 24. Jun.-Jul. Eb. B. T. caninum. Schreb. Füzérkéi 5--20 viráguak, ellenesek, lapitottak, levelei szálas-serte alakuak. élei begöngyöltek, alig szörösek. Tarjagos B. T, cristatum. Schreb.

\section{\%. VADÓCZ. Lolium. L.}

1. Töréröl virágzó szalmákat és nem virágzó levélesomókat hajt. $\mathbf{2}$

Tövéröl csak virágzó szalmákat hajt. 3.

2. Fiatal levelei begöngyölödöttek, levelei szálas láncsások, hegyesek, érdesek, szára felegyenesedö, kopasz. Réteken, legelökön. 24. Maj.-Aug. 1/2-1/1/2'. (Kutya $z a b$; angol perje).

Útféli $V$. L. perenne. $L$.

Kopácsai csaknem olyan hosszuk ragy kurtábbak, mint füzérkéi; levelei szálas láncsások, szalmája egyenes, 
felül érdeskés. - Árua, zab és len retésekben, ritka $\odot$ Maj.-Jun. 1-2'. Mezei V. L. arvense. With.

\section{NYELECZ. Brachypodium. P. B.}

1. Gyökere rostos; levele konya; füzére kétsoru, lefüggü, felsö virágai kalásza hosszabb, mint az ondója. Lirdős helyeken. 4. Jun.-Jul. 2-3'. (Triticum sylicaticum.) Erdei Ny. B. sylcaticum. R. és Sch.

2. Tögyökre terjedö; levelei egyenesen ảllók: füzére leginkább kétsoru s felálló; füzérkéi kalászai kurtábbak, mint az ondója. Vágásokon, füves hegyeken. köves téreken. 4. Jun.-Jul. 2-3.' (Triticum pinuatum.)

Szárnyas Ny. B. pimnatmm. P. I.

\section{CSEnkesz. Festuca. L.}

1. Levelei sertealakuak, gyökere rostos. 2. Levelei szálasok, vagy láncsás szálas laposak. 3.

2. Bugája keskeny, tömött, felálló, kurta kocsánykáju; füzérkéi hosszudadok, 4 viráguak, kalászosak; szalmája vékony. Gyepes helyeken közönséges. 24. Maj.Jul. 1-1 1/2'. (Jul perje). Jnh Cs. F. ovina $L$.

A füvészek különféle változatait ismernek. a milyenek: F. glauca és duriuscula. - F. vaganita stb.

Bugája nyúlt, pongyola, hegye bókoló, füzérkéi 5 viráguak. virágocskái lánesás áralakuak, kalászosak: szalmái pázsitosak. Erdőkben, vágásokon. a Jánoshegyen. 24. Jul.-Aug. 2-3'.

Sertetövï Cs. F. heterophylla. Lam.

3. Kalászai a rirágai hegye alól indulnak, kalásza kétannyi. mint ondója, tekergős; bugája terepély, kocsányjai hegyein lefüggők. - Bokrokban, ligeteken vágásokon, kivált nyirkos helyeken, 4. Jun.-Sept. $3-5$, .

Oriás Cs. F. giganted. Will.

Virágai kalásztalanok, alsó ondója hegye alatt törises. vagy a nélküli. 4. 
4. Bugája terepély, lefüggö ; kocsányjai érdesek, két-két águak, mindeniken 5-15 füzérke van; füzérkéi 4-.; viráguak. Nedves réteken, bokrokban. 24. Jun.-Jul. $3-6{ }^{\prime}$.

Yádas Cs. F. arundinacea. Schvel). Bugája egyoldali, tömött, virágzás idején lefüggő; kocsányjai érdesek, rendszerint két águak, egyike ezeknek kurta s rajta egy füzérke van, másika fürtös s :-4 füzérkéjü ; füzérkéi 6-10 viráguak. Réteken igen közönséges, azonban található árkokban és mocsáros helyeken is. 24. Jun.-Jul. 2-4'.

Magas Cs. F. elatior. $L$.

\section{ROZSNOK. Bromus. L.}

1. Funzérkéi, elvirágzás után is, a hegyök felé keskenyeb. bek. 2 .

Füzérkéi a hegyök felé szélesebbek; alsó kopácsa 1, a felső 3 inú; felsö ondója fésűalakulag sertés szemszörös. 8.

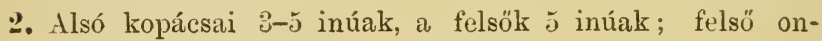
dója szélén kemény szemszőrök vannak. 3.

Alsó kopácsai 1 inúak, a felsök 3 iníak; felsö ondója. szélén kurta s puha szemszörök vannak. 7.

:. Levele hüvelyei kopaszok; termést tartalmazó virágai végre kifelé hajlók, hengerdedek, kopaszok, kalászai tekergősek vagy egyenesek, bugája lefüggö. - Közönségesen vetések között s füves téreken. $\odot$. Jun.Aug, 1-1/1/2. (Rozsnot.) Grabona R. B. secalinus. $L$. Levele hüvelyei, vagy legalább az alsó levelek hüvelyei szörösek; termést tartalmazó virágai széleivel egymást fedelékesen hátalják; alsó ondója 7 inú. 4.

4. Bugája felálló, vagy csak a hegye függö. 5. Bugája lefüggő. 6.

j. Füzérkéi tojásdad hosszudadok, lapitvi puttiudtak, kopaszok, 6-10 viráguak, virágocskái körkörösek, halászai egyenesek, ép. de csonka végü ondóival egyenől 
hosszuk; szalmája egyenes, felső része érdes. Füves helyeken, útfeleken, vágásokon. $\odot$ Jun.-Jul. 1-1 $1 / 2^{\prime}$.

Fürtös R. B. racemosus. $L$.

Füzérkéi tojásdad hosszudadok, lapitva puffadtak, érdesecskék, puhán szörösödők, 6 - sok viráguak, virágocskái körkörösek, kalászai egyenesek s kétfogu ondóival egyenlö hosszuk; az egész növény szörösödö. Vindenütt. $\odot$. Maj.-Jnl. 1-1 1/2'.

Puha R. B. mollis. $L$.

6. Füzérkéi tojásdad láncsások, alig lapitottak, วั-8 viráguak, kopaszok, kalászai egyenesek, kétfogu ondóival egyenlö hosszuk; szalmája egyenes, kopasz. Füvesek-

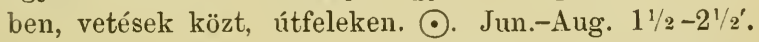
Ugar R. B. arrensis. $L$.

Füzérkéi hosszudad láncsások, lapitottak, sok viráguak fényesek, kalászai elébb egyenesek, de éréskor berzedten kifelé hajlók, néha meg is tekergettek. Száraz mezökön. homokon. $\odot$ Jun.-Jul. 1-1 1/3'.

Berzedt R. B. squarrosus. $L$.

7. Bugája bókoló; füzérkéi szálas láncsások, 6-10 viráguak, szörösödők, kalászosak, kalászai ondójánál kurtábbak, egyenesek; levelei szálas láncsások, borzasok. Jigetekben, hegyi erdők vágásain. 4. Jun.-Jul. 2-4",

Durva R. P. asper. Murr.

Bugája felálló, csaknem egyenlö ; füzérkéi szálas láncsások, hengerdedek, J-8 :viráguak, kopaszok, kalásztalanok, vagy igen kurta kalászuak: levelei szálas lánesások, kopaszok. Füves téreken, útfeleken, árkokban. 4. Jun.-Jul. 1-3'. Árva R. B. inermis. Leys.

8. Bugája egyszerű, pongyola, kevés virágu ; füzérkéi szálas láncsásosak, lapitottak, i-10 viráguak, virágai áralakuak, kalászosak; levelei, valamint levele hüvelyei is szörösek, érdesek, szalmája kopasz. Füves helyeken. legelökön. vágásokon.

๑. Maj.-Jul. 1-2'.

Yeddö R. P. sterilis. L. 
Bugája pongyola, sok virágu; fuzérkéi szálasok, szörösödők, 5-6 viráguak, virágai kalászosak, kalászai ondóival csaknem egyenlök; levelei s levélhüvelyei szörösek. Fűves téreken, legelökön, házfedeleken, kőfalakon. $\odot$. Jun.-Jul. 1-2'. $\quad$ Fedél R. B. tectorum. L.

\section{Czinczor. Cynosorus. L.}

Szalmája sugár, egyenes, 1-2'; bugája füzéralaku, tömött: mindenik füzérkéje tövén egy szárnyasan szabott murvája van. - Gyepes hegyeken, de nem gyakori. 4. Jnn.-Jul. 1-2'. Tarjagos Cz. C. cristatus. L.

\section{REZGE. Briza. L.}

Levele nyelve igen kurta, csonka; bugája felálló; füzérkéi szives-tojásdadok, oldalról lapitottak, 5-9 riríguak. Gyepes helyeken. 4. Jun.-Jul. 1-2'.

Közép R. B. media $L$.

\section{EBIR. Dactylis. L.}

Bugája felálló ; füzérkéi tömötten esomósak; füzérkéi láncsások, lapitottak, érdesek. alsó ondói 5 inúak; levelei szálasok, hegyesek. Gyepes téreken, legelökön, útfeleken, stb. 24. Maj.-Aug. 1-4'.

Csomós E. D. glomerata. $L$.

\section{PerJe. Poa. L.}

1. Bugája és füzérkéi kocsányjai kurták, füzérkei tömöttek, fökocsányja lapos, törékeny: ondói bőrnemüek, tompák. Az egész növény halványzöld. Útfeleken $\odot$. Maj.-Jun. 3-8".

Durva P. P. dura. L. Bugája pongyola, kocsánykái részben nyult vékony águak. 2.

2. Levele hüvelye nyelvecskéi, kivált a felsőké, hosszukásak, elörenyultak. Gyökere rostos, ostorindája nincs. ङ. Levele hüvelye nyelvecskéi, még a felsőké is, igen kurták és csonkák. 7 . 
3. Szalmája a töre felett bütykös; bugája 2-3 águ érdesecske; virágai nélna levélnemü (hagymaalaku) borsócskákká alakulnak. Mindenütt, de különösen homokos téreken. 24. Kora tavasztól Jul. '²-1'.

Borsókás P. P. bulbosı. $I$.

Virágai nem alakulnak borsócskákká. 4.

4. Bugája kocsányjai kétáguak, ritkán egyesek, söt hármasok is. 5.

Bugája alsó kocsányjai többnyire 5 águak; szalmája 1-3 láb magas. 6.

๖. Bugája kocsányjai elvirágzás után lefelé hajlanak, kopaszok; füzérkéi hosszukás tojásdadok; szalmája kissé lapitott, hajlós. Úton, útfélen; egész nyáron át virágzik. $\odot$. 3-10".

Nyári P. P. anmua $L$.

Bugája kocsányjai nem hajolnak lefelé; szalmája tövét gyepes tömött tőlevelei fogják körül, melyeket szalmájával együtt egy közös burok foglal be; polyvája sarlós és csolnak-alaku. A budai, buda-örsi és budakeszi magasabb hegyeken. 24. Maj.-Jun. '²-1'.

Bérczi B. P. alpina. $L$.

6. Szalmája és levele hüvelyei kopaszok; levelei tövön ránczosak, a legfelső rendszerint hosszabb, mint a hüvelye; ondói inai alig látszók. Mocsárokban és vizenyös réteken. 24. Jun.-Aug. 11/2-4'.

Kövér P. P.fertilis. Host.

Szalmája érdes; felső levele sokkal kurtább, mint a hïvelye; ondóin kiálló inúak. Réteken, kivált nedves helyeken. 4. Maj.-Jul. 1-3’. Sovány P-P.trivialis. L.

7. Füzérkéi többnyire 6 viráguak, láncsások; bugája tömött, gyakran egyoldali, kocsányjai érdesek; szalmája kétélűvé lapult, tövén henyélö; levelei kurták; gyökere erősen terjedő. Réteken, legelökön, köves helyeken, szöllöskertekben. 4 . ' ${ }^{\prime} \_-1 \frac{1}{1} 2^{\prime}$.

Fejes P. P. compressa. L. 
Füzérkei 3-5 viráguak, virágocskáit háta ina alsó részén és élein gyapjunemü szörszál foglalja öszsze. 8 . 8. Virágai 5 inúak; bugája mindenfelé egyenlően terűl ; levele tövén nincs ráncz; felö levele kurtább, mint a hüvelye; töve ostorindákat hajt. Réteken közönséges, a vizenyős helyet leginkább szereti. 4. Maj.-Jul. 1-3’.

Mezei P. P.pratensis. $L$.

Virágai imnélküliek; bugája gyakran féloldali: levelei hüvelyei felett kissé ránczosak; felső levele hosszabb. mint a hüvelye; nyelvecskéje igen kurta, néha alig látszik; bugája kocsányjai csak kettősek. Árnyas erdőkben és gyepeken. Némely változatát az előbbitöl igen nehéz megkülönböztetni. 4. Maj.-Jul. 1-3'.

Ligeti P. P. nemoralis. I.

\section{BAJUSZPÁZstT. Eragrostis. P. B.}

1. Bugája 4-:j legalsó ága félgyürüben áll; füzérkéi szálasok, 5-12 viráguak, meglehetős hegyesek, laposak, fényesek, barna pirosak; levelei szálas láncsások. érdes élüek. Gyepeken és vetések közt. $\odot$. Jun.-Jul. 1/2-11/2. (Poc pilosa L.) Szörös B. E. pilosa. P. A.

2. Füzérkei szálas láncsások, 8-20 viráguak, laposak. fényesek, szürkés pirosak, virágai tompák, inasok; levelei láncsások, érdes élüek, tövön, valamint hüvelyeiken is szörösek. Homokos réteken, legelökön, söt a futó homokon is. $\odot$. Maj.-Aug. 3-12". (Poc Eragrostis. L.) Kesely B. E. pocceoides. P. B.

\section{6. ĖDPÁZSIT. Glyceria. R. Br.}

1. Füzérkéi 4-11 viráguak. 2.

Füzérkéi többnyire 2 viráguak, szálasok, lilaszinüek; virágai hosszukások, három inúak, töve ostorinda által terjedö. Mocsárokban, tavak és árkokban. 4. Maj.-Jul. 1-1 1/2'. (Aira aquatica $L$.

Vízi E. G. aruatica. Presl. 
2. Bugája féloldalıa hajló, kocsányjai virágzás idején derék szöglet alatt lefelé, alsó kocsányjai kettőnként, állók ; virágai láncsás hosszudadok. - Árkokban, mocsárokban. 24. Maj.-Sept. 2-3'. (Festuce fluitans. L.)

Harmat E. G. fluitans. R. Br.

Bugája egyenlően terepély; virágai tompák. 3.

3. Bugája sepröalaku, hosszu farku, igen ágas s nagy; szalmája 4-6 láb magas, vastag, nádnemü. - Álló vizek szélein s folyók partjain. 4. Jun.-Aug. (G. (equatica IVlb. Poa aquat. L.) (Fodorsás.)

Fodorsás E. G. spectabilis. M. és $K$.

Bugája kocsányjai terpedtek, alsó kocsányjai leginkább ötönként, a termést hordók lefelé állanak; virágai tojásdad líncsások. - Vizenyös helyeken, árkokban, kivált szíkes helyeken. 24. Maj.-Aug.

Vígály É. G. distans. Wahl.

\section{1\%. BOGNád. Phragmites. Trin.}

Levelei láncsások, hosszan kihegyezettek; bugája terepély. verhenyes barna; füzérkéi 4-5 viráguak. - Álló vizekben. 4. Jun.-Jul. 8'. (Arundo Phragmites L.) (Niil.)

Fedö B. Ph. communis. Trin.

\section{KÉHENCZ. Molinia. Schrank.}

1. Bugája sötét kékes összeszorult; füzérkéi felállók, kalásztalanok, többnyire 3 viráguak, virága 3 inú; szalmája csaknem kopasz. Nedves erdei réteken, árkokban, tavakban. 4. Jun.-Sept. 2-š'.

Kékellö K. M. coerulea. Mönch.

2. Bugája nyílt; füzérkéi 4-5 viráguak, kalászai kurták; virága 5 inú, szalmáját egész a tetejéig levele hüvelyei boritják. - Buda magas hegyein. 24. Jul.-Aug. $3-5$.

Kései K. M. serotina. M. és $K$. 


\section{LÉHAPÓT. Melica. L.}

1. Alsó ondói szélei tömötten szemszőrösek, gyapjasok; bugája füzéralaku. Köves és gyepes hegyeken, gyepükben. 4. Maj.-Jul. 1-2 ${ }^{1 / 2}$ '.

Prémes L. M. ciliata. $I$.

Alsó ondói szemszőrtelenek; bugája féloldali. 2.

2. Fűzérkéi bókolók. 3.

Füzérkéi felállók. 4.

3. Füzérkéi tojásdadok, alig 3 viráguak, melyek közül kettö tökélyes, egy osak durvány. Árnyas és ligetes hegyeken, erdei patakok partjain. 4. Maj.-Jun. 1-2'.

Függö L. $M$. mutans. $L$.

Füzérkéi hosszukások. hengerdedek, alig három viráguak, a harmadik tökélytelen; ondói fiatal korukban verhenyesek, később szalmaszinüek. - Buda, BudaÖrs, Tétény erdejei szélein. 24. Jun.-Jul. 3-6'.

Óriás L. $M$. altissima. $I$.

4. Füzérkéi tojásdadok, két viráguak, virága egyike tökélỵtelen. Árnyas erdőkben. 24. Maj.-Jun. 1-2'.

Egy virágn L. M. uniflora. $i$.

\section{ə). Polyvabur. Koeleria. Pers.}

Levelei laposak, szálasok, kihegyezettek, az alsók szemszörösek; bugája füzéralaku, füzére alsó részén elvált ; füzérkéi 2-4 viráguak; alsó ondója kihegyezett, kalásztalan vagy fulánkos. - Mindenütt. 24. Maj.-Jul. $1-2$ '.

Taréjos P. K. cristata. P'er's.

\section{BIBIKRA. Sesleria. Ard.}

Levelei láncsások, hirtelen hegyesedök, azonban tompák: füzére tojásdad losszukás, többnyire féloldali; füzérkéi sötét hamuszinüek. 2-3 viráguak; alsó ondója 2-4 sertén s közepéről eredö 1 kalászon végződik. Száraz hegyoldalokon kora tavaszszal gyepet alkot. 4. $1 / 2-1$.

Kék B. S. coerulea. Aril. 


\subsection{HARMADMAG. Hielochloa. (tmel.}

Kocsánykái kopaszok; tökélyes virágai kalásztalanok, a csupán porodát tartalmazók hegyén egy kis kalász van s ugyanennek az ondói szemszörösek. - A veresegylázi szőlöhegyek homokos dombjain. 24. Maj.Jun. 1-2'.

Jószagu H. H. borealis. R. és Schult.

\section{?:P. PORODAPÁR. Anthoxanthum. L.}

Bugája füzéralaku, hosszukás, laza; alsó polyvája felényi, mint füzérkéje s hegyes; ondónemü murvái alsó virágai mellett páronként, lelapult szőrösek, lekerekitve tompák. felényiek, mint a belsö kopácsa. Közönséges. 24. April.-Jun. 1/2-1'. (Borju prizsit).

Illatos P. A. odoratum. $L$.

\section{MÉZFÜ. Holcus. L.}

Gyökere rostos; levelei minclkét oldalán puhaszörïiek; porodás virága kalásza polyvájába van zárva, ragy abból alig ér ki. végén horogalakulag hajlik meg. Réteken, erdökben. 24. Jul.-Aug. 1'²-2'.

Pelyhes M. H.lanatus. $L$.

\section{5. ÜREZAB. Arrhenatherum. P. B.}

Levelei laposak, szálas láncsások: bugája virágzás idején terpeszkedő; tökélytelen virága kalásza kétannyi, mint a polyvája, tökélyes virágáé kurtább. - Hegyi és alföldi gyepeken egyaránt. 24. Jun.-Jul. 3-5”.

Magas $\ddot{\mathbf{U}}$. A. elatius. Glatthafter.

\section{ZAB. Arena. L.}

1. Maghona hegye szörös. 2.

Maghona kopasz. 9.

2. Füzérkéi, legalább virágzás után, lefüggők, polyvái 5-9 inúak. 3.

Füzérkéi nem függők; polyvái 1-3 inúak. 8 . 
3. Virága koesányjai kopaszok, virágai tövén esomósan szörösek. 4.

Virága kocsányjai durva szőrrel gyapjasok; bugája egyenlöen kiterűlt; polyvái leginkább 3 viráguak; felsỏ polyvája 9 inú; virága tövétől egész a közepéig sertésszörös, hegye két metszetü, hátán kalászos. - Tetések közt. ńtfeleken. ○. Jun.-Jul. 1-2'. (Üre- hélavad- szörös-fekete zab.)

Héla Y. A. fatua. $L$.

4. Virágai hosszukások, tompák, kopaszok, vagy felsö részén sertések, akkorák, mint polyvái; felső polyvája 7 inú; bugája féloldali. - Vetések közt. ๑. Jun.-Jul. ?-3’.

Kurta Z. A. brevis. Roth.

Virágai láncsások, hegye igen vékony. 5.

๖. Polyvái leginkább 2 viráguak, hosszabbak, vagy akkorák, mint a virágai: alsó polyvái börnemüek, háta alól síma. hegye felé kiálló ina van. 6.

Polyvái 3 viráguak, kurtábbak, mint virágai; virígain tövüktöl hegyökig erös ina van; hegyök hajszál vékony s kétágu, a felső kalásztalan; bugája féloldali. -Tetések közt. $\odot$ Jun.-Jul. Kopasz Z. A. mudı. L.

6. Polyvái hosszabbak a virágainál; felső polyvája 9 inú; virágai kopaszok, hegyökön két metszetủek és fogasok, felsö virága kalásztalan. 7 .

Polyvái akkorák, mint a virágai ; felsö polyrája 7-9 inú; virágai hátáról meggyökönt kalásza nő, viríga hegge két metszetü. metszetein egyenes kalászocska van; bugája esaknem féloldali. - Vetések közt. • Jun.-Jul. Borostás Z. A. strigosa. Schreh.

7. Bugája egyenlöen kiterülö. - Vetik mindenütt. $\odot$. Jun.-Jul.

Abrak Z. A. sativa. I.

Bugája féloldali, összehuzódó. Vetik és vadon is terem. $\odot$ ○. Jun.-Jul. Zászlós Z. A. orientalis. Schreb.

8. Alsó levelei hüvelye serte szörü, levelei tompa szálasok, mindkét oldalán szörösek; bugája egyenlően terpedt, csaknem fürtös, kurtább kocsánykáin egy, a hosz- 
szabbakon két, az alsón 5 füzérke van; füzérkéi 2-3 viráguak; alsó virágának a hátából nő ki a kalásza, polyvái hegye felé ezüst szinü hártyások. - Kiváltképen hegyi gyepeken. 24. Maj.-Jul. 1-3'.

Csíkos Z. A. pubescens. $I$.

Alsó levele hïvelyei kopaszok; bugája összetartó, fürtös, alsó kocsánykái kettenként állnak, a felsök egyenként; fözérkéje mindeniken magános vagy az alsó leghosszabban kettö van; füzérkéi $4-5$ viráguak, kalásza ondója háta közepéről indul. Hegyi gyepeken, a homokon ritkább. 24. Maj.-Jul. 1-3'.

Mezei Z. A. pratensis. L.

9. Kalásza alsó virága hegyén van; polyvája 7-9 inú ; füzérkéi leginkább 3 viráguak; felső virága hajszálhegyü. két kalászú, ennek, a hátáról indul meggyökönt nagyobb kalásza. - A legszárazabb hegyi réteken Buda körüil. (. Maj.-Jun. 1-1 $\frac{112}{2}$

Czérna 7. A. tenuis. Mönch.

Kalásza nem a virága hegyéböl indul. 10.

10. Bugája egyenlően terpedt. hosszabb kocsánykáin j-8 füzérke van; füzérkéi \& viráguak, virága tengelyei szörösek. Kövér gyepeken. 24. Jun.-Jul. 1-3’.

Sáloga Z. A. flacescens. $L$.

Bugája kinyílt 3 águ; virágai apróbbak, mint a polyvája ; levelei sertealakuak. A budakeszi erdőben. $\odot$. Maj. 2-6". (Aira caryophylla L.)

Szegfii 7. A. caryophyllen. Wigg.

\section{2\%. Bunkọpót. Corynephorus. Palis.}

Tövén tömött pázsit nö; levelei sertealakuak, szürke zöldek: bugája barnás ezüstszinü, kocsányjai virágzáskor lefelé hajolnak, azután összehuzódnak. Solmár. Ửröm, Kalász legszárazabb hegyi rétein. 4. Jum.-Jul. 1' $2-1$ '.

Sziipke B. ('. canescens. T. B. 


\section{NÁPICZ. Aira. L.}

1. Tövén tömött gyep nö; levelei laposkák, nyelvecskéje hosszukás; kalásza sertealaku, akkora, mint az ondója, tövén alig tekeredett. Nedves réteken. 24. Jun.-Aug. ${ }^{1} 2-2^{1} / 2^{\prime}$.

Gyepi N. A. caespitosa. $L$.

2. Levelei keskenyek, csaknem serte-, azonban hengerded fonálalakuak, nyelvecskéi igen kurták, csonkák; második virága kocsányja négyszer kurtább a virágánál; kalásza meg van gyökönve, tövén csavaros. - Soroksár vidékén száraz homokos gyepeken. 4. Jun.-Jul. ${ }^{1} 2-1 \frac{1}{1 / 2}$. (Avena flexuosa. II. és K.)

Vanyiga N. A. flexuosa. $L$.

\section{NÁdTIPPAN. Calamagrostis. Roth.}

1. Második virágához nincs durványa. 2.

Második virágához egy kocsányalaku durványa van. 5.

2. Kalásza a hegyéböl indul s egyenes. 3.

Kalásza háta közepéről vagy azon alól nö ki s egyenes. 4.

3. Kalász igen rövid, ondója hegye kicsipéséböl indul s annál alig hosszabb; szöre hosszabb mint a virágocskája. Nedves réteken, nádasokban. 24. Jun.-Aug. 2-3'.

Fiókos N. C. lanceolata. Roth.

Kalásza akkora, vagy hosszabb, mint ondójának fele; szöre hosszabb, mint a virágocskája. - Mint az elöbbi, a Duna kiöntéseiben Soroksár felé. 24. Jul.-Aug. $1^{1 / 2}-2^{1 / 2^{\prime}}$.

Parti N. C. litorea. DC.

4. Bugája súgár, csomósan karélyos; egyenes kalásza ondója közepéből indul. Hegyi száraz réteken, kivált szőlökben. 24. Jun.-Aug. 2-4'. (Siska).

Siska N. C. Eligeios. Roth.

5. Bugája pongyola, polyvái hegyesek; kalászai ondója hátáról nönek ki, meg vannak gyökönve, ondóinál hosszabbak. Sz.-Endre, Sz.-László és Visegrád erdeiben. 4. Jun.-Aug. 2-4'. Eriei N. C. sylvatica. P. B. 


\section{TIPPAN. Agrostis. L.}

1. Kalásza mindjárt ondója hegye alól indul, hosszu. 2. Kalásza ondója hegyénél jóval alább kezdődik, vagy nincsen is. 3.

2. Bugája buglyos; porodái szálas hosszukások, kalászai 3-4-szer hosszabbak, mint az ondói. Réteken és vetések közt $\odot$. Jun.-Aug. 1-21/2'. (Apera Sp. v. Adans) (Harmattartó). Harmattartó T. A. spica venti. L. Bugája keskenyebb, összetartó, rongyos, porodái kerekded tojásdadok. Száraz, kiváltképen homokos gyepen. $\odot$. Jun.-Jul. 3-12". (Apera interr. P. B.)

Rongyos T. A. interrupta. Trin.

3. Levelei mind laposak, nem igen szélesek, kalásza többnyire nincs. 4.

Tölevelei sertealakuak, nagyon keskenyek. 5.

4. Nyelvecskéje kurta és csonka; bugája kocsánykái virágzás után terepélyen állanak; bugája tojásdad. Száraz és vizenyös gyepeken egyaránt. 4. Jun.-Aug. 1-1 1/2. (Agrostis polymorpha, Huds.)

Czérna T. A. vulgaris. With.

Nyelvecskéje hosszu, elörenyult. Bugája kocsányjai vízirányosan, vagy lefelé állanak, virágzás után összehuzódók, kurtább kocsánykái szörösek; bugája hoszszukás kúpalaku. - Vizenyős gyepeken, tavakban. 4. Jun.-Aug. 1-1 1/2/2. (Agrostis stolonifera. L.)

Fejér T. A. alba. Schrad.

5. Bugája kocsányjai érdesek; bugája buglyos, tojásdad; levelei sertealakuak. Veresegyház közelében levö homokos mezökön. 24. Jun. $1 / 2-1 \frac{1 / 2}{2}$. Eb. T. A. canina. $L$.

\section{KÁSAFÜ. Milium. L.}

Szalmája kopasz ; levelei szálas láncsások ; bugája lefüggö ; ondója hegyes. Hegyi ligetekben. 24. Maj.-Jul. 1-21/2'.

Ziláltfejü K. M. effusum. $L$. 


\section{HAJKA. Stipa. L.}

1. Kalászai tollasok, tekeredetten‘ meggyököntek, néha egy láb hosszuk; alsó ondója alsó részén selymes szőrü 5 vonal van : bugája alsó részét a levele behüvelyezi. A legszárazabb, kivált homokos gyepeken. 24. Maj.Jun. 1-2'. (Árvalányhaj.) Árvalány H. S. pennata. L.

2. Kalászai fonálalakuak; egyéb tekintetben hasonló az elöbbihez. - Ott terem, a hol a másik. 4. Jun.-Aug. $1-3$.

Kunkorgó H. S. capillata. $J_{\text {. }}$.

\section{Csillagpázsitt. Cynodon. Rich.}

Tögyökere ostorindás; levelei alól szörösek; füzérkéi 3-5 ujjasok; ondói kopaszok, alig szemszőrösek. Házaknál, csapásokon és útfeleken közönséges. 4. Jun.Sept. 6-18". (Digitaria stolonifera. Schrad. Panicum. I.) Ujjas Cs. C.Dactylon. Pers,

\section{HERNYÓKA. Beckmannia. Host.}

Füzérei összetettek, ágai féloldaliak; füzérkéi két oldalra fedelékesek, igen kurta kocsánykájuak; levelei láncsások, laposak, hegyesek, érdesek; gyökere terjedö. Ártéreken, árkokban, szíkes helyeken. a síkon mindenütt. 24. Jun.-Aug. 1-3'.

Nyulánk H. B. erucueformis. Hest.

\section{PolyvacsukK. Phalaris. L.}

Bugája megnyult, kinyílt; füzérkéi csomósak; polyvái szánytalanok. - (A kertekben mivelt faját pántlika fünek hivják.) Szíksós és nádas tavakban, árkokban. 4. Jun.-Aug. 2-6'. Pántlika B. P. arundinaceat. $I$.

\section{Komócsin. Phleum.}

1. Füzéralaku hugája egyszerưi, nem karélyos; füzérkéiben nincs egy másik virágnak durváuya; polyvája kalásza, harmadrésznyi mint a polỵra: füzére hengeres, külön- 
bözö hosszusága s halvány zöld. Réteken, kivált a vizenyös helyeket szereti. 4. Maj.-Aug. 1-3'. (Lóper;ie; macskafarki-per;je.)

Mezei K. Ph. pratense. L. Füzéralaku bugája ágas, ágai ugyan fökocsányjához lapultak, de ha bugáját meghajtjuk, ágai azonnal láthatók: füzérkéiben egy másik virágnak is van durványja 2.

2. Polyvája ékalaku, csonkal, hegye felé puffadt, szögletes, fulánkos. Köves gyepes helyeken Buda körül, kivált a. Szt Gellért hegyén. $\odot$. Jun.-Jul. 1/2-1'.

Durra K. Ph. asperum. Fill. Polyvája hosszukás szálas. ferdén csonka, kihegyezett fulánkos, háta durva szemszörös, vagy érdes. - Száraz hegyi és homokos gyepeken. 4. Maj.-Aug. ${ }^{1 / 2}-1^{1} \cdot 2$. Violaszárn K. H. Ph. Böhmeri. Wibel.

\section{3\%. BAJUSZFÜ. Crypsis. Aith.}

1. Szalmája ágas, lapos. 2.

Szalmája egyszerü, hengerded. 3.

2. Levélnemü s bajuszos gallérba foglalt bugája füzére s félgömbalaku : virágai 2 porodások. - Szíkes tavak környékén az egész megyében. ๑. Jul.-Sept. 1-8".

Búbos A. C. aculeata. Aith.

Tojásdad hosszukás bugája tövét felsö levele hüvelyezi ; virágai 3 porodások. Vizenyős helyeken. $\odot$. Jul.-Aug. 6-8". (Phleum Schoenoides L.)

Eeset B. C. Schoenoides. Lam.

3. Bugája füzéres, hosszukás láncsás. kopasz pirosas; virága 3 porodás. Gyepeken mindenütt. $\odot$. Jul.-Sept. 2-4" Füzéres B. C. alopecuroides. Schrar.

\section{ECSE'TPÁZıIT. Alopecurus. T.}

1. Szalmája egyenes. 2. Szalmája felegyenesedö. :3.

2. Bugája füzéralaku, hengeres, tompa, ágain 4-6 füzérke van; polyvái hegyesek, közepén alól összenöttek, 
bolyhosak, ormói szemszörösøk. Réteken s gyepeken mindenütt. 2. Maj.-Jul. s a sarjuban öszszel. 1-3'. (Rókafarkfü.)

Mezei T. A.pratensis. $L$.

Bugája füzéralaku, hengeres, mindkét vége felé elhegyesedö, ágain 1-2 füzérke van; - polyvái közepén alól összenöttek, kopaszok, ormói kurta szemszörüek. Agyagos földön s szántóföldek barázdáin. $\odot$ Jun.-Jul. $1-2^{\prime}$.

Pallagi E. A. agrestis. $L$.

3. Bugája füzéralaku, hengerded füzérkéi tojásdad hosszukások; ondója középen alól kalászos, kalászai csaknem két akkorák, mint az ondója; portokai sárgás fehérek, virágzás után barnák. - Vizenyős helyeken, tavak, patakok és árkok mellett. 24. Maj.-Jul. 1/2-1.

Biitykös E. A. geniculatus. $L$. Bugája füzéralaku, hengerded; füzérkéi körkörösek, kalásza ondója közepéröl nö ki, polyvájánál alig hoszszabb; porodája verhenyes sárga. Talán az elébbi változata. - Az elöbbivel egy helyen terem. 4. Maj.Jul.

Kesely E. A. Fulvus. Sm.

\section{DURCZA. Leersia. L.}

Levelei igen érdesek; bugája kinyílt; kocsányjai hullámosak; füzérkéi 3 porodások, féltojásdadok, szemszörösek. - Vizenyös helyeken a Duna partjain Soroksár felé. 24. Jun.-Aug. 1-2'. Rizs S. L. oryzoides. Sw.

\section{BolyvaborZ. Tragus. Dest.}

Szalmája ágasan elterült, henyélö, bütykein gyökerezö, vagy felegyenesedö; levelei laposak, élökön ritka tüske szemszörök vannak; bugája fürtös. - Homokon. 4. Jun.-Aug. 5-6". (Lappago racemosa. Schreb.)

T'iiskés P. L. recemosus. Desf.

\section{KÖLES. Panicum. L.}

1. Fủzérkéi egyszerüek, csaknem ujjasok, páronként állanak, a pár egyikének hosszabb kocsányja van. 2. 
Füzérkéi bugát alkotnak. 4 .

2. Levelei s levele hüvelyei meglehetősen szörösek; füzérei leginkább ötönként újjalakuak. 3.

Levelei kopaszok; füzerei hármanként újjalakuak; füzérkéi körkörösek szörösödők, inai kopaszok. Zöldség’es kertekben, szőlökben, homokföldeken stb. (•). Jun.Aug. 1/2-1'. (Digitaria filiformis. Koel.)

Kopasz K. P. glabrum. Gaudin.

3. Terméketlen virága ondója kopasz, élén szőrösödö, inai külső oldalán nincsen szemször. - Ez is, mint az előbbi, mivelt helyeken. ○. Jul.-Sept. 1-1/1/2. (Digitaria sanginalis. Scop.)

Pirók K. sangcinale. $L$. Terméketlen virága ondója inai külsö oldalán serte szemszőrök vannak. Mint az elébbiek. (. Jun.-Aug. 1/2-1'. (Digitaria ciliaris. Koel.)

Szemszörös K. P. ciliare. Hetz.

4. Összetett füzérekböl álló bugája féloldali, polyvái kalászosak. - Szántóföldeken, telekes helyeken.. •. Jun.Sept. 1-2'. Echinochloa crusgalli. P. B.)

Kakasláb K. P. Crusgalli. $L$.

Bugája egyenlően kiterült, lefüggő ; polyvái kurta fulánkúak. - Ázsiából került. Mivelik. ๑. Jun.-Jul. 1-3̊’. (Köles.)

Kása K. A. mileaceum. $I$.

\section{MUHAR. Setaria. P. B.}

1. Füzéralaku bugája hengeralaku. ․

Füzéralaku bugája összetett, karélyos; sertealaku murvái elöreálló fogai miatt érdesek; tökélyes virágai ondói meglehetös símák. Mivelik, itt-ott vadon is terem. $\odot$. Jun.-Jul. 7-3', (Rókafarkiı köles; olasz köles.)

Olasz M. italica. P. B.

2. Murvái visszásan álló fogai miatt érdesek; bugája tömött, tövön néha megszakadt; tökélyes virágai ondói meglehetős símák. - Zöldséges kertekben, szántóföldeken. szölökben. $\odot$. Jul.-Aug. ${ }^{1 / 2}-2^{\prime}$.

Ragàló M. S. revticillata. P. P. 
Murvái elöre álló fogainál fogva érdesek 3.

3. Tökélyes virágai ondói meglehetös símák s akkorák, mint tökélytelen virága ondói. Mivelt gyepes téreken mindenütt. - Jun.-Aug. 1'-2'.

Zöld M. S. vividis. P.B.

'T'ökélyes virágai ondói keresztbe ránczosak; murvái rozsdás barna sárgák. Homokos téreken, vetések közt ○. Jun.-Aug. $1-1^{1 / 2}$ '.

Széna M. S. glauca.P. H.

\section{FENYER. Audropogon. L.}

1. Levelei szálasok. válusok, tövön szörösek; füzére újjas j-10 águ ; főkocsányja és kocsánykái szőrősek. — Hegyi és homoki száraz réteken és legelőkön. 4. Jun.Sept. $1-2$.

Szuirke F. A. Ischaemum. L.

2. Levelej szálasok, hegyesek, felül érdesek, szemszörösek ; bugája buglyos, kocsánykái 3 viráguak, kocsánykái tövön szakálasok. - Hegyi és homoki száraz gyepeken, Jun.-Aug. 2-5'. (Élesmosúfï.)

Élesmosó F. A. Gìyllıs. $L$.

\section{KUKORICZA. Zea. I.}

Termés füzéreit alsóbb levelei hüvelyei burkolják, bibeszárai igen hosszuk; porodás virágai szára tetején szélylyelterpedt bugában vannak. - Mivelik. •. Jul.Aug. 3-6'.

Csöres K. Zeฯ Mays. L.

\section{Ł5. Kásakalász. Piptatherum. Beaur.}

Bugája nyílt; füzérkéi tojásdad láncsások; ondója szörösödö; levelei laposan láncsások. érdesek, az alsók hegye konya. Buda, Sz.-Kereszt, Sz.-Endre árnyas berkeiben patakok mentén. 24. Jun.-Aug. 1-3'. (Milium paradoxum L.)

Fekete-fejér h. paradoxum. Beauv. 
2. Rend. Palkafélék. Cyperaceae. $D C$.

\section{SÁs. Carex L.}

A sásnemet, négy alnemre szokás osztani, hogy igy a fajokat annál könnyebben lehessen meghatározni:

\section{BALHASASOK. Psyllophorae. Lois.}

Füzérkéi gazza hegyein magánosak; maghona tövén nincs kalásza.

2. PALKAFAJTÁK. Cyperoideae. Koch.

Ezen fajtából nálunk nincs.

3. SÁTÉK. Vigneae. Koch,

Füzérkéik füzéresek, tökélyes viráguak; füzére tövén murva van.

4. VALÚDI SASOK. Tegitimae. Koch.

saárhegyi füzérében porodás, oldalfüzéreiben termésvirágai vannak; szíra hegyén ritkán van termésvirága.

1. BALHASASK . Psyllophorae.

Sziurtetéző füzérkéi magánosak, kétlakiak; horogvégü termése polyvájából kiálló; levelei keskenyek, élükön érdesek, gazza is érdes. - Nedves réteken Pest körül. 4. April-Maj. 8-15".

Tömöttfejü S. C. Davalliana. Sm.

\section{SÁTÉK. Vigneae.}

1. Felsö füzérkéi leginkább porodás virágokból állanak; bibéje kettö. $\mathbf{2}$.

Alsó füzérkéi állanak leginkább porodás virágokból, füzérei egyszerűek; bibéje kettő. 10.

2. Tögyökere hosszu ostorindákat hajt. 3. Tögyökere ostorinda nélküli, pázsitos. 5.

3. Füzére tojásdad vagy gömbalaku, polyvanemü pikkelye széle hegye felé fejéres hártyáju; termése tojásdad 
9-11 inú; gazza síma. - Gyepes, kivált homokos téreken bőven. 4. Apr.-Maj. 8-15".

Szitytyós S. C. stenophylla. Whlnb.

Fủzére hosszukás, polyvanemü pikkelyei nem fejér hártyások. 4.

4. Füzére összetett; termése széles tojásdad, háta domboru 3-11 inú; gazza teteje felé érdeses. Mocsárokban, söt réteken és homok-dombokon is. 4. Jun.-Jul. 1-11/2. (C. Schoenoides. Host.)

Csátés S. R. C. divisa. Huds.

Füzére kétszeresen összetett, hosszu, tömött, alól megszakadt; a legfelsö és legalsó füzérkéje termés-, középső füzérkéi porodás viráguak; termése tojásdad, kissé domború 9-11 inú; gazza élei érdesek.

Kétsoros S. C. disticha. Huds,

5. 'Terméseik háta nincsen puposan felpuffadva, hanem vagy laposan boltos, vagy lapitott. 6 .

Terméseik puposan felpuffadtak, tojásdadok s hegyökön két fog van. 8.

6. Termései kocsánykáitól felfelé nézve elállók; gazza karcsu, kissé bókoló, felfelé érdes ; termése tojásdad, laposan domboru. Ligetekben mindenütt. 24. Maj-Jul. $8-15^{\prime \prime}$.

Keshedt s. C. divul.sa. Good.

Termései kocsánykáikból terzedten elállók. 7.

7. Gazza élei igen érdesek; tüzére kétszeresen összetett. tojásdad láncsás; termése 6-7 inú. Mocsárok-, árkokban $\mathrm{s}$ folyók mellett, és Buda magasabb erdeiben. 4. Maj.-Jul. 1-1 $1 \frac{1}{2}$.

Róka S. C. vulpina. L.

Gazza élei csak felsö rèszén érdesek: füzére összetett, hosszukás tömött, vagy tövön megszakadt; termése síma, vagy alig inas. - Minden réten, úton, szántóföldeken, árkokban, ligetekben gyakori. 4. Maj.-Jul. $1-1^{1 / 2^{\prime}}$.

Sulymos S. C. muricate. I.

8. Tőgyökere dülten nö s kissé terjedő; gazza felsö része háromélü, lapjai kissé domboruak; füzére összetett 
vagy kétszeresen összetett, tömötten csomós. - Mocsárokban, árkokban, stb. Pestmegye síkjain gyakuri. 4. Maj.-Jun. 1-2'.

Hengergazu S. C. teretiuscula. Good.

Gyökere rostos, töve tömötten gyepes; füzére bugás ; gazza felfelé igen érdes. 9.

9. Gazza háromélü oldalai laposak; polyvái szélei ezüst szinü hártyások, fénylők; termése innélküli, síma háta tövén kissé rovátkos. Mocsárokban a Rákos melletti nedves réteken, ritka. 24. Maj.-Jul. 1-2'.

Buglyos s. C. paniculata $L$.

Gazza háromélü, oldalai kissé domboruak ; polyvái keskeny hártya szegélyűek, vagy szegélytelenek; termése köröskörül erősen rovátkolt. Mocsárokban, a városligeti folyó partjain. - 4. Maj-Jun. 1-1/2'.

Abajácz S. C. paradoxa. Wild.

10. Tögyökere gyökerező indákat hajt; füzérkéi sötétbarnák, többnyire 5 van, tömöttek, egyenesen állók ; tojásdad hosszuk; termései felfelé állók, akkorák, mint a polyvái, hosszukás tojásdadok, élén csaknem a tövétöl finom fürész fogaitól szemszőrösek, hegye kettős. Gyepeken, kivált a hegyek oldalain bőven. 4. Apr.-Maj. 6-12". Kopári S. C.Schreberi. Schranl.

Tögyökere töve inda nélküli tömött gyepet hajt. 11.

11. Füzérkéi többnyire hátával állanak közel egymáshoz, vastagok, kerekdedek, körkörösek; termései felfelé állók, tojásdadok, köröskörül rovátkoltak, szárnyas prémüek, kétfoguak; polyvái szürkésbarnák. Legelökön, réteken, hegyi gyepeken. 24. Maj.-Jul. 6-12". Nyúl S. C. Teporina $L$.

Füzérkéi egymástól elállók ; terméseinek nincsen szárnya. prémje. 12.

12. Füzére összetett, füzérkéi váltogatók, aláfelé porodás viráguak, a 3-4 alsó füzérke egymástól jó távol áll s ezek tövéröl a főkocsány hegyéig érö hosszu mur- 
va nött; termései hosszabbak, mint polyvái. Ligetekben, árnyas és nedves helyeken. 24. Maj.-Jun. 8-15".

Ritkás S. C. remota.L.

Füzére összetett, füzérkéi mintegy négyen vannak s egymástól távolocska állanak; termései terpedten kinyiltak, kétfogu, finoman, fürészelt csörön végződők ; murvái kurtábbak, mint füzérkéi. Gödöllö vizenyőseiben . 4. Maj-Jul. 6-15". Csillagos S. C. stellulata. Good.

\section{VALÓDI SÁSOK. Legitimae.}

1. Két bibéjüek. 2 .

Három bibéjūek. 4.

2. Levelök hüvelye nincsen felhasadva; gazzuk egyenes, éles ormóju; alsó murvája hosszabb, mint a fökocsányja; porodás füzére 2-3; termés füzére 3-4, ez utóbbiak virágzás alatt felállanak, azután lehajolnak. Mocsárnkban s folyók kiöntéseiben. árkokban. 4. Apr.Jun. 1-3'.

Éles S. ' ' acuta. $L$.

Levelök hüvelye hálózatosan van hasadva. 3.

3. Gazza sugáron felálló, éles ormóju, érdes, mindenik levelye hüvelye hálózatosan fel van hasadva; termése körkörös, lapos, mintegy 6 inú. - Ingoványos mocsárokban, közönségesen tömött gyepet alkot. 4. Apr.Мaj. 2-3'.

Sugár S. C. stricta. Good. (Kazza konya, alsó levelei hüvelyei hálózatosan felhasadtak; termése mindkét oldalán kissé domboru, inatlan. Az elöbbive! együtt terem. 4. April.-Maj. $1-1^{1 / 2}$.

Gyepi S. C. caespitosa. L.

4. Termésük csőrnélküli vagy kurta csörü. 5.

Termésök csörös, csőrük párkányos, két fogu, vagy két hegyü. $\mathbf{2 0 .}$

5. Murvái, füzére tövét nem hüvelyezik, vagy alig hüvelyezik. 6.

Murvái, füzére tövét nem hüvelyezik. 11.

6. Termései kopaszok; 1-2 termés füzére kocsánytalan, 
kerekded, összetartó: termései, gömbded-körkörösek tompa 3 élüek, fénylök; tögyökere terjedö. - Homoki réteken gyakori. 24. Maj.-Jun. 3-6".

Henye S. C. supina. Wahlb.

Termései szörösödök, vagy molyhosak. 7 .

7. Polyvái fekete barnák, tompák vagy csonkák, fulánkosak; murvái hártyások,"szárölelök, fulánkosak ; porodás füzére magános, termés füzére 1-2, összetartó tojásdad; gyökere rostos, töve tömötten gyepes. A budai hegyi és ligeti gyepeken bőven. 4. Maj.-Jun. 6-15". Hegyi S. C. montana L.

Polyvái sárgák vagy sötétbarnák. 8 .

8. Polyvái visszás-tojásdadok, kurta szemszörüek, igen tompák, a hegye alatt alig látszó inai vannak, fejéren szegélyezettek; tögyökeréböl ostorindák nönek. Homoki gyepeken, a városliget háta megett, igen ritka. 4. Apr.-Maj. 3-8". Hanga S. C. ericetorum. Poll. Polyvái hegyesek vagy fulánkosak, közép inai kiállók szemszörtelenek. 9.

9. Porodás füzérei vastagok, visszás tojásdad-ékalakuak. magánosak, termés füzérei 1-3 összetartók, hoszszukás-tojásdadok; termése visszás tojásdad, 3 lapu: töve ostorindás. Hegyi és homoki száraz gyepeken mindenütt. 24. Apr.-Jun. 3-12".

Korai S. C.praecox. Jaqu.

Porodás füzérei vékonyak, hosszas szálasok, mindkét. végökröl kıhegyezettek; termései gombosan visszás tojásdadok. 10.

10. Tögyökere rostos, gazza magva érésekor legörbűl; porodás füzére magános, termés füzére rendszerint 3 , melyek összetartók, kerekdedek, kocsánytalanok ; alsóbb murvája levélnemü, egyenes és kinyílt. A Zugligetben, ritka. 24. April.-Maj. 6-12". Epres. S. C. pilulifera. L. Tögyökere ostorindás; gazza sugár s egyenes; termés füzére 1-2, hengeres; termése kurta szörrel molyhos; alıó murvája hosszu s többnyire vizirányosan kinyílt. 
Kivált vizenyős, minden réten közönséges. 4. Apr.Majj. 8-15".

Molyhos S. C.tomentosa. L.

11. Termésök molyhos. 12.

Termésök kopasz; murvái levélnemüek. I4.

12. Polyvája nyilásánál kissé lecsonkított, termésének csak a hegye molyhos; levelei válusok, hosszabbak, mint à gazza; porodás füzére magános, termés füzére 2-3 virágu, egymástól távolodók, rendszerint 3 viráguak, kocsányosak. Hegyi gyepeken kora tavaszszal. 4. 1-2".

Cseplesz S. C. humitis. Leysser.

Polyvája nyilásánál kissé kicsípett, termése egészen molyhos. 13.

13. Termés füzére $2-3$, többnyire 5 virágu, a felsök egymáshoz közelállók, az alsók fökocsányja tövéről indulván hosszu kocsánykájuak s ezeket alsó murvája behüvelyezi; gyökere rostos. tövén tömött gyep nö. - Minden ligeti réten. erdők mellett. 24. Apr.-Maj. 6-12". C. alpestris. Alt. Havasi S. C. gynobasis. Will.

Termés füzére leginkább 3, szálas, füzérkéi egymástól kissé távol állnak, kocsánykások; termései akkorák, mint az egy kissé kicsípett és fogasolt polyvái : rézsut lecsapott hártyás murvái kocsánykáit behüvelyezik. Erdei árnyas gyepeken. 4. Apr.-Maj. 6-10".

Ujjas \$. C. digitata. $I$.

14. Termés füzérei 2-3, egymáshoz közelállók, vagy csak az alsók távolodnak egymástól el ; termése csőrnélküli, körkörös hosszukás; levelei s alsó levele hüvelyei szörösek; gyökere rostos. Árnyas ligetekben s körér hegri réteken. 24. Maj.-Jun. 8-15".

Sáppadt S. C.pallescens. L.

Termés füzére 1-4 egymástól távol állanak, ritkás viráguak s hosszukások. 15.

15. Alsó murvája hártyanemü, murvája hátán zöld esík van; termése tojásdad gömbalaku, gödrös, hengeres, 
kurta csörfi; levelei keskenyszálasok, töve ostorindás. Pilis Csaba tölgyeseiben böven. 4. April-Maj. 6-12".

Fejér S. C. alba. Scop.

Alsó murvái levélnemïek. 16.

16. Alsó murvája szálkahegyü; termés füzére 2, hosszukás, az alsó kifelétartó hosszu kocsánykáju, tömött, többnyire 12 virágu, a felsők esaknem kocsánytalanok; termései tojásdad-gömbalakuak, éles inúak, csőrük kurta, hártyás hegyü, két karélyu; töve ostorindás. Homoki és hegyi gyepeseken gyakori. 24. April-Maj. $6-12^{\prime \prime}$.

Fényes S. C.nitida. Host.

Minden murvája levélnemü. 17.

17. Termés füzérei ritkás viráguak, felállók. 1-3̊; porodás füzérei magánosak, kocsányosak ; tövei ostorindásak. 18. T'ermés füzérei, lefüggők, bókolók vagy végre lefüggök. 19.

18. Virágot nem termö levélcsomójában levö levelei szörö: szemszörüek, széles szálasok, hosszabbak, mint az alig leveles gazza; termése csaknem gömbösen visszás tojásdad. 3 oldalu; gyökere terjedő. Minden hegyi ánnas erdöben. 4. Apr.-Maj. Szörös S. C.pilosa. Scop. Minden levele, valamint leveles tövü gazza is kopasz; porodás füzére mindig felálló ; töve ostorindás. Vizenyös réteken, tavak és folyók mellett. 4. Maj.-Jun. 8-12".

Muhar S. C.panicea. $L$.

19. Porodás füzére többnyire 3 , termés füzére $2-3$, hoszszu kocsányuak; termése tompa, igen kurta csörü, lapitottan boltos, kissé érdes, innélküli; gazza síma; töve ostorindás. - Mocsáros erdök árnyasain. 24. AprilJun. 12-18".

Hamvas S. C. glauca. Scop.

Porodás füzére magános, mellette rendesen meggörbült 4 termés füzére van; termése háromszögü s ezen háromélü csőre van; gazza 3 élü; levelei láncsás szálasok; gyökere rostos. A tótfalui hegyi patakban. 4. Maj. $1^{1 / 2}-3^{\prime}$.

Magas S. C.maxima. Scop. 
20. Porodás füzérök magános. 21,

Porodás füzérök rendszerint több egynél. ⒎

21. Murvái hüvelyezök, körülbelül akkorák, mint a füzére, és sokkal kurtábbak, mint a gazza, termés füzére 1-2, porodás füzérétől messze álló ; termése visszás tojásdad, hasas, háromélü, kétágu hegye csőrben végződő; töve ostorindás. - Árnyas erdei gyepeseken böven. 4. Maj.-Jun. 1-1 $1 / 2^{\prime}$. Korhadó S. C. Mrichelii. Host. Nurvái levélnemüek, hosszuk. kurta hüvelyüek, alsó füzérénél hosszabbak. 22.

22. Termése csöre görbe, termése felfuvódott; murráija széles, hosszabb, mint a gazza. végre kinyílt vagy letüremlett; termés füzére 2-3, meglehetösen összetartó, kerek-tojásdad, az alsó kocsányostól együtt murvája hüvelyébe záródott, a felsö kocsánytalan; töre gyepes. gyökere rostos. Mocsáros és turfás réteken böven. 4. Maj.-Jun. 6-18".

Sárga S. C. flaca. I.

Termése csöre egyenes. $\mathbf{2 3 .}$

2. Termése kerekded, puffadt, apró. csőre széle finom fürészesen-érdes; gazza síma, töve gyepes, gyökere rostos. - Az elöbbivel együtt terem s mintegy harmadrésznyi magas. 24. Maj.-Jun.

öder s. C. Oederi. Ehth.

Termése tojásdad, alig puffadt. $\mathbf{2 4}$.

24. Termés füzére 2. az alsó a felsőtől távol van, mind kettő kocsányos, vagy három s ilyenkor a két felső egymáshoz közel áll. felálló, tömött virágu; murvái hosszu hüvelyüek; az alsó levélnemü, a porodás füzért csaknem érö, néha elérö, vagy tetézö is ; termés csőre fulánkos; polyvája hegyes; töve gyepes és kurta ostorindás. A sílon fekvő minden mocsárban. 4. Maj.Jun. 1-1 $1 \frac{1}{2}$.

Pej S. C. fulter. Gond.

Termés füzére kettönél több. $\mathbf{2 5}$.

25. Termés füzére 4, szálas, ritkás virágu, függö : termése körkörös, 3 éln̈, egészen síma. csőre szálas; gazza 
síma; levele széles szálas. Erdőkben gyakori. 4. Maj.Jul. 1-1 ${ }^{1}{ }^{\prime}$ '.

Erdei S. C.syliatica. Huds.

Polyvái tojásdadok. 26.

26. Murvái hegyesek, de nem fulánkosak, porodás füzéreig alig érnek. vagy csak odáig érnek; termése kerekded, felegyenesedö; gyökere kurta, töve ostorindás. Nedves réteken és a pesti mocsárokban böven. 4. Maj.Jun. 1-1 1/2'. Hornschuch S. C. Hornschuchiana. Hoppe.

Murvái fulánkos høgyủek; termései inasok, oldal inai kissé kijebb állnak. zöldek, vagy biborpirosan pettegetettek, vagy biborpirosak; füzérei egymástól távol állanak. - Többnyire árkokban, nedves réteken, mocsárokban és félig kiszáraztott helyeken. 4. Maj.-Jun. $1-1^{1 / 2^{\circ}}$.

Ritkás S. C.distans. $I$.

97. Termésök kopasz. 28.

Termésök kurta szörü. 32.

28. Gazza síma vagy csak a teteje felé érdes. 29.

Gazza éles, ormói érdesek. 30.

29. Porodás füzére 1-3, termés füzére 2-3. hengeres kurta kocsányu, termései fökocsányjától messze elállók csaknem gömbalakuak, puffadtak, hátukon többnyire 7 inúak, levele tengerzöld; gazza tompa ormóju. Patakok, árkok s mocsárokban. 4. Maj.-Jun. 1-2'.

Bögrés S. C. ampullacea. Gond.

Porodás füzére 1-2, termés füzére 3-4, hengeres vagy tojasdad, kocsánytalan, vagy csak az alsónak van kocsányja; termése tojásdad kúpalaku. finomul barázdolt. kopasz. A pilisi járás mocsáraiban, a Szt. Gellért alatti nedves réteken \& a kincstári erdőknél. 4. Maj.Jun. 1-2'.

Bókoló S. C. nutans. Host.

30. Termése tojásdad, vagy hosszukás tojásdad, lapos, inas. kopasz; termés füzére 2-3, hengeres tömött virágu, felálló; polyvái kihegyezettek; murvái levélneminek, 
nem hüvelyezök; gyökere terjedö. - Patakok, folyók, és árkokban. 4. Maj.-Jun. 1-1 $\frac{1 / 2}{2}$.

Posvány S. C.paludosa. Good.

Termése kupalaku, vagy tojásdad kupalaku. 31.

31. Porodás füzére $3-5$, termés füzére $3-4$ hengeres vastag; kupalaku termése éle le van kerekitve, mindkét oldalról domboru, sok inú, kopasz; gyökere terjedö. - Árkokban, mocsárokban, vizek partjain. 4. Maj.Jun. 2-4'.

Parti S. C. riparia. Curt.

Porodás füzére 1-3, termés füzére 2-3, távol állók hosszukás hengeresek, kocsánytalanok; termései dülten elállók, tojásdad kupalakuak, puffadtak, kopaszok, hátukon 7 ina van; gyökere terjedö. Az elébbivel együtt terem. 2. Maj.-Jun. 1-2'.

Hólyagos S. C. vesicaria. $L$.

32. Murvája vagy nem hüvelyezö, vagy alig hüvelyezö; porodás füzére 1-2, termés füzére 2-3, távol állók hosszukások, vagy tojásdadok; gazza tompa ormóju; levelei válusok, gazzánál alig szélesebbek; gyökere nagyon terjedö. A síkon levỏ mocsárokban böven. 4. Maj.-Jun. 2-4'.

Czérna S. C. filiformis. $L$.

Murvája hosszan hüvelyezö; porodás füzére 2, termés füzére 2-3, felálló hosszukás hengerded: termése tojásdad, kurta szörü; levelei és levele hüvelyei szörösek; gyökere terjedö. - Mindenféle nedves és száraz gyepeken, kivált a homokon. 4. Maj.-Jun. 6-18".

Borzas S. C. hirta $L$.

\section{SÁTORSÁs. Cladium R. Br.}

Gazza leveles; sátora kétszeres, egy szárhegyi, a többi oldaltálló: füzérei gombosan csomósak; levele éle és gerincze egyaránt szúrós. Mocsárokban mindenütt. 4. Jun.-Sept. 2-4'.

(Cladium germanicum. Schrad.)

Szúrós S. Cl. Mariscus. R. Br. 


\section{KẢKA. Stirpus. I.}

1. Füzérkéi szárhegyen növök, gazzok hegyén, vagy gazzok ágain magánosan állók ; ágaik azouban nem ernyösek. 2. Virágzata ál oldali esomó, vagy sátorozó. 5.

Füzérkéi szárhegyi füzért alkotnak, két soruak, összeállók, füzérei magánosak. 15.

2. Bibéje kettö; füzérkéje hosszukás, polyvái hegyesek, alsó polyvája a következöt nem tetézi s a füzérkéjét félig öleli; makkja visszás tojásdad síma; gazza magános, hengeres, lapított. - Necives helyeken és mocsárokluan, itt-ott. 24. Jun.-Aug. 6-18". (Heleocharis palustris $R . B r$.) Árva K. S. palustris. $L$. Bibéje három. 3.

3. Makkocskája négy oldalu, hosszukás, rajta sok finom vonal van; gazza igen vékony, sertealaku, borozdátlon; gyökere terjedö. - Vizenyös s félig kiszárađt helyeken, mocsárok partjain. ๑. Jun.-Aug. 1-4". (Heleocharis acicularis R. Br.) Ször K. S. acicularis. L. Makkocskája három oldalu, síma. 4.

4. Gazza felsö hüvelye kurta levelen végzödik; polyvái tompák, a legalsó a többinél nagyobb, fulánkos; virága sertéi hosszabbak, mint a makkjai. - Vizenyös helyeken, a Rákos partjain. 4. Jun.-Jul. 2-10". (Bcethryon caespitosum. Dietr.) Gyepi K. S. caespitosus. L.

Gazza minden hüvelye levél nélküli; polyvái fulánktalanok; virága sertéi kurtábbak, mint a makkjai. Mocsárokban és nedves réteken. 24. Jun.-Jul. 1-4". (Baethryon pauciflorum. Dietr.)

Kevésvirága K. S. pauciflorus. $L$.

5. Virágzata ál oldali esomó. 6. Virágzata ernyö alaku, vagy gombos. 9.

6. Ál oldali csomója gömbalaku, tömött fejü, kocsánytalan; murvája csomója felibe hosszan nyulik; polyvái cson- 
kítottak, fulánkosak; bibéje 3. - Pocsolyákban. 4. Maj.-Jul. 1-2-3'. (Holoschoenus vulgaris. L. K.)

Szuirkelábu K, S. Holnschoenus. I.

\section{Ál oldali csomóji nem gömbalaku. 7 .}

7. Gazzi háromélü; füzérkéi kocsánytalanok, tojásdad hosszukások; polyvái fulánkja tövén kicsípettek ; bibéje 2, makkja síma. - Mocsárokban. 4. Jun.-Jul. $1-1 \frac{1 / 2}{2}$.

Szúró K. S. Rothii. Hopipe.

Gazza hengeres. 8.

8. Füzérkéi kettősök vagy hármasok; murvája sokkitl kurtább, mint a gazza, felálló, végre oldalra hajló; bibéje 3; makkocskája lapított, hosszálhan vonalozott. Vizenyös helyeken, mocsárok partjain. $\odot$. Jun.-Aug. 1-4". (Isolepis setacea. R. Bir.) Serte K. S. setaceus. I..

Füzérkéi hármasoknak látszó csomóban rannak; murvája felálló s akkora, mint a gazza; bibéje 3 ; makkocskája három oldalu, keresztes ránczos. Nedves helyeken, partokon. $\odot$ Jul.-Aug. 2- $8^{\prime \prime}$. (Isolepis sulina. R. Br.) Henye K. S'. supims. $L$.

9. Ernyőalaku virágzata ál oldali. 10.

Ernyőalaku vagy gombos virágzata szárhegyi. 12.

10. Gazza háromélï; füzérkéi tojásdadok, csomósak, csomói kocsányosak, vagy a nélküliek; bibéje 2; makkocskája síma, háta domboru. A Tisza folyó mocsáraiban. 4. Jun.-Jul. 1 1'2-3'.

Háromélï K. S. triqueter. $L$.

Gazza hengeres. 11.

11. Fűzérkéi esomósak, kocsányosak ; polyvái símák ; bibéje 3 ; makkocskája három oldalu síma, portokai szakálosak. - Mocsárokban és tavakban. 4. Nyáron át. 4-12'.

Tavi K. S. lacustris. 1 .

Füzérkéi, mint az elöbbié ; polyvái pontozottan érdesek: bibéje 2; makkocskája csaknem háromoldalu, domboru. portokai szakálnélküliek. - Árkokban. mocsároklıan. 4. Jun.-Jul. 1-2'.

Hamras K. S. Tabernaemontani. Gme?. 
12. Polyvái fulánkosak kétmetszetüek; bibéje 3 ; gazza. báromélü, igen leveles. - Taraklan és árkokban igen közönséges. 24. Egész nyáron.

Villás K. S. maritimus. $I$.

P olyvái épek; gazza háromélü. ig’en leveles. 13.

13. Ernyöalakı virágzata sokszorosan összetett, bibéje 3. 14. Füzérgombjai tojásdadok, kerekdedek, karélyosak, halványak. 4-j hosszu murvába foglaltak; polyvái láncsások; biluéje 2. - A tiszai mocsárokban. •. Jum.Aug. 3-6". (Cyperus Micheliams. L. K.)

Sallangos K. S. Micheliamus. $L$.

14. Füzérkéi tojáscladok. kocsányosak és koesánytalanok: polyvái tompák. igen finomul hegyezettek. Kivált hegyi mocsárukban. 24. Jun.-Aug. 1-3'.

Erolei K. s. sylicaticus. L.

Füzérkéi hosszukások, hosszu kocsányuak ; polyvái fulánktalanok. - A megye síkjain levő mocsárokban és árkokban. közönséges. 24. Jun.-Aug. 1-3'.

Gyökerezö K. S. radicans. Schli.

15. Gazza alig háromélï. levelei válusan ormozóttak ; füzérkéi $6-8$ viráguak: viríga sertéi hátrafelé tüskések. Nedves gyepeken és a mocsárokban. 24. Jun,-Ang. 6-12". (Blysmus compressus. Panz.)

Lapitott K. S. commessus. P'ers.

\section{GYAPU. Eriophorum. L.}

1. Gazza teteje felé háromélü; levelei laposak. hegye három ormóju ; kocsányjai érdesek. Mocsáros és turfás helyeken. 24. Maj.-Tul. 6-12".

Széleslevelü Gy. E. latifolium. Hoppie.

Gazza csaknem hengeres; levelei szálas válusok, hegyökön három ormójuak; kocsányjai símák; gyapjuja háromszorta nagyobb. mint füzérkéje. - A Tisza mocsáraiban gyakori. 24. Maj.-Jul. 6-12".

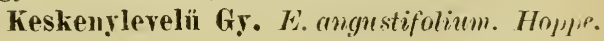




\section{5. ĊÁTE. Schoenus. L.}

Gazza hengeres kopasz, meglehetős vékony; virágzata 5-10 füzérkéből álló gomb, szárhegyi; külső murvája dülten felegyenesedö; levelei áralakuak, felényiek, vagy akkorák, mint a gazza. 'Tavakban és nedves réteken. 24. Maj-Jun. ${ }^{1 / 2}-1$ '.

Kormos C's. St. nigricans. $L$.

\section{Patha. Cyperus. L.}

1. Virágzata esomós; füzérkéi csaknem öten vannak; két polyvája egyenetlen; makkocskái csaknem háromszögüek; gazza felegyenesedö, a levele hüvelyezi alólról; levelei aprók. - Vizenyös helyeken, kivált szíkes és homokos földön. $\odot$. Jun.-Aung. 2-6".

Bogár P. C.pannonicus. $L$.

Virágyata ernyös. ‥

2. Bibéje 2; makkocskája kerekded-tojásdad, polyvái sárgásak, hátukon zöld csík van; levelei igen keskenyek. gazzánál kurtáblıak. - Vizenyös helyeken, árkok és tavak mellett. $\odot$. Jun.- lug. 3-8".

Sárgálló P. C. flavescens. $L$.

Bibéje 3 ; makkocskái körkörösek; polyvái feketés barnák, hátukon zöld csík van; levelei igen keskenyek, akkorák, mint a gazza. Nedves helyeken és mocsárokban. $\odot$. Jun.-Aug. C-12".

Barua P. C. fuscus. L.

3. Rend. Hidőrfélék. Alismaceae. $R$. $B r$.

\section{HUTSZA. Triglochin. L.}

1. Termése szálas, ormós, tövefelé elkeskenyedö, tőkocsánja felé hajló, 3 tokra szakadó; tőkocsányja alját hüvelyezö levelei keskeny szálasok, ormósak, kopaszok. -- Nedves réteken és mocsárokban. 4. Jun.-Jul. $1-1^{1 / 2^{\prime}}$.

Savanyu H. T. palustre. L.

2. Termése tojásdad, ormós, legörbült bibéje alatt begyüremlett, 6 tokra szakadó; fürtje megnyult; levelei 
kövérek. - Mocsárokban, kivált szíksós tavakban bören. 21. Tun.-Jul. $1^{1} 2-2$ '.

Hatbibés H. T. maritimum. $L$.

\section{ə. HIDŐR. Alisma. L.}

Tökocsányja gyürủsen bugás; levelei szíresek, tojásdadok, vagy láncsások; termése hegye lekerekitett tompa, hátán barázdolt; virága fejér vagy verhenyes. Az ártéreken, mocárokban, árkokban s mindenütt. 24. Jun-Ang. $1 / 2-3{ }^{\prime}$. (Vizi utifí.).

Vízi H. A. Plantugn. I.

\section{NYILFÜ. Sagittaria. L.}

Levelei tövéröl nőttek, hosszu nyelüek, nyílalakuak; virágzata három virágu gyürüben áll, szirmai fejérek, nyaka piros. - Mocsárokluan. árkokban bören. 4. Jun-Aug. 6-15". $\quad$ Nyillerelï $\mathbf{N y}$. S. sagittaefolir. $L$.

\section{ELECS. Butomus. L.}

Magáuos tőkocsánja hegyén galléros ernyös virigzata ran; levelei töréböl nönek, hosszuk. szálasok, rálualakulag háromélüek; virága piros. - Tavakban, patakokban és a folyók mellett. 24. Jun.-Jul. 2-э. (Tirigos $v$. ̈̈reg licilic ; fülemilefü.)

Ernyös E. B. umbellatus. L.

\section{Rend. Szitytyófélék. Juncaceae. Agar`d.}

\section{SZITYTYÓ. Juncus. I.}

1. Gazzok leveletlen, tövén csak levele hüvelye van meg. ㅂ.?. Gazzok leveles. 4.

2. Bibcszára kivehetö; porodíija 6 ; tokja hosszukás körkürös, tompa, fulánkos; gazza mélyén larázdolt, béle fiókosan szakgatott. - Mocsároklan, árkokban s túrfás téreken. 24. Jun.-Jui. 1-3’. Fakó S\%. J. glaucus. $I$ : Bibeszárának csak a töve van meg; porodája három. :;. 
3. Tokja visszás tojásilau, csonkil, bileszári töve feldomborodott pupja végére van növe; ernyöalaku virágzata oldalt ill ; gazza szíjjas. Az elöbbivel együtt nö. 4. Jun.-Jul. 1-3'.

Bunkós Sz. J. conglomeratus. $L$.

'Tokja benyomottan csonka, bibéje töve egy kis gödröcskébe van nōve ; ernyöalaku virágzata oldalt áll : gazzat törékeny. Az elöbbivel egyuitt. 4. Jun.-Jul.

Béka sz. J.effiusus. $L$.

4. Leveleik béle rekeszes (fiókos.) 5.

Leveleik béle nem rekeszes (folytonos.) 7 .

5. Levele hengeres; sátoros virágzata szárhegyi, kétszeresen összetett; leple szirmai egyenlök, lekerekitetten tompák, csaknem ezïst színüek. - Mocsírokban. árkokban. 24. Jum.-Aug. 1-2'.

Tompavirágu Sz. Jo obtusiflorus. Ekh.

Levele kerekdeden lapított. 6.

6. Leple szirmai egyenetlenek, a belsö hosszabb, hegye letüremlett. - Az elébbivel együtt terem. 4. Jun.Aug.

Göresös Sz. J. sylluaticus. Reichh.

Leple szirmai egyenlök, egyenesek, hegyeik kurta fulánkıak. - Az elébbiekkel. 24. Jun.-Aug.

Bütykös Sz. J.lumprocarpus. Fhrh.

7. Gazza közepén egy levél van; gazza lapított; leple kurtább, mint gömbded tokja; bibéje felényi, mint, a maghona. Réteken, legelökön, kivílt vizenyös helyeken. 4. egész nyáron át.

Sivatag Sz. J. compressus. Jucuu.

Gazza több levelü; sátra megnyult ágai két-két águak, egyenesek; virágai egyesek. egymástól, távolodók ; hoszszukás tokja hosszabb, mint láncsá szirmai. - Réteken és mocsárokban, kivált ártéreken. ○. Jul.-Aug.

Két-kétágu Nz. J. bufonius. T. 


\section{ข. LUCZA. Luzula. D. (C.}

1. Virágzata sátorozó. 2.

Virágzata tojásdad vagy hosszukás füzéres. 3.

2. Sítora egyszerü, kocsánykái többnyire három viráguak, a felsők elvirágzás ntán lehajlók, virágai egyesek; tölevelei szálas láncsások, szörösek. A magasan fekvö budai ligetekben, ritka. 24. Maj.-Jun.

Perje L. L. pilosa. Wild.

Sátora többszörösen összetett, kinyílt; galléránál alacsonyabb; kocsánykái többnyire 4 viráguak; leple szirmai hosszabbak. mint a tokja: szálas levelei éle szörös. - Virágai fejéreslök, van azonban verhenyes virágu fajtája is. - Ligetekben bőven. Maj.-Jun. 1-2'.

Fejéreslö L. L. albida. $D C$.

3. Füzérei ernyös formák, kocsánytalanok vagy kocsányosak; leple szirmai láncsások, hegyesek, hosszabbak, mint tompa s fulánkos tokja; tôlevelei szálas láncsások, élök szörös, végre kopaszok. Homoki és ligeti legelökön böven. 4. Maj.-Jun. 3-8".

Mezei L. L. campestris. $D C$.

\section{Rend. Kikericsfélék. Colchicaceae. $D C$.}

\section{ZÁsZPA. Veratrum. L.}

1. Fürtös virágzatiz bugás, szőrösödö; leple szirmai hoszszukás láncsások, fogasoltak, kocsánykáinál sokkal hoszszabbak; levelei tojásdadok, alsó lapjai szörösödök. - Vizenyös réteken s mocsárok mellett a síkságon. 4. Jun.-Jul. 1'1/2-3'. Mérges. (Fejér hunyor; fejér ziczpa.)

Fejér Z. V. album.. .

2. Fürtös virágzata bugás; leple szirmai körkkörösek, épélüek, akkorák, mint kocsínykái; alsó levelei széles körkörösek, kopaszok. - Ligetekben, Vágásokon Buda körül• 4. Jun.-Aug. 1 1/2-?'. Mérges. (Fekiete zíszpua.)

Fekete Z. V. nigrum. L. 


\section{KIKERICs. Colchicum. L.}

1. Levelei szálas láncsások, élök lapos: bibeszárai leple hasábjainál kurtábbak; tokja tojásdad hosszukás. Hegyi vizenyös réteken; öszszel virágzik, leveleit és termését tavaszszal hajtja ki. 24. Sept.-Oct. 8-12' Mérges. (Őszi kö̈iörcsin; öszile; törpe zászpa ; fejér zászpa.)

Zászpa K. C. autumnale. I.

2. Levelei láncsás szálasok, válusok; bibeszárai leple hasábjainál hosszabbak; tokja mindkét végén hegyes. 4 Homoki rétekell. - Kisebb és vékonyabb, mint

az elöbbi. Homoki K. C.arenarium. $W$. $K$.

\section{Rend. Liliomfélék. Liliaceae. Juss.}

\section{LILIOM. Lilium. L.}

Levelei gyürüsek, körlkörös láncsások, kihegyezettek, élök érdes; szára szörösödö-érdes; virágai lefüggök; leple szirmai kikunkorodnak. - Ligetekben, vágásokon Budi körül. 24. Jun.-Jul. 2-4'. (Erdei liliom; török turbain; szcizréti yyöliér.)

Turbán L. L. Martagon. I.

\section{HÖLYE. Anthericum. I.}

1. Tökocsányja magános ; virágzata fürtös ; bibeszára lefelé hajló; termése tojásdad tok. Hegyi réteken, a homokos erdőkben ritkább. 4. Jun.-Jul. 1-3’.

Ágatlan H. A. Litiago. L.

2. Tőkocsányja felül ágas; bibeszára egyenes; tokja kerekded. - Az elébbivel együtt. 4. Jun.-Jul. (Hölye). Ágas H. A. ramosum. L.

\section{ZöLDCsík. Ornithogalum. Link.}

1. Virágzata fürtös. 2.

Virágzata sátorozó. 4.

2. Fürtje ingadozó, virágzáskor már féloldali és lefüggô; leple nyílt lıarangalaku, szirmai körkörös láncsások. 
tompálk; szálesái 3 foguak. hosszabl, szálcsái szélsö foga a portokot tetézi. Gyümölesösökben, szántútüludeken, vetések közt. 24. Maj.-Jun. 1-1 ${ }^{1} 2^{2}$.

Konyuló Z. O. mutans. $L$.

Fürtje rendes és megnyult. 3.

3. Kocsánykái főkocsányjától elállók, termése kocsánykái a fökocsányjához lapultak, murvái tojásdad láncsások, lassanként hegyesednek ki; maghona tojásdad ; lerelei szálasok. válusok. - Bozótokban. gyepük mcllett, szántóföldeken böven. 24. Jun.-Jul. 2-3'.

Hegyi \%. O.pyrenaicum. I.

Kocsánykái fỏkocsányjától mintegy félderék-szöggben állanak el. régre mindnyájan egyeulö hosszuk; levelei szálasok. szemszörösek. - Teröféuyes gyepes sziklákon, a Sz. Gellérten és a Sashegyen bören. 4. Jun.-Jul.

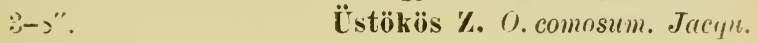

4. Terméses alsó kocsánykái vízirányosan állanak; levelei szálasok. kopaszok. egy fejér ronal ran rajtok. Kertekben, réteken, szántóföldeken stb. 4. Maj. 3-12". (L'ri circág; madcirtéj.)

Éri Z. O. umbellatum. $I$. Terméses alsó kocsánykái. fökocsányjától szélylyeltart va rannak lekonyulra, termése azonban felegyenesedü; ievelei szálasok, kopaszok, rajtok egy fehér vonal van. -. A pesti színtóföldeken, exdökben, bozótokban s kertekben. 4. Maj.-Jun. 6-12".

Letört Z. O.refractum, hit.

\section{SÁrMA. (Gagea. Salish).}

1. Két hagywáját egy közüs hártya takarja, egyik hagymájából gyökérrostok nőnek, a másik következö évbea hajt gyökérrostokat. 2.

Egy hagymája van, melyből nö gyökér rostja lef.lé, tőkocsányja és egy levele felfelé. 3.

2. Tőlevele kettö, szálas gallérlerelei ellenesek ; kocsányjai ágasok, gyapjasok ; szirmai láncsások, hegyesek: hagy- 
suája kerekded. - Szántóföldeken, gyepeken igen közönséges 4. Apr.--Maj.

Pallagi S. G. arvensis. Schult. T'ölevele magános, szálas, lapos, vagy alig válus; gallé1levele egy, hüvelyezö, láncsás, 2-5 virágkocsányt foglal be; szirmai szálás láncsások, hegyesek: hagymája tojásdad. - Buda körül, erdőkben, kövér hegyi réteken. 4. Maj. 1-3". (Kis tyuktaréj.)

Apró s. G. minima. Śchult.

3. Tölevele magános, felálló, szálas láncsís, hirtelen kihegyezett, lapos, éles ormóju ; két gallérlevele csaknem ellenes; virágzata ernyős ; kocsányjai kopaszok; szirmai hosszukás tompák: hagymája tojásdad. Erdőkben bokrokban. 24. Maj. 4-8". (S'rirga marlir.liliom; sárge tyuktaréj.)

Sárga S. r. lutea. Schult. 'Tőlevele magános keskeny szálas, válus; két gallér l'vele ellenes. az alsó nagyobb; ernyöje 2-3 virágu; kocsányjai kopaszok: szirmai láncsások, tompák. Homoki legelökön. 4. Kora tavaszszal - igen apró.

Picri S. Gr.pmsilla. Schult.

\section{j. Csilla. Scilla. L.}

1. Hagymája szálas lánccás két levelet hajt; tőkocsányja hengeres, murvája nines; szálcsái tövei fejérek. A síkon és szigetekben nedves réteken. 4. April-Maj. "j-8". (Erdei jáczint.) Kétlevelï Cs. St.bifolia. L.

2. Hagymája sok levelet hajt: tökocsányja szegletes; kocsányjai tövén lecsapott vagy fogas kurta murvái vannak; szálcsái kékek. - Csepelsziget ligetein. 4. Apr.-Maj. ${ }^{1 / 2}-1^{\prime}$.

Ékes Cs. S. amnena. $L$.

\section{HAGYMA. Allium. L.}

1. Tökocsányja, tölevelei csomója oldala mellöl hajt ki, tölevelei essomóját, tőkocsányjával együtt, közös hártya burkolja be; tőkocsányja felsö része élesen ormós; 
levelei laposak, szálasok, grerinczei ormósak; porodái fogatlanok; hagymája keresztbe fekvö tögyökéröl nö. - Vizenyös réteken, s Buda köves hegyein. 4. Jul.Sept. 3-12". (Kö̈i luagyma.)

Kél'ges H. A. ucutangulum. Schurad.

Szára alsó részén, valgy közepéig leveles. 2.

2. Váltogató porodái szélesek, tövei fogatlanok. $\mathbf{3}$.

Váltogató porodái tövén vagy tetején fogasok. 4.

3. Levelei hengeresek. keskenyek s mélyen barázdoltak; levele hüvelye egy kopácsu s fulánkos hegyü; porodái, leplénél háromszor kurtábbak; hagymája hártyája végei hálózatosan rojtosak. - Veröfényes hegyek száraz oldalain. 4. Aug.-Sept. 4-8". (Allium setaceum IV. és K.)

Pézsma H. A. Moschatum. L.

Levelei szálasok, laposak, alig válusok; levele hüvelye teteje dülten metszett, két kopácsu s kurtább mint levele nyele; porodái másfél akkorák. mint a leple; hagymája hártyája hegyei szabálytalanul hasgatottak. - Nedves réteken az ördögmalmánál. 24. Sept. 1-2'.

Jószagu H. A. sicareolens. Jacqu.

4. Váltogató pordái tövén mint két oldalról egy-egy tompa fog van, fogai sokkal kurtábbak, mint a szálcsája; hagymája hosszukás tojásdad, gerezdei foğalakuak; levelei széles szálasok, laposak. Mivelik. 4. Jul.-Aug. 1-1 $1 / \mathbf{2}^{\prime \prime}$.

Fog H. A. sativum. $L$.

Porodái váltogatva szélesebbek, hármas hajszálhegyüek, középsö hajszál hegyén van a portoka, oldalt álló hajszál hegyei fonálalakuak. ŏ.

5. Ernyője tokot termö. 6 . Ermyöje hagymácskákat termő. 12.

6. Szálcsái három hegyüek. 7. Szálcsái áralakuak. 10.

7. Minden szálcsája háromhegyü; váltogató szálcsái tövén mindkét oldalról egy-egy kurta fog van; szára köze- 
pén alól felfuródott tövön leveles; levelei bőrdösek (csövesek) hengeresek, hasasok. - Mivelik 4.

Veres H. A. Cepa $L$.

Három belsö szálczai háromszoros hajszálhegytüek $\mathrm{S}$.

๙. Levelei félhengeresek, felső része mélyen válus; ermyöje gömbalaku, vége csaknem kúpos; portokít tartó szálcsája középhegye szálcsájánál felényivel hosszałb. - Száraz kivált homoki réteken mindenütt. 4. Jun.Aug. 1-1'2'.

Bunkós H. A. Sphcierocephalım. I. Levelei laposak. 9.

9. Hagymája egyszerü gömbded, szálcsái egy kevéssel hosszabbak. mint a leple. Mivelik 4. és -. Jul-Jul. (Póréhag!mma, pairhagyma)

Póré H. A. porum. $I$. Hagymája egy közös hártyába zárt sok hagymácskából áll; porodái ércles hátu leplébe zártak. leplénél knrtábbak. Buda hegyei veröfényes rétein bőven. 4. Jul.-Sept.

Freszes H. A. rotundum. $I$.

10. Levelei szálasok; belesek; Virága burka két kopácsn. egyik kopácsa két annyi hosszú, mint az ernyöje. Hegyi gyepeken. sziklás helyeken. 4. Jul.-Aug. $13 / 2-2^{\prime}$.

Sárga L. A. flavum. $I$.

Levelei bördősek. 11.

11. Levelei egyenlően hengeresek, egrészen bördősek; porodai kurtább:ı. Mivelik. 2 .

Metélö H.A. Schoenoprasum. L.

Levelei hengeresek. bördösek. hasısok: porodái szi:mánál hosszabbak. Mivelik 4.

Bördös H. A. fistulosum. L.

12. Levelei laposok éleiken érdesek; szálcsái leplénél kurtábbak. Erdőkben vágásokon, homoki réteken. 4. Jun.-Jul. 1²-3'. (Magvas hagyma; töröli foghagyma.)

Kigyós H. A. scorodoprasum. $L$.

Levelei szálasok, válusok. hegyök felé ellaposodók, alsó lapjaikon barázdoltak. Tirága burka két kopácsa, ezek közül az egyil hosszú csörü; szálcsái leple töve felibe nöttek, körülbelöl akkorák. mint zöldes fejér 
vaggy verhenyes szimmai. - Giyepükben. bozótokban,

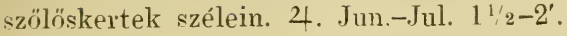

Érdes H. A. oleraceum. $L$.

\section{\%. GYÖngYIKE. Muscari. Tourn.}

1. Felsö virágai felállók és sokkal hosszabb kocsányuak, mint az alatta állók; ezen alattálló fürtös virágai, vizirányosak, hengeresek, ormósak, piszkos zöldek. Hegyi réteken, szántóföldeken, vetések között. 24. Maj.Jul. ${ }^{2} 2-2$ '. (1Lеžei jáczint; liél ligyyólıagynu.)

UUstökös Gy. MI. comosum. Mill.

Minden virága egyenlö kocsányu, az alsók lefüggök 2.

2. Levelei szálasok ívalakulag hátrahajoltak, kunyák; virágai tojásdadok. - Szántóföldeken·és legelökön igen sok van. 4. Mart.-Maj. 3-8".

Fürtös Gy. MI. racemosum. Mill.

Levelei szálas láncsások, felállók ; virágai majdnem gömbalakuak. - A Pest melletti vizenyös réteken kiváltképen a szigeteken. April-Mrj. 6-18".

Eper Gy. MI.botryoides. Mitl.

\section{NYULÁRNYÉK. Asparagus. L.}

Levelei csomósak, sertések az ágak mellett kopaszok és símák; virága leginkább kétlaki. Szántóföldeken, útfeleken mindenütt. 24. Jun.-Aug. 1-2'. (Sprírga: myı)(imyéli; lilárisfü; lóf(urlfü.)

Spárga $\mathbf{Y y}$. A. officinalis. $L$.

\section{Rend. Tukmafélék. Smilaceae. R. Br.}

\section{CZILlák. Paris. L.}

Szára tetején gyürüsen álló 4-7 tojásdad hegyes levél van. - Magasan fekvő árnyas ligetekben. 4. Maj.-Jun. 6-12". (Czillár; párizsfü; farkiasszöllö; négylevelï fü.)

Négylerelü Cz. P. quadrifolia. L. 


\section{GYüngrviráG. Convallaria. L.}

1. Kopasz tőkocsányja tövét két levele nyele behürelyezi; levelei tojásdad- vagy körkörös láncsások. - Árnyas erdëkben. 24. Maj-Jun. 1/2-1'. (Gyÿngyvircig; liakukrix(i!! : szelenczevir(i!.)

Majusi Gy. C.majalis. $L$.

Szára leveles; kocsányjai a levél hóna alól nönek ki. ․ 2. Levelei nyelesek, tojásdadok hegyesek, alsó lapjai inain szörösödők; kocsányjain 4-5 virág van. - Erdőkben, ligetekben. 24. Maj-Jun. 1-1' $2^{\prime}$.

Széleslevelï Gy. C. latifoliu. Jacqu.

Levelei szárölelök. 3.

3. Szára szegletes; levelei tojásdad hosszuk, vagy körköo rösek. kopaszok ; kocsányjai 1-2 viráguak. - Az eléb-

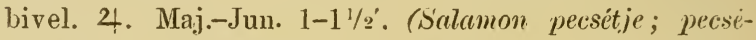
tes gyökier: sok térdüfü; erdei sülyfü.)

Buitykös Gy. C. Polygonatum. L.

Szára hengeres, levelei tojásdad-hosszukások, vagy körkörösek, kopaszok; kocsányjai 3-5 viráguak; szálcsái szőrösek. Az elöbbivel 4. Maj.-Jun.

Fïrtös Gy. C. multiflora. I

8. Rend. Potnyafélék. Hydrocharideae. $D C$.

1. KOLOKÁN. Sratiotes. L.

Levele kardalaku, 3 élü, tüske fogakka] fürészelt; rirága kétlaki, fejér. Álló vizekben libeg, a Tisza kiöntéseiben a csemege sulyommal. 4. Jul.-Aug. 4-10". (Kololiciny; imergyöliér.)

Imer K. S. aloides. $L$.

\section{POTNYA. Hydrocharis. I.}

Uszó levelei nyelesek, köralakuak, tövén mélyen szívesek; virágai kétlakiak. fejérek. - Álló vizekben. 4. Jull.-Aug.

Béka P. H. morsus vanar. $L$. 
9. Rend. Dioscoreafélék. Dioscorene. Kr. Bi.

1. FOLYONDÁR. Tamus. L.

Szára felfutó; levelei szívesek, kihegyezettek, épélüek; virágai zöldesek. A Baja felé eső erdökben. 4. Jun.Jul.

Gönye F. T. communis. $L$.

10. Rend. Nösziromfélék. Irideae. $R$. $\mathrm{Br}$.

\section{NöSZIROM. Iris. L.}

1. Leple külsö metszetei belsö oldalán szakálasok. 2. Leple külső metszetei belsö oldalán szakáltalanok. 4. 2. Szára egy virágu, igen kurta; leple csöve burkából kiér; levelei kardalakuak, hosszabbak, mint il kocsányja. Hegyi és homoki gyepeken. 4. Kora tavaszszal 3-12". (Leciny liliom; apró liliom.)

Apró N. I. pumila. $I$. Szára töbl virágu. 3.

๖. Leple metszetei hossznkás visszás-tojásdadok, belsö metszetei töve felé lassankint keskenyednek; levelei kardalakuak s kocsányjával egyenlők. Hegyi és homoki gyepeken. s erdökben. 24. Maj.-Jul. 6-18". ('Trilin. litiom.)

Tarka N. I. variegata. $L$.

Leple metszetei kifelé hajlók. széleseeskék s hosszukások, a belsők láncsások, fodrosak, bibeszára lemezeit tetézök. kinyíltak; tőkocsányján két virág van; levelei kardalakuak, keskenyek esaknem akkorák, mint a tőkocsányja. Homokos téreken és a legszárazabb hegyteken. 2. Maj.-Jun. 3-4".

Homoki N. I. arenaria. W. és K.

4. Szára kétélü, leginkább 2 virágu; levelei szálasok száránál sokkal hosszabbak; leple külsö metszetei pótléknak tetszők, tojásdadok, kurtábbak, mint kiszélesedett nyaka: maghona hatszögü. - Erdökben Buda környékén. 24. Jun-Jul. ${ }^{\prime \prime} 2-1 \frac{1}{2} 2^{\prime}$.

Pázsitos N. I. graminer. $L$.

Szćra hengeres 5. 
5. L.evelei solkviráqu szárával egyenlök; leple sạ́rga : külső metszete széles nyaku, tojásdad, a belsök szálasok, bibéje lemezeinél kurtábbak. Mocsárokban. 4. Maj.-

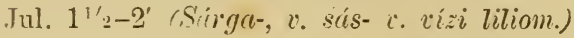

Sás N. I. Pseudacorus. $L$.

Levele, kevés, vagy kétvirágu száránál kurtább. 6.

6. Śzára csöves: leple külsö metszete lilaszínnel erezett világos kékszinü, visszás tojásdad keskeny s kurta nyaku, belsö metszetei lilaszinüek; maghona háromszögü. - Nedves réteken gyakori. 4. Maj.-Jul. 1-3’.

Mezei N. I. sibirica. $L$.

Szála teli bélü, leple külsö metszetei kékkel erezett fejéres sárgák, knrtábbak, mint ferde csíku s lánesás nyakaik, belsö metszeteik lilaszinüek; maghona hatszögü. Mocsárokban és vizenyös réteken gyakori. 4. Jun.-Jul. 1-2'.

Fátyol N. I. spuria. L.

\section{DÁKOSKA. Gladiolus. I.}

Hagymája reczés, szára felálló, magános; levelei kardalakuak, hegyesek, füzére féloldali, sokvirágu; bibéje metszetei felfelé kissé elszélesednek s törétöl mindenütt bibiresókkal szemszörözött; tokja háromszögü, felső részén éles ormóju. A Rákoson és a budai hegyekben a Farkasvölgyön. 4. Jun.-Jul. 1-2'.

Bókoló D. G. communis. $L$.

\section{SÁFÁN. Crocus. I.}

Higymája burka rostjai hagymáját egymásba nyíló szemü hálóval boritják be, e háló szemei tojásdadok, vagy kerekdedek; tőkocsányja tetején 1 , néha 2 virág van; bibéje három metszetü, leplénél felényivel kurtább, leple torka kopasz, hasábjai láncsások, hegyesek, halvány lilaszinüek; levelei szálas sertések. - A Köbánya felé eső homoki legelökön, kora tavaszszal, azonban nagy ritkaság. 4. 3-6". (Crocus reticulatus II. B.)

Tarka S. C. variegatus. Hoppe. 
11. Rend. Amarillisfélék. Amaryllideae. $R$. $B r$.

\section{HóviRÁG. Galanthus. L.}

Tökocsányja egy virágu; levelei szálasok. Ligetekben mindenütt kora tavaszszal. 4. 1-12". (Hóvircig; fejér tacaszilia; fejèr kankós: fejér viola.)

Kikeleti H. G. nivalis. $L$.

\section{TÖZIKE. Leucojum. L.}

Burkából 3-6 kocsány indul s azokon ugyanannyi virág van; bibeszára fonalas-kupalaku; levelei szálasok, tompák. - Vizenyös réteken. 4. Maj.-Jun. 1-1 1/2'. (Tözek viola.)

Nyári T. $L$. aestivum. L.

\section{SÁRIKA. Sternbergia. W. Kit.}

Levelei szálasok, tökocsányja kétélü; virága felálló; leple metszetei tojásdad hosszukásak, a külsők hegyesdedek; virága sárga. - Hegyi gyepeken Buda körül (Lipótmezön, Kecskehegyen, Sashegyen s a kincstári erdökben.) 24. Öszszel virágzik, tok termése tavaszszal fejlik ki, tokja kocsányos, tojásdad sárgás.

Kikeries S. S. colchiciflora. W. K

\section{Rend. Kosborfélék. Orchideae. Juss.}

\section{KOSBOR. Orchis. L.}

1. Golyós vagy két karélyu gyökerủek (a bodza kosbor golyója két karélyu.) $\mathbf{2}$.

Tenyeres gyökerüek. 11.

2. Murvájuk egy inú. 3.

Murvájuk három s több inú. 10.

3. Alsó ajaka (mézajaka) három hasábu, közép hasábja elöl kiszélesedö, két metszetü, metszete karélyában legtöbbször egy kis fogacska van. 4. Alsó ajaka három metszetü vagy három karélyu. 7.

4. Murvája maghonánál sokkal kurtább. 5.

Murvája felényi, mint a maghona. 6. 
5. Levelei hosszukás tojásdadok: alsó ajaka eesetesen pontozott, oldali két hasábja szálas, a középső, tövétől kezdve lassankint kiszélesedö, visszás szíves, karélyai tojásdadok, csaknem csonkák; füzére hosszu, sokvirágu. - Hegyi réteken, s erdökben. 24. Jun.-Jul. 11/2-21'. - A nálunk levö kosborok közt a legszebb és a legnagyobh.

Kesely K. O. fusca.Jar\%.

Levelei hosszukás körkörösek; alsó ajaka ecsetesen pontozott; oldali két hasábja szálas, a középső hasáljji is szálas, a hegye felé szélesedik el, két metszetii, metszetei hosszukások, szélylyeltartók; füzére tojásdad. - Az elöbhivel. 24. Jun.-Jul. 1-1'1/2'.

Vitéz K. O. milituris. $L$.

6. Levelei tojásdad hosszukások; alsó ajaka pontozott, kopasz : oldali két hasábja hosszukás, a középső széles visszás-szives; sarkantyuja felényi. mint a maghona; tojásdad füzére tömött. - Hegyi réteken. a homokon ritka. 24. Maj.-Jun. 6-18". Tarka K. (). variegatı. Jacq.

Levelei hosszukás láncsások; alsó ajaka oldali két hasábja hosszukás szálas, a középső két metszetü. karélyai hosszukás-szálasok; sarkantyuja harmadrésznyi. mint maghona; füzére elöbb tömött, azután kinyulik, - Minden réten közönséges. 24. Jun.-Jul. 4-8".

Sömörös K. O. ustulutı I..

7. Alsó ajaka három metszetü. lefüggö, metszetei csaknenı egyenlök, a középső hosszukás, ép; murvája akkora. mint a maghona, ritsán hosszabb; füzére hosszukás hengeres, tömött: levelei szálas láncsások. - Mindeu réten, kiváltképen a nedveses homoki réteken. 4. .Jun.-Jul. 6-12". Palaczka K. O. coriopluora. I.

Alsó ajaka három karélyu. karélyai szélesek, kurták. S. 8. Leple szirmai sisak módra állanak össze, tompák; murvái egy inúak. az alsók többnyire 3 inúak, akkorák, mint a maghona; füzére kurta, laza s kevés virágu; lovelei hosszukás láncsások. - Minden ríten a leg- 
közönségesebl. 4. Apr.-Maj. 4-10". (Vitézfü; liosborfü: ag(irfü.)

A gár K. O. morio. $L$.

Felsö ajaka oldali két szirma végre hátrahajlik. 9.

9. Levelei hosszukás-visszís tojásdadok, alsó ajka alig három karélyu, épélü, vagy igen finomul csipkés; kifejlett füzére visszás tojásdad; virága többnyire sárgás fejér. Hegyi réteken. 24. Apr.-Maj. 6-10".

Sápadt K. O.pallens. $L$.

Levelei hosszukások; alsó ajaka mélyen három karélyu, karélyai szélesek, fogasok; kifejlett füzére megnyult * laza virágu; virága piros. Minden réten. 4. Jun.Jul. 10-13". (Piros liöliöresin.)

Fiiles K. O. mascule. $L$.

10. Levelei szálas láncsások: alsó ajaka 3 karélyu, oldalkarélyai elöl lekeritettek, a közép mélyen kicsípett; sarkantyuja hengeres, vizirányosan áll, vagy felegyenesedö. kurtább, mint a maghona : szirmai hosszukások, tompák, az oldalt levök hátrahajolnak; füzére hosszı, ritka virágu. - Vizenyös rétekeu és a mocsárokban. 4. Jun.-Jul. 8-12". Lazavirágu K. O. Iaxiflora. Lam.

Levelei hosszukás láncsások; alsó ajaka kurta 3 karélyu ; sarkantyuja kuposan hengeres, lefelé tartó, akkoria, mint a maghona, szirmai szélylyeltartók ; füzére tömött, virága szaga hasonlit a bodzavirágéhoz, virága sárgásfejér, ajaka világos sárga, tövén pirosan pontozott, vagy az egész leple piros. Magasabb helyeken fekri; réteken. 4. Maj.-Jun. 6-12". Bodza K. O. sambucina. J..

11. Szíra bördős 4-6 levelü; levelei kihajlók, az alsók tojásdadok vagy hosszukások, tompák, a felsők kisebbek, láncsásosak, kihegyezettek, néha barna foltosak: virágai pirosak. Nedves réteken és mocsárokban. 4. Maj.-Jun. 9-18".

Bördös K. O. latifolia $I$. Szára telebélü, mint egy 10 levelü, felsö levelei igen aprók, murvához hasonlók, a legfelsö füzérétől távol áll; virága piros pontok- s ronalokkal ékesitett vilá- 
gos lilaszinü, levelei rendszerint barnafoltosak. - Erdökben, nedves réteken. 4. Jun.-Jul. 1-11/2'. (Tenuyeres gyöker"ü, v. tarka levelü kökörcsin.)

Foltos K. O. maculata. $L$.

\section{RAGIKRA. Anacamptis. Rich.}

Alsó ajaka félig három karélyu, tövén két lemezecske van, karélyai hosszukások, tompák; sarkantyuja fonálalaku, akkora. mint a maghona, vagy valamivel hosszabb; szirmai lánesások, meglehetős hegyesek; murvái tövén 3 inúak; füzére tömött levelei láncsásszálasok. - Hegyi réteken, erdökben. 24. Jun.-Jul. ij-18". Tornyos R.A.pyramidalis. Rich.

\section{SODORTAJK. Himanthoglossum. Sp.}

Sisakja fejér, belöl piros zöld csíkos; ajaka fejéres zöld, verhenyesen pontozott, 3 hasábu, karélyai szálasok, a középsö igen hosszu, sodrott, az oldaliak sokkal kurtábbak, fodrosak; levelei széles láncsások. - Hegyi gyepeken. 4. Jun.-Jul. 1-2'.

Bakbüzü S. H. hircinum. Rich.

\section{t. CSORIKRA. Gymnalenia. R. Br.}

1. Sarkantyuja fonalaku, csaknem kétannyi, mint a maghona ; oldalszirmai széllyelállók ; füzére hengeres, megnyult, levelei hosszu láncsások; gyökere tenyeres. Hegyi réteken. 24. Jun.-Jul. 6-12".

Szunyoglábu Cs. G. conopsea. $R$. Br.

2. Sarkantyuja fonalaku, csaknem akkora, mint a maghona; szirmai igen széllyelállók; füzére hengeres, megnyult ; levelei szálas láncsások és szálasok; gyökere tenyeres. - $\mathrm{tz}$ elöbbivel. 24. Jun.-Jul. 6-12".

Jószagu Cs. G. odoratissima. R. Br.

\section{NYELvÜR. Coeloglossum. Hartm.}

Alsó ajaka szálas, hegye 3 fogu, középső foga igen kurta sarkantyuja igen rövid, zacskó alaku; levelei tojásda- 
dok, tompák, a felsők láncsások; gyökere tenyeres. - Hegyi és homoki száraz és nedves réteken. 2. Maj.-Jul. 3-8". (Habenaria viridis. R. Br.)

Zöld Ny. C. viride. Hartm.

\section{SARKAR. Platanthera. Rich.}

Alsó ajaka ép, szálas; sarkantyuja 11/2-2-er hosszabb, mint a maghona, fonalalaku; portoka rekeszei párhuzamosak; szárán 2-3 láncsás kis levele vau; virága fejéres. Erdőkben böven. 24. Maj.-Jul. (Habenaria bifolia $R ., B r$.

Kétlevelii S. P. bifolia. Rich.

\section{BANGó. Ophrys. L.}

Alsó ajaka hosszukás visszástojásclad; közepén 2-4 piszkos sárga, tövén keresztbe összefoglalt, hosszára nyuló vonal van, bóltos, felpuffadt, szélen legyüremlett, hegye tompa, vagy alig kicsípett; gumója ép.-Minden gyepen, kivált a homoki nedves réteken. 4. Maj.-Jul. 6-12".

Pókos B. O. aranifera. Huds.

\section{S. GÉRBICZ. Limodorum. Tourn.}

Levélnélküli, világos lilaszinü növény ; tőkocsányja hártyás, pikkelyes; ajaka tojásdad, fodros; sarkantyuja áralaku, akkora, mint a maghona. A budai erdőkben, a. Hárshegyen, ritka. 4. Jun.-Jul. 1/2-1'.

Violaszín G. L. abortivum. Schu:

\section{PORFEJ. Cephalanthera. Rich.}

1. Maghona kopasz. 2.

Maghona szörösödő; leple szirmai mind kihegyezettek; ajaka lemeze tojásdad, kihegyezett, akkora, mint belső szirmai; leple szép piros; levelei láncsások. hegresek. Buda körül a ligetekben. 2. Jun.-Jul. 6-15".

Veres P. C. vubra. Rich.

2. Levelei tojásdadok, vagy tojásdad láncsások, kihegyezettek; leple sárgás fejér, mindenik szirma tompa; 
ajaka lemeze szives-tojásdad, szélesebb. mint hosszabb; murvája hosszabb, mint a maghona. - Hegyi és homoki erdőkben. 4. Jun.-Jul. Sáppadt P. C.pallens. Rich.

Levelei láncsások, a felsök szálas lánesások s keskenyek; leple fejér, ajaka hegyén egy sárga folt van, külsö szirma hegyes; murvája sokkal kurtább, mint a maghona. - A budai hegyeken ritka. 4. nyáron.

Kardlevelï P. Ć. ensifolia. Kirll.

\section{BIBAK. Epipactis. Rich.}

1. Ajaka lemeze kerekded, tompa, akkora, mint szirmai; levelei tojásdad láncsások, szárölelök, virága zöldes piros. - Vizenyös réteken, mocsárokban böven. 4. Jun.-Jul. 6-15". Mocsári B. F. palustris. Crantz.

Ajaka lemeze kihegyezett s hátrahajlott. 2.

2. Ajaka lemeze tövén levö pupjai símák; levelei száröIelök, az alsók széles tojásdadok, a felsők tojásdad láncsások, a legfelsö 1-2 láncsás; virága zöldes verhenyes, ajaka Iilaszinü. Ligetekben. 24. Jun.-Jul. 1-2'. Széleslevelï B. É. latifolia. Alll.

Ajaka lemeze tövén levö pupjai ránezosan fodrosak. 3. 3. Levelei tojásdadok. éle és inai szörösödők, felső levelei nyeletlenek, láncsások; virága sötét piros. - Hegyi nyílt gyepeken, kivált a Farkasvölgyön. 24. Jun.-Jul. 6-12". Verhenyes B. E. mubiginosa. Gaud.

Levelei tojásdad lánesások, vagy láncsások, aprók, élök szörösödö-érdes, inai kopaszok; virága zöldes, széle verhenyes, ajaka széle fejéres. Buda erdeiben ritka, legtöbbet lehet találni a budakeszi erdöben. - 4 . Jun.-Jul. 6-12". Aprólevelï B. E. micropluylla. Eihrh.

\section{TOKAFÉK. Neottia. I.}

Az egész növény piszkos sárga, végre barnássá lesz; szára leveletlen, e helyett hártyahüvelyekkel fedett; ajaka visszás-szíves, alig :3 karélyu. - Árnyas erdők- 
ken a fák törzsein és gyökerejn élödik. 24. Maj.-Jun. 6̈-12".

Madárfészek T. N. Vidus avis. Rich.

\section{BIBEKonty. Listeria. R. Br.}

Szára kétlevelü; levelei ellenesek, tojásdadok; leple zöldes sírga, ajaka szálas, két metszetü. - Ligetekben, kivált nedves helyeken. 4. Maj.-Jul. 6-12".

'Tojásilad B. L. ocata. R. Pir.

\section{FÜZÉRTEKERCS. Spiranthes. Rich.}

Szárán csak levélhüvelyek vannak, tölevelei tojásdad hosszukások, szára féloldala felöl állanak; fiizére csavaros; leple apró, fejér. - Gödöllö körül esö homoki gyepeken és a Tisza vidékén levö legelökön. - 2. Nyáron át. 6-9".

Öszi F. S. antumnalis. Rich.

\section{Hagymabur. Sturmia. Rich.}

Szára háromszögű, ezt tövön körīörös láncsás két levél hïvelyezi; füzére $3-3$ virágu; virága zöldessárga, ajaka tojásdad, tompa, apró csipkéjü; tojásdad gumóját élesen vonalozott burok fedi. - A pesti városliget vizenyös gyepein, nagy ritkaság. 4. Jun.-Jul. $2-5)^{\prime \prime}$.

Libaszinï H. S. Loselii. Rehb.

\section{BIBEFOG. Malaxis. Swartz.}

Háromszögrỉ szára rendszerint ègylevelï; levele szárölelö tojásdad hegyes; virágzata fürtös ; ajaka homoru, kihegyezett, virága zöldes-sárga. A sz.-endrei erdöbeli réteken. - 24. Jun. 3-6". (Microstylis monophyllos. Nuttal.)

Egylevelï B. II. monophyllos. Sw.

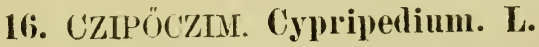

Háromszögü szára leveles; levelei körkörösek, kihegyezettek, leple pirosbarna, ajaka sárga. kissé lapitott, 
ásitó, belöl gyapjas; virága a mi kosborféléink között legnagyobb és legszebb. - A budai hegyen, a szép juhászné körül fekvő gyepeken. - 4. Jun.-Jul. 6-12". Tarka Cz. C. calceolus. $L$.

\section{Rend. Hinárfélék. Najadeae. A. Rich.}

\section{HináR. Najas. L.}

1. Levelei szálasok, csavargós éllel fogasoltak, fogai fulánkosak; levele hüvelye épélü. - A Tisza mocsáraiban. $\odot$ Nyáron át.

Nagy H. N. major. Roth.

2. Levelei keskeny szálasok, csavargós éllel fogasoltak, hátra kunkorodottak, fogai fulánkosak; levele hüvelye finom szemszőrökkel fogasolt; szára igen törékeny. A Tisza mocsáraiban. $\odot$. Aug.-Sept.

Apró H. N. Minor. All.

\section{¿. GALÁZ. Zanichellia. L.}

Szára fonąlalakn, bütykös, vizen uszó; levelei ellenesek s alig gyürüsök, sertés szálasok, kopaszok; virága hónalji; bibe-szára felényi. mint a termése. A megye síkjain eső posványokban, árkokban. 24. Jul.-Sept. $3-12^{\prime \prime}$.

Fogas G. Z. palustris. $L$.

\section{Uszány. Potamogeton. L.}

1. A tökéletesen kifejlett növény levelei vizen úszók, alakjok, sőt sejtszövetökre nézve is alámerült leveleitöl különbözők, váltogatók, csupán a kocsánytövén ellenesek. 2.

Minden levelök egyenlö, hártyás. áttetszö; az egész növény viz alá merült. a virágzás idején csupán füzérei emelkednek ki a vizböl. 3.

2. Viz alá merült levelei lemezei virágzás idején elkorhadván, csupán levélnyelei maradnak meg, alámerïlt ifjabł, levelei keskenyebbek, láncsások vagy hosszukások, fen ıs‡ó levelei kerekdedek vagy hosszukás körkörösek, 
börnemüek, vállok alig szíves, tompa élü termése lapított. - Minden folyócskában s nocsárban. 4. Jun.-Aug.

Békatutaj U. P. natans. $L$.

Viz alá merült levelei hártyások, áttetszők, keskenyek vagy széles láncsások, tövön elkeskenyedettek, nyeletlenek, élökön kissé érdesek, fennúszó levelei börnemüek, láncsások vagy tojásdadok, hosszu nyelüek; tompa élü termése lapitott; szára igen ágas. - Lassan folyó minden vízben és mocsárban. 4. Jun.-Aug. (P.heterophyllos. Schreb.) Pázsitos U. P.gramineus. $L$.

3. Levelei váltogatók, legfeljebb a virága alattiak ellenesek. 4.

Minden levele ellenes, nyeletlen, szárölelö; füzére villás, virágzás után hátrahajlik; termése széles ormóju és csörös. - Ó-Budán kivül, a puskaporos malom környékén levö mocsárokban. 4. Jun.-Jul.

Villás U. $P$. densus. $L$.

4. Levelei nyelesek, tojásdadok vagy láncsások, fulánkosak, élök érdes; kocsányja felsö része megrastagszilk; tompa élü termése lapitott, alig ormós. - Lassan folyó minden vízben s a mocsárokban. 24. Jun.-Aug. Üveglevelï $\mathbf{C}$. P. lucens. $L$.

Levelei éle éles vagy finom fürészes. 5.

5. Levelei nyeletlenek, szálas-hosszukások, meglehetösen tompák, apró fürészfoguak, fodrosak; termése csörös; szára ágas, lapos. Az elébbivel. 4. Jun.-Aug.

Bodros B. P. crispus. $L$.

Levelei pázsitnemüek. 6.

6. Levelei hüvelynélküliek, nyeletlenek, igazi szálasok, meglehetös hegyesek, 3-J inúak; kocsányjai 2-3-szor hosszabbak, mint 4-8 virágu többnyire szakgatott füzére; termése ferdén körkörös. - Az elébbiekkel együtt. 4. Jun.-Aug.

Hajszál B. $P$. pusillus. $L$.

Levelei hüvelyesek, szálasok vagy sertések. 1-inúak, keresztben erezettek, erei rastagocskák; füzére hosszu 
kocsányu; termése ferdén tojásdad. szárasztva háta ormós, felegyenesedő kurta bibeszára rajta van. Az elébbiekkel együtt, böven terem a Rákos folyóban. 4. Jun.-Aug.

Borostás B. $I$. pectinatus. $L$.

14. Rend. Lepcsefélék. Lemnaceae. DC. és Duby.

\section{LEPCSE. Lemna. I.}

1. Lombja tagjai láncsások, végre nyelesek, keresztet alkotnak; egy szál gyökere van. - Âlló vizekben, viz alá merül. $\odot$. Nyáron és öszszel.

Keresztes L. $L$. trisulca. $L$.

Lombja tagjai tojásdadok. $\mathbf{2}$

2. Csomós gyökerủ; lombja tagjai kerekded-visszás tojásdadok. - Álló vizeken uszkál. ๑. Nyáron és öszszel. Fanos L. $L$. polyphiza. $L$.

Egy szál gyökerüek. 3.

3. Lombja tagjai visszás-tojástadok. alíl felül laposak, nyeletlenek. Az elébbivel. $\odot$. Igen apró.

Apró L. $L$. minor. $L$.

Lombja tagjai visszás tojásdadok, meglehetös domboru, alól taplósan domboru. Álló vizeken. ๑. Nyáron s öszszel.

Lenesés L. $I$. gibha. $L$.

15. Rend. Kontyvirágfélék. Aroideae. JIss.

1. KontyvirÁg. Arum. I.

'Tökocsányját egy nagy burok hüvelyezi, ezen burok fogja be torzsáját; levelei dárdás-nyílalakuak, egyenlö szinüek vagy barna-foltosak. - Árnyas ligetekben. Budán a Béla-kutjánál. 4. Maj.-Jul. 3-12". (Kigyjótring; prirkinyfü; (tnyafü.)

Mocskos K. A. muculatum. $L$.

\section{KÁlMos. Acorus. L.}

Tökoesányja levélnemü, lapított, egyik éle éles a másik válus, ebben van gömbded-hengeres torzsája; levele 
hosszu, kardalaku. - A folyó vizek melléken. a Zagyva és Tisza mocsáraiban. 4. Jun.-Jul. 2-4'. (Kálmus.)

Orvosi K. $A$. Calamus. $L$.

16. Rend. Gyékényfélék. Typhaceae. $D . C$.

\section{GYÉKÉNY. Typha. L.}

1. Levelei széles láncsások; termésfüzére szorosan porodás füzére alatt áll.-Mocsárokban. 4. Jun.-Jul. 4- $\delta "$. (Gyéliény.) Bodnározó Gy. T. latifolia. i.

Levelei keskeny szálasok, alól válusok; termés füzére porodás füzérétöl 1-1/1/2" távol áll. Mint az elöbbi. de ritkább. 4. Jun.-Jul. Hati Gy. T. angustifolia. L.

\section{BAKA. Sparganium. L.}

1. Levelei felállók, tövön háromélủek; bibéje szálas; terméskéi hosszu csörüek $\mathbf{2}$.

J.evelei lecsepültek, vagy úszók, vagy a víz szinén vagy az alatt lobálódók. 3.

2. Szárán ágas virágzata van; oldal levelei behorpadtak, az alsók szárhüvelyezök a többiek szárölelök. - Nocsárok- és posványokban. 24. Jun.-Aug. 1-3'.

Buzogány. B. S. ramosum. Huds.

Srárán egyszerü fürtös virágzat van; oldal levelei laposak. - Az elébbivel, de ritkább. 4. Jun.-Aug. $1-3^{\prime}$.

Nyeles B. S. simplex. Huds.

3. Terméskéi hosszu kocsányuak, áralaku bibeszáránál kurtábbak; szárán ágas virágzata van, melyek 10-12 porodás gömbböl állanak; levelei laposak, keskenyek, ıgen hosszuk s úszók. - Patakocskákban s csendesen folyó vizeken, a Rákosban bőven. 4. Jul.-Aug. 1-4'.

Sulymos B. S. natans. $I$. 
III. Al-OSZtály.

\section{Csúc:skör’nörök. Acramphibrya.}

I. csoport. Csupasemagruat: Gymmospermae.

17. Rend. Toboztermők. Coniferae. L.

\section{BoRÓKA. Juniperus. L.}

Levelei hármával állanak, szálas-áralakuak, szúrósak, felül alig válusok, alól ormósak, ormóján végig egy besüppedt ronal van ; bogyói tojásdadok, érett korukban 2-3-szorta kurtábbak a levelénél. - Terméketlen száraz hegyi erdökben. †. Maj. 2-s’. (Gyalogfemyö.) Gyalogfenyö B. J. communis. $L$.

\section{BOGYÓPIKK. Ephedra. L.}

Szára cserjésedő, le vélnélküli, czikkes, hengeres, kopasz; virágos ágacskái gyürüsök; barkái kocsányosak s magánosak, ellenesek, hármasok, bogyónemü termése veres. - A budai veröfényes hegyek, és a pesti homokbuczkák oldalain. 5. Aug.-Sept. 1-1'².

Törpe B. E. monostycha. $L$.

II. Csoport. Seiromtalanoli. Apetalae.

18. Rend. Locsagazfélék. Ceratophylleae. Gray.

\section{Locsagaz. Cerathophyllum. T.}

Levelei villások, 2-4 szálas fonálra hasogatottak; termése tojásdad, nem leppendékes, 3 törisü, két tövis az alján van s hátragörbült, egy a régén s ez akkora, mint a termése, vagy ralamivel hosszablo. - Álló vizekben. 4. Jul.-Aug. Szarvas L. C. demersum. $L$. 
19. Rend. Mocsárhúrfélék. Callitrichineae. Link.

\section{MoCśś ÁRÚr. Callitriche. L.}

Ágai alsó levelei szálasok, a felsők visszás tojásdadok; murvái kör-sarlóalakuak, hegyök horgas; bibeszárai hosszuk, szélylyelállók; termése éle szárnyason ormós. Álló és csendesen folyó vizekben. 4. Jun.-Sept. (C. (erna. L.) (Irocsiri lencsefü.)

Tavaszi Y. C.hamulata. Kütz.

20. Rend. Ryyirfélék. Betulaceae. Bartl.

\section{NYÍRFA. Betula. L.}

Levelei kótaalaku háromszögüek. hosszan kihegyezettek, kétszer fürészesek, kopaszok; termés barkái hosszu kocsányon függenek; leppendékecskéje szárnyai kétszer olyan szélesek, mint a magra s egészen a bibéjéig felérnek. - A budakeszi erdökben s a pesti szigeten. †. April-Maj.

Fejér Ny. B. allar. $L$.

\section{2. ÉGERFA. Alnus. I.}

1. Levelei kopaszok, esupán alsó lapjaik, gerinczök s inaik által alkotott zugaiban szörösek, kerekclekek, igen tompák, egyenetlen fürészesek. Vizenyös, mocsáros helyeken, patakok, partjain. i). Mart.-April 3-6".

Mezgés É. A. glutinosa. Gärtn.

2. Levelei alsó lapjaikon szörösödök, vagy csaknem molyhosak, tengerszín zöldek, tojásdadok, hegyesek, kétszer fürészeltek, fogai hegyesek, inai zugai kopaszok. Az elébbivel, ez nálunk bövebben van. ந. Mart.-April $3-6^{\circ}$.

Hamvas É. A. incana. $W$. 
21. Rend. Kopáncstermők. Cupuliferae. Rich.

\section{VEnICZFA. Ostyra. Michel.}

Tobza tojásdad, lefüggö; levelei tojásdad kihegyezettek, vállain alig szívesek. - A vizsegrádi erdőkben. †. April-Vaj. (Carpinus Ostrya L.) (Veniczfa.)

Komlós V. 0. carpinifolia. Scyp.

\section{Gyertyánfa. Carpinus. L.}

Tobza pikkelyei 3 hasábuak, oldal hasábjai láncsísok, a középsö megnyult, épélü vagy fürészelt; levelei tojásdadok. kihegyezettek, ránczosok, kétszer fürészesek. - Erdőkben. 1). Maj. Fejér Gy. C. Betulus. I.

\section{Mogyonófa. Corylus. L.}

1. Kopánesa harangalaku, hegye széllyelálló. rongyos fogas száju; levelei kerekdedek, szívesek kétszer fürészesek, kihegyezettek. - Erdőkben. bozótokban mindenütt. †. Febr:-Mart. Közönséges M. C: Avellana $L$.

2. Kopáncsa csöves-hengerded, bevagdalt fogas-szájú, felül össze van szorúlva; levelei. kerekded-szívesek, hegyesek. kétszer fürészesek. - Itt-ott vadon, azonban mivelik. †. Febr:-Mart. Csöves M. C. tubulosa. W.

\section{Tölgyfa. Quercus. I.}

1. Kifejlett levelei kopaszok. ‥

Kifejlett levelei alsó lapjain molyhosak. 3.

2. Hármával vagy négyével együtt ïlö makkjai kocsánytalanok, pelyhes murvái hegyesedök; jó nagy makkját kopáncsa harmadrésznyire fedi; levelei felül szélesek, alól e nyelébe keskenyedők, különféleképen öblözöttek. karélyai tompák. - Erdőkben. †. Maj.

Kocsányos T. Q. sessiliflora. Sm. Kettejével együtt ülö makkjai $1-2$ hüvelyknyi. váltogatva álló kocsányon függenek; keskeny murvái fehér kurta szörrel vamnak fedve; makkja nagy. kopánesa aránylag 
kisebb. mint az elébbié: levelei felül ennek is szélesek, aláfelé elkeskenyedők. nyeletlenek, öblei nagyok, karélyai tompák. - Erdökben. Maj.j.Jun. b.

Kocsányos T. (2. pedunculata. Ehrir.

ə. Makkopánesa pikkelyei kurták. lelapultak. 3-4 makkja fürtösen ül egy vastag mintegy $8-10$ vonalnyi molyhos kocsányon: levelei alakjokra nézve hasonlitanak a kocsánytalan tölgyéhez, de attól levele molyhosságánál fogva feltünỏen különbözik. -- Az elébbiekkel. 1). Maj.-Jun. Szörösödö T. Q. mubescens. Will. Makkopáncsa pikkelyei megnyultak. szálas áralakuak, széllyelállók s tekeredettek; termése kettö-három iil együtt, levelei nagyon változékonyak, többnyire szárnyason behasogatva kikanyargatottak, karélyai hegyesek. - ${ }^{-A z}$ elöbbiekkel. b. Maj.-Jun. (C'serfa.)

Cser T. Q. Cerris. $I$.

\section{GESZTENYEFA. Castamea. 'Touru.}

Levelei hosszukás láncsások, kihegyezettek. szálkahegyü fürész fogasok. kopaszok: ragy alól szörösödök. A budai hegyeken itt-ott. azonban mivelik. 5. Jun.Jnl.

Szelíl G. C.mulgaris. Lam.

\section{(i. BIKKFA. Fagus. $\mathrm{K}$.}

T.evelei kopaszok. tojásdadok. alig fogasok. fényesek, élök bolyhosan szemazörös; virága egylaki. - $\mathrm{Az}$ erdők északi oldalain. t. Maj. Erdoi B. F. sılluticu. L.

\section{Rend. Szílfélék. Ulmaceae. Mirbel.}

1. Levelei félfaruak, hosszukás tojásdadok, kétszer fürészesek; virága esaknem kocsánytalan; leppendéke kopasz, kocsánytalan; fája kérge síma. - Erdőkben. †. Kora tavaszszal. (Alcisfa, szilfa.)

Sima Sz. U. campestris. $L$. Levelei félfaruak, széles tojásdadok, kétszer fürészesek, felül kopaszok. alól szörösödők, nyelesek, függőok, 
kocsányos leppendéke éle gyapjason szemszörös. Erdökben. 5. Kora tavaszszal.

Nyolez porodás Sz. U.effica. Wild.

\section{Rend. Czeltiszfélék. Celtideae. Duby.}

\section{CZELTIS. Celtis. L.}

Levelei félfaru tojásdadok, kihegyezettek, fürészesek; felsö lapjain érdesek; termése fekete csontár. - Mivelik. Ђ. Maj. Napnyugoti Cz. C.occidentalis. $L$.

\section{Rend. Eperfélék. Moreae. Encll.}

\section{EPERFA. Morus. L.}

1. Levelei mélyen szívesek, egyenetlen válluak, néha tojáskerekek. fürészesek; termésbarkái akkorák. mint a kocsányjai, leple éle kopasz; gyümölcse fejér, piros és fekete. - Mivelik a selyemtenyésztés kedvéért. 5 . Maj.

Selyem E. M. alba. L.

2. Levelei szíves-tojásdadok, fürészesek; termésbarkái csaknem kocsánytalanok, leple éle és bibéje érdes. Mivelik. 5. Maj. (Szederjfr.) Szederj E. M. nigra. L.

\section{FIGEFA. Ficus. L.}

Levelei szivesek, tenyeresek, :3-6 karélyuak, felül érdesek, alól szörösödők; vaczka körtealaku. - A Szt.Gellérthegy déli oldalán. 五. Maj. Édes F. F. carica. $L$.

\section{Rend. Csalánfélék. Urticaceae. Endl.}

\section{CSALÁN. Urtica. L.}

1. Levelei ellenesek, tojásdadok, hegyesek, bevagdaltan fürészesek; bugája a levél hónaljából nö, kettösek, kocsányjánál kurtábbak. - Mivelt helyeken. ๑. Jul.Sept. 1-1 $1 / 2 . '$.

Apró Cs. U. urens. L. 
2. Levelei ellenesek, hosszukás szívesek, kihegyezettek, durva fürészfoguak; bugái a levél hónaljából nőnek, kocsányjánál hosszabbak, lefüggők; virága kétlaki. - Mindenütt. 24. Jun.-Octob.

Kétlaki Cs. A. dioica. L.

\section{FAlfü. Parietaria. L.}

Szára felálló, magános; levelei hosszukás tojásdadok; leple harangalaku, porodás virágain akkora, mint a porodái. - Gyepükben, útfeleken. ๑. Jul.-Aug.

Orvosi F. P. crecta. $M I$. és $K$.

26. Rend. Kenderfélék. Cannabineae. Endl.

\section{KENDER. Cannabis. L.}

Levelei ötösek, újjasok, nyelesek; levélkéi keskeny-láncsások. élesen fürészesek; virága kétlaki. Indiából került, mivelik. ๑. Jul.-Aug.

Közönséges K. C. sativa. $L$.

\section{KoMLÓ. Humulus. L.}

Szára felfutó; levelei ellenesek, szívesek. karélyosak, durva fürészesek; virága kétlaki. - Sövényeken, bozótokban. 4. Jul.-Aug. Felfató K. H. Lupulus. L.

27. Rend. Boglárfafélék. Plataneae. Letisb.

\section{Boglárfa. Platanus. L.}

Levelei ötszögủek, karélyosak, fogasok, válluk ékalaku, alól szörösöcskék, murvái fogasoltak. - Mivelik. †. Virginiai B. $P$. occidentalis. $L$.

28. Rend. Fúzzfélék. Salicineae. L. C. Rich.

\section{FÜZ. Salix. L.}

Jegyzet. A füzek fajai meghatározásában ügyelni kell, 
barka megvizsgálásán felül a termés virágokra és a fiu termésére is. - És mivel a korán virágzó fajok levelei virágzáskor még kifejlve lenni nem szoktak: a fát kilevelezése után is. még egyszer meg kell vizsgálni. Igy lehet aztán a barkiki, termésvirágai, trlija kopaszsága vagy szölössége, lerelei alakja. kopaszsága vagy molyhossíga, ismerete ntán a fajokat bi\%ton meghatározni.

1. Barkája minden pikkelye egrszinü, sárgás-zöld. 2. Barkája felsö pikkelyei barnák vagy feketések. (6.

2. Levelei alsó lapjain fejéres szïrke molyhosak, felső lapjai homályosak és szuirkés-zöldek, szálas láncsások, élök kissé begöngyölölött s ikrás fogasok; barkái a levelek kihajtásakor virágyanak s ívalakulag hajolnak meg. Bibeszára hosszn: tokja kopasz, tokja kocsánykája kétannyi. mint a mézikrája. - Patakok partjain. kiilönösen a szigetek füzeseiben. ந. April.-Maj. (Sali.r riparia. II.)

Szöke F. S. incrma. Schranti.

Levelei mind a két oldalon kopiszok vagy lelapult selyemszörüek, fényesek, barkiii egyenesek. :.

3. Termés virága pikkelyei termése megéréséig megmaradnak: bibeszára alig van : porodája : : tokja kopas\%. kocsánykája 2-3 akkora. mint mézikrája: levelei kopaszok, lánesások. - F’üzeseklıen, « Dnma szigetein, josványokban, leginkább cserje. 5. Maj. (S. triandru I. Sm. szerint.) Mandolalevelï E. S. cmygdalina. $L$. Termésvirága. pikkelyei viráğzís ntán lehullanak: bibeszára kurta, vagy alig van, tokja kopasz. 4.

4. Tirágcsái 2 porodájuak, levclei keskenyek, láncsások. ¡. Tirágcsái 4-10 porodájuak ; levelei tojásdadok, láncsások vagy körkörösek, kopaszok. fénylö zöldek; pálhai, ha vammak. hosszukások, egyenesek; tokjai kocsánykáikét annyiak, mint mézikráik. - Vízpartokon, posvínyokban. 5. Jun.-Jul. (Vover füz.)

Baber F. S. pentamdira. $L$. 
э. Levelei rendszerint kopalszok, gyenge korukban kissé selymesek, felsö lapjaik fényes zöldek ; tokjaik kocsánykái 2-3-szor hosszabbak, mint mézikráik. - Útfelekeu. füzesekben, vizek partjain böven.

Csörege $\mathbf{F}$. $F$. fragitis. $L$.

Levelei mindkét oldalou selyem-szörüek, szürke zöldek: tokjai aligg kncsányosak. A mi füzeink között legmagasabb. - Útfeleken. rízpartokon, füzesekben. ا. Apr.-Maj.

Fejér F. S. allhu. $L$.

6. Bibeszáruk már virát̨zísuk idején hosszu. $\boldsymbol{7}$ Bibereszáruk igen kurta, vagy alig van. 9.

7. Levelei keskenyek, mintegy négyszer vagy többször hosszabbak, mint szélesebbek, hosszukás láncsísok, végre kopaszok: pálhái félszíralakuak: barkái leveleinél korábban nönek ki s kocsánytalanok; tokja kopası, kncsánỵkája kurtább, mint mézikrája. - Útfeleken s árokpartokon. 5. Apr.-Maj. (S. pracen.r. Hoppe.) Jókori F. S. daphnnides. Vitl.

Levelei négyszeres szélességénél sokkal hosszabbak. S. s. Levelei megnyúlt láncsások, kihegyezettek. épélïek, alig kanyarosak. alsó lapjaikon selymesek, fejéreslön fénylök; pályhái knrtábbak. mint levele nyelei: tokja kncsányk̨ája kurtább, mint mézikrája. - Folyó vizek partjain, a szigeti erdőkhen és mocsárokhan. b. April. $1-1^{1} 2^{\prime \prime}$ eserje. Kötö F. S. Viminalis. $I$.

Levelei meğnyúlt lánesások, kiheg’yezettek. kanyarosim ritkásan fogasoltak, fiatal korukban alsó lapjaikon finom molyhosak, idösehl, korukban alól ritkás molyhosak. alól felül zöldek: portokai felnyilásuk elött sárgák: tokja tojásdad kupalaku. moḷhos, kocsánytalan. - A Duna és Tisza füzeseiben. ந. April.

Puha F. S. mollissima. Elırh.

9. Levelei kopaszok : nem ránczosok, lánesások, fürészesek. alúl kékes szuirkék; barkái kocsánytalanok: virágesái egy porodások, portokai felnỵilásuk elött pirosak: 
tokja tojásdad. molyhos, kocsánytalan. - Vízpartokon, mocsárokban, a megye hegyi és sík vidékein. f. April.-Maj. (S. monandra. Ard.)

Csigolya F. S. purpurea. $L$.

Levelei kisebb nagyobl mértékben szörösek; tokjuk kocsányja :-4-szer hosszabb, mint mézikráik. 10.

10. Levelei nem ránczosak, legalább gyenge korukban, mindkét lapjaikon lelapult selyem-szörủek, fénylök, hegyök kajszán kinyuló. - Homoki kivált vizenyős gyepeken. †. April-Maj. 1-3'. Terjedö F. S. vepens. L. Levelei. kivált alsó lapjain kiülő inúak s ránczosak, kisebb-nagyobb mértékben molyhosak, fénytelenek, élök néha hullámosan fogasolt. 11.

11. Rügyeit fedö pikkelyei, valamint fiatal hajtásai is szörösödök; levelei körkörösek, vagy lánesás visszás-tojásdadok, alól molyhosak, felül szörösödők; pálhái vesealakuak. A megye síkján minden füzesben kivált mocsáros helyeken. †. Mart.-A pril.

Hamvas P. S. cinerea. $L$.

Rügye pikkelyei kopaszok, levelei kajsza hegyüek. 12. 12. Levelei tojásdadok, vagy körkörösek, alól kékes-zöldek, molyhosak, felül kopaszok; tokjai hosszu kocsányuak. - Hegyi erdőkben. †. April. Keeske F. S. caprea. L.

\section{NYÁRFA. Populus. L.}

1. Nyolcz porodáju; barkája pikkelyei szemszőrösek. 2. Tizenkét-husz porodáju; barkája pikkelyei kopaszok. 4.

2. Levelei kerek-tojásdadok. szegletesen fogasok, alól molyhosak. 3.

Levelei esaknem köralakuak, fogasok, fiatal korukban selymesek. gyapjasok, végre kopaszok. - Erdőkben. 5. April.

Rezgö Ny. P.tremula. L.

3. Levelei alsó lapjaikon hófejér molyhosak; termés barkái pikkelyei csipkések, szemszörösek. A Duna szigetein, vizek mellett, posványokban. b. April. Magas fa. Fejér Ny. P. alba. $L$. 
Levelei alsó lapjaikon szürke molyhosak; termés barkái pikkelyei bemetszettek, szemszörösek. Az elébbivel. †. Mart.-April. Magas fa. Szöke Ny. P. canescens. Sin. 4. Ágai felállók; levelei kótaalakuak, kihegyezettek, élök fürészes; kopasz. - Keletröl hoztál, útfelekre ültetik. †. April. Igen magas fa.

Jegenye $\mathbf{~} y$. P.pyramidalis. Rozim:

Ágai terepélyesek; levelei háromszög-tojásdadok kihegyezettek, fürészesek, élök kopasz. Erdőkben, kivált nedves helyeken. - Mivelik is. 1). April.

Fekete $\mathbf{N y}$. P. nigy.a. L.

29. Rend. Libatoppfélék. Chenopodiaceae. Tent.

\section{CZÉKLa. Beta. L.}

Tögyökere, ha mivelés alá reszik. vagy kerekdedenn vagy hosszukáson megvastagodik; tölevelei tojásdadok, tompák, alig szívesek; szára felálló, szárlevelei kótaalakuak. Mivelik. $\odot . \odot$. Veres Cz. B. vulgaris. L. Ennek válfaja a fejér cz. B. cicla, - melyet tehén répa vagy burgundi répa név alatt részint takarmánynak, részint czukornak termesztenek.

\section{LIBATOPP. Chenopodium. L.}

1. Levelei szívesek, karélyosak, karélyai szegletesek. hegyesek: virágzata bugás; magva horpadozottan pontozott. Omladékokon s telekes helyeken. ○. Jun.-Aug. 1/2-3'. (Pololvarfü.) Pokolvar L. Ch.hybridum. L. Levelei másalakuak. ..

2. Lelvelök élei küilönféle szabásuak. 3. Levelök élei épek. $\mathbf{S}$.

3. Levelei csaknem szárnyasan metszett öblösek, hosszukásak, a legfelsők murvanemüek, láncsások, épélüek ; bogernyös virágzata megnyult fürtté válik, - Homokos réteken, a megye sík részén fekvő tarak és szöl- 
löskertek környékén. •. Jul.-Aug. 1-2. (Füıtüsq ; foclorke; bajfü; ribijumlio ; s.zollösfü.)

Rubiánka L. Ch. Botrys. $L$.

Levelei egyenetlen fogasok. $t$.

1. Levelei fényesek és nem lisztesek. ‘.

Levelei fénytelenek, kisebb-nagyobb mértékben lisztesek. 6.

5. Levelei háromszögüek, válluk in levél nyelére futó, öblösek vagy kikanyargatottan fogasok; füzéres virágzata összetett, felálló, csaknem leveletlen; magva fényes, síma. Omladékokon. telekes helyeken. ๑. Jun.-Aug. 1-3'. T'elekes L. C'h. urbicum. $I$.

Levelei kótaalakulag-tojásdadok, fényesek, hegyes foguik; virágzata szélylyelálló; magva fénytelen, ormós szélü. - Büzös. Az elébiekkel. ○. Jun.-Aug. 1-2'. (Lurlkíh; latiorla.) Gáti 1. ('h. murale. L.

6. Magvai símák, fényesek. i.

Magvai finom horpadással pontozottak, fényesek, alsó levelei csaknem dárdaalakulag három karélyuak. fogasok, közép karélyai megnyúltak, hosszils láncsások, tompák, a felsők szálas láncsások, épélüek. Az elébbiekkel. - $\odot$. Jun.-Aug. 1-2'.

Késöi L. 1\%. ficifolium. s'm.

¡. Levelei kótaalakuan-tojásdadok, apró foguak, felsö levelei hosszukások, épélüek. - - tz elöbiekkel. $\odot$. Jun.-A ug. 1-2'. (Esterpuréj.)

Fejér L. Ch. ulbum. L. Ha a virágzata füzéres, akkor fejér 1 ; ha a virágzatil bogernyösen gombos, akkor zöld l. Ch. ciride. L. a neve. Levelei kerekded kótaałakuak esaknem három karélyatak, igen tompák. kicsípett fogasolk, a felsök körkörös láncsások. - Az elöbiekkel. $\odot$. Jun.-Aug. 1-2".

Kereklevelü 1. Ch. opulifolium. Schrad.

s. Levelei tojásdadok, finom hegyűek, kopaszok, termésleplei kinyíltak. - Romokon, árkokban, sís helyeken, nádasokban. ๑. Jun.-Aug. 1-3'.

sokmagu L. Ch. polyspermum. L. 
Levelei kotás-tojásdadalakuak, szürke lisztesek; magva fényes, finomul pontozott. - Útfelekeu, mivelt téreken, omladékokon. ๑. Jun.-Jul. Kellemetlen szagu. (Ch. olirlum. (urt.) (Büdös laboda ; liutya laboda.)

Biidös L. Ch. melvaria. $I$.

\section{MÁNGOL'T. Blitum. L.}

1. Leple virágzáskor bogyónemü ; levelei hosszukás háromszögủek, esaknem dárdaalakuak, mélyen fogasok; virágcsomói hónaljiak, levelesek; termése skárlátpiros. Vivelik. $\odot$. Jun.-Aug. Veszszös M. B. viryatum. $J$. Leple virágzáskor nedvnélküli, nem bogyónemü. 2.

ฉ. Levelei fényesek, kótaalakuan híromszögủek, esaknem dárdaalaku három karélyuak. öblösen fogasok; szárit verhenyes, magva síma. - Útfeleken. ๑. Jun.-Aug. (Chenopodium. Bonus Henricus.) (Kenöfü; rad spincit.) Paréj M. B. Boms Henricus. A. Mety.

Levelei hosszukások, vagy tojásdad hosszukások. tompák, ritka foguak, alól szürke zöldek; szára buglyos. magva síma. - Nedves helyeken. $\odot$. Jun.-Ang. ('henopod. glaucum. I..) Fakó M. B.glaucum. Konh.

\section{MaglapéL. Atriplex. L.}

1. T'ermés virága leple magva megérésekor is fï- vagy hártyanemü s egészen az aljáig van hasadva. 2. T'ermés virága leple tővétöl egészen a közepéig porezogós-kemény, fejéres és félig össze van nőve. 7.

․ Minden levele szálas láncsás, vagy szálas, hegyesen. fogasolt vagy néha épélü; leple szirmai kótalakuan tojásdadok, fogasok, füzére sugár. - Legelökön vagy szíksós gyepeken az egész megyében. $\odot$ Jul.-Sept.

Parti M. A.litoralis. $L$.

Alsó s felsö levelei alakja közt különbség van. 3. 3. Alsú levelei szívesded háromszögüek, fogasok. 4. 
Alsó levelei tökéletes dárdaalakuak, vagy csaknem dárdaalakuak. 5 .

4. Levelei egyenlö színüek fénytelenek, a felsők hosszukások, néha háromszögüek vagy csaknem dárdaalakuak. - Zöldséges kertekben mivelik is $\odot$. Nyáron át. 2-5.' (Német paréj; laboda paréj; izetlen fü.)

Kerti M. A.hortensis. $I$.

Levelei felső lapja fénylö, alsó lapjai ezüstös és kékes zöldek, 'felomlásosak; magva leple épélü. - Omladékokon, sövények, szöllöskertek s útak mellett. $\odot$. Jul.-Aug. 3-6".

Fényes M. A. nitens. Rebent.

5. Alsó levelei háromszögü dáralakuak, fogasok, a felsök dárclás-láncsások, a legfelsök láncsások. épélüek; termése leple háromszögü, épélü vagy fogasolt. Nedveses gyepeken, szíkes helyeken. ๑) Aug.-Sept. 2-3'. (Válfaja az Aprómagu M. A. mirosperma. W. KF.) Széleslevelï M. A. latifolia. Wah.

Alsó levelei láncsások vagy tojásdad-láncsások. csaknem dárdások. 6.

6. Alsó levelei tojásdad-láncsások, fogasok csaknem dárdások, a felsők láncsísok, épélüek; leple magva érése idején tojásdad, csaknem kótaalaku, épélü. - Omladékokon, keritések mellett, útfeleken. $\odot$. Jul.-Aug. 1-4'. (A. oblongifolia. W.K.) Tatár M. A.tatarica. I.

Levelei láncsások, az alsók fogasok, esaknem dárdások, alsó ágai szélylyelállók; termése leplei magva megérésekor dárdás-kótaalakuak. Omladékokon,. gyepeken, uitfeleken, mezökön. ๑. Jul.-Aug. 1-2'.

- Úti H. A. patulà. L.

7. Levelei mélyen öblösek, fogasok, csaknem dárdaalakuak, az alsók háromszög kótaalakuak, a felsők dárdás hosszukások; füzére szárhegyi, levél nélküli, csupán a tövén leveles. - Omladékokon, útfeleken, házalk mellett. $\odot$. Jul.-Aug. 1-2'.

Kárélyos M. A. laciniata. $L$. 
Levelei karélyosak, fogasok, az alsók kótaalakuak, a felsők tojásdadok; füzére nem folytonos, leveles. Az előbbivel. •. Jul.-Aug. 1-2'.

Rózsás M. A. rosen. $L$.

\section{SZIKÖR. Camphorosma. L.}

Szára lecsepült, elágazó. levelei áraknak, felsö fiatal levelei hosszu szőrüek, az alsók kopaszok husosak, háromszögdedek. - Szíkes helyeken mindenütt, még ott is, hol más növény nem nö. $\odot$. - Aug.-Sept. $1-4^{\prime \prime}$.

Sós Sz. c.orata. W. $h$.

\section{SEPRÖFÜ. Kochia. Roth,}

1. Levelei áralakuan-fonalosak, alig husosak, alsó lapjaikon egy vonal barázda van; virágai levele hónaljaiban hármával ülnek; termése leple murvája csaknem kotaalaku, egyenetlen; szára, verhenyes. - A futó homokon az egész megyében mindenütt. $\odot$. Jun.-Octob. 1-1 1/2'.

Homoki s. K. arenaria. Roth.

Levelei szálasok vagy szálas láncsások. 2.

2. Szára kórósodó. levelei szálasok laposak, szőrösödök, vagy gyapjas szürkék; virágai levelei honaljaiban hármával ülnek; termése leple murvái kerekdédek, a virág átméröjénél valamival hosszabloak. - Szíkes és homokos száraz mezőkön. 4. Jul.-Sept. (Salsola qnostrata $D($.)

Lecsepïlt S. $K$. prostrata. Schrad.

Szára fünemü, szőrösödő. Levelei szálas láncsások, szemszőrösek; virágai levele hónaljaiban csomósak; termése leple murrái igen kurták, háromszögüek, hegyesek. - Kertekben mivelik, elvadulva terem omladékokon. ๑. Jul. 1-3". (Salsola scopraria. M. P.) (Seproffü: lierti seprö.) Kerti s. K. scoparia. Schrast. 


\section{i. Poloskamag. Corispermum. L.}

1. Magva szálnya fogasolt, a hegyén szálnya ki van csípve, kicsípése mindenik oldaláról egy-egy hegyes fogaeska nö; magva kopasz; murvái tojásdad-láncsísok, elkeskenyedve hegyesedők; levelei szálasok. - Futó homokon. ๑. Jul.-Sept. (C. Marschalli. Steven.)

Szöke P. C. canescens. Kituit.

2. Magva szárnya hegye ép, két fulánkú; magva kopasz; murvái tojásdadok, árhegyüek, élöket fünemü részével egyenlö szélességü hártya segélyezi; szára verhenyes s fényes. - Az elébbivel. •. Jul.-Aug.

Fénylï A. C. nitidum. Kitaỉ.

\section{SoMócstng. Salicornia. L.}

Sxíra fünemü. ágai egymís hegyibe nött husos czikkelyekböl állanak; virágzata husos füzér, füzére minden oldalon három virágu; leplei háromszögöt alkotnak. A T'isza és a Zagyva körül fekvö szíkes helyeken. $\odot$. Ang*-Sept. 6-12".

Húsos S. S. herhacen. $L$.

\section{SUTLAP. Schoboeria. C. A. Meyer.}

Szára fünemü, terepély, ágas; levelei félhengeresek, hegyesek; virágai levelei hónalja alatt hármankint ülnek; leple ormós; magva finomul pontozott. Szíkes helyeken közönséges. $\odot$. Jun.-Jul. 3-S". (Chenopodium maritimum Is.) Tengerparti s. S. maritima. Mey.

\section{SAVAR. Salsola. I.}

1. Szára terepély, ágas, szőrös vagy kopasz; tövises hegyü ; levelei áralakuak; virágai hónaljiak, magánosak ; leple magva megérésekor porczogós. Homokos téreken, útfeleken, vetések közt, at tarlókon. $\odot$. Jul.-Sept. 1'2-11/2' (Kamborz; szükségfü.)

Kamborz S. S. kiali. $L$. 
2. Szíl’a kopasz, ígas; ágai felegyenesedök; levelei szálasok, fél hengerdedek, hegyesedök, kurta fulánkúak, termése leple hártyanemü. Solt s a megye Bács felé "sö vidékén. •. Jul.-Sept. Szíksós S. S. Socla. I.

\section{SÜNHAJ. Echinopsilon. Moฯ.}

Szaira fünemü, felálló, gyapjas, ágas ; levelei szálas-fonalalakuak, kövérek, tompák, igen szörösek: virágai hónaljiak, csonósak; termése leple ötszögü, kurta tüskékkel boritott. - Útszéleken szöllök küzt. p. o. ¿ Szent-Gellért-hegyen. - Jul--Sept. 1/2-11/2'. (S. sertioides. Poll.)

Szaka S. H. serlioides. Moq.

30. Rend. Amarántfélék. Amaranthaceae. Juss.

\section{Amaránt. Amaranthus. L.}

1. Szára felálló, szörös, levelei tojásladlok, elhegyesedők, tompák, murvái két akkorák, mint leplei, csaknem tïvises fulánkosak; virága 5 porodás. - Omladékokon, telekes helyeken. $\odot$. Jun.-Oct. $1^{1 / 2-33^{\prime}}$ - (I)iszmóprevéj.)

Gyom A. A. retroflexus. $L$.

Szára szélylyelterült vagy lecsepült. 2.

2. Szára szélylyelterült, felegyenesedö, kopasz; levelei tojásdad-kótaalakuak, hegyök kicsípett vagy tompa; virágzata szárhegyi kopasz füzér; murvái kurtábbak, mint a leple; tokja kerek-tojísdad. - Omladékokon, mezökön. kivált a szöllökben. $\odot$. Jul.-Aug. 11/2-2'.

Kövér A. A. Blitum. $L$.

Szára leesepült. felsö része szörös; levelei tojásdad-kótaalakuak, tompák vagy kicsípett hegyüek, élök habos ; virágzata szárhegyi kopasz füzér; murvái akkorák. mint virága leplei; tokja hosszukás tojásdad. - Homokon és réteken. kivált a szíkes nedves helyeken. ๑. Jul.-Aug. 1-3’'.

Lecsepült A. A. prostratus. $L$. 


\section{TORZON. Polychuentm. L.}

1. Szára felálló. karcsu, ágas, szőrösödő-enyves; levelei fonalalakuak, alig tövisesek, tömötten állók, konyák. - A gyömrői és reresegyházi erdőkben fedezte fel Heuffel. - Aug.-Sept. Karesú T. P. Heuffclii. Lring. Szára lecsepült. 2.

2. Szára ágas, símáskás; levelei áralakuak, alig négyszögïek, szálkások, felállók s szélylyeltartók. - Szántóföldeken s homoki réteken. •. Jun.-Sept.

Mezei T. $P$. ariense. $L$.

Ṡára igen ágas, bibircsós, érdes; levelei áralakuak, négyszögüek, szálkáshegyüek, szárra lapultak. - Homokos téreken, mindenütt a megyében. - •. Jun.-Sept.

Bibiresós T. P. ierrucosum. Lány.

31. Rend. Czikkszárfélék. Polygoneae. Juss.

1. Lórom. Rumex. I.

1. Virágai tökélyesek vagy zürtzavartak; levelei törön elkeskenyedettek, kerekdedek vagy szívesek, de nem dárdások. 2.

Virágai kétlakiak, vagy zürtzarartak; levelei dárdavagy nyílalakúak. $\mathbf{8}$.

2. Magrejtője mindenik belsö metszete. vagy legalább egy közülök mirigyes. 3.

Magrejtöje belsö metszetein ninesenek mirigyek, tölevelei szíves-tojásdadok, hegyesek, tövön kiszélesedettek. - Tavak és folyók partjai körül. árkokban. 4. Jun.-Aug. 3-5'. (T'izi lapu: tizi lórom.)

Vízi L. $R$. aquaticus. $L$.

3. Nagrejtöje mindenik belső metszete mirigyes. 4.

Magrejtője belső metszeteinek csak egyikén van mirigy, metszetei szálas láncsások, tompák. épélüek; legalsí levelei szíres-hosszukások; virágzata gyürüi murralevél nélküliek. vagy csak a legalsó gyürü alatt vin 
murvalevél. - Legelökön, réteken, útfeleken. 24. Jun.Aug. 2-3'. (R. Nemolapathum. Ehr.h.)

Véres L. $R$. sunguineus. $L$.

4. Virágzata mindenik gyürüje tövén vall murva-levél. ち. Virágzata gyürüi tövén nincs murva-levél. 6.

5. Magrejtője belső metszetei épélüek, szálas-hosszukások, tompík; alsó levelei szíves- vagy tojásdad-hosszukások. közép levelei szíves láncsások, kihegyezettek; ágai terepélyek; virágzatának csak felsö gyürüi tövén nincs murva-levél. - Legelökön, réteken, erdők szélein. 4. Jun.-. Iul.

Gyürüs L. R. conglomeratus. Murr.

Magrejtöje belsö metszetei mind két oldalán két sertefog van fogai olyan hosszuk mint a magrejtö belsö metszetei: levelei láncsás szálasok, nyélre futók. Tavak és folyók partján. árkokban, közönséges. 4. Jun.-Jul. (Sóstórom; lósósta; lieserü̈lapu.)

Sós L. $R$. maritimus. $L$.

6. Magrejtöje belsö metszetei hosszu, tompa s épélü hegybe nyulnak ki, tojásdad háromszögüek. töveiken egy áralaku fog van; alsó levelei szívesek, tompák; a középsök szíves hosszukások, hegyesek, a legfelsök láncsások. - Omladékokon, házak körül, szíkes helyeken gyakori. 24. Jun.-Aug. 2-4'.

Tompalevelï L. R. obtusifolius. $L$.

Magrejtöje belsö metszetei nem nyulnak hosszu hegÿiekké; leveleik láncsások. 7.

7. Magrejtöje belsö metszetei kerekdedek, csaknem szívesek, épélüek, vagy tövön alig fogasoltak; levelei fodrosak, hegyesek. - Legelökön, réteken, szántóföldeken, útfeleken. nagyon közönséges. 24. Jun.-Jul. $1^{1 / 2}-4^{\prime}$.

Bodros L. $R$. crispus. $L$.

Magrejtö belsö metszetei tojásdad háromszögüek, épélüek vagy hátul fogasok; levelei tövön elkeskenyedettek, élök habosan esipkézett; levele nyelei felül 
laposak. - Mocsároklıan, folyók mellett és füzesekben. 4. Jum.-Aug. - Èz a legnagyobb lórom-fiıj.

Parti L. R. Hydrolapathum. Huls.

\$. Lerelei nyíl- vagy dárdaalaknak, eresek; pálhái sallangosan fogasok. - Gyümölcsösölkben, legelökön. réteken. 24. Jum.-Aug. 1-2'. (Mezei sóstia; sósdi; sóslórom.)

Erdei sóska L. $R$. acetosa. $L$.

Levelei dárdaalakuak láncsások, v. szálasok. - Hegri és homoki száraz gyepeken. 24. Nyáron át 1-1/2'. (Mezei füles sóslia; marlà sósta.)

Madár I. R. acetosella. I..

\section{Cziknszár. Polygonum. I.}

1. Virágzata füzéres. 2.

Virágzata más állásu. 7 .

2. Füzére sürï, tömött. hengeres. :3.

Füzére ritka, vékony. fonalalaku. .).

3. Tögyökere terjedö : virága öt porodás : levelei hošznkás lánesások, nyelesek.

Vidra Cr. $P$. amphilumm. $L$.

Irilfajai : a) felsö levelei és szára vizen uszók, hoszsæu nyeln̈ek. kopaszok: natans; (1)) levelei félfaru šívesek, nyelesek. kopaszok, élei érdesesek, szára csaknem felálló: aquaticnm; c) levelei hosszudadok. hegyesek, nyelesek, mindkét lapján lelapult szörüek, élök szemszörösen fürrészelt, szára felálló, terjedö; palustre; (d) levelei láncsások, hegyesek, kurta nyelüek mindkét lapján lelapult szörüek, fogasoltak; szára felegyenesedö: terrestre. - Posványokban, mocsároklıun körz̈nséges. 24. Jun.-Jul.

Gyökere ncm terjedő; virága hat porodás. 4.

4. Hártyatölcsér pálhai kopaszok, vagy egy kissé gyaljusok, kurta s finom szemszörösek; kocsányja és csészéje ikrásau-érdes; levelei tojásdadok, körkörösek vagy lúnesísok.

Lorom C\%. L'. Iniathifolium. $L$. 
Vülfr.jai: a) bütykei görcsöek: nodnsum. Per.s.; levelei alsó lapjain gyapjasok: incamım. Sm. - Posványokban, mocsárokban, árkokban, szántóföldeken, telekes helyeken. (๑) Jul.-Aug. 2-3'.

Hártyatölcsér pálhái borzasok. hosszu szemszörủek, kocsányja és esészéje ikrátlan. - Az elöbbivel. ๑. .Jnn.Jul. 1-3'. (Hinnyorfü; his hunyor; baraczklecelü fü: disznólunyor.) Hódos Cz. P. Persicaria. L.

Vírága öt porodás; levele elkerekedett tövétöl kezdve csaknem egyenlő széles. vége felé lassankint elkeskenyedö, láncsás szálas; hártyatölcsér pálhái lelapult szörüek, hosszu szemszörösek. - Az elöbbiekkel böven. $\odot$. Jun.-Aug.

Apró Cz. 1' minus. Huds.

5. Virága hat porodás. 6.

6. Hártyatölcsér pálhái csaknem kopaszok, kurta szemszörüek, a virágzata alattiak esaknem szemször nélküliek; virágai ikrásan pontozottak: levelei láncsások vagy körkörösek. -- Árkokban. mocsíros és kiáradási helyeken nagyon közönséges. $\odot$. Jul.-Sept. (Vizi bors; rizi kumyor; balhafü; eligyömbér; légfü: keserüfü.)

Borsos Cz. P. Hydropiper. $L$.

Hártyatölesérei borzasok, hosszu szemszörüek; virága! ikrátlanok: levelei láncsások vagy hosszukás láncsások. - Buda melletti mocsárokban. ๑. Jul.-Oct. (P. Taxiflorum. Weihe.) szelíd Cz. 1'. mite. Schranki.

7. Virágzata levele hónaljaiban van, csomós, vagy levelei elkicsinyedései miatt szakadozott füzéresnek látszó. 8. Virágzata fürtös, fürtje bugás vagy szára hegyén sátorozó is; makkocskája kihegyezett háromélin; levelei nyílalakuan-szívesek, kihegyezettek. - Mivelik, (•). Jul.-Sept. 1-41/2'. (Pohámlia; liruspa; hajdina; hariesher; tatrirlea.) Pohánka Cz. P. Fagopygrum. I.

8. Virágai levelei hónaljaihan magánosak, vagy 2-:3-4-enkint ülnek. !. 
Virágai, levelei hónaljaiban csomósan vannak. 11.

9. Virágai levele hónaljaiban magánosak; három kurta bibeszára van; szára henyélö, ágas, ágai egészen a hegyökig levelesek; levelei körkörös-láncsások, élökön érdesek; hártyatölcsérei két metszetüek. - Szántóföldeken, mivelt téreken, útfeleken csaknem mindenütt. ๑. Jul.-Aug. 3-18". (Porcsin ; porcsfü; disznó-pázsit.)

Poresin Cz. P. ariculare. L.

Virágai levele hónaljaiban 2-3-4-enkint üinek. 10.

10. Śzára felálló ; ágai vesszőalakuak; virágzata szakgatott füzérnek látszó, füzére felül leveletlen; levelei eresek, laposak, körkörösek. a felsők láncsások, kihegyezettek ; hártyatölcsérei rongyosak. - Telekes helyeken, hegyi útak mellett: a szentgellérti szőllökben bőven. $\odot$. Jul.-Sept. 1-4'.

Sugár C'z. P. Bellardi. Altl. Szára henyélö, tövön girbe-gurba, ágas és terepély ; levelei láncsás-szálasok, hegyesek, épélüek; hártyatölcsére rongyos. - A legterméketlenebb homokban az egész megyében, virágai világos rózsaszinüek. $\odot$. Jul.-Sept. Homoki Cz. P. arenarium. W. $K$.

11. Szára felfntó; levelei szíves-nyílalakuak, hártyatölcsérei csonkák; leple belsö három szirma tompa ormojú, háromszögü makkocskái fénytelenek. - Sövényeken, szántóföldeken. •. Jun.-Aug. (Fo!yófü; szulák; haricska.)

Szulák Cz. P. convolvulus. $L$.

Szára felfutó; levelei szíves-nyílalakuak; hártyatölcsérei csonkák; leple külsö szirmai hártyás-szárnyuak; háromszögü makkocskái fényesek. - Sövényeken, bozótokban. •. Jul.-Aug. (Folyoófü.)

Folyó Cz. $P$. dumetorum. $L$.

32. Reud. Szantálfélék. Santalaceae. $R$. $B r$. 1. BÖGRETOK. Thesium. L.

1. Szára felálló, felül bugás; levelei láncsások, vagy szálas lánesások, 3-5 inúak; murvái hármasok; termése 
kerek-tojásdad, kocsínyos; begöngörödött leple termésénél háromszor kurtább. - Minden száraz réten. 2. Maj.-Jun. ' $/ 2-1^{1 / 2}$ '. Hegyi B. T. montamum. Ehr.7.

2. szára felálló vagy felegyenesedő águ, ágai fürtösek ágacskáival egyïtt felállók, terepélyek; levelei láncsásszálasok, alig 3 inúak; murvái hármasok, fogasoltan érdesek; begöndörödött leple termésénél háromszor kurtább. - Az elébbivel. 4. Maj.-Jun.

Ágas B. T.ramosum. Hayne.

33. Rend. Boroszlánfélék. Daphnoideae. V'ent.

\section{Boroszlán. Daphne, L.}

1. Levelei virágzás után hajtanak ki, láncsások, tövön ékalakuak, keskenyek, kopaszok; virágai kocsánytalanok, szára oldalára leginkább hármanként vannak füzve, pirosak; borsó nagyságu exontárja veres. Vácz vidéki ligetekben. 15. Mart-April. 1-3'. (Farkashurs; tetüfa.)

Farkas B. D. Mezereum. $L$.

2. Szára henyélö; levelei láncsás-ékalakuak, tompák, kurta szálka hegyủek, kopaszok ; virágzata szárhegyi, csomós. kurta kocsányu, murvái és szára felsö része szörösödö; virága piros, jószagu ; termése száraz barnálló. - A budai kincstári erdők száraz gyepein. i). Maj.

Henye B. D. Cneorum. L.

\section{CZICZŐ. Passerina. L.}

Szára felálló, egyszerü. vagy ágas: levelei rendetlen állásuak, szálasok, szárától kissé elállók ; virágai hónaljiak, zöldek, leple metszetei virágzás után összetartanak. - Szántóföldeken, homoki és hegyi gyepeken gyakori. $\odot$. Jul.-Aug. 1-1 $1{ }^{\prime} 2^{\prime}$.

Egy nyári Cz. P. anmua. Wickisti. 
34. Rend. Ezüstfafélék. Eleagneae. $R$. $B$ i.

\section{EZÜsTfA. Eleagnus. L.}

Levelei lánosások, hegyesek, épélűek, mindkét lapjukon ezïstszinü felomlásısak, kocsínyos virágai hónaljiak, kivïl ezüst, belül narancsszínüek. - Mivelik. 5. Maj. (Füz slajfa; ceziustfüz.) Olaj E. E. angustifolica. $L$.

35. Rend. Gégevirảgfélék. Aristolochiaceae. 'Jıss.

\section{GÉGEVIRÁG. Aristolochia. L.}

Szára egyszerü, felálló; levelei tojásdadok, mélyen szívesek, nyelesek. kopaszok; virágai hónaljiak, csomósak. sárgák; termése nagy, hatszögü-körtealakn. Bozótokban, szántóföldeken, stb. 4. Jun.-Aug. :3-4'. (Farkasalma; likasir.) $\quad$ Farkas G. A. Clematili.. L.

\section{ə. KAPOTNYAK. Asarum. I.}

Tögyökere terjedö; szára igen kurta. enrek tetejéröl nö hosszu nyelü s vesealaku két levele; két ágra induló levele nyelei közt van. kurta kocsányu. kivül zöldes, belöl sötétbarna piros virága. - Bozótokban fák alatt. 4. Apr.-Ang. (Kapotnyati: mogynóóalja; lierek kapor.) Kerek K. A. europaeum. L.

III. Csoport. Forrtssirmuali. Gamopetalae.

36. Rend. Utifủfélék. Plantagineae. Vent.

1. U'TIFÜ. Plantago. I.

1. Tỏkocsányosak; leveleik mind a tövéböl nönek. … Szára leveles, ágas; levelei szálasok; esészéje elöálló metszetei ferdén lapiczkások, tompák, a hátsók láncsások, hegyesek. - Minden gyepen. kiváltképen i. homokon, szántóföldeken. $\odot$. Jul.-Oct. 1-11/2'.

Homoki U. P. arenaria. W. KS.

2. Bokrétája csöve kopasz. 3. 
Bokrétájit csöre gyapjas; levelei szálasok. husosak, válualakuak; murvái tojásdadok, hegyesek, körülbelől akkorák. mint a csészéje. - Vizenyős legelőkön, kiváltképen a homokon és szíkes helyeken. 24. Jun.-Oet. 6-18". (Hagymalerelï. utif"̈; tengeri utifü.)

Szíki U. P. maritima. I.

3. Tokjába zárt magtartója két szárnyu. szárnya mindenik oldalán 2-4 mag van. 4.

Tokjába zárt magtartója mindenik oldalán 1 mag van. ๖.

4. Levelei nyelesek, tojásdadok, kopaszok, vagy alig szörösödők : tökocsányja felegyenesedö, körülbelöl akkol゙r, mint a levelei : füzére hengeres, fedelékes; murvii tompák, a esészéjével egyenlők. - Gyepeken, legelökön, útfeleken, tarak mellett. 24. Jul-October 3-18".

Széles U. I'. major. I.

Levelei tojásdad-körkörösek, csuklyások, hosszu nyelüek; tökocsányja igen hosszu; füzére hengeres, tömött; murvái a legtompábbak. A Rákos posványos helyein, ritka. 24. Jul.-Sept. 2-8'. (Utifü: liözönséges utifü : szélesleretii utifü.)

Nagy U. P. maxima. Jacqu.

5. Gyökere évelö. 6.

Gyökere egy nyári; levelei husosodók, szálasok, alig rálusok, tőkocsányjával egyenlök: tőkoesányja hengerded, szőröskés : füzére ritkás, karesu. Homokos, szíkes téreken. szíksós tavak körül. •. Maj.-Jım. 2-4’.

Apró U. 1'. temiflora. H. K.

6. 'Tökocsányja mélyen barázdolt. 7.

Tökocsányja alig barázdolt, hengerded. \$.

7. Tőkocsányja 5 barázdáju ; levelei láncsások. mind két végök felé elkeskenyedők, 3-6 inúak, kopaszok. vagy érdesek, alig fogasok; csészéje metszetei tompa hegyüek. kopasz szélüek. Gyepeken. homoki száraz legelökön. 4. Maj.-Tnl. 3-24". (Hegyes utifü: hosszu utifï : lieslienylerelï utifü.) Keskeny U. P.lanceolata,. .. Tőkocsányja sok barázdáju; levelei láncsások, mindkét 
régén elkeskenyedettek, alig fogasok, j-i inúak; esézzéje metszetei lekerekitettek, tompák, szemszörösek.

- Nedves réteken és szíkes helyeken bőven. 4. Jun.Aug. $3-4^{\prime}$.

Legnagyobb U. P. altissima. Jacqu. S. Levelei körkörösek. alig' fogasok, mindkét lapjok kurta *zörii, rövid azonban széles nyelére futók. - Minden réten és legelön, nítfeleken. 24. Jun-Aug. 1-3'.

Közép U. P. media. L.

Levelei láncsások. mindkét régök felé elkeskenyedök, alig fogasok, 3-5 inúak. lelapult, csaknem selymes «zörủek, murvái tojásdadok. hegyesek, közepökön zilált zzörüek. -- Szíkes és száraz mezökön. 24. Maj.-Jul. 1-1's'. (P. sericen. W. K.)

Selymes U. P. virtorialis. Poiret.

37. Rend. Ikracsófélék. Plumbagineae. Juss.

\section{LELLEG. Statice. L.}

Szíra felálló, alig szegletes, ágai szára tetején csaknem sátorozók ; levelei hosszukás visszás tojásdadok, vagy visszás-tojásdadok, szálkahegyủek; füzére féloldali; virágai tömöttek; bokrétája verhenyes kék. - A megye nedres és szíkes rétein. - Budán az akasztólhegy alatt (Galgenberg). 24. Aug.-Sept. 1-1'1/2'. (I.elleg.)

Szíki L. S. Limonium. L.

38. Rend. Gyökönkefélék. Valerianeae. D. C.

\section{GaLAmbBegY. Valerianella. Mönch.}

1. Termésén nőtt csésze metszetei alig lát:zó kurták, 1-3 foguak. ..

Termésére nött csésze metszetei jól kivehetök. 3.

2. Termése kerek-tojásdad, lapított, mindkét oldala meglehetös lapos, oldalain két zsinór van. - Gyepeken és zzántóföldeken. ○. Mart.-Maj. 3-10"". CGalcumbbegy; taraszi bárány-salcita.) Tavaszi (x. V. olitoria. Mrönch. 
Termése hosizuká-, caaknem négyszögü, hát×ó lapján mélyen válus: esészéje alig egঙ fogu. - Hegyi grepeken böven. •. Mart.-Maj. 3-10".

Ormós (i. V. carinata. Lois.

3. C'sészéje karimája ferdén cæonkított, hátsó foga nagyobb. 4.

Csészéje karimájar hat sertefogı. 7.

4. Tokja tojásdad-kupalaku, kopasz vagy borzas. ŏ. Tokja caaknem gombos-tojásdad. 6.

5. Tokja hátul domboru, finom 3 zsinóru. elöl meglehetö: lapos, felemelkedö szélei között egy hosszukáson benyomott térecske van : caészéje metrzete felényi széles, mint a termése. - Szántóföldeken, kivált homokos réteken. (-) Maj.-Jun. 2-10". (T. dentata. Betlie.)

Fogas (4. I. Morisonii. I). (:

Tokja hátul :; sinóru, elöl laposảs. borzas, hosszíral barázdolt; esészéje harangalaku. hártyás, if fogu. fogai hegrei horgasok. - Hegyi gyepeken. •. Maj-Jum. $3-10 "$.

Borzas G. T. lasiocepluala. Betli.

6. Tokja finom öt sinóru, eleje egy barázdás, teteje 3-.̃ fogn, eg: foga megnyult; levelei szárölelök, borzaskák. a felsők tövön fogasok. bevagdaltak. vagy szárnyasok. Gyepeken. •. Maj.-Jun. 1-11/2.

Fiiles G. I. auricula. 7). (:

Tokja elöl domborı. hátul homoru. teteje horpadt, kurtı. 3 fogu; levelei mind épélüek ragy csak szálas hoszszudadok, szárlevelei fogasok. - Hegyi nyílt gyepeken. kivált a Sz. Gellért-hegye déli oldalán. •. Maj.-Jın. $2-6^{\prime \prime}$.

Törpe G. T. pumila. Faht.

7. Tokja tojásdad, csaknem négyszögü, bolyhos; csészéje karimája, belöl kopasz, 6 sertefoga horgas; bokrétája metszetei "gyenetlenek, veresellök. - Hegyi gyepeken. ๑. Maj.-Jun, ¿-12". Koronás G. 1. coronatu. 7). C. 


\section{ə. (†YÖKÖNKE. Valeriana. L.}

1. Virágai egyenlők, levelei (7-11 pár bordával) szá1nyasok, levélkéi láncsások. épélüek vagy fogason fürészesek; szíra barázdolt. - Hegyi erdökben és a mocsárokban. 4. Maj. 2-5'. (MIacslia gyötiér; mezéi mivedus; terjélifü.) Macska Gy. I. officinalis. $I$.

2. Virágai egyenetlenek, egyik szárán nagyobbak, másikon apróbbak; töve ostorindás; alsó levelei kerekdedtojásdadok, vagy körkörösek; nem virágzó töve tölevelei hosszunyelüek, tojásdadok, hegyesek, szárlevelei félbeszírnyasok, felső levelei leginkábl hármasok. Nedves réteken. 4. Maj.-Jun. ${ }^{1} 2-11^{1 / 2}$ '.

Kétlaki Gy. V. dioica. $L$.

39. Rend. Mácsonyafélék. Dipsaceae. I). C

\section{MÁCSONYA. Dipsacus. L.}

1. Levelei nyelesek, nyelén fülesek; gallérkái lefelé állók: murvái egyenesek, sertés szemszörüek. - A pilisi járás hegyi patakaiban, ritka. $\odot$. Jul.-Sept. 1-3'.

Élgombos M. D. pitosus. L.

Levelei nyeletlenek, a középsők tövön összenöttek. ‥ 2. Levele éle kopasz, vagy ritka fulánkos, alsó levelei tövön elkeskenyedettek; gallérkái szálas áralakuak, ívilakuan felegyenesedök; murvái egyenesek, hajlósak, virágánál hosszabbak. - Szántóföldek barázdáin, iitfeleken, folyók mellett, nedves bozótokban. $\odot$. Jul.-Aug. 3-3'. (Gólgahugy; csapóecset.) Erdei M. D. syliestris. L. Levelei serte szemszörüek, az alsók karélyosan csipkések, a többi szárnyason szabdalt; gallérkái láncsásáralakuak; murvái hajlósak, egyenesek. - Az elébbivel, de annál gyakoribb. ๑. Jul.-Aug. 3-5’' (V'́musfürdö; prisatorvesszö ; szomjutöris ; héjakut.)

Héjakut M. D. luciniatus. $L$. 


\section{FeJviRÁG. Cephalaria. Schrad.}

Levelei szárnyasok, tölevelei félbeszárnyasok, borzasok, élökön szemszörösek; galléra és murvái tojásdad-láncsások, szálkahegyüek; virág gombjai félgömb, vagy gömdedalakuak; virágai sugárosak, virága lila vagy fejér szinü. - Útfeleken, szöllőskertek s gyepük mellett Budán. 4. Jul.-Aug. 1/2-6'. (Scabiosa tran:ylianica. L.) Erdélyi F.C.transylianica. Schrarl.

\section{KAZUPA. Knautia. Coult.}

1. Szára kurta szörei miatt szőkéllö, hosszu szörei miatt borzas; alsó levelei épek, közép levelei szárnyason bevagdaltak: virága baraczkvirág vagy testszinü. Réteken és legelökön. 4. Maj.-Aug. 1-2'. (Scabiosct arensis L.) (Rühfü; rarfü: felélyfü; lios.zü; lelésfü"; sennyedéstï.)

Mezei K. K. arvensis. Coult.

2. Szára tövén borzas felül igen kurta szöre miatt puhaszörü, hosszu szörei miatt azonban borzaska; levelei körkörös láncsások, esipkések, épek vagy tövön bemetszettek; virága kékespiros. - Erdők szélein, köves és árnyas helyeken. Jun.-Aug. 1-2'. (Scabiosa sylcaticr. L.) Firiei K. K. sylvatica. Duls.

\section{t. SUUTABÚb. Succisa. M. és K.}

Tőgyökere olyan, mintha el volna harapva; szára csaknem kopasz; alsó levelei tojásdad hosszukások, nyélre futók. közép levelei hosszukás láncsások : virágesoportjai félgömbalakuak, késöbb gömbalakuak; csészéje levelei tojásdadok, hegyesek, fulánkosak; virágai kékek. - Minden vizenyős és posványos gyepen, folyócskák partjain. 24. Jul.-Sept. 1-3’. (Silkantyn; "likar(upott gyökeriäü.) Réti S. S. pratensis. Mönch.

\section{э. SIKKANTyU. Scabiosa. R. és Sch.}

1. Tölevelei hosszukás lánesások at legépebbek, ritka fogasok; szárlevelei szárnyasok. szárnya bordái szála- 
sok, épek, mind l relei, mind a szára szörösödö s e miatt szürke: virágai 4-5 metszetủek, sugárosak. szép kékek. - A hegyek nyílt oldalain. 4. Jul.-Sept. 1/2-1'. (Asterocephalus canescens. Spreng.)

Sziirke S. S. canescens. $L$.

2. Tölevelei alig félbeszárnyasok, hosszukások, bevagdaltancsipkézettek; szár levelei szárnyasok, alsóbb bordái szárnyason szabdaltak, felsőbb bordái szálasok: szára felegyenesedö, érdesecske; virága kék és sárga is. Gyepeken, útfeleken. 24. Jun.-Sept. 1-2'. (Asterorephalus columbarius. Spr.) Galamb S. S. cohumbarin. $I$.

40. Rend. Fészkesek. Compositae. Adars.

\section{PARÓCZA. Eupatorium. I.}

Szára sugár; levelei nyelesek, hármasok, vagy ötösek virágzata sátorozó; virága fakó. - Vizenyős helyeken s itt-ott erdőkben. 4. Jul.-Sept. 3-6'.

Kender P. E. comnabinum. $L$.

\section{KALAPFü. Petasites. 'Tour'ı.}

Levelei szívesek, egyenetlen fogasok, vállai lekerekitettek, alsó lapján molyhos; virágzata fejes buga; termésvirágai fonalalakuak; tökélyes virágai bibéi tojásdadok, kurták. virága piszkos piros, néha fejéres. Árkok szélein, vizek partjain. 4. Kora tavaszszal virágzó tőkocsányja 6-12" termését hordó tökocsánr.ja 12-24"-re megnö. (Kialapfï $r$. édeslapu.)

Orrosi K. P. officinalis. Mrimril.

\section{S7aTTYu. Tussilago. L.}

Tökocsányja tetején egy fészke van; virága sárgal levelei elvirágzása után hajtanak ki : levelei szívesek. szögletesek, fogasok, alsó lapjáu molyhosak. - Nedres agyagokban, patakok partjai oldalain. 24. Tavasz kez- 
detén, virágzó tőkocsányja 2-6" ; termése tökocsányja c-12". (Martilapu; ; lis édeslapu ; lókörömfü.)

Lókörmü Sz. T. F'arfara. L.

\section{Gerepcisin. Aster. L.}

1. Szára és levelei kopaszok. legfeljebb leveleik éle érdes. 2. Szára és levelei kurta szörüek, alsó levelei körkörösek vagy visszás-tojásdad lapiczkások, a felsők hosszukás láncsások; virágzata szélylyelálló sátor; fészke levélkéi lekerekitetten tompák, kissé szélylyelállók, a belsők hegyei színesek; sugárvirágai kékes lilaszinủek. Hegyek és dombok nyílt térein. 4. Aug.-Octob. 6-1 ".

Csillag G. A. Amellus. $L$.

2. Fészke levélkéi egyenetlenek. fedelékesen egymásra lapultak. 3.

Fészke levélkéi csaknem egyenlök. egymástól lazán. elállók. 4.

3. Levelei kissé husosak, kopaszok, épélüek vagy érdesen szemszörösek; tőlevelei tojásdadok, nyélre futók, szárlevelei csaknem nyeletlenek. söt nyeletlenek is és szálas láncsások; virágzata sátorozó; fészke levélkéi belsö sorában lévők hosszabbak a többinél s tompák; sugárvirágai kékek. - Nedves réteken és mocsárokban. (-). Jul.-Oct. 1-2'. (Aster pannonicus. Jacq.)

Pozsgás G. A. Tripolium. $L$.

Levelei láncsások, hegyes végüek, élökön érdesek. alig fürészesek. tövön elkeskenyedők, felsö levelei nyeletlenek, szálas láncsások, épélütk; virágzata sátorozó: virága kinyilásakor fejér. késöbben kékellö. - A megye Tisza felé eső vidékein. 2ц. Jul.-Aug.

Füz G. A. saligmus. Wills.

4. Levelei láncsísok. mindkét végök felöl elkeskenyedök. hegyesek, esaknem épélüek, élök érdeses; szára fürtösen ágas, ágai vesszősek, egy-egy virágfészket 
hordók. - Sadler szerint ezelött ił évvel Pest l'erencz kïlvárosa alatt bőven termett. 24. Jul.-Aug. 2-4'.

Pesti G. A. Pesthiensis. D). (..

\section{Csillagcsin. Galatella. Cass.}

Szára tetején ig’en ágas; fészkei sátorozók; levelei nyeletlenek, szálas láncsások. kihegyezettek, lapjai beszurkáltan pontozottak; sugárvirágai lilaszinüek. - A 'Tisza és Zagyva melléken fekvő nedves és szíkes réteken. 4. Aug.-Sept. 1-31/2.

Pettegetett Cs. G. punctatc. N., ab Es.

\section{(i. RUKERCZ. Bellis. L.}

Tökocsányja egy fészkü; levelei visszás tojásdad-lapicz kások. -- A szigetek és a pilisi hegyek gyepein, ritka 4. Egész évben. 1-6". (Rutiercz; lis nadilyfï.)

Százszorszẹp R. B. perennis. $L$.

\section{KÜLLŐROJT. Erigeron.}

1. Szára bngás; bugái hosszukások; levelei szálas láncsások, sertés szemszőrüek; sugárvirágai igen kurták, piszkos fejér vagy lilaszinüek. - Színföldeken, réteken, legelökön igen közönséges. $\odot$. Jul.-Octob. $1-2^{\prime}$.

Sepreneze K. E. canadense. $L$.

2. Szára felálló, szegletes, fürtösen ígazó, végre csaknem sátorozó ; levelei szálas láncsások durva szőrủek : sugárvirágai hosszuk, halvány test- vagy halvány lilaszinüek. - Hegyi és homoki száraz réteken. 4. Jul.-Aug. 6-1 ".". Bóbitás K. E. acre. $L$.

\section{RITKARÉJ. Solidago. L.}

Szára felálló tetején bugáson fürtös, vagy csak fürtös; levelei tojásdadok és láncsások, nyélrefutók, szőrösek az alsók fürészesek; virága aranysárga. - A homoki 
dombokon és a hegyek nyílt térein s erclei vágásokon. 4. Jul.-Sept. 1-2 $1 / 2$ Iranyos R. S. Virgu curea. $L$.

\section{ARANYFÜRT. Linosyris. C. C.}

1. Szára sugár, felül sátorozó; levelei szárát tömötten fedik, ziláltak. szálasok, hegyesek. kopaszok; fészke levélkéi berzedtek; virága aranysárga. - Hegyi száraz gyepeken. 4. Aug.-Sept. 1-2'.

T'ág 1. L. culgaris. DC:

2. Szára felálló, hengerded, felül alig sátorozó; levelei váltogatók, láncsások, aláfelé elkeskenyedők, tompák; szára és levelei szökéllö tömött gyapjasok; fészke levélkéi pikkelyesek, lelapultak, élökön aszottasok. Száraz szíkes téreken Tápió-Szele és Rákos vidékén. 4. Jul.-Sept. 6-18".

Gyapjas A. I. villosa. DC:

\section{MOLYHÁR. Micropus. L.}

Levelei váltogatók, láncsások; fészke levélkéi fulánktatalanok, virága sárgás-fejéres, az egész növény gyapotosan gyapjas. - Budakeszi, Sz.-Endre és Vácz száraz rétein, ritka. ๑. Jun.-Jul. 2-6".

Gyapotos II. M. erectus $L$.

\section{SERTECSÉK. Inula. $\mathrm{L}$.}

1. Fészke belsö levélkéi hegyökön elszílésedettek, lapiczkások; levelei egyenetlen fogu fürészesek, alól molyhosak, az alsók nyelesek, a felsők szárölelők, szívestojásdadok, kihegyezettek; vi rága sárga. - I megye síkjain fekvő vizenyös réteken, füzesek- és égerfásokban. 4. Jun.-Aug. 3-5'. (Örrénygyöliér.)

Örvény S. I. Helenium. L.

Fészke belső levélkéi kihegyezettek. ․

2. Magva kopasz. 3.

Magva borzas vagy szörösödö. 6 . 
3. Fészke levélkéi gyapjasok, vagy élökön kurta szemszörüek. 4.

Fészke lerélkéi molyhosak. ragy serteszörüek. J.

4. Levelei láncsás szálasok, hegyesek. kiálló inúak. kopaszok, érdes élüek, szárlevelei nyeletlenek; fészke levélkéi gyapjasok és szemszörösek. - Száraz réteken mindenütt. 24. Ang.-Sept. 6-18".

Kardos s.. I. ensifolia. $L$.

Levelei láncsások, kihegyezettek, élök alig észrevehe. töen ritka fogasok, kopaszok, felsö levelei szívesek. szárölelők, hátrahajoltak; fészke levélkéi kurta szemszörüek. - Hegyi réteken, ligetekben, kertek és szőllök mellett. 24. Jul,-Aug. $1^{11} 2-2$.

Füzlevelï \$. I. sulicina. $L$.

э. Levelei alsó lapján szörösek, szárlerelei szíresek; sátorozó viráğ soli fészkü. gombos; sugárrirágai. közép virágainál alig hosszabbak; csaknem hengeres fészke levélkéi molyhosak. - Szöllök szélein, utfeleken, kiváltképen hegyi gyepeken. 24. Jul.-Ang. 1-2’.

Hengeres F. I. germanica. $L$.

Levelpi és szára ikrás durva szőrn̋ek; sugár virágai, közép. virágainál jóval hosszabbak; fészke lerélkéi keskenyek láncsa hegÿuek. serteszörüek. - Ligetek ben és száraz gyepeken bören. 24. Jul. Sept. 6-18”".

Borzas S. I. hiveta. $L$.

6. Fészlielevélkéi szélỵlyelállók s hátrahajoltak: sugárrirágai három metszetüek, alig nyelvalakuak s akkorák, mint fészke levélkéi; szára kissé molyhos, tetején bugásan ágas, ágai sátorozók; tömött viráguak ; levelei körkörös láncsások; hegyeskék, felsö lapjaikon szőrösödők, alól molyhosak. - Ligetekben, vizmosások mellett. 24. Jun.-Aug. $1^{1}: 2-2^{1}$ 2. (Comyza squarosa. L.)

Berzedt S. I. ('onyza. I). '.

Fészke levélkéi lámcsások vagy szálas lánesások, lelilpultak $\%$. 
7. Szára s levelei gyapjasok. alsó levelei láncsásol. nyélretutók. a felsök szívesek, szárölelök; fészke levélkéi láncsások, a külsők fokozatosan kurtulók. gyapjasok. -Homoki és hegyi száraz réteken. 4. Jun.-Aug. Selymes S. I. Oculus Christi. $L$. Szára s levelei bolyhosan gyapjasok; alsó levelei nyelesek, a felsök szívesek, szárölelők. néha törön fogasok; fészke külsö levélkéi hosszuk, sugárvirágait érök. azonban ezeknél kurtábbak. - Gyepük és utak mellett. homoki nedves réteken és patak partokon. 24. Jun.tug. 1-2'.

Lapály S. I. britanica. L.

\section{Balhafü. Pulicaria. Gärtn.}

Sugálvirágai közép virágainál alig hosszalıbak : virága piszkos sárga; levelei hosszukás láncsások. habosak. tövön elkerekitettek, nyeletlenek, ragacsosan szörösödök. - Az egész növény kellemetlen szagnu. - Vizenyős és posványos helyeken. $\odot$. Jul.-Aug. 6-18". (Immla pulicaria L. Ballafü.)

Közönséges B. P. rulgaris. Gürn. Sugárvirágai közép virágainál sokkal hosszabbak; virága aranysárga; levelei hosszukások mélyen szíves-szárölelök, alól szörös molyhosak. Vizenyös réteken. patakok mellett, szántóföldeken. 24. Jun.-Aug. 2-3'. (Inula (lysenterica. L.)

Réti B. P. dysenterica. Fört».

\section{NAPVIRÁG. Helianthus. L.}

1. Mindenik levele szíves, 3 inú, fürészes: kocsányja megvastagodik \& fészke alatt elhusosodva terül ki; fészke bókoló. Mivelik. ๑. Jul.-Sept. 6-i'. (Nainaforgó; túnyérvircig.) Napraforgó N. H. amuus. $L$.

2. Alsó-levelei szíves-tojásdadok, a felsők hosszukás-tojásdadok, vagy láncsások, kihegyezettek, fürészesek, az egész növény élesen érdes; töve gumókat terem. Mivelik. 4. Octob--Nov. 6-7'. (Csicsóka; picsóka.)

Csiesóka X. H. tuberosus. $L$. 


\section{Villamag. Bidens. L.}

1. Levelei 3-5 hasábuak, fürészesek; virága felálló, sugára nincs. - Kiöntésekben, árkokban. mocsárokban. ๑. Jul.-Sept. 1-3'. (Falliasfog; ragadó villa.)

Subás V. R. tripurtitu. I. Levelei épek, láncsások. fürészesek; virága sugáros vagy sugártalan, bókoló. - Az elébbivel. ๑. Jul.-Sept. $1 / 2^{\prime}$.

Bókoló V. B. cernua. I.

\section{CzICZKónó. Achillea. L.}

1. Levelei fésüfogason hasgattak, bordái szálas áralakuak, épek; virágzata gombos sátor; virágai sárgások. jószaguak. - Homokon közönséges. 4. Jun.-Sept. $12-18^{\prime \prime}$.

Fésüs Cz. A. pcctinata. Willt.

Levelei kétszer szárnyasan hasadtak. vagy kétszer-szárnyaltak. $\mathbf{2}$

". Virágai sárgállók, erõs szaguak; szára felegyenesedö, szegletes; alsó levelei nyelesek. a felsök nyeletlenek. *zárnya sallangjai szálasok, tompák, 2-3 hasábuak; az egész növény szöke-szörös. - A Naszálhegyi szöllők közötti köves helyeken. 24. Jul.-Aug. 12-1 $8^{\prime \prime}$.

Hegyközi C\%. A. chvythmifolia. W. K.

Virágai fehérek. néha pirosak. 3.

3. Levelei fönyele gatyás, azaz: levele szárnya bordái a nyelére futnak $\mathrm{s}$ a levél nyelét bordái között két oldalról kiprémezik. 4.

Levelei fönyele nem gatyás. 5 .

4. Szára sugár, magas, alig szegletes; levelei gyapjason bolyhosak, vagy meglehetős kopaszok; szárlevelei körrajza hosszukás. vagy láncsás, kétszer szárnyason hasgattak, szárnyacskái fogasolt fürészesek. fogai kihegyezettek, alsó levelei gatyája fogas; az egész növény bolyhos. - Homoki és hegyi száraz gyepeken, 4. Jul.-Sept. $1^{1 / 2}, 2 \frac{1 / 2}{2}$.

Gyapjas Cz. A. lanata. Syremg. Szára egyenes hengerded, bolyhosan borzaskás; szárle- 
velei körrajza hosszukás. kétszer szárnyason hasgattak; gatyája, valamint szárnyacskái is fogasoltan fürészesek; virága fehéres vagy pirosolló. - Bokrokban, hegyi és erdei réteken. homokon ritka. 24. Jul.-Ang. 2-4'.

Varádicslevelï Cz. A. tancectifolia. All.

э. Levelei körrajza láncsás. vagy csaknem szálas. kétszerszárnyaltak. szárnyacskái 2-3 sallanguak. vagy ismét szárnyalva 5 sallanguak; sallangjai szálasok vagy tojásdad-kihegyezettek; az egész növény szörösödő, vagy csaknem kopasz; virága szennyes fehér. - Mindenütt terem, a legközönségesebb. 24. Jun.-Sept. 1-2'. (Égérfarlitióri: (szicafarti; ezerlevelu fü.)

Egérfark Cz. A. Millefolium.L.

Vilfajai: Levelei keskenyek. sallangjai kurták, hegyökön porczogósak vagy megvastagodottak: A. crustata. Roch. - Sátorozó virágzata bolyhos: A. sordicla. - Levele sallangjai igen keskenyek: szirmai felsö lapjai sárgások, alsó lapjai fejérek; szára érdes: sertés Cz. A. setacea. $\Pi$. $K$.

Levelei körajza tojásdad. kétszer szárnyaltak. szárnyacskái szárnyason hasgatott-fogasok, a nagyobb sallangjai ;-7 foguak. fogai kurták fulánkosak; fönyelei keskenyek. tetején álló levélkéje egészen a közepéig fogasolt. -- Száraz és veröfényes gyepeken. grepek mellett és szántóföldeken. 24. Jul.-Ang. (j-18".

Nemes Cz. A. nobilis. I.

\section{MUNTIKA. Anthemis. I.}

1. Vaczka poḷrvái szálas-sertések; vaczka hosszukás kuyalaku, tele béln̈; sugárvirágai fejérek: magva karczolt, karczolatai bütykösek. - Útfeleken, szántóföldeken a vetések közt. -- ๑. Jun.-Aug. 1-2'. (Eblicupor.)

Büdös M. A. Cotula. I.

Vaczka polyvái szálasok vagy láncsások. 2.

2. Vaczka csaknem félgömbalaku; termése négy ormojju, lapitott. kétélü, éle éles szegélyï. : 
Vaczka. magva érése idejére kupalakuvá nyúlik; termése tompa négy ormóju, ormói közt levő horpadása egyenlök. 4.

3. Levelei szárnyacskái fésüfoguak, fürészesek; virágai sárgák. - Hegyi és homoki száraz réteken, útfeleken, bokrokban. 24. Jun.-Sept. 1-3'.

Festö M. A. tinctoria $I$.

Levele szátrnyacskái épélüek; sugárvirágai fejérek. középvirágai sárgák. - Szántó és telekes földeken, vetések közt: •. Jun.-Aug. 1-2'. Szöszös M. A. austriaca. Jacq.

4. Vaczka polyvái láncsások, fulánkos kemény hegyüek; magvai párkányos pártások; virága kissé szagos. Útfeleken, szántóföldeken, vetések közt. ๑. Jun.-Aug. $1-2^{\prime}$.

Pallagi M. A. arvensis. $L$.

\section{1\%. SZÍKFÜ. Matricaria. L.}

Sugárvirágai délig kiterültek. délután lekonyultak, fejérek, középvirágai sárgák, négyfuguak. - Szíkes gyepeken. ๑. Maj-Jun. 6-12". (Szilifü.)

Orvosi Sz. MI. chamomilla. $L$

\section{ARANYVIRÁG. Chrysanthemum. L.}

1. Levelei egyszerüek. 2.

Levelei füzöttek. kétszer vagy háromszor szárnyaltak. §.

2. Alsó levelei hosszunyelüek, višzás tojásdad lapiczkások, csipkések, felsö levelei nyeletlenek, fürészesek ; magvai tetején párkánytalanok. - Réteken és legelökön mindeniitt. 24. Jun--Tul. 1-2'. (Ölä̈rszemvirág: papvirag.)

Ökörszem A. C. Leucanthemum. L.

Minden levele láncsás, ritkán álló nagy fürész fogu. borzason érdes; tőlevelei nyélrefutók; magvai tetején párkányosak. - A Tisza mocsárai és posványaiban böven. 24. Aug.-Sept. 1/1/2-3'.

Iszap A. C'. uliginosum. W. K.

3. Szára teteje felé sátorozó ; levelei szárnyasok, alsó levelei szárnyai szárnyason hasgattak, metszetei élesen füré- 
részesek, puhaszörẗek. - Erdei gyepeken, bozótokban

a legközönségesebb. 24. Jul.-Sept. 11/2-3'. (Pyrethrum crvymbosum. Wild.)

Sátoros A. C. corymbosum. $I$.

Szára egyenes, ‘ágas; levelei kétszer, háromszor szárnyason hasgattak, sallangjai szálas-fonalakuak. Útfeleken, szántóföldeken, a vetésék között. •. Jul.-Aug. $2-33^{\prime}$.

Szagatlan A. C. indorum. L.

\section{9. ÜRöM. Artemisia. L.}

1. Virágai tökélyesek. 2.

Sugár virágaiban csak terme van. 3.

2. Minden virága tökélyes; levelei hófejér molyhosak, vagy végre kopaszok, kétszer háromszor szárnyaltak, sallangjai szálas czérnaalakuak. tompák; fészkei hoszszukások, molyhosak. - Szíksós téreken. 4. Sept.Oct. 6-12".

Sós Ü. A. maritima. $L$ :

Termésvirága csak egy van, vagy egy sincs; levelei szöke molyhosak ; tölevelei nyelesek, kétszer számyasan sok sallanguak; szárlevelei alig szárölelök, szárnyas sok sallanguak, áglevelei egyesek, szálasok. - A Tisza és a Zagyva mentén, szíkes téreken. 4. Aug.Sept. 6-28". Egyterméjü Ü. A. monogyna. W. K.

3. Vaczka bolyhosan-gyapjas; levelei fejér szürke-selymesek, tölevelei kétszer s háromszor szárnyasok; szárlevelei kétszer, vagy csak egyszer szárnyaltak, metszetei lánesások, tompák. Kellemetlen erös ürömszagu. Telekes helyeken, útfeleken, falak mellett, kertekben. 24. Aug.-Sept. 2-4'. (Fejér üröm.)

Fejér $\ddot{\mathbf{U}}$. A. A. Absinthium. $L$.

Vaczka kopasz. 4.

4. Levelei épek (csak a legalsók kihajtáskor három metszetüek) kopaszok, láncsás-szálasok; fészkei csaknem gömbalakuak. - Mivelik. 4. Aug.-Sept. (Tárkony.)

Tárkony $\ddot{\mathbf{U}}$. A. Dracunculus. $L$. 
Levelei hasogatottak, tövön fülesek. ̃.

5. Gyökere terjedö. 6.

Gyökere nem terjedö. 7 .

6. Levelei alsó lapjaikon fejér molyhosak, kétszer szárnyasok, sallangjai szálasok; fészkei csaknem gömlalakuak, szürke szőrı̈ek. - A legszárazabb legelökön, köves sziklákon. szöllőskertek gyepüi mellett. 4. Sept.-Oct. 1-2'. (Bárainy üräm.)

Bárány $\ddot{\mathbf{U}}$. A. pontica. ..

Levelei szürke molyhosak, szárlevelei csaknem ujjason hasgattak, fészkei durva szörrel molyhosak, kerekded tojásdadok. Veröfényes hegyi réteken Buda környékén. 24. Aug.-Sept. 1-18".

\section{Selymes $\ddot{\mathbf{U}}$. A. austriaca. Jacqu.}

7. Nem virágzó szárai pázsitosak, virágzó szárai felegyenesedök, bugások; levelei szürke selymes szörüek, vagy kopaszok, kétszer-háromszor szárnyaltak; fés\%kei tojásdadok. - Réteken, szántóföldeken. 24. Aug.Sept. 1-2'.

Mezei $\ddot{\mathbf{U}}$. A. campestris. $I$.

Szála nem pázsitos. $\mathbf{8}$.

8. Szára magános, egyenes, bugásan ágas, leveleivel együtt vagy borzas, jragy kopasz, sötét veres; levelei körrajzban tojáscladok. kétszer háromszorosan szárnyasou hasogatottak; fészke kerek-tojásdad, bókoló. - A homokon bőven. ๑. Aug.-Sept. 1.-3'. (Homoliseprö.) seprö Ü. A. scoparia. H. $\pi$.

Levelei szárnyason hasogatottak, metszetei láncsások, kihegyezettek, élök be van metszve vagy fürészesek. felsö lapjaik sötét zöldek, az alsók fejérek feketén pontozottak; fészkei tojásdadok. vagy hosszukások. - Gyepük s árkok mellett úton, útfelen. 24. Aug.Sept. 3-6'. (Fekete $\ddot{\text { urom.) }}$

Fekete $\ddot{\mathbf{U}}$. A. vulgaris. $L$. 


\section{ə). VARÁdIĆS. 'Tamacetum. L.}

Levelei kétszer szárnyason hasogatottak, metszetei fürészesek. -- Mocsárokban, füzesekben gyepükben. 4. Jul.-Sept. 2-4'. (Varidicskóró; gilisatarirág.)

Giliszta V. T. vulgare. L.

\section{PAMÁr. Filago. L.}

1. F'észke levélkéi kopasz, szurós hegyüek; szára villás: fészkei szárhegyi gombokban vannak; az egész növény molyhosan gyapjas. - A homoki és hegyi réteken színtóföldeken ritka. $\odot$. Jul.-Oct. 6-18".

Kétkétágu P. F. germanicu. L.

Fészke levélkéi láncsások, vagy szálas láncsások, tompa kopasz hegyủek, virág gombjain felül nem érnek. ․

2. Ágai villások; levelei szálas láncsások, molyhosak. - A budai s kincstári erdökben és hegyi réteken igen ritka. ○. Jul.-Sept. 3-10',

Hegyi P. F. minima. Fries.

Bugásan álló ágai ısaknem füzéresek; levelei láncsások. Az egész növény igen molyhos. - Szántóföldeken. réteken mindenütt. $\odot$ Jul.-Ang. 6-18".

Gyepi P. F. arvensis. $L$.

\section{פ.). GYOPÁR. GHaphalium. I.}

1. Fészke egylaki; sugár virágai termések. közép virágai tökélyesek; bóbitája fonalaku. 2.

Fészke kétlaki; tökélyes virágu fészkeiben levő bóbitái hegyei meg vannak vastagodva. 5 .

2. Sugárvirágai kevesen vannak s egy sorban állanak; levelei molyhosak, alsó levelei visszás-tojásdad láncsások; sátora összetett; fészke fénylö czitromsárga. - Homoki réteken böven. 24. Jum.-Sept. (j-18". (Helichrysum arenarium DC.)

Sárga Gy. G. arenarium. I. 
Sugárvirága több soru. 3.

3. Fészkei gombosak. 4.

Fészkei füzéresek. vagy fürtösek; szára egyszerü; alsó levelei láncsások, közép levelei kevéssel kisebbek, alsó lapjaikon fejér molyhosak, felsö lapjaikon zöldek s végre kopaszszá levők. - Ligetekben gyakori. 4. Jul.-Aug. 6-24". $\quad$ Erlei Fy. G. sylvaticum. $L$.

4. Szára tövétöl fel ágas, terepély; gombjai levelesek. Homoki posványokon, mocsárokban, szántóföldeken. 2. Jul.-Sept. 3-12". Iszap Gy. G. uliginosum. L. Szára magános, vagy tövétől fel ágas; fészke gombjai levél nélküliek; levelei láncsások, vagy kerek végü szálasok. - Az elöbbivel homoki és hegyi réteken. 4. Jul-Sept. 6-18". Halovány Gy. G. luteo-culbum. $L$. 5. Szára magános, töve gyökerezö ostorindákat hajt; tölevelei visszás-tojásdad lapiczkások, felső lapjaikon kopaszok, az alsón hófejér molyhosak; sátorozó tömött virágzata szára tetején van; fészke fejér. vagy bibor piros. - Veröfényes homoki és hegyi száraz s terméketlen réteken. 2. Maj.-Jul. 3-12". (Pallagi gyopar; lis egérfïl.)

Kétlaki Gy. G. dioicum. $L$.

\section{TARKÖR. Doronicum.}

1. Föld alatti indái hosszuk. vékonyak. végeiben · megvastagodnak. kileveleznek s ujra indákat hajtanak; tölevelei hosszu nyelüek. mélyen szívesek, szárlevelei tojásdladok, fogasok; virága sárga. - A kincstári erdökben Buda mellett. 4. Maj.-Jun. (Zergefü; vadkecsliefii.)

Zerge T. D. Parlalianches. $L$.

2. Gyökere gumós; szára egyenes, ikráson gyapjas, 1-3 virágu: levelei gyapjasok; tölevelei nyelesek tojásdadok, tompák; szárlevelei váltogatók szárölelők, hosszudad-tojásdadok, hegyesek; fészke levélkéi szálas láncsások, szemszőrösek. - Homokdombokon és száraz hegyi réteken. 2. Jun.-Jul. 1-2'.

Gumós T. D. plantagineum. L. 


\section{4. ÜsZÖGÕR. Senecio. L.}

1. Minden rirága csöres, vagy ran félszer sugárrirága is. ażonban sugárvirágai legöngyölödöttek. ‥

Félszer sugárvirágai is vamnak \& ezek kiterülve állanak 3.

2. Murvaköre lelapult kurta, 10 pikkelyü, fészke levélkéi hasszuk s fekete hegyulek: levelei kopaszok, ragy pókhálósan gyapjasuk, szárnỵason hasogatottak, az alsók nyélre futók, a felsők szárölelők. fülesek; félszer rirága nincs. - Omladékokon, mivelt téreken. ๑. Tavasztól késő öszig. 6-15)". (Rontófü; aggófü; szö)szösfü.)

Aggó $\ddot{\mathbf{U}}$. S. vulgaris. $L$.

Murvaköre levélkéi pongyolán állanak s fészke levélkéihez mérve felényiek; fészke lerélkéi. mélyen szárnyason hasogatott leveleivel együtt ikrásszörü-ragacsosak: félszer virágai hátrakunkorodottak. - Omladékokon s a pilisi járás rágásaiban. ๑. Jul.-Aug. 1-1 1/2'. Enyres $\ddot{U}$. S. viscosus. 1 .

3. Levelei bevagdaltak, szárnyasok, ragy szívesek s törön szárnyason bevagdaltak. 4.

Levelei épek, fürészes vagy épéln̈ek. ๖.

4. Minden magra érdes szörü s egyenlö bóbitájú ; levelei *zárnyason hasogatottak. szárnyacskái szálasok, fogasok és szárnyason beragdaltak, tövön épélü, apró füln̈ek; fészke pikkelyei reres hegyüek. - Hegyi és homoki réteken, útfeleken, szántóföldeken bören. 2 . Aug.-Oct. $1^{1 / 2}-2$. Veresövï $\ddot{\mathbf{U}}$. S. encaefolins $L$.

Középmagvai kurta-érdes szürke szörüek, sugárvirágaitól származó szélső magrai kopaszok. ez utóibjiak bóbitája kevés szőrű, lehulló; alsó levelei félbeszárnyasok, a felsők szárnyason hasogatottak. szárnyacskái fogasok ragy esaknem szárnyason bevagdaltak. nyeletlenek és sok hasíibu fülökkel szírölelök. - Az elébbivel együtt. ๑. Jul.-Aug. 2-3'.

Berzedt $\ddot{\boldsymbol{C}}$. S. Jacolaca. $t$ 
5. Murvaköre levélkéi igen kurták; sugár virága öt van; murvalevelei tojásdadok, csaknem szíves válluak, szálason áralakuak; levelei kopaszok, tengerszínre hajlók, fogasok vagy épélüek, hosszukások, az alsók nyélı’e futók, a középsők nyeletlenek, csaknem szárra futók, nagyok, a felsők kicsinyek, hegyesek. - Nedves. réteken, legelőkön, szántóföldeken. 4. Jul.-Aug. 3-5’. (Anyufï.)

Kiivér Ü. S. Doria. $L$.

Murvaköre levélkéi felényiek, vagy akkorák. mint fészke levélkéi. (6.

6. Murvaköre 5 levelü; sugárvirága 7-8 van; magrva kopasz ; levelei meglehetősen kopaszok, hosszukás láncsások, igen hegyesek, egyenetlen fürészerek, fürészfoga hegyei elöretartók. - A szigetek bozótaiban és ligeteiben. 4. Jul.-Sept. 2-5'.

Aranyos $\ddot{U}$. S. saracenicus. $L$. Murvaköre leginkább 10-levelü; sugárvirága leginkább 13 van; magva kissé szörösödö vagy kopasz, levelei nyeletlenek; szálas láncsások, megnyult hegyüek. élesen fürészesek, felül kopaszok, alól molyhosak. Mocsárokban. 24. Jun.-Aug. 2-5'.

Posvány Ü. S. paludosus. L.

Valiuja: Levelei széles láncsások, élesen fürészesek, mindkét lapján tömötten hófejér molyhosak: Senecior tomentosus, vagy Láng szerint Senecio Salleri.

\section{\%5. DUGASUR. Cineraria. L.}

Levelei szöszös gyapjasok; tölevelei tojásdaulok, vagyy kerekdedek, nyélrefutók, épélüek vagy alig csipkések; szára közép levelei hosszukások, a felsök láncsosak; fészke töve gyapjas, egyéb része kopasz. - Réteken, erclökben, leginkább vizenyös helyeken. 24. Jun.-Jul. $1 ' 2-2$ '.

Mezei D. C. crmpestris. $L$.

\section{LAPTABORZ. Echinops. I.}

1. Levelei szárnyason hasogatottak, tövisfoguak; felül szöröskék, alól fejér szöszös molyhosak; fészke külsö levél- 
kéi ikrás szörüek; virága fejér. - Hegyi és a szigreti gyepeken nem ritka. - 4. Jul.-Aug. 1-2'. (L(t) tatövis.)

Fejér L. E. sphaeroceplaclus. $L$.

2. Levelei kétszer szárnyason hasogatottak, tövisfoguak, alól hófejér molyhosak; fészke levélkéinek a gerinczei kopaszok; virága kék. - Az elébbivel, de ritkább. 24. Jul.-Aug. 1-2'.

Kék I. E. Ritro. I.

\section{2\%. VAsvirÁG. Xeranthemum. L.}

1. Fészke félgömbalaku, levélkéi kopaszok, fulánkosak, a külsők tojásdadok, a belsők láncsások, lilaszinı̈ek, közép virágainál kétszerte hosszabbak. - Száraz réteken, útfeleken, töltéseken inindenütt. $\odot$. Jul.-Aug. (Vastirig.)

Kinyiló V.X. anuum. $L$.

2. Fészke hengeres, külső levélkéi épélüek, kopaszok, tojásdadok, tompák, hátukon molyhosak, a belsők láncsások, összetartók, lilaszinüek. - A legszárazabb mezökön, útfelen, Sz.-Endre megett levö szántóföldeken. az elöbbinél ritkább. - ๑. Jul.-Sept. 6-18".

Húnyó V. X. cylindricum. Sim.

\section{KÖRFÉNY. Carlina. L.}

¿zárán $2 \mathrm{~s}$ több fészke van s ezek csaknem sátorozók; csészéje sugáros $\mathrm{s}$ belsö sárgálló levélkéi töve szélesecske. tövöktöl közepökig szálasok, teteje felé láncsások, közepökig egyszersmind szemszörösek; murvái fészkeinél kurtábbak. Száraz s miveletlen helyeken. $\odot$. Jun.-Sept. 1-2'.

Molyhos E. C. vulgaris. $L$.

\section{Bóbitagyász. Crupina. Cass.}

Fészke levélkéi láncsások, kihegyezettek; levelei szárnyasok, érdesek, bordái szálasok, hegyesek, fulánkosan apró fürészfoguak. - Veröfényes réteken, hegyi útfeleken, szöllök körül Buda vidékén. $\odot$. Maj.-Jun. 1-2.

Közönséges B. C. vulgaris. Pers. 


\section{CsÜkÜllố. Centaurea. L.}

1. Fészke levélkéi töristelenek, aszott végüek, végei épek vagy rongyosak. 2.

Fészke levélkéi háromhasábu ragy szárnyas tövisüek. \$. 2. Fészke levélkéi végső rongyai a többi rongyaival egyenlök. 3.

Fészke levélkéi régsö rongyai szélesek, néha törisnemüek. 4.

3. Bóbitája nincs; fészke levélkéi aszott végei fészkét egészen boritják, kerekdedek ragy tojásdadok, ragy épek, lełasogattak, vagy az alsók fésủfogalakulag rongyollottak; levelei láncsások, épek. ragy az alsók ritka öblüek, vagy szárnyasan hasogattak. - Gyepeken. 24. Jun.-Öszig. 1-2'. (Imola.) Imola Cs. C. Jacea. L.

Bobitája magránál háromszor kurtább; fészke levélkéi belső során levő prémjei kerekdedek, hasadt foguak, a külső levélkék rongyai által fedve vannak, a többiek tövön láncsások, azután hosszu áralakuak, hátragörbültek, szárnyason rongyosak; levelei hosszukás körkörösek, fürészesen fogasok. -- Erdökben, kivâlt vágásokon s erdök szélein. 24. Jul.-Aug. $1^{1} \geq-2$ '.

Idöérzö C's. C. phrygia. I.

4. Levelei szárrafutók. jo.

Levelei szárra nem futók. 6.

5. Levelei hosszukás láncsások, épek, épélüek, ragy fogasoltok, molyhosak; fészke lerélkéi fekete prémüek. fürészesen rongyosak, rongyai akkorák, mint a prémje; sugárvirágai buzavirág, közép rirágai pirosas lilaszinüek. - A pilisi járás hegyein, ritka. 24. Jun.-Aug. $8-16^{\prime \prime}$.

Hegyi Cs. C. montana. L.

Levelei szálas láncsások, épek vagy kikanyargatottak; fészke levélkéi fekete prémüek. fürészésen rongyosok, rongyai csaknem porczogósak s majdnem kétannyiak. mint porczogós prémje; rirága szép buzarirág szinü. 
- Hegyi réteken és homok dombokon gyakori. 4, Jun.-Aug. 6-18".

Hónalj Cs. C. axillaris. Willth.

6. Bołitája magvánál mintegy egy harmadrésznyivel hoszszabb, fészke prémje sárga börszinü. prémjei 5 inú levélkéit nem fedik el, azonban rongyosak; levelei érdesek, molyhosak, az alsók kétszer. a száron levők egyszer szárnyasok; szára felső részén bugásan ágas. - Homoki és hegyi réteken, útfeleken, szántóföldeken. -). Jul.-Oct. 1-3'. Bugás Cs. C. paniculata. Lam. Bóbitája magvával egyenlö. 7 .

7. Levelei szálas láncsások, a legalsók tövön fogasok; fészke levélkéi fekete prémủek, fürészesen rongyosak. - Tetésekben, pallagokon, réteken. $\odot$. Jul.-Aug. 1-2. (Buzavirag; lékvirag.) Buzavirág Cs. C.Cyamus. $L$. Levelei csonkatollas szárnyasok, vagy szímyason hasogatottak és kétszer szárnyaltak; bordái lánesások, épélűek, vagy fogasok; fészke levélkéi prémjei háromszögüek, feketések, rongyosak s keskenyebbek, mint innélküli levélkéi. - Minden réten, szántóföldek barázdáin. bozótokban. 24. Jul.-Sept. 2-5’.

Sikkantyus Cs. C. scabiosa. L.

8. Virágai halvány pirosak; levelei mélyen szárnyason hasogatottak, sallangjai szálasok, fogasok; fészke levélkéi kopaszok. - A megye síkjain fekvő legelökön, útfeleken. $\odot$. Jul.-Sept. 1-2'.

Sulymos Cs. C. Calcitraya. $L$.

Virágai czitromsárga szinüek; levelei szálas láncsások, szárrafutók, épélủek. az alsók félbeszárnyasok; fészke levelkéi gyapjasok. - Terméketlen veröfényes helyeken közönséges. $\odot$. Jul.-Oct. 1-2'.

Sáfrányos Cs. ('. solstitiatis. $I$.

\section{PuHonCZ. Jurinea. Cass.}

Levelei alól fejér molyhosak, szárnyason hasogatottak, sallangjai szálasok, épélủek; fészke levélkéi molyhosszürkék; magva síma. kissé horpadásos; virága bi- 
borpiros. - Hegyi és homoki száraz gyepeken, kivílt erdökben. 24. Jun.-Aug. $1^{1 / 2-3}$. (Carduus mollis. L.)

Molyhos P.J. mollis. Rehb.

\section{GORDON. Kentrophyllum. Neck.}

Alsó levelei szárnyason hasgatottak, fogasok, a felsök szárölelök, szárnyason hasadt-fogasok, tövisesek; szára a fészkével együtt gyapjas; sugárvirágaiból származó magvai bóbitátlanok. - Barázdákon, útfeleken, köves helyeken. $\odot$. Jun.-Aug. 1-2'.

Gyapjas G. K. lanatum. $D C$.

\section{BORDON. OHopordum. L.}

Levelei körkörös-hosszukások, öblösek, tövisesek; szöszös gyapjasok; gatyáson szírrafutók; fészke tövisei tojásdad töröl indulnak, szálas áralakuak, az alsók széllyelállók. - Útfeleken, ugarakon, árkok mellett igen gyakori. $\odot$. Jul.-Aug. 4-8'. (Szamii-v. fejér lucitu tövis: szörös bogucics.)

Fejérhátu B. O. Acanthium. L.

\section{BOGÁCs. Carluus. L.}

1. F'észke levélkéi lelapultak, vagy hátrahajoltak, de hátra nem gyököntek. 2.

Fészke levélkéi tojásdadok, töve felett kissé elszükültek és egy keresztráncznál fogva hátra gyököntek; az egész fészke kerekded, magános, nagy és bókoló. Útfeleken, ugarokon és hegyi réteken. $\odot$. Jun.-Jul. $1-3$.

Bókoló B. C. mutens. L.

2. Fészke magános. 3.

Fészke csoportos, kivévén a folros bogácsot, melynek néha csoportos, néha magános. 4.

3. Kocsányja kurta, fodrosocska, tövises; fészke kerekded; levelei többnyire kopaszok, mélyen szárnyason-hasgatottak, hegyei fulánkosak. - Telekes földek@n, út- 
feleken, legelökön, réteken, erdökben a legközönségesebb. -). Jul.-Ag. 2-6;. Akánt B. C. acanthoides. L. Kocsányja levéltelen; fészke bókoló ; levelei láncsások, kissé tengerzöldek, vagy esaknem egyenszinüek, tövises-szemszörösek, fürészesen fogasok. - Erdei réteken. $\odot$. Jun.-Jul. 1-2'1/2'.

Csiiggedö B. C. defloratus. $L$.

4. Felső levelei épek tojás-vagy láncsásalakuak, az alsók széles tojásdadok, egészen a gerinczéig szárnyason hasogatottak, az alsó lapján minden levele szöszösgyapjas; fészkei a bojtornáéhoz hasonlók. - Hegyi vizmosásokban Visegrád és Vácz körül, igen ritka. 4. Jun.-Jul. 1'^-3'. Bojtorjános B. C. Personata. Jacqu. Vinden levele mélyen vagy öblösen szárnyason hasogatott. .ั.

๖. Vesszös ágai kopasz kocsányon végzölnek. 6. Ágai tövises kurta kocsányon végzödnek; levelei alsó lapjain szöszösen molyhosak, inai csaknem bolyhosak, öblösen szárnyason hasogattak, szárnyacskái három karélyuak, közép karélyai a szélsőknél nagyobbak, minden karélya fulánkos. - A pilisi járás bokrosaiban és a szigetek gyepein. $\odot$. Jul.-Ang. 1-4'. (Fodor a. szam(irtöris.)

Fodros B. C.crispus $L$.

6. Fészke levélkéi szálas lánesások, lelapultak; levelei szárrafutók, alól szöszösen molyhosak, félbeszárnyarsok, szárnyacskái tojásdludok. 3 metszetủek és karélyuak, karélyai tövises szemszörüek s egy erös tövisen végzödők. Homokdombokon Gödöllö vidékén. ¿. bndai és a pilisi hegyeken. $\odot$. Jun.-Jul. 1'1/2-3'.

Patyolat B. C. collinus. W. $K$. Fészke levélkéi láncsás tövüek, szálasok, belsö levélkéi horgosan hátrahajoltak; levelei szárrafutók, felül zilált szörüek, alól szöszös-gyapjasok, vagy meglehetös kopaszok, mélyen szárnyason hasgattak, szárnyacskái tojásclad 3 metszetñek. vagy karélyuak, karélyai tövi- 
ses szemszörüek s egy erös tövisen régzödnek. Száraz réteken a megye sík szántóföldein s a budai erdök körül. •. Jun.-Aug. 1'1/2-3'.

Horgas B. C. hamolosus. Ehih.

\section{BÁRCS. Cirsium. 'Touru.}

1. Tirágai mindenik fészkében tökélyesek. 2.

Virágai kétlakiak; fészkei aprók, tojásdadok, bugásan sátorozók; virága halvány piros; levelei hosszukás láncsások, tövises szemszörüek. - A vetések közt igen böven, ngarokon, útfeleken. 24. Jun.-Aug. 2-3'. (Aszottas; zabtövis; gyengénszúró.)

Aszottas B. C. arvense. Scop.

2. Levelei felső lapjaikon tövises kurtaszörüek; virága piros. 3.

Levelei felsö lapjain nincsenek tövises szörök; fészke levélkéi hegyei egyszerü tövisen végzödnek, vagy tövistelenek. 4.

3. Levelei szárrafutók, alsó lapjaikon pókhálós szörủek, mélyen szárnyason hasgattak, fészkei tojásdadok, hasoulóul pókhálós szörťek. - Telekes földeken, legelökön. szántóföldeken. $\odot$. Jun.-Sept. 3-6'.

Lánesás B. C. lanceolatrm. Scop. Levelei szárölelök, szárra nem futók, alsó lapjaikon molyhosak, mélyen szárnyason hasgattak; fészkei gömbalakuak, pókhálós-szörűek. - Az elöbbivel, azonban nálunk az erdőkben és a vágásokon is. -). Jun.-Sept. 3-8,

Gyapot B. C. eriophorum. Scop.

4. Levelei szárrafutók; vìrágai pirosak. 5.

Levelei szárra nem futók; virágai sárgás fejérek. 7 .

5. Gyökere csomós, gyökér rostjai orsóalakuan meg vannak rastagodva; szára tetején egy fészke van, vagy legfelül ágazik el s ágain ekkor is egy-egy fészek van ; levelei hosszukás láncsások. tövis szemszőrüek. Nedves homoki réteken böven. 4. Jun.-Sept. 2-4'.

Pöszke B. C. camum. MI, Ti. 
Gyökere rostjai fonalakuak. 6.

6. Szára hegyén levö ágain sok fészke van; fészkei fürtösen csomósak. - Legelökön, bokrokban és nedves réteken. ๑. Jum.-Sept. 2-5'

Tavi B. C. palustre. Scop). Szára közepétöl kezdve leveletlen, 1-3 fészkü; tögyökere ferdén nö, rostjai fonalakuak; levelei hosszukás láncsások, épélüek vagy fogasok, egyenetlen tövis szemszörüek. - Hegyi nyílt réteken, ligetekben gyakori. 24. Jun.-Aug. 11/2-3'. (Cirsium seratuloides. Scop.)

Zsoltina B. C. punnonicum. Gaud.

7. Fészkei szárhegyiek, csomósak. murvások, külső murvái tojásdadok, sápadt zöldek; levelei kopaszok, vagy ritkásan-szörösödők, fogasok, egyenetlen tövis-szemszörösek, szárölelök, az alsók szárnyason bevagdaltak. Vizenyős réteken és árkokban igen ritka. 4. Jul.-Ang. $3-5$

Halovány B. C.oleraceum. Scop.

\section{BoJTORJÁn. Lappa. Tourn.}

I. Fészke mindenik levélkéje áralaku s hegyeik horgosak. 2. Fészke belsö levélkéi láncsások, tompák s hegyeik egyenesek, színesek; fészke pókhálós. - Omladékokon, telekes helyeken, útfeleken. $\odot$. Jul.-Aug. (Arctium Bardana. Will.) Pókhálós B. L.tomentosa. Lam.

2. Fészke minden levélkéje egyenlö zöld színü, kopasz; virágzata csaknem sátorozó; virága piros. - Az elébbivel. @. Jul.-Aug. (Arctium Lappa. L.) - (Széles r. keserülapu; bojtorján.) , Nagy B. L.major. Gä̈rtn. Fészke belsö levélkéi hegyei pirosak, levélkéi közei kissé pókhálósak; virágzata csaknem fürtös. - Az elébbiekkel. $\odot$. Aug.-Sept.

Kis B. L. minor. D. C.

\section{3\%. ZSOLTINA. Serratula. L.}

1. Szára igen ágas; fészkei sátorozók, hosszukások; levelei tojásdadok, épek vagy félbeszárnyasak, vagy szárnyason 
hasogattak. - Hegyi és síksági nedves réteken. 4. .Jul.-Sept. 1-3'. (Zsoltina : fürészlevelü fü; festöfü.)

Festö Zs. S. tinctoria. $L$.

2. Szára magános vagy ágas. ágain egy fészke van; levelei szőrösödők; érdesek, fésüalakuan szárnyason bevagdaltak, bordái láncsások, hegyesek, épélủek vagy alig fürészesek. - Hegyi réteken, p. o. a budai Farkasvölgyben. 24. Jun.-Aug. 1 1/2-2 ${ }^{1} 2^{\prime}$.

Sugár\%ó Zs. S. radiata. M. T.

\section{VÁLUPIKK. Lapsana. Vaill.}

Levelei szegletesen fogasok. az alsók félbeszárnyasok; szúra bugásan ágas. - Réteken. szántóföldeken. kertekben, erdőkben. nagyon közönséges. ๑ Maj-Aug. $1-3^{\prime}$

Czérnaágu V. I. communis. $L$.

\section{Ka'TÁNG. Cichorium. I.}

1. Fészkei kocsánytalanok, vagy kurta kocsányuak. kettönként vagy többen ülnek együtt; virágai között levő levelei csaknem szárölelők. széles aljuak, láncsások ; rirága kék. - Mindenïtt. 24. Jun.-Aug. 11²-3'. (Kattánglióró : licttan.)

Mezei K. ('. Intybus. I.

2. Fészkei kocsánytalanok. vagy kurta kocsányuak, kettönként vagy többen ülnek együtt; viríga közt levő levelei széles tojásdadok, szívesek szárölelők; virága kék. Mirelik. (Caikória: entivia; téli salcita.)

Endivia K. C. Endivice. L.

\section{1). Polyvahordó. Hypochaeris. $\mathrm{L}$.}

1. Szália ágas, kopasz, tőlevelei a földre lapultak, kaczurosak, tompák, érdesek; virága fészke levélkéinél hosszabbak; virágai aranysárgák. - Réteken. legelökön. 4. Jun.-Aug. (i-12".

Kaczuros P. H. radicata. L.

2. Szúra 1-3 fészkü; tölevelei tányéralakuan kiterülnek. tojásdad hosszudadok, tompák, öblösen fogasok; veres 
pettyesek; fészke levélkéi épélüek; rirágai aranysárgák. -- Hegyi gyepeken. 24. Jun.-Jul. 1'z-2'. (Teres $l\left(t_{i}, \mu.\right)$

Veres P. $H$. maculata. $L$.

\section{ARSZlá́NFOG. Leontodon $\mathrm{L}$.}

1. Tögyökere csonka, igen rostos. 2.

Tögyökere orsóalaku, egyesen lefelé növö, alig rostos; szára egy fészkủ kopasz; levelei hoszukás láncsások, nyélrefutók, épélneek, igen kurta szőrü, szürke, majdnem molyhos. - Hegyi és homoki száraz réteken. 4. Jun.-Sept. 6-18". Szöke A. L. incumus. Schronl.

2. Szára egy és több fészkü, leveletlen, kocsányja lassankint vastagodik meg; felül pikkelyes, virágzás elött felálló ; levelei karélyosan vagy szárnyason hasgatott fogasok. - Réteken és legelökön mindenütt. 4. Jun.-Oct. (i-18".

Öszi A. L. antumnalis. $L$.

Szára egy fészkü, leveletlen vagy 1-2 pikkely van rajta, tetején vastagabb, mint egyébütt; levelei hoszszukás láncsások, kaczurosan fogasok, vagy szárnyason bevagdaltak, szöreik 2-3 villájuak. - Száraz hegyi és homoki réteken gyakori. $\odot$. Jun.-Oct. 4-12".

Dárdafogu A. L.hostilis. $I$.

\section{Magvarótt'. Picris. L.}

Szára ágas, sátorozó; levelei hosszukás láncsások. öblösen fogasok, csonka vagy dárdás aljjal szárölelök, sertés horgas szörei miatt az egész növény durva tapintatı. - Vágásokon, bozótokban, útakon. 4. Jul.Aug. 11/2-3.

Ékes M. P.hieracinirles. $I$.

\section{KeCsKedisz. Tragopogon. L.}

1. Virága kocsányja teteje ékalakura vastagodik; fészke levélkéi rendszerint 12 vannak s virágainál hosszabbak; fészke felsö része homoru. - Dombokon, száraz réteken. $\odot$. Jun.-Jul. $\quad$ Yagy K. T. major.Jacqu. 
Virága kocsínyja mindenütt egyenlö, csupán virága alatt kissé vastagabb, mint egyebütt; fészke levélkéi leginkíbb 8-an vannak. 2.

?. Fészke levélkéi virágainál kurtábbak, sugárvirágaitól származott magvai tövön símák; teteje felé bóbitája alatt finom pikkelyesek s puha fulánkuak, kurta csörüek. Az egész növény szöszösen molyhos. - A Soroksár felé eső homokon ritka. Csepel szigetén azonban van elég. $\odot$. Maj.-Jul. $1^{1 / 2} 2-3^{\prime}$.

Szöszös K. T. floccosus. W. $K$.

Fészke levélkéi virágaival egyenlök, vagy annál hoszszabbak. 3.

3. Sugárvirágaitól származó magvai fonalaku csöreikkel egyenlök. görcsösen érdesek. - Veröfényes réteken, telekes földeken. $\odot$. Jun.-Jul. 1-3'. (Baliszalial ; kaliulpogicsa.)

Réti K. T.pratensis. $L$.

Sugárvirágaitól származó magvai fonalaku csöreiknél kétszerte hosszabbak, pikkelyesen puha fulánkosak. - Minden gyepen található. $\odot$. Maj.-Jul. 1-3'.

Keleti K. T. orientalis. $L$.

\section{POZDOR. Scorzonera. L.}

1. Virága sárga. ․

Virága lila- vagy rózsaszinü ; szára egy vagy 2-4 fészkü ; levelei szálasok ; termése karczolt, karczai símák ; virága kellemes illatu. - Száraz hegyi és homoki gyepeken böven. 24. Maj.-Jun. 1-3'. Piros P. S. purpurea. L.

2. Töve tetején levö üstöke czérnás; fészke levélkéi kihegyezettek, hegyeik tompák, külsö levélkéi tojásdadok ; kopasz szárán leginkább egy fészke van. - Száraz hegyi és homoki gyepeken gyakori. - 24. Maj.-Jun. 6-18".

Egyiigyii P. S. austriaca. Wild.

Töve tetején levö üstöke pikkelyes, vagy síma. 3.

3. Fészke felényi, mint a virága. 4.

Fészke akkora, mint a virága; termése síma; szíra 1-3 
fészkü; töve teteje síma, vagy alig pikkelyes. Nedves réteken Pest környékén; a városligetben és a Ríḱkoson. ๑. Maj.-Jun. 6-18".

Kisvirágu P. S. parriflora. Jacq. 4. Szál’a egyszerü, leginkább egy fészkü, gyapjas; magva síma. - Vizenyős, kivált homoki gyepeken. - 2. Maj.-Jul. 3-12".

Alacsony P. S. humilis. I. Szára felső része ágas, ágai egy f’észküek; fészke kopasz; sugárvirágaitól származott magvai finom puha fulánkosak. - Hegyi és homoki száraz réteken gyakori. ๑. Maj.-Jul. $1^{1{ }^{\prime}} 2-3$ '. Átifi P. S. hispanica. L.

\section{Magpoczok. Podospernum. D. C.}

Gyökere évelö, tögyökere teteje több fpjü, melyek közül némelyik virágzó, a másik nem virágzó szárat hajt; szára felsö része barázclolt; levelei szárnyason hasgattak, sallangjai szálasok; sugárvirágai kétakkorák, mint a fészke levélkéi. - Gyepeken, szántóföldeken. uitfeleken. 24. Maj.-Jul. 1-2'.

Sallangos M. P. Jacquinianum. Koch.

\section{PITYPang. Taraxacum. Juss.}

1. Tökocsínyja egy fészkü. börclös; levelei láncsások, kaczurosok, fogasok, vagy épélüek; magvai szálas viszszás-tojásdadok. barázdoltak, teteje felé pikkelyes, puha fulánkosak. - Gyepeken. 24. Tavasztól fogva késö öszig. Igen változékony. (Pitypang; gyermeklanczfï; limbófï.) Pongyola P. T. officinale. Wigg. Vúlf(ujai: a) Fészke levélkéi mind szálasok. a külsök lefelé hajlottak: $T$. genuimum; b) Fészke levélkéi szálasok, láncsás külsö levélkéi vízirányosan nyíltak ki. az egész növény tengerzöld színü: $T$. glaucescens ; $c$ ); Fészke belsö levélkéin rövid szarvacskák nöttek: $T$. corriculatum. - d) Fészke külső levelei tojásdadok, hegyesek. lelapultak; levelei láncsások, öblösen fogasoltak, vagy szálas láncsások s épek. T. lividum. 
2. Tőkocsányja egy fészkü, bördős; levelei hosszukások, tavaszszal épek, később fogasok vagy kaczurosok; magvai mindkét végén elkeskenyedettek. s hegyén apró görcsök vannak. - Száraz legelökön, homokdombokon s al hegyeken. 24. Jun.-Nov. 3-19".

Késöi P. T. serotinum. Poir.

\section{4\%. KAKICS. Condrilla. L.}

Alsó levelei kaczurosok, a felsők szálas láncsások; ágai vesszősek; oldali fészkei egyenkint, vagy 2-3-ként állanak: magva öt fogu; virága sárga. - Hegyi és homoki száraz réteken közönséges. 4. Jun.-Sept. 2-4'. (Apró katcing; disznóliék.) Káka K. C.juncea. L.

\section{SALÁTA. Lactuca. L.}

1. Virága sárga: magva mindkét oldalán kiálló vonalok vannak 2.

Virága kék; magva mindkét oldala közepén csak egy kiálló vonal van; levelei kopaszok, szárnyason hasogatottak, bordái elö oldalain fogasok. - Száraz gyepeken. bozótokban és erdökben. - 4. Maj.-Jul. $1^{1 / 2}-2$.

Kék S. $L$. peremis. $L$.

2. Levelei nem futnak a szálária. 3.

Levelei szárrafutók, az alsók mélyen szárnyason hasogattak, sallangjai szálasok, kissé fogasok, a felsök szálasok, épélüek. - Köves helyeken szöllök mellett. vágásokon. -). Jul.-Aug. $1^{1} 2-3$. (Phoenixopus riminens. Rehb.)

Gatyás s. L. riminea. C. H.Sch.

3. Levelei nyeletlenek, szárölelök. 4.

Levelei nyelesek, félbeszárnyason-szárnyason hasogattak, végsö karélya $3-\check{\jmath}$ szögü s nagy. - Bozótokban. ligeteken. $\odot$. Jun.-Aug. 1-3'. (Phoenixopus muralis. Kioch.) (Tolvajfü; sebfï.) Bugás S. L. muralis. Fresen.

4. Levelei tövön szívesek, bugái terepélyen álló s egyenm:lgasságu sátort alkotnak; magva barna, fejér csöre 
akkora vagy hosszabb, mint a magva. - Mivelik. $\odot$. Jum.-Aug. (Salcita.)

Kerti S. I. sativa. 1 . Levelei tövön nyílalakuak. כ.

†. Magra csőre felényi, mint a magva. 6. Magva esöre akkora, vagy kétannyi, mint a magra. ‘. 6. Levelei alsó lapja síma, alsóbb levelei kaczurnsak, fogasok, a felsők kac\%urosan-szárnyason hasogatottak, magvai feketék. - Erdökben s vágásokon Buda körül. ๑. 3-8'. (L. quercina.)

Sugár S. L. stricta. W. K. Levelei alsó lapja síma, tőlevelei nyélre futók, szárlevelei nyilason szárölelök, épek, fogasok, az alsók és középsők hosszas-tojásdadok, a felsők kihegyezett láncsások: magvai feketék. — A gödöllöi vágásokon s a budai erdökben. ๑. Jun.-Jul. 2-4'.

Nyilas S. L. sagittata. W. K.

7. Magva csőre magváral egyenlö, fejér, magva barnás szürke, keskenyen prémezett, hegye kurta sertésszörili : levelei kaczurosak, fulánkos foguak, gerincze is fulánkos. - Telekes és köves helyeken. szöllők mellett. útfeleken. - $\odot$. Jul.-Aug. 2-4'. (Tar salita.)

Keszeg S. L. scariola. L.

Magva csőre kétannyi, mint a magva, fejér ; tengerszinzöld levelei szálasok. kihegyezettek, épélüek; az alsók kaczurosan-szárnyasok, gerenczeik fulánkosak. - Telekes és köves helyeken, homoki réteken, bozótokban. $\odot$. Jum.-Aug. $1 / 2-3$.

Szálas S. L. saligna. $L$.

\section{4!). CsAKkör. Prenanthes. I.}

Levelei szívesen szárölelők, kopaszok. alsó lapjaikon tengerzöldek. alsó levelei tojásdadok. vagy hosszukások. nyeleikre gatyásan futók, fogasok. a felsők láncsások, kihegyezettek, épélüek; virágzati bugás: virágai pirosak. - Magas hegyi erdőkben. ritka. 4. Jul.-Sept. 2-4'.

Piros Cs. P. purpurea. I. 


\section{CSORBOKA. Sonchus. I.}

1. Srára ágas, ágai elnyösen sátorozók. 2 . Szálra egyszerü a hegyéll sátorozó. 3.

2. Magvai keresztbe ránczosak, mindkét oldalon 3 vonalnak; felső levelei kihegyezetten fülesek; rirági kénsárga. - Mivelés alatti kertekben és telekes szántóföldeken. 24. Jun.-Jul. 1-3'. Dudva Cs. S. oleraceus. L.

Magva síma, prémes. 3 vonalu; felső levelei tompa füle-

sek: gyökere orsóalakú; virága aranysárga. - Az elöbbivel. - Jun.-Oct. 1-3’. Ériles Cs. S. asper. Till.

3. Gyökere terjedö; levelei láncsások, kissé kaczurosak, szárlevelei tövöin szívalaknak, egyenetlen szálkás foguak, a felsök épek. - Szántóföldeken, retések közt gyakori. 4. Jul-Ang. 1-2'. Mezei Cs. S. arvensis. L. Gyökere ostorindátlan, levelei kaczurosan-szárnyason hasogattak, sallangjai láncsások. kihegyezettek, szállevelei nyilas rálluak. a felsők épek. - Mocsáros réteken, vízmosások mellett. 24. Jul-Aug. 1-2'.

Zsemlyéki Cs. S. palustris. L.

\section{j1. AszÁsz. Crepis. L.}

1. Magrai csörösek. $\mathbf{2}$.

Magrai hegyök felé elkeskenyedők, azonban csörtelenek. 3.

2. Kocsányai virága kinyilása elött bókolók : szára és levelei érdes szörn̈ek; szélső magvai fészke levélkéinél kurtábbak, a be]sők pedig hosszabbak: fészke levélkéi szürke ikrás szörökkel vannak fedve. - Szántóföldeken, zöldséges kertekben, réteken, erdők szélein. Bakszagu. ○. Jul.-Sept. 6-18". (Barchausia foetida. (Mïnch.)

Büdös 1. C. foetida. $L$.

Kocsányjai felállók; minden magva egyenlő. vagy a kï̈lsők és belsök közt alig van valami különbség; c๔öre magránál kurtább; kocsányai és fészkei durva 
keményszörüek. - Gyepeken és útfeleken nindenütt. ○. Maj.-Jul. 1-3'.

Borzas A. ('. setosa. Haller.

刃. Tökocsányja hegyén fészkei fürtösen állanak; tölerelei tojásdad-hosszukások, törön elkeskenyedettek, fogasok - Réteken és gyümölcsösökben. 24. Maj.-Jun. 1-:3'.

Csonka A. C.prctemursa. Tuusch.

Leveles szára tetején sátorozó virágzata van. 4.

4. Tölevelei tojásdad ékalakuak, érdesek szárlevelei tojás. dadok, szárölelök, nyilas rálluak, mindnyájan fogasok; fészkei szöke-molyhosak. - Budı körül. veröfényes helyeken. 4. Jul.-Szept. 2-4'.

Kemény A. C. vigidu. W: K.

Tölevelei kaczurosok. vagy kaczuros szálnyason hasogaltottak. うे.

5. Fészke kopasz, fészke külsö levélkéi igen kurták, tojásdadok lelapultak; bugái egyenlö magasak. -- Budar szöllöhegyei lejtöin, ritki. $\odot$. Jun.-Aug. 1-21/2'.

Szép A. C.pulchira. I.

Fészke szőkén szörösödö. 6.

6. Szárlevelei nyeletlenek, csaknem szárülelök, vállaik fülesen fogasoltak, a felsök épélüek; fészke külsö levélkéi kissé kinyíltak, a belsők hátukon kemény szőrn̋ek vagy kopaszok, belsö oldalukon selymes szörüek. Árkok mellett, szántóföldeken, hegyi és erdei réteken. $\odot$. Jun.-Oct. 2-4'. Kétnyári A. C. biennis. L. Szairlevelei nyeletlenek, szálasok, nyílalakuak, élök hátrasyüremlett; magra 10 vonalú, annyira elhegyesedö, hogy majdnem csőrösnek tetszik, hegye érdes. Mindeniitt, még a kőfalak és házak tetején is. ( )

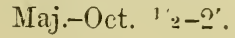

Hamras 1. . . teciorum. $J$.

\section{HOLGYOMÁL. Hieracium. L.}

1. Tökocsányja kopasz, egy virágu; töre ostorindákat hajt; tőlevelei risszás tojásdad-láncsások, sertésszörüek, alúl 
szürke molyhosck; fészke kurta hengerded. - Szíriz réteken és legelökön. 4. Jun.-Oct. 3-12". (Kis egérfuil.)

Egérfiil H. H. Pilosellu. L.

Szára tökocsínyalaku, vagy igen leveles. $\mathbf{2}$.

உ. Szára egylevelü. 3.

Szára soklevelü. 6.

3. Szára 2-う fészke, töve ostorindákat hajt. 4. Szára sátorosan sok fészkü, $\mathbf{5}$.

4. Szára kétágu, 2 fészkü, vagy két-két águ, 3 s töbl fészkü; levelei szálas láncsások, szürke-zöldek, felül durva szörüek, alól szürke molyhorak; fészke tövön hasas. - Száraz hegyi réteken Buda mellett, a homokon Pest, Palota környékén. 4. Jun.-Sept.

Villás H. H. bifucum. M. R. Szára egy levelü, vagy néha tökocsánya van; 2-5 fészkü levelei kékes zöldek, nyelvalakuak, vagy láncsísok, csaknem kopaszok, vállaiknál szemszörösek; fészke kurta-hengerded. - Minden száraz réten. 4. Jun.-Aug. $1 / 2-2^{\prime}$.

Nyuilfül H. H. Auricula. L.

5. Szára egy vagy kevés levelü; fészkei szélylyelállók; levelei kékeszöldek, láncsások, élökön s felsö lapjaikon szörösek; kocsányja elvirágzás után felálló, fészke ritka vagy tömött szörétöl szürke szinn̈. - Hegyi, erdei és homoki réteken. 4. Jun.-Aug. 1-3'.

Bogernyös H. H. praealtum. Foch.

Vuilfujai közül elöfordul : a kopasz száru s kemény serteszörrel boritott levelü: $H$. fallax, vagy $H$. cymosim. Szára egy levelü, teteje és fészke szürke, vagy fekete kurta ikrás szörrel van boritva; levelei füzöldek; tölevelei tojásdadok, csaknem szívesek, fogasok, válla körül eső fogai hátrafelé állók; szárlevelei kurta nyelüek, vagy nyeletlenek. - A ligetek köves helyein, vágásolkban. 4. Jul.-Sept. $1^{1 / 2} 2-1 \frac{1 / 2}{2}$.

Köfali H. H. murorum. L.

6. Levelei kékeszöldek, a felsöbbek apadólag kisebbedők, láncsások, mindkét oldalukon durra serteszörück; ssí- 
toruk sok fészkü, nyílt s fejér molyhos. - Hegyi és homoki száraz réteken böven. 4. Jun-Sept. 11/2-2'.

Kígyószisz H. H. echioides. W. K.

Levelei füzöldek, tölevelei vagy vannak vagy nincsenek. 7.

7. Tölevelei vanmak, levelei tojásdad-láncsások, vagy tojásdadok, alól elkeskenyedök, fogasok, alól és élökön durva szörüek; kocsányjai és fészkei szürke vagy fekete ikrás kurta szörüek. - A pilisi hegyen. 4. Jun.-Jul. Közönséges H. H. vulgutum. Fries.

Tölevelei nincsenek. S.

\$. Levelei tojásdadok, a felsök nyeletlenek s szíves vállaikkal szárölelők, ritka foguak; kocsányja és fészke szürkészöld, gyakran kurta szörü és sokkal hosszabb. mint tövén ïlö murvája. -- A Buda körüli magasabban fekvö erdökben. 4. Jul.-Sept. '1/2-3'.

Olasz H. H. sabaudum. L.

Levelei láncsások vagy szálasok, épélủek, vagy fogasok, az alsók kurta nyélbe elkeskenyedök, a felsök nyeletlenek; virágzata csaknem ernyös; fészkei levélkéi hegyei hátragörbültek. - Hegyi és homoki száraz gyepeken gyakori. 24. Jul.-Sept. $1^{1 / 2} 24^{\prime}$.

Ernyös H. H. umbellatum. $L$.

41. Rend. Ambruskafélék. Ambrosiaceae. Link 1. CsImpaJ. Xanthium. I.

1. Levelei szíves háromszögalakuak, egyenetlen fogasok; termése tojásdad, két szarvú, tövises, tövisei között puha szörös. - Telekes helyeken, szemétdombokon, zöldségesekben. $\odot$. Jul.-Oct. 1-3'. (Decilimogyoró; 7ioldustetü; disznó mogyoró ; disznó bojtorjuin.)

Szurós Cs. X. strumarium. $L$.

૧. Levelei három karélyuak, a középsö hosszu s hegyes; levelei tövein három águ tövisei vanuak. - Útfele- 


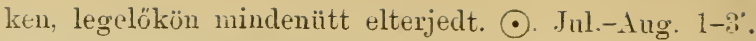
(Disznó töris; gyengén szúró.)

Disznótövis Cs. X. spinosum. $L$.

42. Rend. Csengetyükefélék. Campanulaceae. D. C.

\section{CsékCsillag. Jasione. L.}

Szára ágas, ragy legalább ágasodásra hajló; levelei szálasok, kissé habos élüek, borzasok. - A gödöllöi homokhegyeken, s Buda vidékén bőven. $\odot$. Jun.-Jul. $1-2$ '.

Erdei C's. J. montanu. $L$.

\section{RAPONCZ. Phyteuma. L.}

1. Virágzat: füzéres, füzére gömb ragy hengeralaku. ․ Virágzata fürtös, vagy bugás; virágai kurta kocsányiuak; levelei nyeletlenek, az alsók tojásdadok, csipkésen fürészesek, vállban elkeskenyedők, a felsők láncsások, csaknem épélüek. - Buda reröfényes hegyi rétein az erdök szélén. 4. Jul.-Sept. ${ }^{1 / 2}-11_{1}^{\prime} 2$ '.

Szöke R. P. canescens. W. K.

2. Tirágzata sokvirágú füzéres gomb, mely elvirágzás után tojásdaddá nyúlik meg; külső murvái tojásdad-keskeny láncsások, alig fürészesek; alsó levelei hosszu nyelüek, tojásdadok vagy tojásdad-láncsások, szára felső levelei szálasok, csipkésen fürészesek. - Hegyi gyepeken. 24. Jun.-Jul. 1-2'. Gombos R. P. orbiculare. I.

Virágzata hosszukás füzér; virága sárgás-zöld hegyü fejér, levelei kétszeresen csipkés-fürészesek, az alsók nyelesek, szíves tojásdadok, a felsők láncsások. - A pilisi hegyek magas ligeteiben. 24. Jun.-Jul. 1-2'.

Erdei R. $P$. spicatum. $I$.

\section{Csengetyüre. Campanula. I.}

1. Csészéje öblei nem pillenpátyosal; ; virága kék. ‥ Csészéje öblei pillenpátyosak; pillenpátyai maghonára letüremlettek; virága kék vagy lilaszinű; csészéje äblein levö pillenpátyai akkoráli, mint a cst́széje csö- 
ve; bokrétájil metszetei, hegyei kopaszok; virágzata luugás, virágai kocsányai lehajlók; levelei láncsások, élei habosak; az egész növény kurta szőrrel van boritva. - Hegyi és homoki réteken. ๑. Maj.-Jul. 1-1';

Pongyola Cs. C. sibirica. 1 .

๑. Virágai kocsányosak. 3.

Tirágai koesánytalanok. 9.

3. 'Tokja lefüggő, tövén nyiló. 4 . Tokja felálló, közepén vagy tetején nyiló. 7.

4. Felső levelei szálasok, az alsók kerekcled-rese-, vagy szívalakuak, épélűek; szára bugás, sok virágu. - Sziklákon, hegyi réteken és erdőkben. a homokdombi erdőkben ritkább. 24. Maj.-Jul. 1-1' 2 '.

Kereklevelï Cs. C. rotundifolia. $L$.

Levelei másformák és szélesebbek. 5.

๖. Puha szörü, szára hengeres, felálló : levelei csipkések, alsó lapjaikon szürke-molyhosak, az alsók hosszu nyelü szívesek, a felsők tojásdadok elkeskenyedök. - Hegyi és homoki réteken gyakori. 24. Jul.-Sept. $1-4^{\prime}$.

Ökörfarku Cs. C. bononiensis. I.

Szára tompa vagy éles ormóju. 6.

6. Levelei egyenetlen fürészesek, kurta szőrüek, az alsók hosszu nyelesek tojásdad hosszukások, a felsők láncsások: fürtje féloldali; gyökere terjedö. - Bokrokban, vágásokkon, ligetekben. 4. Jun.-Jul. 1-2'.

Füzött Cs. C. rapunculoidles. $L$.

Levelei kétszeresen fürészes durva foguak; kemény szőrüek, az alsók hosszu nyelesek, szíves-tojásdadok, a felsök hosszukások, nyeletlenek, virága fürtjei szára mindenik oldalán állanak. Erdökben. 24. Jun.-Jul. 1-2’.

Villás Cs. C. Trachelinum. I..

7. Csészéje metszetei láncsások; fürtje kevés virágu: virága nagy, széles harangalaku, kék, néha fejéres; levelei olyanok, mint a barıczkfáé. - Ligetes erdőkben. 4. Maj.-Jul. 1-2'. (Öreg harangviraig.)

Baraczklevelï Cs. C. persicifolic. $L$. 
Csészéje metszetei áralakuak; virágzata bugás. S. 8. Bugája pongyola, csaknem sátórozó; virága lila vagy kékszinü; levelei csipkések, tölevelei hosszukás viszszís-tojásdadok. - Minden gyepen. 24. Jun.-Jul. $12-1 \frac{1}{2} 2^{\prime}$.

T'erepély Cs. C. patula. L.

Bugája hosszu, csaknem fürtös; levelei csipkések, tölevelei hosszukás visszás-tojásdadok, nyélrefutók, szárlevelei szálas láncsások. - Ligetekben és hegyi réteken. •. Maj.-Jul. 1-3'. Raponcz Cs. C. rapunculus. $I$.

9. Szára és levelei ritkás kurta szőrüek, vagy kopaszok; levelei csipkések, tö- és szárközépi levelei nyelesek, tojásdadok vagy tojásclad láncsások, kerek vagy szíves válluak, felsö levelei szíves szárölelők; virágzata szárhegyi vagy oldali csomóban van. - Erdei réteken. 4. Maj.-Aug. 1-3̊'.

Bunkós Cs. C. glomeratı. $L$.

Szára és levelei borzas és érdes szörüek. 10.

10. Levelei aprófoguak, tőlevelei láncsások, nyélbe keskenyedők, szárlevelei láncsás szálasok, a legfelsők szárölelők; virágzata oldali és szárhegyi csomókban van. - Hegyi és lapályi, kövér ligetekben. 4. Jul.-Aug. 1-3'. (Harangfï; nyalefü; csengetö; ciillas torolifï; erde i répuc.)

Vállas Cs. C. Cervicaria. L.

Levelei csipkések, hosszudadok, mindkét lapjukon igen borzasok; tölevelei csaknem nyeletlenek, szárlevelei félig szárölelök, virágzata csomós, de csomói szárboritó hosszu füzért alkotnak. -- Szent-Endre hegyi száraz létein. 4. Jun.-Jul. 1-3’.

Sokvirágu Cs. C. multiflora. IT. K.

43. Rend. Buzérfélék. Rubiaceae. Juss.

\section{GALAJ. Galium. L.}

1. Virágzata levele hónaljában ül, vagy levele hónaljából indul s végre bugás, ez utóbbi esetben visszásan görbe tüskéi miatt érdes. .. 
Virágzata szárhegyi, bugás vagy gyürüs; virágai tökélyesek; kocsínykái virágzás után egyenesen állanak; szára tüske nélküli. 10.

2. Virága egylaki, kocsányjai virágzás után lehajolnak. 3. Virágai tökélyesek, szára gindár, visszás tüskés. 6.

3. Levelei hatosak, szálas lúncsísok, fulánkos-hegyüek, egyinúak, élök tüskésen érdes; kocsányjai 3 viráguak. Vetések között. $\odot$. Jun.-Jul.

Czukros G. G. saccharatum. All.

Levelei négyesek, 3 inúak. virágzás után úgy türemlenek hátra, hogy a lehajolt kocsányokat is fedezik. 4.

4. Virága kocsányjai egyszerüek, vagy két metszetüek, murvátlanok. bolyhosak; magvai símák, kopaszok; levelei körkörösek. - Hegyi és homoki, terméketlen száraz gyepeken. ๑ Maj.-Aug. 3-12".

Szúrós G. G*. pedemontamum. All.

Virága kocsányjai ágasok, murvások. ฮ.

5. Szára felegyenesedö, érdes szőrü; levelei körkörös hosszudadok, vagy tojásdadok: magva síma. Az egész növény sárgás-zöld. - Gyepeken, árnyas helyeken nindenütt. 4. Maj.-Jul. 1-1 1/2'.

Keresztes G. G. Cruciata. Scol'

Szára kopasz, vagy csak az alsó részén szörösödő; levelei hosszukások, vagy tojásdadok; magva síma. Az egész növény zöld. - Magasan fekvő erdők árnyaiban. 24. Jun.-Jul. 6-18". 'Tavaszi G. G. vernum. Scop.

6. Levelei négyesek, ritkán hatosak, szálas hosszudadok, lekerekítetten butúlók, kalásztalanok, 1 inúak, élök visszásan érdes; búgája pongyola; kocsányjai virágzás ntán felállanak. - Posványos és mocsáros helyeken. 4. Maj.-Aug. 1-2'.

'Tóparti G. G.palustre. L.

Levelei hatosak, vagy nyolczasok, egy inúak. 7.

7. Levelei tölbnyire hatosak, szálas láncsások, fulánkos hegyüek, élök elörefelé tüskésen érdes; szára gindár, 
igen ágas, risszás tüskésen érdes. - A sz.-endrei sorány mezökön és szántóföldeken. ๑. Maj. 6-15". (D. divaricatum. Lam.) Berzedt G. G.parisiense. L.

Levele éle visszás tüskésen érdes. $\mathbf{8}$.

९. Kocsányjai többuyire háromviráguak s virágzás utún hátragörbülnek, hosszabbak, mint ripacsos magrai. Szántóföldeken retések közt. ๑ Jun.-Jul. 6-12"(Ragadofuï; ragadcily; ragadéniny.)

Háromszarvú G. Cr.tricorne. Tith.

Kocsányjai egyenesek. \%.

9. Tirága keskenyebb, mint a kifejlett magra; magvi horgas keményszörü vagy síma; virága fejér. Gyepükben, árnyas helyeken vetések közt. ๑. Maj.Jul. 1-6. Ragadó G. G. Aparine. L.

Virága szélesebb, mint a kifejlett magra; magra gürcsösen érdes; virága fejér. - Postányokban és mocsárokban. 4. Maj.-Aug. 1-2'.

Posvány (i. G. uliginosum. L.

10. Levelei négyesek, 3 inúak, fulánktalan hegyủek. 11. Levelei, négyes, hatos- és tizenkettösek, egy inúak s töblnyire fulánkos hegyüek. 12.

11. Szára felálló, sugár, négyszögü, kopasz ragy szörö:ödö, tetején búgás; magrai molyhosan keményszörủek; levelei láncsások, élökön érdesek. -- Sövényekben, erdők szélein. vágásokon, Buda körül, ritka. 4. Jun.Jul. 1-1'á. Észahi (tr. Cr. boreale. $L$.

Szára terepély, felegyenesedő, kopasz, tetején bugás; magrai kopaszok, ragy egy kissé szörösödök levelei tojásdadok ragy husszukás láncsások, élökön érdesek. - A megye síkján fekrö vizenyős réteken böven, a száraz helyeken gyepükben ritka. 4. Jun.-Aug. 1$11^{\prime} 2^{\prime}$.

Mézszagí G. G. rubioides. $L$.

12. Tirága tojássárga; levelei $8-12$, keskeny szálasok, fulánkos hegyüek, élük legyüremlett, alsó lapjaikon kurta, puha szőrüek; bokrétája metszetei butúlók igen 
kurta hegyüek; magva kopasz és síma. - Vinden gyepen. 2. Maj.-Sept. 1-2'. (Téjsugoritófü; licisafii.)

Téjoltó G. G. verum $L$.

Virága fejér, vagy sárgás fejér, levelei hatosak vagy nyolczasok. 13.

13. Szára hengeres, négy barázdájú; levelei hosszudad láncsások, tompák, fulánkos végüek, alsó lapjaikon tengerszín zöldek: bugája buglyos ; kocsánykái hajszálvékonyak, virágzás elött bókolók. - A Buda körül fekvö magias erdökben. 24. Maj.-Jun. 2-4'.

Errlei G. G. syliaticum. L.

Szára négyszögü. 14.

14. Szára felálló; hosszukás bugája alsó ágai vízirányosan szélylyelállók, elvirágzott kocsánykái séztterpettek; bokrétája metszetei hajszálhegyüek; levelei szálasok fulánkos végüek, mind két oldalán fénylö vonal van kopaszok, vagy szörösödök. - - łz erdők szelein. 24. Jun.-Jul. 1-2'. (G. erectum. Huds.)

Fényes G. G.lucirlum. All.

Szára lecsepült vagy felegyenesedö. 15.

15. Levelei láncsások vagy visszás-tojásdad lánesások: bokrétája metszetei hajszál régüek; termése kopasz. kissé ránczos, - Erdőkön, gyepükben, bokrokban. 4. Maj.-Jun. 2-5'.

Puha G. G. Mollugo. I.

Levelei szálas láncsások, elöl szélesebbek, kihegyezettek, az alsók visszás tojásdad láncsások; bokrétája metszetei hegyesek; termésén néhány csekély göb van. - Hegyi gyepeken, sziklákon. 24. Jun.-Jul.

Csere G. G. syluestre. Pollich.

\section{BUZÉR. Rubia. L.}

Gyökere évelö; szára egynyári; levelei négyesek rag: hatosak, láncsások; kocsányjai a levélhónalja alól nőnek, három águak; fekete bogyója síma. -- Buda. 
Buda-Örs és Szent-Endre környékén, ritka. 24. Jun.Sept.

Pirositó B. R. tinctorum. $I$.

\section{MÜGE. Asperula. L.}

1. 'I'ermésén kemény horgas szörök vannak; levelei hatosak-nyolczasok, az alsók visszás-tojásdadok, a felsők láncsások. Jószagu. - Árnyas erdökben bőven. 4. Apr.-Maj. ${ }^{2}{ }^{2}-1 '$. (Csillagsaivfü; csillagns m'ijfü.)

Szagos M. A. orlorate. I.

Termése kopasz. 2.

2. Murvái serteszemszörüek; virágzata szárhegyi csomó; virága kékes; levelei hatosak-nyolczasok. szálas láncsísok. - Vetések közt gyakori. ๑. Maj.-Jun. 1'-1'1'. (béla ragadcily.)

Ugari M. A. areensis. 1 .

Murvái szemször nélküliek. 3.

3. Bokrétája karimája esövénél hosszabb. csaknem harangalaku; levelei többnyire nyolczasok, törékenyek, fulánkos hegyűek, élök begönyölödött; felálló szára ormótlan. - Minden hegyi és homoki száraz réteken és a sziklák közt. 4. Maj.-Jun. 1-3’.

Galaj M. A. galioides. Mr. R.

Bokrétája töleséres karimája akkora, mint a esöve. 4.

4. Bokrétája leginkább három metszetủ : alsó levelei hatosak, a középsők négyesek. szálasok. murvái tojásdadok, hegyesek, fulínktalanok. - Erdőkben, sziklí kon, árnyas bokrokban. 24. Jun.-Aug. 1-2'.

Festö M. A.tinctoria. $L$.

Bokrétája leginkább négy metszetii, kivülről érdes: murvái láncsások, fulánkosak; levelei négyesek; magva szemesésen érdes. - Gyepeken, sziklákon. 24.Jun.Jul. 1-2'. Veresfijas M. A. cymanchica. $I$.

\section{MagaBÁR. Scherardia. (*.}

Levelei leginkább hatosak, láncsások; virága lilaszinü.

- Színtöföldeken, vetések közt. $\odot$. Jun.-Sept. 2-6".

Ugari M. S. artensis. $I$. 


\section{Rend. Lonczfélék. Lonicerere. Endl.}

\section{LONCZ. Lonicera. L.}

1. Szára felfutó ; virágzata esomósan gyürüs. Ellenes felső levelei össze- és általnőttek; bibeszára kopasz. --- Kertekben mivelik. 5. Maj.-Jun. (Jerikói rózsa; liecskesactkailfü; ; szulcil.) Jérikói L. L. Caprifolium. $L$.

Szára felálló ; virágai párosan állanak. ‥

2. Szára egészen kopasz; levelei szíves-tojásdadok, ép, élüek. alig hegyesek; két murvája szálas sertés; bogyója fekete. - Kertekben mivelik. †. Maj.-Jun. $\therefore-10^{\circ}$.

'ratár I. L.taterice. $L$.

Szára szörösödö : levelei tojásdadok. vagy körkörös tojísdadok, épélı̋ek; murvái szálasok; bogyói veresek. - Bozótokban. 5. Maj.--Jun. 5-10.

Ükörke I. L. Xylosteum. $L$.

\section{BANGITA. Viburmum. L.}

1. Levelei három vagy öt karélynak. fürészesek: szélső virágai sugárosak, tenyészszerv nélküliek. - Bozótokban. ligetekben. D. Maj.-Jun. 6-18'. (Kímyafa; g(imyafa.)

Kánya B. V. Opulus. $L$.

2. Levelei tojásdadok, fogasolt fürészesek. molyhosak. Az elébbivel. böven. †. Maj.-Jun. 3-18'. (Ostorménfa; iszalag.) Ostormén B. V.Lantanu. L.

\section{BODZA. Sambucus. L.}

1. Sárgás virảgai tojásdad fürtï virágzatot alkotnak, bogyói sötét pirosak. - Pest környékén, kertekben mivelik. I). 8-15'. (Veres bod:a.)

Fiirtös 13. S. racemosa. $I$.

Fejéres virágai bogernyős virágzatot alkotnak. 2 .

2. Bogernyöje 5 főkocsánynyal ágazik el; portokai sárgák. - Gyepükben. erdökben. J. Jun.-Jul. 24-30'. (Fii borlza.)

Gyepui B. S. nigren. $I$. 
Bogernyöje 3 fökocsánynyal ágazik el; portokai pirosak; szára fünemü. 24. 2-5’. (Földi bodzc.)

Földi B. S. Ebuhus. $L$.

\section{t. KOCZKAGYÖNGY. Adloxa. L.}

Virággombjai öt virágból állanak; tölevelei, hosszu szárlevelei kurta nyelüek, hármasok, levélkéi két-három karélyuak. - A budai városerdő gyepein s a hegyeken árnyasokban. - $\odot$. Mart.-Maj. 2-3'. (Y'́zsmaboglir.) Pézsma K. A. Moschatellina. L.

45. Rend. Jásminfélék. Jasmineae. $R$. $B$ '

\section{JÁsmin. Jasminum. L.}

Csészéje fogai áralakuak; bokrétája csöve csészéjénél kétszerte hosszabb, ágai szögletesek; levelei hármasok, visszás-tojásdad ékalakuak, mindig zöldek. Budán a szöllök gyepüiben. 占. Jul.-Aug.

Bige J. J. fruticans. $L$.

\section{Rend. Olajfafélék. Oleaceae. Lindl.}

\section{LILA. Syringa. L.}

1. Levelei tojáskerekek, vagy szívesek épélủek; bugás virágzata szárhegyi. - A budai hegyeken, gyepükben s kertekben mivelik. 1). Apr.-Maj. 5-10'. (Indicii mo(yyoró; borostyán ; boroszlain; orgonafa ; szelencze.)

0rgona L. S. vulgar is. $L$.

2. Levelei láncsások, kilhegyezettek, olykor szárnyason hasogatottak. - Mivelik. †. Maj.-Jun. 3-6'. (Töröli borosty(in.)

Persiai L. S. persica. L.

\section{FAGYAL. Ligistrum. L.}

Levelei hosszukás láncsások, kopaszok, épéln̈ek; fejér töleséres virágai szárhegyi tömött bugát alkotnak Gyepükben, erdökben böven. †. Maj.-Jul. 5-8'. (Fagyalfa ; madairthir.)

Vesszës F. L. vulgare. $L$. 


\section{KöRISFA. Fraxinus. T.}

1. Levelei 3-6 pár szárnyuak, levélkéi nyeletlenek, láncsás hosszkások, kihegyezettek, fürészesek virágai zürzavart lakiak, barnák. - Erdőkben, kertekben. i. Magasfa. April.-Maj. (Körisfa; sebfa.)

Büdös K. F. excelsior. $L$.

2. Levelei leginkább 3 pár szárnyuak, levélkéi nyelesek, lánc๔ások vagy körkörösek, kihegyezettek, fürészesek; virágai tökélyesek vagy tökélytelenek, fejérek. - Hegyi erdökben, böven. †. April.-Maj. Az elöbbinél alacsonyabb fa.

Virágos K. F. Ornus. $L$.

\section{Rend. Apoczinfélék. Apocynaceae. $R$. $\mathrm{Br}$.}

\section{METÉng. Vinca. I.}

1. Levelei láncsás körkörösek, a felsők mindkét végökön. kihegyezettek; csészéje metszetei kopaszok; szára henyélö s gyökerezö. - Ligeti árnyasokban s kertekben. Ђ. April.-Мaj. 1/2-1'. (Bervény; börtény; meténg; szciszfï; loncz; erdei puszpcing; földi borostycin.)

Börvén H. $V$. minor. $L$.

2. Alsó levelei tojásdadok, a felsők láncsások; csészéje metszetei szemszörösek; szára henyélö, de nem gyökerezö. - Hegyi nyílt és száraz gyepeken, a homokdombokon is. 24. Apr.-Maj. 1/2-1'.

Szász H. V.herbacea. W. K.

48. Rend. Krepinfélék. Asclepiadeae. $R$. $B r$.

\section{KrePIN. Asclepias. I.}

Szára tengerzöld, vagy verhenyes színü; levelei tojásdadok vagy tojásdad-körkörösek, kopaszok, elöl habosak; virágzata szárhegyi sok virágu ernyő; bokrétája tojásdad hosszukás, csuklyája alig 3 karélyu. - A pesti városligetben elvadulva. 4. Jul.-Aug.

Pamut K. A. syriaca. $L$. 


\section{CZINKA. Cymanchum. L.}

Szára felálló; levelei ellenesek, szíves-tojásdadok, kihegyezettek; egyszerü ernyője kocsányjai kocsánykáinál háromszor hosszabbak; öt karélyu bokrétája fejér. - Frdőkben. bokrokban. 24. Maj.-Aug. 1-2 ${ }^{1 / 2} 2^{2}$. (Fecskegyölirr ; mérẹg̈löfü, ; eslutípfüve.)

Méregölö Cz. C. Vincetoxicum. I.

\section{Rend. Tarnicsfélék. Gentianaceae. Juss.}

\section{ELECZKE. Limmanthenum. Gmel.}

Levelei fenúszók. szíves-kerekdedek; ernyöi levélhónaljiak. kocsánytalanok; sárga virága szemszörös. - A Duna és a Tisza mocsáraiban böven. 4. Maj.-Aug. (Elecerie.)

Vizi E. L. nymphoides. ..

\section{VIDRAFÜ. Menyanthes. L.}

Hosszunyelü hármas tölevelei vannak, levélkéi viszszás-tojásdadok; virágzata tömött fürt; fejér szakállı virágai fejéres testszinüek. - A megye sík részén minden mocsárban. 4. Maj.-Jun. (Vidrafü; keserü hiromlevelü. fii.)

Háromlevelü V. MI. trifolicta. $L$.

\section{TARNICS. Gentiana. I.}

1. Bokrétája torka kopasz. :.

Bokrétája torki szakálas; levelei tojásdad láncsások, hegyesek, az alsók visszás tojásdadok, nyelesek, it felsők nyeletlenek; bokrétája 5 metszetü, lilaszínü. csészéje 5 fogú. - Buda, Vörösvár, Szánthó ligeti és hegyi rétein. ๑. Jul.-Aug. 6-12".

Öszi T. G. Amarella. L.

2. Virágzata gyürüs; gyertyatartóalakú bokrétája 4-metszetï, esaknem ékalakú ; ellenes levelei vállai hártyások s hártyái egymással összenöttek. - Hegyi gyepeken Buda környékén. 24. Jun.-Aug. 6-18".

Keresztes T. G. cruciata. I. 
Virágai szála hegyén vagy a levelei hónaljából magáinosan nöttek. $\mathbf{3}$.

ə. Virága szárhegyi : bokrétája 4-metszetü; metszetei hegyökön fürészesek, oldalaikon rojtosan prémesek: levelei szálas láncaások - Hegyi és erdei réteken. •). .Jul.-Aug. 2-6".

Prémes T. F. ciliata. $L$.

Virágai oldaliak és szárhegłyiek; bokrétája j̃ metszetü, bokrétája csöve ékharangalaku; égszínkék bokrétája belső oldalán pettegetett öt zöld csík van; levelei szálas láncsások, alsó levelei aprók, pikkelyalakuak. A megye sílkágán, nedves réteken. a budai és s\%. endrei hegyek patakjai mellékén. 24. Jul.-Aug. 1-2' (Kornisfü.) Kornis T. G. Pnemmonanthe. L.

\section{t. KLókA. Chlora. I.}

Ellenes háromszögü, tojásdad szárlevelei rgész szélességükben összenöttek $s$ a két levél közepén búvik által a szára: virága sárga. - A pesti városliget vizenyös túrfás rétein. (- Jul.-Aug. 3-8".

Általbúvó K. ('. perfoliata. $I$..

\section{FöLDEPE. Erythrea. I.}

1. Szára igen ágas; virágai levelei hónaljából nőttek: baraczk virágszínüek. mint a többi fajoké is: levelei tojásdadok, többnyire .) inúak. - Nedves. kivált homoki réteken, a Rákoson. @. Jun.-Ang. 3-12".

Csínos F. E. pulchella. Fries.

Szára egyszerü. virágzata sátorozó. 2.

2. Levelei hosszukás-tojásdadok. leginkább 5 inúak; sátorozó virágzata szárhegyi. egyenlö magas. - Mindenféle réteken. $\odot$. Jun.-Sept. ${ }^{1} 2-1^{1 / \frac{1}{2}}$. (Fül-tepe; lii.. rantancira: szrizforintos fü; lis ezerjófü.)

Ezerjó F. E. Centaureum. Pers.

Levelei szálasok, vagy szálas hosszukások. többnyire 3-inúak; bugáisan fejlödvén ki. virágai lejebb feljebb 
állókká lesznek. - A megye síkjain esö posványos helyeken nagy böséggel. $\odot$. Jun.-Aug. 3-8".

Gyujtovány F. E. linariaefolia. Pers.

50. Rend. Ajakasok. Labiatae. Juss.

\section{MENTA. Mentha. L.}

1. Virágzata füzére hengeres; murvái szálas áralakuak; termését záró esészéje hasas, felül összehúzódott; levelei csaknem nyeletlenek, tojásdadok vagy láncsások, fogason fürészesek. - Patakok, vízmosások, partjain, nedves réteken. 24. Jun.-Oct. 1-3'. (Bairzing; ló-, fejér-, hegyes-, vadmenta.) Bárzing M. M. sylvestris. $L$. Virágzata neın füzéres. 2.

2. Gombos virágzata szára hegyén ül, mely alatt vagy épen semmi, vagy egy pár gyürüs virágzata van : levelei nyelesek, tojásdadok, fürészesek; csészéje fogai háromszögüek, áralakuak. - Vizenyös és posványos réteken, patakok mellett bőven. 4. Aug.-Sept. ${ }^{1 / 2-2}$. (Vizi, fekete menta.) Vízi M. MI. aquatica. $L$. Virágzata gyürüi levele hónaljaiban egymástól távol iilnek 3.

3. Bokrétája csöve töleséres; levelei tojásdadok, vagy körkörösek, ritka fürészfoguak, meglehetösen kopaszok, mint az egész növény. -- Posványos és nedves réteken. 4. Jul.-Sept. ${ }^{1 / 2}-1^{1 / 2} 2^{\prime}$. Szelíd M. M. sativa. L. Bokrétája harangalaku; csészéje fogai, háromszögüen láncsások, vagy tojásdadok; levelei nyelesek, tojásdadok, vagy körkörösek, fürészesek s szárával együtt érdeses szörüek. - Az elöbbivel ugyanazon helyeken. 4. Jul.Sept. ${ }^{1 / 2}-1 \frac{1 / 2}{2}$. (Torlói menta.)

Tarlói M. M. arvensis. $L$.

\section{Csombor. Pulegium. Mill.}

Virága gyürüi gömbalakuak, egymástól távolocska állók ; csöves magtartó csészéje tetejét egy szörkör zárja be, 
felsö fogai hátrahajoltak; levelei nyelesek, körkörösek, tompák, alig fogasok. - Szántóföldeken. árkokban, nedves réteken böven. 24. Jul.-Aug. ${ }^{1 / 2}-1^{1}{ }^{\prime} \mathbf{2}^{\prime}$. (Csombor; polá, ; kösscénymenta ; putnok.)

Közönséges Cs. P. vulgare. Mill.

\section{PeszérCz. Lycopus. L.}

1. Levelei nyelesek, tojásdad-hosszuk, nagy fürészfoguak, vállaiknál pillenpátyosak; apró fejér virágaiban piros pontok vannak. Vízpartokon, árkokban, nedves bozótokban. 4. Jun.-Sept. 1-2 1'². (Vizi peszércze.)

Vízi P. L. europaens. $L$.

2. Alsó levelei körrajza széles tojásdad. a felsőké láncsás, mindnyája félbeszárnyason behasogatott, szőrösödök. - Az elébbivel ugyanazon helyeken. 4. Jun.-Sept. Magas P. L. exaltatus. $L$.

\section{MurvapikK. Origanmm. L.}

1. Levelei hegyes tojásdadok, csaknem kopaszok; csészéje 5) fogu; bokrétája sötét piros, néha fejér. - Bokrokban, ligetekben vágásokon. 4. Jun.-Jul. 1-3'. (Szurokfüi: felietegyopar; ; varga majoranna; szuifü.)

Szurokszagu M. O. vulgare. $L$.

2. Levelei tompa tojásdadok, nyelesek, mindkét lapjokon szürke molyhosak; murvái tömöttek, csészéi felezettek, fogatlanok; bokrétája verhenyes fejér. - Mivelik. $\odot$. Jul.-Aug. 1/2-1'. (Majorcinna.)

Majorámma M. O. Majoranna. $L$.

\section{DÉMUTKA. Thymus. L.}

1. Szára henyélő levelei láncsások, vagy kerekded körkörösek; piros színü bokrétája felsö ajaka kicsípett, tojásdad, csaknem négyszögü. - Gyepeken mindenütt. J. Cserjésedö. Jul.-Sept. (Kakulkfü; vad zsombor.)

Kakuk D. T. Serpyllum. $L$. 
Sokféle vilfıjai közül nevezetesebbek: u.) Minden része borzas, szára ellenes oldala kopaszocska: T. lumuginosus; b.) szára mindenik oldala egyenlöen szörös, levelei láncsás-inosszukások, vagy szálasok: T. cingustifolius; c.) nagyobb, mint az elébbi, levelei válla felöl elszükültek, néha szálasok és egészen szörös : $I$. nonicus. stb.

2. Szíra és ágai felállók, ormói szörösek; levelei tojásdau körkörösek, vagy kerekdedek, símák, virágzata gyürüsen füzéres. - Magasabban fekvö erdei réteken, erdöszéleken, Sz. Endre, Visegrád és Vácz felé. 4. Jul.Oct. ${ }^{1} 2-1$ '. (Koch ezt is a $T$. pannonicus válfajjal azonosnak tartja.) Hegyi D. T. montanus. $H: K$.

\section{Kalaminta. Calamintha. L.}

1. Virágzata hat virágu gyürükből áll, kocsányja egy’szerü ; termése csészéje tetején össze van huzódva s ráborult fogainál fogva be van záródva, világos lilaszinü. Szántóföldeken, hegyi és homoki veröfényes helyekell. $\odot$. Jul.-Sept. $1 / 2-1$ '. Mezei K. C. Acinos. Cluirv.

:-Virágzata sátorozó gyürükböl áll ; kocsányjai villásak, 3-5 viráguak; levelei tompa tojásdadok, fürészesek; viríga piros; magva kerekded. - Hegyi erdők bozótjaiban Vácz köriil. 4. Jul.-Aug. 1-2'.

Orvosi K. Coffecinalis. $L$.

\section{Pereszlien. Clinoporimu. L.}

Szára felálló, gyapjas; levelei tojásdadok; gyürüi sok viráguak, virága piros. - Hegyi és ligeti réteken. 4. Jul.-Oct. 1-2'. (Perveszléu; szöszz̈ssü.)

Szöszös P. C.vulgare. L.

\section{S. ZśÁlyA. Salvia. L.}

1. Szára alsó része kórós; ágai s gyenge levelei szürke molyhosak; levelei láncsísok, ránczosak, murvái lehul- 
lók; esészéje metszetei egy kis tövisen végzödnek; virága lilaszinü. Kertekben mivelik. †. Jun.-Jul. 1-2'.

Orvosi Zs. S. officinalis. $I$.

Szíra egészen fünemü. ‥

2. Virága barnán pontozott sárga; enyves csészéje ikrás gyapjas; levelei szíves dárdások, kihegyezettek, nagy fürész foguak. - A pilisi hegyek árnyas helyein a patakok mellett sziklákon. 24. Jun.-Sept. 1-3'.

Enyres Zs. S. glutinosa. $L$.

Virága kék. piros, lila vagy fejér szinü. 3.

3. Bokrétaja csövében szörkör van ; gömbded gyürüi sok viráguak; virága lilaszinü; szíves levelei csaknem háromszögủek, egyenetlenül csipkések alsó levelei nyele felsö részén két füle van. - Gyepeken, útfeleken. 4. Naj.-Aug. 1-2'. (Lózsśilya.)

Ló Zs. S. verticillata. $L$.

Bokrétája esövében nines szörkör. 4.

4. Crészéje fogai hosszu tövis fulánkuak; murvái széles tojásdadok, hajszálhegyüek; ágas szárain sok virággyürü van; tojásdad, csaknem szíves levelei öblösen. csipkések, szárával együtt szöszös gyapjasok. - Mezökön, útfeleken. ๑. Jun.-Aug. 1-3'.

Szereesen Zs. S. Aethiopis. I.

Csészéje fogai nem tövisesek. Ј.

5. Porodái bokrétájánál kétszerte hosszabbak; tőleveler tojásdadok, kétszeresen csipkések, karélyosak vagy csaknem szárnyason bevagdaltak, nyelesek, szárlevelei nyeletlenek, aprók; virága sárgás fejér. - Gyepeken böven. 4. Jun -Aug. 2-3'. Polyhos Zs. S. austriaca. I.

Porodái bokrétájánál vagy kurtábbak, vagy valamivel hosszabbak. 6.

(i. Szíra alig leveles; tőlevelei hosszu nyelüek, szíves-hoszszudadok, tompák, kétszeresen és durván csipkések, két párlevele kurta nyelü, gyürüi alatt álló piezi levelei nyeletlenek, mindnyája felül síma, alól gyapjas: 
szára hegyén ülö virágzata gyürüs-füzéres. - Kecskemét Csongrád felé eső száraz legelöin. 4. Maj.-Jun. $2-4^{\prime}$.

Konya Zs. S. nutans. Wr. $K$.

Szára meglehetösen leveles. 7.

7. Szára, murvái, csészéje és bokrétája enyves szörös; felsö ajaka aarlóalaku, sötét lilaszinü, ritkán fejér; csészéje felsö ajaka kurta, 3 fogu; levelei tojásdadok vagy hosszukások. - Réteken, legelökön, hegyi erdőkben. 4. Maj.-Jul. 1-3'.

Mezei Zs. S. pratensis. L. Szára levelei alsó lapjai és csészéje szürke. puha szőrösek; murvái pirosak, vagy lilaszínüek; felső levele vállai szívesek vagy tojásdadok, nyeletlenek. - Útfeleken, hegyi és homoki réteken. 4. Jun.-Aug. 1-1 $\frac{1 / 2}{2}$. (Kaliasturéj; erdei-, mezei-, slicurlútzsállya.)

Erdei Zs. S. sylvestris $L$.

\section{CsIPKEPITTY. Nepeta. L.}

1. Levelei tojásdadok, legyesek, alól szürke molyhosak, fürészesek; magva síma és kopasz; virága fejér vagy verhenyes. --- Bozótokban. útfeleken. 24. Jul.-Octob. 1-3'. (Macskafü ; nàdra; mézelle ; ménta.)

Macska Cs. $N$. cataria. $L$.

2. Levelei hosszudadok, csipkések, mindkét lapjokon kopaszok; magva görcsösen érdes, hegye szörösödö, virága fejér vagy sötéten pontozott világos lila. - Veröfényes dombokon, hegyi réteken, bozótokban. 4. Jul.Aug. 2-4'. (A lila virágu változatát hivják N. paniınica-nak Jacq.) (Mezei ménfü.) Kopasz Cs. N. muda.L.

\section{REPKÉNY. Glechoma. L.}

1. Szára gyökerezö, kopasz; levelei csipkések, vesealakuak, a felsők csaknem szívesek; hónalji kocsányjai 1-j viráguak, virága világos vagy sötét lilaszinü. - Minden nedveses réten, bozótokban. 4. Apr.-Jun. 3-10".

Két iksz R. G.hederacea. $L$. Szára gyökerező borzas; levelei csipkések, szívesek, nye- 
lesek, szörösek; hónalji kocsányjai \& riráguak. -- A megye hegyes vidékein a ligetekben. 24. April-Jun. ${ }^{1}{ }_{2}-1^{1}{ }^{1} 22^{\prime}$. (Földi borostyán: Tierek nádrafü; repplény; katona-petrezselyem.)

Borzas R. G. hirsuta. W. K.

\section{POFÓKA. Dracocephalum. L.}

Levelei szárnyason öt hasábuak, hasábjai szálasok. tompák, ágain s virágjai alatt levő levelei három hasábuak; virága lilaszinü. - A Palota és Fóth felé esö homoki gyepeken. 24. Maj.-Jun. 3-18".

Sallangos P. D. austriacum. $L$.

\section{Villahini. Prumella. L.}

1. Hosszabb porodái hegyén tövisalaku fog vall. 2. Porodái fogatlanok, a hoszabbakon azonban egy-egy kis púp ran; csészéje felsö ajaka széles-tojásdad és szálkás fogu; nagy rirága lilaszinü. - Hegyi s ligeti nedves gyepeken. 24. Jun.-Aug. ${ }^{1 / 2}-1^{1} 2^{\prime}$.

Nagyvirágu Y. P.grandiflora. $I$.

2. Hosszabb porodái szálkafoga egyenes; csészéje felsö ajaka fogai kurták, csonkák, szálkahegyüek, alsó ajaka fogai tojásdad láncsások, alig szemøzörösek; virága lilaszinü, néha fejér. - Az elébbivel. 4. Jun.-Aug. (Gyélfü; tüzfü; szilvalevelü fü; békararfü; torolifü; torokörö̈me.)

Torok Y. P. vulgaris. L.

Hosszabb porodái szálka foga elörehajolt; csészéje felső ajaka széles tojásdad, az alsó láncsás áralaku fésủ fogasok szemszörös; virága sárgás fejér. - Az elébluiekkel. 4. Jun.-Aug. Fejér V. P.alba. Pall.

\section{CsUKóKA. Scutellaria. L.}

1. Virágai magánosak, levelei hónaljában ülnek. 2. Virágzata fürtös, fürtjei szárhegyiek. 3.

9. Levelei nyelesek, szíves-hosszudad-láncsások, apró tompa esipkéjüek; rirágai féloldaliak; bokretája nyakr 
tövén esaknem derék szöglet alitt meggyökönt. Nedves szíkes réteken, patakok és mocsárok mellett. 4. Jun.-Aug. ${ }^{1 / 2} 2-1{ }^{1 / 2} \mathbf{2}^{\prime}$. (Cscíkólicf ï.)

Vízmelléki Cs. S. galericulata. $l$.

Levelei kurtanyeln̉ek széllyeltartók, vállaikon levö két foguknál fogva esaknem dárdaalakuak, épélüek; virágai egyoldaliak. - Az elöbbivel böven. 24. Jun.-Aug. ${ }^{1 / 2}-1^{\prime}$.

Nyillevelï Cs. S. hastifolia. L.

刃. Felálló szára magános, felül ikrás szörü; levelei szíveshosszudadok, nagy fürészfoguak, szörösödők; fürtje esaknem füzéres, féloldali; nyeles murvái a csészéjénél hosszabbak. - A budai erdökben, különösen i Hárshegyen. 24. Maj.-Jun. 1-2'.

Borzas Cs. S. Columnce. All.

Felálló szára ágas. felső részén gyapjas; levelei nyelesek, szíves hosszudadok, nagy fürészfoguak, kopaszok; fürtje csaknem füzéres, féloldali; nyeles murvái tojásdadok, szemszörösek, az alsúk a csészéjével egyenlök. - A budai és kovácsi erdőkben nem igen gyalori. 4. Maj.-Jun. 1-3'. Nyulánk Cs. S. peregrinu. L.

\section{MOZsÁRVIRÁG. Melittis. I.}

Levelei szíves tojásdadok, csipkések, szőröskék; virágai egyenkint, vagy 2-3-anként ülnek levele zugaiban; csészéje tág, harangalaku; nagy bokrétája fejér vagy piros. - Az erdők és bozótok árnyékaiban. 24. Maj.-

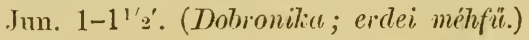

Édes M. M. melissophyllum. L.

\section{BIBETYÜ. Sideritis.}

Levelei lánc:ások, nyélbe keskenyedők, hegyök felé fürészesek, szöke szörüek; csészéje bokrétájánál hosz:zabb, felsö ajaka 3 metszetü; virága sötét piros. Száraz dombokon bőven. $\odot$. Jun. ${ }^{1 / 2-1}$ '. (Tisztesfii.)

Tisztes B. S. montana. L. 


\section{PENET. Marrubium. L.}

1. Szára igen ágas. ágai széllyelterpeszkedők : levelei szürke molyhosak, alsó lapjain hálózatosan erezettek; az alsók tojásdadok. a felsők hosszukás-láncsások. csipkések ; virágzata gyürüi 6 több viráguak, csaknem egyenlö magasak; csészéje; 2-10 fogu, csészéje fogai murvíival együtt molyhosak. - Legelökön, réteken,

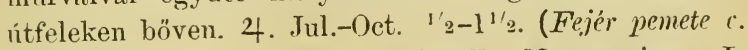
[ies.tercze.)

Fejér P. M. peregrinm. $L$.

Villljui: a.) Ha a levelei szélesebbek, mint a leirotté. molyha lazább, csészéje hegyei kopaszok, akkor : II. latifolium, r. Tr. remotum. h.) Ha a levelei keskenyebbek, hegyesebbek, ritka csípkejüek, csészéje fogai tömötten molyhosak, akkor: II. angustifolium, $v . M T$. reticum. stb.

2. Szára fejér molyhos. tövön ágas, ágai felegyenesedök; tojásdad levelei nyélrefutók, egyenetlen csípkéjüek. ránczosak, molyhosak, àlól hálózatosan horpadásosak: gyürüi sokviríguak; csészéje 10 fogu, fogai molyhosak. közepétöl lefelé kopaszok; csészéje hegyei horgason hátrahajoltak. - Telkeken, homoki réteken közönséges. 4. Jun.-Sept. 1-2'. Orvosi P. M. vulgare. L.

\section{1\%. BÉTONIKA. Betonica. L.}

Levelei szívesek, tojásdad-hosszudadok, csipkésen fürészesek; piros bokrétája kiviilről tömötten puha szőrü. - Ninden gyepen. 24. Jun-Aug. 1-1/2. (Bétonilia: bralifü, ; sel,fï.)

Orvosi B. B. officinalis. $L$.

\section{HUNYÁS'Z. Stachys. L.}

1. Gyürüi sokviráguak; murvái csészéjével egyenlők. vargy fẹlényiek; szára tömött gyapjassága miatt bolyhos; levelei szíves tojásladok, gyapjison molyhosak, virága. 
piros. - Útfeleken, szántóföldeken. hegyi és homaki gyepeken. $\odot$. Jun.-Aug. 1-3’. (Mezei fejér zsálya.)

Fejér H. S.germanica. L.

Gyürn̋i kevés viráguak; murvái igen aprók. ․

૧. Bokrétája piros 3.

Bokrétája halványsárga vagy sárgás fejér. 4.

3. Szára felálló durva szörü, teteje felé ágas és ikrás szörü; levelei nyelesek, tojásdad-szívesek s kihegyezettek, fürészesek, érdes szörüek; föld alatti hajtási vége egyenlö vastag. -- Ligetekben, vágásokon. bozótokban. 24. Jun.-Sept. $1^{1 / 2}-3^{\prime}$. (Erdei holt csalion.)

Erdei H. S. sylvatica. $L$.

Szára felálló, magános, kemény, vagy végén meggörbült szőrü; levelei szíves válluak, láncsások, hegyesek. esipkésen fürészesek, szörösödők, az alsók kurta nyelủek, a felsők félig szárölelők; földalatti hajtása vége ékalakúan vastag. - Nedves réteken, kiöntéseken, árkokban és szántóföldeken böven. 24. Jul.-Sept. 1-2'.

Seppedék H. S. palustris. $L$

4. Szára felsö részén puha szőrü; kopasz levelei nyelesek, az alsók körkörös hosszúdadok, a felsük láncsások; csészéje gyapjas. - Szántóföldeken, vetések közt. kivált a tarlón. $\odot$. Jun.-Sept. ${ }^{1 / 2-1}$ '.

Egy nyári H. S. anmua. $L$.

Szára és levelei kurta szörüek levelei hosszúdad-láncsások. a felsők tojásdad kihegyezettek; esészéje érdes szörü, de fulánkos hegye kopasz. - Minden gyepen közönséges. 24. Jun.-Ang. 1-2'. (Tisatesfüi; tarlóvircig.)

Tisztes H. S. recta. $I$.

\section{Foganö'T'T. Galeopsis. L.}

1. Szála lefelé álló, lelapúlt puha szörős s czikkei alatt nincs megvastagodva. $\mathbf{2}$

Szára keményszöri̋ s czikkei alatt meg van vastagodva. 3. 2. Levelei láncsások. vagy hosszukás lánesások, csaknem 
épélüek; virága piros. - Szántóföldeken. vetések közt $\odot$. Jul.-Oct. 1/2-1'. (Kenderikefii; ieres vajfii.)

Veres F. G. Ladanum. $L$.

Vailfajai: a.) Levelei láncsások, hosszúdadok. egyenlö fürészesek, csészéje zöldes, durvaszörü: G. latifolia : b) Levelei szálas lánesások, ritka fürészfogúak; csészéje szürke bolyhos: G. angustifolia.

Szára levelei tojásdadok, ága levelei tojásdad-lánesások, virága fejér. - Ugarokon, vetések közt, bozótokban. $\odot$ ○. Jul.-Sept. 1-2'. Sárga F. G. ochrolenca. Lam.

3. Bokrétája nyaka esészéjével egyenlö vagy kurtább, alsó ajaka közép karélya csaknem négyszögü, csipkés; virága piros, vagy fejér, alsó ajaka tövén pirosan pontozott sárga folt van; levelei hosszas-tojáscladok, kihegyezettek; szára kemény. durva szörös. - Az elöbbiekkel. ๑. Jul.-Aug. (Tarka lienderfü; tarka va,jfüi.)

Körönséges F. G. Tetrahit. $I$.

Bokrétája nyaka hosszabb, mint a csészéje. 4.

4. Szára keményszőrü ; nagy bokrétája kénsárga. alsó ajaka tövön czitromszínü, lilaszínü közép karélya fejér szegélyü, oldalmetszetei közepöktől fogva fejérek. levelei hosszúdad-tojásdadok, kihegyezettek. - A szigetek bozótaiban a ligetek vízmosásai mellett. $\odot$. Jun.-Sept. $1-3$.

Tarka F. G. versicolor. Curt. Szára lefelé álló lelapult. czikkei alatt kemény szőrös; virága piros; levelei széles tojásdadok, kihegyezettek. -- Az elébbiekkel. ๑. Jul.-Sept. 1 1/2-3'.

Szörösödö F. G. pubescens. Bess.

\section{GYÖNGYHIM. Leomurus. $\mathrm{L}$.}

Alsó levelei tenyeresen öt metszetüek, bemetszett fürészesek, 3 karélyúak, felsö levelei tövön ékalakúak, apró virágai halvány verhenyesek. - Romokon, árkok mellett, bozótokban. 4. Jul.-Sept. 2-4'. (Sziverỏsitöfï.)

Szúrós Gy. L. cardiaca. L. 


\section{ఖ1. KAJ'TÁR. Chaiturus. Host.}

Levelei alsó lapjai fejér ikrások, alsó levelei kerekdedtojásdadok, ritka fürészfoguak. felsö láncsás levelein néhány fürészfoga van; apró virágai világos rózæaszinüek. - Az elöbbivel, házak körül. ๑. Jul.-Sept. $1-3$.

Pemet K. C. Marrubiastrum. Relib.

\section{TÁtKANAF. Lamium. L.}

1. Bokrétája nyaka egyenes, virága piros: alsô levelei ṇelesek, kerekdedek vagy szíves tojásdadok, csíkosak, a felsők nyeletlenek, szárölelök. karélyosak: csészéje fogai virágzás elött és után be vannak záródva. Mivelt földeken. uítfeleken. $\odot$. Febr.-Nov. 2-10". (Bi)somy csalcinka.)

Szárölelö T. $L$. amplexicaule. $L$.

Bokrétája meggörbült, görbülése alatt el van szükülve. ‥

2. Virága fejér, bokrétája görbülése felett csipkésen elszélesedik, e csipke alatt meg elszükül s ebben belöl egy ferdén álló szőrkör van; levelei tojásdad-szívesek, kihegyezettek, egyenetlen fürészesek. - A pilisi hegyek bozótaiban ritka. 4. Maj.-Jun. 1-2'. (Fejér holt csalcin; (irva csalun.) Fejér T. $L$. allmem. $L$.

Virága piros. 3.

3. Levelei egyenetlen csipkés fürészesek; bokrétája nyakik alig görbe. elsz,nkn̋lésénél szörkör ran benne. Kellemetlen szagu. - A legközönségesebb mindenütt. $\odot$. Felur.-Nov. 1/2-1'. (Büdös holt csalcin.)

Piros T. L. purpurenum. L.

Levelei egyenetlen fürészesek, kihegyezett tojásdad-szí resek: bokrétája csöve keresztbe szükült el s elsziikủlése alatt belöl keresztbeálló szörköre van ; virága nagy. lilaszinü alsó ajakán piros foltok vannak. - Árnỵas erdőkben és mindenütt. 24. Maj.-Aug. ''2-1'.

Hódos T. $I$. maculatum. $L$. 


\section{अ3. MAMÓ. Galeobdolon. L.}

Tövéről gyökerezö ostorindákat hajt: levelei szíves-tojásdadok; virága sárga; nyaka veres, alsó ajakán két narancsfolt van. - Árnyas ligetekben. 4. Maj.-Jun. 1-1 ${ }^{1} 2^{2}$. (Sairga Toltesalain; pettegetett levelü holtcsalin; macskramamó.) Vérestorkú M. Gr. huteum. Hurds.

\section{PESZTERCZE. Ballota. L.}

Levelei szíves-tojásdadok; 5 fogu csészéje fogai tojásdadok. szálkahegyüek. - Útfeleken, pallagokon. 4. Jun.-Aug. 2-3'. (Büdös feliete pesztercze; felete pemet; mujitosó esalin.)

Fekete P. B. nigro. $L$.

\section{Bund. Phlomis. L.}

Tőlevelei tojásdadok. tövön mélyen szívesek, csipkések, a gyürüi alatt állók hosszukás láncsások; murvái áralakuak, kemény szörüek. - Nedves réteken, árkok s töltések mellett, vetések közt. 4. Jun.-Jul. 2-4'.

Csiesókás B. P. tuberosa. $J$.

\section{TARORJA. Teucrium. L.}

1. Virágzata levelei hónaljaiban oldaltálló. 2. Virágzata szárhegyi. 3.

2. Levelei kétszerszárnyason hasogattak. gyürüi 5-6 viráguak. - Hegyi és homoki száraz gyepeseken. köves helyeken. $\odot$. Jun.-Jul. ' ${ }_{2}-1$ '.

Tömjén T. T. Botrys. L.

Levelei nyeletlenek, láncsás-hosszúdadok, csipkésen füré szesek, fejér gyapjasok, az alsók vállban kerekek, a felsők alól elkeskenyedettek; gyürüi 4 viráguak. Vizenyös réteken, árkok és mocsárok mellett. 4. Jun.Ang. 1-1 '²'. (Vizi foghagyma; fodorka.)

Hagymaszagń T. T. Scordium. I.

3. Gyürüs virágzata fürtöt alkot, virágait környezö levelei murvaalakuak; gyürüi 6 virágnak ; levelei ékalakuan- 
tojásdadok; szára henyélö, felegyenesedő, szörösödö. - Hegyi réteken, ligetek mellett. 24. Jun.-Sept. 2-8'. (Gamandor; zsuzsínlia; his cserlevelü fü; sartósfü.)

Gamandor T. T. Chamaëdrys. L.

Gyürüi szárhegyi gömböt alkotnak; levelei szálas láncsások, épélüek, kivált alól molyhosak; kórós szára lecsepült. - Veröfényes hegyeken, homokokon és más mezökön. 24. Jun.-Aug. 3-6"'. Hegyi T. T. montanum. L.

\section{2\%. KACSKANYAK. Ajuga. L.}

1. Virágai levele hónaljaiban magánosak. 2. Virágzata gyürüs. 3.

2. Levelei három hasábúak, hasábjai szálasok; virága sárga, erös kellemetlen szagú. - Szántóföldeken, vetések közt. ๑. Jul.-Oct. 2-10". (Kalincza; földi fenyö; köszrényfii.)

Kalineza K. A. Chamaepithys. Schreb.

Levelei tojásdad-hosszúdadok, csaknem épéli̋ek, felálló. néha henyélö szárával egyuitt gyapjason-borzasok; virága szennyes sárga, vagy szennyes fejér, erei pirosak. - A pere-sz.-mártoni erdöben. 4. Jun.-Jul. 1-1²/2'.

Szennyes K. A. Laxmanni. Bth.

3. Töve gyökerezö ostorindákat hajt; levelei kikanyargatottak vagy alig csipkések; virága kék, néha testszínủ vagy fejér. - Nedves réteken, ligetekben. 4. April.-Jun. 1/2-1'. (Közép nadályfï; fiasfï.)

Ostorindás K. A. reptans. $L$.

Töve ostorindátlan. 4 .

4. Alsó murvái 3 karélyuak, a felsők gyürüinél kurtábbak vagy alig akkorák; levelei hosszudadok, tompák egyenetlen fogasok, virága kék, néha halvány veres. Hegyi és homoki réteken. 2. Maj.-Jun. 3-9".

Halmi K. A. genevensis. $L$.

Felsö murvái gyürüinél kétszerte hosszabbak; kikanyargatottan csipkések, alig színesek; borzas gyürüi gulaalakulag szárboritók; levelei hosszudadok, tompák, 
csipkésen fogasok. - Erdei gyepeken. 4. Maj.-Jul. ${ }^{1} \cdot 2-1$.

Tornyos K. A. pyramidalis. $I$.

51. Rend. Gubóvirágfélék. Globulariaceae. D. C. 1. GubóviríG. Globularia. L.

Tölevelei lapiczkások, hegyök kicsípett; szárlevelei láncsások, nyeletlenek; virágzata szárhegyi gömb ; virágai kékek. - Hegyi nyílt réteken. 4. Maj.-Jun. 6-12". Apró G. G. vulgaris. $L$.

52. Rend. Galambóczfélék. Verbenaceae. Juss. 1. GaLAMBócz. Verbena. L.

1. Szára felálló; levelei ellenesek, 3 hasábuak, sallangosak; virágzata fonalalaku hosszu füzér, virágai aprók, halvány pirosak. - Romokon, legelökön, útfeleken stb. $\odot$. Jun.-Oct. 1-21/2'. (Szaporafï; galambfü; galambócz.) Szapora G. V.officinalis. $\bar{S}$.

2. Szára henyélö; levelei ellenesek, kétszerszárnyasok, a felsök szárnyason hasogattak; virágzata kurta füzér ; apró virágai kékellök. - Faluk körül, Szolnok vidékén. ๑. Jun.-Sept. ${ }^{1 / 2-1 ' . ~ H e n y e ~ G . ~ V . ~ s u p i n a . ~ L . ~}$

53. Rend. Borágófélék. Boragineae. Desv. Juss.

\section{KUNKOR. Heliotropium. L.}

Szára terepélyen ágas; levelei tojásdadok, épélủek, molyhosan érdesek; füzére féloldali, megkunkorodik. Szántóföldeken, árkokban, útfeleken. ๑ Jun.-Aug. $1 / 2-1$ '。 Europai K. H. europaeum. $L$.

\section{SZEPLÉN. Cerinthe. I.}

Szára felálló, felül ágas; levelei símák, tởlevelei nyélbe menö tojásdadok, szárlevelei tojásdad szíves szárölelők; bokrétája 5 hasábu, hasábja hegyes fogu. - 
Szántóföldeken, gyepeken, körakások mellett. $\odot$. 1/211/2'. (Pcivduczfü; szeplölapu ; viaszfü.)

Kis Sz. C. minor. $L$.

\section{KígYószisz. Echium. L.}

1. Bibeszára hegye kétmetszetű. 2.

Bibeszára hegye ép; bokrétája csöve két annyi, mint csészéje; porodái bokrétájánál hosszabbak, bokrétája veres; füzére ép; levelei széles láncsások; az egész növény borzas. - Hegyi gyepeken, p. o. a Sashegyeıl. ๑. és 4. is. April-Maj. 1-3'.

Veres K. E. vubrum. Jacqu.

2. Füzére ép; bokrétája csöve kurtább, mint a csészéje; porodái lefelé hajlók, széllyeltartók s a bokréta karimájához támaszkodók, bokrétája kék; levelei láncsások; az egész növény borzas durva szörü. - Útfeleken, gyepeken. $\odot$. Maj.-Jul. 1-3’. (Törises v. radatraczél; pirrositó gyökér ; terjőlie.)

Terjöke K. E. vulgare. $L$.

Füzére kéttagu, tömött, porodája fejér bokrétájánál kétszerte hosszabb; láncsás levelei és szára a másik kettöénél sokkal borzasabb. - Hegyi és homoki szára\% réteken. $\odot$. Jun.-Aug. 1 $1 \frac{1 / 2}{2} 4^{\prime}$.

Olasz K. E. italicum. L.

\section{APÁCZ. Nomnea. Med.}

Szára csaknem egyszerü; levelei lánesások, lelapult szörüek, virága körül álló levelei tojásdad-láncsások, bokrétája eresze akkora, mint a esöve. - Szírazabb. kivált homoki gyepeken. $\odot$. Maj.-Jun. ''2-1'. (Lycopsis pulla.) Gyászoló A. N. pullu. I. C'.

\section{NADÁLYTÖ. Symphytum. L.}

1. Gyökere orsóalaku, ágas; szári ágas, levelei szárrafutók. tölevelei tojásdad-láncsísok, nyélbe keskenyedök, 
a felsők láncsások; virága veres vagy lilaszinü, ritkán sárgás fejér. - Nedves réteken. 4. Maj.-Jul. $1-2$.

Fekete N. S. officinale. $I$.

2. Gyökere hengerded. ferdén álló, husos görcsös, vége csonkia; szára egyszerü; levelei szárrafutók, tỏlevelei tojásdadok, a felsök körkörösek s ezeknél az alsók kissebbek s virágzás idejére elszáradnak; virága halvány sárga. - Hegyi ligetekben. 24. Maj.-Jum. 1-1/2'.

Gumós N. S.tuberosum. L.

\section{ATRACZÉL. Anchusa. L.}

1. Csészéje 5 fogu, vagy 5 metszetủ; bokrétája csészéjénél hosszabb. boltpikkelyei tojásdadok, selymesek, virága piros-lilaszinü; szára felálló, levelei láncsások. Csészéje 5 hasábu, bokrétája esészéjével egyenlö. 2.

2. Szára felálló, ágas; levelei tojásdadok vagy hosszukás láncsások; bólt pikkelyei hosszudadok. hegyén ecsetszörüek: virága égøzinkék. Az egész növény durvaszörös. - A vetések közt, árkok szélein Buda környékén. $\odot$, néha 4. Jun.-Aug. 2-4'.

Olasz A. A. italica. Retz.

Szári egyszerű, puhán érdeses szörü: levelei hosszukások, mindkét végeiken elkeskenyedők, csaknem fogasoltak; fürtjei párosak; fejér boltpikkelyei tojásdadhos\%szudadok, szélén szemszörösek, hegyén puposan behajlottak. kopaszok, virága kék. - A Naszál hegyén. ๑. Jun.-Inl. 2'.

Tompa A. A. Barrelieri. I. (:

\section{NYAKÓ. Lycopsis. L.}

Levelei láncsások, kikanyargatottan fogasok. kemény durvaszörüek; bokrétája csöve közepén meggörbült: virága kék. - Vetések közt Gödöllő vidékén, böven. ○. Maj.-Jun. 6-18". (Anchusa arvensis. Link:)

Bibiresós Ny. I. arrensis 1 . 


\section{VÉRTÖ. Onosma. L.}

Szára igen ágas; levelei szálas láncsások, serteszőrủek, sertéi egy kopasz göbböl nönek ki; szálcsái felényiek. mint kopasz portokai. - Száraz hegyi és homoki gyepeken. ๑. néha 24. Maj.-Jun. (Pirositó gyökér; sairga atraczél.)

Szúrós V.C. echioides. $I$.

\section{KÖMAG. Lithospermum. L.}

1. Bokrétája elébh rózsa, azután kékszinü, torka szőrős, 5 ránczba van szedve; szára durvaszőrü 2-3 águ, nem virágzó szára terjedő; levelei láncsások, meglehetös hegyesek; magva fejér, síma. - Ligetekben, vágásokon. 24. Maj.-Jun. ${ }^{\prime \prime} 2-1^{1} 2^{\prime}$.

Változó K. L. purpureo coevuleum. I.

Bokrétája fejér vagy sárgás fejér. 2.

2. Szára felálló, igen ágas, levelei láncsások, hegyesek, érdesek; magva fejér, síma. - Ligetekben, útfeleken.

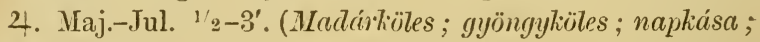
tengeri kömagvu fï.) Gyöngy K. L. officinale $L$. Szára felálló, csak a tetején ágas; levelei láncsások, lelapult kurtaszörüek; termés csészéje ritkán álló, terméseráncza barna. - Gyepeken, vetések közt. $\odot$. Maj.-Jul. 1-3'. Mezei K. L. arvense. $L$.

\section{Gilina. Pulmonaria. L.}

1. Nem virágzó töve külsö levelei nyelesek, szívesek, levele nyele gatyás; virága elébb veres, azután lilaszinü. - Ligetekben, vágásokban. 4. Apr.-Maj. 1-2'. (Tüdöfü: gálna.) Pettegetett G.P.officinalis L.

2. Szára sertésszőrü, sertéi közt puha szörök is vannak; tölevelei hosszunyelüek, körkörös láncsások, szárlevelei hosszudad-láncsások, a felsők félig szárölelök; virága elébb veres, azután kék. - Ligetekben, vágásokban. 4. April.-Maj. 3-18". Tüdö G. P. angustifolia $L$. 


\section{AlKanNa. Alkama. Tausch.}

Szára henyélö s felegyenesedő, alig ágas, borzas; tőlevelei nyélbemenők. lapiczkás láncsások, a felsők láncsások, épélüek, virága szép kék. Gyökere barnapiros, a papirt és kezet sötétpirosra festi. - Homokon mindenütt. 4. April-Jun. 1/2-2'. (Lithospermum tinctorium. D. (.) (Tiros ökürmyelv : pirósitó füt; vad öliörnyelv.)

Festö A. A. tinctoria Tausch.

\section{SÜNMAG. Echinospermum. S.}

Szála felül ágas; levelei láncsások, lelapult szőrüek s szemszőrősek; bokrétája csészéjénél hosszabb; magva oldalán ket sor horgas tüske van. - Romokon, falakon, útfeleken. $\odot$. Jul.-Aug. 1-2'.

Bojtorján S. E. Lappulc. $I$.

\section{NEFELEJTS. Mrosotis. L.}

1. Csészéje lelapult szőrü, magra me̊gérésekor nyílt. ․ Csészéje felálló. horgas szőrü, 5 metszetü. §.

๑. Tögyökere dülten áll, terjedő ; szára négyszösủ ; szárlevelei hosszukás láncsások, meglehetős hegyesek; bibeszára akkora, mint a csészéje; bokrétája égszín kék; boltpikkelỵei elébb sárgák, később verhenyes sárgák. - Posványok, árkok s mocsárokban. 24. Maj.-Jul. 10-15". (Nefelejts.)

Mocsári N. M. palustris. With. Tőgyökere függőleg áll ; szára hengeres; szárlevelei szálas hosszudadok, tompák; bibeszára igen kurta, bokrétája olyan, mint az elöbbié, de a metszetei kisebbek. - Terem az előbbivel együtt. $\odot$. Jun.-Jul.

Pázsitos N. M. caespitosa. Schult.

3. Termése kocsányja esészéjénél kurtább; bokrétája csöve még egyszer akkora, uuint a csészéje; portokai boltpikkelyéig érnek; bokrétája színe kezdetben sárga, azután kékes, végre sötét kék; szárlevelei szálas 
hosszudadok, tompák. - Nedveses gyepeken. ๑. Maj.Jun. 2-12".

Változó N. M. versicolor. Per's,

Termése kocsányja esészéjével egyenlö. vagy annál alig hosszabb. 4.

4. Csészéje metszetei virágzás után felállva záródnak öszsze; bokrétája eresze vizirányos; szárlevelei hosszudad láncsások, hegyesecskék. - A budai sz.-endrei stb. erdők vizenyös helyein. $\odot$. Maj.-Jul. ${ }^{1 / 2}-1^{1 / 2} 2^{\prime}$.

Erdei N. M. sylvatica. Ehrb.

Csészéje metszetei virágzás után is nyitva maradnak. 5.

5. Termése csészéjének kocsányjai vizirányosan állanak; harangalaku bokrétája csöve be van záródva; szárlevelei hosszudadok, tompák. Az egész növény borzas. - Száraz gyepeken. ๑. Maj.-Jun. 1-12".

Borzas N. M. hispida. Schlect.

Termése kocsányjai csészéinél kétszerte, vagy még hoszszabbak. 6.

(j. Termése kocsányjai felállók, vagy egykissé oldalra kihajlók; termése csészéi be vannak záródva; bokrétája eresze homoru; szárlevelei hosszudad-lánesások; szára ágas s leveleivel egyuitt szörös. - Budán ritka, a kerepesi gödöllöi erdőkben böven. $\odot$. Jun.-Aug. $\varepsilon-18^{\prime \prime}$.

Közép N. M. intermedia. Link.

T'ermése kocsányjai letüremlettek; apró bokrétája karélyai épek; kevés virágu fürtje tövén leveles; szárlevelei hosszudad láncsások, ritka szörủek és szemszörösek. - A pilisi és váczi hegyek erdeiben. $\odot$. Maj.-Jun. 1-1 $1 / 2^{\prime}$.

Kevésvirágu N. M. sparsiflora. Mikan.

\section{MAGISZÁK. Asperugo. L.}

Szára ágas, henyélö, kurta visszás fulánkokkal rakott; hosszudad láncsás érdes levelei szemszörösek; kurta kocsányu apró s pirosas kék virágai hónaljiak; ter- 
mése csészéje nagyra megnő. - Útfeleken, árkok partjain mindenütt. •. Maj.-Jun. 1-3’.

Henye M. A. procumbens. $I$.

\section{5. ÁRNÖ. Cynoglossnm. I.}

Szára felálló; levelei finom szürke molyhossága miatt puha tapintatuak; alsó levelei széles láncsások, nyélbe keskenyedők, szállevelei szálas láncsások, mind épélüek ; fürtjei murvátlanok; bokrétája eresze harangalaku. Útfeleken, árokipartokon, szántóföldeken, vágásokon. $\odot$. Vaj.-Jul. 1-3'. Orvosi Á. C.officinale. L.

\section{KÖLDÖNCZ. Omphalodes. T'our'ı.}

1. Tölevelei szíves tojá:dadok ; szárlevelei tojásdad láncsások ; virágot termö szára felálló, kopasz, felül szörös; virágzata fürtös ; terméketlen szára henyélö s terjedő. - A megye síkján a Baja felé eső erdőkben. 4. Kora tavaszszal. 2-6". Tavaszi K. O. verna. Mönch.

2. Tỏlevelei lapiczkások; szárlevelei tojásdad láncsások ;. az alsóbbak ellenesek; mindkét oldalukon érdesek; egy virágu kocsányjai hónaljiak; alig két águ szára henyélö. - Árnyas erdökben, a budai Jánoshegy északi oldalán. (-) Apr.-Maj. 6-9".

Nefelejts K. O. scorpioides. Lehm。

\section{Rend. Szulákfélék. Convolvulaceae. Vent.}

\section{SZUi_áK. Convolvulus. L.}

1. Levelei szálas láncsások, hegyesek gyapjasok; szára ágas, lecsepült; csészéje gyapjas; tölcséres bokrétája világos, szörös ránczai sötét rózsaszinüek. - Hegyi nyílt réteken Buda körül. †. Jun.-Jul. 1/2-1'.

Rózsaszinü Sz. C.Cantabrica. L.

Levelei nyílalakuak: $\mathbf{~ . ~}$

2. Nyílalaku levelei vállban hegyesek; kicsiny murvája 
virágától távol áll; töleséres bokrétája fejér vagy verhenyes. - Szántóföldeken, rétekeu, kertekben. 4. Maj.-Sept. (Kis szulák; szulák; folyófun; iszapfü.)

Kis Sz. C. arvensis. $L$

Nýlalaku levelei vállban csonkák; szíves nagy murvái csészéjét befoglalják; tölcséres bokrétája nagy, fejér, - Gyepükön: bokrokon. 4. Jun.-Aug.

Nagy Sz. C. sepium. $I$.

\section{FÜNYÜG. Cuscuta. L.}

1. Bokrétája esöre kétannyi, mint a karimája, csörében levő pikkelyei oldalára lapulva felállók, egy terméjü; virágzata füzéres; termése majdnem borsónyi. Bokrokon és fákon, kivált nyár- és füzfákon élösködik; található a Sz. Gellérthegy és a Nádorkertje közt a Dunaparton. $\odot$. Jun.-Sept.

Egyterméjü F. C. monogyna. Vahl. Bokrétája csöre akkora, mint a karimája. 2.

2. Bokrétája csővében levő pikkelyei oldalára lapulva felállók; bibéi fonalakuak; virágzata csomós; virágai verhenyesek. - Csalánon, kenderen s füzeken élösködik. $\odot$. Jun.-Jul. (Aranka: fecskefoncil; görényfu": köszvényfüi.)

Fonál F. C. europaea. $L$. Bokrétája csövét egymásfelé hajló pikkelyei bezárják; bibéi fonalalakuak; virágzata csomós; virágai verhenyesek. - A Démutkán, Rekettyén és a Lóherén stb. élődik. $\odot$. Jun.-Aug. Kaknk F. C. Epihymum. L.

\section{Rend. Csucsórfélék. Solanacene. Barth.}

\section{FÁNZÁR. Lycium. L.}

Szára gindár; levelei láncsások, nyélle keskenyedők; bokrétája karimája akkora, mint a csöve. - Gyepükben elvadulva, mivelik is. 5. Jun.-Jul.

Pongyola F. L. barbarum. L. 


\section{CsuCsór. Solanum. L.}

1. Levelei páratlan esonkatollas-szárnyasok; szára szegletes szörös ; földalatti tövein gumókat terem. Mivelik. $\odot$. Jun.-Jul. (Földi alma; pityóka; lirumpér; kolompér; csucsorlia.)

Burgonya Cs. S. tuberosum. $L$.

Levelei nem szárnyasok. $\mathbf{2}$

2. Szára cserjésedő, kapaszkodó, kopasz; alsó levelei szívestojásdadok, a felsők dárdások; virága sötét lilaszinü ; termése veres bogyó. - Gyepükben, bokrokban, vizenyös helyeken. †. Jun.-Aug. 3-4'. (Teres v. vizi clszöllö.)

Keserédes Cs. S. Dulcamara. $L$.

Szára fünemü; levelei tojásdadok, csaknem kótaalakuak, öblösek fogasok, görbehegyü ritka szörüek; virága fejér; termése fekete, néha sárgás $\mathbf{v}$. verhenyes bogyó. Mérges. - Mivelt helyeken, kertekben $\odot$. Jul.-Sept.

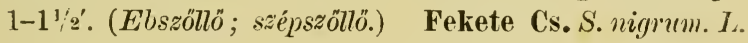

\section{PÁPONA. Physalis. L.}

Levelei rendszerint párosok, egymás mellett indulnak, hosszu nyelüek, tojásdadok, épélüek, vagy habosak; virágai hónaljiak, piszkos-fejérek, pirosan erezettek: skárlátpiros bogyóját felfuvódott veres csészéje zárja magába. - Árnyas erdőkben, gyepük és szőllöskertek mellett. 4. Jun.-Jul. 1/2-11/2. (Muharcz; zsidóesereszmye; körontófü; ; vémusköldöke.) Piros P. P. Alkekenyi. I.

\section{Nadragulya. Atropa. L.}

Szára ágas, párosan álló s egyenetlen nagyságu; levelei tojásdadok, nyélrefutók, épélüek, hegyesek; virága piszkos barna lilaszinü; fénylö bogyója sötét piros ; sőt fekete. Halálos méreg. - Árnyas erdőkben : budai hegyeken bőven. 24. Jun.-Jul. 2-6'. (Nadragulya: nagyfü; farkas-cseresznye: mérges cseresznye.)

Maszlagos $\mathbf{~}$. A. Belladomna. $L$. 


\section{REDŐsZIROM. Datura. L.}

Levelei nyelesek, tojásdadok, öblösen s egyenetlenül fogasok; virágai szára hegye villái közt magánosak; tokja tüskés. Mérges. - Telekes helyeken; trágyadombokon. $\odot$. Jun.-Aug. 1-3'. (Csodafa; maszlag; csattantó.) Maszlagos R. D. Stramoninm. L.

\section{CSAlmatoK. Hyosciamus. L.}

Szára és levelei ragacsos bolyhuak; levelei tojásdadok, szárnyason hasogatott öblösek, az alsók nyelesek, a felsök szárölelök, virágai csaknem kocsánytalanok; bokrétája violaszín erezetü piszkos halványsárga. Igen mérges. - Telekes helyeken, réteken, vágásokon. $\odot$. vagy $\odot . J u n .-A u g . ~ 1-3 '$. (Beléndfü ; beléndel; ; bolonditó fü; disznóbab.) Bolonditó Cs. H. niger. L.

\section{DoHÁNY. Nicotiana. I.}

1. Levelei tojásdadok, épélüek, nyelesek; csészéje metszetei kerekdedek; tompák, bokrétája gyertyatartóalaku, sárgás zöld. Mivelik, most már telekes helyeken s faluk körül vadon is nö. $\odot$. Jul.-Aug.

Kapa D. N. rustica. L.

2. Levelei hosszudad-láncsások, kihegyezettek, nyeletlenek, az alsók szárrafutók; bokrétája torka felfuvódott hasas, piros. - Mivelik, vadon ritka. - $\odot$. Jul.-Aug.

Közönséges D. N. Tabacum. I.

56. Rend. Tákajakfélék. Scrophularineae. $R$. $B r$ r.

\section{FARKKÓRÓ. Verbascum. L.}

1. Virágzata 4- vagy sokvirágu csomókból álló füzérnek látszik. 2.

Virágzata fürtös. 9.

2. Levelei egészen vagy félig szárrafútók. 3. 
Levelei nem futnak a szárára. 5.

3. Levelei félig szárrafutók, csipkések, sárgás molyhosak, körkörösek, vagy hosszudad-lánesások, a felsők tojásdad kerekek, kihegyezettck; hosszabbik két szálesája kopasz, vagy a végén alig szörös, másfélszer, vagy kétszerte hosszabb, mint a féloldalára futś portoka. Erdőkben, szántóföldeken, útfeleken. ๑. Jun.-Aug. ' $2-5$ '.

Szöszevö F. V.phlomoides. $L$.

Levelei oly módon futnak a szárára, hogy levél levelet ér. 4.

4. Bokrétája tölcséres; porodái fejér gyapjasok, két hoszszabbik kopasz szálesája a féloldalára lefutó portokánál négyszerte hosszabb. - Telekes helyeken, ugarokon, útfeleken. - $\odot$. Jul.-Aug. 2-5'. (V. Thapsus. L.) (Ölïrfarlitióró; kircilygyertya; gyapjufü.)

Ökör F. V. Schraderi. Meyer.

Bokrétája kerékalaku; szálcsái fejér gyapjasok, a két hosszabbik kopasz szálesája, másfélszer vagy kétszerakkora, mint a reájok féloldalon hosszan lefutó portokuk. - ○. Az elöbbivel. Jul.-Aug. 2-3'.

Keskenylevelï F. V. thapsiforme. Schrad.

5. Szálcsáin levő gyapja fejér. 6 . Szálcsáin levö gyapja piros. 7.

6. Levelei ép- és habos-élüek, molyhosak, molyha állandó, az alsók hosszuk, hegyesek és nyélbe keskenyedők, szárlevelei szívesek, fülesek s nyeletlenek. - A megye hegyi vidékein, p. o. Sz.-Endre körül, pallagokon 'és patakok mellett. $\odot$. Jun.-Aug. 2-5'.

Ékes F. V. speciosum. Schrad.

Levelei csipkések, felső lapjaik csaknem kopaszok, az alsók porosan molyhosak, felső leveleik nyeletlenek, tojásdadok, kihegyezettek; ágai fel- s kissé széllyelállók, tornyosan bugások, éles ormójuak; virága sárga, néha fejér. - Telekes helyeken, szántóföldek s útak mellett, erdőkben ritka. $\odot$. Jun.-Aug. 2-4'.

Fedelékes F. V. Lychnitis. L. 
7. Virága rozsdaszinü; kocsányai esészéinél sokkal hoszszabbak; levelei csipkések; alsó lapjaikon molyhosak. alsó levelei nyelesek, hosszuk, a felsők hosszas-tojásdadok, hegyesek, nyeletlenek, szívesen szárölelök. A pesti és váczi homoki mezökön, réteken. $\odot$. Maj.Jul. 1-3'.

Füstfogta F. V.rubiginosum. $W . K$.

Virága sárga. $\mathbf{S}$.

3. Szára felső része élesen ormós, pirosas fekete; alsí szárlevelei vállban szívesek, hosszunyelüek, a felsők tojásdad-hosszuk, alól mind molyhosodók, csomókból álló fürtje megnyult. - Mindenféle gyepeken. $\odot$. Jun.-Jul. 1-3'.

Fekete F. V.nigrum. L.

Szára felső része és bugásan álló ágai hengerdedek, pirosas feketék; alsó levelei tojásdad-hosszudadok, nyélbe keskenyedők, vagy alig szíresek. a középsők kurtanyelesek, a felsők nyeletlenek. - A budai ligetek. és a síkság gyepein. $\odot$. Jun.-Aug. 2-3'. (V. austriacum. Schrad.)

Karesú $\mathbf{V}$. $V$. orientale. $M$. $P$.

Э. Levelei alsó lapjaikon molyhosak, tölevelei nyelesek, tojásdadok, vagy hosszukások, csipkések, közép és felsö levelei töleveleinél sokkal kisebbek, nyeletlenek. apró csipkéjüek; kocsányjai murváinál sokkal hoszszabbak; virága sötét lilaszinü. — Réteken, kivált nedves helyeken. $\odot$. Jun.-Aug. 1-2'. (Kélimelyfüi ; kékuirägu ökörfartikóró.) Violaszín F. V.phoeniceum. L.

Levelei kopaszok, az alsók visszás-tojásdadon hosszuk, válban elkeskenyedettek, öblösek, a felsök hosszuk, hegyesek, kétszeres csipkések; kocsányjai murváinál másfélszer vagy kétszer hosszabbak. - Réteken és legelökön mindenütt. $\odot$. Jun.-Jul. 1-3’. (Molyfü; penészfü.)

Molyüzö F. T. Blattaria. I.

\section{GyUJTOVÁNy. Linaria. Tourn.}

1. Szára lecsepült, fonalalaku. 2.

Szára felálló. 3. 
2. Levelei tojásdad-dárdások, a legalsók tojásdadok; sarkantyuja egyenes, virága fejéres, felsö ajaka belöl lila, alsó ajaka sárgaszinü. - Homoki réteken, szántóföldeken, a vetések közt. $\odot$. Jul.-Sept. 2-18".

Cseplesz Gy. L. Elatine. Mill.

Levelei kerekded-tojásdadok, épélüek; sarkantyúja ívalakuan görbe, virága fejéres sárga szinü, felsö ajaka pirosas. - Az elöbbivel. $\odot$. Jul.-Aug.

Kétszinü Gy. L. spuria. Mill.

3. Virágai levelei hónaljaiból magánosan nőnek; kocsányja esészéiénél háromszorta hosszabb; virága világos lilaszinü, ajakai sárgák, levelei tompa láncsások. Az egész növény ikrás szörös. - Réteken, szántóföldeken, a vetések közt. $\odot$. Jun.-Sept. ${ }^{1 / 2-1}$ '.

Apró Gy. L. minor. De:f.

Virágzata szárhegyi fürtös vagy füzéres. 4.

4. Alsó levelei négyenként gyürüsen állanak, a felebb esők váltógatók szálasok, mindkét végökön kihegyesedők; csészéi kocsányjaival együtt ikrás szörösek; magvai szárnyasok, símák. - Száraz réteken és szántóföldeken, vetések közt. $\odot$. Jun.-Sept. $1 / 2-1 \frac{1 / 2}{2}$.

Ugari Gy. L. arvensis. Dest.

Levelei váltogatók vagy ziláltak. ॅ.

5. Főkocsányja kocsánykáival együtt ikrás szörös; fürtje tömött, sőt fedelékes; virága sárga, magva szárnyas, közepén görcsösen érdes; levelei láncsás szálasok, hegyesek, tömött zilált állásuak. - Mindenütt. 4. Jun.-Sept. 1-2 ${ }^{1 / 2}$. (Lenlevelü fï; gyujtovány; pintyö.)

Közönséges Gy. L. vulgaris. Mill.

Fökocsányja és kocsánykái kopaszok. 6.

6. L.evelei szálasok, vagy szálas láncsások, hegyesek, 3 inúak; fürtjei bugásak; hosszu sarkantyúi majdnem egyenesek. - Száraz homoki réteken; p. o. Pest körül. 4. Jul.-Sept. 1-2'. Lenlevelü Gy. L. italica. Trerii. 
Levelei láncsások, kihegyezettek, nyeletlenek; fürtjei vesszősek, girbe-gurbák, bugásak; áralaku sarkantyúi egyenesek. - Hegyi és homoki réteken, útfeleken stb. 24. Jun.-Sept. 1-4'.

Fakó Gr. L. genistifolia. Mitl.

\section{PINTYÖ. Antirrhimum. I.}

Levelei ellenesek, vagy váltogatók, láncsások, kopaszok; virágzata fürtös; csészéje metszetei tojásdadok, tompák, bokrétájánál sokkal kurtábbak. - Szántóföldeken, retések közt. Mérges. $\odot$. Jul-Aug. 3-12".

Gunyás P. A. Orontium. $L$.

\section{4. 'IÁKAJAK. Scrophularia. L.}

1. Virágai hónaljiak; kocsányja 1-2 vagy sokvirágn, \& ez esetben sátorozó; csészéje metszetei hosszukások, prémetlenek, meglehetös hegyesek, hegyeik hátragörbültek; kétszer esipkés és szíves levelei szárával együtt gyapjasok. - Erdőkben bozótokban, a pilisi és visegrádi hegyeken. (-). Maj.-Jul. 1-3'.

\section{Virágai szárhegyi fürtösek. 2.}

Tavaszi 'T'. S. vernalis. $L$.

2. Levelei tojásdad-hosszudadok, vagy tojásdad-szíresek, kopaszok, kétszer fürészesek, a levél válla felett esö fogai hosszabbak s hegyesebbek, mint a levél hegre felé esők; szára élesen négyszögü; csészéje metszetei tojásdadok s hártyával keskenyen szegélyezettek. - Nedves helyeken. ligetes és árnyas réteken. 4. Jun.-Aug. 2-4'. (Feliete cseresznye; felete hodza; tornligyélifii ; var;ju mogyoró.)

Bodza T. S. nodosa. L. Levelei szíves-hosszudadok, vagy tojásdad-szívesek, fürészesek, az alsó fürészfogai a felsőknél apróbbak; szíra és kocsányjai szélesen gatyásak; esészéje metszetei hártyával szélesen szegélyezettek. - Mocsárokban és füzesekben. 4. Jun.-Aug. 2-4'.

Vízi T. S. Ehhlartii. A. Stev. 


\section{Csikorka. Gratiola. I.}

Nyeletlen és láncsás levelei ellenesek, apró fürészfoguak; kocsányjai hónaljiak s egy viráguak. -- Nedves réteken és mocsárokban. Mérges. 4. Jun.-Sept. 1/2-1'. (Csikorgófü; innyujtófü.) Réti Cs. G. officinalis. 1.

\section{IsZAPRoJ'T. Limosella. I.}

Tögyökere fonalalaku, ostorindás; lapiczkás tölevelei hosszu 'nyelüek; tőkocsányja egy virágu ; apró virága fejéres-testszinü. - Kiöntésekben, s az áradás viszszahuzódása után a félig kiszáradt fenekekben. $\odot$. Jun.-Sept. 1-2". Seppendékes I. $L$. aquatica. $L$.

\section{¡. GYÜSZÜVIRÁG. Digitalis. L.}

1. Felálló szára enyvesen gyapjas; tölevelei nyélbe keskenyedők, tojásdad-hosszudadok; szárlevelei félig szálölelők, alól szörösödők; hónalji virágai magánosak: bokrétája kivül szörösödö, piszkos sárga, belsö része barnán tarkázott. - Hegyi és ligeti gyepeken. 4. Jun.-Aug. 1-3'. (D. ochoroleuca. Jacqu.)

Nagyvirágu Gy. I). grandiflora. Lam.

2. Felálló szára teteje felé gyapjas; nyeletlen levelei láncsások. kopaszok. vállban szemszörösek; fürtös virágzata szárhegyi, tömött, gyapjas; bokrétája külső része rozsdaszíni" erezetes, enyveskés gyapjas, belöl fényes. - Pomáz és Békás-Megyer környékén bokrokban s a szöllök gyepüi mellett. 24. Jun.-Jul. 1-3'. (D. lanatı. Ehrh.) Gyapjas (Hy. D. fuscescens. W. K.

\section{SZIGGRÁLL. Veronica. I.}

1. Virágzata fürtös. 2.

Virága magános hónalji; termése kocsányja lefelé goörbült. 18.

2. Fürtje hónalji. 3.

Fürtje szárhegyi. 11. 
3. Üthasábu esészéje hasábjai egyenlök. 4 . Öthasábu csészéje hasábjai közt a hátulsó kisebb. 9.

4. Levelei kopaszok. ๖.

Levelei szörösek. 7.

5. Lapított $\mathrm{s}$ keresztbe széles tokja teteje kicsípett; nyeletlen s hegyes levelei szálas láncsások s hegyök felé alig fogasok; fejéres virágaiban verhenyes vagy kék csíkok vannak. - Vizenyös helyeken, mocsárok mellett. 24. Jun.-Sept. ${ }^{1 / 2}-1^{\prime}$

Hajfiirtös Sz. V. scutellata. $L$.

Lapított kerekded tokja alig kicsípett. 6.

6. Nyeletlen levelei láncsások, vagy tojásdadok, hegyesek. alig fürészesek; virága sötétkékkel erezett világos kékszínü. -- Vizenyős helyeken. 4. Maj.-Aug. 1-2'. (Vizi pólé.)

Pólé Sz. V. Anagallis. L.

Kurta nyelü, körkörös vagy hosszukás levelei tompák, csipkésen fürészesesek; lapított tokja kissé duzadt; virága kék. - Források, patakok és mocsárokban. 4. Maj.-Aug. 1-2'. (Derécze; vizi pólé; vizi saláta; téli saláta.) Derécze Sz. V. Beccabunga. L.

7. Szára két sor szörü; tojásdar levelei csaknem nyeletlenek csipkések; visszás-tojásdad tokja háromszögü; élénk kétszinü virágai sötétkékkel erezettek. - Réteken és legelökön mindenütt. 24. Apr.-Jul. 1/2-1'. (Fattyi verónilia.) Cser Sz. V.Chamaëdrys. L.

Szára köröskörül szörös. 8 .

8. Hosszu nyelü levelei tojásdadok, csipkésen fürészesek; lapos és kopasz tokja igen széles, tövén hegyén ki van esípve, szemszőrös; fejéres kék virága sötéttel csíkozott. - Hegyi réteken és ligetekben, Pilis-Csaba, Sz.-Kereszt és Visegrád felé. 24. Maj.-Jun. 6-8".

Hegyi Sz. V.montana. $L$.

Kurta nyelü levelei visszás-tojásdad körkörösek, vagy hosszukások, fürészesek; szára érdeses szörü, tövön; gyökerezö; fürtje tömött, sok virágu; felfelé álló ter- 
mése kocsányja háromszögü, visssás-szíves, tompán kicsípett tokjánál kurtább. - Hegyi réteken, hegyolda-lokon böven. 24. Jun.-Aug.

Orvosi Sz. V. officinalis. $L$.

9. Terméketlen szárai henyélők, a virágzók felegyenesedök; kurta nyelï levelei szálas láncsások, csipkésen fürészesek; visszás-tojásdad tokja alig kicsípett; virága világoskék. - Száraz réteken. 4. Maj.-Jul. 3-12".

Lecsepült Sz. V.prostrata. $L$.

Mindenik szára felálló, vagy ívalakulag meghajolt tövé-röl felegyenesedö; visszás-tojásdad tokja hegyesen kicsípett. 10.

10. Alig nyeles és láncsás levelei csipkések vagy szárnyason hasogatott fogasok; virága szép kék. - Homoki mezökön, ritka. 24. Maj.-Jul. 1/2-1'.

Sallangos Sz. $V$. austriaca. $L$.

Viilfajai: a) levelei láncsások, vagy láncsás szálasok, ritka csipkés-fürészes foguak: dentata; $b$ ) levelei láncsások, vagy láncsás szálasok, szárnyason hasogatott. fürészesek : pinnatifida.

Nyeletlen levelei tojásdadok vagy hosszukások, vállban alig szívesek, mélyen fürészesek; virága kék. -Hegyi réteken, vágásokon, gyepükben. 4. Maj.-Jul. 1. 2 '.

Széleslevelü Sz. V.latifolia. L.

Vülfajai: a.) Szíves vállu levelei szárölelök: V. latifolia major. Schrad.; b.) tojásdad levelei leginkább hosszukások: V. latifolia minor. Schrad.; A. V. Teucrium. L. vagy ezzel, vagy a $V$. austriaca-val azonos.

11. Szárhegyi fürtje magános, vagy ez alatt még számos oldali fürtje van; bokrétája csöve hengeres. 12.

Fürtjei, vagy a szára vagy ágai hegyén állanak; bokrétája csöve igen kurta; szárlevelei lassankint átmennek murvába. 14. 
12. Murvái kocsánykájával vagy egyenlök, vagy kurtábbak, szálas láncsások; levelei egyszeresen vagy kétszer finrészeltek. -- Magasan fekvő réteken, vágásokon, Budán a Farkasvölgyön. 4. Jun.-Aug. 1-2'. (V. foliosa. W. $K$.)

Fattyu Sz. V.spuria. L.

Murvái kocsánykáinál hosszabbak; hosszu fürtjei igen tömöttek. 13.

13. Kihegyezett láncsás levelei egész a hegyökig élesen kétszer fürészesek; murvái szálas áralakuak. - A szigeti vizenyös réteken, a Zagyva és a Tisza mellett esö mocsárokban. 4. Jun.-Aug. 1'1/2-2'.

Hosszulevelü Sz. V. longifolia. I.

Tojásdad-láncsás, alsó levelei tompák, a felsők hegyesek, csipkésen fürészesek, a hegyök felé épélüek; fürtje igen tömött, csaknem füzér. - Minden száraz réten. 24. Maj.-Aug. 1/2-2'. (Kék macskafark.)

Macskafarku S\%. V. Spicctetu. L.

Egyébféle válfajai közt terem nálunk a szőrösödő alól csaknem kopasz levelü s keskeny metszetü bokrétajú: $V$. cristata. Berrl. avagy V. Orchidea. Cranz.

14. Paizsalaku magvai laposak. 15.

Medenezealaku magvai homoruak. 17.

15. Gyökere évelö; tojásdad vagy hosszukás levelei alig csipkések, az alsók apróbbak, kerekdedek, a felsők láncsások, épélüek; lapított tokja keresztbe szélesebb s tompán kicsípett; fejéres virága kékes csíku. - Erdőkben és nedves réteken. 4. Maj.-Sept. 3-15".

Kakuk Sz. $V$. serpyllifolia. $I$.

Gyökere egy nyári s vékony. $\mathbf{1 6 .}$

16. Levelei szíves-tojásdadok, esipkések, a felsők lánesízok s épélüek; tokja lapított, visszás-tojásdad, két karélyu s szemszörös; virága kék. - Réteken, legelökön. mivelt téreken. $\odot$. Mart.-Jun. 4-12".

Ugar Sz. V. arvensis. $L$.

Alsó levelei tojásdadok s épek, a felsők szárnyason hasogattak, a legfelsők láncsísok; tokja lapított visszís- 
szíves és szemszörös; igen apró virága kék. - Minden gyepen. $\odot$. Apr.-Maj. 1-4'.

Tavaszi Sz. I. verna. $I$.

17. Alsó levelei tojásdadok, a középsők 3-5 ujjúak, a legfelsők láncsások; szára és ágai sokvirágu, ritkís fürtüek. virága kék. - Minden gyepen, kivált a homokon. ๑. Mart.-Maj. 2-6".

Ujjas Sz. V. triplyyllos. $I$.

Alsó és közép levelei szíves-tojásdadok, csipkések tompák, a felsők láncsások; virága sötét kék. - Homoki gyepeken. $\odot$. Apr.-Maj. 2-5".

Kora Sz. V. praecox, $L$.

18. Levelei tojásdadok, csaknem szívesek, fürészesen csipkések; tokja zilált ikrás szörü ; virága téjszinü, felsö karélya kék vagy verhenyes. - Szántóföldeken és legelöken mindenütt. $\odot$. Mart.-Jun. 2-6".

Mezei Sz. V. agyrestis. $I$.

Levelei szíves-kerekdedek, csipkések, csaknem 5 karélyuak; tokja gömbded 4 karélyu; esészéje metszetei szívesek, elvirágzás után felállók. - Gyepeken és mivelt téreken. $\odot$. Mart.-Jul. 6-12".

Pallagi Sz. V. hederaefolia. $L$.

\section{9. ŚZÁlKaCsÉK. Euphrasia. L.}

1. Kurtább porodái tokjain egy hosszu szálka van, hoszszabb porodái tokjai kurtább szálkájuak; nyeletlen levelei tojásdadok, többnyire is foguak; bokrétáji. felsö ajaka két karélyu, karélyai széllyel-állók, 23 foguak, alsó ajaka 3 metszetü, metszetei mélyen kicsípittek, virága fejéres vagy kékellö, alsó ajaka sárga foltos, a felsö lila csíku. - Száraz és nedves gyepeken, ligetekben. $\odot$. Jun.-Sept. 3-12". (Efrüzsia: szemfü; szemcíditó fü.) Szemvídító Sz. E. officinalis. Vailfajai: a) Ikrás ritka szörü, pálhái szálkahegyűek, nagy virágu: pratensis; - b) ikrátlan lelapult göndörszörü, levele fogai hajszálhegyüek: nemorosa. 
Portokai egyenlö szálkájuak. ..

2. Bokrétája testszinü, néha fejér, erősen szörösödö; felsö ajaka lapított, csonka; portokai hegyeit gyapjai egybekötik; széles vállal kezdödö levelei elkeskenyednek, szálas láncsások, ritka fürészfoguak. - Homoki s hegyi réteken gyakori, a nedves helyeket szereti. $\odot$. Jul.-Sept. 6-12".

Fogánes Sz. E. Odontites. L.

Bokrétája sötét sárga, szakálas, szemszőrös; porodái bokrétájánál hosszabbak, portokai kopaszok, szabadok; felsö ajaka lapított, csonka; levelei szálas láncsások, hegyesek, épélüek vagy ritka fürészfoguak. - Az elöbbivel. $\odot$. Jul.- Sept. 6-12".

Sárga Sz. E. lutea. L.

\section{LAPÓR. Rhimanthus. L.}

1. Murvái egyenlö szinüek. a felsők bevagdaltan fürészesek, fogai hegyesek; egyenes csövü bokrétája, felsö ajakán tojásdad-kurta fogai vannak; virága színe sötét. sárga: levelei hosszudad-láncsások; szára kopasz és foltnélküli. - Nedves réteken. ๑. Naj.-Jun. ${ }^{1} 2-1$ '. (Kaliasczimer.) T'aréjos L. R. minor. Ehrh.

2. Murvái különféle szinűek, halványok, a felsők bevagdalt fürészesek, fogai áralakuak, hajszálhegyüek; bokrétája ajaka egyenesen elöre nyuló, csöve kissé görbe; csészéje kopasz vagy kissé szőrösödö; magva szárnyai szélesebbek mint magvának fele része; levelei hosszudad-láncsások; szára kopasz vagy szörösödő. - Nedves réteken. $\odot$. Jun.-Aug. ' ${ }^{1} 2-1^{1}{ }^{\prime} 2$ (Csengölióró; kiaka.staréj.)

Csörgö L. R. major. Ehrh.

\section{KaJMacsór. Pedicularis. L.}

Szára felálló, tövétöl kezdve ágas; levelei szárnyasok, bordái hosszukások, csaknem szárnyason hasogatottak, sallangjai csipkések; csészéje két ajaku, bokrétája felsö ajaka csalinem sarlóalakú, kurta csövü, rózsaszinü. 


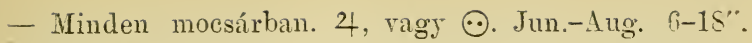
(Kaliastaréj.)

Posvány K. $P$. palustris. $L$.

\section{FINTOR. Melampyrum. L.}

1. Füzére négyszögü vagy kupalaku, tömött; levelei láncsások. .

Füzére féloldali, laza; csésze fogai láncsás áralakuak. 4. 2. Füzére élesen négyszögü, tömött fedelékes ; murvái széles szívesek, kihegyezettek, fésüalakulag fürészesek, hátrahajoltak : csészéje kétsoros szörü. — Homoki körér réteken vetések közt, vágásokon. $\odot$. Jun.-Sept. 6-16".

Taréjos F. M. cristatum. $L$.

Füzére kupalaku, tömött; murvái tojásdadok v. tojásdad láncsások. kihegyezettek, szárnyason fogasoltak, fogai ár- vagy sertealakuak. 3.

3. Csészéje szörösödö, fogai láncsás-sertealakuak; murvái a töve felé fekete pontozottak, laposak, felfelé szélylyelállók. - Réteken, szántóföldeken, vetések közt. $\odot$. Jun.-Aug. ${ }^{1} 2-1$ '. (Csormolya.)

Csormolya F. MT. artense. L.

Csészéje érdes szörü vagy gyapjason bolyhos, fogai láncsás áralakuak, nem pontozottak, tövön rálusok, hegyök kissé behajlik. - Szántóföldeken, vetések közt bőven. $\odot$. Jun.-Aug. ${ }^{1 / 2} 2-1$ '. (Csermelye; felete buza; róliafarlifü.) Csermely F.M.barbatum. $L$.

4. Murvái szíves láncsások, fogasok, virígzás idején kékek, azután meghagyják magukat; csészéje érdes szőrü, felényi, mint a virága; bokrétája ajakai sárgák, csöve rozsdaszinü; levelei szíres tojásdadok, egészen láncsásba menők. - Ligetekben, bozótokban vágásokon. $\odot$. Jun.-Aug. 6-18". (Gyertycinalljafü; kék ïstöküfü.)

Kék iistökü F. M. nemorosum. I.

Murvái láncsísok. 5.

5. Murvái tövén mindkét felöl egy vagy több áralaku foga van, néha épélï; csészéje bokrétájánál sokkal röridebl. 
egyenes. - Hegyi és ligeti réteken itt ott. $\odot$. Jun.Aug. 6-12". Gunyoló F. M.pratense. $L$.

Murvái mind épélüek, vagy csak a felsőknek van két felöl tövön egy-egy kis tompa foguk ; csészéje kopasz, akkora mint a bokrétája; fogai vizirányosan széllyelállók; apró virága sötét sárga, bokrétája csöve görbe. A magasabban fekvö ligetekben gyakori $\odot$. Jul.-Aug. $6-12^{\prime \prime}$.

Szájatátott F. M. sylvaticum. I.

\section{Rend. Szádorfélék. Orobancheae. Juss.}

\section{SZÁDOR. Orobanche. I.}

1. Két levelü tövén egy murva van; csészéje levélkéi több inúak, csaknem egyenlö két metszetüek; bokrétája harangalaku, tövön gugásan hasas, ajaka egyenetlenül fogasoltak, ikrás rojtosak; porodái a bokréta fenekére nőttek, nagyon szörösek. - Ligetekben. bokrokon, hegyi réteken. leginkább az Ernyös Patkóczim és a Szarvas Kerep gyökerén élödik. $\odot$. Jun.Aug. ${ }^{\prime} 2-1 \frac{1}{2} 2$ '. (O. caryophyllacea. Sm.)

Vérpiros Sz. O. cruenta. Bertol.

Egy tagu csészéje tövén 3 murva van. 2.

\#. Egy tagu csészéje 5 fogu, fogai láncsások, hegyesek; kékes bokrétája csöves, elöre görbült, közepén el van szükülve, ajaka metszetei hegyesek, laposak; portokai kopaszok, tövön kissé szörösödök; kékes tőkoesányja magános. -- Száraz dombokon. az Egérfark Cziczkórón élödik. $\odot$. Maj.-Jul. ${ }^{1 / 2-1}$ '.

Kék Sz. O. coerulea. Vill.

Egy tagu csészéje 4 fogu, tojásdad-háromszögủ fogai áralakuan kihegyezettek; portokai kopaszok; szára ágas. - A Kender, Dohány és a Fekete Csucsór tövén élődik.

Elágazó Sz. O. ramosa. L. 


\section{VICSOR. Lathraea. L.}

Gyökere húsos, pikkelyes; tőkocsányja felálló, szörösödö, pikkelyes, bokoló; szárhegyi füzére egy oldali ; bokrétája alsó ajaka 3 metszetü, csípkés. Fák és cserjék gyökerein élödik, az árnyas ligetekben. 24. Apr.-Maj. "- $-6 "$.

Konya V. L. squamaria. $L$.

58. Rend. Renczefélék. Utriculariceae. Endl.

\section{RENCZE. Utricularia. L.}

Levelei minden irányban széllyelállók, számyason sok sallanguak, szallangjai hajszálvékonyak s ritka apró tövisesek; sarkantyúja kupalaku, felsö ajaka akkora, mint az ínye; portokai egybenőttek; virága sárga; szárán apró hólyagok vannak. - Árkokban és mocsárokban. 4. Jun.-Aug. Hináros R. U. vulgaris. $L$.

\section{Rend. Kankalinfélék. Primulaceae. Vent.}

\section{MÜKÖCS. Androsace. L.}

1. Rózsásan nött tölevelei a földön gyepelnek; leveléi éleỉ tőkocsányjával együtt csillagszőrủek; csészéje bokrétájánál hosszabb; fejér bokrétája torka sárgás. - A Sz.-Endre felé vezetö útfeleken, ritka. $\odot$. Jul.-Sept. $2-5 "$.

Gór M. A. elongata. $L$.

2. Rózsásan nött tölevelei a földön gyepelnek, körkörösek vagy láncsások, fogasok ; tökocsányja és ernyője szőrös, zöorei czikkesek; csészéje bokrétájánál hosszabb, termése csészéje igen nagy; virága fejér vagy pirosas, torka sárgás. - Szántóföldeken, le.gelökön, szöllőkben. ๑. Apr.-Mraj. :3-5".

Nagy M. A. maxima. $L$. 


\section{Kankalin. Primula. L.}

Tölevelei tojásdadok; nyélrefutók, ránczosak, alól molyhosak; tőkocsányja és ernyője selymes; gallérai tojásdad tövi̋ek s áralaku hegyüek; tojásdad csészéje élesen ormós, 5 fogu; csöves bokrétája karimája harangalakulag homoru, virága sárga. - Ligetekben. 4. April.-Maj. 1'2-1'. (Kásavirà); sz. György viraiga; liükörics ; kestyüvivag; kankatin.)

Taraszi K. P. officinalis. Jacqu.

\section{TÜrtsziroy. Cyclamen. I.}

Vastag tögyökere gumóalaku; tőlevelei nyelesek, szíres kerekdedek, habosan fngasok; tőkocsányjai egy viráguak, virágzáskor felállók, a termése megérésekor henyélők és csavarosan tekeredettek; virágai igen szép rózsaszinüek. - A sz.-kereszti és sz.-endrei hegyi erdökben. 24, Aug.-Sept. 4-6". (Disznórépa; disznólienyér ; füldilienyér.)

Ligeti T. C. europaerm. $L$.

\section{LIZINKA. Lysimachia. L.}

1. Öt porodája szabad; vagy tövön alig nött össze s maghonát nem fedezi; szára henyélö, gyökerező; levelei ellenesek, szíveskerekdedek; kocsányjai hónaljiak, magánosak; csészéje metszetei szívesek. 一 Vizenyős, kivált erdös helyeken. 4. Jun.-Aug. (Innyíjtófü.)

Pénzlevelï L. L. nummularia. $I$.

Öt porodája mintegy közepéig összenött s maghonát fedezi 2.

2. Szára felálló; levelei ellenesek ragy gyürüsek; kurta nyelthek, hosszukás láncsások, alól kissé gyapjasok; virágzata bugás; bokrétája metszetei tojásdadok, hegyesek, élök kopasz; virága sárga. - Nedves helyeken, mocsárokban. 24. Jun.-Jul. З̊-4'. (F'zzémy.)

Fủzény L. L. vulgaris. $L$. 
Szára felálló, levelei ellenesek vagy gyürüsek, kurta nyelüek, hosszudad láncsások, vagy tojásdadok, szörösödök; hátukon fẻkete pettyesek ; kocsányjai hónaljiak, ellenesek, vagy gyürüsek; bokrétája metszetei hegyesek, ikrás szemszörüek; virága sárga, tövön rozsdaszinủ. - Nedves réteken, patakok \& malmok körül. 4. Jun-Aug. 1-3'. Pettegetett L. L. punctata. $L$.

\section{TIKSZEM. Anagallis. L.}

1. Szára henyélö; levelei nỵeletlenek, tojásdadok, bokrétája metszetei apró csipkéjủek, finom ikrás szemszörösek, a csészéjénél ralamivel hosszabbak; kocsányja a virágánál hosszabb. -- Mezökön. kertekben, vetések közt. ๑. Maj.-Aug. 3-12". (Tyukszem; tyutiberyy; tikszem; kukulterjéke.)

Piros T. A. arrensis. L.

2. Szára henyélö; levelei ellenesek, nyeletlenek, tojásdidok; bokrétája metszetei apró csipkéjüek, csaknem szemszőrnélküliek, csészéjénél valamivel hosszabbak; kocsányja akkora, mint a virága; virága kék. -- Az elébbivel. $\odot$. Maj.-Aug.

Kék T. A. coemtert.

\section{TÓNYA. Hottonia. L.}

Levelei fésűalakuan szárnỵason hasogatottak; virágzata szárhegyi gyürüsen álló fürt; virága. fejér ragy pirosas. Álló és csendesen folyó tiszta rizekben. 4. Maj-Jun. ${ }^{1 / 2}-1^{\prime}$.

Czicz T. H. palustris.

\section{\%. SzÁmolya. Samolus. L.}

Szára felálló; levelei visszás-tojásdadok, vagy hosszukások. butulók; fïrtje regre megnyúlik: murvája kocsánykája közepén van; tokja csaknem gömbalaku. - Tarakban gyakori. 4. Maj-Aug. 1'2-1'.

Szíki Sz. S. Talerandi. L. 
60. Rend. Gazillatfélék. Monotropeae. Nuttcl.

\section{GaZILlat. Momotropa. L.}

Leveletlen tőkocsányját sárgás pikkelyek fedik, ennek a hegyén van sokvirágu fürtje; jószagu bokrétája metszetei tompák és szemszörösek. - A tölgyeken élödik. 4. Jun.-Jul. 3-18". Élöli G. M. Hypopitys. L.

IV. Csoport. Váltszirmúcak. Dialypetalne.

61. Rend. Ernyősök. Umbelliferae. Juss.

\section{GOMBERnYÖ. Sanicula. L.}

Tỏlevelei tenyeresen hasábosak, hasábjai 3 metszetüek, egyenetlenül bevagdalt fürészesek; tökélyes virágai kocsánytalanok, porodás virágai kurta kocsányuak: ernyöje 3-5 sugáru, ernyöcskéi gömbösek; virága fejér vagy verhenyes. - Ligetekben, árnyas bokrokban Buda körül. 4. Maj.-Jun. (Szaniczor; szanikula.) Hegyi G. S. enropaea. L.

\section{ZAPÓCZA. Astrantia. L.}

Tölevelei tenyeresen 5 hasábuak. hasábj̣ai hosszukás visszás tojásdadok, hegyesek, csaknem 3 metszetủek, egyenetlenül hegyes fürészfoguak; fejéres vagy verhenyes galléra épélü, vagy a hegyénél mind kétfelöl 1-2 fogu; csészéje fogai tojásdad-láncsások s fulánk hegyüek. - Sz.-Endre és Visegrád körül a hegyi patakok mellett és a ligetekben. 4. Jun.-Jul. 1-2'. (Һıро́cza.) Berki Z. A. major. L.

\section{IRINGó. Eryngium. L.}

1. Levelei hármason kétszer szárnyaltak, hálózatos erủek, tüskés foguak, tőlevelei nyelesek, szárlevelei fülesen szírülelök, fülei szabdalt fogasok; szára bugás; gal- 
lérkái kerekuled ernyőinél hosszabbak; a csészéje. hosszabb a bokrétáinál. - Legelőkön. réteken, útfeleken. 4. Jun.-Aug. 1-2'. (Ördögszeliér ; bordaoldat-, raliolya-, lievingö-, aitlozott szamár-töris, macsli-, szcizfejü-, merei-tölis.)

Mezei I. E. campestic. $I$.

2. Tölevelei épek. nyelesek. tojásdad-szívesek, csipkésen fürészesek, középsö levelei nyeletlenek, épek, a felsők 5 hasábuak, tövisesen fürészesek; galléra szálas láncsás, ritka tövisfogu, akkora, mint tojásdad ernyökéje, szára tetején sátorozó. - Nedves réteken, a Duna partjain, füzesekben. 24. Jul.-Aug. 1-3'. (Temoneládfü.)

Kék I. E. plamum. I.

\section{Csomorika. Cicuta. I.}

'Tỏgyökere vastag, húsos, belsö része üreges, melyet kereszthártyák rekgretnek el; gyökérrostjai fonalalaliuak; levelei 2-3-szor szárnyasok; levélkéi 2-3 hasábuak, sallangjai szálas láncsások, hegyesen fürészesek, virága fejér. Igen mérges. - Mocsárokban Pest körül. ritka. 24. Jun.-Aug. (Méreg bürök; csomorilia.)

Gyilkos Cs. C. virosa. L.

\section{j. ZelLler. Apium. L.}

Levelei szírnyasok, a felsők hármasok, levélkéi ékalakuak, hegyén bevagdaltak vagy fogasok; virága fejér, magvai kerekdedek. - Mivelt téreken, kertek környékén, termesztik. ๑. Jul.-Aug. 1-3'. (Zeller.)

Nagyszagu Z. A. graveolens. $L$.

\section{Petrezselyem. Petroselinum. Hoffim.}

Szára felálló, szegletes; levelei felül fényesek, alól homályosak, az alsók háromszor szárnyaltak, a felsők hármasok, levélkéi láncsások, épek vagy 3 metszetïek ; virága fejér; magvai tojásdadok. - Kertek mellett. mivelt téreken, nagyban termesztik. $\odot$. Jul.-Aug. 1-3'. (Petrezselyem.)

Közönséges P.P. sativum. Hoffm. 


\section{¡. SARlófü. Falcaria. Host.}

Tölevelei egyszerüek vagy hármasok; szárlevelei hármasok, ezek közt a középső levél 3 metszetü, a két szélső a külső részén 2-3 metszetü, metszetei szálas láncsások, egyenlöen sürú fürészfoguak, fogai tüskésfulánk hegyüek; galléra 6-8 levelü. - Útfeleken gyepük mellett, köves és gyepes helyeken. $\odot$. Jun.Jul. 1-1'2:. (Sirm Falcaria. L.) (S'arlófui.)

Közönséges S. F. Rivini. Host.

\section{KÖMÉNY. Carum. L.}

Levelei kétszer szárnyasok. levélkéi szárnyason hasogatott sok sallanguak, az alsó pár a köznyelen keresztben áll; mind két galléra hiányzik; szára szegletes; gyökere orsóalakú; magva tojásdad, lapított. - Mindenütt, kivált a nedves helyeken. $\odot$. Jun.-Jul. 1-2'. (Kömény.)

Konyha K. C.Carvi. $L$.

\section{BAKTOPP. Aegopodium. L.}

Alsó és közép levelei kétszer hármasok, levélkéi tojásdad hosszukkások, egyenetlen fogasok; a felsők egyszer hármasok; lapos ernyője nagy; galléra és gallérkája nincs; magvai tojásdad-hosszudadok. - Gyepük és nitak inellett, ligetekben, kertekben. 4. Maj.-Jul. 1-3'. (Sison Podagravia. Spr.) (Ludlábfü.)

Bigeesi B. A. Podagraria. I.

\section{Pmpinella. Pimpinella. I.}

1. Virágai tökélyesek. 2 .

Virágai kétlakiak. 3.

2. Szára szegletes, barázdolt. leveles; levelei szárnyasok, levélkéi kurtanyelüek; bibeszára maghonánál hoszszabb; bokrétája fejér ragy verhenyes; magva hosz- 
szukás tojásdad, kopasz. - Magasan fekvö ligetekben, bozótokban, erdőszéleken. 4. Jun.-Jul. 1-4'.

Nagy P. P. magna. L.

Szára hengeres, kopasz, alig vonalozott, tövén kissé szörös, felsö része csaknem levéltelen; levelei szárnyasok, levélkéi tojásdadok; bibeszára virágzás idején maghonánál kurtább: magva tojásdad, kopasz. Száraz réteken. 4. Elsö izben virágzik Maj.-Jun., második izben. Aug.-Sept. 1-2'. (Földi tem.jén; rálifarlifü; bipenella.)

Tämjénes P. P. Saxifiraga. L.

3. Szára felálló, bugás; levelei kétszer-háromszor szárnyaltak, szárnyai 2-3̄-5 szárnyason szabdaltak, sallangjai keskeny szálasok; galléra nincs, gallérkája vagy nincs, vagy csak egylevelü; magva szörösödö érdes. - Hegyi és homoki száraz réteken. 4. Maj.-Jun. 3-18".

Akó P. P. pumila. Jacqu.

Szára felálló, bugás; levelei két-háromszor szárnyason szabdaltak, szárnyacskái 2-3-j szárnyas metszetủek, sallangjai hajszál vékony szálasok; galléra alig egylevelü, gallérkája 5 levelü; levelei serte-áralakuak, egyenetlenek, ernyőjénél rövidebbek; magva síma. Szöllők mellett. száraz gyepeken. - -). Jun.-Jul. 1-3’.

Buglyos P. P. Kitaibelii.

\section{KORSÓKA. Berula. Koch.}

Szára hengerded, rovátkos, igen ágas; töve ostorindás; levelei szárnyasok, levélkéi tojásdad hosszudadok, fürészesek; mind két galléra sok levelü, szárnyason hasogatott, ernyője kurta kocsányu; virága fejér. - Áradásos helyeken, mocsárok és patakokban. 24. Jul.-Aug. 1-2'. (Sium angustifolium. L.)

Szároldali K. B. angustifolia. Koch.

\section{BOLONYIK. Sium. I.}

Gyökere rostos; töve ostorindás; levelei szárnyasok. levélkéi láncsások, vállban egyenetlen, aztán egyenlöen 
éles fürészesek, viz alá merült levelei kétszer szárnyason vagy sokszorosan hasogattak; galléra sok levelü; magtartó kocsánykája magvához van nőve. - Tavakban s csendesen folyó vizekben. 4. Jun.-Jul. 2-4'. (Bélia liorsócslia; bolonyili.) Mérges B. S.latifolium. L.

\section{SZINGalLÉR. Bupleurum. L.}

1. Öt rovátku termése sinórjai közt szemesés puha fulánkjai vannak, sinórjai szemesésen fodrosak; szálas lánesás levelei nem nőttek által ; szárhegyi ernyői három kocsányuak; szálas lánesás levelü gallérkái virágzás idején hosszabbak, mint :3-5 virágu ernyöeskéi. - Szíkes téreken más szíki növényekkel együtt. •. Jul.-Sept. 4-18".

Gindár Sz. B. temissimum. $I$.

Termése rovátkai karczoltak, nem fulánkos :zemcsések. ‥

2. Levelei átnöttek, tojásdadok; galléri nincs, gallérkái tojásdadok, kihegyezettek, sinórjai fonalakuak, rovátkai karczoltak. - Vetések közt, szúraz réteken, köves helyekelı. $\odot$. Jun.-Aug. ${ }^{1 / 2}-1{ }^{1 / 2}$. (B. perfoliatum.) (Buvcili ; citbucófï.) Burák S\%. B. rotundifolium. L.

Levelei nem nöttek át. :3.

3. Gyökere egy nyári. 4.

Gyökere évelö. Б.)

4. Levelei j-7 inúak, inai közei eresek, az alsók körkörösek ragy hosszudadok. nyélbe keskenyedők, a felsök láncsások, mind két végökön kihegyezettek, nyeletlenek; gallérkái láncsások, hajszálhegyüek; kocsányjai akkorák, mint a termése. - Útfeleken, hegyi és homoki réteken. 4. Jun.-Aug. 1-2'.

Gaesos S\%. B. falcatum. I.

Levelei tojásdadok, vagy tojásdad hosszukások, az alsók nyélbe keskenyedök, a felsök nyeletlenek, mélyen sxíves rállal szárölelök; gallérkái körkörösek, kurta hegyüek, akkorák, mint ernyőeskéi. - A budai erdőkben 
¿ Jánoshegyen ritka. több van a pilisi hegyen. 4. Jun.-Jul. 1-3'.

Szárölelö Sz. B. longifolium. $L$.

5. Szára bugás, ágai széllyelállók, hegyei ernyösek; levelei keskeny szálas-láncsások, kihegyezettek $3-5$ inúak; gallérkái láncsás áralakuak, hegyesek, ernyőcskéinél hosszabbak; kocsánykái akkorák, mint szálas hosszudad termései. - Buda körül hegyi gyepeken, található homoki gyepeken is. $\odot$. Jul.-Aug.

Gazos Sz. B. Gerardi. Jacqu.

Szára bugás; levelei keskeny szálas láncsások. kihegyezettek. 7 inúak, szárölelök; ernyöje 2-3 kocsányu; gallérkái láncsás szálasok, hegyesek, terméses ernyökéinél kurtábbak; kocsánykája felényi, mint a termése. - A budai ligetekben ritka, gyakoribb a pilisi hegyell. $\odot$. Jul.-Ang. 1-2'.

T'ejelö Sz. B.juncerm. I.

\section{Haramag. Oenanthe. L.}

1. Orsóalaku tögyökere rostos, rostjai fonalakuak: szára igen ágas, ágai terepélyek, levelei kétszer-háromszor szárnyaltak. sallangjai bevagdaltak, a víz alá merültek, sok metszetủek, metszetei hajszálalakuak; bibeszára tojásdad termésénél kurtább. - Árkokban, tavakban, folyókban. 24. Jun.-Jul. 2-4'. (Vizi liapor; bösörémy.)

Vizi H. O. Phellandrium. Lam.

Csomós gyökerén, több kevesebb gumó van. ‥

2. Gyökere rostjai murokalakuak, hosszukások, vagy fonalakuak ; töve ostorindás; szárnyas szárlevelei bördös nyeleinél kurtábbak; tölevelei kétszer-háromszor szárnyasok; ernyője 2-3 sugáru. - Posványokban, árkokban, mocsárokban. Mérges 4. Jun.-Jul. 1-1 1/2'.

Ostorindás H. O. fistulosa. $I$.

Gyökere rostjai fonalakuak, végei gömb vagy tojásalaku gumóvá vastagodnak; levelei kétszer szárnyasok, szárnyacskái bevagdaltak, metszetei hegyesek; tölevelei tojásdadon bevagdalt tompa esipkéjüek, szára felsö 
levelei szálasok, épek; termése hengerded, töve gyürü puffadásu. - Posványok és mocsárokban a megye sík részén. 24. Jun.-Jul. 1-3'. (Vizi pertrezselye m; vizi mogyoró.)

Mogyorós H. O. pimpinelloides. $L$.

\section{5. ÁNIZs. Foeniculum. Hoff́.}

Szára tövön hengeres; levele metszetei szálas áralakuak, hosszacskák; ernyöje 13-20 kocsányu; galléra nincs. - Mivelt téreken, kertek körül $\odot$. Jun.-Jul. (Meum foeniculum. Spr.)

Édes A. F. officinale. All.

\section{ADÁz. Aethusa. L.}

Levelei mindkét lapjaín fényesek, 2-3-szor szárnyasok; levelkéi is szárnyason hasogattak; galléra nincs; gallérkája 3 levelü, hátra türemlett, ernyöcskéjénél hosszabb; igen mérges. - Kertek ben, mivelt és telekes réteken, a ligetekben. $\odot$. Jun.-Aug. 1-3'. (Adcizú bürrö̈l.) Mérg es A. A. Cynapium. $I$.

\section{1\%. GURGULYA. Seseli. L.}

1. Gallérkájia levélkéi egészen összenöttek, vagy csak tövön nöttek össze. $\mathbf{2}$.

Gallérkája levelei nem nöttek össze. 3.

2. Gallérkája egytagu csésze alaku, fogas ; ernyöje 9-12 kocsányu, kocsányjai ormósak, belsö oldalaikon fatal terméseivel együtt szörösödök; levelei háromszor szárnyasok, szárnyacskái szálasok. - Hegyi és homoki nyílt réteken. 24. Jul.-Aug. 1-2'.

Szilkés G. S. Hippomarathrum. L.

Gallérkái levélkéi tövön összenöttek ; galléra egylevelü; domboru ernyője tömött, molyhos, ernyöeskéi kurta kocsínyuak, tömöttek, virágzás elött lekonyulnak; termései kezdetben molyhosak, azután megkopaszodnak; szára girbe gurba; levelei 3-4-szer szárnyason szabdaltak, levélkéi serteszáluak, levelei nyelei hár- 
tyásan lapítottak, szárhüvelyezők. - A budai hegyi réteken. 4. Aug.-Sept. 1-2'.

Molyhos G. S. leucospermum. W. K.

3. Ernyője 10-15 kocsányu, kocsányjai csaknem hengeresek, kopaszok, kocsánykái hengeresek vagy oldalról lapítottak; galléra nincs, gallérkája áralaku, keskeny hártya prémü, felényi, mint kocsánykái, tőlevelei hármasok, háromszor szárnyaltak, levélkéi láncsás szálasok; magva kopasz vagy alig szörösödö. - Hegyi és homoki száraz réteken. $\odot$. Jul.-Aug. 2-4'.

Fakó G. S. glaucum. Jacqu. Ernyöje 20-30 kocsányu, kocsányjai szegletesek, csaknem egyenlők, belsö oldalukon szőrősödők; galléra nincs, gallérkája láncsás, széles hártyaprémü, ernyöcskéjénél hosszabb; fiatal magva szőrösödö ; tö- és alsó szárlevelei háromszoros szárnyasok, levélkéi szálasok, nyele felső része válus. - Hegyi gyepeken. $\odot$, Jul.-Aug. 1-2'. (S. anmu

\section{BIBEPÁR. Libanotis. Crantz.}

Levelei kétszer-háromszor szárnyasok, levélkéi szárnyason hasgattak, hasábja láncsások, fulánkos hegyüek, levélkéi legalsó párja közép gerinczökön keresztbe állnak; galléra sok levelü; szára ormósan barázdolt; ernyöje félgömb alaku; magva kurtaszörü, hamuszinü. Hegyi nyílt réteken, ligetekben, száraz homoki réteken. $\odot$. Jun.-Jul. (Athamanta Libanotis. L.)

Hegyi B. L. montana. All.

\section{SZILA. Silaus. Bess.}

Szára szegletes; tölevelei 3-1-szeresen szárnyaltak oldalmetszetei épek vagy két hasábuak, a végsők 3 hasábuak, legfelsö levelei egyszeres szárnyasok; galléra nincs, vagy 1-2 levelü; gallérkája soklevelü; termése tojásdad hosszu. - Gyepeken mindenïtt. 4. Jul.-Aug. 2-3'. (Cnidium Silaus. Spr.) Réti Sz. S.pratensis. Bess. 


\section{DEREZLE. Selinum. L.}

Szára barázdolt, éles ormóju; alsó levelei háromszor szárnyasok, levelkéi mélyen szárnyason hasogattak vagy bemetszettek; ernyöje tömött, kissé domboru; galléra nincs; gallérkája soklevelü. - Nedves réteken gyakori. 4. Jul.-Aug. 1-3'. (Angelica Carvifolia. $S_{\perp}$ r.) Köménylevelü D. S.Carvifolia. $L$.

\section{ANGYÉliKA. Angelica. L.}

Levelei háromszor szárnyaltak, levélkéi tojásdadok vagy láncsások, élesen fürészesek, nyélre nem futók, a végső ép vagy hárommetszetü; levele hüvelyei igen nagyok, hasason felfuvódottak. - Nedves réteken, patakok mellett. 24. Jun.-Jul. 3-4'. (Angyalfü,; angyélilia.)

Erdei A. A. sylvestris. L.

\section{Husáng. Ferula. L.}

Szára felálló, hengeres, ágas; levelei háromszor szárnyason szabdaltak, fényesek, szálas sallangjai hegyesek, fürészesen szemszörösek; ernyöi szárhegyiek, leginkább hármasok, a középső kocsánytalan, sokviráguak, laposak; virága sárga; magvai nagyok, tojásdadok, barnák. - Bokrokban, köves helyeken, ritka, a pilisi hegy teteje déli oldalán. - - 4. Jun.-Jul. 3-4'.

Gallértalan H. F. sibirica. $L$.

\section{9:3. KOCSORD. Peucedanum. I.}

1. Galléra nincs, vagy 3 levelü s ez is lehulló. 2. Galléra soklevelü, állandó. 3.

2. Levelei ötször hármasok, levélkéi szálas keskenyek, épélüek, a végsök hármasok ; 3 levelü galléra lehulló; kocsánykája termésénél két- vagy háromszor hoszszabb, kocsányjai kopaszok. - Vizenyős szíkes helyeken, mocsárok s árkok mellett, a Tisza mellett fekvö 
szántóföldeken. 24. Jul.-Sept. 2-4’. (Kénliöves gyöliér; disznó-, ragy erdei vad hömény.)

Kénköves K. P.officinale. $L$.

Levelei mindkét oldalaikon fényesek, szárnyasok, levélkéi nyeletlenek, sokhasábuak, hasábjai szálasok, hegyesek; ernyői kocsányjai belsö oldalaikon kurtaszörủek; ernyőcskéi egy levélből állnak: magva rovátkai 3 olajesíkuak. - A budai erdők szélein, a szép juhászné körül, ritka. 4. Jun.-Jul. 2-3'. (Imperatoria Chabraei. Spreng.)

Rojtos K. P. Chabraei. Reht.

3. Szára szegletes, barázdolt, ágai vesszösek; levelei háromszor szárnyasok, levélkéi tojásdadok, szárnyason hasgattak, metszetei szálas láncsásók, élök érdes ; galléra 5-S levelü, széllyeálló; termésén levö bibeszúral lehajló, termése vánkosánál valamivel hosszabb ; magva lapított fejér prémü. - Gyepeken, kivált a szigetekben. 24. Jul.-Aug. 1-4'. (Cnidium alsaticum. $S_{1}$ sr.)

Buglyos K. P. alsaticum. $L$.

Szára hengeres, vonalozott, galléra letüremlett. 4.

4. Levelei nyele elágazásai minden ízen hátragyököntek s széllyeltartók, levélkéi fénylök, tojásdadon bevagdaltak, vagy csaknem szárnyason hasogatott fogasok; magvai érintkezési lapjain eső olajesíkjai ívalakuak. - Hegyi és homoki száraz gyepeken. 4. Jun.-Aug. 2-3'. (Magva narancshéj ízü, theája czitromhéjszagu.) Czitrom K. P. Oreoselinum. Mönch.

Levelei nyele elágazásai nem gyököntek hátra. う̆.

5. Szára két-két águ; levelei háromszor szárnyaltak. levélkéi tengerzöld szinüek, tojásdadok, csaknem tüskés fürészfoguak ; magvai érintkezési lapjain levő olajcsíkjai párhuzamosak. - Hegyi és homoki száraz réteken. 24. Jun.-Aug. 2-3'. (Hegyi petrezselyem.)

Szarvas K. P. Cervaria. Cuss.

Szára szőke, felül ágas; levelei kopaszok, háromszor szárnyason szabdaltak, levélkéi szálasok, tompák, vas- 
tagok, barnahegyüek, ernyője ร̌7 águ; gallérja alig van; termése hegyén csorba. - Homoki oldalokon a megye sík részén, p. o. Pest, Vácz felé eső homokjain. 24. Aug.-Oct. 3-6'. (Elszaliasztott szárából sairga téj foly.) Sárgatejü K. $P$. arenarium. W. K.

\section{TEJÉR. Thysselinum. Hoffi.}

Szára barázdolt; levelei háromszor szárnyaltak, levélkéi mélyen szárnyason hasgattak, metszetei szálas lánesások, kihegyezettek; galléra és gallérkái soklevelüek, hártyásán prémezettek. - Nedves réteken

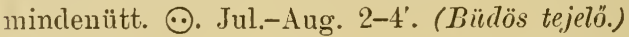

Posvány T. T. palustie. Hoff:

\section{KAPOR. Ancthum. L.}

Levelei tengerszinzöldek, kétszer-háromszor szárnyaltak, metszetei fonalalakuak; galléra nincs; körkörös magva lapos szegélyü. - Kertek körül s kertekben. ๑. Jul.-Aug. 2-3'. (Pastinaca Anethum. Sp.) (Ka)or.)

Kerti K. A. graveolens. $L$.

\section{PasZtinák. Pastinaca. L.}

Levelei szárnyasok, felső lapjaik fénylök, az alsók szörösek, levélkéi tojásdad-hosszukások, vagy hosszudadok, tompák, esipkés-füiészesek; galléra nincs; termése tojásdad, rovátkai két olajesíkuak. - Gyepeken, különösen nedves helyeken. $\odot$. Jun.-Aug. 2-3'. (Peszternák; olasz répa.)

Kerti P. P. sativa. $L$.

\section{2\%. TAPSIR. Heracleum. T.}

Levelei durva szörüek, szárnyasok vagy mélyen szárnyason hasogattak, levélkéi karélyosak, vagy tenyeresek; ernyöje sugárzó; maghona tömött szörü. - Ligetekben, bokrokban, kövérebb réteken. (-) Jul.-Aug. 2-5'. (Mecleetalp.)

Medve T. $H$. Sphondilium. $I$. 


\section{MagtaraJ. Tordylim. L.}

Szára visszás durvaszörös; levelei szárnyasok; levélkéi tompa csipkéjüek; magvai közepén sertés-keményszörüek, négy olajesíkuak. - Útfeleken, szőllök mellett, bokrokban Buda környékén. Jun.-Jul. 1-2'.

Durva M. T. maximum. $L$.

\section{SUJTÁR. Siler. Scop.}

Levelei fényesek, alsó lapjaikon tengerszín zöldek, csípkés fogasok; galléra nincs, magvai sinórosok. - Hegyi erdőkben, bokrokban böven. 4. Maj.-Jul. 1-3'. (Siler aquilegifolium. Gärtn.) Sinóros S. C.trilobum Scop.

\section{Bordamag. Laserpitium. L.}

1. Levelei hármason kétszer szárnyaltak, levélkéi tojásdadadok, fürészesek, vállban szívalakuak, épek; ernyoöje kocsányjai belső oldalaikon érdesek. - Erdők szélein, ligetekben, bokrokban. 24. Jun.-Aug. 3-5'. (Ermyöscink legszebbike.)

Széleslevelü B. L. latifolium. $L$.

2. Levelei nyele és éle borzas, levelei kétszer szárnyaltak, levélkéi szárnyason hasogattak, metszetei láncsások, szára szegletesen barázdolt, alsó része durva risszás szörös. - A budai ligetekben és vágásokon böven. 4. Jun.-Jul. 2-3'.

Bor\%as B. L. pruthenicum. $L$.

\section{Murok. Daucus. L.}

Levelei két-háromszor szárnyaltak, fénytelenek, levélkéi szárnyason hasgattak, hasábjai láncsások, hajszálhegyủek; galléra és gallérkái szárnyason hasogattak. Réteken mindenütt. $\odot$. Jun.-Aug. 1-3'. (Murolirépa.)

Sárga M. D. Carota. L.

\section{SZIROMŐR. Orlaya. Hoff:}

Szélső virágai sugárosak, nagyok ; termése tüskés, teteje 
felé levő tüskéi horgasok. - Köves helyeken. útfeleken. ๑. Máj.-Jul. 1-2'. (Fejër buzavirág.)

Nagyvirágu Sz. O.grandiflora. Hoff'.

\section{BORZON. Caucalis. Hoff.}

Magvai méllék sinórjain egy soru kopasz tüskéi vannak, tüskés áralakuak, horgas hegyüek, akkorák, mint magva átméröje; ernyöje 2-3 kocsányu, szára vonalozott két-két ágas; levelei kétszer szárnyason szabdaltak, sallangjai szálasok, hegyeskék. - Szántó-

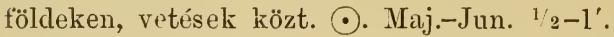

Vigály B. C. daucoides. $L$.

\section{DEGENCS. Turgenia. Hoff́.}

Szára felsö része kurta, serteszőrü, ágas; levelei szárnyasok, levélkéi láncsások, bevagdaltan fürészesek; ernyöje 2-3 kocsányu; galléra 2-5 levelü, gallérkái 5-7 levelủek. - Vetések közt, útfeleken. ○. Jun.Jul. 1-1 1/2'. (Vircigai és magoa horgas sertéi pirosak.) Szárnyas D. T.latifolia. Hoff.

\section{5. 'IÜskemag. Torilis. Hoff.}

1. Galléra soklevelü, ernyöje hosszu kocsányu; magva tiiskéi befelé görbültek, egyszerü hegyüek, nem horgasok; levelei kétszer szárnyason szabdaltak, metszetei hosszudadok, bevagdalt fürészesek. - Gyepük és útak mellett, bozótokban, erdőkben. $\odot$. Maj.-Jul. $1-3^{\prime}$.

Mezei T. T. Anthriscus. Gmel.

Galléra egy levelü vagy ninesen; magvai tüskéi horgasok. 2.

2. Ernyöje kocsányjai hosszulk; bokrétája szirmai akkorák, mint maghonai; bibéje majdnem kétannyi, mint a maghona vánkosa; levelei kétszer szárnyaltak, a felsők szárnyasok és hármasok. Vetések közt, bokrokban, erdökben. $\odot$. Jun.-Aug. 1-3'. T. infesta. Hoff.)

Teleki T. T.helvetica. Gmel. 
Egyszerü ernyöje c:somós, kocsánytalan az ág oldalain; csak külsö magvai horgas-tüskések, a belsők szemcsésen érdesek; szára leesepült; levelei kétszer szárnyasok, levélkéi szárnyason bevagdaltak. - A Sashegy köves helyein a szöllök mellett. $\odot$. Jul.-Aug. ${ }^{1 / 2-1}$ '.

Cseplesz T. T. nodosa. Gärtn.

\section{ORMÁNKA. Anthriscus. Hoff́.}

1. Tojåsdad termése tüskés, tüskéi áralakuak, befelé görbültek; bibeszára igen kurta, bibéje csaknem száratlan; szára kopasz; levelei háromszor szárnyaltak, kopaszok, alsó lapjaikon inai szétszórt szörösek. - Kertekben, ligetekben. bozótokban mindenütt. $\odot$. Jun.-Jul. 1-3'.

Televény 0. A. vulgaris. Pers.

Hosszudad vagy szálas termése kopasz, vagy ritka szemcsés ; bibeszára hosszu. 2.

2. Hosszudad termése ritkás szemesés, szemeséi szálkátlanok; gallérkái 5 levelüek, hosszu szemszörösek; szára alól durvaszörü, felül kopasz; levelei kopaszok, vagy alsó lapjok föbb inain serteszörüek, kétszerszárnyaltak, szárnyacskái szárnyason hasogatottak. - Kertekben, gyümölcsösökben, bozótokban. ๑. Jun.-Jul. 1-3'. (Chccerophyllum sylvestre. L.) $\quad$ Erdei 0. A. sylvestris. Hoff. Szálas termése kétannyi, mint a csőre ; levelei háromszor szárnyasok, kopaszok, alsó lapjaik inain ritka szőrösek, levélkéi szárnyason hasogatottak. - Kertekben, mivelt helyeken. $\odot$. Maj.-Jul. 1-2', (Chaerophyllum sativum. Bauh.) (Turbolya; olasz salíta.)

Turbolya 0. A. Cerefolium. Hoff:

\section{3\%. BARABOLY. Chaerophyllum. L.}

1. Gallérkája kopasz; levélkéi láncsások, hajszálhegyüek; bibeszára lehajolt, akkora, mint maghona vánkosa; gyökere gumós; szára bütykei alatt puffadt, tövön durva szörös, felül kopasz; levelei többszörösen füzöt- 
tek, levélkéi mélyen szárnyason hasgattak, hasábjai szálas láncsások; felső levelei szálasok, igen keskenyek. - Útfeleken, árokpartokon, a homokon. $\odot$. Jun.-Jul. 2-6'. (Myrrthis bulbosa Sp.) (Bubujicslia; baraboly; mogyorósalcita ; csemegebüirök.)

Bubijieska B. C. bulbosum. $L$.

Gallérkája szemszőrös. 2.

2. Bibeszára hátrahiajolt, akkora, mint a maghona vánkosa; szára bütykei alatt felfuvódott, alól keményszörü, felül kopasz; levelei kétszer szárnyaltak, levélkéi tojásdad hosszuk, karélyosan szárnyason bevagdaltak, karélyai tompák. - Mivelt és telekes téreken mindenütt, ligetekben bozótokban. $\odot$. Jun.-Jul. 2-3'. (Myrrhis temula. Gärtn.)

Bóditó B. C. temulum. $L$.

Bibeszára jóval hosszabb, mint a maghona vánkosa; szára bütykei alatt puffadtak; levelei háromszor hármasok, hosszudad tojásdadok, fürészesek, az egész növény borzas. - Erdei patakok mellett, nedves bozótokban, magasabb helyeken. 4. Jun.-Jul. 2-3'. (Myrrhis aromatica. Spr.)

Fïszeres B. C. aromaticum. $L$.

\section{BÜRÖK. Conium. L.}

Szára kopasz, tövén veres pettyes; levelei háromszor szárnyaltak, levélkéi szárnyason hasgattak, láncsások; láncsás gallérkái ernyőcskéinél kurtábbak. - Mivelt helyeken, házak körül árkokban. Mérges. $\odot$. Jun.-Aug. 3-6'. (Bürök; bötöli; sipfü.) Büidös B. C. maculatum. L.

\section{Rend. Aráliafélék. Araliaceae. Juss.}

\section{Borostyán. Hedera. L.}

Szára gyökérrostjainál fogva fákra s falakra kapaszkodik; bőrnemü levelei kopaszok, fényesek, szegletesen 5 karélyuak, virágzó szárain épek, tojásdadok, kihe. gyezettek; egyszerü ernyöje szőrösödő; virágai zölde- 
sek; lisztes bogyói feketék. -- Ligetekłen fákra és sziklákra kapaszkodik. †. Aug.-Sept.

Repkény B. H. Helix. L.

\section{Rend. Somfélék. Corneae. D. C.}

\section{SONFA. Cornus. L.}

1. Levelei tojásdadok, hegyesek, egyenszinüek; kurta lelapult szörüek; bogernyös virágzata lapos; galléra nincs; fekete csontára fejér pettyes. - Erdőkłen, gyepükben. Cserje. †. Jun.-Jul. 6-9'. (Teres gyürü.)

Veresgyürü S. C. sangrinea. $L$.

2. Lerelei tojásdadok. kihegyezettek, a fa elvirágzása után hajtanak ki; ernyös virágai akkorák, mint négy levelü gallérai; csontára tojásdad-hosszukás, régre veres. Erdökben, bozótok- és bokrokban, kertekben, Cserje. 1. Mart.-Apr. 6-12'. (Som.) Húsos S. C. mascula. L.

\section{Rend. Fakínfélék. Loranthaceae. Don.}

\section{FAGYÖNGY. Yiscum. L.}

Szára kétkétágu. igen ágas; levelei ellenesek, láncsás lapiczkások, érhálózat nélküliek, börtapintuak ; rirága sárga; bogyója fejér. - Alma. füz. ihar, hárs stb. fákon élödik. †. Kora taraszszal.

Élödi F. $r$. album. $L$.

\section{FAKIx. Loranthus. L.}

Szára kopasz, igen ágas; levelei ellenesek, nyelesek, tojásdad hosszukások, tompák, vállban elkeskenyedők, alig eresek; füzéres rirágzata szárhegyi; rirága hibás fejlés miatt kétlaki, hatszirmu; sárgás zöld, bogyója sárga. - Tölgyfák ágain élődik. †. Maj.-Jun.

Élödi F. L. europaeus. $L$. 
65. Rend. Posgafélék. Crassulaceae. D. C.

\section{SZAKA. Sedum.}

1. Levelei laposak, szélesek, ellenesek vagy gyürüsek, az alsók széles válluak, a felsők szívesek, nyeletlenek; gyökere sok tövü, évröl évre uj szárakat hajt; virágzata bogernyös; bokrétája zöldes fejér; belső porodái szirmai tövéhez vannak növe. - Köves helyeken, kőfalak és födelek tetején. 24. Aug.-Sept. 1-2'. (Bablevelïfü ; lövérfü ; varjubab; szerelemtaplója.) (S. Telephium L.)

Bablevelï Sz. S. maximum. Sut.

Levelei hengeresek; gyökere vékony; töve gyepes. 2 .

2. Bokrétája fejér, vagy verhenyes; szirmai láncsások, csészéjénél háromszor hosszabbak; bugás virágzata esaknem egyenlő magas; szára alsó része gyökerező. - Sziklákon és köfalakon. 24. Jul-Aug. 3-10". (Kicsiny fülfü.)

Fejér Sz. S. album. L.

Bokrétája sárga. 3.

3. Húsos levelei tojásdadok, hátokon puposak s a szárára tompa válluknál fogva vannak ránőve; szára gyökerezö; bogernyője kopasz; láncsás és hegyes szirmai csészéjénél még egyszer hosszabbak. - Réteken, legelökön, ligetekben. 2. Jun.-Jul. 2-4". (Báríny, vagy egér csecsfü; szaliafü.) Borsos Sz. S. acre. L. Hengerded levelei szálasok, tompák. elhegyesedő vállukkal nönek a szárára; szára gyökerező; bogernyője kopasz; láncsás és hegyes szirmai csészéjénél még egyszer hosszabbak. - Az elöbbivel. 24. Jul.-Aug. 4-6".

Hatszegii sz. S. sexangulare. $L$.

\section{FÜLFÜ. Sempervivum. L.}

1. Rózsaalakuan kinyiló tôlevelei hosszukás visszás tojásdadok, hirtelen fulánkhegyủek, kopaszok, szemszörösek; bokrétája csillagalaku, szirmai csészéjénél még egyszer hosszabbak, pirosak. - Házfedeleken, sziklákon. 24. Jul.-Aug. 1/2-1'. Rózsás F. S. tectorum. $L$. 
2. Rózsaalakuan kinyíló levelei, hosszukás láncsások, hegyesek, kopaszok, szemszörősek; szárlevelei szivestojásdadok, kihegyezettek, alól felül szörösek és szemszörösek; bokrétája harangalaku, sárgás fejér. Sziklákon Buda körül. 4. Jul.-Aug.

Borzas F. S. hirtum. $L$.

66. Rend. Kőtörfélék. Saxifragaceae. D. C.

\section{KÖTÖR. Saxifraga.}

1. Szára magános, felálló, egyszerü vagy ágas, leveles;tőlevelei visszás-tojásdad lapiczkások, három karélyuak vagy hasábuak; szárlevelei váltogatók, tenyeresen három metszetüek; egy virágu kocsányján levő 2 murvája termésénél hosszabb. - Hegyi réteken, köveken, falakon szántóföldeken. $\odot$. Apr.-Maj. 1-4".

Apró K. S. trydactylites. $L$.

Szára felálló, magános, igen leveles; tölevelei vesealakuak, karélyosan csipkések, nyelesek, szárlevelei nyeletlenek, hosszukások, hónaljaik alatt rügyek (hagymák) teremnek; virágzata bogernyős; virága fejér. - Minden termékeny gyepen a hegyeken, ugy mint. a síkon. 24. Maj.-Jun. $1 / 2-1 \frac{1 / 2}{}$.

Riigyes K. S. bulbifera. $L$.

\section{VeselKe. Chrysosplenium. L.}

Levelei váltogatók, vesealakuak, mélyen esipkések, esipkéi kicsípettek; virágzata sátorozó; sárga virágai arany sárgán pontozottak. - A pilisi járás nedves és árnyas ligeteiben. 4. Apr.-Maj. 3-6".

Arany V. C. alternifolium. $L$.

67. Rend. Ribiszkefélék. Ribisaceae. Endll.

1. RIBIsZKe. Ribes. L.

1. Kocsányjai 1-3 viráguak; murvája 2-3 ; csészéje harangalaku, hosszukás metszetei letüremlettek; szirmai 
visszás tojásdalok; bogyója zöldes sárga; fulánkjai hármasok. - Mivelik; vadon terem a pilisi hegy szikláin. J. Apr.-Maj. 2-4'. (Egres, köszméte, pöszméte.)

Pöszméte R. R. Giossularia. L.

2. Fürtös virágzata csaknem kopasz, elvirágzás után lefüggö; csészéje kopasz, medenczealaku, éle kopasz; murvái tojásdadok, kocsánkáinál kurtábbak, levelei csaknem 5 karélyúak; bogyója veres. - Mivelik. †. Apr.-Maj. 2-4'.

Veres R. R. rubum. L.

68. Rend. Szirontákfélék. Ranunculacene. Juss.

\section{Bércse. Clematis. L.}

1. Szára kapaszkodó; levelei szárnyasok, levélkéi tojásdadok, kihegyezettek, épélüek vagy karélyosak, vagy durva fürészfoguak, csészéje levelei hosszukások, mind két felől molyhosak; virága fehér. - Gyepűkön, lokrok- és bozótokban. b. Jun.-Sept. (Tenike; renicz, iszalag, szulcik.)

Iszalag B. C. Vitalba. $L$.

Szára felálló. 2.

2. Levelei láncsások ragy tojásdadok, hegyesek, épélüek, kopaszok, alsó lapjaikon inai szörösödők ; virágai lekonyultak, kékek. - Vizenyős gyepeken, füzesekben. 4. Jul.-Aug. 1-21/2'. (Bérocie.) Éplevelï B. C. integrifolict. $L$. Levelei szárnyasok, levélkéi tojásdadok, kihegyezettek; csészéje levelei hosszukások. tompák, kopaszok, élökön szörösödök. - Hegyi réteken bozótokban. 24. Naj.Jul. 1'1/2-3'. (Lótorma ; nagy palaczkafü; erösfü.)

Lótorma B. C.erecta. $L$

\section{VIRNÁNCZ. Thalictrum. L.}

1. Síma termése három élü, élei szárnyasok s vaczkán egy kis kocsánykán áll; virága zöldes vagy fejér, szálcsái lilaszinüek; levelei 2-3-or szárnyasok, levélkéi, 
alig kerekdedek, kirélyosak vagy csipkések. - I gödöllöi erdőkben gyakori. 4. Jun.-Jul. 2-3’.

Fiiggös V. T. aquilegifolium. L.

Hosszában rovátkolt termése egyenes hegyü s vaczkában ül. 2 .

2. Bugája tornyadzó vigy tojásdad alaku, virágai ritkásak, vagy ágacskái hegyein ermyősek, de nem sürủk. 3. Bugája csaknem sátorozó, virágai s termései az ághegyeken csomóban ülnek, $\boldsymbol{7}$.

3. Kocsányjai szárnyason füzöttek, t. i. kocsányja, alsó oldalágai sokkal kurtábbak, mint a középsö; zilált virágai bólkolók; virágzata bugás; szálas levelei fénylök, a szárhegyiek néha hármasok; felső levelei hüvelyének füle tojásclad-hosszukás kihegyezett s fogasolt; gyökere terjeclö. - A budai hegyi és a pesti homoki réteken. 24. Jun.-Jul. 1-2'.

Galaj V. T.galioides. Nestler.

Kocsányjai hármason füzőttek, azaz: kocsányja oldalágai akkorák, mint a középsö. 4 .

4. Szára kisebb-nagyobb mértékben kékes hamvas. o. Szára nem hamvas. 6.

5. Levelei nyelecskéi kiá]ló vonalaiknál fogva, ormósak; levélkéi kerekdedek vagy ékalakuan visszás-tojiásdadok, 3-5 foguak; levelei hüvelye fülei kurták, lekerekitettek, kissé széllyeltartók, porodái lefüggők. - Hegyi és homoki gyepeken. 4. Maj.-Jul. 1-2'.

Kis V. T. minus. $I$.

Levélkéi kerekdedek vagy visszás tojásdadok, 7 foguak; levelei hüvelyei fülei kurták, lekerekítettek, kissé széllyeltartók ; kocsánykái, virágai és porodái egyenesen előreállók. - Hegyi réteken, a homokdombokon Pest, Gödöllö és Vácz körül, ritkább. 24. Jun.-Jul. 2-3'.

Magas V. T. elatum. Jacqu.

6. Levelei hüvelye fülei szélesek, lekanyarítottak, vizirányosan állók, végre hátra göngyölödöttek, levele 
nyelei első elágazásainál pálhások; ágai és kinyílt bugája szegletes, kocsányjai girbe gurbák, virága és porodái lefüggök. Hegyi és homoki gyepeken, útfeleken. 4. Jun.-Jul. 1/1/2-21/2'. (T. collinum. Wallr.)

Dombi V. T. Jacquinianum. Koch.

Levelei hüvelye fülei háromszög tojásdadok, fogasok, felállók s a szárára lapultak; levelei nyelei első elágazásánál pálhások, bugája terepély, virágai csaknem ernyősek és gyürüsek. - Hegyi réteken, útfeleken és gyepük mellett. 24. Jun.-Jul. 2-3'.

Közép V. T. medium. Jacqu.

7. Gyökere rostos; levelei hüvelye fülei tojásdadok, kihegyezettek; levelei nyelei elágazásainál nincs pálha; levélkéi hosszukás ékalakuak vagy szálasok, fénylők alól halványak; bugája sátorozó; porodái felállók. Vizenyős réteken, mocsárok mellett. 4. Maj.-Jul. 2-4”.

Szäklevelü V. T. angustifolium. Jacqu.

Gyökere terjedö; levele hüvelyei fülei hosszukás-tojásdadok, hosszabbak, mint szélesebbek; levele nyelei alsó elágazásainál pálhások; levélkéi visszástojásdadékalakuak, épek vagy 3 metszetüek, a felsők szálasok, alól halványok; bugája sátoros; porodái felállók. $\mathrm{Az}$ elöbbivel. 4. Maj.-Jul. 2-4". (Vad virnáncz.)

Sárga Y.T.flarum. $L$.

\section{Kökörcstr. Anemone. L.}

1. Levelei egyszerűek, 3 karélyuak, épélủek; csészéhez hasonló 3 levelü galléra közvetlen a leple alatt van; rirága kék, néha piros vagy fejér. A sz.-endrei és visegrádi erdők szélein. 24. Mart.-April. 2-4". (Nemes muijfü; mogyoróaljafü.) Majfï K. A. Hepatica. L. Levelei füzöttek. vagy hasogattak; hármas galléra nyeletlen vagy nyeles. $\mathbf{2}$.

2. Magva csákós. 3.

Magra csákótlan. 4.

3. Tirága felálló; leple alsó része harangalaku, végre a 
közepétöl kezdre hátrafelé hajolva kinyílt, kétannyi hosszu, mint a porodája ; virága sötét, később világos; tölevelei 3-szor szárnyason hasogatottak, hasábjai szálasok, hegyesek. - Száraz, kivált hegyi réteken. 4. Kora tavaszszal. Virágzáskor 3-6", később 1-1 1' $2^{\prime}$. (Lecimy v. lólöliörcsin.) Leány K. A. Pulsatilla. L.

Virága lefüggö; leple harangalakuan összeáll, csak a hegye türemlik hátra; porodái akkorák, mint a leple harangalaku része; virága fekete lilaszinü; tölevelei háromszor szárnyason hasogatottak. -- Réteken. különösen a homokon. 4. April.-Maj. 1-1/1/2'. (Kisebb Té(inyköliörcsin.)

Mezei $\mathbf{K}$. A. pratensis. $L$.

4. Magvai molyhosak; bibeszára kopasz, igen kurta, virága magános; leple 5 szirmu, tojásdad, alól gyapjas, fejér; tőlevelei 5 hasábuak, hasáljai csaknem kótaalakuak. - Erdőkben s hegyi réteken. 4. Maj.-Jun. $6-18^{\prime \prime}$.

Erdei K. A. sylvestris. $I$.

\section{Magvai szőrösödök. 5 .}

๖. Galléra 3 levelü, nyeles, nyelei csaknem akkorák, mint a levele; leple 6 szirmu, szirmai mindkét oldalukon kopaszok, fejérek; tókocsányja egy virágu. - A sz.endrei és visegrádi árnyas berkekben, ritka. 4. Kora tavaszszal. 3-12". (Fejér berektirág; fejér pipacs; szélvirág; patcicz.)

Berki K. A. nemorosa. $L$.

Galléra 3 levelü, nyeles. nyele leveleinél sokkal kurlább; leple 5 szirmu, szirmai alól szörösödők, sárgák; virága többnyire páronkint áll. - Ligetekben, bozótokban. 4. Kora tavaszszal. 3-12".

Boglár K. A. ranunculoides. $L$.

\section{HÉRICS. Adonis. L.}

1. Sárgaszinủ bokrétája 10-20 szirmu. nagy ; csészéje 4-5 levelü; puha szörü; termései csaknen gömbdeden risszástojásdadok, horgas csőrủek; tölevelei csak pik- 
kelyek. - Vindenféle réteken, legelökön, hegyoldalokon. 21. Apr:-Maj. 1/2-1'. (Kökörcsin.)

Taraszi H. A. vernalis. $L$.

Bokrétája :3-6-8 szirmu; gyökere egy nyári. 2.

2. Czészéje szörös; bokrétája lángszinü, néha tövén fekete, néha sárgás veres; termése ránczos, felegyenesedö csöre feketés barna. - Szántóföldeken vetések közt Maj.-Jul. 1-1 ${ }^{1}{ }^{1} 2^{\prime}$. (Tyntiszemrivig.)

Lángszinï H. A. flammea. Jacqu.

Csészéje kopasz; bokrétája minium veres, szirmai töve néha fekete; termése ránczos, felegyenesedő csöre termésével egyenlö színü. - Az elöbbivel. Jun.-Jul. 1-2'. (Kakastircig; pallagi rózsa.) Tyári H. A. aestivalis. L.

\section{MIZURA. Myosuius. L.}

Pázsitos levelei szálasok; szárhegyi virágai magánosak, szirmai piczinyek; vaczka végre kupalakulag megnyulik. - Gyepeken, kertekben. ○. Maj.-Jun. 1-1".

Piczi M. MI. minimus. $L$.

\section{FULÁxCs. Ceratocephalus. Mönch.}

Magva pupjai közt válus, hátán ormós, hegyén sarlóalakuan csörös; virága sárga. - Buda körül az agyagos helyeken, töltéseken. $\odot$. Mart.-Maj. 1-3". ( $R a-$ munculus falcatus. L.)

Sarlós F. C. falcatus. Pers.

\section{\%. SZIRONTÁK. Ranunculus. L.}

1. Bokrétája fejér, szirma töve leginkább sárga. 2. Bokrétája világos sárga vagy aranyszinü. 3.

2. Viz alámerült levelei sertealakulag sallangosak, nyelesek, sallangjai mindenfelé széllyeltartók; vizen uszó levelei vesealakuak, karélyosak vagy bemetszettek; porodái hosszabbak, mint maghonaiból alakult gömbje. - Alló vizekben és patakokban. 24. Jun.-Aug.

Tavi Sz. $R$. aquatilis. $L$. Minden levele riz alá van merülve s sertealakuan sal- 
langos; szára hengeres; bokrétája 9-12 szirmu; porodái maghonaiból alakult gömbjénél kurtábbak. - Az elöbbivel együtt. 24. Jun.-Aug.

Lábbogó Sz. R. fluitans. Lam.

3. Levelei épek; gyökere rostos vagy gumós. 4. Levelei szabdaltak, vagy füzöttek vagy karélyosak. 8.

4. Szára felegyenesedő, vagy henyélö. Ј. Szára felálló, csöves, vagy felálló, vagy úszó. 6.

5. Levelei kerekded-szívesek. a felsök szegletesek; gyökerén sok gumóju; csészéje 3, néha 4-5 levelü. Erdőkben, réteken, legelökön, nedves helyeken. 4. Mart.-Maj. 2-8". (Kis fecsliefü; tavaszi saláta; galambbegy.)

Saláta Sz. R. Ficaria. L.

Levelei körkörösek, láncsások vagy szálasok; felegyenesedő szára félredülő s bütykéinél fogva néha legyökerezö; termései visszás-tojásdadok, símák, kurtaés tompahegyüek. - Árkok, tavak, patakok körül s nedves réteken. 24. Jun.-Aug. (Boglárvirág; békavirág; sömörfü.) Lángos Sz.R. Flammula. L.

6. Termései tüskéskes csőrösek, gömbbe állottak; virágai aprók, lehullók; szára hengeres, két-két águ; hoszszudad-láncsás levelei nyelesek, símák, alig fogasok. - A pomázi erdők álló vizeiben és a Tisza mocsáraiban. $\odot$. Maj.-Jun. 2-8".

Kocsánytalan Sz. R. nodiflorus. $L$.

Termései símák. 7 .

7. Levelei hosszu láncsások, kihegyezettek; felálló sugár szára tövön gyürüsen gyökeres, ostorindás; magvai szélesek és kurta sarlóalaku csőrösek; ághegyi sárga virágai nagyok. - Posványos réteken és mocsárok körül a nádasokban. 24. Jun.-Aug. 1-3'.

Nádi Sz. R. Lingia. L.

Alsó levelei nyelesek, számosak, gyürüsen állók, tojásdad-hosszudadok; szárlevelei váltogatók, ékalakuak, 3 karélyuak vagy 3 foguak, a felsők csaknem szála- 
sok; magvai ferde tojásdadok, csaknem lapítottak. Különösen a Tisza mocsáraiban. 4. Maj.-Jul.

Buglyos Sz. R. polyphyllus. W. $K$.

8. Gyökere gumós. 9.

Gyökere rostos (kivévén a R. bulbosus-t, melynek tőgyökere gumósan van megvastagodva). 10.

9. Szára és levelei szőke selyemszőrösek; tölevele hármasok, levélkéi szálas láncsások; kocsányja hengeres; csészéje letüremlett. - Gyepeken, vetések közt, sziklákon. 24. Maj.-Jun. 1/2-1/1/2'.

Selymes Sz. $R$. illyricus. $L$.

Szára szőrösödő; levelei kopaszok, tölevelei gereblyésen füzött 3-5 hasábuak, kevés szárlevele 3 hasábu, legfelsők épek, mindenikféle levele hasábjai szálasok, csaknem épélüek; szára egyvirágu; csészéje nyílt borzas ; tojásdad szirmai csészéjénél kétszerte hosszabbak; lapított magvai hártyaprémüek. - Hegyi és homoki lejtökön, a budai vérmezőn és az Orczykert mellett. 4. April.-Maj. 6-18".

Villás Sz. R.pedatus. W.K.

10. Termései símák. 11.

Termései vagy ránczosak, vagy görcsösek, vagy tüskések. 17.

11. Kocsányja hengeres és nem barázdolt. 12.

Kocsányja barázdolt. 14.

12. Levele nyelei tövön hüvelyezők, tölevelei $\cdot$ kerekdedek vagy vesealakuak, csipkések: szárlevelei ujjasok, hasábjai láncsások; tavasz kezdetén nyíló virágai sziromtalanok vagy csak egyszírmuak, azután 2-3-5 szirmuak; magvai hasasok és selymes szörüek. Lombos erdőkben, vágásokon és hegji réteken. 4. Maj.-Jun. 6-18". Változó Sz. R. auricomus. $L$.

Levele nyelei szőrösödők vagy gyapjas durvaszőrüek. 13. 13. Tö- és szárlevelei tenyeresek, metszetei csaknem kótaalakuak, bevagdalt hegyes foguak, a felsők 3 hasábuak, 
hasábjai szálasok; termése lencsealakuan lapított kissé görbe csöre kurtább, mint a magva; vaczka, kopasz. - Minden réteken. 4. Maj.-Sept. 1-3".

Réti Sz. R. acris. $L$.

Tö- és szárlevelei tenyeresek, metszetei széles visszás-tojás. dadok, 3 metszetüek s hegyes foguak, a felsők 3-sok; termése lencsealakuan lapított, csöre tövön széles, tetején begönyölödött, csaknem felényi, mint a magva ; vaczka kopasz. - A pilisi, sz.-endrei, sz.-kereszti és a váczi hegyek erdeiben. 4. Jun.-Jul. 1-3'.

Gyapjas Sz. R. lanuginosus. $L$.

14. Tölevelei tenyeresen szabdaltak. 15.

Tőlevelei hármasok és kétszer hármasok. 16.

15. Tỏlevele hasábjai 3 metszetủek s bevagdaltak; magva, csőre horgas; vaczka sertés. - Száraz réteken, bokrok és bozótokban. $\odot$. Naj.-Jul. 1-4 1/2'.

Sokvirágu Sz. R. polyanthemos. $L$.

Tőlevele hasábjai széles visszás tojásdad szívesek; magva, csőre begönyölödött; vaczka sertés. - Magasan fekvő hegyi réteken, a sz.-kereszti, sz.-endrei, visegrádi és váczi erdőkben. 24. Jun.-Jul. 1-2'.

Ligeti Sz. R. nemorosus. D. C\%

16. Töve gyökerező ostorindákat hajt; csészéje kinyílt; magvai finom szurdalással pontozottak. - A legközönségesebb minden nedves és vizenyös helyen. 4. Maj.-Aug. ${ }^{1 / 2}-1^{1 / 2}$. (Boglárka ; kakasláb; hollóltib.)

Boglárka Sz. R. repens. $L$.

Töve gumósan megvastagodott, ostorindája nincs, csészéje letüremlett; magvai símák. - Szántóföldeken, útfeleken, árkokban, nem gyakori. 4. Jun.-Aug. $1 / 2-1^{\prime}$.

Gúmós Sz. R. bulbosus. $L$.

17. Magvai hosszukás füzért alkotnak, aprók, ormótlanok, finom ránczosak; halványsárga szirmai igen aprók; csészéje letüremlett. - Vizenyős helyeken gyakori. Mérges $\odot$. Jun.-Sept. (Torzsilia; istárj; vizi méreg; sebesitöfti.)

Torzsika Sz. R. sceleratus. L. 
Magvai gömbalaku csomót alkotnak. 18.

18. Tölevelei hármasok, vagy kétszer hármasok, levélkéi 3 metszetüek, csészéje letüremlett; magvai közepén sok, vagy a széle körül egy sor görcs van. - A pesti és budai gyepeken nem ritka. ○. Maj.-Jul. ${ }^{1 / 2-1}$ '.

Borzas Sz. R. Philonotis. Ehrh.

Tölevelei épek vagy 3 hasábuak, a felsők hármasok; magvai laposak, csőrösek, görcsösek és tövisesek. -Szántóföldeken, vetések közt. ○. Maj.-Jul. 1/2-11/2'.

Mezei Sz. R. arvensis. $L$.

\section{GólYYhir. Caltha. L.}

Szára felegyenesedö; levelei szíves kerekdedek, csipkések ; virága aranyszínü. - Nedves helyeken. 4. Mart.April. 6-12". (Mocscirvirág; békavirág; gólyaviráag; sárga viola.)

Moesári G. C.palustris. $I$.

\section{SZIRALJ. Eranthis. Salisbury.}

Sárga nagy virága kerek és sok hasábu gallérában ül. - A pesti városligeti tó partján. 4. Febr.-Mart. Igen ritka. $3-6^{\prime \prime}$.

Téli Sz. E. hyemalis. Salisb.

\section{HUNYOR. Helleborus. I.}

1. Kétágu szára kopasz, csaipán elágazásainál leveles; csak virágzás után hajtó tölevelei ujjasok, hosszu láncsások, hegyesek, egyenetlen mély fürészesek, erei kiállók, kopaszok; virága zöld, bibéje felálló. - A budai Jánoshegy tetején, a budaörsi, budakeszi és csabai erdőkben, bokrokban. 4. Apr.-Maj. 6-12". (Pap)lialap; páponya ; hunyor.)

Zöld H. $H$. viritis. $L$.

2. Felálló szára felül alig szegletes, leveles; tölevelei ujjason hasábosak, hasábjai épek s ismét 2-3 hasábuak, egyenetlen kétszer fürészesek, szárlevelei 3 hasábuak, hasábjai 2-3-szor behasítottak, fürészesek; kékesen piros virágai kurta kocsányuak, bókolók. - A csabai 
sz.-keressti, sz.•endrei, visegrádi és a váczi erdökben. 4. Mart.-Maj. 6-12".

Piros H. H. purpurascens. W. $K$.

\section{Galdàó. Isopyrum. L.}

Gyökere terjedö, rostjai csomósak; tölevelei hosszunyelüek, kétszer hármasok, levélkéi tompa három karélyuak, fogasok; szárlevelei nyelesek, pálhások, kétszer hármason vagy csak hármason szabottak; kocsányjai egyviráguak; fejér bokrétája szirmai tompák. - Árnyas berkekben. 24. Kora tavaszszal. 3-8".

Virnáncz G. I. thalictroides. $L$.

\section{KANDILLA. Nigella. L.}

Pilise sziromnemü levele 5-10; portokai kalászosak, kalászai felényiek, mint a portokai; tokjai símák, a tövüktől középig összenőttek; magvai három ormójuak, finom szemcsésen érdesek. - Vetések közt, útfeleken. ○. Jun.-Aug. 6-18". (Feliete lioricindrum; parasztbors.)

Mezei K. N. artensis. $L$.

\section{CzÁmoly. Aquilegia. L.}

Pilise sarkantyui hegyei horgasok, ereszei tompák, kicsípettek, akkorák, mint a porodái; levelei kétszer háromszorosak, levélkéi 3 karélyuak, csipkések. Csaba és Visegrád körül az erdőkben, igen ritka. 4. Maj.-Jun. 1-2'. (Har'angvirág.)

Harang Cz. A. vulgaris. L.

\section{SARKVIRÁG. Delphinium. L.}

Pilise egy tagu 4 metszetü; kocsányja murvájánál hoszszabb, tokja kopasz; szára egyszerüen ágas, levelei vékony sallangra szabdaltak. - Vetések közt, útfeleken, pallagokon. ○. Maj.-Aug. 1-2'. (Kék sarkantyuvivaig; liéli szarlialáb.)

Mezei S. D. Consolida. $L$. 


\section{SisakVIrÁG. Aconitum. L.}

1. Pilise sarkantyuja hátra tört horgas, sisakja félgömbalaku, boltos; virága sárga, virágzata bugás; levelei sokhasábuak, sallangjai szálasok. - Ritkás erdőkben Csaba, Visegrád és Vácz körül ritka. 4. Aug.-Sept. 1-2'. (Sárga sisalifü; szelid sisalfï; kuklás- vagy csulilycisfiu.)

Méregölö S. A. Anthora. L.

2. Pilise sarkantyui pergék, sisakja kétszerte magasabb mint széles, csaknem hengeres, lapított; virága halvány sárga; levelei tenyeresek 5 hasábuak, hasábjai 3 metszetủek, metszetei egyenetlen fürészesek. - Lombos erdőkben mindenütt. 24. Jun.-Aug. 2-4'. (Farkasölöfü ; répa-, gyökér-bab; méregfü.)

Farkasölö S. A. Lycoctonum. L.

\section{TAKTA. Actea. L.}

Levelei hármason kétszer szárnyaltak, levélkéi tojásdad hosszukások, egyenetlenül kétszer fürészeltek; fürtjei tojásdadok ; szirmai akkorák, mint a porodái ; bogyója kerekded tojásdad. - Hegyi berkekben. 4. Maj.-Jun. 1-2'. Mérges.

Békabogyó T. A. spicata. L.

\section{Rend. Borbolyafélék. Berberideae. Juss.}

\section{BORBolya. Berberis. L.}

Tövisei három águak, levelei csomósak, visszás-tojásdadok, szemszőrösen fürészesek; fürtje sok virágu, lefüggö; szirmai egészen vagy alig kicsípettek, sárgák. Erdőkben, gyepükben. ち. Maj.-Jun. (Sóskafa; fái sóslia; lecinysom; üröm borbolya.) Sóska B. B. vulgaris. L.

70. Rend. Mákfélék. Papaveraceae. Juss.

1. MÁK. Papaver. L.

1. Kerekded tokja keményszörü, borzas; porodái felül kiszélesedettek; leveles szárán egynél több veres virá- 
ga van. - Szántóföldeken, kertekben. ๑. Maj.-Ju . $1-1^{1 / 2}$ '.

Csekély I. P. lyydridum. $L$.

Tokja kopasz. 2.

2. Az egész növény kopasz, kékes zöld ; levelei szárölelők, hosszukások, egyenetlen' fogasok, a felsők épek, az alsók öblösek; tokja csaknem kerekded. - Mivelik. •. 2-3'.

Kerti I. $P$. somniferum. $L$.

Az egész növény szörös. 3.

3. Szálcsái áralakuak; tokja kurta visszás-tojásdad; bibéje lemezei szélökkel egymást fedezik; levelei szárnyasok, vagy kétszer szárnyasok, szárnyai hosszukás láncsások s bevagdaltan fogasok; virága veres. - Vetések közt, útfeleken. $\odot$. Maj.-Jul. ${ }^{1 / 2}-1^{1 / 2} \mathbf{2}^{\prime}$. (Pipacs.)

Pipaes M. P. Rhoeas. $L$.

Szálcsái áralakuak; tokja ékalaku, töve felé lassankint keskenyedik el; bibéje csipkéi különváltak; levelei kétszer szárnyasok, metszetei szálasok, ritka fogasok; virága veres. - Az elöbbivel. ๑. Maj.-Jul. 1/2-11/2'.

Bujdosó M. P. dubium. L.

\section{SZARUTOK. Glancium. Tourn.}

Szára és levelei szőrösek; felsö levelei nyeletlenek, szárnyason hasgattak; beczője sertés-keményszőrü. Útfeleken, hegyi és homoki gyepeken. $\odot$. Maj.-Aug. 6-18". (Szarvasmcil.) (G. phoeniceum. Sm.)

Szarvas Sz. G. corniculatum. Curt

\section{GÓdIRCZ. Chelidonium L.}

Virágzata ernyős; csészéje csaknem kopasz; szára felső része szélesebb; virága sárga. Az egész növény verhenyes sárga tejjel van megtelve. - Kertekben, árnyas helyeken, árokpartokon. Mérges. 4. Maj.-Jul. 1-3'. (Czinadónia; vére hullófü; nagy fecskefü; gódircz.)

Czinadónia G. C. majus. $L$. 


\section{LIKAsír. Corydalis. D. C.}

1. Gyökere gumós, gumója üreges : szárán két levél nő, melyeknek nyelei tövén nincs pikkely; levelei kétszer hármasok, bevagdaltak; murvái épek. - Bozótokban ligetekben. 4. Kora tavaszszal. 1/2-1'. (C. bulbosa Pers.) (Likasir; taraszi gerézdes; kakasláb; hüvelykes füldfüsti.)

Gumós L. C. cara. Schweig.

2. Gyökere gumós, gumója tömött; levelei kétszer hármasok, bevagdaltak; alsó levele nyele leveletlen, pikkelyalaku; murvái ujjason hasadtak: termése kocsányja megnyult, egyenes, termése ritkán áll. - Az elöbbivel. 4 . (C. digitata. Pers.)

Kemény 1. C. solida. Sm.

\section{FÜstike. Fumaria. L.}

1. Csészéje igen-igen kicsiny, nagyitó nélkül alig kivehetö s kocsánykájánál keskenyebb; táskája tojás-kerekded ; termése fürtje laza; piros bokrétája szirmai szálasok. - Mivelt s terméketlen téreken, kertekben, szőllökben. $\odot$. Apr.-Maj. 6-18". Vaillant F. F. Vaillantii. Lois. Csészéje bokrétájánál 3-6-szor kisebb. 2.

2. Csészéje levelei 3-szorta kisebbek szirmainál s szélesebbek mint kocsánykái; táskája kerekded, keresztba szélesebb, hegye csonka, kissé kicsípett. - Az elébbivel. $\odot$. Maj.-Sept. (Földfüsti.)

Föld F. F. officinalis. $L$.

Csészéje levelei szirmainál 6-or hosszabbak s vele egyenlö szélesek; táskája tojás-kerekded, hegyeses; virága fejér vagy halvány piros. $-\mathrm{Az}$ elöbbiekkel. $\odot$.

Kisvirágu F. F. parviflora. Lam.

\section{Rend. Keresztesek. Cruciferae. Juss.}

\section{RÉZSUKA. Nasturtium. L.}

1. Virága fejér; levelei hónaljából növő szárai legyökereznek; levelei szárnyasok, a felsők 3-7 bordájuak, 
az alsók 3-masok, levélkéi kanyarosak, az oldalak körkörösek, a régsök esaknem szíves-tojásdadok; beczöje szálas, akkora, mint a kocsányja. - Források és patakok mellett. 2. Maj.-Jun. 3-18".

Orvosi R. $N$. officinalis. R. Br.

Virága sárga. ․

2. Szirmai akkorák, mint a csészéje; alsó levelei félbeszárnyasok, a felsők mélyen szárnyason hasogatottak, hosszukás hasábjai fogasok; beczöje hosszukás felpuffadt, akkora, mint kocsánykája. - Nedves réteken, árkokban, útfeleken. $\odot$. Jun.-Aug. 6-15".

Tavi R. $N$. pulustre. $D . C$.

Szirmai csészéjénél hosszabbak. 3.

3. Szára igen ágas, terepély; levelei mind mélyen szárnyason hasogattak, vagy szárnyasok, levélkéi hosszukás láncsások, fogasok vagy ismét szárnyason bevagdaltak; táskája szálas, akkora, vagy kissé hosszabl vagy kurtább, mint a kocsánykája. - Nedves réteken, árkokban. 4. Jun.-Aug. 5-16".

Berki R. $N$. syliestre. $R$. Br.

Szára tövön gyökerezö, ostorindás és a vízben felfuvódott csöves; levelei hosszukások vagy láncsások, vállban elkeskenyedők, fürészesek, vagy fogasok, az alsók félbeszárnyasok vagy fésüalakuak; táskája körkörös vagy csaknem gömbalaku, 2-3-szor kurtább, mint a kocsánykája. - Álló vizekben, árkokban. 4. Jun.Jul. 1-2'. Iszap R. N. amphibium. R. Br.

\section{TORMÁNCS. Barbarea. R. Br.}

Alsó levelei félbeszárnyasok, végső levélkéje, igen nagy. kerekded, oldalbordája négy pár; felsỏ levelei épek. visszás-tojásdadok. fogasok; fürtje virágzás idején tömött, gyenge beczői dülten felállók. Útfeleken, gyepűk mellett, agyagos árkokban. ๑. Maj.-Jul. 1-2'.

Téli T. B. vulgaris. R. Br. 


\section{TORONSZAL. Turritis. L.}

Tölevelei kaczurosak, vagy fogasok vagy épélüek, 3 águ szöreiknél fogva érdesek; szárlevelei kopaszok; szívesen nyilas vállaiknál fogva szárölelők; beczői sugáron felállók., kocsánykáiknál 6-szor hosszabbak; virága sárgás fejér. Hegyi és homoki száraz réteken, erdőkben. ๑. Maj.-Jun. 1-3'.

Kopasz T. T. glabra. L.

\section{IKRAPIKK. Arabis. L.}

1. Magvai szárnytalanok, vagy keskeny szegélylyel szárnyaltak. $\mathbf{2}$.

Magvai széles hártyaszárnyuak; beczői felálló kocsánykáiról lefelé görbültek, laposak, degeszek, szélökön vastag szegélyűek; levelei ágas szörösek, fogasok, tölevelei körkörösek, nyélre keskenyedettek; szárlevelei hosszukások, mélyen szíves vállukkal szárölelök, ritka fogasok; virága fejér vagy sárgás fejér. - A budai sziklás berkekben ritka. $\odot$. Maj.-Jun. $1 / 2-2$ '.

Tornyos I. A. Turrita. $L$.

2. Szárlevelei vállban szívesek, szárölelök, nyeletlenek. 3. Szárlevelei 'vállban elkeskenyedettek, kurta nyelüek. a legfelsök épélüek, szörösek; tölevelei nyelesek, félbeszárnyason kaczurosak, mindenik oldalán 6-9 bordával, minden levele ágas szörös; széllyelálló beczöi szálasok, csaknem laposak; egy hosszába menö finom in van rajtok; virága lila, ritkán fejér. -- Köfalakon fedeleken, sziklákon, száraz réteken. ๑. Jun.-Jul. $6-18^{\prime \prime}$.

Sivatag I. A. arenosa.Scop.

3. Szára levelei ágas szörösek; tölevelei nyélbe keskenyedettek, szárlevelei tojásdad-láncsások, fogasok, vállban mélyen szívesek; végre megnyult fürtje tekergös; lapított beczői széllyelállók, csaknem 3 inuak, kocsánykáinál alig ssélesebbek; virága fejér. - Nyílt és száraz réteken mindenütt. ๑. Maj.-Jun. 6-12".

Terepély I. A. auriculata. Lam. 
Szára alól széllyelálló szőreinél fogva érdes; levelei hosszukások, fogasok, ágas szörösek, tölevelei nyélbe keskenyedők; szárlevelei felállók, vállban csonka fülesek vagy szívesek; beczöi felállók, keskeny szálasok, lapítottak, hosszában eresek s egy kiálló inuk van virága fejér. - Hegyi, erdei és homoki száraz réteken. $\odot$. Maj.-Jun. 1-3'. Borzas I. A. hirsuta. Scop.

\section{כ. Foszlár. Cardamine. L.}

1. Levelei nyele tövén szárölelö fülek vannak; levele i szárnyasok, alsó levele levélkéi tojásdadok 3-5 metszetủek, nyelecskések, felső levele levélkéi hosszukás láncsások, hátsó élökön fogasok, nyelecske nélküliek; szirmai rendszerint nincsenek. - Erdei gyepeken, a pilisi hegyi erdők útfelein. $\odot$. Apr.-Jun. 1-2'.

Virágrugó F. C. impatiens. $L$.

Levelei nyelei nyele tövén nincsenek fülei. 2.

2. Portokai felrepedésök elött pirosak; visszás-tojásdad szirmai 3-szor akkorák, mint a csészéje ; szára ormósan barázdolt; szárnyas levele levélkéi kerekdedek vagy hosszukások, szegletesen fogasok; virága fejér. - A pilisi hegyek magasabban fekvő erdeiben, nedves helyeken. 24. Maj.-Jun. 6-12",

Keserï F. C. amara. $L$.

Portokai sárgák; visszás-tojásdad szirmai háromszor akkorák, mint a csészéje; szára hengeres, felül alig rovátkos; levelei szárnyasok, tőlevele levélkéi kerekdedek, fogasok vagy kanyarasok, a végsők igen nagyok; szárlevele levélkéi szálasok, épek; virága lilaszinü, néha fejér. - Minden vizenyös helyen. 24. Maj.-Jun. bi-18". Kakuk F. C.pratensis. $L$.

\section{FOGASIR. Dentaria. L.}

1. Hármas levelei gyűrűsen állanak, levélkéi egyenetlen fürészesek; porodái akkorák, mint a szirmai, sárgás. 
fejérek. - A budai árnyas erdőkben, különösen a Jánoshegyen. 4. April-Maj. 1-1/1/2'.

Kilenczlevelü F. D. emeaphyyllos. $L$.

Levelei váltogatók, az alsók szárnyasok, a felsők épek; levele hónaljaiban gumócskák rannak. - Az előbbirel, de gyakoribb. 4. Maj.-Jun. 3-18". (Foganöttfü.)

Gumótermö F. D. bulbifera. L.

\section{\%. ESTIKE. Hesperis. L.}

1. Szirmai visszás-tojásdadok, igen tompák. 2. Szimai szálas láncsások, tompák; kopasz és lapított degesz beczöi kocsánykáival együtt széllyeltartók, kopácsai felényi szélesek, mint a válaszfala; levelei tojásdad láncsások, kihegyezettek, épélüek, vagy alig fogasok; virágai fakósárgák piros erezettel. - Hegyi és homoki erdök gyepein. $\odot$. Maj.-Jun. 1-2'. (Ejjeli riola ; estvellie.)

Szomoru E. H.tristis. $L$.

2. Levelei tojásdad láncsások, kihegyezettek, fogasok, az alsók néha félbeszárnyasuk; szára felálló, kopasz ragy ágas szőrökkel szörösödö; beczöi széllyeltartó kocsánykáin felállók, kopaszok, csaknem hengeresek, degeszek; virága lilaszinü vagy fejér. - Árnyas berkekben ritka, található a budai kincstári erdőkben. ๑. Maj.-Jun. 1-2'. $\quad$ Pompás E. H. matronalis. $L$.

Levelei tojásdad láncsások, kihegyezettek, fogasok, az alsók félbeszárnyasok; szára felálló, egyszerü vagy ikrás szőrökkel szörösödő; beczöi széllyeltartó kocsánykáin felállók, hengeresek, degeszek; virága lilaszinü. - A Széchenyihegy szántóföldei barázdáin és a bozótokban. $\odot$. Maj.-Jun. 2-3'.

Kaczuros E. H. runcinata. $W . h$.

\section{MÁliKa. Malcholmia. R. Br.}

Szára felálló, alig szegletes, igen ágas; levelei hosszudad láncsások, vállban keskenyek, alig fogasok, érdesek; apró rirágai halvány rózsaszinüek ; beczői bor- 
zasok. - Budapest körül a szántóföldek barázdáin, útfeleken, nem gyakori. $\odot$ A pril-Maj. 3-10".

Borzas M. M. africana. $R$. Br.

\section{ZSOMBOR. Sisymbrium. L.}

1. Levelei különféleképen szabdaltak, néha a legfelsök épek. 2.

Levelei épek. $\mathbf{S}$.

2. Levelei kaczuros szírnyason hasogattak, néha a legfelsők egyszerüen szárnyason hasábosak vagy dárdaalakuak. 3.

Levelei két-háromszor szárnyasok, minden levele sallangja szálas; beczői felfelé görbék, kocsányjainál másfélszer hosszabbak; virága sárga. - Telekes helyeken, útfeleken mindenütt. $\odot$. Maj.-Sept. 1-2'. (Kámyafï; sebforrasztófü; szófica.)

Szófia Zs. S. Sophica. L.

3. Beczői áralakuan kihegyezettek, szorosan fökocsányjára lapultak; végső levélkéje nagy és dárdalaku; virága sárga. - Telekes helyeken, útfeleken, házak körül. $\odot$. Jun.-Sept. 1-2'.

Szapora Zs. S. officinale. $L$.

Beczöi hengeresek, széllyeltartók, vagy lefelé hajlók. 4 .

4. Kaczuros-szárnyason szabdalt levele sallangjai tövön fülesek; kocsánykái kurták, csaknem olyan vastagok, mint a beczöi. 5.

Levelei hasábjai tövén nincsenek fülei; kocsánykái karcsuk és vékonyak. 6.

5. Összetartó csészéje felálló; levele véglevélkéi szegletesek vagy dárdások, tövén fülei felfelé tartók; virága sárg:.. - Útfeleken, telekes helyeken, p. o. a budai vár mellett böven. $\odot$. Jun.-Aug. 1-3'.

Hamvas Zs. S. Columnae. L.

Csészéje igen széllyelnyílt; felsö levele szárnyai s véghasábjai keskenyszálasok; virága sárga; beczői tere- 
pélyen kiállanak. - A homoki gyepeken igen gyakori, az erdőkben sziklás helyeken. ๑. Maj.-Jul. 1-3’.

Dunamelléki Zs. S. pannonicum. L.

6. Gyenge beczöi sátorozó virágzatán jóval felül érnek s 4-szer akkorák, mint a kocsányjai; csészéje kissé kinyílt. - Telekes helyeken, kőfalakon, sziklákon. (-). Maj.-Jul. 1-3'.

Irió Zs. S. Irio. $L$.

Gyenge beczői sátorozó virágzatán nem érnek felül. 7 .

7. Beczői kocsánykáinál kétszerte hosszabbak; felegyenesedők, kissé görbék, egymástól távolodók; szára és alsó levelei keményszőrủek; virága sárga. - Útfeleken, telkeken, sziklákon gyakori, réteken ritka. (.). MajJul. 1-3'.

Borzas Zs. S. Löselii. L.

Beczöi kocsánykáinál sokkal hosszabbak, széllyel vagy épen lefelé hajlók, számosak és tömöttek; szára és levelei kopaszok vagy ritka szörủek. - A budai várhegy oldalán. $\odot$. Jun.-Jul. 2-2 ${ }^{1} 2^{\prime}$ '.

Síma Zs. S. austriacum. Jacq.

8. Virágai sárgák. 9.

Virágai fejérek. 10.

9. Szára felálló hengeres, fakó; alsó levelei kaczurosak, a felsők épek láncsás szálasok, borzaskák; virágzata fürtös; beczői felállók. - Az Orezykert gyepein. 24. Jun.-Jul. 1-2'.

Káka Zs. S. junceum. W. B.

Szára sugár, merev, levelei hosszukás láncsások, egyenetlen fogasok, szörösödők; beczői meröen terepélyek. - Erdőkben, szántóföldeken Buda körül. 24. Jun.Aug. 2-4'.

Merö Zs. S. strictissimum. L.

10. Alsó levelei vesealakuak, durva kanyaros-csipkések, a felsők szíves-tojásdadok. hegyes foguak. - Gyepek mellett. útfeleken. $\odot$. April-Jun. 1-2'. (Foghagymaszagufï.)

Hagymaszagu Zs. S. Alliaria. Scop.

Levelei hosszukás láncsások, ritka foguak, villás szöröktől szőrösödők; szirmai a csészénél kétszerte hosszab- 
bak. - Gyepeken. $\odot$. April-Maj. és öszszel ismét. $3-12^{\prime \prime}$.

Gyomos Zs. S. Thalianum. Gand.

\section{SZEGECS. Erysimum. L.}

1. Szárlevelei vállban szívesek, szárölelők, alsó levelei visszás-tojásdadok, közép- és felsö levelei körkörösek; beczői felállók, kopácsai 3 inúak; virága világos sárga. - Bozótokban, hegyi réteken és a vetések közt Buda körül. $\odot$ és $\odot$. Maj.-Jun. 1-2'.

Burján Sz. E. austriacum. Bmg.

Szárlevelei hosszukások vagy szálasok, vállban nem szívesek; virága sárga. 2.

2. Kocsánykái csészeinél 2-3-szor hosszabbak, majdnem felényiek, mint négyszögü s kissé lapitott beczöi; levelei hosszukás láncsások, kanyarosak, egyenlöen háromágu szöreitöl érdesek. - Bozótokban, kövecses helyeken, vízpartokon. ๑. Jun.-Jul. 1-2'.

Ibolya Sz. E. cheiranthoides. $L$.

Kocsánykái akkorák, mint a csészéje. 3.

Ð. Szálas láncsás levelei egyszerű szőreitől érdesek, épélüek vagy ritkán fogasoltak; terméketlen ágai levelei hónaljából nönek; félrehajló zöld ormóju beczői derékszög alatt négyszögüek, szőkék. - Homokon igen böven, azonban van a hegyi gyepeken is. $($. Maj.-Jun. 1-11/2. Szöke Sz. E. canescens. Roth.

Kocsánykái kurtábbak, mint a csészéje. 4.

4. Kocsánykái csészéjénél 2-3-szor kurtábbak; beczöje tompa négyormóju, háta felül kissé lapított, egyenszinű; levelei lánesások, öblösen fogasok, épélủek, érdesek, alól sömörösek, egyszerü vagy csillag szőreitö1 érdesek. -- Hegyi és homoki gyepeken. $\odot$. Jun.-Aug. $1-1^{1 / 2^{\prime}}$.

Sömörös Sz. E. crepidifolium. Rchb.

Kocsánykái felényiek, mint a csészéje. 5.

כ. Levelei hosszukás láncsások, kanyaros fogasok, egyenlő csillgszöreitöl érdesek; beczöi szőkék, zöld ormói 
kopaszok. Hegyi réteken, gyepük és útak mellett bỏven, at homokon ritka. $\odot$. Jun.-Aug. 1-2 $2^{1 / 2}$.

Jószagu Sz. E. ndoratum. Ehrh.

Levelei lánesás-kihegyezettek, kissé öblösen vagy kanyarosan fogasok, vagy épélüek; csaknem hengeres beczöje alig vastagabb, mint vizirányosan elálló vastag kocsánykája. - Szántóföldeken, mezökön útfeleken. ๑. Maj.-Jul. 3-12". Fürtös Sz. E. repandum. L.

\section{1. ÁlszegeCs. Syrenia. Andrzej.}

Szára felálló, lelapult szőrủ; levelei keskeny láncsások, épek; sárga virágai csaknem kocsánytalanok; beczői felállók, szőkék, négyszögüek. - Gyepeken s a legterméketlenebb homokon böven. $\odot$. Jul.-Sept. 6-18". Szüklevelü Á. S. angustifolia. $R b$.

\section{KÁposzta. Brassica. L.}

1. Beczöi főkocsányjához lapultak; minden levele nyeles, alsó levelei félbeszárnyasok, fogasok; a felsők láncsások, épélüek; csészéje levelei, vizirányosan kinyúltak. - Szántóföldeken, vetések közt. ๑. Jun.-Oct. 2-4'. (Sinapis nigra. I.) (Repcsény.)

Repesény K. B. nigra. Koch.

Beczöi fökocsányjától elállók; felsö levelei nyeletlenek, széles válluak, vagy szíves vállal szárölelök. 2.

2. Csészéje levelei felállók, alsó részükön egymáshoz érnek; minden porodája felfelé áll ; fürtje laza, már virágzás elött megnyult; felső levele vállai nem szívesek. - Mivelik, azonban a mezökön itt-ott vadon is terem. $\odot$. Maj.-Jun. 1-1 1/2'.

Fözelék K. B.oleraceu. $L$.

Csészéje levelei félig vagy egészen kinyíltak; kurtább porodái széllyelállók, felegyenesedök; felsö levelei vállai szívesek. 3.

3. Levelei tengerszínzöldek, az alsók félbeszárnyasok, a 
felsők hosszukások, - Szántóföldeken, vetések közt, mivelik is. $\odot$ és $\odot$. Maj.-Jun. 1-21/2'. (Karórépa.)

Karórépa K. B. Napus. $L$.

Mivelés alatti válfajai: a.) A két nyári vékony gyökerü kíposzta repcze. B. Napus oleifera; - b.) az egy nyári vékony gyökerü 7 . repcze. B. Napus anmua; c.) a husos gyökerü $l$. licalarábé. B. Napus esculenta. Levelei füzöldek, vagy csak végre tengerzöldek, alsó levelei félbeszárnyasok, a felsők tojásdadok, kihegyezettek; fürtje virágzás ideje alatt lapos, kinyílt virágai tömött virággombjánál magasabbak. - Mivelik, azonban itt-ott vadon is terem. $\odot$ és $\odot$. Maj-Jul. 1-2 ${ }^{1 / 2^{\prime}}$. Kerekrépa K. B. Rapa. $L$. Mivelés alatti vailfajai: a.) Vékony s egy nyári gyökerü a tavaszi répa repcze. B. Rapa oleifera annua. és a vékony gyökerü két nyári, öszi répa repcze. Br. Rapa oleifera biennis; b.) a töves répa. Br. Rapa esculenta.

\section{MUSTÁR. Sinapis. L.}

1. Levelei tojásdadok, egyenetlen fogasok, alsó levelei vállban fülesek, vagy félbeszárnyasok; beczője kopáesai akkorák vagy alig kurtábbak, mint kétélü esőre, kopácsai 3 inúak, kopaszok, vagy kurta serteszőrủek; virága sárga. - Szántóföldeken vetések közt és réteken közönséges. $\odot$. Maj.-Aug. 6-18". (Repcze.)

Vetési II. S. arvensis. $L$.

2. Levelei szárnyasok, levélkéi egyenetlen durva fogasok, kissé karélyosak; beczője kopácsai akkorák, vagy kurtábbak, mint lapított vagy kardalaku esőre; kopácsai kiálló 5 inúak, keményszörüek; virága sárga. - Vetések közt, Budán ritka. $\odot$. Jun.-Jul. 1-1/1/2'. (Sárga v. lierti mustúr ; kerti repcze.)

Fejér M. $S$. alba $L$.

\section{NYUlga. Erucastrum. Schimp. és Spen.}

Ágas szára felálló, fakó; levelei nyelesek, az alsók bibircsós szőrrel bolyhosak, öblösen szárnyaltak, karélyai 
kerekdedek, alig fogasok; szárlevelei lassanként elkeskenyedő karélyuak, a legfelsők szálas láncsások, kopaszok, épélüek; pongyola fürtje megnyult; virága sárga; beczői kardhegyüek. - Töltéseken. köves helyeken, a budai szőllők gyepüi mellett, a pesti homokon

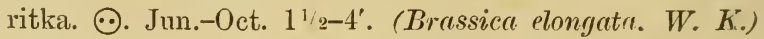
Haraszt $\mathrm{Ny}$. E. elongatum. Reht.

\section{SORAPÁR. Diplotaxis. D. C.}

1. Szára leveles, alja esaknem kórós; alsó levelei szárnyason hasogattak, hasábjai szálasok; felsö levelei épek, szálasok, épélủek, inind kopaszok; kocsányjat kétannyi, mint a virága; szirmai kerekded visszás-tojásdadok s kurta nyakuak. - Hegyi és homoki réteken bőven. 4. Jun.-Sept. 1-1 $1 \frac{1{ }^{\prime}}{}$. Sallangos S. D. tenuifolia. D. $C^{\prime}$.

2. Szára csak tövön leveles, fünemü; levelei ziláltan szîrösek, öblösen fogasok vagy félbeszárnyasok, kerélyai tojásdadok vagy hosszukások, fogasok, a végsö visszás tojásdad, szegletes, fogas: kocsányja virágával egyenlö; szirmai kerekded, visszás-tojásdad, kurta nyakuak. - Az elöbbivel. $\odot$. Jun.-Oct. ${ }^{1}{ }^{\prime}{ }^{-1} 1^{1 / 2}{ }^{\prime}$.

Köfali S. D. muralis. D. C.

\section{TERNYE. Alyssum. L.}

1. Szálcsái belső oldalán tompa fogacskák vannak; táskája rekeszeiben két vagy több magcsa van; törzse kórós; tãvaszi hajtásai hegyökön fürtösön ágasok; fürtje bugás, termése bugája sem nyulik meg; törzse levelei hoszszukások, nyélbe elkeskenyedök, puha molyhosak. Mészsziklákon, a Sz. Gellért oldalán igen bőven. 4. Apr.-Maj. 6-12". Kövi T. A. saxatile. I.

Hosszabb szálcsái tövüktől közepökig szárnyas élīek; kurtább szálcsái tövén hasonlóul szárny forma pót van. 2. 2. Téskája rekeszeiben egy magesa ül: táskája tömött s lelapult csillagszőreitől szőke; tojásdad magva egyik 
oldalán keskenyszárnyu; fürtje lapos bugás; fünemü szárai felegyenesedők, töveiken kórósak; visszástojásdad vagy hosszukás szőke levelei vállban elkeskenyednek. - A homoki mezökön böven. 4. Maj.-Sept. 3-12". (A. alpestre. L.) Sodros T. A.tortuosum. W. K.

Táskája rekeszeiben 2 mag’sája van. 3.

3. Crészéje termésén is állandó; szálcsáin nincs fog, a két kurtább szálcsa töve mindkét oldalán sertefogak vannak; táskája kerekded, igen kurta csillagszőreitől szőke; fürtje szárhegyi ; szára fünemü ; levelei láncsások, az alsók visszás-tojásdadok. - Minden gyepen. • Maj.-Jul. 3-18".

Csészés T. A. calycinum. $L$.

\section{Csészéje lehulló. 4.}

4. Lecsepült s felegyenesedö szára tövön végre kóróssá lesz; fürtje szárhegyi, magános ; táskája tojásdad vagy kerekded, lelapult csillagszöreitöl szöke; levelei szürkék. láncsások, az alsók visszás-tojásdadok. — Száraz réteken bőven. 4. Kora tavasztól juliusig. 3-12".

Hegyi T. A. montanum. $L$.

Szára felegyenesedö, fünemü; fürtje szárhegyi; hosszabb szálcsái fogatlanok. a kurták számyasok s mindkét oldalukon egy-egy sertefoguk van; táskája kerek, egészen kopasz vagy csak élén szemszörös; szürke levelei láncsások; az alsók visszás-tojásdadok. - Homoki és hegyi réteken mindenütt böven. - 'Tavaszszal. $1-6^{\prime \prime}$.

Apró T. A.minimum. Willd.

\section{1\%. Hamuka. Farsetia. R. Br.}

Fünemü szára felálló; szirmai kétmetszetüek; hosszałb porodái tövön szárnyasok, a kurtábbak fogasok; táskája körkörös, domboruan lapított, szőrösödö; levelei láncsások, az alsók nyélbe keskenyedők; virága fejér. - Minden száraz réten, útfeleken, csapásokon. $\odot$. Maj-Jul. 1-1 $1 \frac{1}{2}$ '. (Ternye.) Fejér H. F. incana. $R$. Br. 


\section{LAPICZ. Lunaria. L.}

Szára felálló, hengeres; alsó levelei ellenesek, a felsük váltogatók, szívesek, hegyesek, csipkésen fürészesek, szörösödök; kékes piros virágai sátoros bugát alkotnak; táskái körkörös láncsások, mindkét végök felé kihegyezettek. - I pilisi árnyas erdökben. 4. Maj.Jun. 2-4'.

Begyes L. L. rediviva. $L$.

\section{DARAVIRÁG. Draba. L.}

Szára ágas és leveles; közép és felsö levelei tojásdadok, szárölelök; kocsánykái vizirányosan állanak, kétszer akkorák, mint a táskái; szirmai épélüek, fejérek. Hegyi és homoki minden gyepen. ๑. Maj.-Jun. 6-12". Kövi D. D. muralis. $L$.

Tökocsányja van. 2.

Tökoczányja kopasz; törékeny levelei szálasok, hegyesek, serteszörü szemszörösek; porodái szirmaival egyenlök; bibeszára akkora, mint a táskája kereszt átméröje, virága sárga. - Mészsziklákon Buda körül. 4. Kora tavaszszal. 1-6". Kövér D. D. aizoides. $L$

Tőkocsányja tövön szörös, felsö része s ágai kopaszok; tölevelei láncsások, hegyesek, vállban elkeskenyedök; táskái láncsások, hosszukások v. kerekdedek, kocsánykáinál kurtábbak; bibeszára igen kurta; szirmai eresze bemetszettek; virága fejér. -- Minden gyepen, kora tavaszszal. $\odot$. 2-6". (Füstvirag; korpavirág; ködvir'ig.)

Köd D. D. verna. L.

\section{TORMA. Cochlearia. L.}

Tölevelei hosszukások, szívesek vagy tojásdad-szívesek, csipkések, alsóbb szárlevelei fésüsen szárnyason szabdaltak, a felsök tojásdlad-láncsások, csipkésen fürészesek, a legfelsők szálasok, csaknem épélüek; táskái kopácsai 
és a magrai símák; virága fejér. - Mivelik, azonban vadon is nö. 24. Jun.-Aug. 2-3'.

Orrtekerö T. C. Armoracia. I.

\section{Gomborka. Camelina. Crantz. D. C.}

1. Hengeres és borzas szára közép levelei hosszukás láncsások, épélủek, vagy fogasoltak, vállban nyílalakuak; virága sárga; táskája körtealaku. - Mivelik, azonban réteken és retések közt vadon is terem. $\odot$. Maj.Jul. ${ }^{1,2}, 2$ '.

Magras G. C. sativa. Crantz.

2. Szegletes és kopasz szára igen ágas; szárölelö levelei fülesen nyilasok, hosszudad-láncsások, hegyeskék, fogason fürészesek, kopaszok, a legfelsők szálasok; rirága sárga ; táskája tojásdad-gömbalaku - Agyagos nedves helyeken, nádasokban, szántóföldeken. 4. Jun.-Jul. $1-3$.

Fakó G. C. austriaca. R. Br.

\section{TARsóKA. Thlaspi. L.}

1. Táskái háromszögü-szívesek; alól el vannak keskenyedve; rekeszeiben 4 magesa van; bibeszára igen kurta; szára ágas; fürtje nyult; szárlevelei nyeletlenek, szíresek, annyira szárölelők, hogy a szára általbuvónak látszik. - Hegyi és berki gyepeken. $\odot$. Kora tavaszszal. $3-12 "$,

Általbuvó T. T. perfoliatum. $L$.

Táskái köralakuak, vagy tövön lekerekítettek, felül kicsípettek, laposak. ..

2. Tövéről kurta pázsitos levelü törzseket hajt; virágzó szára egyszerủ; tőlevelei nyelesek, lapiczkás visszástojásdadok, szárlevelei hosszukások, nyilas-vállal szárölelők; táskája rekeszei 1-2 magvuak, bibeszára hosszu; virága fejér. - Hegyi réteken és ligetekben. 4. Maj.-Jun. 6-12".

Hegyi T. T. montanum. $L$.

Termése megérése után az egész növény elszárad; szára ágas; szárlevelei nyilas-válluak, nyeletlenek, fogasok, széles szárnyu táskái nagyok, sok magvuak; virága fejér. 
- Szántóföldeken, vetések közt. zöldséges kertekben.

๑. Maj.-Jul. 6-18". (Nyïfü; nagy borocska; temondcid; vadmustir.)

Vetési 'T. T. arvense. $i$.

\section{PAIZSPÁR. Biscutella. L.}

Táskája tövén és hegyén kikanyarított; cseszéje töve sarkantyutlan; tölevelei hosszukások, nyélre keskenyedők, szárlevelei is hosszukások, nyeletlen, lekerkített vállukkal félig szárölelök, a legfelsök láncsások, virága sárga. Hegyi réteken, mész sziklákon, Buda körül. 4. Jun.-Aug. 6-15". Síkált P. B. laevigata. $L$.

\section{ZSÁZSA. Lepidium. L.}

1. Táskája felső vége nagyon ki van csípve. 2.

Táskája felső vége alig van vagy nincs is kicsípve. j.

2. Szárlevelei szárölelök. 3.

3. Szárlevelei fogasoltak, nyilas vállal szárölelők, ‡lsó levelei hosszukások, nyélbe keskenyedők, vállban öblösen fogasok; tojásdad- és közepétöl szélesen szárnyalt táskái ripacsosan pontozottak; virága fejér; az egész növény szőkén szőrösödő. - Pallagokon, vetések közt, útfeleken közönséges. ๑. Maj.-Jul. 6-18". (Palaczkafï ; vadmustír ; temondádfü.)

Mezei Zs. L. campestre. R. Bro

Szárlevelei épek, mélyen szíves-szárölelök; alsó levelei nyelesek, szárnyasok, bordái sokszorosan sallangosak; táskái kerekded-körkörösek, hegyökön keskeny szárnyuak; virága sárgálló. Telekes helyeken, fedeleken, útfeleken. $\odot$. Maj.-Jun. 6-18".

Felemás Zs. L. perfoliatum. $L$.

4. Táskái kerek tojásdadok, szárnyasok, tompák, fökocsányjához lapulók; alsó levelei nyelesek, szabálytalanul bevagdaltak, karélyosak, szárnyasak, vagy kétszer-szárnyasok; a felsök nyeletlenek, szálasok, épek; 
virága apró fejér. - Mivelik, azonban a kertek körül vadon is nö. $\odot$. Maj.-Jun. 1-2". (Rézsulia; salata-torma.)

Kerti Zs. L. sativum. $L$.

Táskái széllyelállók, kerek-tojásdadok, tompák, hegyökön keskeny szárnyasok; alsó levelei nyelesek, szárnyasok, vagy kétszer-szárnyasok; a felsők nyeletlenek, épek és szálasok; virágai két porodások, sziromtalanok. - Telekes helyeken, zöldséges kertekben, házfedeleken $\odot$. Maj.-Jul. 4-15".

Mecsek Zs. L. ruderale. L.

j. Levelei hosszukások, kanyaros fogasok; tölevelei nyélbe keskenyedők. szárlevelei nyílalaku vállaikkal szárölelök; táskai szívesek, szányatlanok, felpuffadt kopácsai miatt csaknem két-görcsüek; bibeszára akkora, mint táskája válaszfala; virága fejér. - Útfeleken, telekes helyeken, mindenütt. 4. Maj.-Jul. 1-1'1/2. (Borsilico) Borsika Zs. L.Draba.L.

Levelei pozsgások, szökéllök, épek, az alsók nyelesek, tojásdadok, a felsük szárölelök, nyilas tojásdadok, a legfelsök láncsások; táskái tojásdadok, hegyesek, ránczoskák; virága fejér. - A legszárazabb szíkeken, kiváltképen szíksós tavak közelében. 4. Maj.-Jun. 'j-12".

Szíki Zs. L. crassifotium. W. K.

\section{SZIRTŐR. Hutchinsia. R. Br.}

Levelei szárnyasok; leveles szára ágas; szirmai csészéjénél alig hosszabbak; táskái körkörösek, tompák; virágai apró, fejér. - Hegyi nyílt réteken Buda körül, p. o. a Sashegyen $\odot$. Kora tavaszszal. 1-3".

Sziklai Sz. H. petraea. $R$. Cr.

\section{CSAPKA. Capsella. Vent.}

Levelei kaczurosak, szárnyason szabdaltak, sallangjai tojásdad háromszögűek, hegyesek, kissé fogasok; szárlevelei épek, sokféle alakuak ; táskái háromszögü viszszás-szívesek; virága fejér. - Mindenütt. ๑. Apr.- 
Oct. ${ }^{1 / 2}-1^{1 / 2} \cdot 2^{\prime}$. (Paperszény; pásztortáslia; békatarsoly; szüliés; vérállatfü ; porczogófü ; vadmustár.)

Pásztortáska Cs. C. Bursa pastoris. Mönch.

\section{2\%. Táskarag. Senebiera. Pers.}

Szára lecsepült; levelei mélyen szárnyason hasogattak, hasábjai épek vagy elöl bevagdaltak, kocsánykái virágainál kurtábbak; táskái csaknem vesealakuak, lapítottak; hálózatosan ránczosak, tornyadzóalaku bibeszára tetejökön ül; virága fejér. - A Budaörs felé vivő budai ország-útfeleken, ritka. $\odot$. Jun.-Aug.

Pikkelyes T. S. Coronopus. Boir.

\section{TÁsKazÁr. Euclidium. R. Br.}

Szára felálló, hengeres szőrösödő; levelei nyelesek, érdeses szőrűek; tőlevelei öblösen szárnyasok, szárlevelei láncsások, ép, vagy fogas-élủek;; táskái tojásdadok, kurta szöreiktöl érdesek; virágai fejérek vagy verhenyesek. - Ugarokon, vetések közt homokon böven. -. Maj.-Jun. 3-14".

Madárorru T. E. syriacum. R. Br.

\section{CSÜlleng. Isatis. T.}

Szára felálló, szegletes, igen ágas; levelei símák, töve és szára alsó levelei nyélrefutók, hosszudad-láncsások, tompák, csipkések; szárlevelei nyilas vállal szárölelők; táskái hosszukások, igen tompák, lefüggők ; virágai sárgák. - Szántóföldek barázdáin. homoki réteken, vetések közt. Az egész növény tengerszinzöld. $\odot$. Jun.-Aug. 2-4'. (Festöfüi.) Festö Cs. I. tinctoric. L.

\section{BUNKONCZ. Myagrum. L.}

Szára felálló, ágas, kopasz; tölevelei nyélre keskenyedők, hosszukások, öblösen fogasok; szárlevelei nyilas válluak, szárölelök ; táskái visszás-szíves, négy 
czikküek; virága sárga. - Vetések közt. útfeleken gyakori. Az egész növény tengerszinzöld. $\odot$. Maj.Jun. ${ }^{1 / 2}-1^{1 / 2}$. Szives B. $M$. perfoliatum. $L$.

\section{SöMÖrGE. Neslia. Desv.}

Szára felálló, szörösödő; szárölelö levelei nyilas láncsások, épélűek v. alig fogasok; táskái csaknem gömbalakuak; apró virágai sárgák. - Vetések közt, igen ritka. $\odot$. Jun.-Jul. ${ }^{1 / 2}-1^{1 / 2}$.

Pallagi S. N. paniculata. Desi.

\section{Matryó. Calepina. Desr.}

Szára felálló, alig szegletes; levelei kopaszok; tőlevelei pázsitosak, nyelesek. csaknem félbeszárnyasok, szárlevelei öblösen fogasok, a felsők szárölelök, nyilasválluak; tojásdad táskái ránczosak; virága fejér. - Telekes helyeken, szántóföldeken, Budán a várhegyen és a Sz.-Gellérthegy alatt. $\odot$. April.-Maj. 6-12".

Ránezos M. C.Corvini. Dest.

\section{SzÜMCsÖ. Bunias. L.}

Szára felálló, hengeres, ágas, szőrös; tő- és szárlevelei nyelesek, kaczurosan félbeszárnyasok, vagy öblösen fogasok, a középsők alig nyilas kaczurosak, a legfelsők láncsások, vagy szálasok; tojásdad táskái két rekeszüek, bibircsós szümölcsösek; virága sárga. Szántóföldeken, vetések közt, útfeleken. ๑. Jun.-Jul. 1-3'. Napkeleti Sz. B. orientalis. $L$.

\section{ReKEnYŐ. Rapistrum. Boerhave.}

Felálló szára barázdolt, ágas bogas; alsó levelei kaczurosak, öblösek, fogasok, borzasok, a felsök láncsások, csaknem kopaszok, gerinczeiken borzasok; táskája két czikkü, az alsó czikke hengeres, a felsö to- 
jásdad; virága sárga. - Száraz gyepeken, szántóföldeken, útfeleken. 24. Jun.-Jul. 1-2'. (Relienyö.)

Évelö R. R. perenne. Alll.

\section{TÁtorJáx. Crambe. L.}

Fiatal levelei keményszörüek, az idösbek száråval együitt kopaszok; tölevelei kétszer-szárnyasok, szárnyacskái hosszukások, fogasok vagy bevagdaltak; hosszabb porodái hegyei villások, táskáin nincs rajta a bibeszára. - Szántóföldeken. útfeleken, gyepeken a Tisza vidékén. 24. Jul.-Aug. 1-3'.

Buglyos T. C. Tataria. Jacqu.

\section{RETEK. Raphanus. L.}

1. Levelei félbeszárnyasok; beczöje hengeres, kihegyzett, kocsánykájánál alig hosszabb; virága sötét erezetü, világos lilaszinü. - Mivelik kertekben. ๑. Maj.-Jun.

Kerti R. R. sativus. $L$.

2. Levelei félbeszárnyasok; beczöje czikkelyes, czikkelyei egy magvuak, hosszabb, mint a bibeszára, virága sárga vagy fejér. - Szántóföldeken. vetések közt. $\odot$. Maj.-Aug. ${ }^{1 / 2-1 '}$. Repesén R. R. Raphanistrum. $L$.

\section{Rend. Rezedafélék. Resedaceae. D. C.}

\section{REZEDA. Reseda. L.}

1. Csészéje 4 hasábu; levelei zilált állásuak, megnyultláncsások, tompák; vállban két oldalról egy-egy foguak; szára felálló, többnyire magános. ritkán ágas; virágzata tömött füzérnek látszó fürt; virága halványsárga; tokja hosszudad, 4 fogu. - Útfeleken, árokpartokon, réteken, szántóföldeken, mivelik is festéknek. $\odot$. Jul.-Sept. 1-3'. (Korbácsfii.)

Fogas R. R. luteola. $L$. 
Csészéje 6 hasábu. 2.

2. Alsó és közép levelei kétszer számyasok, a felsök 3 hasábuak, hasábjai láncsások, fényesek; szára ágas, virágzata fürtös; kocsánykái akkorák. mint a csészéje ; virága sárgás; tokja hosszúdad, 3 fogu. - Vetések közt, gyepeken, útfeleken, sziklákon. ๑. Maj.-Oct. 1-2'. (Olasz mustír; olasz repcze; vad rezeda.)

Repcze R. R. lutea. $L$.

Alsó levelei épek, a felsők 3 karélyuak vagy 3 hasábuak. 3.

3. Virágai kellemes illatuak; kocsánykái akkorák, mint sárgálló csészéje, tokja 3 fogu, levelei láncsások, tompák, a felsők 3 hasábuak. - Kellemes illatáért mivelik. (Tavasztól-öszig. ${ }^{1 / 2-1 '}$.

Szagos R. R. odorata. L.

Virágai illatnélküliek. 4.

4. Szára felálló, szegletes, ágas, felül érdes; virágzata fürtös; kocsánykái és fejéres bokrétájával egyenlö magas csészéi érdesek; hatszögü tokja élei fulánkosan érdesek, teteje 3 orru. - A Szt.-Gellérthegy déli oldalán, homoki réteken ritka. - Maj.-Aug. 1-1'1/2'. (R. mediterranea. L.) Szagatlan R. R. inodora. Rchb. Szára lecsepült, ágas, ágai felegyenesedők ; alsó levelei lapiczkások; hatszögü tokja 3 fogu ; apró virága fehéres. - Szántóföldek barázrláin, homoki réteken s a vetések közt Budapest körül. - ๑. Maj.-Jul. 3-12".

Kis R. R. Pl, teuma. $L$.

73. Rend. Nimfafélék. Nymphaeaceae. Salisb.

\section{NIMFA. Nymphaea.}

1. Levelei mélyen szíves kerekdedek, épélüek, börtapintatuak; maghonát csaknem tetejéig porodái benövik; sárga bibéje 10-12 sugáru; virága fejér. - Álló és lassan folyó vizekben. 4. Jun.-Aug.

Fejér N. N. albu. L. 
2. Levelei mélyen szíves-kerekdedek, öblösen fogasok, alsó lapjaikon pirosodók, vizen uszó levelei tojásdad-nyílalakuak; virágai fejérek. - A budai Császárfürdő mellett eső meleg forrásban. 4. Jun.-Aug.

Melegrízi $\mathrm{N} . \mathrm{N}$. thermatis. $D$. C.

\section{2. 'I'ÓRÓZSA. Nuphar. Smith.}

1. Levelei tojásdad-szívesek, börtapintatuak, épélüek; válla karélyaiközel állanak egymáshoz, mindkét lapján zöldek; kocsányjai négyszögüek, ormói élesek; rirága sárga; bibéje lapos, épélü; portokai hosszukás-szálasok. - Álló és lassan folyó vizekben, kivált a Tisza körül. 宁. Jun.-Aug. (Vizi tök.)

Sárga T. N. luteum. Smith.

2. Levelei szíves-hosszudadok: válla karélyai tárolodnak egymástól; kocsányjai hengeresek, felomlásosan selymesek; virága sárga, bibéje fogas. - A Duna kiöntéseiben Vácz körül, ritka. 24. Jul.-Aug.

Selymes T. N. sericeum. Láng.

\section{Rend. Szuharfélék. Cistineae. D. C.}

\section{Tetentoldó. Helianthemum. Tourn.}

1. Bibeszára akkora, mint a maghona; kórós szára henyélö; ágai felegyenesedők; pálhátlan levelei ellenesek, szálas hosszudadok, vagy tojásdadok, molyhosak vagy az élök felé csomós szörủek; virágai sárgák. Veröfényes dombokon; sziklás és homokos helyeken bőven. †. Maj.-Jul. 2-4'.

Sziklai T. H. oelandicum. Wahl.

Bibeszára maghonánál 2-3-szor nagyobb. 2.

2. Henyélő szára kórós; pálhátlan levelei ziláltak, szálasok, finom fulánkhegyüek, kissé érdesek, alig szemszörösek; termése kocsányjai risszahajoltak; rirága 
sárga. - Veröfényes mészhegyeken Buda vicékén és homoki gyepeken böven. 5. Jun.-Jul, 3-8".

Kacskörös T. H. Fumana. Mill.

Felegyenesedö szára kórós, pálhás levelei tojásdadok, vagy szálas hosszukások, kurta szőrüek vagy alól molyhosak, szemszörösek, élökön letüremlettek; termése kocsányjai megcsavarodva hajolnak le; viraga sárga. - Minden száraz gyepen és legelön. †. Maj.Sept. 3-18". (Tetemtoldófit.)

Közönséges 'T. H. vulgare. Hürt.

\section{Rend. Harmatfúfélék. Droseraceae. D. C.}

\section{BOGLÁRPót. Parnassia. L.}

Szirmai kurta nyakuak; pilise 9-13 gombos sertével van prémezve; tölevelei nyelesek, szívesek, tompán épélüek, szárlevelei szárölelők; virága fejér. - Hegyeken, nedves gyepeken és tavakban. 4. Jul.-Sept.

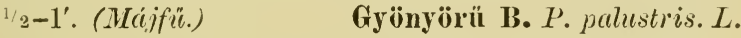

76. Rend. Ibolyafélék. Violariceae. D. C.

1. IBOLYA. Viola. L.

1. Száratlanok; leveleik s kocsányjaik mind a tövéböl nöttek. 2.

Szárba indulók. 4 .

2. Töve ostorindákat hajt; levelei szíves-tojásdadok, alig szörösek, idei ostorindái levelei vesealakuak; levele nyelei tövén levö pálhái tojásdad-láncsás hegyesek, rojtos élüek, kopaszok, hegyökön szemszörösek; termése kocsányja henyélö, tokja szörösödö; kellemes illatu virága sötét lila szinü. - Árnyas helyeken, gyepủk és bokrok mellett. 4. Mart.-April. (Kék viola; szederjes viola; martiusi viola; ivolya; lis ibolya.)

Tavaszi I. $V$. odorata. $L$.

Töve nem hajt ostorindákat. 3. 
ઇ. Levelei tojásdadok, vagy hosszukás tojásdadok, belső későbbi levelei mélyenszívesek: borzas szőrüek, alsó pálhái tojásdadok, a felsők láncsások, rostjaival együtt kopaszok; termése kocsányjai henyélök; tokja szörösödő; illattalan virágai világos vagy közép lilaszinüek. - Gyepeken, gyepük mellett. 24. Apr.-Maj.

Borzas I. V.hirta. L.

Levele vállai széles kikanyaritása miatt szívesek, a külsők tojásdadok, a belsők hosszukás tojáscladok, vállai csuklyásan behajlók; pálhái láncsások. elkeskenyedett hajszálhegyüek, rojtosak, kocsányjai henyélök; tokja sz"jrösödö; virága lilaszinü. - Homoki réteken és homok hegyi erdökben. 24. Apr.-Maj. (V. campestris. M. B.)

Csuklyás I. V. ambigua. W. K.

4. Szára henyélö, s felegyenesedő. ๖. Szára felálló. 6.

5. Szára kurta, szöke szörü vagy kopasz; levelei szívesek. tompák, apró csipkéjüek, az alsók vesealakuak; pálhái tojásdad hosszudadok, hegyesek, levele nyeleinél sokkal kurtábbak; tokja tompa tojásdad, virága halvány viola vagy fejér szinű. - Minden homoki. kivált vizenyős gyepen, e mellett a budai hegyek nyílt oldalain. 4. Maj.-Jun. 1-2".

Homoki I. V. arenaria. D. $C^{\text {. }}$ Szára kopasz vagy alig szörösödö; levelei szívesek. hosszukás-tojásdadok. kurta hegyüek; pálhái hoszsznkás láncsások. rojtos-fürészesek. levele nyelénél sokkal kurtábbak; virága sarkantyuja kétannyi, mint a csészéje pillenpátya; színe sárgás fejér. holott bokrétája sötét lilaszinü. - A hegyi és síki erdökben gyakori, nyílt gyepeken ritka. 24. Maj.-Jun. 6-12". Sovány I. V. canina. $L$.

6. Lefelé álló bibéje horgas, madárcsöralaku. 7. Felegyenesedő bibéje felsö része ékalaku. 9.

7. Szára egysoru szőrü, levele nyele ormóján szörös ; levelei széles szívesek, kurta hegyüek, az alsók csaknem 
resealakuak: elsö tövirágai szirmasok. de terméketlenek, későbbi szárrirágai szirmatlanok; virágai halvány pirosak vagy lilaszinüek. - Minden erdöben. 4. Maj.-Jun. 3-12". Szirmatlan I. T. mirabilis. L. Szára kopasz. 8.

8. Levelei szíves vállal hosszukás-láncsások, nyelei felfelé kissé gatyások; közép szárlevelei pálhái láncsások. hegyesek, felényiek, mint levele nyelei, a felsők akkorák, mint levele nyelei; bokrétája sarkantyuja akkora, mint hegyes levelü csészéje pillenpátyjai; virága fejér, vagy lilaszinü. - Posványos réteken böven. 4. Maj.-Jul. 2-6". (V. lactea. Sm.) Iszap I. I. stagnina. Kit.

Levelei alig szíves vállal-láncsások, nyelei gatyások; közép szárlevelei hosszudad-lánesások, bevagdalt fürészesek, levele nyeleinél hosszabbak; bokrétája sarkantyuja akkora, mint hegyes levelü csécséje pillenpátyjai; virága kék, ritkán fejér. - Hegyi és ligeti réteken, szöllök gyepüi mellett. 4. Jun.-Jul. 6-18". (V.persicifolia. Roth.) Réti I. V.pratensis. M.és K.

9. Levelei csipkések. az alsók tojásdad-szívesek; pálhái félbeszárnyas-szárnyason hasogattak, középső hasál,jai csipkések; sarkantyuja kétannyi. mint csészéje pillenpátyjai; gyökere egyszerü ; szára felegyenesedő ágas. - Gyepeken, telekes helyeken, szántóföldeken. $\odot$ és $\odot$. Maj.-Jul. 2-18". (Csúszair szakiall ; háromsimü viola.)

Háromszínü I. V.tricolor. $L$.

Igen sok válfaja közül nálunk leginkább kettö van : a.) bokrétája kétszinü s csészéjével egyenlő, apró és karcsu : Apró I. (V. arvensis. Murray; b.) bokrétája igen nagy 1-2-3 színü, csészéjénél nagyobb: Kerti I. $V$.

\section{Rend. Tökfélék. Cucurbitaceae. Juss.}

\section{TöK. Cucurbita. I.}

1. Szára kapaszkodó; kaccsai ágasok; levelei szíresek, 5 karélyuak, érdesek, nyelei bördösek; egylaki virág̨ 
sárga; kabakja kerekded vagy tojásdad, síma. - Mivelik. - Jun.-Aug. (Úvitöli; dinka; linka.)

Úri T. C. Pepo. L.

2. Szára kapaszkodó; kacsai ágasok, levelei 5 karélyuak, karélyai szárnyason kikanyargatottak, egylaki virága sárga; kabakja rendszerint gömbalaku, zöld (béle fejér, sárgás vagy piros). Mívelik. •. Jul.-Aug. (Görög(linnye.) Görögdinuye T. C. Citrullus. L.

\section{UGORKA. Cucumis. I.}

1. Szára kapaszkodó; kacesai egyszerüek; levelei szívesek, j szögüek, szögei hegyesek; virága sárga; kabakja hosszukás, szömölesös. -- Mívelik. •. Maj.-Sept.

Savanyító $\mathbf{U}$. C. sativus. $L$.

2. Szára kapaszkodó ; kaccsai egyszerủek; levelei szívesek, 5 szögüek, fogasok, szögei kerekdedek; kabakja gömbvagy tojásalakú, síma, vagy hálózatosan eres, vagy rücskös. - Mivelik. •. Máj.-Sept.

Sárgadinnye U. C. Melo. L.

\section{GÖNYE. Bryonia. L.}

Szára kaccsainál fogva kapaszkodó; levelei szívesek, 5 karélyuak; virágzata fürtösen sátorozó, egylaki virága szennyes-sárga; bibéje kopasz; bogyója fekete. - Gyepükben böven. 24. Jun.-Jul.

Büiös G. B. alba, $L$.

\section{Rend. Porcsinfélék. Portulacaceae. Juss.}

\section{Porcsin. Portulaca. I.}

Szára ágaival együtt lecsepült; levelei hosszukás ékalakúak, pozsgások ; sárga virágai hónaljiak v. szárhegyiek, magánosak vagy 2-3 kocsánytalanok; csészéje metszetei tompa ormójúak. - Gyümölesösökben, szántóföldeken, homoki réteken. $\odot$. Jun.-Oct. (Kövér porcsin; disznóorja; kerti porcsfü.) Kövér P. P. oleracea. $L$. 


\section{Rend. Szegfúfélék. Caryophyllaceae.Fenzl.}

\section{PORCZIKA. Helniaria. I.}

Szára lecsepült, alól kórós; levelei és csészéje kurtaszöszőrüek, levelei hosszúkások és láncsások, vállban elkeskenyedők; pálhái tojásdadok, szárra lapultak; 35 virágú csomói hónaljiak. - Homoki gyepeken és a budai mészhegyeken. 24. Jun,-Jul.

Szöke P. H. incana. Lam.

\section{AsZgallér. Paronychia. Juss.}

Szára lecsepült v. felegyenesedő ; levelei láncsások vagy körkörösek, tompák, szemszőrösek; murvái szélestojásjásdadok, kurta szálkahegyüek, ezüstszínű száraz hártyások, szárhegyi csomójukkal zöldes virágait takarják. - Mészsziklákon, hegyi nyílt téreken Buda körül. 4. Jul.-Aug.

Gombos A. P. capitata. Lam.

\section{CSIBfHur. Spergnla. L.}

Felálló v. felegyenesedő, ágas szára felül enyves, szőrös ; szálas áralaku levelei gyürüsen állanak, felső lapjuk domború az alsón egy barázda nyúlik végig; kocsányja elvirágzás után lekonyul; virága fejér, magvai gömbded-lencsealakuak, apró szemcsés felülete érdes. Szántóföldeken vetések közt, bőven. ๑. Maj.-Jun. $3-10^{\prime \prime}$.

Pallagi Cs. S. arvensis. $L_{\text {r }}$

\section{SZIKLÁR. Scleranthus. L.}

1. Virága többnyire 10 porodás, szirmai fejérrel keskenyen szegélyezett zöldek; csészéje metszetei tojásdadok, hegyesek, keskeny hártyaprémüek, termése csészéje kissé kinyílt; szára henyélő, ellenes levelei szálasok, hegyesek, szemszörösek. -- Szántóföldeken, kertekben, hegyi és homoki réteken, $\odot$. Jun.-Aug. 3-18".

Egynyári Sz. S. annuus. $L$. 
2. Virága 10 porodás, szirmai fejérrel szélesen szegélyezett zöldek; csészéje metszetei hosszukások, lekerekített tompák, széles hártyaprémüek, termése csészéje zárt; szára henyélö ; vastagocska levelei kurták, tengerzöldek. - Szántóföldeken. hegyi és homoki száraz réteken. 24. Maj.-Sept.

Érelö Sz. S. perennis. $L$.

\section{SZAGIÁN. Sagina. L.}

1. Szára lecsepült. tövön gyökerezö, ágai felegyenesedök; levelei szálasok. fulánkos hegyủek, egészen kopaszok; elvirágzott kocsányjai hegyei horgasok, a termést hordók felállók; csészéje levelei tompák, kalásztalanok. - Szántóföldeken, homoki legelökön s erdei gyepeken. 4. Maj.-Jul. 2-4". Heverö Sz. S. procumbens. I.

2. Szára felálló, tövétöl kezdve ágas, oldalágai felegyenesedők; levelei szálasok, fulánkosak, tövön szemszörösek; elvirágzott kocsányjai felállók, alig egy kissé befelé hajlók; csészéje levelei tompák, a két külső igen kurta fulánkos hegyü, fulánkjai befelé görbültek. - A budai szántóföldeken és gyepeken. ๑. Maj.-Jul. $2-6 "$.

Emelkedö Sz. S'. apetala. $L$.

\section{PIKKELYHÚR. Lepigonum. Wahl.}

1. Szára lecsepült, felegyenesedő, ágac, ágai fürtösek; levelei szálas fonalakuak, laposak, fulánkos hegyüek, csészéje levelei láncsások. tompák, innélküliek, élőkön hártyások; virága piros; szárnytalan magvai 3 szögüek, alig ránczosak. - Homoki réteken. szántóföldeken, mocsárok mellett. $\odot$. Maj.-Sept. 3-6". (Alsine muba. Wahl.) Veres P. L. rubrum. Wahl.

๑. Szára lecsepült, felegyenesedö, ágai fürtösek; levelei szálas fonalakuak, alól felül domboruak; kocsányjai virágzás után letüremlettek; csészéje levelei láncsások innélküliek. élökön hártyások. virága piros; hártya karimáju s lapított maggvai finom ránczosak. 
- Szíkrs téreken. sziksós tarak mellett. - Maj.-Sept. 3-6". (Alsine marina. M. K.)

Szárnyasmagru P. L. medium. Waht.

\section{LUDHÚR. Alsine. Wahl.}

1. Töve henyélö törzseivel együtt pázsitos: szirmai csészéje leveleinél hosszabbak. 2.

Töre alig vagy nem is pázsitos; csészéje levelei szirmainál hosszabbak. 3.

2. Levelei szálas áralakuak, ` inúak ; virágzó szára felegyenesedö, vagy egyenes, 1 vagy sok virágu; csészéje levelei tojásdad-láncsások, hegyesek, 3 inúak, szélük hártyás. - Gyepelien. 24. Egész nyáron át. 3-8".

Tavaszi L. A. verna. Bart?.

Levelei áralakuan-sertealakuak; virágzó szárai felegyenesedők, felül bugások; csészéje levelei tojásdadok, hegyesek, csaknem porczogósak, fejérek, rajtok egyegy zöld csík van; tojásdad szirmai a esészéjénél alig hosszabbak. - Minden hegyi és homoki gyepen, köves helyeken. 24. 5-14". Sertelevelü L. A. setacea. M. és K.

3. Csészéje levelei egyenetlenek, szálas áralakuak. igen hegyesek, fejér porczogósak, rajtok egy-egy zöld csík van; kocsánykái murváinál kurtábbak; virágzata csomúsan sátorozó; szára felálló sugár. f łlül ágas, alól szก̋rösödö. - Hegyi és homoki száraz gyepeken a budai mészhegyek köresein. $\odot$. Jun.-Ang. 3-8". (A. fasciculata. M. K.) Csomós L. A.Jacquinii. Koch.

Csészéje levelei egyenetlenek, igen hegyesek, fejér széles szegélyủek, kocsánykái igen kurták; virágzata gombosan sátorozó; szára felegyenesedö, tövön igen ágas ; az egész növény szőrösödő. néha ragacsos ikrásszőrü. - Az elöbbivel. 24. Jun.-Jul. 3-8".

Gombos L. A. glomerata. M. B. 


\section{HoNoKHÚR. Arenaria. L.}

1. Szára felegyenesedö. villásan bugás; levelei tojásdadok, kihegyezettek, nyeletlenek; virágai magánosak, ágai villáiban, vagy levelei hónalja alatt vannak; láncsás esészéje levelei szirmainál másfélszer hosszabbak; szirmai tojásdadok. fejérek. - Legelökön, réteken, szántóföldeken, ligetekben bőven. $\odot$. Maj.-Jul. 3-12".

Kakuk H. A. serpyllifolia. L.

2. Szára felálló sugár; levelei áralakuan sertealakuak, tölevelei csomósak, szárlevelei öszszenőtt ellenesek; sátorozó virágzata háromágu; tojásdad csészelevelei tompák; hártyások ; szirmai tojásdadok, csészéje leveleinél háromszor hosszabbbak. - Nyílt gyepeken Sz.-Endre, Vácz és Gödöllö körül. 4. Maj.-Jun. 1-1¹/2'. (Alsine graminifolia.)

Pázsitlevelü H. A.graminifolia. Schrad.

\section{CSITRE. Moehringia. L.}

Levelei tojásdadok, hegyesek, 3-5 inúak, az alsók nyelesek; kocsányjai akkorák, mint a levelei ; csészéje levelei hegyesek, 3 inúak; szirmai csészéjénél kurtábbak, fejérek. - Ligetekben bőven. ○. Maj.-Jun. :3-12". Hárominú Cs. M. trinervia. Clair.

\section{OLOCSÁN. Holosteum. L.}

Szára kékes-zöld; levelei ellenesek, körkörösek; virágzata ernyös. kocsányjai egyenetlenek, ikrás szörüek. - Szántóföldeken, gyepeken, keritések körül, útfeleken. $\odot$. Maj.-Jun. 2-8".

Ernyös 0. H. umbellatum. $L$.

\section{MadÁrhúr. Cerastium. L.}

1. Murvái és csészéje levelei hegyei füneműek s szakálasok. 2. 
Murvái és csészéje levelei hegyei hártyások és kopaszok. 3.

2. Levelei kerekdedek vagy tojásdadok, az alsók nyélbe keskenyedök; termése kocsánykái akkorák vagy kurtábbak, mint a csészéje; szirmai csészéjével egyenlö hosszuk. - Réteken, legelökön, köves helyeken, köfalakon. - Maj.-Aug. 1/2-1'.

Gombos M. C.glomeratum. Thuill.

Levelei hosszukások és tojásdadok, az alsók nyélbe keskenyedők; bugája felső ágai csomósak termése kocsánykái esészéjénél 2-3-szor hosszabbak, szirmai csészéje leveleivel egyenlők. - Hegyei és ligeti száraz réteken Buda körül bőven. ๑. Jun.-Aug.

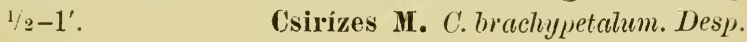

3. Szára felegyenesedő, vagy feálló; levelei hosszukások és tojásdadok; csészéje levelei hegyei kicsípetten fogasoltak; termése kocsánykái csészéjénél 2-3-szor hosszabbak s letüremlettek; szirmai csészéje leveleivel egyenlők v. kurtábbak. - Réteken, legelőkön, kivált a homokun. $\odot$. Maj.-Aug. 1-8".

Herélt M. C. semidecandrum. L.

Szára felegyenesedö, az oldalt állók tövön gyökerezők ; levelei hosszukások v. tojásdadok; termése kocsánykái 2-3-szor hosszabbak, mint épvégü csészéje levelei. - Minden réten, legelön, köves helyeken, köfalakon. (-. Maj.-Aug. ''2-1'. Pongyola M. C. triviale. Link.

\section{CSILlaghúR. Stellaria. L.}

1. Virágzó szára alsó levelei nyelesek 2. Virágzó szára minden levele nyeletlen. 3.

2. Szára hengeres; levelei szálasok; levelei éle kocsánykái és csészéi ragacsos szörösödők; szirmai kissé bemetszettek, fejérek, mint a többiek is. - Homoki réteken, szántóföldeken, legelőkön és szíkes mezőkön. $\odot$. Maj.-Jun. 3-6". $\quad$ Ragaesos Cs. S. viscida. M. B. 
Szára felegyenesedö, villás, egy soru szörös; levelei tojásdadok, kurta hegyüek; virágai szárhegyiek és szára villáiban ülők, szirmai kéthasábuak, csészéjénél kurtábbak; porodája 3-5, csészéjénél hosszabb ; tokja hosszukás. - Kertekben. szöllökben, mivelt téreken. ๑. Egész nyáron, őszön. 3-16". (Ludhư ; tikszúr ; رipehur ; tyulibegy; egérfüil ; “rnyék szeretö fü.)

Gyenge Cs. S. media. Vill.

3. Szirmai középig bemetszettek; levelei nyeletlenek. láncsások. hosszan kihegyezettek s érdes élüek; murrái fünemüek: szirmai csészéjénél kétszer hosszabbak; gömbalaku tokja akkora, mint a csészéje. - Bozótokban, ligetekben, gyepük körül a budai hegyeken. 4. Maj.-Jun. $1 / 2-1^{1 / 2}$ '.

Olocsán Cs. S. Holostea. L. Szirmai egész a tövéig kéthasábuak. 4.

4. Szára leginkább elterült, 4 szögü, kopasz; levelei füzöldek, vállban szemszörösek; murvái is szemszörösek; szárhegyi sátorozó virágzata végre igen kinyíló; szirmai csészéjével egyenlők; tokja hosszukás. - Gyepeken. 24. Maj.-Jun. 1-2'. Pázsit Cs. S.graminea. L.

Szára leginkább felálló; levelei kopaszok, szálas láncsások, többnyire kékes zöldek ; murvái hártyások, élökön kopaszok; bugája nem igen nyílik ki, majdnem oldalt álló ; szirmai csészéjénél hosszabbak; tokja hosszukástojásdad. - Vizenyős réteken; árkokban, mocsárok mellett. 24. Jün.-Aug. 1-1'²'. Fakó C's. S'.glauca. With.

\section{PUHAR. Malachium. Fries.}

Szára lecsepült és kapaszkodó, tövön gyökerezö; levelei szíves-tojáscladok, kihegyezettek, nyeletlenek, a nem virágzó szárain levők nyelesek; bugája villás, ikrás szörös; kéthasábu szirmai esészéjénél hosszabbak. Vizenyös helyeken, árkokban, patak széleken. 4. Jun. -Aug. 1-2'.

Vizi P. H. aquaticum. Fries. 


\section{SZEGFÜ. Dianthus. L.}

1. Hat levelü galléra hártyanemü áttetszö, zörgős, a 3 külsö felényi, mint a 3 belsö, a külsök fulánkos hegyüek, a belsök tompák, csészéjénél hosszabbak; csészéje levelei a hozzájok hasonló gallérba vannak beburkolva, szára kopasz; szárhegyi virágzata gombos vagy magános; halvány piros, apró szirmai asszuk. - Hegyi és homoki réteken. sziklákon. $\odot$. Jul.-Aug. ${ }^{1 / 2}-2$ '.

Asszú S\%. D. prolifer. $I$.

Galléra pikkelyei fünemüek, vagy nincsenek. 2.

2. Szirmai épélüek v. fogasok, rízsa- vagy testszinüek. 3. Szirmai ujjason bevagdaltak. 7.

3. Virága magános; körkörös csésze pikkelyei kalászosak s kettösek; szára szörösödö, érdes; levelei szálas láncsások; szirmai visszás-tojásdadok, fogasok, rózsa v. testszinüek, fejér pettyes szirmai torkolatán sötét rózsaszinü karika van. - Homoki, hegyi és erdei réteken. 24. Jul.-Aug. ${ }^{1 / 2}-1^{1 / 2}$

Klárizsos Sz. D. deltoides. $L$.

Virágzata csomós, vagy csomósan gombos. 4.

4. Börnemű barna galléra zörgős. 5.

Fünemü galléra nem zörgös, szörös v. szemszörös. 6.

5. Szárhegyi virágzata többnyire 6 virágu gömböt alkot; galléra pikkelyei tompák, áralakuan kalászosak, kalászai felényiek, mint a csészéje csöve; szirmai ereszei akkorák, mint a nyakuk; levelei szálasok, hüvelyei hosszabbak, mint a levele négyszeres szélessége. Gyepeken. 4. Maj.-Jul. 1-21/2'. (Barait v. német szegfü.) Barát Sz, D. Carthusianorum. $L$.

Szárhegyi virágzata 12-30 virágu gömböt alkot. A többi jegyeiben a Barát Szegfüvel egyenlö. - Homoki hegyoldalokon. 24. Maj.-Aug. 1-2'. (D. polymorphus. M. B.) Gyászoló Sz. D. atrorubens. All. 
6. Murvái és csészéje pikkelyei láncsás-áralakuak, érdes szőrüek; levelei láncsások, elörészökön elkeskenyedettek, tompa hegyüek s szárával együtt szőrösödők; fürészes élü, piros szirmai fejér pontuak. - Ligetekben, vágásokon, gyepük mellett. ๑. Jul.-Aug. 1-3’. (Mezei szegfü.)

Szeplös Sz. D. Armeria. L.

Murvái láncsások, csésze pikkelyei tojásdadok, fünemü kalászai akkorák, vagy 2-3-szor hosszabbak, mint a csészéje csöve; levelei szálas láncsások, elkeskenyedve hegyesek, 5 inúak, hüvelyei akkorák, mint a levele szélessége, kurta szemszőrösek; szirmai pirosak, nyaka fejér. - Hegyi réteken, erdei utak és gyepük mellett. 2. Jul.-Sept. 1-2 ${ }^{1 / 2}$ '.

Dombi Sz. D. Seguerii. Vill.

7. Szára 2-5 virágu; virágai magánosak; csészéje pikkelyei kerekded-tojásdadok. kurta fulánkos hegyủek; levelei szálas-áralakuak, élökön érdesek; ujjason bevagdalt fejér szirmai közepe visszás-tojásdad; törzse henyélö, ágas, gyökerező és pázsitos. - Mészhegyi sziklákon böven. 4 . Jul.-Aug. ${ }^{1 / 2}-1$ '.

Tollas Sz. D. plumarius. $L$.

Ennek válfaja a homokon termö, s September-Octoberben virágzó :

Késöi Sz. D. serotinus. W. $K$. Szára többnyire magános 2 s több virágu; csészepikkelyei tojásdadok, kihegyezett kalászosak; szálas láncsás levelei kihegyezettek; szárnyason hasogatott szirmai sertehasábuak, közepe hosszukás ; virága halvány piros. - Nedves réteken. 24. Jul.-Sept. 1-3’.

Buglyos Sz. D. superbus. $L$.

\section{DERCZEFU゙. Gypsophila. L.}

1. Szára felálló, csaknem villás, ágas-bogas ; virágai ziláltak, világos pirosak; csészéje körtvélyalaku, 5 fogu; mindkét végök felé elkeskenyedö levelei szálasok. Szántóföldeken, gyümölcsösökben. $\odot$. Jul.-Sept. 3-18".

Gyepi D. G. muralis. L. 
Szára tövén felegyenesedő, vagy tövétöl kezdve elágazó. ․ 2. Szára teteje tömötten sátorozó, felsö része ágaival együtt ragacsos szőrösödö; levelei láncsások, mindkét végök felé elkeskenyedők; csészéje harangalaku; porodái és bibeszára bokrétájánál hosszabbak, virága fejér vagy verhenyes. - Homoki gyepeken. 4. Jun.-Aug. 1-3'.

Homok D. G. fastigiata. $L$.

Szára bugás, alól kurta szőrü; bugája terepély, pongyola, kopasz; levelei láncsások igen hegyesek, többnyire 3 inúak; csészéje medenczealakulag harangalaku; bokrétája fejér. - Homokon, szántóföldeken, köves helyeken. 4. Jul.-Aug. 2-4.' Boglyos D. G. paniculata. L.

\section{6. ÉKFU゙. Tunica. Scop.}

Levelei kurták, szálasok, hegyesek, élökön érdesek ; vállban hártya szegélyüek, szárra lapultak; csészéje harangalaku, tompa 5 fogu; bokrétája halvány piros. - Száraz és szíkes mezőkön. 4. Jul.-Sept. 1/2-1'.

Kötörö É. T. saxifraga. Scop.

\section{1\%. SZAPPANFÜ. Saponaria. L.}

Virágzata csomósan sátorozó; csészéje hengeres, kopasz; verhenyes fejér szirmai csonka tákosak; szára felálló; levelei hosszukás körkörösek. - Szántóföl. deken, útfeleken, kertek körül. 24. Jul.-Sept. 1-2'. (Szappanfü; tajtékzófü ; lcibmosöfü.)

Tajtékzó Sz. S. officinalis. $L$.

\section{BöGresZeG. Vaccaria. Medik.}

Virágzata ritkásan sátorozó; csészéje ormói szárnyasok ; piros szirmai csipkéi egyszerủek, felálló szára kopasz; levelei láncsások, tövön összenöttek. - Szántóföldeken, vetések közt. $\odot$. Jun.-Aug. 1-21/2'.

Vetési B. $V$. parviflora. Mönch. 


\section{SZILÉNE. Silene. L.}

1. Szirmai bokrétája torkolatánál egyszerüek (táknélkü liek). 2.

Szirmai bokrétája torkolatánál tákosak. 5.

2. Tirágzata sátorozóan bugás. villás és szárhegyi; csészéje tojásdad, felfuvódott, fejér hártyanemü, sinóros, hálózatosan erezett kopasz; szirmai lemeze 2 hasábu, tövén két pup van. - Gyepeken, legelökön, gyepük mellett. 4. Jun.-Sept. 1-3'.

Hólyagos Sz. S. inflata. Sm.

Virágzata bugás vagy fürtös. 3.

3. Szirmai épek, szálasok, zöldek, kopaszok; fürtje ágai ellenesek, kocsányjai gyürüsen fürtösek; tölevelei lapiczkások, láncsás szárlevelei tövön összenöttek nyeletlenek. - Száraz gyepeken, hegyeken és a homokon egyaránt. 24. Maj.-Jul. $1^{1 / 2}-2^{1 / 2} 2^{\prime}$.

Fodorszirmu Sz. S. Otites. Sm.

Szirmai két hasábuak. 4.

4. Gyapjas szöre ragacsos; fürtje gyürüs; kocsányjai ellenesek, 1-3 viráguak; csészéje hengeres, közepén kissé hasas; fogai tompák; levelei fodrosak. - Homoki réteken gyakori, hegyi gyepeken ritka. $\odot$. Jun.-Jul. 2-3:.

Enyves Sz. S. viscosa. Pers.

Az egész növény szőrösödö ; fürtje nyult, gyürüs forma ; csészéje ékalaku, sinóros; levelei érdesek, tölevelei nyelesek, ékalakuan láncsások, szárlevelei szálas láncsások, tövön összenőve szárölelők. - Homoki, kiváltképen nedves réteken böven. $\odot$. Maj.-Jun. 1/2-3'.

Sokvirágu Sz. S. multiflora. Pers.

๖. Csészéje 30 sinóru; szirmai visszás-szívesek; tokja hosszukás tojásdad; levelei szálas láncsások. - Vetések közt, homokon, köves helyeken. ๑. Maj.-Jun. 3-18".

Kúpos Sz. S. conica. L.

Czészéje 10 sinóru v. 10 karczolásu. 6. 
6. Szirmai épek, kicsípett élüek; csészéje csövesen ékalaku; szárhegyi virágzata tömött csomóban álló sokvirágu buga; az egész növény kopasz, azonban szára felsö bütykei gyürüsen ragacsosak; levelei tojásdadok. - A budai Széchenyi (Sváb) hegyen. ๑. Jun.-Aug. $1-1^{1} \cdot 2^{\prime}$.

Szegfï Sz. S. Armeria. L.

Szirmai két hasábuak. 7 .

7. Virágai villás águ szára hegyén magánosak, felállók ; szára kocsányjaival együtt ragacsos, gyapjas; levelei hosszukások, hegyesek, a legfelsők láncsás tövükkel keskenyen összefutók, a legalsók visszás-tojásdadok ; virága halvány testszinü. — Bozótokban, vágásokon. gyepük mellett, ritka. •. Jul.-Sept.

Estveli Sz. S. noctiflora. $L$.

Virágai nem szárhegyiek s nem magánosak. S.

\$. Virágzata fürtös. 9.

Virágzata bugás. 10.

9. Fürtje kétágu, fürtje virágai párosak; csö,ves s kissé hasas csészéje kurta kocsányjával együtt bókoló. termése csészéje tojásdad-hosszukás s felálló; levelei körkörös-láncsások, kihegyezettek, lapiczkások; virága fejér. - Hegyi szántóföldeken, ligetekben, Buda körül. $\odot$. Maj.-Jun. 1-2'.

Kétkètágu Sz. S. dichotoma. Ehrh.

Fürtje ritka virágu; hosszu kocsányu virágai ellenesek; csészéje igen hosszu, a termésén bunkós; alsó levelei hosszu nyélbe keskenyedők, visszás láncsások, a felsők összenőve nyeletlenek. láncsások, tövön szemszörösek; magános szára felegyenesedő. - Hegyi réteken, köves helyeken, homoki réteken s szántóföldeken. 24. Jul-Octob. 1-3'.

Gór Sz. S. longifora. Ehrh.

10. Ágai és bugái ellenesek, ágai háromfelé ágasok, 3-7 viráguak, egy soruak, bugái konyák; csészéje csöves. fogai hegyesek; levelei hegyesek, láncsás körkörösek, az alsók majdnem lapiczkások, a felsök szálas láncsá- 
sek; szára felegyenesedö. - Hegyi réteken és ligetekben. 4. Maj.-Jun. 1-2'. Konya Sz. S. nutans. I.

Bugája terepély, kevés virágu ; szára felül enyves; tőlevelei tojásdad lapiczkások, szárlevelei tojásdad hegresek; csészéje áttetszö, termése csipkéje hasas; virága zöldes fejér. - A pilisi hegy tövén találta Heuffel - ritkaság. 24. Jun.-Jul. 1-2'.

Zöldvirágu Sz. S. viridiflora. L.

\section{KUKUBA. Cucubalus. Tourn.}

Szára kapaszkodó, ágai terepélyesen széllyeltartanak; levelei hosszukás tojásdadok, hegyesek; csészéje hasason harangalaku; zöldes fejér szirmai kétmetszetüek; fekete fénylö bogyói gömbalakuak. - Gyepükben, bozótokban a hegyeken ritka, a szigeteken gyakori. 4. Jun.-Aug. 2-6'.

Bogyótermö K. C.bacciferus. $L$.

\section{MécsviráG. Lychnis. D. C.}

1. Szirmai épek, tákosak; levelei és szára tömötten molyhosak; kocsányjai esészéinél sokkal hosszabbak; levelei tojásdad-láncsások, börtapintatuak. - Ligeti réteken, berkekben, a budai kincstári a sz.-endrei s ráczi erdőkben. ๑). Jun.-Jul. 1-3’. (Kassai rózsa.)

Rózsás II. L. coronaria. Lam.

Szirmai bemetszettek 2.

2. Szirmai 4 hasábuak, hasábjai szálasok, tenyeresek, veresek, szárlevelei szálas láncsások. - Nedves réteken. 4. Maj.-Jul. 1-3'. (Kakuk szegfü.)

Kakuk M. L. Flos cuculi. $L$.

Szirmai 2 metszetüek, 3.

3. Szára aláfelé gyapjas; felső levelei tojásdad-láncsások, elkeskenyedve kihegyezettek, kocsányjai csészéive, együtt ikrís kurta szörüek: tokja tojásdad-kupalaku, 
fogai elöreállók; kétlaki virága fejér, estve nyílik. Réteken. gyepeken mindenütt. $\odot$. Jun.-Aug. 2-3'.

Esti M. L. vespertina. Sibthorp.

Szára levelei, kocsányja és csészéje gyapjas ; felső levelei tojásdadok, hirtelen kihegyezettek; tokja kerekded-tojásdad, fogai lekunkorodottak; két laki virága piros; nappal nyílik. - A pilisi hegy magasabban fekvö berkeiben. 24. Jun.-Aug. 2-3'.

Nappali M. L. diurna. Sibthorp.

\section{ENYVENCZ. Viscaria. Röhl.}

Szára kopasz, felső bütykei alatt enyves; levelei láncsások, kopaszok, vállban szemszörösek; virágzata. fürtösen bugás, csaknem gyürüs; szirmai pirosak, épek, tákosak. - Ligeti réteken, berkekben. 4. Maj.Jul. $1-2^{1 / 2}$.

Közönséges E. V.vulgaris. Röhl.

\section{KONKOLY. Agrostemma. L.}

Szára és levelel lelapult szörrel bolyhosak; levelei szálas láncsások, hegyesek; magános virágai hosszu kocsányuak, pirosak; szirmai hullámosan csipkések; csészéje metszetei szirmainál hosszabbak. - Vetések közt böven. $\odot$. Jun.-Jul. 1-3’. (Konkioly.)

Vetési K. A. Githago. L.

80. Rend. Mályvafélék. Malvaceae. Juss.

\section{Paizssajt. Lavatera. L.}

Szára fünemü, molyhos; alsó levelei szegletesen karélyosak, a felsők 3 karélyuak; kocsányjai magánosak, levele nyeleinél hosszabbak; halvány piros szirmai két karélyuak. - Hegyi és homoki réteken, szántoföldeken. 24. Jun.-Aug. 11'2-3'.

Nagyvirágu P. L. thuringiaca. $L$. 


\section{ZiLIZ. Althea. L.}

1. Kocsányjai sokviráguak, leveleinél kurtábbak; levelei mindkét lapjokon puha-molyhosak, egyenetlen csipkések, szívesek vagy tojásdadok, az alsók öt-. a felsők három-karélyuak. - Nedves helyeken, füzesekben. szántóföldeken gyakori. 4. Jun.-Sept. 2-5’. (Fijèr múlyva ; malıola; mazola; ziliz.)

Mahola $\boldsymbol{Z}$. A. officinalix. $\boldsymbol{L}$.

Kocsányjai 1-2 viráguak. 2.

2. Koccányjai leveleinél kurtábbak, egy viráguak, felsö kocsányjar csészéjénél kurtábbak s tág füzért alkotnak; külsö csészéje belsö csészéjével egyenlö; szirmai kicsípetten 2 karélyuak, hosszabbak, mint szélesek, lilaszinüek, tövön sárgák; levelei csipkések, az alsók szíves-kerekdedek, a felsök 3 karélyuak. - . A budai száraz réteken és szántóföldeken böven. ( $\odot$. Jun.-Sept. 3-5'. Halovány Z. A. pallida. W. K. Kocsányjai leveleinél hosszabbak. 3.

3. Levelei molyhosan érdesek, egyenetlen fürész-foguak az alsók tenyeresek, a felsők ujjasok, a legfelsők hármasok; kocsányjai 1-2 viráguak, virágai rózsaszínủek, tövön sötét pirosak. -- Útfeleken, szántóföldeken, bozótokban böven. 4. Jul.-Sept. 3-5'.

Kender Z. A. cannabina. $L$.

Levelei csipkések, vizirányosan széllyelálló durva szörösek, az alsók vesealakuak s karélyosak, a középsők tenyeresek, a legfelsök 3 hasábuak; csészéje hascíbjai megnyult láncsások, virägai pirosak. - Szántófüldeken, réteken, vetések közt, bozótokban, ritka. @ . Jun.-Sept. 1-3'. Borzas Z. A. livisuta. $L$.

\section{MÁlyVA. Malva. L.}

1. Alig kicsípett szirmai csészéjével egyenlők; külső csészéje szálas láncsás; termései prémesek. horpadozottan ránczosak; kocsányjai csomósak, virágzás után 
lefelé hajlók; szirmai akkorák. mint a csészéje, világos rózsaszínüek; lecsepült s felegyenesedő szárán levelei szíves-kerekdedek, 5-7 karélyuak. - Telekes helyeken, szíkes legelökön. •. Jun.-Oct. 6-12".

Északi M. M. borealis. Wallm.

Mélyen kikanyarított szirmai csészéjénél hosszabbak. 2. 2. Szára lecsepült, vége felegyenesedő; levelei szíves-kerekdedek, 5-7 karélyuak; kocsányjai csomósak. virágzás után lefelé hajlók, szirmai csészéjénél 2-3-szor hosszabbak, világos rózsaszínüek; terméseik éle lekerekített, síma v. alig ránczos. - Az elöbbivel, házak körül. ๑). Jun.-Oct. 6-18". (Apró, vagy kerelinályva; lis papsajt; haslígyitófü; úti mályva.) (Malva rotundifolia. L.)

Kerek M. $M$. vulgaris. Fies.

Szára felálló vagy felegyenesedő; levele nyelei kocsányjaival együtt érdes szőrüek; levelei 5-7 karélyosak; kocsányjai csomósak, elvirágzás után felállók; szirmai csészéjénél sokkal hosszabbak, piros erezetü rózsaszínüek; termése prémes, horpadozottan ránczos. Az elöbbiekkel ègyütt. $\odot$. Jun.-Oct. 1/2-3’. (Nagy p'apsajt.)

Eroilei M. $M$. sylvestris. $L$.

\section{HIBIK. Hibiscus. L.}

Levelei fogasok, az alsók esaknem épek, a felsők 3 hasábuak, hasábjai láncsások, közép hasábjai igen hosszuk; csészéje felfuvódott, hólyagos, erezett; bokrétája sárgás, szirmai tövei sötét pirosak. - Szán-

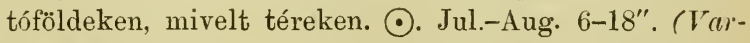
jumcili ; dinnyefü.)

Dinnye H. H. Trionum. $L$.

\section{SÁRDA. Abutilon. Gürtı.}

Levelei kerekded szívesek, kihegyezettek, csipkések, molyhosak; kocsányjai levele nyelénél kurtábbak; virága sárga; mintegy 15 kettős csonka csőrü érdes 
magvacskája van. - Faluk körül, telekes helyeken a Tisza felé eső réteken. $\odot$. Jul.-Sept. $1^{1 / 2}-5^{\prime}$. (Sida Abutilon L.) (Sćrda-mályva.)

Selyem S. A. Avicennae. Gärtn.

\section{Rend. Szódokfélék. Tiliaceae. Juss.}

\section{SZÓDOKFA. Tilia. I.}

1. Levelei kerekdedek, szíves ferde válluak, kihegyezettek, alól apró szőrüek, levele inai zugaiban fejér szakáluak; sátorozó virágzata 2-3 virágu; bibéje karélyai felállók; levele és gyümölcsei nagyobbak, mint a következő fajé s annál 1-2 héttel korábban virágzik. Erdőkben és sétatéreken. ち. Jun. (Hírsfa; szilldolifa; szódókfa.)

Nagylevelï Sz. T. grandifolia. Ehrh.

2. Levelei kerekdedek, szíves ferde válluak, kinegyezettek, mindkét lapjukon kopaszok, alsó lapja tengerszín zöld levele inai zugaiban rozsda szinü szakáluak; sátorozó virágzata 5-7 virágu; bibéje karélyai vízirányosan széllyelállanak. - Az elöbbivel együtt. ち. Aprólevelü Sz. T. parvifolia. Ehrh.

\section{Rend. Linkafélék. Hypericineae. D. C. \\ 1. LINKA. Hypericum. L.}

1. Csészéje levelei épélüek. 2.

Csészéje levelei ikrás fürészfoguak. 3.

2. Szára felálló kétélü; levelei tojásrlad hosszukások, áttetsző pontokkal pettegetettek; virágzata sátorozó; csészéje hegyes levelei, maghonánál kétszerte hoszszabbak; porodája 50-60. - Réteken, szántóföldeken, bozótokban bőven. 4. Jun.-Aug. $1^{1 / 1} 2-2^{\prime}$. (Csengöfü; orbainczfü ; lyukias levelüfü.)

Csengö L. $H$. perforatum. $L$. Szára felálló, négyszögü; levelei tojásdadok, áttetszően pontozottak; csészéje tompa levelei körkörösek, kö- 
rülbelöl akkorák, mint a maghona. - Nedves réteken, mocsárok mellett bőven. Jun.-Aug. 11/2-2'.

Négyszögï L. $H$. quadrangulum. $L$.

3. Felálló szára hengeres; nyeletlen levelei szíves-tojásdadok, a felsők áttetszőn pontozottak, alól érdesek, csészelevele szemszőrein levő ikrái nyelesek; magvai finom pontozatuak. - Berkekben, bozótokban, vágásokon és hegyi réteken. 24. Jun.-Jul. 1-3'.

Hegyi L. H. montanum. L.

Felálló szára hengeres; kurta nyelü, levelei tojásdadok, vagy hosszukások, áttetszö pontozatuak s szárával együtt érclesek; esésze levelei szemszőrei igen kurta nyelüek; magvai bársonyosak. - Az előbbivel együtt. 4. Jun.-Jul. 2-3'. Borzas I. H. hirsutum. I.

83. Rend. Látonyafélék. Elatineae. Cambess.

\section{LÁTONYA. Elatine. L.}

1. Levelei ellenesek, nyeleiknél kurtábbak; virágai kocsánytalanok vagy igen kurta kocsányuak; 8 porodás virága 4 szirmu, fejér vagy rózsaszinü. - Kiszáradt mocsárok- és posványokban. $\odot$. Jun.-Jul. 2-4".

Cseplesz L. E. Hydropiper. L.

2. Levelei hármával-négyével gyürüsök, nyeletlenek, a vízben levők hajszál, a vízből kiérők tojáskerek alakuak; virágai fejérek. - Az előbbivel. ๑. Jun.-Jul. 4-6".

Pocsolya L. E. Alsinastrum. $L$.

84. Rend. Jávorfélék. Acerineae. D. C.

\section{JÁvor. Acer. L.}

1. Virágzata fürtös. 2 .

Virágzata sátorozó. 3.

2. Levelei szíves-tojásdadok, alig karélyosak, kétszer fürészesek; nyelei veresek, szöröskék; virágzata fürtjei 
billengesek; leppendéke szárnyai csaknem párhuzamosan állók, éretlen korukban alig szörösödők, érett korukban vérpirosak. - A budai erdőkben. Ђ. Maj.Jun. 10-15'. (Feketegyürï.)

Feketegyürü J. A. tataricum. $L$.

Levelei tenyeres 5 karélyuak, alól bágyadt és tengerszínzöldek, karélyai kihegyezettek, egyenetlen csipkés fürészesek; fürtjei lefüggők; termése szárnyai kissé széllyelállók. - Magasan fekvő erdőkben és kertekben. †. Maj.-Jun. 16-30'. (Jívorfa; juluarfa.)

Juhar J. A. Pseudoplatanus. L.

3. Levelei tenyeres 5 karélyuak, öblösen $3-5$ foguak, fogai elkeskenyedve hajszálhegyủek; sátorozó virágzata felálló, tövön fiatal leveleivel együtt ikrások; maghona kopasz; leppendéke szárnyai nagyon szély. lyelállanak. - $\mathrm{Az}$ elébbivel együtt. †. April.-Maj. $15-25^{\prime}$.

Jókori J. A. platanoides. $L$.

Levelei tenyeres 5 karélyuak, karélyai épéli̋ek, hoszszukások, a középső tompa 3 karélyu; sátorozó virágzata felálló; csészéje levelei szirmaival együtt szálasok, gyapjasok; leppendéke szárnyai vízirányosan állók. - Berkekben, gyepükben, bozótokban. †. Apr.Maj. 6-15'. (Fodor-jivor; juthar ; iharfa.)

Fodor J. A. campestie. $L$.

\section{2. ÁTORNA. Negundo. Mönch.}

Levelei füzöttek, páratlan szárnyasok, levélkéi száma 3-5, állásukra nézve ellenesek, alig vagy durva fogasok, páratlan levélkéje többnyire 3 karélyu. Virága sárgás fejéres verhenyes. - Ültetett ligetekben, mivelik. †. Febr.-Mart.

Körislevelï A. $N$. fraxinifolium. Nutt. 
85. Rend. Bokrétafafélék. Hippocastaneae. D. $C$.

1. Bokrétafa. Aesculus. L.

Levelei ötösek; felálló virágzata bugás, termése tokja tüskés. - Mivelik. †. Maj.-Jun. (Vadgesatenyefa.)

Gesztenye B. A. Hippocastanum. I.

86. Rend. Csészeszárnyfélék. Polygalene. Juss.

\section{Csészeszárny. Polygala. L.}

1. Maghonának alig van kocsánykája; csészeszárnyai hoszszukások vagy tojásdadok, 3 inúak, oldalinai alig erezettek, erei nem hálózatosak; tölevelei pázsitosak, visszás-tojásdadok vagy lapiczkások, szárlevelei szálas-láncsások; virága kék. - Homoki nedves réteken, hegyeken ritka. 4. Maj.-Jun. 6-8".

Keserï Cs. $P$. amara. $L$.

Maghona kocsánykája virágzáskor akkora, mint a maghona vagy annál hosszabb. 2.

2. Csészéje szárnyai körkörösek, 3 inúak, inai a hegyénél egy ferde érrel vannak egybekapcsolva, oldal inai halózatosan erezettek; maghona kocsánykája maghonanál 3-4-szer hosszabb; levelei szálas-láncsások, hegyesek, az alsók visszás-tojásdadok, tompák \& nem pázsitosak; viráza rózsaszinü. - Hegyi és homoki száraz réteken. 2. Maj.-Jul. 1-1/1/2'.

Nagyobb Cs. P. major. Jacqu.

Csészéje szárnyai körkörösek vagy tojásdadok, 3 inúak, inai a hegyénél egy ferde érrel vannak egybekapcsolva, oldalinai hálózatosan erezettek; maghona kocsánykája akkora, mint a maghona; alsó levelei körkörösek vagy visszás-tojásdadok, tompák, pázsitot nem alkotnak, szárlevelei szálas-láncsások, virága kékes, rózsaszínű v. fejér. - Az elöbbivel. 4. Maj.-Jun. 4-12". (Pacsirtafü; téjhozófü.) Pacsirta Cs. P. vulgaris. $L$. 
87. Rend. Halyogfafélék. Staphyleaceae. Bartt.

\section{HALYOGFA. Staphylea. L.}

Levelei szárnyasok, 5-7 levélkéi hosszukás láncsások, kopaszok, fürészesek; virágzata fürtös; fejéres verhenyes; tokja hártyanemü, felfuvódott. - Erdőkben, bozótokban mindenütt. †. Maj.-Jun. (Halyogfa; hólyagmogyoró.)

Iogyorós H. S. jinnata. $L$.

88. Rend. Csutkalomfélék. Celastrineae. $R$. $B$ r.

\section{KECSKERÁGó. Evonymus. L.}

1. Ágai négyszögüek, símák; levelei körkörös-lánesások, apró fürész-foguak, kopaszok; szirmai zöldesek, hoszszukások; tokjai leginkább 4 karélyuak, tompaélüek, símák. - Erdőkben, gyepükben. - ち. Maj.-Jun. 8-18'.

Csíkos K. E. curopaeus. L.

2. Ágai hengeresek, bibircsósok; levelei körkörösek, apró fürész-foguak. kopaszok ; kocsányjai ezérnaszáluak; kerekded zöldes szirmai, barnapirosan, pontozottak; tokjai leginkább 4 karélyuak, tompaélüek, símák. Erdökben, gyepükben. ち. Maj.-Jun. 4-8'.

Bibircsós K. E. cerrucosus. Scop.

89. Rend. Szőllőfélék. Ampelideae. Kunth.

\section{SZÖLLÖ. Vitis. I.}

Levelei szíves-kerekdedek, 5 karélyuak, durva fogasok, leveleivel átellenben vagy billenges fürtje, vagy 2-3 águ kaccsa van; szára kaccsainál fogva kapaszkodó. - A szigeti erdőkben. ち. Мaj.-Jun.

Bortermö Sz. $V$. vinifera. $L$. 
90. Rend. Bengefélék. Rhamneae. R. Br.

\section{TÜskepÁr. Paliurus. Tourn.}

Ágai szőrösödők, töris fulánkjai párosak, az alsó hátragörbült; levelei tojásdadok, kurtahegyüek, 3 inúak; termése szárnya apró fürészfogu; virágai zöldes sárgák. - A budaörsi szőllők gyepüiben. †. Maj.-Jun.

Szárnyas 'T'. P. aculeatus. Lam.

\section{BeNGe. Rhammus. L.}

1. Ágai ellenesek, törishegyüek; levelei kerekded-tojásdadok, apró fürészfoguak, vállban csaknem szívesek; kocsányjai pálháinál 2-3-szor hosszabbak. - Gyepükben, berkekben. †. Maj.-Jun. 10-20'. (Varjutöris; ebtöcis; festölükény; hashajtó liölény.j

Varjutövis B. $R$. cathartica. $L$.

2. Ágai váltogatók, tövistelenek; körkörös levelej épélüek, hegyesek; virágai tökélyesek. 5 porodások. Berkekben, bokrokban, gyepükben, kivált nedves helyeken. ち. Maj.-Jun. 8-15'. (Kutyafa; büdösfa; büdös cseresznye.)

Kutya B. R. Frangula. $I$.

\section{Rend. Fütéjfélék. Euphorbiaceae. $R$. $B r$.}

\section{FÜTÉJ. Euphorbia. L.}

1. Fedője kerekded r, keresztben-tojásdad és épélü. ‥ Fedöje félholdalaku v. kétszarru. 8.

2. Magvai sejtesen hálózatosak, tokja síma; ernyője 5 águ, azután 3, régre két-két águ; levelei visszástojásdadok. elején fürészesek. - Mivelt helyeken szántóföldeken, útfeleken. (. Jun.-Sept. 3-18".

Éklevelü F. F. helioscopia. $\boldsymbol{L}$.

Magrai símák. 3.

๖. Tokja szümölcsös. 4. 
Tokja síma v. finomul pontozott. 6.

4. Ernyője sok kocsányu, azután 3, végre 2 águ; galléra

levélkéi körkörösek, tompák, tövön elkeskenyedettek ; levelei nyeletlenek, láncsások, épélük v. alig fogasok, kopaszok. - Nedves réteken, mocsárokban, folyók partjain. 4. Maj.-Jun. 2-0'. 'Tavi F. E.palustris. $L$. Ernyője 3-5 kocsányu 5.

5. Tokja szümölcsei csaknem félgömbalakuak; gallérkái csaknem 3 szögüen tojásdadok, fulánkhegyüek, apró fürészfoguak; levelei hegyesek, visszás-láncsások, nyeletlenek, szíves-válluak, a legalsók visszásstojásdadok igen tompák, nyélbe keskenyedök. — Szántóföldeken, mivelt téreken, nedves helyeken. ๑. Jun.-Sept. 1/2-2'.

Nagylevelï F. E. platyphyllos. $L$.

Tokja szümölcsei megnyult fonalakuak; leple metszetei akkorák, mint a gallérkái ; gallérkái körkörösek, tompák, kicsípettek, tövön elkeskenyedettek, kurtanyelüek; levelei hosszukások, nyeletlenek, bolyhos szőrüek. - Hegyi réteken, erdökben, vágásokon, kertekben. 4. Maj.-Jul. 6-18".

Borzas F. E. epithymoides. $L$.

6. Levelei nyeletlenek, hosszukás-láncsások, igen apró fürészfoguak, alólról épélüek, minden oldalukon gyapjasok; gallérkái tojásdadok, tompák, - Nedves réteken, mocsárokban, vizek partjain. 24. Maj.-Jul. 1-2'. (E. jilosa. $L$.

Gyapjas F. E. procera. $M . B$.

Levelei kékes zöldek, láncsások, vagy láncsás-szálasok, épélüek, vagy csak a hegyök felé finom csipkések. 7.

7. Gallérkái háromszögüek, tojásdadok, keresztbe szélesebbek, kalászosan fulánkosak, tövön csonkák v. szíresek; tokja kopasz. - Hegyi és homoki legszárazabb réteken. 4. Jun.-Aug. 6-12".

Parti F. E: Gerardiana. Jacqu.

Gallérkái széles-tójásdadok, tompák, fulánkosak: síma (szümölestelen) tokja tömött szőrü. - Az agyagos 
földeken, kivált hegyeken, igen közönséges. 4. Maj.Aug. 1-1 $1 \frac{1}{2}$. (E. nicaeensis. L.)

Dunamelléki F. E. pannonica. Host.

8. Magvai símák. 9.

Magvai ránczosak. 14.

9. Gallérkái kerekdeden összenöttek; tokja kopasz, finomul pontozottan érdes; levelei visszás-tojásdad-hoszszukások, nyélbe keskenyedők, puhaszőrủek. - Hegyi és homokdomkokon fekvő erdőkben. 4. Maj.-Jul. (2-13". Baraczklevelü F. E. amygdaloides. $L$.

Gallérkái nem nőttek össze. 10.

10. Levelei szálasok, v. szálas-láncsások, válluk felé kissé elkeskenyedők. 11.

Levelei szálas láncsások, közepöktöl hegyök felé lassanként keskenyednek el. 13.

11. Levelei tömötten szőrösődők, épélüek, hegyesek, vagy fulánkos hegyủek; szára szörösödö; gallérkái kótaalakuak vagy háromszögü tojásdadok, szélesebbek, mint hosszabbak. - Bokrokban, erdei útfeleken. 4. Maj.-Jul. 1-2'.

Füzlevelü F. E. salicifolia. Host.

Levelei kopaszok. 12.

12. Keskeny szálas levelei épélüek, ziláltak; ágai levelei igen keskenyek; gallérkái kótaalakuak, v. háromszög-tojásdadok, szélesebbek, mint hosszabbak, kurtán kihegyezettek, épélüek. - Mindenütt a legközönségesebb. 4. Maj.-Jul. 6-12".

Farkas F. E. Cyparissias. $L$.

Lánesás v. szálas láncsás levelei kopaszok, hegyök felé kissé érdesek, az alsók kurta nyelesek, az ágain levők keskenyebbek; gallérkái kótaalakuak, v. háromszögtojásdadok, tompák, fulánkos hegyüek. - Szántóföldeken, útfeleken, nem gyakori. 4. Maj.-Sept. 1-1 $\frac{1 / 2^{\prime}}{}$. (Kis scirfi".)

Kissár F. E. Esula. L.

13. Levelei fénytelenek, kopaszok, épélüek; szára vesszős; 
tögyökere lefelétartó, sok tövü. -- Árkok, uitak, szántóföldek mellett, gyepeken. 24. Maj.-Jul. 1-2'.

Vesszös F. E. virgata. W. K. Levelei felül fényesek, kopaszok, épélüek; szára sugár, vastag, végre pirosodó; tögyökere vízirányosan terjedő. - Vizenyős réteken, mocsárok s patakok mellett, Csepel szigetén böven. 24. Maj.-Jul. 1'1/2-3'.

Fényes F. E. lucida. W. K.

14. Tokján egy érdes csík vagy két ormó van. 15. Tokja síma. 16.

15. Levelei kékes zöldek, szálasok. kihegyezettek, fulánkosak, kopaszok, a felsők szélesebbek; gallérkái vesealakuak v. csaknem kótások, fulánkos hegyüek. - Vetések közt. $\odot$. Maj.-Sept. 4-12".

Vetési F. E. segetalis. $L$.

Levelei nyelesek, visszás-tojásdadok, igen tompák, épélüek. az alsók csaknem köralakuak; gallérkái tojásdadok; magvai belső oldala hosszában 2 barázda van, a másik oldalán horpadozottan pontozott; 2 ormóju tokja éle kissé szárnyas. - Vetések közt. Jul.-Oct. 6-12". (Ebtéj.) Dudva F. E. Peplus. L.

16. Levelei láncsások, vállban keskenyek, hegyesek v. kihegyezettek, alsó levelei lapiczkások; galléra levelei tojásdadok, tövön csaknem sarlóalakuak, épélüek v. hegyök felé fürész fogacskájuak. - Vetések közt, mivelt helyeken. $\odot$. Jul.-Sept. 6-12".

Kaszás F. E. falcata. $L$.

Levelei szálasok, vagy szálas ékalakuak, hegyesek vagy tompák \& fulánkosak, vagy csonkák, kopaszok; galérkái szálasok, csaknem szíves válluak, hegyesek. - Vetések közt. $\odot$. Jun.-Oct. 2-10". Apró F. E. exigua. $L$.

\section{SZÉLFU゙. Mercurialis. L.}

1. Szára egyszerü; levelei nyelesek, tojásdad-hosszukások, vagy láncsások; termésvirágai hosszu kocsányuak; 
virága zöldes; termése borzas. -- Árnyas berkekben böven. 2. April.-Maj. 6-10",

Tartós Sz. MI. peremis. $L$.

2. Szára ágas, levelei nyelesek, tojásdad-láncsások, vagy tojásdadok; termés virágai csaknem kocsánytalanok; virága zöldes; termése tüskés. - Telekes helyeken, gyepük. árkok mellett. Tetések közt. $\odot$. Jun.-Aug. $1-2 "$.

Egynyári Sz. M. аппиа.L.

\section{Rend. Diófafélék. Juglandeae. $D$. C.}

\section{Drófa. Juglans. L.}

Levelei páratlan szárnyasok, többnyire 9 levélkéjök van, ezek tojásdadok, kopaszok; alig fürészesek, csaknem egyenlők; csontára csaknem gömbalaku. - Mivelik. ち. Nagy fa.

Pompás D. J. regia. L.

93. Rend. Anakardfélék. Anacardiaceae. Juss.

1. SZÖMÖRCZE. Rhus. L.

1. Levelei egyszerüek, viszás-tojásdadok; virágzata bugás, szárhegyi; virágai tökélyesek. - Bokrokban, berkekben s Buda köves helyein. †. Maj.-Jun. 3-18'. (Parókafa.)

Sárga Sz. R. Cotinus. L.

Levelei füzöttek. $\mathbf{2}$.

2. Levelei hármasok, levélkéi szegletesen fogasok. Igen mérges. - A Margitszigeten és a füvészkertben ültetve van. ち. Jun.-Jul. 4-12'.

Mérges Sz. R. Toxicodendron. $L$.

Levelei szárnyasok, bordái 8-10 párból állanak; ágai gyapjasok, virágzata tömött. veres, füzéres. - Kertekben ültetik. 5. Jun.-Jul. 6-12".

Virginiai Sz. R. typhina. $L$. 
94. Rend. Rutafélék. Rutaceae. Juss.

\section{Harmala. Peganum. T.}

Levelei váltogatók, szárnyason sallangosak, sallangjai szálasok, hegyeskék; virágai szárhegyiek, szirmai hosszucladok, tompák, szennyes fejérek. - A Sz.-Gellérthegy déli oldalán. 24. Jun.-Aug. 1-2'.

Sallangos H. P. Harmala. $L$.

\section{EZERJÓ. Dictammus. L.}

Szára felálló; levelei váltogatók, páratlan szárnyasok, levélkéi hosszukás-tojásdadok; virágzata fürtös, tőkocsányja és kocsánykái virágaival együtt ikrás szörösek; virága halvány piros, igen szagos. - Hegyi gyepeken és erdőkben, 4. Jun.-Jul. 1-3'. (D. alluus. L.) (Ezerjoófü ; körislevelüfü; szarvasgyöliér ; dictamnos.)

Köris E. D. Fraxinella. Pers.

95. Rend. Lompárfélék. Zygophyllaceae. $R$. Br.

1. SZURDANCS. Tribulus. L.

Elágazó szárai henyélők; szárnyas levelei 6 pár bordájuak, ellenes levélkéi tojásdad-láncsások; 5 púpú tokján 3-4 tövis van. - A homokon mindenütt. $\odot$. Jun.Oct. (Kiválydinnye; földi sulyom ; koldustetü.)

Sulyom Sz. T. terrestris. L.

96. Rend. Gerelyfélék. Geraniaceae. D. C.

\section{1. ÁroRr. Erodium. L.}

1. Ernyöi sok viráguak, szirmai egyenetlenek; teljesen kifejlett porodái kopaszok s szálcsái tövön kiszélesedettek; levelei szárnyasok levélkéi csaknem a gerinczökig szárnyason bevagdaltak, metszetei fogasok. Gyepeken, útfeleken s telekes helyeken $\odot$. Mart.-Oct. $1-15^{\prime \prime}$.

Bürök Á. E. cicutarium. L. Herit. 
2. Krrnyöi 3-5 viráguak; szirmai esaknem egyenlök; teljesen kifejlett porodái tövüktől középig láncsások, szemszörösek, közepen felül fonalakuak, kopaszok, levelei körrajza tojásdad, szárrafutók, szárnyason bevagdaltak, sallangjai fogasok. - Bozótokban, köves helyeken, a Sz.-Gellérthegyén böven. $\odot$. Maj.-Jun. (i) $-18^{\prime \prime}$.

Gólya Á. E. ciconium. Willd.

\section{Gerely. Geranium. L.}

1. Tögyökere évelö csonka, hosszu rostu; szirmai esészéjénél hosszabbak. $\mathbf{2}$.

Tögyökere egy nyári, orsóalaku, karcsu; szirmai aprók, kocsányjai kétviráguak. 3.

2. Kocsányjai 2 viráguak, kissé hátra türemlett szirmai fodrosak, kerekded, visszás-tojásdadok, egyenetlenül csipkések; porodái félig keményszőrü keményszörösek; levelei tenyeresen 7 hasábuak, bevagdalt fogasok. -Magasan fekvő berkekben Visegrád és Vácz körül. 4. Jun.-Jul. 1-3'.

Fodros G. G. Phoeum. L.

Kocsányjai 1-2 viráguak, virágzás után lehajlók; szirmai visszás-tojásdadok, kiesípettek, kalászos csészéjeinél kétszerte hosszabbak; tokja kopácsai símák, felül szörösek; körrajzban vesealaku levelei 7 hasábuak, hasábjai 3 - sok metszetüek; virága piros. - Veröfényes dombokon hegyi és homoki réteken, bozótokban. 4. Maj.-Jul, 1-3'. (Varju v. csókaláb; vérállatófü.)

Rózsás G. G. sangvineum. L.

3. Levelei hármasok, ötösek; levélkéi nyelesek, 3 hasábuak, hasábjai szárnyason bevagdaltak; tokja kopáesai hálózatosan ránczosak; szára széllyelálló szőrös; virága rózsaszinü. - Sziklás, homokos, helyeken, berkekben, bokrokban. ๑. Maj.-Sept. 1-2'. (Róbertfüve; büzös gólyaór.)

Bakbïzü G. G. robertianum. L.

Levelei más szabásuak. 4. 
4. Levelei kör v. resealakuak, tenyeresen $5-9$ metszetüek, metszetei elöl kurta 3 metszetüek, tompák, épélüek ragy csipkések. 5 .

Levelei kör vagy vesealakuak, tenyeresen $5-7$ hasábuak, hasábjai egyszerüen vagy kétszer szárnyason hasogattak, sallangjai szálasok, épélüek; csészéje levelei kalászosak. 9.

5. Szirmai szívesek vagy hosszukás-visszás szívesek. 6. Szirmai ékalakuan hosszuk, vagy hosszukás visszás-tojásdadok; szirmai nincsenek kicsípve; csészéje levelei kurta kalászuak. 8.

6. Tokja és magvai símák, lelapulva szőrösödök; szirmai nyaka finom szemszörösek, szirmai-akkorák mint a csészéje, vagy valamivel hosszabbak. -- Köfalakon, ítfeleken, szántóföldeken közönséges. ๑. Maj.-Aug. C-12".

Apró G. G. jussillum. L.

Tokja ránczos, magvai símák; szára leveleivel egyuitt gyapjas. 7.

7. Visszás-szíves szirmai kurta fulánku csészéjénél hosszabbak, nyakban finom szemszőrösek; vesealaku levelei 7-9 metszetüek. - Gyepeken, legelőkön, gyümölcsösökben. $\odot$. Maj.-Aug. 6-18".

Puha G. G. molle. L.

Visszás-szíves szirmai akkorák, mint a kalászos csészéje ; levelei 5 metszetüek, a felsők 3 metszetüek, oldalmetszetei közül egy a többinél hosszabb; szára csaknem felálló, buglyos. - Szöllők közt, gyepükben. $\odot$. Maj.Jun. 2-3'.

Berzedt G. G. divaricatum. Ethrh.

8. Szára szörös, kissebb-nagyobb mértékben a növény egyéb részeivel együtt ikrásan ragacsos; csészéje levelei rirágzás jdeje alatt lefelé állók; tokjai ráncztalanok, símák; magvai sejtesen pontozottak. - Gyepeken, legelőkön, gyümölesösökben. $\odot$. Jun.-Aug. 6-18".

Kereklevelï G. G. rotundifolium. $L$. 
Szára, a növény egyéb részeivel együtt kopasz, legfelebb felsö része finomul szőrösödö; csészéje levelei virágzás alatt összetartók, keresztbe ránczosak; szirmai csészéjénél másfélszer hosszabbak; tokja hálózatosan ránczos, felsö része csőrével együtt finomul szörösödő; magva síma. - Árnyas sziklákon és berkeklen, p. o. a Jánoshegy tetején. ๑. Maj.-Jun. 3-12".

Csillogó G. G. luciclum. L.

9. Kocsányja az alatta álló levélnél sokkal hosszabb; szirmai csészéjénél valamivel hosszabbak; tokja kopasz, csőre, szára s az egész növény lelapuló szőrü vagy csaknem kopasz. - Réteken, bozótokban, vágásokon. ๑. Jun.-Sept. 1/2-1'. (Galambláb; gólyaköröm.)

Galamb G. G. columbinum. L.

Kocsányja az alatta álló levélnél kurtább vagy vele egyenlő hosszu; szirmai csészéjével egyenlö; tokja csörével együtt ikrás szörös; szára és az egész növény kurtaszörü. - Mivelt helyeken, zöldségesekben, szántóföldeken. •. Jul.-Sept. 1-2'.

Metélt G. G. dissectum. $I$.

\section{Rend. Lenfélék. Linaceae. D. C.}

\section{LEN. Linum. L.}

1. Csészéje levelei élei ikrás szemszőrüek. 2. C'sészéje levele élei ikrátlanok. 4.

2. Virága sárga; csészéje levelei láncsások, kihegyezettek, tokjánál hosszabbak; levelei kopaszok, 3 inúak, élök síma, tövén mindkét oldalról egy-egy ikra van; szára felül 4 élü. - Minclen réten, kiváltképen a budai szöllök mellett fekvő hegyi gyepeseken. 4. Jun.Aug. ${ }^{1 / 2} 2-1^{1 / 2} 2^{\prime}$. (Stírga vadlen.) Sárga L. L. flavum. L. Virága kék vagy verhenyes lilaszinü. 3.

3. Szára molyhosan gyapjas; levelei tojásdad-láncsások v. láncsások, 5 inúak; csészéje és murvái ikrás szem- 
szörüek; csészéje láncsás, levelei tokjánál hosszabbak. - Hegyi homok és agyag talaju réteken, útfeleken. 24. Jun.-Jul. 1-2'.

Borzas L. L. hirsutum. L.

Szára és levelei kopaszok; szemszörösen érdes élü levelei szálasok, kihegyezettek; csészéje körkörös levelei árhegyüek és ikrás szemszörösek, tokjánál alig hosszabbak. - Száraz réteken. - 4. Jun.-Jul. 1-1 1/2'.

Árlevelï L. L.tenuifolium. L.

4. Levelei ellenesek, érdes élüek, az alsók visszás-tojásdadok, a felsők láncsások; csészéje levelei körkörösek, hegyesek; virága fejéres. - Gyepeken, kivált a vizenyős helyeken. ๑. Jun.-Jul. 3-12". (Békalen; apró 7en.)

Béka I. L. catharticum. L.

Levelei váltogatók vagy ziláltak, vagy csak az alsók ellenesek. 5.

5. Crészéje levelei apró szemszőrösek, tojásdadok, kihegyezettek; levelei láncsások, kopaszok; felálló szára magános. - Mivelik. •. Jul.-Aug. 2-3'.

Házi L. L. usitatissimum. $L$.

Csészéje levele élei kopaszok. 6.

6. Szirmai széles visszás-tojásdadok, melyek széleikkel egymást hátalják, nyaka hosszukás háromszögü; tokja kerek-tojásdad, kocsányja felálló; levelei szálasláncsások. - Homoki réteken bőven. 24. Jun.-Aug. $1-2^{1 / 2^{\prime}}$.

Bokros L. L. pereme. $L$.

Szirmai kerekded visszás-tojásdadok, oldal széleikkel egészen hátalják egymást, nyaka háromszögü, olyan széles, a milyen hosszu; tokja gömbalaku; kocsányja rirágzás után ívalakulag oldalra kihajlik; levelei szálas láncsások, kopaszok. - Réteken, köves helyeken, útfeleken. 4. Jun.-Aug. 1-21/2'.

Hegyi L. L. austriacum. $L$. 
98. Rend. \$ósdifélék. Oxalideae. D. C.

\section{SósDI. Oxalis. L.}

Szára nincs; töre gyökerező, fogas; levelei hármasok, levélkéi visszás-szívesek, szörösödők ; tőkocsányja leveleinél hosszabb, közepén 2 murvája van; hosszukás tojásdad piros vagy fejér szirmai alig kicsípettek. Magasan fekvö berkek árnyaiban. 4. Apr.-Maj. 3-6". (Erdei- v. madcir- v. fecske v. apró sóska; allelujafü.) Madár S. O. Acetosella. L.

99. Rend. Fájvirágfélék. Balsamineae. A. Rich.

\section{FÁJVIRÁG. Impatiens. L.}

Kocsányja 3-4 virágu, sárga veres pettyes virágai lefüggök, sarkantyuja hegye hátragörbült; tojásdad levelei durva fogasok; szára bütykei felpuffadtak. - A váczi és pilisi hegyek patakjai mellett. $\odot$. Jul.-Aug. 1-1 ${ }^{1 / 2} 2^{\prime}$. (Ne nyul, hozzaim; ne baints engem; üvegszírufü.) Üvegszáru F. $I$. noli me tangere. $I$.

100. Rend. Csészekürtfélék. Oenothereae. Juss.

\section{CSÉSZEKÜRT. Oenothera. I.}

Elsö évben növö legalsó levelei körkörösek vagy hoszszukás visszás-tojásdadok, nyélrefutók, tompák s egy kis hegyecskéjök van; alsó szárlevelei körkörösek vagy széles láncsások; porodái bokrétájánál hosszabbak. - A homokos részeken, a szigetek ligeteiben. $\odot$. Jun.-Jul. 1-3'. (Idegen sírga viola.)

Ligetéke Cs. Oe.biennis. L.

\section{CSŐVIRICS. Epilobium. I.}

1. Levelei ziláltak, láncsások, épélüek, apró ikrás fogasok, eresek; piros szirmai kissé nyakasok, visszás-tojás- 
dadok; bibeszára végre lekonyul. - Erdei réteken, vágásokon, bozótokban. 24. Jun.-Aug. 2-6'.

Keskeny Cs. E. angustifolium. $I$.

Alsó levelei ellenesek, a felsők váltogatók; szirmai tölcséresen állanak össze. 2 .

2. Virágzata és szára teteje mindig felálló. 3.

Virágzata és szára teteje virágzás elött bókolók, vagy lefüggők és csak a virágzás alatt lassanként egyenesednek fel. 5 .

3. Szárán 2-4 kiálló vonal van, igen ágas, csaknem kopasz; levelei láncsások, tövüktöl hegyökig lassankint keskenyednek el, fogasolt fürészesek, a középsők vállaikkal szárrafutók, az alsók kissé nyelesek; bibéje bunkós; virága rózsaszinü. - Vizenyős és mocsáros helyeken. 24. Jun.-Jul. 1-1'1/2'.

Négyszögï Cs. E.tetragonum. L.

Szárán nincsenek kiállỏ vonalok. 4.

4. Levelei szárölelők, válluk egykissé szárrafutó, szálas láncsísok, hajszálhegyüek, fogasolt fürészfoguak, fogai befeléhajoltak; szára hengeres, igen ágas, elálló szőrei miatt bolyhos; gyökere ostorindás; virága nagy, rózsaszinü. - Füzesekben, nedves réteken, magas hegyek vizmosásai mellett. 24. Jul.-Aug. 1-3'.

Piros Cs. E. hirsutum. $L$.

Levelei nyeletlenek. láncsások, hegyesek; fogasok, alsó ellenes levelei kurtanyelüek. magános, hengeres szára egyszerü szőreitől bolyhos; bibéje metszetei kifelé göngyölödők. - Az előbbivel. 24. Jul.-Aug. 1-2'.

Apróvirágu Cs. E. parviflorum. Schreh.

๖. Levelei nyelesek, tojásdadok v. tojásdadhosszukások, egyenetlenül fogasoltak, ereiken és élökön szörösödők szára hengeres, szörösödő; bibéje metszetei kifelé hajlók, apró virágai rózsaszinüek. - Hegyi ligegetekben. 24, Jun.-Jul. ${ }^{1 / 2} 21^{1 / 2} 2^{\prime}$.

Hegyi Cs. E. montanum. $L$. 
Levelei láncsások, hegyök felé lassanként elkeskenyedők, épélüek vagy fogasoltak, ékalaku vállukkal a szárára nöttek; szára hengeres, kissé szörösödő ; ostorindája fonnal alaku; bibéje bunkós; virága halvány piros vagy fejér Mocsárokban és turfás téreken. 4. Jun.-Jul. ${ }^{1 / 2} \mathbf{2}^{1} 2^{2}$. (Derécze.)

Derécze Cs. E. palustre. $L$.

\section{SZIROMPÁR. Circaea. L.}

Levelei tojásdadok, kissé szíves válluak, kikanyargatott fogasok, szőrösödők, nyelesek; fürtje szárhegyi; fejér szirmai kicsípettek. - Nedves ligetekben, a Duna szigetein. Jul.-Oct. 4-6". (Var'izslófü.)

Varázs Sz. C. lutetiana. 1 .

101. Rend. Toborostafélék. Halorageae. R. Br.

1. USZSZAKÁL. Hippuris. L.

Levelei szálasok, levélgyürüi 8-12 levélből állanak; tenyészszervei, később termései, levelei tövén vannak. - Álló és lassan folyó vizekben, árkokban. 4 Maj.Aug. 3-11". (Vizi lófarti.)

Lófark U. H. vulgaris $L$.

\section{TÓBOROSTA. Myriophyllum. L.}

1. Gyürüben álló levelei szárnyason hasogattak, sallangjai sertealakuak; gyürüs-füzéres virágzata hónalji ; murvái fésűalakulag szárnyason hasogattak, virágainál hoszszabbak. - Mocsárokban, árkokban. - 4. Jun.-Aug. Gyürüs 'I. MI. rerticillatum. $L$.

2. Levelei gyürüsek, szárnyason hasogattak, hasábjai sertealakuak; virágzata gyürüs, gyürüi füzérformák, fiatal füzérei felállók; felső murvái épek, az alsók levagdaltak. - Az elöbbivel. 4. Jul.-Aug.

Füzéres T. M. spicatum. $K$. 


\section{SUlYOM. Trapa. L.}

Lábbó levelei kóta, a víz alámerültek czérnaalakuak; fehér virágai hónaljiak; kocsányjai gyapjasok; termése 4 szarvu makk, szarvai kupos vastag tövisüek. A Tisza és Zagyva kiöntéseiben. $\odot$. Jun.-Jul. Termését tavaszszal szedik. (Sulyom; vizi dió; vizi gesatenye.)

Csemege S. T. natans. $L$.

102. Rend. Fủzényfélék. Lythrariaceae. Juss.

\section{Locsahúr. Peplis. L.}

Szára lecsepült; levelei ellenesek, visszás-tojásdadok, nyelesek; :virágai hónaljiak, magánosak, verhenyesek. - Ártéri berkekben, kivált a Tisza körül. $\odot$. Jun.Sept. 3-12".

Henye L. $P$. portula. $L$.

\section{FÜZÉNY. Lythrum. L.}

1. Virága magános, hónalji; levelei ellenesek, a legalsókat kivéve, szálas-láncsások; porodája 5-6; szirmai lehullók; csészéje tövén áralaku igen kurta 2 murva van. - Ártéreken, nedves réteken. mocsárok körül. $\odot$. Aug.-Sept. ${ }^{1 / 2}-1^{1 / 2}$.

Alacson F. L. Hyssoppifolium. $L$.

Virágzata gyürűs, hosszu füzért alkot; alsó levelei ellenesek; virágai 12 porodások. 2.

2. Levelei láncsások, vállban szívesek, nyeletlenek; füzére egészen gyürüs virágzatból áll; csészéje fogai váltogatva hosszabbak; virága piros. - Vizenyős helyeken, füzesekben, nádasokban. 4. Jun.-Sept. 1-4'. (Füzlerelü fü; piros füzény.)

Réti F. L. Salicaria. $L$.

Levelei láncsások, vállban lekerekítettek; virágzata alól gyürüs, a felsők váltogatók; csészéje fogai egyenlők. - Az elöbbivel. 24. Jun.-Sept. 1-3'.

Vesszös F. $L$. virgatum. $L$. 


\section{JÉZSAFA. Philadelphus. L.}

Levelei körkörösek, kihegyezettek, fürészesen fogasoltak, felsö lapjaikon kopaszok, alól kurta szörüek; virágzata fürtös; csészéje metszetei kihegyezettek; bibeszára 4 hasábu, porodáinál kurtább. Mivelik, ittott elvadulva. †. Maj.-Jun. 3-6'. (Olasz jizmin.)

Korona J. P. coronarius. $P$.

\section{Rend. Almafélék. Pomaceae. Juss.}

\section{BIRs. Cydonia. Tourn.}

Levelei tojásdadok, tövön tompák, épéli̋ek; alsó lapjaikon csészéikkel együtt molyhosak; virágai magánosak. - Szőllők gyepüiben. 5. 6-10'. (Birs v. büs alma.)

Közönséges B.C. vulgaris. Pers.

\section{KÖRTEFA. Pyrus. L.}

1. Bibeszárai szabadok; termése alsó része felé elkeskenyedő; levelei tojásdadok, akkorák, mint a virága kocsányjai, apró fürész foguak. - Erdőkben, ligetekben. Ђ. Maj. 2-3․

Vad K. P. communis. $L$.

2. Bibeszárai tövön összenöttek; termése kocsányja körül bemélyedett; levelei tojásdadok, kurtahegyüek, kopaszok vagy alól molyhosak, nyelei felényiek; mint a levelei. - Erdökben. †. Maj. 2-3?

Vadalma K. P. Malus. $L$.

\section{BEREKENYE. Sorbus. T.}

1. Levelei páratlan szárnyasok. 2.

Levelei tojásdadok vagy karélyosok. 8.

2. Fiatal levelei bolyhosak, az idösek kopaszok; levélkéi hegyes fürészesek; bimbói kopaszok, ragacsosak; virágzata bogernyős termése körtealaku. - Mivelik, vadon ritka. 5. Maj.-Jun. 3-4․ (Berekienye; barliócza.) Fojtós B. S. domestica. L. 
Fiatal levelei bolyhosak, az idösbek kopaszok, levélkéi hegyes fürészfoguak; bimbói molyhosak; virágzata ágas-bogas ernyö; termése gömbalaku, veres. - Erdökben. 5. 2-3․ (Veres berekienye; piros lintyacseresznye.)

Veres B. S. aucuparia. $I$.

3. Levelei kétszer fürészesek, vagy alig karélyosak, fürészfogai és karélyai levele közepétöl válla felé kissebedők, alól molyhosak; virágzatr sátorozó; termése veres vagy sárgás. - Hegyi erdőkben. †. Maj.-Jun. 2-3․

Lisztes B. S. Aric. Crantz.

Levelei tojásdad karélyosak, kifejlett korukban kopaszok. karélyai kihegyezettek, egyenetlen fürészesek, alsó karélyai a felsőbbeknél nagyobbak; virágzata sátorozó, kocsánykái szörösödők ; körkörös termései barnák. - Ligetekben. bozótokban. †. Мaj. 2-3․ (Barkócza.) Barkócza B. S. torminalis. Crantz.

\section{NÁszPolya. Mespilus. L.}

Levelei láncsások, épek, alól molyhosak; virágai magánosak, csészéje metszetei bokrétájánál hosszabbak. Mivelik, itt ott vadon. 4. Maj. 1-2. (Nászpolya; noszpolya; miszpulya; lisponya.)

Borízï N. M.germanica. I.

\section{Galagonya. Crategus. L.}

1. Virágai egy bibeszáruak; veres termése egy magvi; virága kocsányja gyapjas, csészéje metszetei letüremlettek s csészéje csövére lapultak; levelei mélyen 3 metszetüek; fája tövises. - Erdőkben, bokrokban, böven. †. Apr.-Maj. 6-18'.

Egymagu G. C. monogyna. L.

Virágaibın egy bibeszámál s terméseiben egy magnál több van. $\mathbf{2}$.

2. Bibeszára rendszerint 2-3; veres termése 2-3 magu, kocsányjai kopaszok; levelei kisebb bevágásu 3 karé- 
lyuak; fája tövises. - Erdőkben, bokrokban, gyepükben. 5. April.-Maj. 6-18'. (Galagonya.)

Csere G. C. oxyacantha. L.

Bibeszára 5; fekete fénylö termése 5 magu; kocsányjai és ágai molyhosak; csészéje metszetei hegyesek, alig hátrahajlók. - Csepel szigetén a Duna partjain. †. Maj. 6-18'.

Fekete (x. C. nigra. W. K.

\section{Renł. Rózsafélék. Rosaceae. Juss.}

\section{Rózsa. Rosa. L.}

1. Csészéje aljába zárt maghonai kocsánykátlanok; csészéje metszetei szárnyason hasogattak, kurtábbak, mint a bokrétája, letuiremlettek. végre lehullók; bokrétája sötét piros; kocsányjait és esészéit ikrás serték fedik; levélkéi körkörösek vagy kerekdedek. alsó lapjaikon kissé érdesek; pálhái szálas hosszukások; virága alatti leveleivel egyenlők; idei fáján egyenetlen. tömött fulánkjai közt ikrás serték vannak. - Hegyi réteken, ligetekben és erdőkben. †. Maj.-Jun. 6-12".

Tarka R. R. gallica. L.

Csészéje aljába zárt maghonai kocsánykások. 2.

2. Maghonai kurta kocsánykájuak; esészéje metszetei épek, felényiek. mint a szirmai, szálas kihegyezettek, állandó csészéje metszeteivel borított termései lapos golyóalakuak, bőrnemủek; fulánkjai egyenetlenek árés sertealakuak, egyenesek; 6-9 levélkéje kerekded vagy tojásdad, egyszerüen vagy kétszer fürészeltek. - . Hegyeken, bozótokban, útfeleken. †. Maj.-Jun. 2-3'. Tompalevelü R. R. pimpincllifolia. D.C.

Maghonai kocsánykái olyan hosszuk, mint a maghonai. 3. 3. Fulánkjai egyenesek, tövön lapítottak; levélkéi szürkezöldek, körkörösek vagy tojásdadok; virága alatt állú levelei pálhái kiszélesedettek, körkörösek; porczogós 
termése kerekded; virága halvány rózsaszínü. - Bozótokban, kivált a szőllök gyepüiben. †. Maj.-Jul.

Borzas R. R.tomentosa. $L$.

Fulánkjai sarlóalakuak. 4.

4. Levélkéi körkörösek. éles fürészfoguak, felsö fürészfogai összetartók ; csészéje inetszetei szárnyason hasogattak, csaknem akkorák, mint a bokrétája ; termése kerekcled vagy körkörös, por’czogós ; fája teteje ivalakuan meghajlik. - Bozótokban, ligeteken. †. Maj.-Jul.

Csipke R. $R$. canina. $L$

Viilfajai: a.) Levele nyelei, kocsányjai és csészéje csöve kopasz: canina vulgaris. b.) Levele nyelei, levélkéi kocsányjai szörösek: canina dumetorum. c.). Kocsányjai ikrás, keményszörűek; levelei kopaszok, szörösek; csészéje csöve kopasz v.ikrás szörös; canina collina. d.) Levelei és levélkéi alól, vagy mindkét oldalon ragacsosak, ikrások; kocsányjai és csészéje csövei kopaszok: canina sepium.

Levelkéi körkörösek, rozsdaszín ikrások, kétszeres hegyes fürészfoguak, fürészfogai széllyeltartók; termései kerekdedek, porczogósak. - Bózótokban, bokrokban. ந. Maj.-Jul.

Rozsdás R. R. rubiginosa. $L$.

\section{SZEDERJ. Rubus. R.}

1. Szára felálló, ágas, cszerjésedő; levelei szárnyasok, a felsők hármasak ; szirmai visszás-tojásdadok, ékalakuak ; csészéje letüremlett. - A visegrádi és sz.-kereszti magas erdőkben. †. Maj.-Jun. 3-5’. (Málma.)

Málna Sz. R. Idceus. L.

Szára ívalakulag meghajolt v. henyélő. 2.

2. Virágzata bugás; szirmai tojásdadok s csészéje metszeteivel együtt széllyeltartók; termése fényes; termése csészéje letüremlett; levelei ötösek-hármasok, alól fejér molyhosak. - Erdökben, szántóföldeken. †. Maj.-Jul. Hạ̣tásai néha 15-20'.

Seregély Sz. $R$. fruticosus. $L$. 
Vilfajai: a.) Levelei alól zöldek, szörösek: $R$. corylifolius. Sm. b.) Levelei mindkét lapjokon molyhosak: R. temontosus. Borlik.

Virágzata sátorozó. 3.

3. Levélkéi csaknem kerekdedek, egyenetlen fürészesek, felül barázdoltak, alól fejér molyhosak, levelei 3-sok, ritkán 5-sek; kocsányjai és csészéje fejér molyhosak és ikrás gyapjasok; termése apró, fekete. - A budai és váczi erdőkben ritkább, a síkon fekvő szántóföldeken és bozótokban. 4. Maj.-Jun. Hajtása 1-3'.

Mezei Sz. $R$. agrestis. $W . K$.

Levélkéi szíves-tojásdadok. 4.

4. Lecsepült szára és termése kékes hamvas, vékony fulánkjai ziláltak; levelei :3-masok, ritkán 5 -sek, levélkéi kétszer fürészesek, alól alig szörösödők; felálló kocsányjai és csészéi ikrásan szőrösödők; termése nagy és hamvas. - Szántóföldeken, árokpartokon, bozótokban. 24. Jun.-Jul. (Szederj.)

Hamvas Sz. $R$. caesius. $L$.

Szára piros és ikráson borzas. 5.

5. Levelei 5 -sek és 3 -sok is; levélkéi kétszer-fürészesek, alól szőrösödők ; sátora tömötten álló fulánkjaitól borzas; felálló kocsányjai és csészéje is ikráson borzasok; termése verhenyes fekete. - Magasabban fekvö erdőkben. $\odot$. Jun.-Jul. Borzas Sz. R. hirtus. W. K. Levelei 3-masok, levélkéi hagyesek, kétszeres szálkásfürészesek, borzasok; felálló kocsányjai és esészéi ikrás-borzasok; termései verhenyes feketék. Az elöbbitöl csak leveleinél fogva különbözik. - A budai, váczi és sz.-kereszti erdőkben. 4. Jun.-Jul.

Ikrás Sz. R. glandulosus. Bell.

\section{SZAMÓCZA. Fragaria. L.}

1. Kocsányján levő szörei felfelé állók vagy hozzálapultak. .. 
Kocsányján levő szörei vízirányosan elállók; termése csészéje nagyon kinyílt, v. letüremlett; bokrétája igen nagy, gyümölcsöt termö virágai porodái husos vaczkával egyenlők, terméketlen vírágaié vaczkánál kétszerte hosszabbak. - Erdőkben, kivált vágásokon. 4. Maj.-Jul. 1-1' ${ }^{1} 2^{\prime}$.

Kerti Sz. F. elatior. Ehrth.

2. Csészéje terméséhez lapult. $\mathbf{3}$.

Csészéje termésétöl elálló, vagy letüremlett; porodái alig akkorák, mint husos vaczka. - Erdökben, vágásokon böven. 24. Maj.-Jul. 3-6".

Földieperj Sz. F. resca. $L$.

3. Termései gömbalakuak, aprók; terméketlen virágai porodái vaczkánál kétszerte hosszabbak. - Száraz hegyeken és homoki réteken. 4. Maj.-Jun. Az elöbbinél alacsonyabb.

Csattogó Sz. F. collina. Ełhrh. 'Termései kúpalakuak. ananászszaguak, nagyok; levélkéi felül csaknem kopaszok. - Mivelik kertekben. 4. Maj.-Jul. 6-12". Ananász Sz. F. grandiflora. Jihrh.

\section{PIMPÓ. Potentilla. L.}

1. Alsó levelei páratlan szárnyasok. 2.

Levelei tenyeresen $3-5$-sek. 4.

2. Virága fejér, visszás-tojásdad szirmai csészéjénél hoszszabbak; felálló szára pirosas, felül villás; felső levelei 3-masok, szörösödök, egyenetlenül bevagclalt fürészesek; pálhái épel. - A visegrádi sziklákon. 4. Naj.-Jun. 1-2'.

Kövi P. P. rupestris. $L$.

Virága sárga. 3.

3. Szára indanemü, legyökerezö, levélkéi hosszukások, éles fürészfoguak; szárán levỏ pálhái sokmetszetüek, hártyások; kocsányjai hónaljiak, gyapjasok, egy viráguak. - Vizenyös réteken és legelökön. 4. Maj.-Sept. (Pipefü; hudpaizsit ; fejér v. ezüstös huitufü ; vadvarcidics.)

Liba P. $P$. anserina. $L$.

Szára henyélö, két-két águ; levélkéi hosszukások, bevagdalt fürészesek, a felsök nyélre futók; virágai ma- 
gánosak, kocsányjai virágzás után hátra kunkorodnak. - Vizenyős helyeken, szántóföldeken. ๑. Jun.Aug. 3-12".

Henye P. P. supina. $L$.

4. Virága fejér.

Virága sárga. 6.

כ. Törzse gyökerezö; szára vékony, felegyenesedö tölerelei 5-sek, levélkéi hosszukás-láncsások, vállban elkeskenyedők, felül kopaszok, alól és élökön selymes-szörösek, elöl fürészesek, fogai hegyesek, összetartók; porodái és makkocskái kopaszok, ez utóbbiak kötölékök felöl szőrösek. - Hegyi gyepeken, ligetekben Buda körül. 4. Maj.-Jun.

Fejér P. P. alba. $L$. Töve henyélő, néha gyökerezö; szára vékony, lecsepült; tölevelei 3-sok, levélkéi kerekded-tojásdadok, csonkák, felül csaknem kopaszok, alól gyapjasok, a középsők elöl, az oldaliak csaknem a válloktól kezdve fürészesek; makkocskái kötölékei felöl szörösek. Terméketlen dombokon, buzótokban, erdőszéleken, Sz.Endre s Vácz vidékén. 4. April-Maj. 1-4".

Szamóczás P. P. Fragariastrum. Ehırh.

6. Csészéje 8 metszetủ; bokrétája 4 szirmu; szára felálló vagy henyélö, de nem gyökerező; levelei nyeletlenek vagy kurtanyelüek, 3-sok, az alsók néha 5-sek; pálhái 3 - sok metszetüek. - Erdőkben, bozótokban, száraz és nedves réteken. 4. Jun.-Aug. 6-18".

Timpó P. P. Tormentilla. Sibthor'p.

Csészéje 10 metszetü; bokrétája 5 szirmu. 7.

7. Szára indaalaku, lecsepült, bütykein gyökerezö; levelei 5 -sek. köztük azonban vannak 3 -sok is; levélkéi hoszszukás visszás-tojásdadok, felül kopaszok, alól lelapult szörüek, csakiknem a válluktól fürészesek; magvacskái szemcsésen érdesek. - Legelökön, réteken, ugarokon, kivált nédves helyeken. 4. Mart.-Sept. (ötlevelü fü.)

Terjedö P.P. reptans. L.

Szára felegyenesedő vagy felálló. S. 
8. Szára földön fekvő s többnyire @yökerező törzséröl egyenesedik fel. 9.

Szára tövéröl indulva felálló vagy felegyenesedő; teteje bogernyősen ágas és sokvirágu. 10.

9. Alsó levelei 5-sek, nyelei szárával együtt szürke molyhosak; levélkéi hosszukás visszás-tojásdadok, csonkák, mélyen fürészesek, füı'észfoga mindkét oldalon leginkább 4 van; legalsó pálhái keskeny-szálasok; magvai alig ránczosak. - Minden hegyi és homoki réten a legközönségesebb. 24. Mart.-Jul.

Hamvas P. $P$. cinerea. Clair.

Levelei 5̆--7-sek, levele nyelei szárával együtt durvaszörösek; levélkéi hosszukás ékalakuak, mélyen fürészesek, csonkák; magvai ránczosak. - Hegyi gyepeken, ligetekben és a homokon. 4. Maj.-Jun.

Czérnás P. P. opaca. $L$.

10. Levelei mindkét lapjaikon egyenlö szinüek, $5-7$-sek, levélkéi hosszukások. vállban ékalakuan elkeskenyedők, durva fürészfoguak; szára felálló durvaszörü, púpon ïlö hosszabb szőrei közé kurta ikrás szőrök is vegyültek; virága világos sárga; halvány ormóval szárnyformán kerített magvai kiülö ránczosok. - Száraz hegyi és síki réteken, kivált kövér homokföldeken. 4. Jun.-Jul. 1-2'.

Egyenes P. P. recta. $L$.

Válfajai: a) Levelei és pálhái bevagdalt fürészesek, czitromszinü virága alig ér ki a csészéjéböl. $P$. obscura. b) Pirosolló, felálló, szörös, levelei metszetei fogason fürészeltek; szálas-láncsás, pálhái épek; kénkőszínü szirmai csészéjével egyenlök: $P$. pitosa. b) Levelei metszetei sallangos-szárnyas szabásuak; aranyszínü szirmai csészéjénél nagyobbak: P.laciniosa.

Levelei kétszínüek, alól fejér vagy szürke molyhosak, felül zöldek. lelapult szörüek vagy csaknem kopaszok. 11.

11. Szára felálló vagy lefekvő tövéről felegyenesedő, puha gyapjas és egyszersmind molyhos; levelei 5 -sek, levél- 
kéi hosszukás láncsások, ránczos nıagvát fonalalaku vékony ormó keriti körül. - A Széchenyi hegyi nyílt réteken és szántóföldeken ritkább, gyakoribb a Soroksár felé eső kövér gyepeken. (P. canescens. Bess. $P$. (ascendens. Kit.) Felegyenesedö P. P. inclinata. Vill. Szára felegyenesedő, molyhos; levelei 5-sek; levele elkeskenyedett épélü vállu s visszás-tojásdad, mélyen bevagdalt fürészes, vagy szárnyason sallangos, éle begöngyölödött, alól fejér molyhos; ránczos magva prémetlen. - Dombokon, verőfényes réteken, száraz gyepeken, söt berkekben is. 24. Maj.-Jul. ${ }^{1 / 2}-1^{1 / 2}{ }^{\prime}$.

Eziistös P. P. argentea. L.

\section{CZIKLÁsz. Geum. L.}

1. Alsó levelei félbeszárnyasok, a felsők hármasok; csészéje letüremlett; sárga szirmai visszás-tojásdadok; magvai szőrösek, magva kalászai 2 czikkűek, alsó czikke kopasz s ennél a négyszerte nagyobb felső czikk töve szörösödő; gyökere jóféle szegfü szagu. - Bozótokban, erdőkben, gyümölesösökben. 24. Maj.Jun. 1/2-2'. (Gyömbéres gyötér; szegfüszagu gyöliér; erdei szegfü.) Szegfïszagu Cz. G.urbanum. I.

2. Alsó levelei félbeszárnyas csonka szárnyasok, melyek 5 karélyosnak látszanak, fürészesen-csipkések, szárlevelei 3 karélyuak, bevagdalt fogasok; sárga szirmai harangalakuak csészéjénél nagyobbak, lehullók; egytagu magvai magva kalászaival együtt gyapjasok. - A pilisi magasabb hegyek árnyas berkeiben. 4. April.Maj. 1/2-1'. (Waldsteinia geoides. W.)

Karélyos Cr. G. montanum. $I$.

\section{PÁRLÓ. Agrimonia. L.}

Levelei csonka-tollas szárnyasok, fürészes levélkéi alól szürke kurtaszőrủek; virágzata hosszu füzér; sárga szirmai tojásdadok; termése csészéje visszás-kup- 
alaku, hosszában barázdolt, puha horgas sertéjü. Száraz réteken, gyümölcsösökben. bozótokban. 4. Maj.-Aug. 1-3'. (Párlófü; ; apró bojtorjicin.)

Bojtorjános P. A. Eupatoria. L.

\section{BAJNÓCZA. Spirea. L.}

1. Levelei csonkatollas szárnyasok, levélkéi tojásdadok, épek, a régső nagyobb. tenyeresen 3-5 metszetü ; virágzata bogernyös; kepasz tokja összekunkorodott. - Nedves réteken, vizek partjain. 24. Jun.-Aug. 2-4'. (Legyezöfü; borvircig.) Legyezö B. S. Ulmaria. L.

2. Lerelei csonkatollas szárnyasok, levélkéi hosszukások, szárnyason bevagdaltak; virágzata bogernyös: szörösödő tokjai egymáshoz lapultak; gyökere gumóitól kolonczos. - Minden réten böven. 24. Maj.-Jun. $1-1^{1} 2^{\prime}$.

Kolonezos B. S. Filipendula. L.

\section{CśábaIr. Poterium. L.}

Szára szegletes, verhenyes; termése csészéje kemény, hálózatosan ránczos, 4 ormóju, ormói tompák; levelei páratlan szárnyasok, levélkéi kerekcledek, fürészesek. - Hegyi és homoki száraz réteken. 24. Maj.-Jun. 1-2'. (Cscibair; pimpinella.)

Vérfejü Cs. P. sangrisorba. L.

\section{VÉRFö. Sangrisorba. L.}

Füzére tojásdad-hosszukás, barna piros; 4 porodája csészéjével egyenlö magas; levelei számyaltak, levélkéi szíves-hosszudadok. - Vizenyős réteken. 24. Jun.-Aug. 2-3'. (T'érfü.)

Orvosi Y. S. officinalis. $L$.

105. Rend. IMondolafélék. Amygdaleae. Juss.

1. Mondola. Amygdalus. L.

1. Lerelei láncsások, ikrás fürészfoguak, levele nyelei felsö részén ikrások, akkorák, mint a levele keresztmet- 
szete vagy valamivel hosszabb; csészéje harangalaku; csontára héja lyukacsos. - Kertekben, szöllökben mivelik. 占. Kora tavaszszal. $2-3^{0}$. (Mondola.)

Csemege I. A. communis. $I$.

2. Levelei láncsások, kurta nyelökre keskenyedettek, ikráson fürészesek, vállban épélüek; csészéje hengeres; csontára héja nem lyukacsos. -- I Széchenyi-hegyen, a Farkasvölgyön s Vácz körül. †. April. 1-2 $1 / 2^{\prime}$. (Hangabracacki) Hanga M. A. nana. $L$.

\section{BaraczK. Persica. Touru.}

Levelei szálas-láncsások, hegyes fogakkal fürészesek, kurtanyelüek; virágai kocsánytalanok, világos rózsaszínüek. - Kertekben. ち. Kora tavaszszal. 1-20. (Szörös baraczk.) Öszi B. P. vulgaris. 1till.

\section{Szilva. Prumus. L.}

1. Virága kocsányjai igen kurták, gyümölcse mélyedésébe zártak; tojásdad levelei alig szívesek, kihegyezettek, kétszer fürészesek, nyelei ikrások. - Mivelik kertekben. †. 1-2 ${ }^{9}$. (Apró fajtáit tengeri baraczl-nak hivják.)

Kajszímbaraczk Sz. P. Armeniaca. L.

Virága kocsányjai hosszuk; termése kopasz, hamvas. 2. 2. Ágai tövishegyüek, ágacskái szörösödök vagy selymesek. 3.

Ágai kopaszok, tövistelenek. 4.

3. Bimbói egyviráguak. magánosok. v. kettösek, v. hármasok; levelei körkörösek vagy széles láncsások; csontára golyóalaku, felálló. - Gyepükben. bozótokban, szántóföldek barázdáin. †. April-Maj. 2-5'. (Köliény; lititienytöris.)

Kökény Sz. P. Spinosa. L.

Bimbji leginkább két viráguak, kocsányja finomul szörösödö, ágacskái selymesek; levelei körkörösek; csontára golýalaku, lefüggö. - Mivelik. 5. April-Maj. 1-2?. (Kölénenszilen.) Közép Sz. P. insititia. $L$. 
4. Bimbói leginkább két viráguak; kocsányjai szőrösödők; levelei körkörösek, csontára hosszukás, függö. - Mivelik. 少. April-Maj. 1-2". (Szilvafa.)

Kerti Sz. P. domestica. $L$.

Bimbói egy viráguak; kocsányjai kopaszok; levelei körkörösek; csontára veres, golyóalaku, lefüggö. - Mivelik. 5. April-Maj.

Cseresznye Sz. P. cerasifera. Ehrh.

\section{MEgGY. Cerasus. F1. vett. Härtn.}

1. Virágzata fürtös vagy sátorozó. 2.

Virágzata csomóalaku, ernyős vagy kettős. 3.

2. Fürtje legfüggő; levelei körkörösek, csaknem kétszer fürészesek, kissé ránczosak, nyáron lehullók, nyelei ikrások. - Mivelik, azonban magas helyen fekvő erdőkben is található. †. Maj. 1-2'. (Kutya-, vad-, gerezdes cseresznye; zelnicze.)

Zelnicze M. C. Padus. D. C.

Sátora kocsányos, egyszerủ; levelei kerekded-tojásdadok, kissé szívesek, tompa fürészfoguak. - Gyepükben. erdőkben, sziklákon. 宁. Maj.-Jun. 4-8'.

Saj M. C. Mahaleb. L.

3. Levelei nyele tövén két ikra van; levelei körkörösek. kihegyezettek, kissé ránczosak, alól szőrösödők ; gyökerei sarjakat nem hajtanak. - Erdőkben. 占. Apr.-Maj. 3-30. (Piunus avium. L.)

Cseresznye M. C. dulcis. Fl. cett.

Levelei nyele tövén nincs ikra. 4.

4. Levelei laposak, kopaszok, fényesek, bőrtapintatuak, körkörösek, mind kihegyezettek; szirmai kcrekdedek; gyökere sok sarjat hajt. - Mivelik, gyepükben vadon. ந. Apr.-Maj. 1-20. Savanyu M. C. acida. Fl. vett.

Lerelei laposak, kopaszok, fénylök, kissé börtapintatuak, a felsőls hosszukások v. láncsások, kihegyezettek, oldali rügyei visszás-tojásdadok, lekerekített tompák; szir- 
mai hosszukás visszás-tojásdadok; gyökere sarjakat

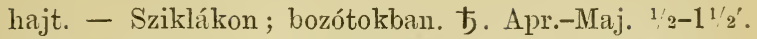
(Vadmeggy.) Cseplesz M. ('. Chamaecerasus. Host.

106. Rend. Pillangósok. Papilionaceae. $L$.

\section{JenesZTER. Spartium. L.}

Ágai liengeresek, ellenesek és váltogatók, zöldek, üres belüek; levelei magánosak, láncsások; sárga virágai az ághegyeken vannak. - Mivelik, a pesti városligetben. 5. Maj.-Jun. 3-6'. (Jenesater.)

Szagos J. S. junceum. $I$.

\section{REKETTYE. Genista. L.}

1. Csészéje felső ajaka 2 kurtafogu, az egész csésze lelapult szőrrel fedett; kocsányjai egy csomó levéltől környezve magánosan vagy többen oldalt állanak; virágai kopaszok; levelei hosszukás láncsások, alsó lapjokon és élökön lelapult szörủek. - Mész sziklákon és ligetekben Buda körül. 'j. Jun.-Jul. 1-1/2' .

Henyélö R. G.procumbens. Ir. K.

Csészéje felsö ajaka 2 hasábu. 2.

2. Virága kocsányjai oldaltállók; magánosan vagy többen vannak egy levélcsomó által környezve; vitorlája és csólnakja selymes szőrös; szára henyélö vagy felegyenesedö ; levelei hosszukás láncsások, alólról, ágai-, kocsányjai- és csészeivel együtt lelapult szőrủek. Hegyi és homoki száraz réteken. 5. Maj.-Jun. 3-8".

Virágzata fürtös. 3.

Szörös R. G. pilosa. L.

3. Szára lefekvö, kurta törzséről felálló, mélyen barázdolt, kopasz, felül szőrösödő; levelei láncsások v. körkörösek, élökön szörösödők; virága és hüvelyei kopaszok. - Hegyi és homoki száraz és nedves réteken bören. †. Jun.-Sept. 1-2'. (Scirya festöfü; myulvelettye.)

Nyul R. G. tinctoria. L. 
Szára hengeres vonalozott, s leveleivel együtt ritka durvaszörü; levelei láncsások, körkörösek, v. tojásdadok; virága kopasz; hüvelye tömött, durva szőrrel borított.

- Budán a hegyi s erdei gyepeken, különösen a Farkasvölgyön. Ђ. Jun.-Jul. 6-18".

Szöszös R. G. ovata. W. K.

\section{ZANÓT. Cytisus. L.}

1. Csészéje harangalaku, szélesebb, mint hosszabb; virágzata leveletlen fürt. $\mathbf{2}$.

Csészéje csöves; virágzata szárhegyi gombban vagy oldali csomóban van. 3.

2. Gazdag virágu fürtjei lelapult szőrủek, lefüggők; hármas levele levélkéi körkörösek, felül kopaszok, alól lelapult szörủek; hüvelei selymes szörủek. - Mivelik kertekben. 卢. Maj. 1-1 $1 / 2^{0}$. Fái Z. C. Laburmum. .

Gazdag virágu fürtjei felállók, kocsányjai és csészéi lelapult szőrüek; csészéje kurta, harangalaku; virága kopasz ; hármaslevele levélkéi visszás-tojásdadok v. lelapult szörüek. Ligeteken. bokrokban a homokon is. ち. Jul.-Aug. 2-4'.

Feketéllö Z. C. nigricans. $I$.

3. Szára henyélő, igen ágas, ágai felegyenesedők, leveleivel együtt ritkás szőrủek; 2-4 virágból álló szárhegyi ernyője van; kocsányjai murvások. - Veröfényes dombokon, erdei réteken, bokrokban. 5. Maj.-Aug. 1-3'.

Henye Z. C. supinus. $L$.

Vrilfaja: a homokon termö kisebb és keskenyebb levelü Kétvirágu Z. C. biflorus. W. K.

Szára felálló, vagy tövön megdülö. 4.

4. Szára sokágu gyapjas; levélkúi láncsások, szálkahegyüek, mindkét oldalon selyrnes szörösek; virágzata szárhegyi ernyős gomb; esészéje hosszukás, durva szőrű. - Ligetekben, bokrokban, hegyi és homoki réteken. 占. Jul.-Aug. 1-3'. Buglyos Z. C. anstriacus. $I$. 
Szírai sugárok, felfelé és széllyelállók, csaknem egyenlök, ágai és levelei széllyelnyílt durva szörüek; levélkéi visszás-tojásdadok vagy visszás-tojásdad láncsások, gyapjasok; virágzata szárhegyi ernyős g’omb ; csészéje hosszukás, gyapjas. - Az elöbbivel, de ritkább. 5 . Jul.-Sept. 1-2'.

Gombos Z. C. capitatus $I$.

\section{IGLICZ. Ononis. L.}

1. Szára henyélö, tövön gyökerezö, gyapjas ; felegyenesedö ágai hegyei tövisesek; virágai hónaljiak, magánosak; hüvelye felálló, tojásdad, esészéjénél kurtább; virága piros. - Legelökön, réteken, szántóföldeken. †. Jun.Sept. 1-2'.

Terjęö I. O. repens. $L$.

Szára felálló vagy felegyenesedö. 2.

2. Ágai tövistelenek; levelei csészéjénél kurtábbak, levélkéi visszás-tojásdadok, fogasok, ikrás szörösek; pálhái láncsások, kihegyezettek, éles foguak; felálló hüvelye tojásdad, gyapjas; virága sárga. - A városligetben Sashegyen és a budaörsi sziklákon. 4. Jun.-Jul. 2-6".

Sárga I. O. Columnae. All.

\section{Ágai tövisesek.}

3. Szárán egy sor gyapjas ször van, ágai tövesei leginkább párosak; hónalji virágai magánosak; levélkéi tojásdad hosszukások, pálháikkal együtt fogasok, kopaszok; hïvelyei tojásdadok, felállók, akkorák vagy hosszabbak, mint a csészéje; virága piros. - Legelőkön, réteken, szántóföldeken mindenütt. 4. Jun.-Sept. 1-2'. (Igliczev. gerlicze-tövis; ökörgrizs; eleakadaily; szcumártövis.)

Tövises I. O. spinosa. $L$.

Szára gyapjas, hónalji virágai kettősek, ága hegyein tömött füzéresek; levélkéi tojásdadok, pálháival együtt fogasoltak, ikrás szörösek; hüvelye felálló, tojásclad, csészéjénél kurtább ; virága halvány piros. - Réteken, kivált vizenyös helyeken, a megye síkjain. 4, Jun.Sept. 1-3'. (Balbüzӥ töris.) Büzios I. O. hircina. $L$. 


\section{SZAPUKA. Anthyllis. L.}

Szárhegyi virágzata kettös gombu; galléros levelei szárnyasok, levélkéi egyenetlenek; csészéje hasas, ferde nyílásu. - Száraz hegyi és homoki réteken. 4. Maj.Aug. 6-18". (Nyulherefï.) Nyul Sz. A. Vulneraria. I.

\section{CsIGaCsö. Medigago. L.}

1. Hüvelyei csaknem gömbalaku, csigamódra ötször tekeredett, éle kétsoru, tövises, tövisei horgasok; pálhái tojásdadok, kurta foguak, a felsök csaknem épélüek; levelkéi alsó részén fogasoltak, szőrösödők; virágai aprók, sárgák. - Száraz réteken, a homokon bőren. ๑. Jun.-Sept. 4-12". Piczi Cs. M. minima. L. Hüvelye egyszer vagy többször csigamódra tekeredett, vagy sarlóalaku, hüvelye tövistelen. 2.

2. Hüvelye közepén nyílt. 3.

Hüvelye közepén be van záródva. 5 .

3. Hüvelye sarlóalaku; vagy egyszer tekeredett, szörösödő, vagy ikrás szörös; fürtje tömött, kurta; kocsánykái csészéinél kurtábbak, virágzás után felállók; pálhái tojásdad-láncsások, kihegyezettek; levélkéi hegyök felé fogasok, fulánkos hegyüek; virága sárga. Száraz réteken, útfeleken, erdőkben. 24. Jun.-Sept. 1-4'. (S'irkerep.) Sárkerep Cs. M. falcata. $L$. Hüvelye csigaalaku, 2-3 csavarodásu. 4.

4. Hosszukás fürtje sok virágu; kocsánykái csészéinél kurtábbak, virágzás után felállók; pálhái tojásdadláncsások, kihegyezettek; levélkéi kicsípett hegyüek, fulánkosak, hegyök felé fogasoltak, az alsók visszástojásdadok, a felsők szálas ékalakuak; virága kék. Réteken, nagyban mivelik. 4. Jun.-Sept. 1-3'. (Luczerna; burgundiai széna.) Kék Cs. M. sativa. L. Kurta fürtje 5-10 virágu; kocsánykái csészéinél hosszabbak vagy akkorák, virágzás után lekonyulnak; levélkéi kicsípett fulánkos hegyüek, az alsók ékalakuak, hegyök 
felé kissé fogasok, a felsőli szálas ékalakuak, épélüek; virága sárga. - Mészsziklákon, hegyi és homoki száraz réteken. 4. Jun.-Aug. 6-18".

C'seplesz Cs. MI. prostrata. Jacqu.

5. Füzéres virágzata sok virágu, tömött; kocsánykái akkorák, mint a levele; hürelyei resealakuak, felfuródottak, hegyökön csavarodottak, ívesen erezettek, kopaszok vagy szőrösödők; pálhái tojásdadok, esaknem épélüek; levélkéi visszás-tojásdadok, alig kicsípettek, elöl fogasok; virága kárga. - Legelőkön, réteken, vágásokon. ๑. Maj.-Aug. 6-18". Komlós Cs. M. Mujulina. L.

Kocsányjai 1-3 viráguak, kurtábbak, mint levelei esigás hüvelyei kerekek, lencsealakulag lapítottak, mindkét oldalról domboruak, esavarodása leginkább 6 ; pálhái szárnyason hasogatott serte sallanguak; apró fürészfogu levélkéi szárával együtt kopaszok, az alsók viszszás-szívesek, a felsők visszás tojásdadok. - A Sashegy keleti és déli lejtöin. ๑. Jul. 6-24".

Karikás Cs. MI. orbicularis. All.

\section{¡. LePKeszeG. Trigonella. L.}

Szára leesepült; levelei hármasok, levélkéi visszás-tojásdad kótaalakuak, hegyesen fogasoltak; virágzata 5 ragy több, ernyősen csomós; hüvelye szálas, ferdén erezett; szörösödö; virága apró, sárgás. - A Sz.-Gellért oldalán. s a Duna bal partján esö homoki gyepeken. $\odot$. Jun.-Jul. 2-6". $\quad$ Heverö L. T. monspeliaca. $L$.

\section{MÉZKEREP. Melilotus. L.}

1. Virágzata felálló, kerekded-tojásdad, tömött fủrt; hüvelye hosszukás tojásdad, csörös, hosszában erezett-csíkos; levélkéi hosszukás láncsások, éles fürészesek; virága kék. -- Hegyi réteken, erdőkben; nem gyakori. ( ). Jun.-Aug. 6-18". (Kerti vagy szagos lóhere; molyfü.)

Kék M. M. coemelea. Lam. 
Virígzata lefüggő megnyult fürt. $\mathbf{2}$.

2. Virága fejér, szárnyai akkorák, mint a csolnakja, a vitorlájánál azonban kurtább; hüvelye tojásdad, tompa, fulánkos hegyü, hálózatosan ránczos, kopasz ; alsó levélkéi visszás-tojásdadok, a felsők hosszukás-láncsások. Homoki gyepeken, útfeleken. $\odot$. Jul.-Sept. 2-6'.

Fejér M. M. alba. Desroussecaux.

\section{Virága sárga. 3.}

3. Bokrétája szárnyai akkorák, mint a vitorlája, csolnakjainál hosszabbak; hüvelye tojásdad, tompa, fulánkos hegyü, keresztbe ránczos, kissé hálózatos, kopasz; alsó levélkei visszás-tojásdadok, a felsők lánesások. - Minden réten, legelön, úton, útfelen. $\odot$. Jun.-Sept. 1-4'. (Somkóróó ; dutkóró.)

Somkóró M. Mr. officinalis. Desv.

Bokrétája szárıyai vitolájánál kurtábbak, csolnakjánál hosszabbak; hüvelye tojásdad, hegyes, hálózatosan ránczos, felső forradásánál lapított, kopasz; pálháí széles aljuak, bevagdalt fogasok, árhegyűek; hosszukás láncsás levélkéi tompák; élesen, csaknem tüskésen fürészesek. - - A megye síkjain fekvő sóstavak és mocsárok mellett. $\odot$. Jun.-Jul. 1-3'.

Fogas II. M. dentata. Pers.

\section{LÓHERE. Trifolium. L.}

1. Kerekded vagy hosszukás füzért vagy gombot alkotó virágai kocsánytalanok. 2.

Kerekded vagy hosszukás füzért vagy gombot alkotó virágai kurtább vagy hosszabb kocsányuak; csészéje torka belöl kopasz. 13.

2. Csészéje torka belöl kopasz; vitorlája lehulló ; termése csészéje felfuvódott. :

Csészéje torkában belölről egy kiálló vonal vagy szörkör nött. 4. 
3. Szára gyökerezö; virággombja golyóalaku, melynek tövén egy sok hasábu gallér van; hátán gömbalakulag felfuvódott termése csészéje hálózatosan erezett, szörös; virága verhenyes fejér. - Nedves réteken és legelökön böven. 24. Jun.-Sept. 3-10".

Eper L. T: fragiferum. $L$.

Szára felálló; füzére tojásdad, gallértalan; csészéi hártyások, sinórosak, felfuvódottak, tojásdadok; levélkéi hosszudad-láncsások, alig fürészesek, kopaszok; pálhái áralakuak; fejér virága veres pettyes. - Szántóföldeken, a Tisza vidékén. 24. Jul.-Aug. 1-3'.

Hólyagos L. T. vesiculosum. Santi.

4. Csészéje csöve kivïlröl puhaszörü v. gyapjas. 5. Csészéje esöve kivülröl kopasz. 12.

5. Csészéje csöve 20 sinóru; gyapjas, fogai fonalalakuak, szemszörösek; füzére gömbalaku, kettös, galléros; levélkéi hosszukás láncsások, igen finomul fogasok; virága piros. - Hegyi réteken, ligetekben, bozótokban. 4. Jun.-Jul. 1-1 $\frac{1}{2} 2$. Bérezi L. T. alpestre. $L$. Csészéje csöve 10 sinóru. (6.

6. Bokrétája fejéres vagy vajszinü. 7. Bokrétája piros. 9.

7. Füzére gyapjason igen bolyhos, hengeralaku; esészéje fogai áralakuan sertealakuak, bokrétájánál hosszabbak; bokrétája elébb fejéres, azután verhenyessé válik; szára ágas, kiterült, leveleivel együtt gyapjas ; pálhái tojásdadok, kihegyezettek; levélkéi szálas hosszukások, alig fogasok. - Gyepeken és szántóföldeken. •. Jul.Sept. 6-18". (Macskahere; herehura; nyullábfï.)

Herehura L. T. arvense. $L$.

Füzére gömbalaku, végre tojásdad vagy hosszukás tojásdad; virága vajszinü. $\mathbf{8}$.

8. Szára felegyenesedő tövéröl indulva felálló, durva szörü, felül csaknem leveletlen; pálhái láncsás áralakuak; levélkéi körkörös hosszukások, szőrösek, virágzata néha 
galléros; csészéje széllyelnyílt, dlurva szörü ; bokrétája kétannyi, mint a csészéje. - Hegyi gyepeken, vágásokon, a homokon nem igen terem. 24. Jul.-Aug. $1-2^{1} 2^{\prime}$.

Vajszin L. T. oeluroleucum. $L$.

Szára sugáran felálló, pálháival s levele nyeleivel együtt durva szörü; pálhái szabadon álló része láncsás áralaku, szára közepún akkora, mint a levele nyele; levélkéi hosszukás láncsások, épélüek, szörösek, az alsók hegyei kicsípettek; csészéje fogai lánesás áralakuak, termése mellett felállók. - Ligetekben az erdők útai mellett, vágásokon Sz.-Endre és Vácz viclékén. A nálunk levök közül ez a legnagyobb. 4. Jun.-Jul. $2-4$ '.

Dunamelléki L. T. pannonicum. Jacqu.

9. Füzére tövön gallértalan; virággombja kerekded-tojásdad, alíg borzas szörü, esészéje fogai sertẹlakuak, akkorák, mint a bokrétája ; szára felálló, ágai buglyosan állanak, leveleivel együtt gyapjas, levélkéi tojásdaul láncsísocskák, tompák, épélỉek : pálhái .hasasok, inasok, szálas láncsások, kihegyezettek. - A homokdombokon levö erdei vágásokon, s a tiszai sík gyepesein. $\odot$.Jun.-Aug. 1-3'. Bugly os L. T. diffisum. Ehth. F’üzére tövön galléros. 10.

10. Tojásdad pálhái meggyökönt kalászon végzölnek; virággombjai rendszerint kettősek; szára felegyenesedö; levélkéi tojásdadok, esaknem épélüek, szörösödők, szörei lelapultak. - Minden réten; mivelik nagyban. ๑. Maj.-Sept. 1-2-3'. (Réti piros lóhere.)

Réti L. T. pratense. $L$.

'T’ojásclad pálhái áralakuak, kihegyezettek. 11.

11. Csészéje fogai kinyíltak, egyenesek, termése esészéje hasasan felpuffadt; levélkéi visszás-tojáscladok, vagy visszásszívesek, elöl apró fürészfoguak, a felsök hoszszukís ékalakuak. - A sz.-endrei száraz réteken és a Tisza körül fekvö gyepeken. 24. Maj.-Jun. 6-18'. Karezoit L. T. striatum. $L$. 
Csészéje fogai gyapjasok, felállók; levélkéi kurta nyelecskések, hosszudad-tojásdadok, alik fogasok; szára henyélö, azután felegyenesedő, alig tekergös, igen ágas, borzas. - A sz.-endrei és váczi hegyi gyepeken nem gyakori, bőven terem a Tisza rétjein. 24. Jun.-Jul. 2-3'.

Gyapjas. L. T. expansum. W. K.

12. Füzére gömbalaku, magános, gallértalan; csészéje $\mathbf{1 0}$. sinóru. piros bokrétája felénél is kurtáblo, fogai fonalakuak szemszörösek; termése csészéje felálló ; pálhái szabadon álló része láncsás, hegyes; levélkéi körkkörösek, igen finom fogasok; szára tekergös. Hegyi és ligeti réteken, lozótokban 24. Jun.-Jul. $1-2^{\prime}$.

Gacsibás L. T. medium. $L$.

Füzére hosszukás-hengeres, leginkább kettős, a töve néha galléros; csészéje 20 sinóru, fogai áralakuak szemszőrösek, 4 felsö foga csövénél 2-3-szor kurtább; pálhái szabadon álló része láncsások, kihegyezettek, ritka fürészfoguak; levélkéi hosszukás láncsások, tövises fürészfoguak $\mathrm{s}$ felálló szárával együtt egészen kopaszok. - Ligeti és hegyi réteken böven. 4. Jun.Jul. 1-2'.

Piruló L. T.rubens. L.

13. Csészéje! fogai egyenlö hosszuk vagy a két felső foga hosszabb ; virággombjai kocsányosak, gallértalanok 14. Csészéje két felsö foga a többinél szembetünően rövidebb. 19.

14. Csészéje akkora vagy hosszabb, mint a bokrétája. 15. Csészéje felényi, mint a bokrétája. 16.

1.). Pálhája hártyás, zörgős; levélkéi visszás-tojásdadok fürészesek; szára ágas, igen vékony, tekergős, elterült; kocsányja igen kurta, csészéje csövénél sokkal kurtább, virágzás után lehajló; termése csészéje alsó oldalín tövig behasadt; virága apró fejér. - A jászsági és kunsági szíkes mezőkön. - ๑ Jun.-Jul. $3-18^{\prime \prime}$.

Kisvirágu L. T. parviflorum. Ehrh. 
Pálhája kótaalaku, fejér szegélyü, ikrás fogas; levélkéi risszás-tojásdad láncsások, tompák, egyenetlen fürészfoguak; szára csaknem magános, kopasz, felálló; 10 sinóru csészéje fogai áralakuak, egyenetlenek, verhenyes bokrétájával csaknem egyenlők. - Száraz réteken, a 'T'isza vidékén. ๑. Jun.-Jul. 3-8".

Sugár L. T: strictum. L.

16. Kocsánykái igen kurták, csészéje csövénél 2-3־\$zor kurtábbak, virágzás után lehajlók; levélkéi körkörösek, éles fürészfoguak, alsó lapjaikon szárával együtt szörösek. élökön sürün erezettek, erecskéi megvastagodottak, szára felálló vagy felegyenesedő; virága fejér. - Minden gyepen. 24. Maj.-Jun. 6-18".

Háromfejii L. T. montanum. $L$.

Virággombjai belsejében álló kocsánykái csészéi csöveivel egyenlők, vagy azoknál 2-3-szor hosszabbak. 17.

17. Szára henyélö, győkerező; pálhái száraz hártyájuak, széles láncsások, fulánkosak; virága fejér vagy verhenyes fejér, kocsánykái virágzás után lehajolnak. -Réteken, legelökön mindenütt, kiváltképen nedves helyeken. 4. Jun.-Sept. Földön fekvö szára 1-2'. (Fejér lólere.)

Gyökerezö L. T. repens. L.

Szára nem gyökerező. 18.

18. Szára felegyenesedö, kopasz, bördős, könnyen összenyomható; levélkéi kótaalakuan körkörösek. tompák, apró fürészfoguak, élén kétfelöl mintegy 20 ere van; kocsánykái virágzás után lehajolnak; bokrétája fejér, azután rózsaszinü, közép virágai felül fejérek, alól pirosak, a szélsők pirosak. - A megye síkján eső minden réten, kivált a nedves helyeken. 4. Maj.Sept. 1-1 1/2'. Kores L. T. hybridum. $L$. Szára henyélő, szegletes-barázdás, girbe-gurba. kopasz; levélkéi visszás-szívesek v. visszás-tojásdadok, hegyök kicsípett, fürészesek, fürészfogai sertések ; pálhái fejér szegélyüek, tövön szárölelök ; virága pirosolló, kocsány- 
kái virágzás után lehajlók. - Homoki gyepeken a tiszaí vidéken, Pesten ritka a Ludoviceum megett. ๑. Jun.-Jul. 1-2'. Szeges L. T. angulatum. W. $K$.

19. Mindenik levélkéje nyeletlen; pálhái hosszukás-láncsások, tövön nem szélesebbek; bokrétája aranyszinü, vitorlája kanálalaku, karczolt, szárnyai lehajlók, virága megszáradva zörgős. Kövér gyepeken. 24. Jun.-Aug. $6-18^{\prime \prime}$.

Zïrgö I. T' agrarium. L.

Közép levélkéje nyeles; levélkéi visszás-tojásdadok ; pálhái tojásdadok; bokrétája világos-sárga, vitorlája kanálalaku, karezolt, szárnyai lehajlók; szárai leginkább henyélök. - Minden gyepen. ๑. Jun.-Sept. $6-18^{\prime \prime}$.

Henyélö L. T. procumbens. $L$.

\section{DORNIK. Dorycnimm. L.}

1. Levélkéi szálas ékalakuak, csaknem selymesen bolyhosak, szöre lelapult; virággombjai rendszerint 12 viráguak; bokrétája fejér, csolnakja vége sötét lilaszinü; hüvelye gömbalaku. - Hegyi és homoki száraz réteken. sziklákon. 4. Jun.-Aug. 6-12".

Cserjésedö D. D. suffruticosum. Vitt.

2. Levélkéi hosszukás ékalakuak, zilált szörüek, szörei széllyelállanak; virággombja leginkább 20 virágból áll; bokrétája fejér. csolnakja orra alig foltos, kisebb. mint az elébbié. - A pilisi hegy szikláin. 4. Jul.Aug. 6-12".

Fünemü D. D. herbaceum. Vill.

\section{KEREP. Lotus. L.}

Szára henyélö, kemény; virrággombja rendszerint 5 virágu; csészéje metszetei háromszögü tövüek s árhegyn̋ek, egyenlők, virágai kinyilása előtt bezáródtak; bokrétája szárnyai láncsás visszás-tojásdadok; csolnakja csaknem kótaalaku, derékszög alatt felegyenesedö; 
hüvelye szálas, hengeres, egyenes. - Réteken, szántóföldeken. 4. Jun.-Sept. 6-18". (Szarvas sairga here.) Szarvas K. L. comiculatus. $L$.

\section{SZÁRNYÓK. 'Tetragonolobus. Scop.}

Szára henyélő; levélkéi visszás-tojásdad ékalakuak; virágai magánosak, sárgák; hüvelye négyszögü gatyás. - Kövér, kivált nedves réteken. 4. Maj.-Jun. 6-15". Gatyás Sz. T. siliquosus. Roth.

\section{HIGVIRICZ. Glycyrrhiza. L.}

1. Szára felálló, karczolt, szőrös, felïl ragacsos; levélkéi tojásclad-láncsások, alsó lapjaikon enyves szörösödők; fürtjei hónaljiak, bokrétája lilaszinü; hüvelyei sarlóalakuak, ikrás tüskések. - A Margit-sziget gyepein és bokraiban böven. 4. Jun.-Jul. 2-3'.

Ikrás H. G.glandulifera. W. K.

2. Szára telálló, barázdolt, szörösödö; levélkéi hosszukás tojásdad-láncsások, alól pontozottak, virággombjai hónaljiak; bokrétája lilaszinü; hüvelyei veres tüskések. - Vizenyős réteken és bokrokban s mocsárokban. 4 Jun.-Aug. 1-21/2'. T'iiskés H. G. echinata. L.

\section{GÁlgA. Galega. L.}

Szária felálló; levelei szárnyasok; levélkéi láncsások, nyílalakuak, fulánkos hegyüek, kopaszok; bokrétája fejér és lila, vitorlája kékesszinü; hüvelye felálló, egyenes, czikkes. - Réteken, vizenyős bozótokban, gyepükben stb. 24. Jul.-Sept. 1-2'.

Kecskere G. G. officinalis. $L$.

\section{5. ÁKÁsZ. Robinia. L.}

Fürtjei lecsüggők, kocsánykái egy viráguak; levelei páratlan szárnyasok, levélkéi hosszukás-körkörösek; fiatal ágain pálhái fulánklká keményednek; virága 
fejér. - Mivelik, most már vadon is nö. 卢. Maj.-Jun. $4-1 j^{0}$.

Fejér i. R. Pseudoacacia. $L$.

\section{DUDAFÜR'T. Colutea. L.}

Levélkéi körrkörösek, esonkák; szárgaszinű bokrétája vitorláján 2 rövid puposodás van; hüvelye felfuvódott hólyag. - Ligetekben, bokrokban, gyepükben. †. Maj.-Jun. 5-10'. (Hólyagos borsófa, var,jukiöröm.)

Pukkantó D. C. arborescens. $L$.

\section{1\%. SAJKORR. Oxytropis. D. C.}

Szára felálló vagy felegyenesedö, leveleivel együtt bolyhos szörös; levelei szárnyasok, alsó levele levélkéi hosszudadok, a felsök láncsások; füzérei tojásdadhosszukások; virága sárga; hüvelyei felállók, szálasok, 2 rekeszüek, bolyhosak. - A Sz.-Gellérten, a pesti Városliget mögött és Csepel szigetén. 4. Jun.Jul. 1-2'.

Szörös S. O. pilosa. D.C.

\section{BÓKA. Astragalus. L.}

1. Virágai töve tetején csoportosak, alig kocsínyosak; szárnyas levelei is mind a tövéröl nöttek; hüvelyei tojáskerekek, valamint az egész növény, gyapjasok. A homokon bőven. 4. Maj.-Jun. Másodizben Sept.Oct. 3-6".

Száratlan B. A. exscapus. $L$.

Virágzata füzéres vagy fürtös; száraz növény. 2.

2. Szára felálló kóros vagy fünemü. 3.

Szára megdűlt vagy lecsepült. 4 .

3. Az egész növény szökén szörösödö, kóros, ágai veszszösök; szárnyas levelei 5-7 bordájuak, levélkéi hoszszudad-láncsások; virágzata fürtös, virága lilaszinű; hüvelyei csaknem négyszögüek, esészéjökböl alig érnek ki. - A Pest körül fekvő homok dombokon, p. o. a váczi temetö felé, Csepel szigetén és Vácz. köriil. 4. Maj.-Jun. $1 / 2-2^{1 / 2}$ '.

Vesszös B. A. virgatus. Pall. 
Szára mereven felálló, szörösödő, szőre lelapult; szárnyas levelei 12-15 bordájuak, levélkéi láncsások és szálasok, füzérei megnyultak, tömöttek, vajszinü virágai felállók; hüvelyei hosszukás-szálasok, szörösödők, a fökocsányhoz lapultak. - Homoki nedres réteken és dombokon. 24. Maj.-Jul. 1-3'.

Durva B. A. asper. Jucqu.

4. Bokrétája lilaszinü vagy pirosolló. 5. Bokrétája sárgás vagy vajszinü. 7.

5. Szára kórosodó, szárba induló, azután széllyel ágazó; az egész növény szőkéllö; szárnyas levelei 5-7 pár bordájuak, levélkéi hosszudadok vagy körkörösek ; füzére csaknem gombos; termése csészéje hólyagos, hüvelye hosszukás, csészéjénél kevéssel hosszabb, durva szörü. - A mészhegyeken levő száraz gyepeken. 24. Maj.Jun. 3-10". (A. albidus. W. K.) Szöke B. A. vesicarius. $L$. Szára fünenü. 6.

6. Szára megdült, szörös, szöre lelapult; szárnyas levelei 8-12 pár bordájuak, levélkéi láncsások; füzérei gombosak, tojásdadok; kékes piros bokrétája vitorlája szálas-hosszukás, szárnyainál 3-szor hosszabbak; maghona és hüvelye kocsánytalan; hüvelye felálló, tojásdad, kihegyezett, durva szőrű. - Minden gyepen, igen közönséges. 24. Jun.-Jul. 1-3'.

Vitorlás B. A. Onobrychis. $L$.

Szára megdült kopasz; szárnyas levelei 7-10 pár bordájuak, levélkéi szálasok, kicsípett végüek; fürtjei megnyultak, ritkások; bokrétája szárnyai kétáguak; hüvelyei függők, szőrösödők. - Hegyi és homoki gyepeken. 24. Maj.-Jun. 6-12".

Hasadtszárnyu B. A. austriacus. $L$.

7. Szára és levelei csaknem kopaszok vagy egészen kopaszok, henyélők; szárnyas levelei 5-6 pár bordájuak, levélkéi tojásdadok; füzérei tojásdad-hosszukások; 
hüvelyei szálasok, csaknem 3 szögüek, alsó forradásuknál mélyen benyomottak, ívalakuak, kopaszok, felállók, végre egymáshoz lapulók. - Hegyi és erdei réteken, vágásokon, gyepükben. 4. Jun.-Aug. 3-5'. (Héjja liöröm.)

Édeslevelï B. A. glycyphyllos. $L$.

Szára és levelei szörösödök vagy gyapjasok. 8.

8. Szára henyélö; szárnyas levelei sok bordájuak, levélkéi kurta nyelecskések, hosszudadok tompák, szálkahegyüek; sok virágu fürtjei hónaljiak; hüvelyei csaknem gömbdedek, puffadtak, szálkavégüek, szöröskék. Bozótokban, réteken, szántóföldeken, erdökben. 4. Jun.-Aug. 2-3'. (Hólyag lóbor'só.)

Bagolesa B. A. Cicer. $L$.

Szára lecsepült gyapjas; szárnyas levelei 8-sok bordájuak, levélkéi visszás-tojásdadok, kicsípettek; hónalj fürtjei magánosak, tömöttek; hüvelyei összetekert facsartak, szöröskék. - Száraz mezökön a Tisza vilékén. 4. Jun.-Jul. 2-4'.

Sugori B. A. contortuplicatus. $L$.

\section{Kornilia. Coronilla. L.}

1. Szára henyélö; pálhái láncsások, szabadok; levelei leginkább 10 pár bordájuak, levélkéi hosszukás visszástojásdadok, tompák; ernyője többnyire 20 virágu, kocsánykái csészéje csövénél 3-szor hosszabbak; bokrétája fejér piros tarka; czikkhüvelye négyszögü. Mindenütt. 4. Jun.-Sept. 1/2-3'. 'Tarka B. C. varia. $L$.

2. Szára felálló; pálhái aprók, levélellenesek, lehullók ; levelei páratlan szárnyasok, levélkéi tojáscladok vagy visszás-tojásdadok, az alsó pár a levélnyelét öleli; ernyője 15-30 virágu; kocsánykái csészéje csövénél 3-szor hosszabbak; bokrétája sárga; czikkhüvelye négyszögü, lapított. - - Hegyi szíraz réteken, bokrokban, köves helyeken. 4. Jun.-Jul. 12-18".

Koronás K. C. montana. Scop. 


\section{PATKÓCZIM. Hippocrepis. L.}

Ernyöi gombosak, kocsányjai levelénél hosszabbak, czikkhüvelyei görbék, érdes szörüek, czikkein benyomottak, kopaszok. - Mészhegyek verőfényes rétein és a homokon. 2. Maj.-Aug. 6-12". (Lópatiófï.)

Ernyös P. H. comosa. $I_{\text {. }}$.

\section{EspÁrCzet. Onobrychis. Tourn.}

Szára felegyenesedő; levelei 9-12 pár bordájuak; levélkéi szálas hosszukások; fürtje kétanynyi, mint a levele; hüvelye köralaku, közepén domboru s hálózatos. - A budai hegyi réteken böven, vetik nagyban. 4. Jun.Aug. 3-4'. (Espairczet; szamirhere; spanyol lóhere; varjuborsó.)

Takarmány E. O. sativa. Lam.

\section{BABÓ. Vicia. L.}

1. Bibeszára köröskörül egyenlöen szörös, alsó oldalán nem szakálas. 2.

Bibeszára alsó oldalán a hegye felé szakálas, egyéb reészén kopasz, vagy a felső részén köröskörül bolyhos. 4.

2. Fürtjei leveleinél hosszabbak; levelei leginkább 8 pár bordájuak, levélkéi tojásdadok, tompák; pálhái félholdalakuak, bevagdaltan sok foguak; bokrétája fejéres. vitorlája kéken erezett; hüvelyei szálas hosszukások. - A pilisi hegyek ligeteiben. 24. Jul-Aug. 2-4'.

ligeti B. I. sylvatica. $L$.

Fürtjei leveleinél kurtábbak. 3.

3. Levelei leginkább 5 pár bordájuak, levélkéi tojásdadok, tompák, a legalsók a szárra símulók ugy, hogy pálháit is elfedik; virága vajszinü. - Bozótokban, erdőkben, gyepük mellett. 24. Jun.-Aug. 2-4'.

Borsóka B. I. pisiformis. $L$.

Levelei sok pár bordájuak s három águ összekunkorodott kaccson végzödnek, levélkéi tojásdad hosszukások vagy láncsások; pálhái féldárdalakuak, épélüek; hüve- 
lyei csaknem kótaalakuak. - Erdökben és rágásokon. 4. Jun.-Aug. 2-3'.

Vitéz B. V. cassubica. $L$.

4. Kocsányjai megnyultak, sok viráguak, az alattok nőtt levélnél hosszabbak vagy kurtábbak. 5.

Kocsányjai 1-2, vagy 4-6 viráguak. 8 .

5. Pálhái félholdalakuak, bevagdalt sok foguak, fogai hajszálhegyüek; levelei leginkább 5 pár bordájuak, levélkéi tojásdadok, tompák, a legalsó szárától távolocska van; virága fejér vagy verhenyes lilaszinü. - A hegyi, szigeti és homoki bozótokban. 4. Jun.-Aug. 2-3'.

Csere B. $V$. dumetorum. $L$.

Pálhái féldárdalakuak, épéln̋ek. 6.

6. Levelei szárával együtt gyapjasok, 8 pár bordájuak, levélkéi láncsások ; virágai egymást hátalják; vitorlája lemeze akkora, mint a nyaka; bokrétája sötét vagy világos lilaszinü, szárnyai fejéresek; hüvelye körkörös. - Vetések közt. ○. Maj.-Aug. 3-4'. (Kaszamyïg.)

Szörös B. V. villosa. Roth.

\section{Levelei lelapult szörüek. 7.}

7. Vitorlája lemeze akkora, mint a nyaka, bokrétája lilaszinü; hüvelye szálas hosszulkás, kocsányja csészéinél kurtább; levele 10-11 pár bordáju levélkéi hosszukások vagy láncsások. - Bozótokban, ligeteken, vágásokon, gyepükben. 24. Jun.-Aug. 3-4'. (Kaszanyüg.)

\section{Kaszanyüg B. $V$. cracca. $L$.}

Vitorlája nyakánál kétszerte hosszabb, bokrétája lilaszinü; hüvelye szálas hosszukás, kocsánykája csészéjénél kurtább, levelei 10 pár bordájuak, levélkéi láncsások, 3 inúak. - Az előbbivel. 4. Jun.-Aug. 3-4'.

Inaslevelï B. V. tenuifolia. Roth.

8. Párosan szárnyas levelei 4-8 pár bordájuak. 9.

Párosan szárnyas levelei 2-3 pár bordájuak. 15.

9. Bokrétája szennyes- vagy sárgás fejér, nyaka olajszinű vagy barna, néha kékes-piros foltos; vitorlája kopasz, kétannyi mint a szárnyai ; csészéje fogai láncsás árala- 
kuan felényiek, mint a csöve, csaknem egyenlök; hüvelyei vizirányosan állanak; levélkéi visszás-tojásdadok vagy visszás-szívesek vagy hosszukás szálasok, csonkák. - A budai gyepeken ritkább, sok van Üröm és Weindorf körül. ๑. Maj.-Jun. 1-3'. (Szennyes B. V. snidida. W. K.)

Nagyvirágu B. $V$. grandiflora. Scop.

Bokrétája lilaszinü vagy piros; (a pamnonicáé néha fejér.) 10.

10. Hüvelyei kopaszok, vagy alig szőrösödők. 11. Hüvelyei borzas szőrösek. 14.

11. Virágai egy hónalji fürtben $2-5$-en vannak; vitorlája kopasz, egész bokrétája szennyes lilaszinü; csćszéje fogai egyenetlenek; hüvelye szálas-hosszukás; levélkéi tojásdadok vagy hosszukások, tompák. - Bozótokban, gyepükben, erdökben gyakori. 4. Maj.-Jul. 1-2'.

Gyepüi B. V. Sepium. $L$.

Virágai a levél hónaljában leginkább kettönként állanak. 12.

12. Levélkéi ékalakuak, a felsők két karélylyal csorbák az alsók visszás-szívesek; vitorlája kopasz, csészéje fogai láncsás áralakuak, előreállók; hüvelye szálas. Mivelt helyeken, gyepeken vetések közt. (. Maj.-Aug. $1-2^{\prime}$. Szíveslevelï B. $V$. corlata. Wulf.

Levélkéi egyszer kicsípetten csorbák, néha hegyesek. 13.

15. Hüvelyei felállók, hosszukások, szőrösek, magva golyóalaku, kétfelöl behorpadt; vitorlája kékes, szárnyai bibor pirosak, csolnakja fejéres; levélkéi viszszás-tojásdadok. - Nagyban vetik. ○. Jun.-Aug. 1-3'. (Ló-v. abrak-borsó; lednel; vad lencse; bülizöny.)

Ibrak B. $V$. sativa. $L$.

Hüvelyei lehajlók, szálasok, ha megérnek, kopaszok; feketék, magva golyóalaku; bekrétája piros, vitorlája kopasz; levélkéi hosszudadok, keskenyek, az alsók 
kissé csonkák, a felsök hegyesek. - Az elöbbivel $\odot$. Jun.-Aug. 1-3'.

Keskenylevelï I. V. angustifolia. Roth.

14. Levélkéi tojásdadok, tompák, alig fürészesek vagy épélüek; vitorlája kopasz, bokrétája szürke lilaszinü; hïvelyei lapítottak, kopaszok vagy ször ösek, éle puha tüskés szemszörös. - Gyepeken, kivált vizenyös és sós helyeken, a Tisza felé. $\odot$. Jun.-Ang. 1-2'.

Fogas B. V. narbonensis. I.

Vuilfaja: levélkéi csomósan a vállukról fürészesek: $V$. serratifolia. Jacqu.

Le vélkéi hosszukások és visszás-tojásdadok, tompák vagy csorbák; vitorlája szőrös, bokrétája fejéres, van lilaszinü is; hüvelyei hosszukások, lefordultak, durva szőrösek. - Vetések közt bőven. ๑. Maj.-Jul. 1-2'.

Dunamelléki B. $V$. pannonica. Jacqu.

Vialfaja: bokrétája kisebb, vitorlája szörösödö, piros : V. purpurascens. D. C.

15. Virágai magánosak, hónaljiak, kocsínytalanok; 2-3 pár levélkéi fulánkos végüek, a felsők kaccson végzödnek; csészéje fogai csaknem egyenlők; bokrétája világos lilaszinü, apró ; hüvelye szálas, kopasz; magvai koczkaalakuak, szemcsésen érdesek. - Hegyi és homoki gyepeken, p. o. a szép juhásznénál. ๑. Maj.Jun. 3-8".

Piczi B. V. lathyroirles. L.

Virágai 2-4 virágu hónalji fürtöket alkotnak; csészéje fogai egyenetlenek; virága fejér, szárnyain fekete fóltok vannak; hüvelyei börnemüek. puhaszörüek. Vetik. ๑. Jun.-Jul. 2-3'. (Bab; kerti-, disznó; lóbab.)

Bal) B. V. Faba. L.

\section{9:. LENCSE. Ervum. L.}

1. Fürtje 2-6 virágu, körülbelől akkora, mint a levelei; levelei leginkább 6 pár bordájuak, levélkéi szálasok, tompák, vagy csonkák ; pálhái féldárdaalakuak, hüvelye 
hosszukás, 2 magu, szörösödõ. - Vetések közt, gyepeken, kertekben. $\odot$. Jun.-Sept. 2-4'.

Kocsányja 1-2 virágu. ․

Borzas L. E. hirsutum. L.

2. Hüvelye 1-2 magu, kopasz; levelei leginkábls 6 pár bordájuak; pálhái láncsások, épélüek. - Vetik. $\odot$. Jun.-Jul. 6-12". (Lencse.) Fözelék L. E. Lens. L. Hüvelye 3-4 magu. 3.

3. Kocsányja 1 virágu, akkora, mint a levele; levelei $3-4$ pár bordájuak, levélkéi láncsások, tompák; pálhái féldárdaalakuak; virága lilaszinü ; hüvelye kopasz, szálas. - Hegyi gyepeken, vetések közt. $\odot$. Jun.-Sept. 2-3',

Négymagvi L. $E$. tetraspermum. $L$. Kocsányja 1 virágu, akkora, mint a levele, levelei többnyire 7 pár bordájuak, levélkéi láncsások, tompák, vagy esonkák; pálhái egyenetlenek, egyik szálas, épélü, nyeletlen, a másik félholdalaku, sertefogu, nyeles ; virága lilaszinü; hüvelye széles hosszudad, többnyire 3 magvu. - Vetések közt Pest körül. $\odot$. Jun.-Jul. Egyvirágu L. E. monanthos. $L$.

\section{Borsó. Pisum. L.}

Pálhái tojásdadok, félig szívesek, tövön egyenetlen fogasok; levelei 2-3 pár bordájuak, levélkéi tojásdadok, csipkések; bokrétája kékes piros; magva horpadásos. - Vetések közt; vetik is. $\odot$. Maj.-Jul.

Mezei B. $P$. arrense. 1 .

\section{BÜKKÖNY. Lathyrus. L.}

1. Levelei hiányzanak, levél nyelei levélalakuak, láncsások, kaccstalanok; kocsányjain 1-2 virág van; virága apró veres tarka. - Szántóföldeken, s gyepeken Hidegkut körül. $\odot$. Maj.-Jun. 6-12".

Kacestalan B. L. Nissolia. L.

Levelesek. 2. 
2. Levelei egy pár bordájuak; kocsányjain 1-2 virág terem gyökere egynyári. 3.

Levelei 1-3 pár bordájuak; kocsán yjain sok virág terem, gyökere évelö. 4.

3. Kocsányja egy virágu, levelénél kurtább ; virága kékes, pirosas vagy fejér; hüvelye körkörös, hosszukás. lapított, kopasz, 4 magvu, felső éle meggörbült, két szárnyu ; magva szegletes, síma. - Vetések közt, mivelik is. $\odot$ - Maj.-Jun. 2-3'. (Szzerges borsó.)

Szeges B. $L$. sativus. $L$.

Kocsányja két virágu, levelénél hosszabb ; virága kékes piros, azután kék; hüvelye szálas, hosszu, durva szörü ; magra gömbölyü érdes. - Hegyi réteken ritkábl, nedves homoki réteken a szigetekben gyakoribb. $\odot$. Jun.-Ang. 1-2 $1 / 2^{\prime}$.

Borzas B. L. hirsutus. $L$.

4. Szálara ormós, gatyátlan. 5 . Szára gatyás, 6.

5. Levelei 1 pár bordájuak, levékéi tojásdadok, szálkahegyüek, pálhái láncsás féldárdások; csészéje felső foga kurta háromszögü; bokrétája piros, hüvelye szálas hosszukás, kopasz; magva alig görcsös ; gyökere gumós. - Vetések közt, agyagos mezökön. 24. Jun.-Aug. $1^{1}$ z-3'. (Földi mogyoró.) Mogyorós B. L.tuberosus. $L$. Levelei egy pár bordájuak, levélkéi láncsások; pálhái láncsás-féldárdások; csészéje fogai láncsás-áralakuak, maghonánál kurtábbak; bokrétája sárga; hürelyei kopaszok, dülten erezettek. - Réteken. szántóföldeken. erdőkben. 4. Jun.-Sept. $1^{1} 2-3^{\prime}$.

Pallagi B. $I$. pratensis. $L$.

6. Levelei gatyátlanok, levelei 2-3 pár bordájuak, lerélkéi szálas láncsások, szálkahegyüek; pálhái fülecskéi láncsások, kihegyezettek; bokrétája kék; hürelỵe szálás hosszukás, egyenes, kopasz; magvai símák. Tizenyös réteken, sásasokban, füzesekben. 4. Jun.Aug. 2-2'.

Tavi B. L. palustris. L.

Levelei nyelei gatyások. 7 . 
7. Szára gatyája kétszer olyan széles, mint levele nyeléé; magva kötöléke magvát félig keríti; vitorlája háta verhenyes zöld, töve belöl bibor piros, onnan felfelé testszinü. Buda körül ritka, bőven van a szigetekben. 4. Jun.-Aug. 2-6'.

Erdei B. L. sylvestris. $L$. Szára gatyája fulánkos, szemszörős, olyanforma széles, mint a levelei nyeléé; magva kötöléke alig egy harmadra keríti be a magvát; magvai görcsösek, görcesei hosszukások, egymásba olvadók; bokrétája nagy s szép pirns. - Hegyi gyepeken, kertekben is mivelik. 4. Jum.-Aug. 3-6'. (L. grandiflorus. Laing.)

Széleslevelï B. L. latifolius. $L$.

\section{LEDNEK. Orobus. L.}

1. Bokrétája piros vagy kékellö. 2.

Bokrétája sárgás fejér vagy vajszinü. :

2. Levelei 2-3 pár bordájuak, levélkéi tojásdadok vagy hosszukás tojásdad-láncsások, hosszan kihegyezettek, alsó lapjaikon fénylök; bokrétája piros, késöbb kék, végre zöldes kék; hüvelye kopasz. - Ligetekben. 4.

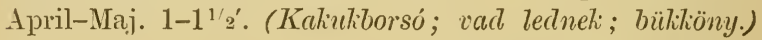

Tavaszi L. O. vernus. $L$.

Levelei leginkábl 6 pár bordájuak, levélkéi tojásdadhosszukások, tompák, alól tengerszínzöldek, fénytelenek; bibeszára szálas, közepétöl tetejéig szakálas, bokrétája piros; hüvelyei feketék. - Erdökben, bokrokban. 4. Maj.-Jun. 1-2'.

Fekete L. O. niger. $L$.

3. Levelei sok pár bordájuak, levéllééi kurta nyelecskéjüek tojásdad-láncsások, szálka hegyủek; sok virágu fürtjei hónaljiak; hüvelyei kissé lapítottak, láncsásolk, símák, mintegy 4 magvuak. - A budai és pilisi hegyi erdök-

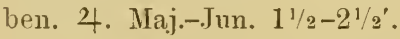

Vajszín L. O. ochroleucus. W. K.

Levelei 1-4 pár bordájuak. 4.

4. (†yökere esomós, rostjai ékalakuan meggumósodnak; szára szegletes; levélkéi szálas-láncsások és szálasok, 
kopaszok, szálkahegyüek; pálhái féldárdások; bibeszára szálas; hüvelye egyenes, szálas. - Hegyi és homoki réteken. 2. Maj.-Jun. 1-1/1/2'.

Fejér L. O. albus. $I$.

Vuilfajai; a) Virága fejér vagy sárgás fejér, vitorlája háta néha rózsaszínbe játszik: O.pannonicus. Jacqu.; b) Vitorlája piros, szárnyai és esolnakjai sárgák: C. rersicolor. Gmel.)

Gyökere rostos. nem gumósodó ; szára szegletes; levélkéi kopaszok, megnyult szálas kardalakuak, szálkahegyủek ; pálhái serte- vagy áralakuak, féldárdások; bokrétája fejéres. leginkább gyengén pirosodó, bibéje lapiczkásan elszélesedö, hïvelye egyenes szálas. - A Széchenyihegyen levö ligeti réteken, a budai kincstári erdőkben. 4. Jun.-Jul. 1-1 ${ }^{\prime 2}$ '. Sáppadt L. O. pallescens. MI. B.

\section{Paszuly. Phaseolus. L.}

1. Fürtjei leveleinél hosszabbak, kocsányjai kétáguak; bokrétája fejér vagy veres; hüvelye lefüggö, kissé sarlóalaku; levélkéi tojásdadok, kihegyezettek. - Mivelik. $\odot$. Jul.-Aug.

Nagyvirágu P. P. multiflorus. W.

2. Fürtjei leveleinél kurtábbak, kocsányjai kétágual; bokrétája fejér vagy verhenyes; hüvelye lefüggö, meglehetösen egyenes : szára felfutó. - Mivelik. ๑. Jul.-Aug. Futó P. P. vulyaris. $L$.

\section{CZERCZisz. Cercis. L.}

Levelei kerekdedek, szívesek, kopaszok; piros virágai fája kilevelezése elött ágai oldalaiból csoportosan hajtanak ki. - A pesti városligetben s a Margit-szigeten. J. April-Maj. 6-15'. (Judaisfája; timyérlerelü fa.) Tányéros Cz. C. Siliquastrum. K. 


\section{Nïvénytani rïvid müszótár.}

Ajakas, lubicutum. Az ajakas szó alatt rendesen a két ajcklu-t (bilabiatum) értik. Ajakas, vagy két ajaku az egytagu csésze vagy bokréta, midőn alja csővé van nỏve, teteje pedig ugy van bevágva, hogy két fömetszete egymással szemben áll s nyilása egy tátott szájhoz hasonlít. - Az ajakasnak két fömetszete ismét vagy ép, vagy 2-3-szor bemetszett. Ajakas csészéje van a Zanótnak, Cytisus; ajakas bokrétája van a Zsályának, Salvia.

Alakos, personatum. Ezen könyvben csak a bokrétáról van mondva, midön az ajakas bokréta alsó ajaka kidomborodásíval a bokréta torkát bezárja, mint a Pintyö, Antirhinum bokrétájában.

íllevél, Phillodium. Olyan levél, mely egy kiszélesedett levélnyélböl áll, tulajdonképen egy levél-lapalaku levélnyél. Ilyen állevele van a Kaccstalan Bükkönynek. Lathyins Nissolia.

Alma, Pomum. Bogyónemü termés, mely a csésze és a maghon meghusosodásából fejlik ki, a közepében pedig bőr-vagy pergamenszerü béllésben vannak a magvak. Ilyen termése van a Körtefának. Pyrus.

Alsó, inferum. Valamely szerv, mely egy másik szervnek, legalább látszólag, alatta áll; használják különösen i virág különbözö körei egymás közti viszonyai kifejezésére. Ha például azt mondják: alsó bolirétı, az azt 
teszi, hogy a virág legbelsö köre alján, a maghonon alól kezdődő bokréta; - alsó maghon, azaz a bokrétr és csésze alatt álló stl.

Áralakn, subulatum, ha valamely szerv, p. o. a levél keskeny tövön kezdődvén lassanként finoman elhegyesedik, p. o. a Boróka, Juniperus és a Savar, Salsnla levelei.

d́sitó, ringens. Olyan ajakas bokréta, melynek egymáshoz közelebb vagy távolabb álló ajakaitól a torkába jól be lehet látni; mint a Tátkanaf. Lamium. Alkalmazzák ezen kifejezést az olyan sok szirmu bokrétára is, melynek a szirmai állása az ajakosak szája állásához hasonlít, mint a Dákoskáé. Gladiolus.

Aszottas, scuriosum. Vékonyabb vagy vastagabb száraz hártyanemű szerv, mint a Vasvirág Xercanthenum fészke pikkelyei, az Utifü Plantrıgo bokrétája.

itnött, perfolictum, ha a levél válla a szárat körülfogja, mint a Buvák Szingalléré. Bupleurum perfoliatum.

\section{IB.}

Babug, Papilla, a bokréta szirmain vagy a bibén egymás mellett kidudorodott ikrák vagy szümölcsöcskék, mint az Atraczél, Anchusa boltpikkelyein levö apró ikrás kidudorodások.

Barázda, Sulcus. A növény felszinén egymás mellett fekvö egyenlö keskenységü bemélyedések, mint némely növény szárain láthatni, mint a Nagy Pimpinella szárán.

Barka, Amentum. Olyan virágzat. melynek a fökocsányjára egymás mellé, rendesen váltogatva nőtt pikkelyei alá különvált tenyészszervek nönek, aztán virágzás után rendszerint mindenestöl egy darabban lehullanak; ilyen a Dió, Füz, Nyár porodás virágzata.

Beczö, Siliqua. Két termölevélböl alakult olyan magrejtö, melynek ellenesen álló két forradása között 
belső részében, közepén egy hártya rálaszfal nyulik végig s a forradásairól nőtt sinórocskák vagy kötölékeknél fogva táplálkozó magvacskák ezen válaszfal által vannak elkülönözve : hossza szélességénél 4-6-szorta nagyobb; két kopácscsal nyilik fel s kopácsai kocsányja felöl alól kezdenek felfeselni. Ilyen termésök van a keresztes virágok nagyobb részének, mint $p$. o. a Káposztának. Brassica.

Befelé fordult, introrsum, vagy belső oldalon nyiló, p. o. az olyan portokok, melyek a szálcsák belső oldalára nővén a virág közepe felöl hasadnak ki, mint a Takta, Actea portokai.

Bél, Nucleus, a magnak a hámján vagy kérgén belöl eső fejérnyéből és keményitőből és néha olajból álló azon része, melyből a csira kikelése idején első táplálékát veszi.

Berzedt, squarrosum, ha a levelek vagy az ágak minden irányban széllyelterpeszkednek, mint a Berzedt Galaj Gatium Parisiense ágai

Beszegett, induplicatum, ha a levél vagy a levélnemü részek élei bekunkorodnak, mint a Bércse, Clematis bimbóban levő szimmai éle lenni szokott. Mondják ezt a magban levö kelö levélkék éléröl is, ha azok is be rannak kunkorodva s ilyenkor feleserélik a ránczos szóval.

Bibe, Stigma, a rirág terméje hegyén ikrás szörök, ragy babugokból álló ragacsos rész, mely a reá hulló virágport felfogja s azokat termékenyítő szütyőkké kifejleszti, - Ez a terme lényeges része.

Bibiresós, tuberculatum, apró pupokkal vagy göcsökkel fedett felület, mint a milyen szokott lenni az Ugorka, Cucumis kabakjának a felülete.

Bibeszár, Stylus, a maghon tetejéröl nöni szokott száracska, melynek a tetején inl a bibe. A bibeszára régig csatornás, melyen a virágporból kifejlödő termé- 
kenyitö szütyök a maghonig lenyulhatnak; néha a bibeszár levélnémüleg ellapul, mint a Nösziromé.

Bibeták, Gynostemium, azon kis pótlékocska, mely p. o. a kosborfélék bibéjével a termére nött porodát öszszeköti.

Biggyesztett, incumbens, midön a növény valamely része hegyére egy másik része vagy a közepérel, ragy a közepe tájával van ránőve, mint a Liliom. Hagyma és a Zöldesík, Ornythogalum portokai nöttek a szálcsáira.

Billenges fürt, Racemus compositus, olyan fürtös virágzat, melynek a kocsánykái ismét fürtöcskékké ágaznak el, mint a Szöllő és a Feketegyürü Jávor, Acer tataricum virágzatáé.

Bimbó, Gemma, az ágak oldalán vagy végén növö pikkelyekkel fedett olyan szerv, melynek közepén fekrö uj ágacska vagy ágacskák durványain levél és virágrészek durványai vannak alakulva.

Bóbita, Pappus, a magcsák vagy a kifejlett magrak tetején ször vagy tollasszőr, néha pikkely formában kifejlett csésze, mint a milyenek nagyrészben a fészkesek, a Gyökönke, Valeriana termésein látható szörök vagy pikkelyek.

Bogernyö, Cyma, olyan virágzat, melynek $3 \mathrm{~s}$ több kocsányja egy pontból indul ki, ezek azután ágbogosan ugy ágaznak el, hogy ez ágacskáikon levő virággal végre egy síkban terülnek ki, mint a Bodzafa, Sambucus virágzata.

Bögrealaku, urceolatum, olyan hasas, belöl üreges tetején nyílt szerv, melynek a hasa felett s nyilása alatt el, szükült nyaka van, mint p. o. a Rózsa csészéje.

Bogyó, Bacca, olyan husos leves magrejtö, melynek a magrát a husa közt finom hártya vagy meg nem fásult bör, vagy pergamen környezi, mint a SzöllöBod zafa termése.

Bókoló, cermum, ha a felálló szár tetején levö ág, vagy 
virágkocsányja ugy hajlik meg, hogy vége vagy a rajta levö virág vízirányos vagy lekonyúlt állásuvá lesz, mint a Napraforgó Napvirágé, vagy a Bókoló Bogácsé,

Bokléta, Corolla, a csészén közvetlen belöl eső színes levelekböl (szirmokból) álló része a virágnak.

Boltpikkely, Fornix, az egytagu bokréta torkában különféle alakulag kifejleni szokott s a torkot elszükítö vagy bezáró pilisnemü pótlék, a milyen van a Mizsót, Myosotis, a Nadálytő, Symphytum, bokrétája torkában.

Borla, Jugum, a szárnyas levelek főnyelén ellenesen vagy usaknem ellenesen álló levélkepár; innen p. o. a Ba\ó szárnyas levelei 5-11 bordájuak.

Borsókás, granulatum, midön a növény valamelv része szemcsés felületü.

Börolös, fistulosum, midőn a növények száxa vagy a levelek nyele vagy kocsányja belső részén jó hosszan üregres, mint a Veres Hagyma levele, a Bürök, Conium szára, a Tök levele nyele.

Buga, Panicula, olyan virágzat, melynek a fökocsányjából küiönböző magassáğban fejlő kocsánykái különféleképen ágaznak el s_virágai az így elágazott kocsánykák hegyein vannak, mint p. o. a Fagyal, Ligustrum virágzata. (Lásd a különféle bugákat a XXIII. lap, 4. szám. b. alatt.)

Buglyos, diffusum, effusum, supra decompositum, az ágaknak s ezekből ismét az ágacskáknak a szárból 45 foku szegletböl 90 foku szeglettel való elhajlása, mint az Egynyári Hunyász, Stachys anmua ága s a Harmattartó Tippan, Agrostis Spica renti virágzata stb.

Burok, Spatha, egy darabból álló hártyanemü takaró, mely majd egyes virágokat takar bimbó korukban be, mint a Hóvirágé, majel virágzatokat, mint a Konty. vi ìágé. 
Butuló, obtusum, ha valamely szervnek a hegye vagy tompa szegletü vagy alig észrevehetö szegélyen végzödik, mint p. o. a Farkas Gégevirág, Aristolochia Clematitis levele.

Biitykös, geniculatum, ha a növény valamely szervén hellyel-közzel kiálló görcsök támadnak, mint a pázsitfüvek szalmáin.

Buityökköz, Internodium, a növényszervo, például a szár azon része, mely a görcsök között egyenlö átméröjüvé fejlik, mint a pázsitfüvek bütykei között eső csöves vészei.

\section{Cs. és Cz.}

Csákó, Cauda, a mag tetejére a megmaradt bibeszárból alakult fonalaku hajlós, néha szörös nyujtvány, mint a milyen van a Kököresin, Anemone magvain.

Csavargós, repandum, a levél éle, midőn az csekély mélyedéssel hullámzó vonalban van kikanyargatva, mint az Ostorindás Kacskanyak, Ajuga repitans levele éle.

Cserje, Finutex, olyan faféle növény, mely tövéböl több vékony derekat hajt, melyek 1-2 ölnél magasabbra nem nönek, mint p. o. a Kökényszilva, Prumus spinosa.

Csésze, Calyx, a virág négy förészei közt mindig a külső kört alkotó zöld rész. (Lásd XXVI. lapon a alatt.)

Czikk, Articulus, a növény valamely szerve két választó vonal. vagy bütyök között esö része, p. o. a pázsitfüvek zzalmája bütyök közén esö része, vagy a Kornilla hüvelye két vonal között esö tagjai.

Czikkhiively, Lomentum, olyan hüvely termés, mely keresztben el van rekgetve $\mathrm{s}$ mindenik rekeszében egy mag van s megérésekor kereszt rekgetéseiben válnak el egymástól, mint a Kornilla és a Patkóczím Hippocrepis, termése. 
Csigaalaku, cochleatum, midön valamely szerr, mint a Csigacső, Meclicago némely faja termése, csararosan kétszer s többször van megtekeredve.

Csillagos, stellatum, midőn az egynemü szervek egy központ körül sugárosan terülnek ki, mint p. o. a Galaj, Galium fajai levelei. vagy mint az Ostormén, Bangita Viburnum Lantanc fiatal ágain levö szőrök. Csipkés, crenatum, ha valamely szerv, (például a levél) éle szűk szeglet alatt van bevagdalva, azonban kiülö, hegyei tompa karélyuak, mint a Tavaszi Ibolya levele éle.

Csípök, Stimuli, olyan ször fulánkok, melyeknek a tövén égető nedvet tartó hólyagocskák vannak s magokon a szörökön végig csatorna vomul; ilyenek a Csalán, Urticı fajai szörei.

Csira, Embryo, a mag belébe foglalt növény durványa, melyben már a gyököcske s a szára és a levelek elemei is megrannak.

Csirabimbó, Gemmula embryonalis, a mag belébe foglalt magszíke hegyén levő bimbócska, melyloól a kelölerél vagy levelek, azután a nörény felfelé növö részei fejlenek ki.

Csö, Tubus, az egy levelü csésze, ragy az egytagu bokréta vagy lepel elkeskenyedö, azonban egyenlö śtmérövel biró alsó része.

Csolnak, Cavina, így hívják a pillangós virágok éles alju s felegyenesedö végü, azon szirmát, mely a porodákat és a termét betakarja, ilyen csolnakja van p. $0 . a z$ A kászfa, Robinia, pillangós virágának.

Csomó, Fasciculus, olyan virágzat, melyben a virágok a szár hegyén kurta, vagy kurtán elágazó kocsányokon tömötten ülnek együtt, mint a Barát Szegfü. Dianthus Carthusianorum virágzatában.

Csonka, truncatum, midőn a növény valamely lapos szervének a vége egyenes ronalon, vagy valamely tömör 
lészének a vége egyenes síkon végzödik, mint a Mezei Perje, Pon pratensis levele hüvelyei nyelvecskéjének a vége, és mint a Gyöngyhím Leonorus, vagy a Pemet Marrubium magvainak a vége.

Csonkatollas-szárnyas, interrupte alatum vagy pimnatum, olyan szárnyas levél, melynek bordái váltogatva nagyobbak és kisebbek, azaz: egy pár szemben álló levélke kicsiny, a következö pár nagyobb, azután ismét kicsiny és így tovább, mint a Burgonya vagy Kolompér Csucsoré.

Csontár, Dirupa, husos termés, melyben a magtakaró csont kemény héjjá alakul, ilyen a Cseresznye, Szilva termése.

Csoportos, aggregatum, midőn egynemü szervekből egy pontra vagy kis térségre sok halmozódik össze, mint a Sikantyu, Scabiosa virágai.

Csör, Rostrum, a növény különféle részei hegyein növö kisebb-nagyobb kemény nyujtvány; ilyen csőre van például a Káposzta és a Mustál beczőjének, Kecskedísz, Tragopogon makkocskájának stb.

Csuklyás, cucullatum, az olyan üreges növényi rész, mely szélesebb részén, vagy alján nyílt kupot vagy félhengert vagy félgömböt alkot, mely aztán majj egyenes, maja görbe ; ilyen például a Csuklyás Ibolya, Viola ambigua levele, a Sisakvirág Aconitum pilise felsö vége.

\section{D.}

Dárdaalaku, hastatum, az olyan levél, vagy pálha, mely nek mindkét válla oldalra kihegyesedik s ezen kihegyesedés a levél nyeléhez derékszeglet alatt áll; ilyen a Madársóska Lórom, Rumex acetosella levele.

Degesz, torosum, vagy torulosum, midön a magrejtö helylyel-közzel puposan vagy hólyagosan feldomborodik, mint a Paszuly hüvelyei vagy a Kaczuros Estike, Hesperis matronalis beczöi. 
Derekánnyiló, circumscissum, ha egy csöves ragy valamely üreges szerv közepe kerületén ragy derekán pattan fel, mint a Tikszem, Anagallis, vagy a Csalmatok, Hyoscicmms magrejtöje.

Domboru, conrexum, az olyan szerv vagy növényi rész mely egyenlöen feldudorodó boltozatos felülettel bir, mind a mellett félgömbalaku.

Durvány, Rudimentum, egy ki nem fejlett vagy eltörpült szervnek a kezdete, mint az Árpa vagy a Rozs füzérkéjében a második és harmadik virág kezdete. 2. A kezdete valamely szervnek, mely még ki fog fejleni, mint p. o. a maghonban levö magcsák, melyek a mag durványai.

\section{E.}

Eesetalaku, pennicyllatum, valamely szerv hegyén tömött, szőrből vagy szörhöz hasonló vékony részecskékből álló csomó, mint p. o. a Csábair, Poterium bibéje.

Egyenes, erectum, a függöleg növő szerv.

Egytagu, gamo, midőn egynemű részek egymással összenöttek, p. o. egytagu bokréta, Gamopetala corolla.

Ékalaku, cuneiformis, olyan vékony és lapos részek, melyek a hegyökön szélesek s aláfelé lassankint keskenyednek el, mint a Szász Meténg, Vinca herbacea szirmai.

Él, Mar:go, a levél vagy a levélhez hasonló lapos szerv széle vagy kerülete.

Ellenes, oppositum, ha a két rész egyenlö magasan, azonban a szemben álló oldalokon nö, mint a Tikszem, Anagallis levelei.

Élödi, parasiticum, olyan növény, mely egy másik élö növénybe ereszti gyökereit s annak a nedrét szívja el, mint a Fünyüg, Cuscuta a Csigacsön.

Éplevél, Folium integrum, ha a levél éle be van metszre, de metszetei nem hatolnak a szélétöl meszsze a közepe felé, mint például a Tavaszi Ibolya levele. 
Épélï levél, Folium integerrimum, az olyan levél, melynek az éle nincsen bevagdalva, mint p. o. a Loncz, Lonicera levele.

Enyves, viscidum, midön a növény valamely szerve olajos gyantát izzad ki s a miatt ragacsos, p. o. az Enyvencz, Viscaria szára bütykei alatt.

Érdes, scabrum, ha a növény szára, levele felülete, ormója vagy éle kemény kurta fogakkal vagy szörökkel be van nőve, melyet leginkább ujjaink e felületen való huzgálásával reszünk észre, mint p. o. az Atraczél, Anchusa szára és levele.

Eres ragy erezett, renosum, ha a levél vagy levélnemü részek vékony ágazatokkal hálósan vannak keresztiilkasul szöve. mint p. o. a Körtefa levelében lévö legrékonyabb elágazások, ragy a Csészeszárny, Polygala színes esészéjében levő piros ágazatok.

Lresz, Limbus, lásd : Karima.

Ereszték, Commissura, az ernyösök kétfél magra egymást érő belső lapjai, melyek egy๋másra levén támasztva, valóban egygyé is nőnek.

Érintkezési lap, Commissura, ugyanaz, a mi az elébbi.

Ernyö, Umbella az olyan virágzat, melynek a kocsányjai egy pontból inclulván, esaknem egyenlö magasságra jutnak s hegyeiken aztán kifejlik a virág, mint a Kankalin, Primula virágzata. Kétszeres ernyö, C'mbella composita,'pedig az olyan virágzat, mely miután ernyővé kifejlödött, mindenik kocsányja tetején ismét egy kis ernyö = eruyöke fejlik ki, mint p. o. a Kapor Anethum virágzata.

Évelö, perennis, olyan gyökér vagy szár, mely kifejlése után több éven át elél, szárat hajt és virágzik.

\section{F。}

Faj, Sprecies alatt olyan nörényeket értünk, melyek mind. külső bélyegeikre, mind belszerkezetökre nézre egy- 
mással megegyeznek, vagy összes jellenök arra mutat, hogy vagy egy ös növénytöl vagy egymáshoz hasonló ös növényektöl származnak; ilyen faj minden e gyes növény.

Fedelékes, imbricatum, midőn a növény szervei, p. o. a levelek, vagy a pikkelyek széleikkel egymást úgy hátalják, mint a házfedél cserepei, vagy a hal pikkelyei; ilyen fedelékesen állanak p. o. a Csüküllö, Centaurec fészke pikkelyei.

Fejérnye, Albumen, a mag belében levö, rendesen a csirát környező szíjjas vagy porczogós állomány, mely vegyi alkotó részeire nézve megegyezik a madártojás fejérnyéjével. Ilyen fejérnye környezi p. o. a buza és kukoricza magva csiráját.

Fejes buga, Thyrsus, lásd buga. és a XXIII. lapon s a 4 szám, $b$ betük alatt.

Félbeszáruyas, lyratum, az olyan levél, melynek éle a levél közepéig vagy annál is belebb karélyosan van bevagdalva s a végzö páratlan karélya a többihez mérve igen nagy; ilyen a Vetési Mustár, Sinapis arvensis levele.

Felegyenesedö, ascendens, szár vagy ág, ha az vízirínyosan kezd nőni, azonban megfordul s függöleges irányban nö fel, mint p. o. Cser Szigorál, Veronica Chamaëdrys szára.

Felemás, polygamum, olyan virágu növény, melynek a virágzatában álló tökélyes (porodát és termét tartalmazó) virágai között vannak olyan virágok is, melyek ben vagy csupán poroda, vagy csupán terme van; ilyen virágai vannak a. Jávor, Acer, a Falfü, Parietrivia fajainak.

Felfutó, volubile, az olyan növény szára, mely valamely tárgy, például fa vagy karó körül felfelé menö csavarformán tekergődzik; így csavarodik fel jobbra tartva a Komló, Humulus, balra tartva a Paszuly, Phaseolus szára. 
Féloldali, secundum, ha a növény egy esoportban álló részei, egy és ugyan-azon irány felé vannak hajolva, mint p. o. a Májusl Gyöngyvirág, Convallaria majalis virága fürtje.

Felomlásos, lepidotum, a fiatal ágakon és leveleken csillagszörök együvé növéséböl támadó pikkelyesforma apró pontocskák, mint a milyen az Ez üstfa, Eleagnus levele felülete.

Felsö, superum, a növény szervei azon állása, midőn legalább látszólag, egyik szerv a másik felibe nö, azt mondjuk p. o felsö virág, midön a csésze és bokréta, vagy pusztán a lepel a maghona felett kezdödik, mint a Csengettyüke, Campanula, a Nöszirom, Iris virágában.

Félszer virág, Flos lingulatus, ha a bokréta alsó része csövé van növe, azonban ezen cső egy helyen elkezd lappá kiterülni, s felső része vagy láncsa, vagy nyelvalakuvá fejlik ki, mint a milyenek a Cziczkóró, Achillece és a Napraforgó, Helicanthus szélsö vagy sugárvirágai.

Fenúszó, natans, a vízben termö növények olyan levele vagy szára, mely a víz felszínén terül el, mint a Lepese, Lemna szára és levele és a Nimfa, Nymphaea levele. Feslés, Deliscentica, valamely bezáródva volt szerv felnyilási vagy felpattanási mozzanata, p. o. midőn a beczö termés a kocsányja felöl, tehát alólról kezd felnyilni, azt mondjuk, hogy : feslik.

Fészkes virág, Flos compositus, midőn egy csészealaku gallérban (fészekben $=$ calathidium) a szár vagy kocsány kiszélesedett tetején sok virág van együtt, mint a milyen a Napvirág, Helianthons virágzata.

Fodros, undulatum, midőn a levél éle hullámos vonaluan ránczos. mint a Bodros Uszány, Potamogeton crispum levele.

Fogas, dentatum, midön a növény szerve éle csekély be- 
vágásai tompa szögüek, kiülő részei pedig hegyesek mint a Füz, Salix levelei éle.

Foltos, maculatum, midőn a növény valamely szervén a szerv alapszínétől elütő szinü pettyek vagy területecskék vannak, mint a B ürök, Conium szárán.

Fonalalaku, filiforme, midön a szerv hosszában menöleg jó darabon egyenlö vékony átméröjü mint p. o. a Kukoricza csövéből kinyuló bibeszárak.

Forradás, Suturct, válu, barázda vagy sinóralakú növés, mely helyeken két szomszéd szerv nőtt együvé, ezen összenővés rendesen a szerv kifejlődéseig tart a midön ugyanis azon a helyen a szerv felfeslik, ilyen forradásuk van p. o. a beczöknek.

Forrtportokuak, Syngenesia, az egy feszekben egyesült, virágok portokai olyan csővé nőnek, melyen kétágu bibeszáruk átnyulik, mint a milyenek a Napvirág közép virágaiban levő portokok

Forrtszirmuak, gamopetala, minden egytagu bokréta.

Füféle, herbaceum, olyan növény, melynek rostjai puhák és meg nem keményednek. Ellentéte a fafélének, melynek rostjai megkeményednek.

Fulánk, aculeus, a növények felszinén vagy élén növő szurós szerv, mely csak a felbörre nö s arról kőnnyen leválásztható, mint a Rózsa-és Akászfákon.

Fürészes, serratum. ha a levél vagy a levélnemü szerv éle fennyedén ugy van bevagdalva, hogy bevágásai szükszegletn̋ek, kiálló részei is hegyesek, mint a Rózsafa levélléé.

Fürt, Racemus, olyan virágzat, melynek a fökocsányjából kinövő s el nem ágazó kocsánykáin vannak a virágok kifejlödve. mint a M. Gyöngyvirágé. Convallaria majalis.

Füzér, Syica, olyan virágzat, melynek a fökocsányjára kocsánytalanul vannak a virágok felfüzve, mint az Árpa, az Utifü, Plantago virágzatában. 
Füzérke, Stricula, az olyan virágzat, melyben ¿ füzéres vagy bugás virágzat egyes virágai helyén $1-2$, s több virágocska van kocsánykátlanul egyesủlve, mint a polyvás füvek virágzataiban. (Lásd LI. lap) alatti 1. 2. számokat.

Füzött, compositum, midön egynemü szervek egy közös száron, nyelen vagy kocsányon egyesülnek, mint például némely növény levelei. Füzött levél p. o- a Lóheréé, a Bokrétafáé, a Rózsafáé stb.

\section{G.}

Gallér, Invohucrum, egy vagy több körben, vagy fedelékesen álló, egymással vagy össze nem nött, vagy bizonỵos részben összenőtt levélnemü részek, melyek rendszerint. a virágzat közelében vagy épen alatta fejlenek ki, mint a Kökörcsin, Anemone tökocsányján, az ernyösök virágzata alatt lemni szokott.

Gallérka, Involucellum, fejlésére és alakjára nézve a gallérral egyenlö, azonban ez vagy egyes virág, ragy a virágzat egyes részei közelében vagy alatt szokott állani, mint az ernyösök ernyőkéi alatt gyakran látható.

Gatyás, alcutum, ha a levél válla ngy nö a szárára, vagy a nyelére, hogy két oldalán széles szegélyt alkot, mint a milyen az Erdei és a Széleslevelü Bükköny, Lathyrus levele nyele.

Gaz, Culmus, olyan szár, melynek izei, czikkei vannak; azonban bütykei belöl egymásba nyílnak és belseje általában likacsos bélü, mint a Sás, C'arex szára.

Gerincz, Costa, a levél aljától a hegyéig nyuló kisebb nagyobb mértékben kiálló egyenes vonal. vagy is a levélnyelének a levélben levő folytatása.

Gindár, F'laccum, r. flaccidum, olyan szár, mely felállóvá fejlett, azonban gyengesége, hajlóssága, vagy a rajta kifejlett részek sulya miatt egyenes állásában megmaradni nem birván, elhajlik ragy le is fekszik, mint $\mathrm{p}$. o. a Burgonya Csucsóré, a Kölesé. 
Göcsös, nodosum, midön a növény valamely, részén helylyel-közzel megcsomósodások vagy felemelkedések vannak, mint a pázsitfüvek szalmáin.

Gïrbe-gurba, flexuosum, midön valamely szerv, p. o. a szál jobbra balra, vagy ellenkezö oldalra, tompa szöglet alatt többször van meghajolva, mint a Keserédes Csuesór, Solanum Dulcamara szára.

Gyapjas, villosum, hosszu vagy kurtás kisebb nagyobb mértékben széllyelálló puha szörboritéka a szárnak vagy a levélnek, mint p. o. a Földieper Szamóczán. Fragaria Vesca.

Gyertyatartó alaku, hypocrateriforme, ha valamely, esaknem egyenlö átméröjü cső teteje szélesecske karimává (ereszszé) terïl ki, mint a Kankalin, Primula bokrétája.

Fyökerezö, repens, midőn a szár vagy az ág a földre feküdvén, helylyel-közzel gyökereket hajt, mint a Boglárka Szironták, Ramunculus repens szára.

fyököeske, Radicula a mag csirájának a kötölékkel egybekapesolt, kifejlésekor pedig lefelé induló része.

Gyöngysoralaku, moniliforme, apró golyóalaku s szorosan egymást követö tagja valamely szervnek, mint például a Retek beczője.

Gyürü, Verticillus, a levelek vagy virágok nyelei vagy kocsánykáinak a szár vagy kocsány körül egyenlö magasságban való kiindulása, mint a Galaj levelei (lásd csillagos) vagy a Tátkanaf, Lamium virágzata,

Gugás, strumosum, midőn valamely csöves szerv egyik oldalon boltosan puffad ki, mint a Szádor. Orobanche bokrétája csöve.

Gnmó, Tuber, olyan vékony héjú tömött bélü szerv, melynek felülete besüppedéseiben csirák fejlenek ki, mely csirák kedvezö helyzet és körülmények között uj növénynyé fejlenek ki, mint a Burgonya Csúcsór földalatti terméseié. Meg kell ettől különböztetni a 
Mogyorós Bükköny, Lathyrus tuberosus megrastagodott tögyökereiböl fejlett kolonczokat, melyeknek sem besüppedései nincsenek, sem elvetre ki nem hajtanak.

\section{II.}

Habos, undulatum. (Lásd fodros.)

Hagyma, Bulbus, évelö, többnyire kurta, törön (hagymatő = Lecus) egymást bekeritö hártyákból álló termény, melynek a közepén végig nyulik a szár durránya, más szóval földalatti rügy. Ilyen hagymája van a Teres Hagymának, Allium Cepa, a Liliommak.

Hagymabimbó, Bullitlus vagy Bulbulus, a hagyma rétegei között fejlődött apró hagymácska, mely nem az anyanövényen, hanem attól elválva fejlik ki uj növénynyé, mint a Zöldcsík, Ornitloggalum hagymáiban látható.

Hám, Epidermis, a növény különféle részeit beboritó színtelen, áttetszö felbör.

Harangalaku, campanulatum, olyan egy tagu csésze vagy bokréta, melynek az alja hasason tágas, felsö része kissé összefelé tart, karimája pedig ísmét kifelé tårt, mint a Csengettyüke bokrétája.

Hártyanemü, membranaceum, vékony áttetszö szịjas levélnemü színtelen képződmény, mint a Dudafürt, Colutea magrejtöje.

Hártyatölesér, Ochrea, hártyanemü ljurok, mely a levelek nyelei tövét foglalja be, mint a milyen van a $\mathrm{Czikk-}$ szár, Polygonum fajai levelei nyele tövén.

Hasábos, partitum, midőn az egy tagu csésze vagy az egy tagu bokréta közepénél lejjebb van bevagdalva.

Hát, Dorsum, a szerv külsö, vagy a tengelylyel átellenben álló része.

Hátraszegett, reflexum, midön a növény valamely szerve, p. o. a levele töve irányánál alább van hajolva, mint a Tejóltó Galaj, Galium verum levele, vagy a Gumós Szironták, Ranunculus bulbosus csészéje levelei Hengeres, teres, (lásd XIII. lap 5. sz.) 
Henyélö, procumbens, ha a növény szárai ugy terủlnek el a földön, hogy végei felfelé állanak.

Hóldalaku, tulajdonképen félholdalaku, lunatum, midön ¿ félköralaku szerv közepe ugy van kikanyaritva, hogy a két vége szarvalakuvá lesz, mint a Farkas Fütéj virága fedője.

Hólyagos, vesiculosum, midőn valamely szerv a benne levö levegötől ki van puffadva, mint a Dudafürt, Colutec hüvelye.

Homoru, concavum, midőn a szerv vagy több szerv együtt egyenlöen besüppedö bóltozatos felülettel bir, mint a Zelnicze Megy szirmai, vagy mint a Murok, Daucus vírígzati.

Hóllalj, Axilla, a levélnek vagy a levélnemü szerveknek, vagy az ágaknak a szárból való kiindulásánál támadó szeglet.

Horgiıs, hamulosum, kurtà visszahajlott végü ször- vagy szuró szervek, mint a milyenek példaul a Bojtorján Lappa fészke pikkelyei végei.

Horpadozott, lacunosum vagy fovectum, midön valamely szerv felülete gidres gödrös.

Hosszullad, oblongum, midön valamely körkörös végü szerv, p. o. a levél 2-4-er hosszabb, mint széles, p. o. a Vitéz Koskor, Orchis militaris levele.

Hullékony, caducus, midőn valamely szerv a vele egyidőben kifejlö szervek kifejlése után esakhamar lehull mint a Szódokfa és a Mák esészéje,

Husos, carnosum, olyan tömött és leves növényrészek, melyeket késsel könnyen lehet vágni, mint az alma gyümölcs, a Fülfü, Sempervirum levelei.

Hiively, Legumen, két kopácsú s rekesznélküli száraz magrejtö, mint a milyen a Paszuly termése.

Hiivelyezö, vaginans, ha a levél vagy annak esővé alakult alja vagy nyele, a szárat vagy az ágat, vagy a másik levélnyelét beburkolja, mint a pázsitfüvek levelei burkolják a szárukat, a MI. Gyöngyvirág levelei egymást. 
Ikra, Glandula, a növény felbörén különféle alakban kifejlö hólyagnemü szervecskék, melyek bizonyos idöben repülö olajjal vagy gyantás stb. folyadékkal vannak megtelve; ilyenek p. o. az Ezerjó, Dictamnus kocsánykáin levő, olajjal telt hólyagesák.

Ikrásszörï, glanduloso-pilosum, midön az ikrák a szörök hegyein fejlenek ki.

Ikrás gyapjas, glanduloso villosum, midőn az ikrák a gyapjak végein vannak.

In, Nervus, a levél gerinczéböl vagy a gerincze aljából kiinduló oldal-elágazás (lásd XIV. lap. 2. szám.)

Inধla, Flagellum, némely növény tövéböl növö s a földön elterülni szokott hajtás, melyen helylyel-közzel levélcsomók nönek; jelleméhez tartozik, hogy a földbe legyökerezik s azon felül azon évben, melyben keletkezik, virágot nem terem. Ilyen indája van a Földieper Szamóczának.

Ingadozó, laxum, tágon álló, ellentéte az összetartónak, mint p. o. az Egyvirágu Léhapót, Melica uniflora füzérkéi.

Iny, Palatum, a bokréta alsó ajaka bóltozatosan feldomborodó közepe, melylyel a felsö ajakhoz feküdvén, a torkát bezárja, mint a Pintyö, Anti๗hinum alsó ajakán láthatni.

I\%, Articulus, valamely megtagolt szerv tagjai két határvonala közé eső része; mint a pázsitfüvek czikkei.

\section{K.}

Kabak, Pepo, a csészével összenött s vele együtt kifejlett rendezerint 3 rekeszü bogyó; mint a milyen a Tök s Ugorka termése.

Kaces, Cirrhus, fonalalaku, különféleképen kunkorodó hengeres növényi rész, mely vagy a növény szárából. 
ragy a levél végéről szokott nöni és a melynél fogra a növény más növénybe szokott kapaszkodni : Szöllö, Babo. Kaczuros, runcinatum, a szárnyason kikanyargatott levélnek azon faja, midőn a levél karélyai végei lefelé vagy hátrafelé tartanak, mint a Pongyola Pitypang, Taraxacum officinale levele.

Kalász, Avista, fonalaku, leginkább kemény, hosszabl vagy kurtább szálkanemü növés, mely valamely szervnek vagy a végéröl vagy a hátáról szokott nőni, mint a milyen a Buza és a Zab polyvájáról növő szálka.

Kancsóalaku, urceolatum, lásd : bögrealaku.

Kanálalaku, cochleare, egy homoruan kivölgyelt szerr, mint a Tátkanaf, Lamium felsö ajaka s a Zörgő Lóhere, Trifolium agrarium vitorlája.

Kapaszkodó, scandens, vékony száru növény, mely kacscsainál fogva más növényekbe vagy tárgyakba fogódzva állhat fel.

Karczolt, striatum, lásd : sinóros.

Kardalaku, ensiforme, egyenlő szélességü vagy láncsásan elhegyesedő olyan levél, melynek mind a két éle éles ; ilyen a nöszirom, Iris levele.

Karélyos, lobatum, ha a levél közepéig ható szük vagy tágszegletüen van bevágva, kiülö részei pedig tompahegyüek, mint a Szőllö és a Kánya Bangita levelei. Karima, Limbus, a csöves alju egy tagu csészének, bokrétának vagy lepelnek kiszélesedett s kiterült teteje, mint a milyen példaul a Tüdő Gálna, Pulmonaria angustifolia bokrétája kiterült felső része.

Kelö, Plumula, a mag csirájának a gyököcskével átellenben fekvő kikeléskor felfelé törö rége.

Kerek, orbiculatum, az olyan levélnemü szerv vagy mag. melynek éle egy központ körül a központtól csaknem egyenlő távolságra van; ilyen a M. Gólyahir, Caltha levele s a Lencse magva.

Kerékalaku, rotatum, az olyan lepel vagy bokréta, melynek alsó része alig kivehetö kurta csővé nött egybe, felső 
része (karimája) pedig, ha bár be van is vagdalra. laposan terül ki; ilyen a Farkkóró, Verbascum bokrétája. Kerekded, subrotundum, olyan alak, mely a körhöz közel áll.

Keresztes, cruciatum, ha egy síkban fekvö négy tagu levél vagy szirom közül az átellenesek ugy állanak szemben, hogy együtt hasonlitanak a kereszthez. mint p. o. a Káposzta bokrétája.

Kérges, cortigosum, az olyan szerv, mely porezogós, vagy vastag kemény börrel van bevonva, mint a korsóka Berula termése.

Kétajaku, bilcbiatum, lásd: ajakas.

Kétfalkás, Diadelphus, ha a porodák szálcsái két csomóba nőttek össze, azonban a portokai szabadok, mint p. 0 . az A kászfa vagy a Borsó virágában. (Pillangósok).

Kétféle, vagy felemás levelï, heterophyllum, az olyan növény, melynek a levelei alakjokra nézve különböznek egymástól, mint p. o. a Felemás Zsázsa, Lepidium perfoliatum levele.

Két föbb porodások, Didynamia, midőn a :virágban levő négy poroda közül kettö egyenlően magas, kettő egyenlöen alacsony, mint a Tátkanafban, Lamium.

Két-két águ, dichotomum, midön valamely két ágria induló szár ágai ujra s mind végig két ágra oszolnak, mint a a Fagyöngy, Viscum ágai.

Kétlaki, dioicum, olyan virág, melynek egyikében a terme másikában a poroda van s a mely növényen amaz található, azon meg a porodás virág nem fejlik ki, mint a milyen a Kender és Komló virága.

Kétnyári, bienne, olyan gyökér. mely azon a nyáron, melyen a magról megnevekedett, virágot és termést nem hoz, hanem magot a következő évben, a mikor aztán azt megérlelvén, el is szárad, ilyen p. o. a Murok, Daucus.

Kétrekeszï, biloculare, az olyan termés vagy magrejtö, melynek a közepén régig huzódó válaszfala a magra- 
kat egymástól elválasztja, ilyen minden beczö termés. Kétszeres ernyö, umbella composita, lásd ernyö.

Kicsípett vagy esorba, cmarginatum, midön a levélnemü szerv hegye sekélyen ugy van bevágva, hogy az által két kurta hegyes vagy tompa karélyocska áll elö, mint a tavaszi Pimpó, Potentilla verna szirmai hegyein. Kigönyölödött, revolutum, az olyan levélnemü szerv, mely hátra felé nem csak lehajolt, hanem össze is tekeredett, mint p. o. a Csövirics, Epilobium és a Csengetyty üke, Campanula bibéje.

Kiharapott, prccemorsum, midön valamely szerv hegye ugy van megcsonkitva, hogy felülete darabos, mint a śutabub, Succisa gyökere.

Kinyílt, patens, midön az egynemï részek egynástól elállanak, mint p. o. a Mezei Sarkvirág, Delphinium consolida kocsánykái, és az Abrak zab bugája.

Kocsány, Pedunculus, a szárnak azon hajtása, melyen a virág fejlik ki.

Kocsányka, Pedicellus, a kocsány apróbb elágazása.

Konya, nutans, lásd bókoló.

Kopács, Valva, a magrejtö forradásain feslö egyes darabok v. ajtók p. o. a beczö két kopácsesal nyílik fel.

Kopánes, Cupula, a murvákból alakult néha poháralaku, a magot félig, néha a magot egészen betakaró boriték, mint a milyen van p. o. a Tölgyfa és Gesztenyefa makkjának.

Kopasz, glabrum, olyan növény, melyen sem szörök, sem serték nem nönek.

Körkörös, cllipticum, az olyan levélnemü szerv, melynek mind két vége csaknem egyenlöen van elkerekedve, azonban olyan hosszukás köralak, mintha két központtal két kör volna benne leirva, ilyen levele van p. o. a Kökény Szilvafának. Prunus Spinosa.

Kórós, frutescens, suffiuticosum, midön a növény szára megkeményszik, azonban fakeménységre még sem jut, 
mindemellett épen ugy évélö mint a fák és a eserjék dereka, ilyen p. o. a Kerti Zsálya szára.

Körtvealaku, turbinatum. egy talpával felfelé forditott kup, mint a milyen a Jézsafa, Philcudelphus esészéje. Korsó,vagy kanesóalaku, ưceolatum, lásd bögrealaku. Kótaalaku, rhombeum, egy elhuzott négyszögalak mint a milyen a Libatopp, Chenopodium némely faja levele.

Kötölék, Podospermium, azon kis szálacska, melynél fogva a mag mig ki nem fejlik a megrejtö forradásával vagy a növény valamely részével összeköttetésben s általa táplálkozik.

Kupos, conicum, olyan alak, mely egy széles talpról indul s lassanként hegyesedik el, ugy azonban, hogy ha végig liletszjük, az igy nyert lap egyenszáru háromszög képü, ilyen a Varádics, Tanacetum és a Szíkfü Matricarict vaczka.

Kiilsö esésze, Epicalyx vagy caliculus, miclön a esészét még egy másik csésze foglalja be, mint a milyen a Föld ieper Szamóczáé, Fragaria Vesca.

\section{L.}

Lábbó vagy lábbogó, fluitans, olyan levél vagy szál, mely vagy a víz szinén, vagy a vízben lóbálódik, mint p. o. a Sulyom, Trapa natans levelei.

Lándzsás, lanceolatım, a levél vagy levélnemü szerv olyan alakja, melynek mind két vége egyenlöen keskenyedik el s a közepe kihasasodik, vagy két görbe vonal által alkotott két hegyes szögï lap, mely mintegy négyszer hosszabb, mint széles, ilyen levele van a Fagyalfának, Iigustrum.

Lapiczkás, spatulatum, az olyan nemü szerv, melynek a válla ugy keskenyedik el, mint a láncsís levélé, hegye pedig oly szélesen van elkerekedve, mintha a láncsás levelet közepén keritenék le, ilyen levele van a Gubóvirágnak, Globularia. 
Lapított, compressum, az olyan szár. nyél, ragy kocsány, melynek két oldala kissé domboru, élei pedig lekerekitettek s ha keresztül metszjük keresztmetszete felülete körkörös; ilyen p. o. a Fejér és Fekete Nyárfa levele nyele.

Lárvás, personatum, lásd : al a kos.

Lecsepuillt, prostratum, vagy procumbens, midőn a szál ágaival együtt ugy terül el a földön, hogy semmi része nem emelkedik fel, azonban gyökeret nem ver, mint p. o. a Lepkeszeg, Trigonella.

Lefelétartó, descedens, olyan növényi rész, mely hegyével a föld felé van irányozva. vagy épen a földbe is nyomul Lefutó, decurrens, az olyan levél válla, mely még a levél tövén alól is vagy a nyélre, vagy a szárra nö, mint a milyen a Fekete Nadálytö, Symphytum officinale levele.

Léha, steritis, olyan magrejtö, melyben vagy ninesen kifejlett mag, vagy nem is terem magot, mint $p . o$. az Árpa füzérkéiben levő két szélső virág.

Lemez, Lamina, a levél vagy a levelnemü szerv kiterült része, mint j. o. a levél lapos része, vagy a váltszirmu bokréták közül a Keresztesek vagy a Szegfüfélék szirmai kiterűlt felső széle.

Lepel, Perigonium, a virágban a csésze és a bokréta helyét pótló rendszerint színes külső takaró; ilyen leple van a Tulipánnak, Gyöngyvirágnak, stb.

Leppendék, Samava, olyan egy vagy két magvu toknemü termés, melynek vagy köröskörül vagy legalább a féloldalán hártya szárnya van, mint a Szilfa és a Jávor termésének.

Levél, Folium, lásd a XIII. lapon 3 §.

Levélke, foliolum, a füzött leveleket alkotó egyes tagok neve, p. o. az Akász fa füzött levele, főnyélen (páratlan) szárnyason áll, ennek mindenik körkörös tagja, egy-egy levélke; vagy a Lóhere hármas füzött levele egy-egy tagja is levélke. 
Levélnemï, foliaceum, minden olyan növényi szerv, mely külső termete és belszerkezeténél s kivált felböre puszta szemmel nem lítható nyilásainál fogva, a levél alkotásával vagy származásíval megegyezik.

Lísztes, farinosum, az olyan szerv, melynek felülete durvi porhoz hasonló szemcsékkel be van hintve, mint a Fejér Libatopp, Chenopodium calbum levele.

Lombos, frondosum, szoros értelemben, midön egy esomó levél a törzszsel vagy a nyéllel kisebb nagyobb mértékben olyan egész növényt alkot, melyen a törzs és a levél nyele szorosan egygyé olvadnak, ezek rendszerint legyezőalakulag terülnek ki, mint a harasztokon láthatni; tágabb értelemben azonban, minden olyan laposan kiterült levelü fákat értenek alatta, melyek leveleiket öszszel vagy tavaszszal elhullatván, ismét uj leveleket hajtanak. Ilyenek erdeifáink legnagyobb része, ennek ellentétei a tülevelüfák.

\section{M.}

Iag, Semen, a megtermékenyülés következtében kifejlett olyannemü szerv; mely egy uj életre kelhetö növény durványát foglalja magában; olyan szerv, mely a virágos növények tenyészésének általános eszköze. (Lásd XXXVIII. lap. 7. §.)

Magános, solitarium, ha a növény szerve állása helyén egyedủl, (s nem hozzá hasonló szervek társaságában) fejlik ki, p. o. magános szára nő a tövéről a Házi Lennek, magános virága van a Csipke Rózsának, Rosa canina.

Magesa, Ovulum, a termöleveleken kifejlödö hólyagesa vagy szümölcs, vagy a mag durványa, mely a növény virágzása után maggá fejlödhetik, ilyen magesákkal van megtelve minden maghon.

Maghon, Germen, v. ovarium, a virág legbelső részében kifejleni szokott termőlevelekböl alakuló megesatartó, mely- 
böl a megtermélienyülés után vagy egyenesen a mag, vagy a magrejtö fejlik ki. (Lásd XXXIII. lap. $f$. alatt.) Magoszlop. Trophospermium, Spermophorum, a maghon közepén levö azon hely vagy rész, a melyre a róla növö kötöléknél fogva a magcsák, azután a magvak fel vannak füzve, mint a milyen a Konkoly vagy a Szegfü magrejtöje közepén álló oszlop.

Magrejtö, Pericarpium, a maghont alkotó termőlevélből alakult azon takaró, mely a magvakat beborítja, ez szokott lenni vagy száraz, vagy husos. (Lásd XXXIT. lap. 6. \$.)

Magsinór, Funiculus. Lásd: Kötölék.

Magtanya, Placenta, Lásd: magoszlop vagy magtartó. Magtartó, Spermophorım, a maghon közepén ragy olda. lán alakúlt azon hely, melyre a magesák vagy a magrak fel vannak füzve. Lásd: magoszlop.

Makk, Nux, olyan termés, melyet kivülröl különféle vastagságu kéreg borít, melyen belöl van a mag bele és a szíke, ilyen termése ran a Tölgyfának, Mogyorónak, Bikkfának stb.

Makkoeska, Caryopsis, mucula, achenium. kis makk. Lásd: XXXIV. lap a betï alatt.)

Mászó, repens, lásd : gyökerezö.

Meddö, steritis, lásd: léha.

Medenczealaku, petviforme köralaku s mérsékelten besiippedö szerr, mint p. o. a Veres Ribiszke, Ribes rubrum esészéje kiszélesedett csöve.

Meggyökönt, geniculatum, midön valamely egyenes vonalban álló szerv hirtelen elhajlik, azonban ismét egyenes irányban halad tovább, mint a Zab fajai kalásza.

Metszett, fissum, fidum, midön a levél vagy a levélnemü szerr éle luevágásai a közepénél nem hatnak alább.

Mezgés, viscidum, lásd : en y ve s.

Mézgödör, Nectarium, a bokréta vagy a lepel szirmain támadó mélyedések vagy barázdák, melyek néha pilkelylyel rannak befedve, néha nyíltak s rendszerint 
méznedret izzadnak ki, mint a Szironták szirmai tövén levő pikkely alatti gödröcske, a Lilium szimmán levö barázda.

Mézikra, Glandula nectarifera, a virág szirmai tövén alakult bibircsók, mint p. o. az Ikrapikk. Arabis szirma tövén; vagy a virág közepében kifejlett bibircsók mint a Füz virágában rannak.

Mirigy, Callus, a növény szervein alakuló \& megkeményedni szokott kidudorodás, mint a milyen van a D uda fïrt, Colutea bokrétája vitorláján.

Molyhos, tomentosum, apró puha szörök, melyek a növény valamely szerve felületét ugy lepik be, hogy a miat' fejérlik, mint az ökörfarkkóró levelei.

Murokalaku, dauciforme, olyan tögyökér, melynek a teteje majdnem a legszélesebb s onnan aláfelé lassanként hegyesedik el s e miatt mintegy hegyére állitott kupot alkot; ilyen tögyökere van a Muroknak Daucus.

Murva, Braetea, a virág kocsányján fejlett levelek ragy pikkelyek, melyek rendszerint a virág közelében állanak s ha kettő vagy több van egymás mellett, a kocsányból rendszerint különböző magasságból indulnak ki; ilyen murva van p. o. a Tavaszi Viola, a Szódokfa kocsányján; „néha a murva színes, mint a Csormolya Fintor, Melampyrum arrense.

Murváeska, Bracteola, kis murva, azaz : olyan murva, mely valamely külső murva alatt fejlett. Némely füvész a pázsitfüvek polyváját származása s állásánál fogva murvának nevezi s következetesen a polyva alatt fejlödő ondót, murvácskának hírja.

Murvakör, Involucrum, gaillérféle levélkék a fészkesvirágok fészkei alatt, mint a milyen van az Üszögör, Senecio némely fajainak.

\section{v.}

Yégy föbb porodások, Tetrad:namia, olyan virágok, melyekben 6 poroda van s ezek közül 4 egyenlö magas, 
2 egyenlö alacsony; ilyenek a Keresztesek virágai s azok között p. o, Káposzta.

Yem, Gemus, olyan fogalom mely alá virága részei s termései alkotásában s általában kiilső termet és belszerkezetben egymással megegyező növényfajokat foglalhatni egybe. Ilyen nemi fogalom p. o. a Rózsa, mely alá foglalhatók a virágai s terméseiben egymással megegyezö Tarka R., $R$. gallica. Tompalevelü R., $R$. pimpinellifolia, Borzas R., R.tomentosa, Csipke R., $R$. canina stb-

Nem feslö, indehiscens. azaz fel nem nyiló tok, ellentéte ez a feslőnek.

Nyak, Ungvis, nyakas, ungviculatum, a vált szirmu bokréta szirma elkeskenyedö $\mathrm{s}$ a csészébe nyuló része; ilyen nyaka van p. o. a Szegfü szirmainak.

Nyél, Petiolus, a növény száráról vagy az ágáról növő azon nyujtvány, melynek a vége a levél lapjába benyulván, ott gerinczczé alakul s a melyen a levéllapja áll; ilyen nyele van például a Viola levelének.

Nyelecske, Petiolulus, hasonlóul nyél, csakhogy nyelecskének akkor hívják, midőn a füzött levél közös nyeléböl apró nyelek indulnak; melyeknél fogva a levélkék vannak arra felfüzve; ilyen nyelecskéje van p. o. a Rózsa szálnyas levele levélkéinek.

Nyelvecske. Ligula, a szárat hüvelyezö pázsitféle füvek levele hüvelyei tetején növö hártyanemü nyujtványka

Nyílalaku, sagittatum, igy nevezik az olyan vállu levelet vagy levélnemü szervet, melynek a vállai hegyesen rnegnyulván, azok a levél nyelével párhuzamosan állanak; ilyenek a Nyilfü, Sagittaria, a Kis és Nagy Szulák, Convolvulus arvensis és a C. Sepium levelei.

Nyulánk, elongatum; olyan szerv, mely hosszára terjeclö vagy a mely kezdetben kurta s azután növés közben nyulik meg. 


\section{o. 0̈.}

öblös, simuatum, az olyan levél vagy levélnemü szerv, melynek éle mélyen van kikanyargatva s karélyai is rendszerint kerekek, mint p. o. a Tölgyfa levelei. Olajesík, Vitta, az ernyösök magvai rovátkaiban kifejleni s azokat betölteni szokott olajos gyanta vonal. (Lásd : LXX. lap, *) alatti 5. számot.) A magvak hátán vagy kïlsö részén esö olajesíkokat külsőknek, vittae dorsales, a két fél mag eresztékén esőket belsőknek vittae commissurales nevezik.

Oncló, Palea, a polyvásfüvek virágaiban a polyvák alatt kifejleni szokott 1-2 zöldes fejér murvanemü takaró, mely a magra néha rá is nö, mint a köles magvára. (Lásd LI. lapon a jegyzet 4. száma alatt.)

Ormós, carinatum, midőn a növény valamely szervén kiálló él van, mint p. o. a Polyvacsukk, Placaris polyváján.

Orsóalaku, fusiforme olyan alaku tögyökér, melynek a teteje lassanként kezd aláfelé vastagodni, a közepe felé legvastagabbá lesz, onnan kezdve aztán ismét lassanként vékonyodik el, ilyen a Terjöke Kigyószisz, Echium vulgare tögyökere.

Ostorinda, Stolo, némely növény tövéböl nöni szokott s a földön elterülö hengeres hajtás, mely a végén legyökerezik, rendszerint még keletkezése évében szárat vagy virágot nevel; ilyen ostorindája van a Tavaszi Violának.

Összehúzódott, constrictum, ha a csöves vagy hasas szervek egy vagy több helyen hirtelen elszükülnek, mint a Gyöngyike, Muscari, leple teteje, vagy a Tátkanaf Lamium bokrétája csöva közepén alól esö része.

\section{P.}

Paizsos, peltatum, olyan tányéralaku levélnemü szerv, melynek a nyele vagy kocsányja a közepe tájára van 
nőve s igy a lap a nyélre derék szöglet alatt fekszik; ilyen a Sarkantyurirág, Tropaeolum levele.

Pálha, Stipula, némely levélnyele tövén vagy azzal átellenben nöni szokott apró levélnemü rész, mint p. o. a Borsó levele nyele tövén levő növés.

Pár, t. i. levélpár, Jugum, lásd: borda.

Párkányos, marginatum, midőn valamely szerv töle, legalább színre nézve, különböző anyaggal van szegélyezve, mint az Erdei Mályva és a Tapsír Heracleum magva; az Időérző Csüküllő fészke levelei szegélye.

Párta, Corolla, így nevezil némelyek a bokrétát, de miután Diószeghi és Fazekas a párta szót a müszók közé csak besorozták s e helyett állandóul a "bokréta“ szót használják: az egyformaság és a zavar kikerülése kedveért maradjunk a bokréta szó mellett.

Pázsitfiï, Gramen, az izékes száru, polyvás virágu növény, mint a milyen a Buza. Köles és a Kukoricza stb.

Pelyhek, Plumae, lásd : s zőr.

Pettegetett, punctatum, mikor valamely szerv mintegy be van szurkálva, mint a Csillagesín, Galatella levele; vagy átszurkáltnak látszik, mint a Csengő Linka, Hypericum perforatum levele, vagy mikor színesen van pontozva, mint a Pettegetett Gálna, Pulmonaria officinalis levele.

Pikkelyes, squamosum, értik ez alatt különféle növényszervek egymást hátaló $\mathrm{s}$ a hal pikkelyeihez hasonló állását; pikkelyesek p. o. a fák bimbói, a barkák, némely fészkes virág fészke, a fenyők termése, némely gyökerek, mint a Vicsor, Lathrea, gyökere stb.

Pillangós, papilionaceum, az olyan 4 szirmu bokréta, melynek egyik, rendesen a legnagyobb szirma, ritorlája, fel-s hátraálló; két szirma (a szárnyai), oldalt s 
elöre álló; tenyész szerveit befoglaló egy szirma, csolnakja, pedig két szárnya között áll; ilyen virága van p. o. az Akászfának.

Pillenpáty, Appendix, a csésze alsó részére vagy a bokrétához nőtt levél- vagy sziromnemü pótlék, mint a milyen van a Tavaszi Ibolya csészéjén.

Pilis, Nectarium, sziromnemü levél vagy pikkely, mely a lepel vagy a bokréta valamely részén vagy mellett kivül vagy belől fejlik ki s rendszerint mézedényül szolgál, mint a milyen van a Sisakvirágban; Hunyorban.

Poháralaku, cyathiforme olyan csésze, bokréta vagy lepel, mely egy csonka felfordított karima nélküli kupot ábrázol.

Pókhálós, arachnoideum, egymáson keresztül-kasul állo, pókhálókoz hasonló finom szálakból alakult, szöszszel borított szerv, a milyen p. o. a Pókhálós Bojtorján, Lappa tomentosa fészke.

Polyva, Gluma, a pázsitfüvek virágát kivülről takaró szerv. Lásd LI. lap, a jegyzet 4. száma alatt.

Porczogós, cartilagineum, az állati porczogóhoz hasonló száraz és szilárd, azonban a szarunál puhább nörényi képződmény; ilyen a Gégevirág, Aristolochia magvának a fejérnyéje.

Porlé, Fovilla. Lásd : poroda.

Poroda, Stamen, a virágnak a bokrétán vagy a leplen belöl álló, eredetileg levélnemü állományokból alakult része. Egy kis nyujtványnál fogva, vagy a nélkül van a vaczokhoz vagy a bokrétához nőve, ezen nyujtvány neve: szálcsa = Filamentum; eredetileg a levél nyele. A szálcsa tetején van egy zacskóforma tok; portok = Anthera, mely meg van telve virág-porral = Pollen; a portok eredetileg a levél lapja, mely széleivel úgy nött össze, hogy vagy egy vagy kétrekeszü tokká alakult. A virágpor, ha a bibére hull, 
hólyaggá, majd szütyövé alakul, mely a bonne levö porlénél (Fovilla) fogva, a magcsákat megtermékenyíti. Portok, Authera. Lásd : poroda.

Pót, Appendiculum, v. Appendix, szervhez szorosan nem tartozó toldalék, mely rajta majd mintegy lemezecske. majd mint nyujtvány, majd mint anyagjára nézve a szervtöl különböző szegély szokott kifejleni. A pótnak különféle fajai a fül = Auricula, rendszerint levéltoldalék; a gatya vagy szárny $=A l a ;$ a taréj $=$ Crista; a sarkantyu = Calcar'; a csákó = Cauda; a csör $=$ Rostrum; a szarv $=$ Cornu; a szakáll $=B a r b a$; az üstök = Coma; a pillenpáty stb.

Prémes, marginatum. Lásd: párkányos.

Pupos, gibbum, midőn valamely szerv felülete itt-ott különféle módon feldudorodik, mint a milyen a Fuláncs, Veratocejhalus termése felülete.

\section{R.}

Ránezba szellett, plicatum, a levélnemü szerveken támadó hegyes vagy tompa szeglet alatti felemelkedések, melyek a szerveken vagy hosszára vagy keresztben állanak. Hosszára van ránczba szedve a Fejér Zászpa, Verratrum album levele, keresztbe van ránczolva a Gyertyánfa, Carpinus levele.

Ránczos, rugosum, midőn a levél erei közein levö puha részek kisebb-nagyobb mértékben szabálytalan alakkal dudorodnak fel, mint a $\mathrm{Zsálya} e ́ s$ a Kankalin, Primula levelei felülete.

Reczés, reticulatun, midőn valamely szerv felülete rostocskák vagy fonalszálacska képzödményekkel úgy van átszöve, vagy behuzva, hogy a fonalacskák közein háló szemhez hasonló térecskék támadnak, mint a milyen a Tarka Sáfrán, Crocus reticulatus hagymája felülete. Rekesz, Loculamentum, az üreges szervben, maghonban, vagy magrejtöben alakult válaszfalak által támadó 
fiók vagy tiókok, p. o. három rekeszü tokja van a Hóvirágnak, a 'T'ulipánnak.

Rend, Oirlo, olyan fogalom, mely alá Linné az egy seregbe tartozó s terméjök számára nézve meg’egrvezö növényeket foglalja; olyan fogalom továbbá, mely alá a természetes rendszeralkotók, ¿ külső termetökre egymáshoz hasonló, valamint átalános nemi jegyeikben megegyező növényeket foglalják. Némely fürész e szó helyett a család = Framilia szót, használja.

Rendszer, Systema. Az összes növényvilág egyes tagjainak egy bizonyos elv szerinti egymás mellé és egymás alá állítását hivják növénytani rendszernek. Ha a nörényeket egyetlen, vagy egy pár föbb szerv egyenlősége alapján állítják egymás mellé és alá, akkor a rendszert mesterségesnek (Systema artificiale) nevezik; mivel ilyen esetben, az egy bizonyos szerrökre nézve megegyező növények. habár külső termetökre, sőt fejlődésök és növésökre nézve nagyon kïlönböznek is egymástól, mintegy mesterséggel vannak egymás mellé állítva. Ilyen mesterséges rendszer a Linné Károly svéd tudósé, melynek alapja a növény porodái egyenlösége. Ezen rendszer szerint van rendezre e könyrben a seregek és a nemek meghatározására vezérlö I. táblázat. - Ha pedig a növények belső fejlődése, valamint külső termetének összes jegyeiłen való hasonlóság alapján állítják egymás mellé s egymás alá a növényeket, akkor a rendszert természetesnek (Systema naturale) hivják. Ilyen természetes rendszer az Endlicher István hazánkfiáé, mely szerint e könyvben levő s a fajok meghatározására rezérlö II-dik táblázat össze van állítra.

Ripacsos, scorbiculatum, az olyan felületü szers, melyen reszelöpor nagyságu ritkábl, ragy sürübl emelkedések vannak, mint a milyenek a Kosborfélék magvai. 
Rojtos vagy rostos, fibrosum, midön valamely szervnek fonal vagy czérnaalaku sürü kinövései vannak, mint a gyökerek, vagy az efféleképen sallangossá vált szervek szélei.

Rongyos, lacerum, midőn a levélnemü szervek élei egyenetlenül s szabálytalanul vamnak bevagdalva, mint az Imola Csüküllö, Centaurea Jacea fészke levélkéi éle; vagy a Dudva Csorbóka levelei éle.

Sallangos, laciniatum, a levélnemü szervek élei mélyebb s egyenletes bevágásai, melyek azonban szabályosabbak, niint a rongyos élüröl mondva van; sallangos p. o. a Bárány Ürönl, Artemisia Pontica kétszer szárnyalt levele.

Sarkantyu, Calcar, rendszerint a bokréta, lepel, vagy a pilis zacskósan vagy kuposan megnyult alja, minta milyen a Sarkvirágé, Delphinium.

Sátorozó virágzat, Irflorescentia corymbosa, ha a virágzat kocsányjai különbözö magasságból indulnak s végre mégis egyenlö magasságra érvén virágaikkal egy síkban terülnek ki, mint p. o. az Égerfark Cziczkóró, Achillec Millefolium virágzata.

Sejtes, favosum, az olyan vaczok, melynek besüppedései egyenszögüek s válaszfalai vékony hártyások, nint a milyen a Bordon, Onopordum vaczka.

Sereg, Classis, Linné szerint olyan fogalom, mely alá az alap jegyűl felvett fö bélyegben egymással megegyezö növények tartoznak. Egy seregbe tartoznak p. o. azok, melyeknek 1, 2, 5, 10, stb. porodájok van.

Sertés, setosum, durva keményszőrökkel fedett növényi szerv, mint a milyen a Csekély Mák, Paparer hybridum maghona.

Síma, lacee, az olyan szerv, melyen semmi felemelkedések vagy bemélyedések nincsenek. Nem kell ezt a kopaszszal összezavarni. 
Sinór, Stria, a növények felületén egyenközü sorokban álló felemelkedések, a milyenek vannak az ernyősek magvai felületén. Lásd a LXX. lapon levö jegyzet 3 száma alatt.

Sinóros, striatum, az olyan felület, melyen csaknem egyenközü sorokban álló felemelkedések vannak, mint a Kupos Siléne csészéje oldala.

Sisak, Galea, egy erösen boltozatos csésze. bokréta, vagy pilis, mint a Sisakvirágé, Aconitum.

Sokfalkás, Polyadelphia, olyan virág, melynek sok porodái tövön 3-5 csomóba nöttek, mint a Linkáé, Hypericum. Sugár, strictum, egyenesen felálló nyulánk, a gindár ellentéte; ilyen a Kopasz Toronszál, Turritis glabra szára.

Sugár os, radiatum, midön a szervek egy központ, vagy tányér körül egyenlö magasságban vagy körben állanak, mint a Napvirág szélsö virágai.

Szabar, liber, az egynemü szervek részei semmi részben nincsenek egymással összenöve, mint p. o. a Rózsa szirmai, vagy mint az Ibolya szálcsái.

Szabdalt, incisum, midön a levél vagy a levélnemü szerv éle egyenetlenül van bevagdalva s ez által keskeny szeletei támadnak, a bevagdalás azonban még sem hat a levél közepéig, ilyen p. o. a Gamandor Tarorja, Teucrium Chamaëdrys levele, ilyen a Tollas Szegfü, Dianthus plumarius szirmai éle.

Szálas, lineare, az olyan levél vagy levélnemü szerv, mely aljától hegyéig csaknem egyenlö széles s szélességénél 4-5 szörte hosszabb; ilyen a Hóvirág levele.

Szálesa, Filamentum. Lásd : por oda.

Szalma, culmus, olyan csöves szár mely bütykök által ízekre van tagolva s bütykeiböl induló levelei, buitykös közeit behüvelyezik; ilyen szalmájok = szárok, van a pázsitfï̀ veknek.

Szár, Caulis, a növény tövéböl felfelé növö olyan törzs, melyen ágak vagy legalább levelek. Lásd XI. lap. 2. §. 
Szárboritó, confertum, midön a levelek a száron sürün egymásra borulva formán állanak, mint p. o. a Parti Fütéj, Euphorbia Gerarcliana levelei.

Szárhegyi, terminale, midön a virág a szár vagy kocsány végén áll s a szál vagy a kocsány egyéb részén nincs másutt semmi, mint p. o. a Tulipán.

Szárny, Ala, lásd: pillangós.

Szárnyas, alatum, ha a levél fönyelén úgy fejlenek ki a levélkék, hogy a végső kivételével, mindenik levélkével ellesen áll egy másik levélke, mint az Akás zfa levele. Lásd a XVIII. lapon a szárnyas levél változatait.

Száruyason hasadt, pinnafidum. Lásd a XVIII. lapon.

Szárölelö, amplexicaule, olyan levél, mely vállaival vagy egészen vagy legalábl félig a szárhoz nött, mint a Karórépa Káposztáé, vagy a Szárölelö 'T'átkanafé.

Szárra lapult, vagy lelapult, adpressum, midön a levél egészen a szárhoz fekszik, mint a Toronszál, Turritis levele.

Széllyelterpedt, divaricatum, midön a növény ágai vagy a virágzat kocsányjai a szártól vagy a kocsánytól vagy kinyílva vagy épen derék szeglet alatt elállanak, mint a Vigály Édpázs it virágzata, vagy a Buzér ágai.

Selymes, sericenm, igen finom tapintatu fénylö s lelapult kurta ször, mint a milyen a liba Pimpó, Potentilia anserina levelén levö ször.

Szemcsés, gramulatus, lásd: borsókás.

Szemszörös, ciliatum, ha a levél ragy levélnemü részek élein szörök nönek, mint p. o. a Fïlfü levele éle.

Szerv, Organum, a növény élete fentartását és tenyészését elömozlító $s$ fentartó nörénỵi rész. mint a milyen a gyökér, a levél, a rirág stb.

Szétuyilt, patens, lásd: kinyílt, 
Syigony, Glochis, az olyan ször, serte, vagy fulánk, melynek a vége vissza van fordulva, mint a milyenek az Árnö, Cynoglossum magrai tüskéi.

Szirom, Petalum, a vált szirmu bokréti, vagy a lepel egyes színes részei.

Sziromtalan, apetalum, az olyan virág, melynek nines szirmos bokrétája. mint a Kapotnyaknak, Acarum.

Szives, cordatum, az olyan levélnemü szerr, melynek a lapja a végig vágott fött tojás lapjához hasonlít azonban szélesebb alján ki van kanyarítra, mint i Tavaszi Ibolya levele.

Ször, Pilus, a hám, vagy a felbörből növö vékony átlátszó, rendszerint csöves nyujtvány. Sokféle fajai köziil nevezetesebbek: a molyhok tomentum, lásd eat; a pelyhek plumae hosszu gyenge szörök, melyeknek szálain puha szőröcskék nőttek, mint az Arszlánfog Leondoton, bóbitája szörei; gyapjak, villi lásd ezt; szösz, lana összevissza hajló puhaszörök; selyem sericum, lásd ezt; serte seta. lásd ezt stb.

Szörkör, Annulus pilor um, némely esésze és bokrétit csövében egyenlö magasságban nött szörsinór, nint a Villahim. Prunella bokrétája csövében.

szörösö̈lö, pubescens, kurta s puha szörü felület, mint a Réti Szironták, Ranunculus acris levelei.

Szösz, Lana. Lásd : s zör.

Sziimölesös, verrucosum. ¿ növény szervei felületén támadó különféle felemelkedések, melyek azonban a félgömb alakjához közelítenek, mint a milyen a Bibircsós Kecskerágó kérge.

Sziityö, Utriculus általában hártyanemü zárt zacskó; ha tormésröl mondják, értenek alatta egy vékony hártyáju egymagvu termést, melyben a mag tágon áll; ilyen termése van p. o. az A marántuak. 
Ták, Nectarium, lásd : pilis.

Tányér, Discus, a vaczok laposan kifejlett s attól legalább egy vonal által elkülönülni látszó teteje, mint p. o. az Atraczélé, Anchusa.

Tápszívó, Spjongiola a gyökér felbör nélküli vége, melynél fogva a tápszert magába szívja.

Taréj, Crista, valamely szerven kifejlett fogasolt, majd puha, majd kemény szárnyforma pótlék, mint a milyen van az Espárczet, Onobrychis magván.

Táska, Silicula, a beczö terméshez hasonló alkotásu magrejtö, csakhogy ennek a hossza a szélességével egyenlö, mint a milyen a Csapka, Capsella termése.

Telibélï, solidum, midön a szerv belseje valamely tömöttebb állománynyal van betöltve, ellentéte a csöves vagy bördősnek.

Tengely, Axis, a növény gyökere, szíra vagy ágai közepébe hosszában képzelt vonal.

Tenyeres, palmatum, az olyan levél vagy levélnemü vagy gyökérféle szerv, mely tövén egy darabban terül ki, de éle felöl legalább a közepéig be van vagdalva, mint a Jókori Jávor, Acer platanoides levele, némely Kosbor kolonczos gyökere.

T'erjedö, repens, a gyökerezövel majdnem egy jelentésü azonban föképen az olyan gyökérröl mondják, mely igen szapora, mint a Taraczk Buza, Triticum repens gyökere; a gyökerezö szót leginkább a szárra értik, lásd: gy ökerezö.

Terme, Pistillum, a virág legbelsö részében termö levelekböl alakuló szerv; alsó része, melyben a magcsák vannak, a maghon, Germen; felsö része a bibe, Stigma; a maghon és a bibe között kifejleni szokott szálacska, a bibeszár, Stylus. Lásd XXXII. lapon $f$ betü alatt. 
Termekocsányka, Gynophorum, a vaczokról növő nyelecske, melyre a terme van felnöve, mint a Mécsvirágban, Lychnis.

Térmet, Habitus, az egész növény külsöje.

Toboz, Strobilus, termés virágokat tartalmazó olyan pikkelyes barka, melynek puha pikkelyei a termés megérésekor megkeményednek, söt meg is fásulnak: ilyen termése van a Komlónak és a Fenyöfáknak.

Tojásdad, ovatum, az olyan levélnemü szerv, mely mindkét végén le van kerekitve, az alsó vége azonban szélesebb, a felső vége hegyesebb; vagy olyan lap, mely a megfött és hosszában két féle vágott tojás lapjához hasonlít, mint a milyen a Körtefa levele.

Tok, Capsula. Lásd XXXVI. lapon $f$ alatt.

Tökélyes virág, Flos completus, vagy hermaphroditus, az olyan virág, melyben mind a 4 fö rész: csésze, bokréta, poroda és terme megvannak; szorosabb értelemben véve az olyan virágot értik e szó alatt, melyben poroda és terme is van egyszersmind.

Tökélytelen virág, Flos incompletus vagy unisexualis, az olyan virág, melynek valamely része hiányzik.

Tökocsány, Scapus, a növény tövéböl felfelé növö s szárat helyettesítö olyan szerv, melyen sem ágak, sem levelek nincsenek, hanem a tetején van a virágzat, ilyen tökocsányja van p. o. a Kankalinnak.

Tölcséralaku, infundibuliforme, olyan egy tagu csésze vagy bokréta, melynek az alja el van szükülve s teteje felé menedékesen szélesedik ki, mint a milyen a Szulák, Convolvulus bokrétája.

Tornyadzó alaku, pyramidale, az egynemü szervek összeállásából támadt alak, melynek az alja széles s teteje felé elhegyesedik, oldalai azonban ormósan tünnek fel, mint a Bokrétafa, Aesculus virágzata. 
Torzsa, Spadix, olyan virágzat, melynek meghúsosodott vastag kocsányjára nönek a virág tenyészszervei, mint a Kontyvirágé. Arum.

Törzsök, Truncus, széles értelemben a növény töréböl felfelé növő része a növénynek, szorosabb értelemben a faféle növények dereka.

Tövis, Sرincı, a növény szára belső részéböl induló s ki nem fejlett hegyes végü törpe ág; ilyen tövise van a Kökényszilvának.

T'iiske, Spina, lásd: töris.

Tïszö, Folliculus, egyetlen termö levélböl alakult oly tok termés, mely a szár vagy a kocsány felöl való oldalán egyfelöl feslik fel; ilyen termése van a Sarkvirágnak, Delphinium.

\section{$\mathbf{U}$.}

Ujjas, digitatum, az olyan füzött levél, mely 5-7-érel nő egy közös nyél végére, mint a milyen a Bokrétafa, Aesculus levele.

Üstök, Coma, a virágzat, ragy a mag, vagy a gyökér tetejére egy csomóba nőtt rost, ragy hajszálalaku nyujtvány; mint a milyen ran az Üstökös Gyöngyike, Muscari comosum rirágzata tetején.

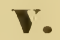

Vaczok, Receptaculum, a kocsány, vagy a kocsányka megvastagodott vagy épen kiszélesedett teteje, melyen aztán a virág részei fejlenek ki. Lásd a XXVI. lapon 2. szám alatt.

Válaszfal, Dissipinentum, a magrejtöt rekeszekre osztó husos vagy hártyás részek, mely a magrejtő alakulásakor a termölevelek befelé fordult széleiböl alakul.

Válfaj, Varietas, valamely növény faj eredeti alakjától némi mellékes jegyekben eltérö oly̨nemű változat, 
nelyben azért a faj lényeges jegyei azonnal megismerhetők; sôt az ilyen válfaj magvai elvetése által az eredeti alapfajra vissza is vihetö.

Váll, Basis, a levél alsó részének a nyele vagy a gerincze tövétöl jobb és llbal felöl eső része. Lásd a XV. lapon. 2. szâmı alatt.

Váltogató, alternum, midőn az egyik ág, vagy az egyik levél a szár egyik oldalán alább, a máiik pedig a szár másik oldalán felebb áll, mint p. o. a Dohány levele.

Váltszirmu, Dialypetala, az olyan bokréta, melynek szirmai semmi részben nem nöttek egymással össze, mint p. o. a Szegfü bokrétájában.

Válus, canaliculatum, midőn a levélen, vagy valamely szerven hosszában menő bemélyedés vonul végig, mint a Bunkós Hagyma, Allium Sphaerocephalum levelén.

Vánkos, Torus, a vaczok feldudorodott teteje, melyen aztán a virág részek fejlenek ki.

Vesealaku, reniforme, az olyan levél, melynek a válla közé szívesen van kikanyarítva, vállai és hegye pedig egészen le vannak kerekítve, mint a Kapotnyak leveléé.

Villás, furcatum, midőn az ágak vagy a szőrök két $\mathrm{s}$ több egyenlö ágra oszolnak, mint s Köd Daravirág levelén levö szörök.

Virág, F’los. Lásd a XXIV. lapon 1. szám alatt.

Világosnövény, Phanerogamen, melynek a virága puszta szemmel látható vagy legalább a virágában levö tenyészszervei egy közönséges nagyítóval megszemlélhetök.

Virágtalan növény, Cryptogamen, melynek a virágait sem puszta szemmel, sem nagyító iiveg segítségével 
334

felvenni nem lehet, hanem e helyett magporai (Sporae) teremnek, mint a harasztoknak.

Virágpor, Pollen, Lásd: poroda.

Virágzat, Inflorescentia, több virágnak egy közös kocsányon való csoportosulása. Lásd a XXI. lapon 4. §.

Vísszás-szíves, obcordatum, az olyan levél, vagy levélnemü szerv, melynek a válla hegyes, hegye pedig szívesen ki van kanyarítva.

Visszás-tojásdad, obovatum, az olyan tojásdad levél vagy levélnemü szerv, melynek a hegye szélesebb, válla pedig keskenyebb.

Vitorla, Vexillum. Lásd pillangós virág. 


\section{NÉVMUTATÓ.}

\section{A.}

Abutilon CV. . . . 239

Acer LXXXI., CXXVIII. 241 Acerineae . . . . 241 Achillea CXVIII. . . 94 Aconitum XCII. . . 198 Acorus LXXX. . . 58 Acramphibrya. . . 60 Actea XCI. . . . 198 Adáz LXXIII. • . 176 Adonis XCIII. . . . 191 Adoxa LXXXIII.,

LXXXVI. . . 128 Aegilops LIII. . . . 1 Aegopodium LXXII. . 172 Aesculus LXXXI. . . 243 Aethusa LXXIII. . . . 176 Agrimonia LXXXVII. . 267 Agrostemma LXXXVI. . 237 Agrostis LV. . . . 17 Aira LVI. . . . . 16 Ajakasok. . . . . 132 Ajuga XCV. . . . 144 Ákász CIX. . . . . 282 Alisma LXXXI. . . . 37
Lap

Alismaceae . . . . 36 Alkanna LXIV. . . 149 Allium LXXIX. • . 42 Almafélék. . . . . 259 Alnus CXXV. • • • 61 Alopecurus LIV. • . . 19 Alsine LVIII., LXXVI.,

LXXXIII., LXXXV. . 227 Álszegecs CIII. • . 208 Althea CVI. . . . 238 Alyssum CII. . . . 210 Amaránt CXXIV. . . 75 Amarántfélék. . . . . 75 Amaranthaceae. . . 75 Amaranthius CXXIV. . 75 Amarillisfélék. . . . 49 Amaryllideae. . . . 49 Ambruskafélék. . . 119 Ambrosiaceae. . . . 119 Ampelideae. . . . 244 Amphibrya. . . . . 1 Amygdaleae. . . . 268 Amygdalus LXXXVIII. . 268 Anacamptis CXIX. . . 52 Anacardiaceae. . . 249 
Anagallis LXV. . . 169

Ápa LII.

Ancikicurlféléli. . . . . 249

Arrhenatherum LVI.

Anchusa LXIV.

Arszlánfog CXII.

111

Andropogon LIII.

Artemisia CXVI.

97

Androsace LXV. . . . 167

Arum CXXIII.

58

Anemone XCIII. . . . 190

Asarum LXXXVII.

82

Anethum LXXIV . . 180

Asclepiadece.

129

Angelica LXXII. . . 178

Angyélika LXXII. . . 178

Ánizs LXXII. . . . . 176

Anthemis CXVIII. . . 95

Anthericum LXXIX. - 40

Anthoxantum LIV. . . 13

Anthriscus LXXVI. . . 183

Anthyllis CVII. . . . 274

Antirrhinum XCIX. . . 158

A pácz LXIV. . . . 146

Apetala. . . . . 60

Apium LXXI. . . . 171

Apocynacecue. . . . 129

Apoczinfélék. . . . . 129

Asclepias LXIX

129

Asparagus LXXIX.

CXXIX. . . . 45

Asperugo LXIII. . . . 150

Asperula L., LX. . 126

Aster CXVII. . . . 89

Astragalus CVIII. . . 283

Astrantia LXX. . . . 170

Aszász CXI. . . . 116

Aszgallér LXVII. . . 225

Átorna CXXVIII. . . 242

Atraczél LXIV. . . . 147

Atriplex LXVIII.

CXXIV. . . . 71

Aquilegia XCII. . . . 197 Atropa LXVI. . . 153

Arabis CIV. . . . 202 Avena LVI.

13

Araliacecue. . . . 184

Arculiafélét. . . . 184

Aranyfǜt CXV. . . . 91

Aranyvirág CXVIII. . 96

Arenaria LVIII.,

LXXXV. . . . . 228

Aristolochia CXXI. . . 82

Aristolochiaceae. . . . 82

Árnö LXIII. . . . . 151

Aroidecie. . . . . 58

Árorru LXXVII.,

LXXXIV., CV.

\section{B.}

Babó CIX. . . . . . 286

Bajnócza LXXXIX. XC. 268 Bajuszfü LIV. . . . 19

Bajuszpázsit LVII. . . 10

Baka CXXII. . . . 59

Baktopp LXXII. . . . 172

Balhafü CXV. . . . 93

Ballota XCVI. . . . 143

Balsamineae. . . . 255 
Bangita LXXYII. . . 127

Bangó CXX.

baraboly LXXVI. . . 183

Baraczk LXXXVIII. . 269

Barbarea CIV. . . . 201

Báres CXIII. . . . 108

Beckmannid LV. . . 18

Bellis CXVIIL. . . . 90

Benge LX., LXIII.,

CXXVIII.

Bengefélék.

245

Berberidecte.

Berberis LXXVIII.

Bérese XCIII.

Berekenye LXXXIX

Berula LXXII.

Beta LXVIII.

Betonica XCVI.

Bétonika XCVI.

Betula CXXVI.

Betulacecie.

Bibak CXIX.

Bibefog CXX.

Bibekonty CXX.

Bibepár LXXIV.

Bibetyü XCIV.

Bibikra LV.

Bidens CXII.

Bikkfa CXXVI.

Birs XC.

Biscutella CI. . . . . 214

Blitum XLVII., LXIX. . 71

Bóbitagyász CXIV. . . 103

Bodza LXXVII. . . . 127

Bogács CXIV. . . . 106
Boglárfia CXXY.

65

Boglairfafélék. . . . . 65

Boglárpót LXXVII. . . 221

Bognád LV. . . . . 11

Bögreszeg LXXXV. . . 233

Bögretok LXI, LXVII. 80

Bogyópikk CXXX. . . 60

Bojtorján CXIII. . . . 109

bóka CVIII. . . . . 283

Bokrétafa LXXXI. . . 243

Bolivétafafúlék. . . . . 243

Bolonyik LXXII. . . . 178

Boraginear. . . . . 145

Boragófélék. . . . . 145

Borbolya LXXVIII. . . 10

Borbolyafélék. . . . . 198

Bordamag LXXV. . . 181

Bordon CXIII. . . . 106

Boróka CXXXI. . . . 60

Borostyán LXII. . . . 184

Boroszlán LXXXII. . 81

Boroszlcinfélék. . . . . 81

Borsó CIX. . . . . 290

Borzon LXXV. . . . 182

Brachypodium LVII. . 5

Brassica CIV. . . . . 208

Briza LVII. . . . . 8

Bromus LVI. • . . . 6

Bryonia CXXIII.,

CXXVIII.

224

Bükköny CIX. . . . 290

Bundi XCT. . . . . 143

Bunias CI. , . . . 217

Bunkonez C. . . . . 216

Bunkópót LVI. . . . 15 
Bupleurum LXXI.

Bürök LXXVI.

Butomus LXXXIII.

Buza LIII

Buzér 'LX.

Buzérfẹlél.

\section{C.}

Calamagrostis LV.

16

Calamintha XCVIII. . 134

Calepina C.

217

Callitriche XLVII. CXXI.

(Callitrichineae.

61

Caltha XCII.

Camelina CII.

61

Campanula LXVII. . . 120

Campanulaceae. . . 120

Camphorosma LXI. . . 73

Cannabineae.

65

Cannabis CXXX.

65

Capsella CII.

215

Cardamine ClV.

203

Carduus CXIV.

106

Carex CXXIII., CXXIX. . 23

Carlina CXIII. . . . 103

Carpinus CXXVI. . . 62

Carum LXXII. . . . 172

Caryophyllacecue . . . 225

Castanea CXXVII. . . 63

Caucalis LXXV. . . . 182

Celastrinecue . . . . 244

Celtideae. . . . . 64

Celtis LXVIII., LXXX. .

Centaurea CXIV. . . 104

Cephalanthera CXIX. . 53
Cephalaria LIX.

Cerastiun LXXVII.,

LXXXVII.

Cerasus LXXXIX

Ceratocephalus LXXVIII.

XCIII. 192 Ceratophylleac. . . . Cerathophyllum CXXI . 60 Cercis LXXXIV., CVI. . 293 Cerinthe LXIV. . . . 145 Chaerophyllum LXXVI. 183 Chaiturus XCVI. . . 142 Chelidonium XCI. . . 199 Chenopodiaceae. . . . 69 Chenopodium LXIX. . 69 Chlora LXXXII. . . . 131 Chondrilla CXI. . . . 114 Chrysanthemum CXVIII. $96^{\circ}$ Chrysosplenium LXXXII.,

LXXXIV. 187

Cichorium CXII. . . 110 Cicuta LXXII. . . . 171 Cineraria CXV., CXVII. 102 Circaea XLVIII. . . . 257 Cirsium CXIII. . . . 108 Cistineae. 220 Cladium LI. . . . . 32 Clematis XCIII. . . 188 Clinopodiun XCVIII. . 134 Cochlearia CII. . . . 212 Coeloglossum CXIX. . 52 Colchiacacere. . . . . 39 Colchicum LXXX. . . 40 Colutea CIX. . . . 283 Compositce. . . . . 88 
Coniferae. . . . . 60

Conium LXXVI. . . . 184

Convallaria LXXIX. . 46

Convoluulaceae.

Convolvulus LXVI.

Corispermum XLVII.,

LXVIII.

Cormophyta.

Cornecue.

Cornus LX. . . . . 185

Coronilla CIX. . . . 285

Corydalis CVI. . . . 200

Corylus CXXVII. . . . 62

Corynephorus LVI. . . 15

Crambe CI. . . . . 218

Crassulacece . . . . 186

Crategus LXXXVIII.,

LXXXIX.

260

Crepis CXI. . . . 116

Crocus L. . . . . 48

Crucifercue . . . . 200

Crupina CXIV. . . . 103

Crypsis LIV. . . . . 19

Csábaír LXXXIX., . .

CXXIII. . . . . 268

Csakkör CX. . . . . 115

Csalán CXXIV., CXXX. 64 Csalúnfélék . . . . . 64

Csalmatok LXVI. . . 154

Csapka CII. . . . . 215

Csáté L. . . . . 36

Csékcsillag LXVII. . . 120

Csengettyüke LXVII. . 120

Csengettyükiefélék. . . . 120

Csenkesz LVIII.
Csészeküitt LXXXII. . . 255

Csészekiütfélék. . . . 255

Csészeszálny CVI. . . 243

Csészeszcirnyfélél: . . . 243

Csibehur LXXVII.,

LXXXVI.

Csigacső CVIII. . . . . 274

Csikorka XLVIII.,

XCVIII. . . . . 156

Csilla LXXIX. . . . 42

Csillagesin CXVII. . . 90

Csillaghur LVIII., LXXVI.,

LXXXVI. . . . . 229

Csillagpázsit LV. . . . 18

Csimpaj CXXIV. . . 119

Csipkepitty XCVI. . . 136

Csitre LXXXII, LXXXV. 228

Csombor XCVII. . . . 132

Csomorika LXXII. . . 171

Csorbóka CXI. . . . 116

Csorikra CXIX. . . . 52

Csővirics LXXXII. . . 255

Csríesköruövök. . . . 60

Csucsór LXVI. . . . 153

Csucsórfélél. . . . . 152

Csukóka XCVII. . . . 137

Csüküllö CXIV. . . . 104

Csüilleng CI. . . . . 216

Csuttialomfélék. . . . . 244

Cucubalus LXXXV. . . 236

Cucumis CXXIII. . . 224

Cucurbita CXXVIII. . 223

Cucurbitacecue. . . . . 223

Cupulifercue. . . . . 62

5 Cuscuta LXI., LXX. . 152 
Cyclamen LXV. . . 168

Datura LXV.

Cydonia XC. . . . . 259

Daucus LXXY.

Cynanchum LXIX., CV. 130

Degenes LXXV. . . 182

Cynodon LV. . . . . 18

Cynoglossum LXIII. . 151

Cynosorus LVIII. . . 8

Cyperaceat. . . . . . 23

Cyperus L. . . . . . 36

Cypripedium CXX. . . 55

Cytisus CVII. . . . . 272

Czámoly XCII. . . . 197

Czékla LXVIII. . . . 69

Czeltisfélék. . . . . . 64

Czeltis LXYIII., LXXX. 64

Czerczisz LXXXIV., CVI. 293

Cziczkoró CXVIII. . . 94

(ziczö LXXXII. . . . 81

Cziklász XC. . . . . 267

Czikkszár IXVII.,

\section{LXXX., LXXXII..}

LXXXIII.

78

Czikliszcivélék. . . . 76

Czillár LXXXIII. . . 45

Czimbor LIII. . . . . 2

Czinczor LVIII. . . . 8

Czinka LXIX., CV. . . 130

Cripöczim CXX. . . . 55

\section{ID.}

Dactylis LVII.

Dákoska L. . . . . 48

Daphne LXXXII. . . 81

Daphmoirlecie. . . . . $\$ 1$

Daravirág CIL. . . . 212

Delphinium XCI., XCII. 197 Demutka XCVII. . . 133 Dentaria CIII. . . . 203 Derczefü LXXXV. . . 232 Derezle LXXIII. . . 178 DialyPe'TALAE. . . 170 Dianthus LXXXIV. . 231 Dictamnus LXXXIT. . 250 Digitalis C. . . . 159 Diplotaxis CIII. . . . 210 Dipsaceae. . . . . 86 Dipsacus LIX. • . . 86 Diófa CXXVI. . . . 249

Diófafélék. . . . . 24?

Dioscoreae. . . . . 47

Dioscoreafélék. . . . . 47

Dohány LXVI. . . . 154

Dornik CVIII. . . . 281

Doronicum CXVII. . . 100

Dorycnium CVIII. . . 281

Draba CII. . . . . 212

Dracocephalum XCVII. . 137

Droseraceae. . . . . 221

Dudafürt CIX. . . . 283

Dugasor CXV., CXVII. . 102

Durcza LIV.

20

Eloir LVII. . . . . 8

Echinops CXII. . . . 102

Echinopsilon IAXVIII. . 75 
Echinospermun LXIII. 149

Eupatorium CXV.

8.9 Echium LXIV. . . . 146

Ecsetpázsit LIV. . . . 19

Édpázsit LVII. . . . 10

Égerfa CXXV. . . . 61

Ékfü LXXXV.

Flatine LVIII., LXXX.,

LXXXIII.

Elatineae.

Eileagneae. . . . . 82

Eleagnus LXI. . . . . 82

Elecs LXXXIII. . . . 37

Eleczke LXV. . . . . 130

Elymus LIIl. . . . . 2

Euphorbia LXXXVIII.

CXXIV. . . . . 245

Euphorbiaceae. . . .245

Euphrasia XCIX. . . . 169

Ezerjó LXXXIV. . . . 250

Ezüstfa LXI. . . . . 82

Ezüstfafélét: . . . . 82

Evonymus LXI., LXII. . 244

Enyvencz LXXXVI. . 237

Eperfa CXXV. . . . 64

Eperfétét. . . . . 64

Ephedra CXXX. . . . 60

Epilobium LXXXII. . . 255

Epipactıs CXIX. . . . 54

Eragrostis LVII. . . . 10

Eranthis XCIII. . . 196

Erigeron CXV., CXVII. 90

Eryngium LXX. . . . 170

Eriophorum LI. . . . 35

Frnyösök. . . . . . 170

Erodium LXXVII.,

LXXXIV., CV. . . 250

Erncastrum CIV. . . 209

Erysimum CIV. . . . 207

Erythraea LXVI. . . 131

Ervum CIX. . . . 289

Espárczet CVIII. . . . 286

Fstike CIII. . . . 204

Euclidium C. . . . . 216

\section{F.}

Fagus CXXVI. .

63

Fagyal XLVIII. . . 128

Fagyöngy CXXVIII. . 185

Fájvirág LXII., LXXVII. 25.5

Fájvirágfélék.

25.5

Fakín LXXVIII.

CXXVII.

185

Futínfélék. . . . . 185

Falcaria LXXII. . . 172

Falfü LXI., CXXIV.. . 65

Fánzár LXVI. . . . 152

Farkkóró LXVI. . . . 154

Farsetia CII. . . . . 211

Fejvirág LIX. . . . 87

Fenyer LIII. . . . 22

Ferula IXXXIV. . . . 178

Festuca LVIII. . . . 5

Fészkesek. . . . . . 88

Ficus CXXV., CXXXI. . 64

Figefa CXXV., CXXXI . 64

Filago CXXIII. CXV. . 99

Fintor XCIX. . . . 165

Foeniculum LXXII. . 176

Foganőtt XCVI. . . . 140 
\begin{tabular}{lr|r} 
& Lap & \\
Fogasir CIII. . . . 203 & Galantluus LXXVIII. & 49
\end{tabular}

Földepe LXVI. . . . 131 Galatella CXVII. . . 90

Folyondár CXXX. . . 47 Galáz XLVIII., CXXI. . 56

Fortsziriunk. . . 82 Galega CVII. . . . 282

Foszlár CIT. . . . 203 Galeobdolon XCT. . 143

Fragaria XC. . . . 263 Galeopsis XCVI. . . 140

Fraxinus XLVIII., $\quad$ Gálga CVII. . . . 232

CXXVIII., CXXX. . 129 Galium L., LX. . . . 122

Fuláncs LXXVIII., Gálna LXIT. . . . 148

XCIII. . . . 192 Gamopetalae. . . 82

Fülfü LXXXI.,

Gazillat LXXXI.,

LXXXVIII. . . . 186

Fumaria CVI. . . . 199

LXXXIT. . . . 170

Gazillatfélék. . . . 170

Fűnyüg LXI., LXX. . . 152 Gégevirág CXXI. . . 82

Füstike CVI. . . . . 200 Gégerircigféléli. . . . 82

Fütéj LXXXVIII.,

CXXIT. . . . . 245

Fütéifélék. . . . . 245

Füz CXXXI. . . . . 65

Füzény LXXXVII. . . 258

Füzényfélék. . . . . 258

Füzértekercs CXX. . 55

Füzfélék. . . . . . 65

Genista CTII. . . . . 271

Gentiana LX., LXII..

LXIX. . . . 130

Gentianaceal . . . 130

Geraniaceae. . . . 250

Geranium LXXXIII..

CT.

2.5

Gérbicz CXVIII. . . . 53

Gerely IXXXIII., CT. 251

Gerelýféléli. . . . 250

Gerepcsin CXVII. . . 89

Gagea LXXIX. . . . 41 Gesztenyefa CXXVII. . 63

Galagonya LXXXVIII., Geum XC. . . . . 267

LXXXIX. . . . 260 Gladiolus L. . . . . 48

Galaj L., LX. . . . . 122 Glaucium XCI. . . . 19 ?

Galambbegy L. . . . 84 Glechoma XCrI. . . 136

Galambócz XCIV., $\quad$ Globularia LX. . . 145

XCVIII. . . . 145 Flobutariacese. . . 145

\begin{tabular}{ll|l} 
Galcmbóczfélét. . . . 145 & Glyceria LVII. . . 10
\end{tabular}

Galamó XCIII. . . . 197 Glyeyrrhiza CTIII. . 282 
Gnaphalium CXVI. 99

Hamuka CII.

211

Gódircz XCI. . . . 199

Haramag LXXIII. . . 175

Gólyahir XCII. • . . 196

Harmadmag LV. . . 13

Gombernyő LXXIII . . 170

Gomborka CII. . . . 213

Harmala LXXXVII. . . 250

Gönye CXIXII., CXXVIII. 224

Gordon CXIV.. . . . 106

Gramineae. .

Fratiola XLVIII.,

XCVIII.

159

Gubóvirág LX. . . . 145

Gubóvivágfélék. . . . 145

Gurgulya LXXIII. . . 176

Gyapu LI. . . . . . 35

Gyékény CXXII. . . . . 5.9

Gyékienyfélék. . . . . 59

Gyertyánfa CXXVI. . . 62

Gymnadenia CXIX. . . 52

Gypsophila LXXXY. . 232

Gyökönke L. . • • . 86

Gyölönkefélék. . . . . 84

Gyöngyhím XCV. . . i41

Gyöngyike LXXIX. . . 45

Gyöngyvirág LXXIX. 46

Gyopár CXVI. . . . 99

Gyujtovány XCIX. . . 156

Gyüszüvirág C. . . . 159

\section{I.}

Hagyma LXXIX. . . . 42

Hagymabur CXX. . . 55

Hajka LV. . . . . . 18

Halorageae . . . . 271

Halyogfa LXX. LXXTI. 244

Halyogfafélék: . . . . 244

I!armatfüfélék . . . 221

Hedera LXII. . . . . 184

Helianthenum XCI. . 220

Helianthus CXVIII. . . 93

Heliotropium LXIII. . 145

Helleborus XCII. . . 196

Heracleum LXXIV. . . 180

Hérics XCIII. . . . . 191

Herniaria LXVII. . . 225

Hernyóka LV. . . . . 18

Hesperis CIII. . . . 204

Hibik CVI. . . . . 239

Hibiscus CTI. . . . 239

Hierochloa LV. . . . 13

Hidör LXXXI. . . . 37

Hidörfélék . . . . . 37

Hieracium CXI. . . 117

Higviritz CVIII. . . . 282

Himantoglossum CXIX. 52

Himár CXXII., CXXIX. 56

Hinrivfélék . . . . . 56

Hippocastaneae . . . 243

Hippocrepis CIX. . . 286

Hippuris XLVII. . . . 257

Holcus LVI. . . . . 13

Holgyomál CXI. • . . 117

Holosteum LVIII.,

LXXYI., LXXXV1. . 228

Hölye LXXIX. . . . . 40

Homokhur LVIII.,

LXXXT. 
Hordeum LlI. . . . . 2

Hottonia LXV. . . . 169

Hóvirág LXXVIII. • . 49

Humulus CXXX. . . . 65

Hunyász XCVI. . . . 139

Hunyor XCII. . . . 196

Husáng LXXIV. • . . 178

Hutchinsia CI. . . . 215

Hutsza LXXXI. . . . 36

Hydrocharidece . . . 46

Hydrocharis CXXVIII. . 46

Hypericinecte . . . . 240

Hypericum CX. . . . 240

Hypochaeris CXI. . . 110

Hyosciamus LXVI. . . 154

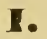

Ibolya LXII. . . . . 221

Ibolyafélék . . . . . 221

Iglicz CVII. . . . . 273

Ikracsöfélék . . . , . 84

Ikrapikk CIV. . . . . 202

Impatiens LXII.,

LXXVII.

Inula CXV.

255

Iricleat . . . . . . 47

Iringó LXX. . . . . 170

Iris L. . . . . . 47

Isatis CI. . . . . . 216

Isopyrum XCIII. . . . 197

Iszaprojt LX. XCIX. . 159

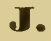

Jasione LXVII. . . . 120

Jasminecte . . . . 128
Lap

Jasminum XLVIII. . . 128

Jázmin XLVIII. . . . 128

Jizminfélék . . . . . 128

Jávor LXXXI., CXXVIII. 241

Jivorfélék . . . . . 241

Jeneszter CVII. . . . 271

Jézsafa LXXXVIII. . . 25y

Juglandecie . . . . . 249

Juglans CXXVI. . . . 249

Juncacecue . . . . . 87

Juncus LXXX. . . . 87

Juniperus CXXXI. . . 60

Jurinea CXIV. . . . 105

\section{II.}

Kacskanyak XCV. . . 144 Kajmacsór C. . . . . 164 Kajtár XCVI. . . . . 142 Káka LI. . . . . . 33 Kakies CXI. . . . . 114

Kalaminta XCVIII. . . 134 Kalaptü CXV. CXVI. . 88 Kalászbojt LIII. . . . 1 Kálmos LXXX. . . . 58 Kandilla XCII1. . . . 197 Kankalin LXV. . . . 168 Kankalintélék . . . . 167 Kapor LXXIV. . . . 180 Káposzta CIV. . . . 208 Kapotnyak LXXXVII. . $\quad \Varangle 2$ Kásafü LIV. . . . . 17

Kásakalász LIV. . . . 22 Katáng CXII. . . . . 110 Kazupa LIX, . . . . 87 
Kecskedísz CXI. . . 111

Körtefa XC.

Kecskerágó LXI., LXII. 244

Kosbor CXIX.

Kéhencz LVIII. . . . 11

Kosborfélék .

49

Kender CXXX. . . . 65

Tenrlerfélék . . . . 65

Kentrophyllum CXIV. . 106

Kerep CVII. . . . 281

Kötör LXXXIV.

187

Kötörfélék

187

Krepin LXIX. . , . . 129

Krepinfélék . . . . . 129

Kereszteseti . . . . 200

Kukoricza CXXII.

22

Kigyószisz LXIV. . . 146

Kukuba LXXXV.

236

Kikerics LXXX. . . 40

Küllörojt CXV., CXVII. $9(1$

Kikiericsféléli . . . . 39

Klóra LXXXII. . . . 131

Knautia LIX. . . . . 87

Kochia LXIX. . . . 73

Kocsord LXYV. . . . 178

Koczkagyöngy LXXXIII.,

LXXXVI.

Kunkor LXIII.

145

Koeleria LVII. . . . 12

Körkörcsin XCIII. . 190

Köldöncz LXILI. . . . 151

Köles LIII. . . . . 20

Kolokán CXXIX. . . . 46

Kömag LXIV. . . . . 140

Könény LXXII. · . . 172

Konıló CXXX. • . . 65

Komóesin LIV. . . 18

Konkoly LXXXVI. . . 237

Kontyvirág CXXIII. . 58

Kontyvircigfélék . . . 58

Koprincstermök . . . 62

Körfény CXIII. . . . 109

Körisfa XLVIII.,

CXXVIII., CXXX. . 129

Kornilla CIX. . . . 285

Korsóka LXXII.

173

Labiatae . . . . 132

Lactuca CXI. . . . 114

Lamium XCV. . . 14'

Lapicz CII. . . . . . 212

Lapór XCIX. . • . . 104

Lappa CXIII. . . . . 149

Lapsana CXII. . . . 110

Laptaborz CXII. . . . 102

Laserpitiun LXXV. . . 181

Lathraea XCVIII. . . 167

Lathyrus CIX. . . . . 290

Látonya LVIII., LXXX.,

LXXXIII. . . . 241

Laitonyaféléli . . . . 241

Lavatera CVI. . . . 237

Lednek CIX. . . . . 292

Leersia LIV. • . . 20

Léhapót LVI. . . . . 12

Lelleg LXXVII. . . . 84

Lemna XLVIII.. CXXI.,

CXXIX. . . . . 58 
Lemnaceae.

Lizinka LXV., CT.

168

Lencse CIX.

Len LXXVII., CV. . . 253

Locsagaz CXXI. . . 60

Lenfélék . . . . . 253

Locsagazfélék

Locsahur LXXVIII. . 2.58

Leontodon CXII. . . 111

Lóhere CVIII. . . . 276

Leonurus XCV. . . . 141

Lepese XLVIII., CXXI.,

CXXIX. . . . . 58

Lepcsefélék . . . . . 58

Lepidium CI. . . . . 214

Lepigonum LXXXV. . 326

Lepkeszeg CVIII. . . 275

Lepturus LII. . . . . 1

Leucojum LXXVIII. • 49

Libanotis LXXIV. . . 177

Lolium LII. . . . . 4

Lompárfélét: . . . 250

Lonez LXVI. . . . . 127

Lonczfélék . . . . . 127

Lonicera LXYI. . . 127

Lonicareae . . . . 127.

Lórom LXXX., CXXIX 76

Loranthaceae . . . . 185

Loranthus LXXVIII.,

CXXVII. . . . 185

Libatopp LXIX. . . . 69

Libatoppfélék . . . . 69

Ligustrum XLVIII. . 128

Likasir CVI. . . . . 200

Lila XLVIII. . . . 128

Liliaceae . . . . 40

Liliom LXXIX. . . . 40

Liliomfélék . . . . 40

Lilium LXXIX. . . . 40

Limnanthemum LXV. . 130

Limodorum CXVIII. . . 53

Limosella LX. XCIX. . 159

Linaceae . . . . 253

Linaria XCIX. . . 156

Linka CX. . . . . 240

Linkafélél . . . . 240

Linosyris CXV. . . . 91

Linum LXXVII., CV. . 253

Listera CXX. . . . . 55

Lithospermum LXIV. . $14 \mathrm{~s}$

Lotus CVII. . . . 281

Lucza LXXX. . . . . 39

Ludhur LVIII., LXXYI.,

LXXXIII., LXXXV. 227

Lunaria CII. . . . 212

Luzula LXXX. . . . 39

Lychnis LXXXVI.,

CXXIX. . . . . 236

Lycium LXVI. . . 152

Lycopsis LXIT. . . . 147

Lycopus XLIX., XCIV. 133

Lysimachia LXV., CV. 168

Lythrariaceae . . . 258

Lythrum LXXXVII. . . 258

\section{I.}

Mácsonya LIX . . . $\$ 6$ Mácsonyafélét: . . . 86 Madárhur LXXVII.,

LXXXVII. 228 
Magabár LX. . . . . 126

Meténg LXVI.

Magiszák LXIII. . . . 150

Mézfï LVI.

Maglapél LXVIlI.,

Mézkerep CVIII. . . 275

CXXIV.

Micropus CXTI.

Magpoczok CXII. . . 113

Millium LIT.

Magtaraj LXXIV. . . 181

Mizura LXXVIII., XCIII. 192

Magvarótt CXI. . . . 111

Moehringia LXXXIl.,

Mák XCI.

LXXXV.

228

Mcikféléli . . . . 198

Malachium LXXXVII . 230

Malaxis CXX. . . . 55

Mocsárhur XLVII.,

CXXI.

Mocscivhuvfẻlék . . . 61

Malcolmia CIT. . . . 204

Mogyorófa CXXTII. . 62

Málika CIV • . . . 204

Molinia LTIII. . . . 11

Mályva CVI. . . . . 238

Molyhár CXTT. . . . 91

Mályrafélék . . . . 237

Malva CVI. . . . . . 238

Maluacecie . . . . . 237

Mamó XCV. . . . 143

Mángolt XLVII., LXIX. 71

Marrubium XCIT. . . 139

Matricaria CXVIII. . 96

Matyó C. . . . . . 217

Mécsvirág LXXXVI.,

CXXIX. . . . . 236

Medicago CVIII. . . 274

Meggy LXXXIX. • . 270

Melampyrum XCIX. . 165

Melica LVI. . . . . 12

Melilotus CVIII. . . . 275

Melittis XCVII. . . . 138

Ménta XCVII. . . . 132

Mentha XCVII. . . . 132

Menyanthes LXY. . . 130

Mondola LXXXVIII. 268

Mondolafélél . . . . 268

Monotropa LXXXI.,

LXXXIV. . . . 170

Monotropeae . . . . 170

Montika CXVIII. . . 95

Morecie . . . . . . 64

Morus CXXY. . . . . 64

Mozsárvirág XCVII. 138

Müge L., LX. . . . . 126

Muhar LIII. . . . . 21

Müköcs LXV. . . . . 167

Murok LXXT. . . . 181

Murvapikk XCVIL. . . 133

Muscari LXXIX. . . . 45

Mustár CIV. . . . . 209

Myagrum C. . . . . 216

Myosotis LXIT. • . 149

Myosurus LXXVII.,

Mercurialis CXXX. . . 248

XCIII. . . . . . 192

Mespilus LXXXIX. . . 260

Myriophyllum CXXII. . 257 


\section{N.}

Nadálytö LXIV.

Lap

Nadragulya LXVI. . . 153

Nádtippan LV. . . . 16

Najadeae . . . . 56

Najas CXXII., CXXIX. . 56

Nápicz LVI. . . . . 16

Napvirág CXVIII. . . 93

Nasturtium CIII. . . 200

Nászpolya LXXXIX. . 260

Nefelejts LXIV. . . 149

Negundo CXXVIII. . . 242

Nepeta XCVI. . . $133^{3}$

Neottia CXX. . . . . 54

Neslia C. . . . . 217

Nicotiana LXVI. . . 154

Nigella XCIII. . . 197

Nimfa XCII. . . . 219

Nimfafélél: . . . . 219

Nonnea LXIV. . . 146

Nöszirom L. . . . . 47

Nösziromféléle . . . . 47

Nuphar XCII. . . . 220

Nyakó LXIV. . . . . 147

Nyárfa CXXXI. . . 68

Nyelecz LVII. . . . 5

Nyelvür CXIX. . . . 52

Nymphaeaceae. . . . 219

Nymphaea XCII. . . 219

Nyilfü CXXIII. . . . 37

Nyirfa CXXVI. . . . 61

Nyirfélék . . . . 61

Nyulárnyék LXXIX.,

CXXIX.

Nyulga CIV.

\section{o.}

Lap

Oenanthe LXXIII. . . 175

Oenothera LXXXII. . . 255

Oenothereae . . . 255

Olajfafélék . . . . . 128

Oleaceae . . . . . 128

Olocsán LVIII., LXXVI.,

LXXXVI.

Omphalodes LXIII. . . 151

Onobrychis CVIII. . . 286

Ononis CVII. . . . 273

Onopordum CXIII. . . 103

Onosma LXV. . . . . 148

Ophrys CXX. . . . 53

Orchideae . . . . . 49

Orchis CXIX. . . . . 49

Orlaya LXXV. . . 181

Ormánka LXXV. . . 18:3

Ornithogalum LXXIX. . 40 Orobanche XCVIII. . . 166 Orobancheae . . . $166^{\circ}$ Orobus CIX. . . . 292 Origanum XCVII. . . 133 Ostrya CXXVI. . . . 62 oxalideae . . . 255 Oxalis LXXXVI., CV. . 255 Oxytropis CVIII . . 283

\section{P.}

Paizspár CI. . . . 214

Paizssajt CVI. . . . 237

Pakócza CXV. . . 88

Paliurus LXIII., LXXVI. 245

Palka I. 
Palkufélék . . . . . 23

Pamár CXIII., CXV. 99

Panicum LIII. . . . 20

Papaver XCI. . . . 198

Papareraceae . . . 198

Papilionaceae . . . . 271

Páponya LXVI. . . . 153

Parietaria LXI,, CXXIV. 65

Paris LXXXIII.

45

Párló LXXXVII. . . . 267

Parnassia LXXVII. . . 221

Paronychia LXVII. . . 225

Passerina LXXXII. . . 81

Pastinaca LXXIV. . . 180

Pasztinák LXXIV. . . 180

Paszuly CIX. . . . . 293

Patkóczim CIX. . . . 286

Pízsitféléli . . . . . 1

Pedicularis C. . . . . 164

Peganum LXXXVII. . 250

Pemet XCIV. . . . 139

Peplis LXXTII. . . . 258

Pereszlén XCVIII. . . 134

Perje LVII. • . . . 8

Persica LXXXVIII. . . 269

Peszércz XLIX., XCIV. 133

Pesztercze XCVI. - . 143

Petasites CXV., CXVI. 88

Petrezselyem LXXI. . 171

Petroselinum LXXI. . 171

Peucedanum LXXV. . 178

Phalaris LIV. . . . 18

Phaseolus CIX. • . 293

Philadelphus LXXXVIII. 259

Phleum LIV.
Phlomis XCT.

143

Phragmites LV. . . . 11

Physalis LXVI. . . 153

Phyteuma LXVII. . 120

Picris CXI. . . . . 111

Pikkelỵhúr LXXXV. . 226

Pillangósok . . . . 27 I

Pimpinella LXXII. . . 172

Pimpó XC. . . . . 264

Pintyő XCIX. . . . . 158

Piptatherum LIV. . . 22

Pisum CIX. . . . 290

Pitypang CXI. . . . 113

Plantagineae . . . . 82

Plantago LX. . . . 82

Plataneae . . . . 65

Plathanthera CXIX. . 53

Platanus CXXV. . . 65

Plumbagineae . . . 84

Poa LVII. . . . . 8

Podospermum CXII. . 113

Pofóka XCVII. . . . 137

Poloskamag XLVII.,

LXVIII. . . . . 74

Polychnemum XLVII. L. $\quad 76$

Polygala CVI. . . . 243

Polygalece . . . . . 243

Polygoneae . . . . . 76

Polygonum LXVII.,

LXXX,. LXXXII.,

LXXXIII. . . . 78

Polyvaborz LIII. . . . 20

Polyvabur LVII. . . . 12

F'olyvacsukk LIV. . , 18

Polyvahordó CXI. . . 110 
Pomaceuc . . . . 259

Populus CXXXI.

Poresin LXXXVII

Porcsinféték .

Porezika LXVII.

Porfej CXIX.

Porodapár LIV.

Portulaca LXXXVII.

Portulacaceae.

Posgafélék

Potamogeton LXI.

Potentilla XC.

Poterium LXXXIX.,

CXXIII.

Potnya CXXVIII.

Potnyaféléli .

Pozdor CXII.

Prenanthes CX. . . . 115

Primula LXV. . . 168

Primulaceae

167

Prunella XCVI. . . . 137

Prunus LXXXIX. . . 269

Puhar LXXXVII. . . 230

Puhonez CXIV. . . 105

Pulegium XCVII. . 132

Pulicaria CXV. . . . 93

Pulmonaria LXIV. . . 148

Pyrus XC. . . . . . 259

\section{Q.}

Quercus CXXVII.

\section{R.}

Ragikra CXIX. Ranunculaceae
Ranunculus XCIII.

Lap

Raphanus CII.

192

Rapistrum CI. . . . . 217

Raponez LXVII. . . 120

Redőszirom LXV. . . 154

Rekenyö CI. . . . . 217

Rekettye CVII. . . . 271

Rencze XLVIII., XCVIII. 167

Rienczeféléli . . . . 167

Repkény XCVI. . . $136^{\circ}$

Reseda LXXXVIII. . . 218

Resedaceae . . . . 218

Retek CII. . . . . 218

Rezeda LXXYVIII. . . 218

Resedafélék . . . . 218

Rezge LVII. . . . 8

Rézsuka CIII. . . . 200

Rhamneae . . . . 245

Rhamnus LX., LXIII.,

CXXVIII. . . . 245

Rhinanthus XCIX. . 164

Rhus LXXVI., CXXVIII. 249

Ribes LXII. • . . 187

Ribisaceae . . . . 187

Ribiszke LXII. . . 187

Ribiszkefélék . . . 187

Ritkaréj CXVII. . . 90

Robinia CIX. . . . 282

Rosa XC. . . . . . 261

Rosaceae . . . . . 261

Rozs LIII. . . . . . 3

Rózsa XC. . . . . 261

Riózsafélék . . . . 261

52 Rozsnok LVI. . . . . 6

Rubia LX. . . . . 125 
Rubiacene . . . . 122

Rubus XC.

Rukercz CXVIII. .

Rumex LXXX., CXXIX. 76 Rutacecue

Rutafélék:

250

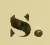

Sáfrán L.

Sagina LXI., LXXVII., LXXXVII.

226

Sagittaria CXXIII.

Sajkorr CVHII.

Saláta CXI.

Salicineare

Salicornia XLVII.,

XLVIII.

Salix CXXXI.

Salsola LXVIII.

Salvia XLIX., XCIV

Sambucus LXXVII.

Samolus LXVII.

Sangvisorba LXI.

Sanicula LXXIII. . . 170

Santalaceae . . . 80

Saponaria LXXXV. . . 233

Sárda CV. . . . . . 239

Sárika LXXVIII. . . . 49

Sarkar CXIX. . . . 53

Sarkvirág XC., XCII. . 197

Sarlófü LXXII. . . . 172

Sárma LXXIX. • . 41

Sás CXXIII., CXXIX. • 23

Sátorsás LI.

32

Saxifraga LXXXIV. . . 187
Saxifragaceae . . . . 187

Savar LXVIII. . . . 74

Scabiosa LIX. . . . . 87

Scherardia LX. . . 126

Schoboeria LXIX. . . 74

Schoenus L. . . . . 36

Scilla LXXIX. . . . 42

Scirpus LI. . . . . . 33

Scleranthus LXVIII.,

LXXXIV.

225

Scorzonera CXII. . . 112

Scrophularia XCIX. . 158

Scrophularineae . . . 154

Scutellaria XCVII. . . 137

Secale LIII. • . . . 3

Sedum LXXXVI. . . 186

Selinum LXXIII. . . 178

Sempervivum LXXXI.

LXXXVIII. . . . 186

Senebiera CI. . . . 216

Senecio CXV. CXVII. . 101

Sepröfü LXIX.. . . . 73

Serratula CXIV. . . . 109

Sertecsék CXV. . . . 91

Seseli LXXIII. . . . 176

Sesleria LV. . . . . 12

Setaria LIII. . . . 21

Sideritis XCIV. . . 138

Sikkantyu LIX. • . 87

Silaus LXXIII. . . . 177

Silene LXXXV.,

CXXIX. . . . . 234

Siler LXXV. . . . . 181

Sinapis CIV. . . . . 209

Sisakvirág XCII. . . . 198 
Sisymbrium CIV. . . 205

Sujtár LXXV.

181

Sium LXXII. . . . . 173

Sulyom LXI.

258

Smilaceae.

Sünhaj LXVIII.

75

Sodortajk CXIX. . . . 52

Solanacecue . . . . 152

Sünmag LXIII. . . . 149

Solanum LXVI. . . . 153

Sutabub LIX. . . . . 87

Solidago CXYII. . . . 90

Somfa LX. . . . . . 185

Somfélék. . . . . . 185

Somócsing XLVII.,

XLVIII.

Sömörge C.

Symphytum LXIY. . 146

Syrenia CIII. . . . 208

Syringa XLVIII. . . 128

Szádor XCVIII. . . 1 tí6

Szcidorfëlék. . . . 166

Szagyán LXI., LXXVII.,

Sonchus CXI. . . . 110

Sorapár CIII. . . . . 210

LXXXYII. . . . 226

Szaka LXXXVI. . . 186

Szálkacsék XCIX. . 163

Szamócza XC. . . . 263

Számolya LXVII. . 169

Szantuilfélék. . . . . 80

Szappanfü LXXXY. . . 233

Szapuka CVII. . . . 274

Szárnyók CVII. . . . 282

LXXXVI. . . . . 225

Spiranthes CXX. . . . 55

Spirea LXXXIX., XC. . 268

Stachys XCVI. . . . 139

Staphylea LXX.,

LXXVI. . . . . 244

Staphyleaceae. . . 244

Statice LXXVII. . . . 84

Stellaria LVIII., LXXVI.,

LXXXVI. . . . . 229

Sternbergia LXXVIII. . 49

Stipa LV. . . . . 18

Stratiotes CXXIX. . . 46

Sturmia CXX. . . . . 55

Szarutok XCI. . . . 199

Szattyú CXVI. . . .88

Szederj XC. . . . 262

Szegecs CIV. . . . 207

Szegfü LXXXIV. . . 231

Szegfüfélék. . . . . 225

Szélfü CXXX. . . . 248

Szeplén LXIV. . . 145

Szigoráll XLIX. . . 159

Szikfü CXriII. . . . 96

Sziklár LXVIII.,

LXXXIT.

225

Szikör LXI.

Succisa LIX. . . . . $87 \mid$ Szila LXXIII. 
Szilfa LXVIII., LXXXII. 63 Szilfélék.

Sziléne LXXXV.,

CXXIX. . . . . 234

Szilva LXXXIX. . . 269

Szingallér LXXI. . . . 174

Ṡziralj XCIII. . . 196

Sziromőr LXXV. . . . 181

Szirompár XLVIII. . . 257

SzIROMTALANOK. . . 60

Szironták XCIII: . . 192

Szirontákfélék. . . . 188

Szirtőr CI. . . . . 215

Szittyó LXXX. . . 37

Szittyófélék. . . . . 37

Szódokfa XCI. . . . 240

Szódolfélék. . . . . 240

Szöllö LXII. . . . . 244

Szôllöfélék. . . . . 244

Szömörcze LXXVI.

CXXVIII. . . . 249

Szularfélét. . . . 220

Szulák LXVI. . . . . 151

Szulákffélék. . . . . 151

Szümcső CI. . . . . 217

Szurdanes LXXXIY. . 250

\section{T.}

Tákajak XCIX. . . . 158

Tákajakfélék. . . . 154

Takta XCL. . . . . . 198

Tamus CXXX. . . 47

Tanacetum CXVI. . 99

Tapsir LXXIV. . . 180

Taraxacum CXI. . . 113
Tarkör CXVII.

100

Tarnics LX., LXII.,

LXIX.

Tarnicsfélék. . . . 130

Tarorja XCV. . . . 143

Tarsóka CI. . . . 213

Táskarag CI. . . . . 216

Táskazár C. . . . . 216

Tátkanaf XCV. . . 142

Tátorján CT. . . . 218

Tejér LXXV. . . . . 180

Ternye CII. . . . . 210

Tetemtoldó XCI. . . . 220

Tetragonolobus CVII. . 282

Teucrium XCV. . . 143

Thalictrum XCIII. . 188

Thesium LXI., LXVII. . 80

Thlaspi CI. . . . . 213

Thymus XCVII. . . . 133

Thysselinum LXXV. . 180

Tikszem LXV. • . . 169

Tilia XCI. . . . . 240

Tiliaceae . . . . 240

Tippan LV. . . . . 17

Tóborosta CXXII. . . 257

Tóborostafélék . . . . 257

Toboztermök . . . . 60

Tokafék CXX. . . . 54

Tök CXXIII. . . . . 223

Töhfélék . . . . . 223

Tölgyfa CXXVII. . . 62

Törzsnövényck. . . . 1

Tónya LXV. . . . . 169

Tordylium LXXIV. . . 181

Törfü LII. . . . . . 1 
Torilis LXXV. . . . 182

Torma CII. . . . 212

Tormánes CIV. . . . 201

Tórózsa XCII. • . . 220

Toronszál CIIL. • . . 202

Torzon XLVII., L. . 76

Tözike LXXVIII. . . 49

Tragopogon CXI. . . 111

Tragus LIII. . • . . 20

Trapa LXI. . . . . 258

Tribulus LXXXIV. . . 250

Trifolium CVIII. . . 276

Triglochin LXXXI. . . 36

Trigonella CVUr. . . 275

Triticum LIII. . . . 3

Tukmaféléli . . . . 45

Tunica LXXXV. . . . 233

Turgenia LXVV. . 182

Turritis CIII. . . . . 202

Türtszirom LXV. . . 168

Tüskemag LXXV. . . 182

Tüskepár LXIII.

LXXVI. . . . . 245

Tussilago CXVI. . . . 88

Typha CXXII. . . . 59

Typhaceae . . . . . 59

\section{v.}

Ugorka CXXIII. . . . 224

Ulmaceae . . . . . 63

Ulmus LXVIII.,

LXXXII. . . . 63

Umbelliferae . . . 170

Ürezab LVI.
Üröm CXVI.

Lap

Urtica CXXIV., CXXX. . 64 Uiticaceae . . . . . 64 Uszány LXI. . . . . 56 Üszögör CXV., CXVII. 100 Uszszakál XLVII. . . 257 Utifü LX. . . . . . 82 Utifüfélek . . . . . 82 Utricularia XLVIII., XCVIII. . . . . 167 Utriculariaceae . . . 167

Vaccaria LXXXV. . . 238 Vadócz LII. . . . . 4 Valeriana L. . . . 86 Valerianeae . . . . 84 Valerianella L. . . . 84 VÁLTSZIRMUAK. . . 170 Válupikk CXII. . . . 110

Varádics CXVI. . . . 99

Vasvirág CXIII. . . . 103

Veniczfa CXXVI. . . 62

Veratrum LXXX. . . 39

Verbascum LXVI. . . 154 Verbena XCIV.,

XCVIII. . . . . 145

Verbenaceae . . . 145

Vérfö LXI. . . . . 268

Veronica XLIX. . . 159

Vértö LXV. . . . . 148

Veselke LXXXII.,

LXXXIV. . . . 187

Vibørnum LIXVII. . . 127 


\begin{tabular}{|c|c|c|c|}
\hline & Lap & & \\
\hline Vicia CIX. & 286 & Z. & \\
\hline Vicsor XCVIII. & 167 & & Lap \\
\hline Vidrafü LXV. . & 130 & Zab LVI. & 13 \\
\hline Villahim XCVI. & 137 & Zanichellia XLVIII., & \\
\hline Villamag CXII. & 94 & CXXI. & 56 \\
\hline Vinca LXVI. & 129 & Zanót CVII. & 272 \\
\hline Viola LXII. & 221 & Zapócza LXX. & 170 \\
\hline Violariceate & 221 & Zászpa LXXX. . & 39 \\
\hline Virnáncz XCIII. . & 188 & Zea CXXII. . . & 22 \\
\hline Viscaria LXXXVI. & 237 & Zeller LXXI. . & 171 \\
\hline Viscum CXXVIII. & 185 & Ziliz CVI. . & 238 \\
\hline Vitis LXII. . . & 244 & Zöldcsik LXXIX. & 40 \\
\hline & & Zsálya XLIX., XCIV. & . 134 \\
\hline $\mathbf{X}$. & & Zsázsa CI. . . . & 214 \\
\hline & 1 & Zsoltina CXIV. & $\begin{array}{l}109 \\
205\end{array}$ \\
\hline Xeranthemum CXIII & 103 & Zygopphyllaceae & 250 \\
\hline
\end{tabular}




\section{FELTÜNÖBB SAJTÓHIBÁK.}

Lap sorban

XLIX. 8. felülröl Gorka. Csikratiola helyett: Csikorka. Gratiola.

XCI. 6. alólról marraja helyett: murvája.

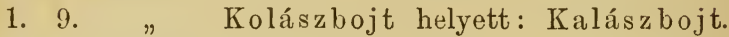

10. 4. felülröl felö helyctt: felsö.

20. 9. alólról Bolyvaborz helyett: Polyvaborz.

24. 12. " terzedten helyett: terpedten.

29. 1. felülről csörfi helyett: csörei.

44. 13. " porum helyett: porrum.

63. 7. alólról kimaradt: Szilfa. Ulmus.

$" 9 . \quad \% \quad$ Erdoi helyett: Erdei.

73. 6. felülröl áraknak helyett: áralakuak.

82. 3. " lánosások helyett: lánesások.

88. 13. " Parócza helyett: Pakócza.

113. 12. " Podospernum helyett: Podosper$\mathrm{mum}$.

\# 3. alólról corriculatum helyett: corniculatum.

130. 9. felülröl Limnanthenum helyett: Limnanthe emum.

152. 7. alólról Epihymum lelyett: Epithymum

153. 17. felülről Pápona helyett: Páponya.

223. 5. alólról V. helyett: V. hortensis.

326. 18. felülröl Irflorescentia helyett: Inflorescentia. 


OK 323. New York Botanical Garden Library

gen Gonczy, Pal/Pestmegye es tajeka viranya

gen

$$
35185001097318
$$


